\title{
EDWIN CHADWICK
}

AND THE PUBLIC HEALTH MOVEMGNT,

$1832-1854$.

THESIS

PRESENPED FOR THE DEGREE OF Ph.D.

$\underline{B Y}$

R.A. L. IIS, B.A. 


\section{UNIVERSITYOF BIRMINGHAM}

\section{University of Birmingham Research Archive \\ e-theses repository}

This unpublished thesis/dissertation is copyright of the author and/or third parties. The intellectual property rights of the author or third parties in respect of this work are as defined by The Copyright Designs and Patents Act 1988 or as modified by any successor legislation.

Any use made of information contained in this thesis/dissertation must be in accordance with that legislation and must be properly acknowledged. Further distribution or reproduction in any format is prohibited without the permission of the copyright holder. 


\section{CONTENTS.}

\section{PART ONE.}

\section{THE PUBLIC ETSAITH AGITATION, 1832 - 1848.}

Chapter 1. The Chadwick Legend.

2. Somerset House. 27

3. The "Sanitary Idea".

4. Interments Report, 1843

5. Health of Towns Commission,

$$
1843 \text { - } 1845 \text {. }
$$

6. Sanitary Profits and Propaganda.

7. Struggle with the Speculators.

8. Retreat from Somerset House.

9. Fublic Health Act, 1848.

\section{PAPT TNOO.}

\section{THE GENERAL BOARD OF HEALTH, $1349-1854$.}

Chapter 10. Cholera, 1848 - 1849.

11. Greoks Street, 1848 - 1849 .

12. A New President.

13. London's Water and London's

14. The inspectors at Work. 
Chapter 15. The Local Boards.

16. Reaction, $1852-185 j$.

553

17. Achievement 3, $1843-1854$.

581

18. The fall of the Board

605

APPGNDIX. Factory Commission, 1833.

635

BIBLIOGRAPHY

653 
PART ONE.

THE PUBLIC HEAIMP AGITATION,

1832 - 1848. 


\section{GHAPTER 1. \\ THE CHADICK LEGEND.}

Few men have done so much for their fellow-countrymen as Bdwin Chadwick, and received in return so little thanks. The memories of an old oppression still cling to his name, and there has grown up around him a legend of bumourless arrogance and inhuman efficiency, of doctrinaire intransigence and ruthless driving power. He has become the type of the Bureaucrat, whose ideal sovernent is a vast panopticon, where under the austerely benevolent eye of the state official every individual lives and works, the spontaneous activities of each moulded by a controlling intelligence to some distant socisl end. He is the suspected channel of foreign ideas, of German absolutism and Trench centraligation, alien transplantations into the free soil of the British constitution. In him is seen the embodiment of that imperial ambition of the civil service, which since his time has assumed so great an ascendancy in the executive, causing Lord Chief Justices in these latter days to prophesy gloomily the undoing of parliaments and Lord Chief justices.

To every legend there is some basis in fact. It cannot be denied that Chadwick possessed certain qualities of chsracter which during his life time isolated him behind a prickly hedge of antipathy and distrust. He nas a bore, a really outstanding speciuon of bore in an age when the species flourished; the fact sticks out in every line of his clumsy, graceless prose, and in his continual revolution of the same fixed circle of ideas. He was too keenly aware of his own merits; while, on the other hand, he did not suffer fools gladly -- and his definition of a fool was a very wide one. He embittered controversy by his unswerving opinion, which 
he rarely attempted to conceal, that any one who disagreed with his views must be guilty of intellectual weakness or moral failing. With a wholesome suspicion of power wielded by others he combined an unbounded confidence in the potentialities of power in his own strong hands, and every scheme drawn up by $\mathbb{E}$ dwin Chadwick seemed to contain at some point a provision for giving more power to Edwin Chadwick. But, granted all this, it would be an error, and a grave injustice to Chadwick, to write off the antagonism he aroused as due to his personal faults. He was for a few years the most hated man in the country; not because he was cruel or vicious or corrupt, but because his name became the symbol of a soulless system of government by the paper regulations of a distant bureaucracy, and because --- a reason with more substance -- his investigations snatched aside the veil of indifference and good breeding which concealed the naked clash of economic forces, leaving starkly displayed the tainted sources of many respectable fortunes. He stirred up a great deal of mud, and it is a tribute not a reproach that so much of it was thrown back at him by his critics. Other men were more in the public eye, comanded greater respect and certainly inspired deeper affection --- and have since bean wore fortunate in their biographers. Sut no inan, not even Lord Shaftesoury, has nore solid achievenents in the field of social reform to his credit, and no man did more to curb and harness the crude capitalist energy which, when Chadwick began his work, was busy building a new earth on foundations laid deep in a new hell. The career of Edwin Chadwick may well serve as the classical illustration of a historical truth too often neglected, that the shaping of events may often owe less to the parliamentary gestures of the statesman than to the whispered advice of some obscurely influential figure, unnamed and unpraised, in a Government office. 
Edwin Chadwick was born on January 24th 1800 in the village of Longsight, near kanchester. His grandfather, "good old Andrew Chadwick", was"the oldest Methodist in all England when he died" in 1815 at the age of 93. "(1) The first Sunday Bchool in Lancashire was founded by him, and Wesley frequently held meetings at his house. He was reputed to be the nearest heir to the fortune of the eccentric inight, Sir Andrew Chadwick, whose will, scrawled on two bits of chandler's shop wrapping paper just before his death in 1768, was for more than a century the subject of Chancery suits; but he persistently refused to take steps to obtain the estate, saying that the things of this world were quite enough for him, and that "it would only make his family proud and thus endanger the salvation of their souls". (2) This was a line of argument quite foreign to his gradson, who never felt his soul in danger from money or anything else, and who gave as an additional and stronger reason for this rare self-restraint that old Andrew did not know that the estate was so considerable. Edwin's father, James Chadwick, was an active liberal politician, a friend of the blind poet and abolitionist, gdward kushton, and joint editor with the radical journalist, Cowdray, of the "Manchester Gazette". (3) It is probable that

1. Alice Boaraman (an American cousin of Chadwick's) - B.C., n.d.; probably c. 1873, when he was collecting facts about his fawily history, apparently with a view to claiming sir Andrew Chadwick's estate, the value of which was estimated in 1836 to be about $21,500,000$.

2. ibid. For Sir Andrew Chadwick, see "Notes and queries", Fourth Series, No. 11, 7 Nov., 1368, p. 441.

3. James Chadwick was a man of some scientific and artistic ability, and is sald to have taught botany and music to John Delton. He edited the "Statesman" during tine imprisonment of its editor, David tovel1 (1311, 1312 - 15). Leaving London for Rxeter, he became editor of the "Nestern Times". About 1837 he emigrated to America with the younger members of his family by a second marriage. Henry Chadwick (1324 - 1908), dwin's half-brother, achleved fame in a different sphere of legislation; he codified the rules and scoring of baseball, and became the "first important sports writer in Anerics" (see D.A.B.) 
Edwin Chadwick's sympathies and understanding were conditioned by a home in which the distress of the lower classes and the means of relieving it were earnestly discussed, but his mind took no direct impress from the nonconforalst and popular radical influences anongst which he was raised. James Chadwick must have been shocked to read his son's gibes at railcal demagogues, while "good old Andrew" would have been horrified to hear his grandson rank the dissenting chapel with the beershop and the Trade Union as the triple corruptions of the poor.

After some schocling at Stockport, Chadwick left Longsight for London when he was ten jears old, and entered an attorney's office as a pupll at the age of fourteen or fifteen. He picked up a little lawyer's latin and sufficient Prench to follow the debates in the Chambres, and read something of Swift and Defoe; but his formal education was fragmentary, and his self-planned studies severely technical and utilitarian. For a career in the public service, he would undoubtedly have said, his equipment was none the worse for that. What was history after all but "one great field of cram", and literature but the study of idlors who read for amusement? As for the classics, if they were brought out $-0-$

1. Details of Chadwick's early life are meagre. We may judge of the relationship between him and his family by this revealing extract from a letter to an Anerican cougin, written towards the end of 1852 when it was clear that the General Board of Health was nearlag its end: "Under the circunstancee I wish you to warn those whom it may concern of the uncertainty of the continuance of any income from me; --- the only thing which has ever seemed to me to concern them. Except from Julia and yourself, and from my brother James, almost the only letters I have ever received from any one member of my family, since I arrived at man's estate, any other than spunging applications cries (of) Give, Give; never a persoual civility, a message or an act that shewed sympathy for my labours, or couched with any view to give me pleasure, nothing but indirect or direct pauper importunities". (E.C. - Andrew Boardman, n.d.). 
anew and sold in Holywell street, the authors and booksellers would be prosecuted by the Society for the Suppression of Vice. (1) He had the deepest contempt for the aristocratic notion that no ideas of value could be expected from anybody who "had never been at either university, written a nonsense verse, or scanned a line of Horace". (2)

Chadwick was admitted to the Society of the Inner Temple in 1823, and, while continuing his reading for the Bar, earned a slender living as reporter on the "lorning Herald". By 1825 he was on good terms with the brilliant group of younger Utilitarians, and was frequently invited to dinner at John Mill's to meet George Grote, J. Eyton Tooke, James Roebuck, and John Graham. (3) He debated morals and metaphysics in a discussion class at Grote's ${ }^{4}$ he heard John Austin lecture at the new College in Gower Street $\$ 5$ daily he encountered the seminal ideas of Benthamism, and the energy of the Benthamite thrust gave direction and vigour to his thought. Of equal significance for the future, he met Southwood Smith and Dr. Neil Arnott, and at University College he becme familiar with current medical doctrine by discussions with students of the 1. I.C., "Subjects for Competitive Fxamination", 1890.

2. E.C., "On Iife Assurances", "Nestminster Review", Feb. 1828.

3. J.3. Mill - E.C., 1825: "I hope you are not the "young law student of Lyon's Inn", whose chere amie tried to throw herself into the Thames yesterday". At one time he seems to have had thoughts of marrying into the Mill family.

4. This is probably the discussion group described in Mrs. Grote's "Personal Life of George Grote", 2nd. ed. 1873, p. 60. The group met on two mornings a week at 3.30 a.m. for an hour or an hour and a half to read Mill, Hartley, Dutrieux, and Whately. But Mrs. Grote does not include Chadwick in the list, which includes the names of J.S.Mill, Charles Buller, Eyton Tooke, J.A. Roebuck, G.J. Graham, H. Grant, and W.G. Prescott.

5. The class 1ists for Austin's lectures from 1828 - 1830 include the names of Chadwick, J.S. Mill, J.A. Roebuck, Eytun Tooke, John, Edward and Charles Romilly, G.J. Graham, G.C. Lewis, and Charles Buller (see Hale Bellot, "History of University Coliege", pp. 187 - 188). 
best medical school in Europe.

In politics and religion alike he began to apply the same test, judging all activities by the volume of social benefit resulting from them. He turned his back on Wesleyan Longsight, and professed himself a nember of the Church of Bngland -- the faith of "Jeremy Taylor, of Bishop Berikeley, of Paley"(2) _.. because in his experience Anglican priests did more practical good amongst the poor than the Dissenters or the Roman Catholics. The parish incumbent who busied himself as agent for the savings bank and the clothing club, and who trusted to soap and water rather than to mystical theology for the redemption of his flock, was worthy of more respect than the Nonconformist preacher who stimulated a dangerous emotionalism in his hearers and weddled in anpractical political agitations; and he was immeasurably superior to the Roman Catholic priest who taught his people to revere stinking saints and impure monks, and who could enter unmoved the overcrowded hovel of an Irish cottier, where the sexes festered together in an atmosphere compounded of the smoke of a chimney with the stench of a privy. (3) In the political sphere he watched with sceptical detachment the 1. "rom discussions with them I derived a strong conviction of the superior importance of the study (as a science) of the means of preventing disease, and I was the better enabled to perceive some of the important relations of the facts, partially expressed by vital statistics, which were brought before me in my public investigations". (E.c. Dr. R. Willis, 31 July 1844). Sir s.H.Sieveking 1a 1838, after spending sole years at the schools of Paris, Berlin, and Edinb gh, ranised university College above them all. (Fale Bellot, op. cit., p. 147).

2. B... - Dr. Buckland, 17 January 1344.

3. 1.C. "INotes on Sanitation", MS draft written at the time of the "papal Aggression", 1850. Florence ightingale, it may be noted, applying the same utilitarian test, came to a diametricelly opposite conclusion. "In all the dens of disgrace and disease", she records in one of her notebooks, "the only clergy who deserve the name of pastors are the Roman Catnolic. The rest, of all denominations--- Church of England, Church of Scotland, Dissenters -... Ere only theology or tea momgers". (Sir sward Cook, "Life of Elorence Nightingale", vol. 1, p. 57). 
clash of party catch-words and the manoeuvrings for Porliamentary majorities. "I am a zealous advocate of all social improvements", he declared, "and am therefore an ally of any people by whom improvements would be made." (1) In the public bealth campaign a few years later he found his friends in both camps, looking to Tory paternalism to restrain the narrow individualism of petty Radical tradesmen, and to Radical irreverence to loosen the bonds of Tory traditionalism. He was not the man to applaud the antics of the "Trijackia", John Mill, John Graham, and John Roebuck, when they made their jaunt to revolutionary Paris in 1830, and startled the French by calling loudly for the "birseilleise" when Louis Philippe visited the Opera. (2)

The struggle for recognition in the hard schools of journalism and the law marked him for life with the selfconsciousness and truculence of the man who owes everything to his own exertions -- the self-made man, proud of his creation but sensitively aware of its imperfections. In pleet street and the Inner Temple he learued habits of tremendous industry and methods of investigation which were later to serve him in sood stead; and with them he acquired a cocksureness of manner wrich, coupled with a natural arcogance, set people's teeth on edge.

At thirty his aim in life was not yet settled, and his abilities, sharpened by application and a hard and varied upbringing, were qwaiting their opportunity. He had been called to the Bar, and was well spoken of in the Courts. Albany Foablanque had made him sub-editor of the "Bxaminer", from whose columns a merciless fire was directed against the Lords, the Church, the magistracy, and the ineptitudes of the 1. S.C. - dward Gulson, July 1837.

2. R. Leader, "Life and Letters ol J.A. oebuck", pp. $29-30$. 3. In Hovember 1330. The first brief offered to hin was to defend a man indicted for bigany; the defonce subgested was to shake the testimony of the wife. He declined to go into Court for such a purpose.( $.0 . \rightarrow$ i. Lewis, 3 Februery 1341). 
Wellington administration, Prom a popular Radical angle with which Chadwick was not always in sympatby. (1) He had caught the eye of Bentham and Brancis Place with a couple of excellent articles on French Medical Charities and Preventive Police, which he had contributed to Blanco White's "Iondon Review", a ponderous quarterly which foundered by its own weight after two issues. (2) Before a Commons Committee he had defended his view that the primary object of a police force was the prevention of crime, the detection and apprehension of the guilty being of subordinate importa.cef 3 and he had been

1. August 1830 . Fie woriced Por the "Examiner" until November 1833, not always on the most cordial. terms with his editor, since the line taken in his political arificles was at times at variance with Fonblanque's leaderg. "Don't take it ill that I remind you that if you have quarrelled wi.th democracy the Examiner has not", wrote sonblanque once (29 October 1833), "and partial arguments against the people, and insulting expressions applied to them, are to be avoided. Fron enlightened Radicals I have many complaints of these things". In another revealing leiter (8 february 1332), he writes: "I an much annoyed by your account of what passed with Burdett. If you allow Bentham to dress you in my plumes. I bee of you to wear ay courage also, and not to fil in with shabby excuses for what requires no excuse at al1. Having acopted the paragraph I was responsible for it, and would have admitted of no epologies, sud you when invested with my feathers by the Prophet of Truth should have simulated my crow. The ldea of Benthail's smoothing down a man he gcorns with no measured scorn, is disgusting; nor is it agreeeble to think that you representing the Examiner were admitted to courtesy under cover of such propitiatory sacrifices.

"Defend me from my Iriends I cannot fear my Ioes," I may heartily lepeat. As for Buriett I c n hardly bring an under the term of 'friends' for he is the friend of ro man who will not prostrate before him".

2. "London keview", vol. 1, lo. 1, pp. 252 - 303, 1330:

"Preventive Police". Ibid, No.2, 2. $536-565$ :

"Contralization. Public Charities in Frace". Of the first francis lace, who was cotemplating a siailar article for the "Westminster", wrote (2l June 1329): "You have published our views and I can do little more than republich tham."

5. F.C., 48 notes "To the Chairman of the Comittee appointed by the House of Commons to enquire into the present state of the Police of the Netropolis", I July 1328. 
prominent in drawing up petitions and Bills for Joseph Hume and Edward Bulwer in their attack on the "Moral and Political Bvils of the Taxes on Knowledge", a subject which -.. he asserts -- had been first broached in Parliament as "lir. Chadwick's question". (1)

Barly in 1831 be met Jeremy Bentham and accepted an invitation to become his secretary. "A queer old Hermit, half gone in dotage, sinking through it into the grave", (2) haunted by gloomy dreams and the dread of blindness, the philosopher was still hard at work on his drafts and codifications. Many men of influence and ability had hurried from Queen's Square, their minds illumined by some bright project for setting the world to rights; but Bentham regarded few with more esteem than this stern disciple of his old age. The gentle recluse, devising the widest schemes of benevolence that the philanthropist could desire in the guise of the most hard-headed self-interest that the economist could postulate, tapped some deep spring of feeling in Chadwick which rarely,

1. E.C. in WS note, n.d., on his own career. He states that his article in the "Westminster Review" on "laxes on knowledge" (1827) "was reprinted and circulated, and laid the foundation of the agitation on the question". He was in correspondence with Joseph Hume and B. Bulwer, who moved in the comons on 15 June 1832 the abolition of the duties impeding the diffusion of knowledge; but, sigaificantiy, he seems to have had no contact with Henry Hetzerington, the real leader of the agitation, the radicalism of whose "Pnor iran's Guardian" was too popular for Chadwick's taste. When he accepted Ponblanque's invitation to join the "Gxaminer", Chadwick told him that "in consequence of what I wrote on the subject of the newspapers, I have been subjected to much inconvenience and excluded from my sources of immediate emolument". The "cxaminer" was almost alone in maintaining that the abolition of the Sianp Duties was essential for the healthy progress of the press, most of the established papers preferring to support a charge wilch could be passed on to their readers rather than facilitate the rivalry of cheap papers.

2. Sentham - D. O'Connell, 15 Eebruary 1327. "Collected Foriks", ed. Bowring, vol.X1, p. 2. 
if ever, broke the surface in later years.

"Bentham was his ideal, his gulding star and had called forth all the tenderness of his nature", writes Chadwick's daughter, "He could not bear the most innocent joke about Bentham's peculiarities". (1) But Chadwick was not the kind of man to become the echo of another, however venerated. When Bentham offered him an annuity if he would undertake to devote his life to preaching the doctrines of Pelicitarianism, Chadwick refused the offer, though it must have had its attractions for a struggling lawyer. He always made it clear that he considered his allegiance to Bentham to be narrowly limited. He was exasperated by those who believed that his administrative ldeas were drawn from the philosopher, and would point out sharply that writings he had published before those of Bentham showed the independence of his own views -- especially on sanitary questions. (2) $-0-$

1. Marion Chadwick (L.C.'s daughter) - Mrs. Aubrey Richardson, 24 October 1928.

2. "inen Nr. Chadwick has entered into any subject, he has professed to have investigated the claims de novo to the extent of his means, and to have based his conclusions upon them, and not upon any preconceived opinions of any school" (k.C., WS notes, n.d., on his own career). It was almost certsinly on his insistence that J. Hill Burton put in the following foot-note in his "Benthamiana" (1843), p. 395: "It would be an injustice to that iriend of Bentham who has so thoroughly laid before the public the grounds on waich Sanitary Legislation ought to be based, to allow it to be presumed that the Constitutional Code contains on this subject anything beyond sinple sugzestions as to the general subjects to which the regulations should apply. The suggestions might have remained unnoticed like many of their author's other valuable hints. The public owe the full inductive sifting which this subject has received soleiy to Mr. Chadwick, some of whose remarks on sanatory re ulations, written long before be could have anticipated an opportunity of bringing forward his views in an authoritative form, were quoted by sentham as dllustrative matter for the Constitutional Code. See Works, vol. 1X, p. $648^{\prime \prime}$. When a correspondent relerred to Bentham as the author of the poor haw system, Chadwick professed himself "somewhat taiken sback" --- and be forwarded copies of his reports to enable the writer to judge of the "independent nature of the grounds" on which they were based. (A.U. - H.D. macleod, 19 January 1360). 
Bentham, eageged on the "Constitutional Code", his last and most ambitious work, asked his secretary to contribute sections on the functions of a Miaister of Public Health and a Minister of Justice, but Chadwick, who had not yet severed his connection with the "Lxaminer" and was also occupied with his strenuous campaign against the Stamp Duties, was obliged to decline. Turaing the pages of the "Constitutional Code", it is not difficult to detect the extent of Chadwick's debt to Bentham; nor is it possible to find a better lllustration of the difference between the methods and achievements of the two men. Chadwick, who was no political philosopher, took his theory ready-made and unexamined from Bentham. At the beginning of the "Constitutional Code" Bentham Lays down three fundamental principles. The first defines the object of the legislator, which is to secure the greatest happiness of the greatest number; the second states that in individuals "selfregard is predominant", or "self-preference has place everywhere". The business of the legislator is to reconcile the first principle with the second, to build the structure of society upon a psychology of atomic individualism; and this is to be eflected by the third of Benthan's principles, the "weans-prescribing, or junction-of-interests-prescribing principle", according to which the laws and administration of the commity should be consciously planned to ensure that in pursuing his seli-regarding activities the individual must promote the weliare of his fellows. (1) The "Coustitutional Code" is thus a beautifully constructed wechanism of checks and incentives for the organisation of a mob of conflicting egoisms. Here is the theory implicit in thadwick's administrative reforms, the justification for endowing the State with indefinitely extensile powers to ensure that the interests of the individual and the ends of society shall be $-0-$

1. "Constitutional Code", I Section II, First Pinciples Enumerated. 
identified -- the justiflcation for aggressive Government action to protect factory children and rallway labourers; to supply a legal ininimum of relief for the able-bodied pauper and institutional care for the slck, blind, and aged; to put under public regulation the supply of water and gas and the burial of the dead; to root out the corruption of parishes and municipalities and Improvement Commissioners, and the nepotism and patronage of central departments; to destroy, adapt, create institutions as the principle of utility might dictate. Here also are the blue-prints for the Utilitarian State -- the new Ministries for Health, Bducation, Justice, Indigence Relief, and Interior Communication; the administrative areas prescribed by bechnical necessities not historical sentiment; the ofricials selected for their tried and proved "appropriate aptitudes". Here are the powerful central departments, supervising, initiating, and inspecting, publishing regular reporis on their activities, collecting statistics and information from the localities, vigilant for every opportunity to exercise their "melioration-suggestive" functions.

In its astonisbing prescience, its inexorable detail, and its neat joinery of efficient means to useful ends, the "Constitutional Code" is the most sustained and fruitful effort of the practical imagination in the literature of government. But that it is a work of the imagination should not be forgotten. It is linited by what Bentham could see and hear from queen's Square. It is linited by the emotional preposgessions of a philosophical recluse of upper viddle class origins, comfortable in his means and his habits, remarisably equable in tempersment, who seems to have felt no stronger passion than a kind of intellectual irritability at the twisted logic of his opponents. The observation and experience of one man, even a man of genius, ${ }^{\text {qF }} \mathbf{m}_{\mathrm{t}}$ oo narrow a foundation for the massive edifice Bentham built upon them. 
In some of his suggestions there are, in consequence, as Graham Wallas has remarked, an odd "combination of ingenuity and ignorance". (1) Bentham grounds his views on Civil Service reform, for exsaple, on the theory that the applicant with the greatest fitness and relish for the service will be prepared to work for a lower remuneration, and may even be willing to pay for the privilege; and he recommends that those candidates who had been adjudged competent by an Examination Judicatory should be allowed to bid for the vacant ofilce, offering either to work for a smalier salary or to pay the public for the permission to serve it. (2)

A philosopher at his desk could in this way erect on paper his construction of pure intellect, building course by course from a priori foundations. He could postulate a Health Winister, ranking in importance before the Foreign Relations kinister, the Trade Minister, and even the sinance Minister, and endowed with whatever powers his philosophercreator inight wish to give him, from the supervision of medical officers of the Army, Navy, and Indigence Relief departments to the maintenance of hospitals, lazarettos, and laboratories, and the inspection of prisons, madhouses, schools, poor law establishments, and shops for the sale of drugs and surgical instruments. Phis ideal Minister would, of course, be armed with "aqua-procurative" powers, and powers to regulate the quantity, quality, and "proportionality of distribution" of water supplies. He would be charged with s comprehonsive range of ciautely defined duties -- a "malaria-obviating" function, involving the inspection of mines, sewers and drains, burial grounds, theatres, and lands covered with stagnant 1. "Bentham as Political Inventor", "Contemporary Review", Masch 1926, pp. $315-316$.

2. Bentham's ideas on the Civil Service are contained in a series of papers collected under the title of "official Apticude Maxinized, Bxpense Mininized" and in the "Constitutional Code", II, secs. 9 ff. 
water, and the control of smoke and efrluents from factories; a "health-regarding-evidence-elicitative-and-recordative" function, involving the collection of reports from local liegistrars, hospitals, and the establishrents under the various Ministries; an "appropriate-publicetion" eunction enjoining that the "utmost publicity" be given to the activities of the Ministry of Health. (1) It was Chadwick's task to test these a priori recommendations against the evidence, to work upwards from the day to day facts of social ills, and to find in actual case histories the arsuments to convince ratepayers and editors and Ministers of the Crown. "I may observe", he says, "that in my service I have never followed any one, not even Bentham, but have deduced aj conclusions not even from Bentham's but solely from close and important collections of evidence".

Perhaps be protested too nuch, perhaps he owed more to Bentham than he would adnit, for ideas which were his by adoption he would sometimes look upon fondly as his own

1. "Constitutional Code", II, sec. X. Some puvilic health duties are also givea to the reventive service Minister (ibid. sec. V); thus, by Art. 3 he is to prevent the ill effects of

"4. Disease and mortality, the results of unhealthy and unmediceted situations.

5. Unhealthy employments, the unhealthiness of which is capable of being removed or lessened by appropriate arrangements.

6. Contagious disease".

2. "On the Evile of Disunity in central and locs Administration" (1885), p. 2, foot-note. Cf. the article by Professor "asson in "North British Review", vol.XIII, pp. $40-34$ (185): "From the results of the Poor Law Comnission", says Mr. Chadwick himself in a conparatively recent paper, "we might question whether there are any acknowledged principles of legislation, on which it would be safe to act without a close iaquiry as to what circumstances there are which modify the principle itself, or linit the means by which effect may be iven to it". A very bit er pill, we conceive, suct an assertion as this would have proved to in. Chadwick's friend, r. Bentham, accustomed as the confident old philospher was, to forward codes of laws to Russia and Egypt and all parts of the world, on the strength of the universality of general principles excogitated in the ciby of Westminster". $(p .55)$. 
children. In truth, however, his resl debt to Bentham does not consist of any speciflc legal notions or administrative gadgets. It shows itself in his hatred of waste and corruption his healthy suspicion of the wielders of power, and his resolution to introduce system and classification into the public service by applying the Benthamite maxim "always to do the same thing in the same way, choosing the best, and always to call the same thing by the same name". (1)

For twelve months Chadwick lived in gueen's Square, aursing Bentham through his last iliness. (2) Before his death Chadwick laid before him the outline of his Poor Law proposals, "and he was satisfied with the proofs I gave him". (3) In his will sentham bequeatied to his secretary a gmall legacy and part of his library of jurisprudence, referring to him with affection and hoping that he would continue the grand work of codilication. (4)

1. "On the Evils of Disunity in central and local Adninistration" (1385), p. 2. The principle first appears, however, in Chadwick's "Sanitary keport" (1842), p. 372. 2. "He comitted himself to my entire care during $h$ is last illness, and I was with him until he died": F. - Bdward Gulson, July 1837. One note from this period has survived: "I am very sorry to hear that Mr. Beutham continues so unwell. I shall be very happy to as ist jou in any way -.. ond if you should be much fatigued by sitting up or reguire to be absent and a new face is admissible, I should be happy to do anything for Mr. Bentham from five in the afternoon to as late (or as early) an hour as you like" (Borsce orant - E. ., A.4.) Benthain died on o June 1832, with (according to Bowrine) his heac on bowrine's bosom. Bowring makes no wention of Chadwlok anymere in his biograpy of Bentham, which, in the words of Leslie stephen, ("kinglish Utilitarians", vol. 1, p. 225) is "one of the worst biographies in the language, out of raberials with might have served for a masterpi ce".

3. H. - H. M. Macleod, 19 January $186 \%$.

4. Chadwick later presented to University College Bentham's books on French, Austrian, Americun, Spanish, snd

Portuguese laws, with the coment "I have been unable to mase that use of Mr. Bentham's bequest which I expected and which he then contexplabed". n.d. 
In 1332 Nazssu Senior, knowing Chadwiok from his contributions to Blanco white's quarterly as an unueuslly wellinformed student of social problems, invited him to assist the Royal Comission which had just begun its inquiry into the Poor Laws. He hesitated long and anxiously before he accepted the offer. his reputation in his profeasion was high; John Ronilly and Henry Biciersteth had recently asked him to take over the editorship of a reforming journal, "The Jurist", and he was about to oifer bimself for practice at the coinmon Law Bar with the prospect of a successful career before him. But Senior had the ear of the Government, and his invitation opened up wide possivilities of Ministerial patronage.

It was no livil service fledgling, docile, well-bred, and ignorant, who entered whitehall in 1332, but an assertive, rather crude youns man, with hablts of mind already fixed, who for years had been elaborating theories of positive government action and was eager for the opportunity to put them into practice. From the first he was an unwelcome and critical alien. "All those who like Lord helbourne are for letting things 'shase right', as he expressed 1t, all those who in the sight of any amount of evil, uge the half inforned econonists' cry of Laissez faire, set me down ss mad". (2) "Why can't you leave it alone?", Lord ifelbourne would ask querulously when a restless subordinate suggested that something should be done (3); and he ewbodied the political philosophy of his class in the sphorism, "Jvery snglish sentleman may bo presumed to possess the ability to discharge the duties of any post which he has ouflicieat interest to obtain". Patronage, the distribution of places in the public service more or less at random amon st the population by the rortune's wheel of favour $-0-$

1. B.e., is note, n.d., on his own career. B.J. - r.u. Hardy, 30 March 1352 .

2. L. - Kev. (Lord) Sidney Godolphin Osborne, 16 April 1847. ("1.0.0." of the "limes").

3. S.C., is fragment, n.d. 
or influence, had bred a race of timid, fainéant officials, who looked with deep uneasiness upon isvestigations into social evils which oust lead to activity on their part. (1) They took the machinery nearest to hand and followed the advice which pronised least trouble, clinging to old forms and worn routines to avoid the labour of inventing and mastering new. To them Chadwick was a dangepous eccentric. Fie was "wild", "unsafe", "visionary", revolutionary even, this man with his ingenuity in dovising novel administrative machinery, his expositions of the preventability of disease and crime, and his inxeverent scorn for the oligarchic doctrine that the most important qualities of a man are his name and stock. Above all these Government servants, Ministers and departmental heads alike, were alarmed by Chadwick's faith in government. Chadwick, the first great modern Civil Servant with a professional sense of the dignity and proper functions of the public service, set himself from the beginning the task of removing the slur that "Government does everything badly". It was universally admitted, declared Lord Lansdowne on one occasion, that governments were the worst or cultivators, the worst of manufacturers, and the worst of traders. "No doubt", comented Chacwick, "as constituted the English fovernment is the worst of cultivators of the public lands of which other Governments are the best and obtain the highest rentals, (the worst of manufacturers) of arus and stores, which other governments manfacture in a superior manner, and is the worst of traders in comissariat supplies, expending in the msintenance of one army badly sums for which Frsnce, prussia and Austria maintain double forces!n(2) "The torpid hands of Government", was Peel's scoraful descriotion when it was suggested that the State should take 1. G.C. Lewis reported to his father, 11 october 1332 , that the home office, according to Benior, were "very sulky" at the activity of the Poor law Comission of Inquiry. "They have set one stone rolling hich they cunnot stop, and probably will not comit the same error again". "Letters of Sir G.C. Lewis", p. 14). 
possession of the railways. Was the adninistration of the rallways by private enterprise so superior in its efficiency? demanded Chadwick. "No lepartment of Government would have been endured, no Government could have stood, which if it had adninlstered them at all had adrinistered them as corrupty and as wastefully as they have been administered by the cormercial classes". (1)

"I fancy what I have glimpses of a ireat future, for other times and other men", he wrote once, valisig his eyes momeatarily to the horizon, "but it is by scientific legislation which can only be attained by special study, special qualifications and freat labour".(2) votbing was to be hoped Iroa the "legislation of the great majority of our rulers, who lift theic heads aloft above instructlon, who praise their own groping in the dark under the name of practice, and abuse as "theory and speculation" all attempts to act upon extended knowledge and aforethought"; such legislation was "a source of continual fumblings and botches; of amendments upon amendxents, often producing new evils, and sggravating the

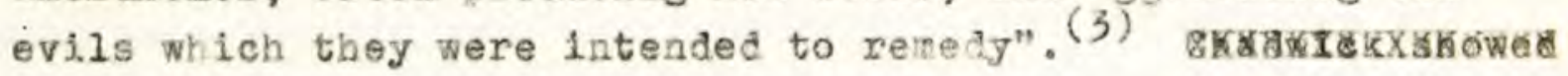

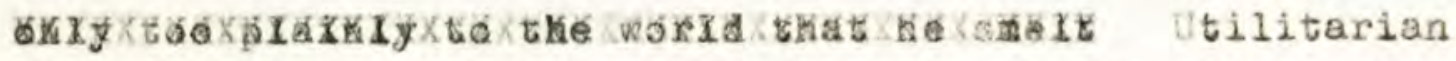
doctrine in both morals and legislation is founded on the certainty of rock-like principle; and to the confidence which the precision of the Benthamite calculus inspired, Chadwick added a personal conviction as to the soundness of bis own reasoning, the purity of his motives, and the objective desirability of the ends for which he worked. Aay one who opposed him wss runing counter to the dictates of reason and ethics; in short, he was either a fool or a rogue, and was likely to be both. "Bir", he remariced with a truly Johnsonian grandeur to youn byon Playfair, "the Jevil was

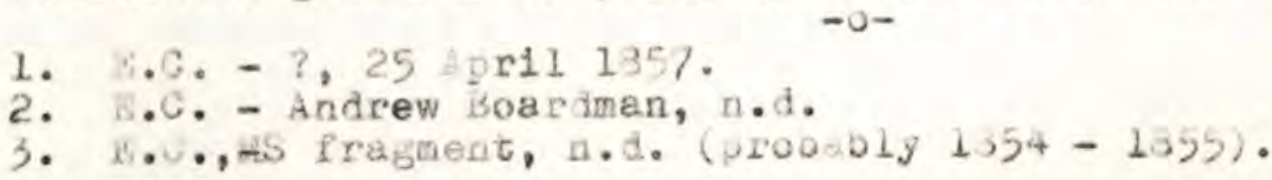


expelied from heaven becuuse he objected to centralization, and all those who object to centralization op ose it on devilish grounds!"(1) He showed only too plalnly to the world that he smelt brimstone whenever he net a isciple of M'croudy, or a paralysed official of the do-nothing school, or one of those "popular politicians who deem every measure for the relief of human pain visionary and the promoters of them impractical, who deen those sanitary measures which are beyond the power of individuals and are not within the capacity of any local administrators to be beyond the province of Government or legislation: - whose notion of duty in respect to governments is that it is an object of patriotism to make then impotent, and making them impotent see no need of special qualifications for administration, and with whom every salary is money paid for no work, and all appointments patronage and mere waste".

'Laissez faire' in economies was the obverse of Melbourne's "leave it alone" in government, and Chadwick's advocacy of positive sovernment action was logically combined with a rejection of the orthodox economic theories of the day. Whon he began his poor law inquiry economic science was a remote, deductive, Ricardian structure, proceeding from premiss to conclusion with the inevitable progress of a geometrical proof. The first absudoned the method, asd then found himself abandoning the principles and the deductions from them. As he explained in an address to the Political Fonomy lub:

"If there be a tendency observable in the pzogress of political economy, it secms to be that of gettin into two schools or sects -.. the hypothesists: the school oi reasoners from unverified or imperfectly verified hypothese cailed principles: and the school of facts, those who prefer inductions from facts incomplete as they may be, and difficult as it may be to examine them and make a complete induction from them. $-0-$

1. Reid, "Hemoirs and Correspondence of Lyon Tayfair" (1899), p. 64 .

c. B.u., ins fragment, n.d. 
I svow my preference for this method unattractive as it may be: at the expense of being classed with those people called matter of fact, who stick to whatever facts they can get, however few. The school is unattractive, for it is very laborious, there is much drudgery sbout, much digging and sifting, and much to weigh and examine and much to throw away, and after all not much to shew, or what may be shewn is comonly in the unattractive form of figures like the results of an analysis.

Whereas any one may at his ease imagine a conjunction of facts, no matter whether they occur or not, deduce consequences from them, and call the result a principle.

There is not only ease but simplicity in working with hypothetical cases. You can at once get it in whatever shape wearing the appearance of system you please. Opponents seeing that your hypothesis is possible, do not encumber you with questions as to its probability, and your premise being got by adrission jour conclusions needs must follow.

My principal objection is to this practice of using unverified hypothesis -- That we are apt to im gine and to use conjunctions of circumstances which never do occur as assumed and from them deduce consequences which never do happen as deduced, and never will so happen.

In fact that, if we do not suard ourselves we may get into discussions about as useful as those of the schoolmen as to how many angels could dance on the point of a needle.

It is possible to do more, however, than idly amuse: to cischievously misdirect human attention: to excite false alams to sive extreme pain: to aggravate human misery oy deducing it upon hypothesis to be ircemoveable.... (1)

1. L.C., "Population question. Two schools of political economy: the geometrical reasoners and the reasoners from facts", M draft, c. June 1345. Chadwick elsewhere ("On the Principles and Progress of the Poor Law 
This is the note which is sounded time and again in Chadwick's reports and correspondence --. the scorn for statesmen and administrators who continually arrived at practical conclusions in incredible ignorance of the grounds on which they could safely be made; the insistence that legislation must be founded on an ample induction, an inquiry safeguarded, as in a scientific investigation, by every security for the attainment of impartial and objective truth. The proper place for the economist or administrator, who was preparing the ground for legislative action, was in the street and workshop not the study or Government office, getting firsthand acquaintance with the problems and persons to be dealt with, not viewing them dimly through a mist of words and preconceptions. What Chadwick thought of an investigating body which sat round a table ia London and listened to paper evidence and the representations of selected witnesses, he revealed in a pungent letter to the chairman of a Royal Commission which had been trespassing without due deference in a field he regarded with a proprietary eye. dependent upon what others bring before you. The merit of my procedure for investigation is, that I have the least of guch dependence. I do not only the work of an attorney but the work of an attorney's clerk. I have gone to see the places myself ....: and I have cross-examined the witnesses there on the spot". (1)

It is clear that he would have had no very high opinion (continued from previous page) Amendient act", "Edinburgh Review", July 1336, vol. LXIII, pp. 437 - 537) criticises Nassau Senior's definition of the subject matter with which the political economist deals: "his premises consist of a very few general propositions, the result of observation, or consciousness, and scarcely requiring proof or even formal statement, which almost every man, as soon as he hears them, admits as familiar to his thoughts, or at least as included in his previous knowledge" (N. senior, "political Economy", p. 3). 
of the procedure of most of our recent Royal Commissions and departmental committees. The method he recommended was that of an open inquiry by a Commission of experts, circulating detailed questionnaires and conducting local inquiries by itinerant investigators. By such inquiries the curious compound of conjecture, prejudice, and arbitrary assumption which went by the name of political and economic theory would be replaced by a bcdy of scientific knowledge, based on experiment, accurate observation, and verifiable evidence. There would no longer be justification for the dangerous insetion of Governments, which was the result partly of an honest bewilderment about the nature of the evils and the means of remedy, partly of apprehension about the public attitude to any proposals that might be made. A full and explanatory report from the Comission would supply all the facts necessary for the framing of legislation and the conduct of Parliamentary debate; while the public inquiry, giving opportunity for all parties to be heard and all objections to receive their due weight, would ensure that the will of the country had been consulted --- and instructed also, since the education of opinion by the inquiry was as important as the exploration of the facts. (1)

1. Of. "A paper on the chief methods of preparation for Legislation .... read at a special meeting of the Society for Promoting Amendment of the Law", 1859, pasaim. B.C. - Nassau Senior, 30 July 1834: "Hy experience would warrant me in stauing that any one who prepures such measures will often find that the ex ress enquiries of other persons are inadequate or unsatisfactory either for his own Guidance or for justifying the deasure to the public; and that hearsay evidence is the less satisfactory in proportion as the object is to prepare any measure of immediate and detailed application". ... - J. Hill Burton, 3 June 1344: "the collector of the information, the investigator who if he is fit for anything should investigate to definite legislative conclusions and to the operative words of the law, and the draughtsman and indeed the supervisor of the execution of the law until (at least) it has got into "semi automatic" and rouline operation nust be for finished work one and the same person". 
The value of Chadwick's influence in the field of social investigation during the twenty two years of his official

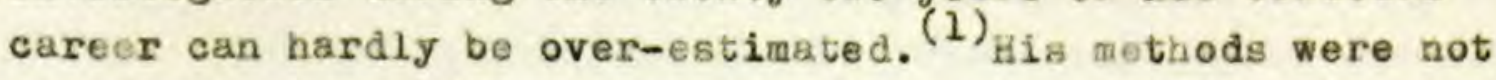
original. John Howard had made the round of the prisons with measuring tape, weighing scales, and notebook, and had refused to take any statenents on hearsay, seeking to confirm everything by cross-questioning keepers, turnikeys, and prisoners; Bentham had laid it down that legislation is "an affair of ubservation and calculation" ${ }^{(2)}$, and that it should be based, not as hitherto "upon the quicissands of prejudice and instinct", but "upon the immoveable basis of sensations and experience" (3); the Poor Law inquiry of 1832 - 1834 was conducted, probably at Lord Brougham's suggestion, by itinerant Comissioners, as was also the inquiry of the Municipal Corporations Comission of 1335. But the full development of the method, and in particular its use as an instrument to defeat the opposition of doctrinaires and of entrenched interests, is peculiariy Chadwick's achievenent. In addition to the models affordedoy his own unequalled series of reports, he was ready with guidance to other investigations, such as, for example, the Children's Employment Comission of 1340. And, under the General Board of Health, the procedure of preilinary inquiry in the locality was used by Chadwick's Inspectors to clear the ground for the appliction of the ublic Health Act.

For Chadwick everybody had his story, his facts, his fragment of experience, with lessons to instruct the acute and sympathetic investigator. The working clas housewife could tell him of her mariket purchases, the quick succession of her 1. "Wany writers, whose merely deductive and indeed long refuted doctrines on economic subjects are still discussed by the modern andists of politics l economy, habitually ignore Dr. (sic) Chadwick's classic labours". A. Wilson and H.Levy, "Burial Reform and Funeral costs", p.25 f.n. 2. "Theory of Legislation", ed. . . Ogden, 1931, p. 10. 3. Ibia, p. 102 . 
confinements, her ineffectual attempts to keep her house clean without water and her family healthy in the midst of damp and filth. The young criminal in the pison cell could describe how te fell to the temptations of the flash-house. The gravedigger had stories of the horrors of the graveyards, and the slaughterer in clare harket could suggest how disease might be spread by nasty feeding. Even the journeyman mason with his ample whiskers could give support to the notion that a beard was not only an addition to manly beauty but slso had a utilitarion value as a protection againsi dust. Chadwick talked to them all, and what they told bim went down in his notes, to reappear, perhaps, in some report as buttress to an argument, or as a clinchins illustration in a speech or a letter. He let them speak for themselves in copious extracts, and his favourite method in the descriptive portions of his reports was to present his facts in the words of his informants, knitting their sccounts together with a few remarks of explanation and comment.

There was usually, however, an admixture, more or less preponderant, of Edwin Chadwick in that evidence. He took a stand on the facts very quickly, sometimes too quickly; he soon made up his mind what he wanted to find out, and he used both the rein and the spur in guiding his witness towards a conclusion he already had clearly in mind. It was not for nothing that he had read for the Bar, and had assisted Brougham In the last case he undertook before be became tord chancellor. (1) The ideal of scientific objectivity which Guadwick set before the social investigator was not easy for any inan to attain; for Chadwick himself, with his training and temperament, it was doubly difficult. Charles derwin had an excellent habit of making an immediate note of every fact which he encountered which seemed at variance with his own theories; because, he said, he was sure to remember those facts which 1. E.C.t Lord Ashley, 15 November 1345. 
supported his case, but was likely to overlook the facts he wished to forget. Had Chadwick done the same he might have lost something of that dogmatic self-assurence which at tines irritated even his best friends.

Chadwick's aim, then, -- however far in practice he fell short of it -- was to probe with his instrument of impartial inquiry to the ultimate causes of pauperism, disease, and crime, for only when the long chain of causes and effects had been uncovered could the legislator determine at what exact point the hand of Government should descend. Phe working of his mind can be seen in such a typical letter as the following: "According to Cobbett poverty is the mother of crime, according to prisoners and to prisoners' counsel all is from distress. "Why did you comit this crime? I had nothing to eat. Why had you nothing to eat? I was out of work. Whypere you out of work? because my master had nothing wore to do for me and discharged me". But we are not to stop there: send for his employer, ask why he discharged him: send to his friends per chaplain: ask the police who were his connexions and what were his satecedent habits of living and then facts of a totally different complexion come out in the majority of cases, except in the case of begsars' and vagrants' children who inherit the sins of the parents. It is only by laborious enquiry case by case over large numbers and in different places that the resl truth can be ade out, or safe general cunclusions be establisted......(1)

\section{Revolutionary conclusions emerged from this close} examination of the facts. Suming up the lessons of a quarter of a century spent in continual investigation, chadwick declared that "the results of every oce of these inquiries was to reverse the largest main principles on which the Government and Parliament ans the economists, professionel persons and the public at large had adopted as requisite and were prepared 1. H.C. - Prederick Hill, 4 Warch 1844. 
to legislate. The results obtained were most of them new to myself as well as to my colleagues". (1) In controversy this close acquaintance with the facts gave Chadwick the moral and intellectual ascendancy of the man who had been and seen for himself. "John Stuart Mill always deferred to me on any question I had examined because as he said, I always got my information first band, whilst he could only get it second hand or from books". (2) He would ask acquaintances round to his house at Stanhope Gate for a "little sanitary chat", and over breakfast or an early dinner would submit them to his "inquisitorial thumb-screw", as one visitor described it with rueful admiration. (3) Not that the flow of information and experiences went all one way; he gave better than he got; and he was always ready with advice to the Chairman of the Board of Guardians who wanted to tighten up the administration of his Union or the enlightened land-owner who was thiniking of putting up some improved cottages for his farm labourers. If you were in doubt about the right depth to lay tiles for drainage, or wanted the name of a man who would plan a farm or a cemetery on the most approved models, or were at a loss for a set of clauses for a Bill or some telling figures for a speech, Chadwick could be depended upon to help. If he did not know, he could always put his hand on somebody who aid. "You know all the clever fellows and who can do everything better than anybody else", wrote James Morrison, in dificulties with bis Railway Committee. (4) "whenever I see a stupiaity going on, I think of you, of course as you can imagine ic", said a German economist, "because you are the man to bring the proper remedium". (5) Altogether, as Joha Mill remaricd, there was nobody quite like Chadwick for being practically us ful. (6)

1. L.C., "kepresentative Reform; jottings down of a letter on a comission", US, n.d., c. 1359.

2. B.C. Lord Branwe11, 3 March 1835.

3. George Sumer - E. .., n.d.

4. James Horrison - E.C., 22 uren 1845.

5. i. Garnier - E.C., n.d.

6. J.5. M111 - E.C., 1846. 


\section{CHAPGR 2.}

SOIBRSET HOUSE.

To the Commissioners, engaged in unearthing the abuses of the old Poor Law system, Chadwick was presently indispensable and his colleagues, uneasily turning over the fragmentary and inadequate schemes which had so far been devised, listened with relief to a voice which spoke with so confident a note of authority. At first he ranked only as one of the twenty six Assistant Commissioners, but it was not long before he was invited, at the unanimous request of the Connissioners, to become one of their number. When it was decided to publish in 1333 extracts from the evidence to prepare the public for the recommendations of the Comission, the selection of material was left to $\mathrm{him}$. (1) As a conspectus of their attitude to the problem it is hard to better the entry under "Paupers" in the index to that volume:

"Generally worthless and profligate .... Most 1 y made so by improvidence and vice .... The chief receivers of donations from charitable institutions and charitable ladies on whom they impose ....

Receiving allowance frequently, much better off than the soldiers ....

1. "Etracts from the Information received by H.M.'s Commissioners, as to the Administration and operation of the foor Laws", 1333. "Mr. Chadwicis's Report from London and Berkshire" occuples 139 of the 410 pages of reports from the Assistant Commissioners ( $p$. 201 - 8339). "In framing the report published in the volume of ixtracts I had put forward such an exposition of the evils as I thought would best suggest the practicable remedies and prepare the public mind for their reception": $\mathrm{E} . \mathrm{C}$. Nassau Senior, 30 July 1834. 
Generally made so by vicious habits, and not by unavoidable causes

Made by lying-in hospitsls, soup kitchens, blanket societies, and permanent charities ....

The originators of riots and fires in sussex .... In Bussex looked upon one who had been hanged for incendiarism as a martyr, exhibited him in his coffin, and subscribed for his family ...." And so on, building up picture of the pauper family, demoralised and worikshy, imposing on magistrates, defraudins the charitable, simmering with discontent, and transmitting the taint of laziness and turbulence to their prodigally conceived ofispring.

The raost influential figure on the Commission was the urbane Oxford professor, Nassau Benior, the Maynard Keynes of his day, to whom the Government looked as the leading interpreter of the science of Ricardo and Walthus. When Chadwick joikned the inquiry, Benior had not conceived any practicable way of offering relief to able-bodied paupers which would not bring all the demoralisation of Speenbamland in its train; and, as is draft of 1351 reveals, he could see in consequence no remedy short of a heroic surgical operation to cut away in its entirety the corruption of the allowance system. (1) Nor had he formulated any suggestions as to the machinery of administration. By September 1832, however, senior was urging on the Government the introduction of the workhouse test; and in a letter to the Lord Chancellor in Janusry 1833 he outlined proposals for a central Comission of three, a body of itinerant inspectors, paid overseers, and compulsory Unions of parishes. (3) In brief, Senior had capitulated to Chadwick's 1. Mowley, "Nassau Senior and Classicul bconomics" (1937), p. 317 .

2. ibid, p. 317: Senior - Lord Chancellor, 14 September 1832.

3. ibid, p. 319: Senior - Lord Chancellor, ? January 1833. Senior nere observes, "A year ago, or even six months ago I should have laughed at the proposal of asking it whex any other than a parochial charge". 
arguments that a legal provision of relief to the able-bodied paupers was necessary, and that it could be given in a form which would neither undernine the character of the recipient nor sap the position of the independent labourer; and, further, Senior had adopted unreservedly Chadwick's administrative scheme. Chadwick's energy and self-assurance, his bold prescription of remedies, and the weight of evidence he had assembled with extraordinary rapidity, had all worked with the utmost success on Nassau Senior, who possessed, as Miss Bowley has shown, a flexibility of outlook which belies his reputation as a doctrinaire of the laissez-faire persuasion. (1)

Chadwick was now asked to prepare "the heads of a Bill, or the outline of the Machinery for the amending the administration of the poor laws, founded an the principles which I had suggested, and in some degree evolved from the Aitnesses on their examination". (2) "I may observe (what is important to bear in mind)", he wrote later to lassau Benior, "that you had found it impracticable to deduce a plan from the Reports of the Assistant Commissioners. The course of investigation which I had taiken, had brought me in Contact with the great majority of persons by whom improvements had been carried into effect, or who were distinguished by their knowledge and ability in the administration of the existing systems and put we in possession of the best evidence on the subject. When you imposed upon me this most importmat task, I had a carte blanche. Plans had been previously submitted to the Board, but an examination of them will show that they were fragmentitious, that they contained scarcely one clear principle of legislation, or any thoroughly sound and well defined rule of administration ...."(3)

1. sa. Bowley, op. cit., p. 237.

2. B.C. - Massau Senior, 30 fuly 1834.

3. ibia. Bowley (op. cit., pp. 317, 321 ) seems unduly reluctant to give Chadwick credit for the conversion of Senior. This letter makes it clear that the scheme submitted to the Government was Dased on Chadwick's principles; and it is most unlikely that senior received aute indedendentiv an identical illumination. 
Brom the outset Chadwick was in revolt against the principles on which philanthropists and economists had hitherto besed their attitude to pauperism. He rejected out of hand the thesis of the evangelicals, volced eloquently by Dr. Chalmers, that all statutory systems of relief were pernicious, and that public doles should be replaced by the alms of the charitable. "The work is too great for any charity", he said. (1) He rejected with equal scorn the sentimental paternalism of the country magistrates, which nould bind the labourer in perpetuity to the thraldom of the parish pay-table. "Indeed, their conception was that the poor man -.- the agricultural labourer -- "must be poor" --- must have a lifelong support on parish doles -- must have his relief as a parish pauper -.. that his future was a parish poorhouse, and when he died he must have a parish funeral in a pauper's grave. The condition was sad, but one that could not be altered, and the evil must be endured"(2) Jut his main battle lay with the "hypothesists", who had maintained that "all inquiry was superfluous for that the real and all pervading cause was the pressure of population bejond the means of population".

"The measure for immediate alleviation was an extensive exigbation. In that sense Mr. Senior wrote and Mr. ilmot Biorton lectured.

The only real effective remedy it was stated by Mr. Ricardo was such a course of legislation as tended to their abolition.

On these views, or in this sense some of the leading statesmen, who were prepared to do anything more than to correct incidental grievances were prepared to leglslate...."(3)

1. B.C., "Notes for a speech at Leicester", us, August 1843. 2..., "for consideration of the comparison of tiberal with Conservative Iegislation and Administration, dfecting especially the Wage Classes", n.

3. E.C., "Investigstion. Popular opinions negatived by as to poor laws", MS, n.d. 
From their a priori law of population, the economists went on to deduce that the labour market was saturated, and that the paupers had been squeezed out by the competition of their fellow workers. Look at the facts, retorted Chadwick, and observe that they in no way bear out this grim picture of a population pressing right up to the margin of subsistence, and in their atruggles pushing the less fortunate over that margin into the gulf of starvation and misery. Conversations with aged labourers in the country parishes convinced him that as a class they had greatly improved in condition; that their real wages had risen, and were still rising; that their expectation of life was greater now than ever before.

1. Cf. F.C. - Archibald Allison, 5 August 1340:

"If in the Poor Law inquiry we had proceeded on the supposition or assumed that Mr. Malthus' principles were correct, we should have been led to others, and widely erroneous measures. One large fallacy is, that the pressure has already filled up the field of production. We were told that all were employed for whom employment was to be had; we were refer ed to the lists of ablebodied paupers -- to the increasing list of able-bodied paupers, as the numbers, of persons, who were surplus, and we were told that emigration was the only remedy, and that it was folly to think of workhouses or any other. If by offering out-door relief, or driving able-bodied peupers by any other means to seek their own subsiatence, and compete in the labour market; since the labour warket is already full, what other efiect can the competition have than to depress much more the condition of the independent labouring class.

by good fortune the power was obtained and wages did not fall, but rose in consequence of forcing the ablebodied paupers into the labour market ...... The rationale of this increase of production, may be sald to be, that the labourer goes into the market as a producer, rather than as a competitor. In the county of suffolk, before the change took place, there were upwards of 30,000 ablebodied persons on the Poors Rates; the sreat mass of them has been cleared off. On the presumption of a vast available aurplus in that county and in Norfolk, slips were prepared, and government enigration agents sent into those counties by the Agent General for enigration; I velieve bowever they scarcely succeeded in seting a dozen families out of the two counties to enigrate; nor do recruting officers, nor masters of ships, nor large (Continued on next page) 
True, there were dangerous congestions of pauperism in particular areas, but there was no general surplus over the country as a whole beyond the average demand for employment throughout the year. The existing mass of pauperism, in fact, was not a disease attacking the very structure of society, but nerely a disorder of its functions, which could be corrected by a proper regimen. If the attractions of relief were lessened by cutting it to subsistence level and accompanying it by an irksome discipline; if it were made impossible for farners to get cheap labour at the public expense, and for landlords to have their rents paid and shopkeepers their hills by subsidies from public money; if the area of the labour market were widened by tearing down the fences of the Settlement and Apprenticeship laws, and by encouraging the migration of labourers from the heavily pauperised south to the industrial North -- if atz this were done, asserted Chadwick, all those apparently surplus labourers would be rapidly (continued Irom previous page) employers of labour of any sort, nor emigration agents now practically find any surplus of able-bodied labourers, except of such whose views render them ineligible for employment, or persons under peculiar and anomalous circumstances. The large fallacy of the field of production being full, which is usually adopted by $4 r$. althus' eriends, is too erequently accompanied by another follacious conclusion as to the existence of a large amount of unavoidable misery, which must necessarily occur, and by assumption of progressive deterioration. the close inquiries I have made from very aged labourers from various parts of the country establish the fact of the improvement of their general condition, instead of their deterioration, concurrent with the increase of population".

Chadwick, who met maltius at the folitical Lconomy Club, asserts that he had begun to vodify his oplnions on overpopulation before he died ( 3.0 . - Nacvey Sapier, 15 June 1336; Macvey Napier Paperg, vol. VII (34,617), 1.458). There is a quite incorrect impression that Chadwick was a disciple of Malthus (Dr. Gilbert Siater, for example, describes him as "eager for the talthusian principles of the Royal Comission's Report": "A Century of Municipal Progress", p. 339.) Chadwick, in fact, lost no opportunity to combat haltbusian doctrine, both in poor Law and in sanitary questions. 
absorbed into productive employment.

There remained those who were too young or too old for work, or who were unemployed through slckness or some temporary dislocation of the industrial machinery. For their benefit Chadwick proposed that, under the control of the new Union authorities, "the rudimentary charities of a civilised community" (1) should be legalised and given the strength and efficiency of large-scale organisation. In view of the later lapse into the horrors of the Genersl Mixed Workhouse, it should be emphasized that Chadwick wanted not a single penal establishment, but a series of specialised institutions, and that, in fact, he urged that the justification for combining parishes into Unions was less the economy in administration than the opportunity it afforded of separating the various classes of paupers for differential treatmeat. "Thus, when a town, which contains four or five parishes, each with its respective workhouses, is incorporated, each house may be exclusively appropriated to a particular set of paupers.

The old and impotent might be placed in one house by thenselves; $-0-$

1. The phrase occurs in a MS draft, "Notes on the retirement of Mr. Nicholls from the Poor law Board", n.d., which reviews Nicholls' efforts to introduce the new law into Ireland between September 1838 and November 1842. "The new union house comprehended organisation of the rudirentary charities of a civilised community: it comprebended un orphan asylum and an industrial school, an alms house for destitute widowhood, a lunatic asyium, a hospital, a ploce of work, and an institution to give the assurance to the labouring classes that whatsoever changes inight be made in the industrial arrangements of the country, they should be secured from perishing outright. The Union house was designed to collect the scattered wrecks of humaity, to place all whom it might be practicable to place in a course of productive iniustry and independence, to relieve the public from the spectacle of misery, and from the tax of mendicancy, and to alleviate the misery that was found to be ircetrievabie. It was proposed as sound economic policy, as well as lezalized chacity on the largest scale, as a foundstion for the good police and civilisation of the country". 
the whole of the pauper children may be placed in another house; the able-bodied females may be placed in a third of the workhouses, and the able-bodied males say be placed in the fourth house, the best adapted for discipilne and regulation. Eack class may then receive an appropriate treatment: the old may enjoy their comiorts, the children may be educated properly for service, and discipline and rigour may (not by the Legislature or the Government, but by the Comissioners' regulations) be concentrated, to stop the influx of pauperism from the able-bodied....(1)

Great, half-formed plans, for government action to an extent sever before contemplated by practical statesmen, flitted through Chadwick's mind as he worked over the evidence. "The tain measure propounded, for execution by a reorganised local - $0-$

1. He. "Heasures proposed with Relation to the Administration of the Poor Laws", quoted in "Health of Nations", ed. B.". Richardson, vol. 2, Pp. 354 - 5. Richardson records Chadwick's comments on the policy adopted by the poor Law Comission: "It was believed by the Commission (i.e. of inquiry) that the amendment of the vestral administration, by the separation of their mischievous adrixtures, and by proviajing for each class separate buildings, would be a 8 reat and lasting reformation. For the children it would provide separtie schocls away from the influence of the depraved paupers; for the old and infirm, institutions of the charucter of simshouses; for the sick, hospitals; for the lunatics, the blind, and the idiots, proper establishments; and for the able-bodied and the vagrants a distinct suitable building. But all this plan was overborne by one started within the dxecutive comission of ireating the separate classes in separate wards of the same house, under one chief manager. The separste system was the most dificult. It required services of speclalists in administration which could not readily be ubtained. For the treatment of the pauper childcen by school teachers on the mixed physical and wental training, the teachers had then sil to be trained. For the aggregation of cases for the purpose of segregation and the special treatment of the segregated cases sussested by w. Chadwick, undivided individual power was requisite. But he had none. All the Assistant Commiasoners -.. lawyers nd soldiers mostly -.- went in for the Union house, and he was driven to adopt it". 
administration was one of repression, the cessation of a mischievous form of relief, outdoor relief as a general rule, and reilef in aid of wages which operated most perniciously upon the labouriag classes, chiefly in the rural districts. A collateral measure of repression was requisite, to be directed against vagrantcy, and mendicancy, involving much juvenile delinquency, and for this it remained to be expounded that the agency of an organised police force which did not then exist (was needed). But an exclusively repressive policy, however completely carried out was in my view a narrow and inadequate one, and I had collected evidence, and had in preparation measures of prevention, one of which was a general system of mixed physical and mental training or elementary education for the children of the wage classes which as comnissioner of enquiry on the labour of young persons I had got introduced into the first factory act, of which I had the preparation. Bishop Blomfield who saw the evidence I had elicited was specially anxious that I should complete this topic. Another leadiag measure of the prevention of pauperism was the prevention of excessive sickness, premature disaoility to work, s.nd premature widowhood and or hanage, arising from the excess of disease, preventible by sanitary measures. I had opened up this topic in $m y$ own reports as one of a great measure of prevention. I pleaded for further time, another year, to bring these subjects forward in their due place, in a complete measure. But the Comission and the assistant comissioners all of whom, nyself included, had given a great deal of gratuitous labour were unprepared to sive mor attention to thera". (1)

In the final Report of the Comission of Inquiry, the abuses of the old system were described by Nassau Senior, while to Chadwick was assigned the exposition of the renedial measures, with the important exceptions of the sections dealing 1. B.J., us memorandut, n.d., c. 1833 . 
with Bastardy, Settlement, and Emigration, which were drafted by his collaborator. $(1)_{\text {Between the impatience of the politicians }}$ and the contentiousness of the Commissioners, Chadwick's scheme was bungled. He had pleaded, as we have seen, for more time, for another twelve months; but hord welbourne (under the inpression, Chadwick observed, that a few weeks were suficient to work out the principles of a revolution in the largest branch of public adrinistration) was continually sending word over to Whitehall lard that he could not understand why the Report was so delsyed. Chadwick had hoped to draft the Bill himself, but the Government, finding that they could not wait until his speculations came to birth, put the preparation in the hands of an attorney and three counsel. (2) Only parts of Chadwick's anbitious project, therefore, found their way into the Report, and were later passed into law --- notably, the machinery of the Centrs. Bourd, with its itinerant Assistant Commissioners and its powers to extend uniform regulations to $-0-$

1. 19.0. - Edward Gulson, July 1337. This is the clearest atatement we have of the respective contributions of Chadwiok and senior to the 1834 Report. Seilior later claimed thet "three-fourths of it was written by me, and all that was not written by me was re-written by me". In a letter to lord velbourne, 30 June 1334 (Senior mss), he describes Chadwick as "the principal frame of the remedial measures in the Report, and the sole author of one of the most important and difficult portions, the Union of parishes: (8. and B. Weob, "Ola Poor baw", vol. 2, p. 56).

2. C. - J. Hill Burton, 3 June 184. Chadwick had intended to make his part of the Report an exercise in Benthamite legislative method. He would have given, he said, "pirst the exemplificative matter -.- the facts and instances of the evils requiring remedy. Then the ratiocinative and expositive -... the premises to

The enactive matier or conclusions".

"I lntendod to conclude in the recise terms of the intended bill". Fraces of this intention are to be seen in the Beport, e.g. pp. $201-2$, the paragraphs in capitals. 
all parts of Kngland and Wales; the widening of the areas of local administration; and the cutring off of the mischievous forms of relief. Ghadwlok never ceased to lament the lost clauses. Unaccompanied by the supplementary preventive measures, the sow law took on harsher, more unsympathetic lineaments than he intended; the omissions, he believed, were the chief cause of the irritation which the Act of 1334 aroused, and a major share of his energy in the following years was devoted to the attempt to supply them.

One fact consoled him, as he railed against the vagaries of ministers and bewailed the maiming of his plen. A part of the regulating machinery he had devised was to be erected and set in motion. The Union would be a more effective and econonics 1 unit of administration then the parish; though he had jisgivings apout entrusting it to a comittee of amateurs instead of the paid experts he had originally sugrested, and a few years later he was calling to mind that "I by no means contemplated the gossibility of a correct administration of any law requiring constant regard to rule and principle, by annual, unskilled, and practically irresponsible, and unpaid officers, guch as are elected as guardians". (1) jore promising still was the central department, from whicb a vigorous and well-informed Commisgioner - and who nore vigoroug than the man who had dominated the por law inquiry, or better informed than the principal architect of the new system? -.- could plan to push forward the frontiers of benericent state control. Confidently Chadwick awaited his reward fron a is rateful Government.

$$
\begin{aligned}
& \text { 1. L.C. - S.G. Osborne, } 22 \text { August } 1344 . \\
& \text { 2. Ci. . - Massau senior, } 30 \text { July 134. "what I would wish } \\
& \text { should be clearly understood is, that the investigation of } \\
& \text { evils and devising of re edies is the jepartment of my } \\
& \text { service to wich chiefly and alliost exc usiveif any } \\
& \text { iaportance can be attached. I pear it may be considered } \\
& \text { that when the bill is passed the measure of legislation is } \\
& \text { carried; although in fact the means only of legislation are } \\
& \text { then carried; and the most important part of the Task } \\
& \text { remains to be commenced". }
\end{aligned}
$$


"The only individual among the candidates, perhaps I may say in the country, who could enter into the office of Commissioner with complete prearranged plans of action", Nassau Senior assured his ministerial friends, urging that Chadwick's name should be the first to be considered for one of the three vacancies. (1) A Commissionership at 22,000 a year, however, could not well be bestowed on one who had no social standing and no claims to distinction save his knowledge and ability. As Lord Althorp explained frankly to Chadwick some years later: "When the Poor Law Amendment Act passed, we, the then uinisters, felt that the bringing into operation a law which made so sweeping a change in the whole existing frame of society it was absolutely necessary that every extraneous difficulty should be smoothed as much as possible, and that therefore in the selection of the Comissioners everything should be avoided which would have a chance to raise objections. We therefore first threw overboard all party considerations. We selected a Privy Councillor opposed to us in Politics but who had been Chairman of Committees in the House of Commons on the Poor Laws and who was rightly considered as a practical man of business. We put him at the head of the Commission. We joined with him one of our under secretaries of state, and another Gentleman unknown to us personally but remarkable for having managed in a firstrate manner a considerable district under the existing Poor Laws. I believe that the care we took in making this selection contributed greatly to the favour with which the Act was first received. With respect to yourself we were so much aware of the value of your knowledge of the subject that we were very glad to have your services in the office of Secretary. I must speak Icankly, your station in Society was not such as would have made it fit that you should be appointed one of the Comissioners. We felt, at 1. Nassau Senior - Lord Melbourne, 30 June 1334 (Senior MSS ). 
least I speak for myself, that as Secretary you would have as much influence as if you were a Commissioner probably a good deal more. "(1)

Thus, it was as a secretary and a subordinate that Chadwick went to Somerset House. He saw the danger at once. Already, with those inflexible notions of his, he had crossed swords with various members of the Commission of Inquiry. In a secretary such contrariness would be unseemly. What, after a11, was a secretary? There were secretaries who were merely recording officers, whose duties did not extend beyond a little prim accountancy and letter writing; and others who, like the Secretaries of the Treasury, prepared minutes and measures for the sanction of the Board. Nassau Senior assured his incensed friend, however, that the Government intended an appointment in the larger sense, and that he would be looked upon rather as a confidential adviser than as a mere clerk with no right or opportunity of expressing an opinion. "When your name was mentioned I said that I conceived jou to be placed in the Commission rather as a fourth Commissioner than as a secretary. To which Lord Althorp assented". (2) portified by this

1. Lord Spencer (Althorp) - B. . 3 , Nay 1841. Whe letter continues: "I never contemplated that you were to hsve anything like a Veto upon the proceedings of the Commissioners. I did expect that you would influence them and you have done so. You have as you tell me prevented bad measures from being adopted and suggested good ones which have been adopted. I am bound to say therefore that your position has been and is very much what I expected and intended it ghould be. Your station however now is a very much higher one than it was when the Poor Law was passed, you are now well known to the public, no objection could now be made on the round of Rank in Society in appointing you a Comissioner, and I think that if sny Comissioner was to be appointed your claims to the office are extremely great indeed".

2. Nassau Senior - R.C., 5 iebruary 1337. C1. B.C. - Lord Spencer, 3 May 1841: "I was thanked with $r$. Senior for my services by my co-comissioners of inquiry, and only not recomended by them because .... my appointment was deemed a matter of course". The "terms" offered to chadwick by senior were, of course, not officially communicated to tie vommissioners. 
assurance, Chadwick took up his position with a very superior view of the scope of his duties. The collision of temperaments between Chadwick and the Colamissioners was aggravated by this underlying constitutional wrangle whether a secretary should be simply seen and not heard.

"A man made for the place", Lord Althorp told Chadwick with enthusiasm when he broke the news of the appointment of J.G. Shaw-luefevre. engaging manners", (2) thought Chadwick; "but about as fit to act for the poor law as a delicate firl would be to assist in performing an amputation."(3) Member of a Whig family, senior Wrangler and Fellow of Trinity, a brilliant linguist with first-hand knowledge of Europe, Shaw-Lefevre had enjoyed all the advantages of birth, education and patronage that had been denied to Chadwick. He bot on well with the Secretary, as he sot on well with everybody; but Chadwick mistrusted amiability which too easily soptened into compliance, and in his eyes social qualities did not make up for lack of special knowledge, and the stiffening that came from the conviction that one was hoding firm to right principles. "Everything was new to him; a labour-rate or a roundsman system, provided it had not a dyslogistic name attached to it". (4) At the colonial office, Chadwick heard, he had been known for his extreme timidity and vacillation, any shadow of opposition scaring bim into inaction. (5)

George Nicholls, a country banker and former Bast India captain, he regarded with more respect. Nicholls had reformed his own parish of Southwell on principles which foreshadowed. those laid down in the Poor Law Report; but his knowledje was limive to the parish and parochial machinery, and a published 1. E.C.- Lord John Russe11, $19^{-0-}$ Juce 1841.

2. E.C. A Lord Liverpool, 14 October 1341.

3. E.C., ks fragment, n.d.

4. E.C., "Notes of personal paper", Mi, n.d. probably 1347. 5. ibid. and E.C. - Lord John Russe11, 19 June 1841. 
paper of his went no further than a cautious opinion that one or two of the smaller parishes might possibly be formed into Unions. He had a sea captain's estimate of law and lawyers, Chadwick noted drily, and thought everything would go on the smoother and better the less the business had to do with any of them. (1) Barnest and humourless (attending a performance of "Don Giovanni" on one occasion, he was heard to murmur "What a shocking state of society!"), "2he had a profound and narrow faith in the "mitigated kind of necessity imposed on the working classes, by a weil regulated workhouse". (3)

With Shaw-Lefevre and Nicholls Chadwick remained on good terms, despite their differences. The guiding spirit of the Commission, however, was a voluble, positive Welshman, Thomas Frankland Lewis, for twenty two years a Tory M.P., with some experience in minor ministerial appointments, who entered Somerset House "with an express warning from Lord Melbourne against theory and speculation". (4) He was, according to Melbourne's comendation, "a pre-eminently safe and superior man of business". (5) A "safe man"! It is the phrase employed by Fenry Taylor in his Machievellian "Statesman", the distillation of long Civil Service experience, to describe the departmental head who attempts oy every mens and shift to reduce the amount of responsible business devolving upon his office; "by evading decisions wherever they can be evaded; by shifting them on other departments or authorities where by any possibility they can be shifted; by giving decisions upon superficial examinations, --- categorically, so as not to expose the superficiality in propounding the reasons; by deferring questions till, as Lord Bacon says, 'they resolve of themselves'; by undertaking nothing for the public good which 1. B.C. - J.H. Burton, 3 June $\mathbf{1 8 4 4 .}$

2. Memoir of George Nicholls by H.G. Willink, prefixed to Nichoils" "History of the Bnglish poor Law", 1893 edition, vol. I, p. Ixxii.

3. ibid, p. xiv.

4. B.C. - J.H. Burtion, 3 June 1844.

5. E.C. - Lord John Russe11, 19 June 1841. 
the public volce does not call for; by conciliating loud and energetic individuals at the expense of such public interests as are dumb or do not attract attention; by sacrificing everywhere what is feeble and obscure to what is influential and cognisable." (1) This is, of course, a composite picture, and too sharply etched to be a life-like portrait of Frankland Lewis; but it is certain that in him Chadwlck saw personified the do-nothing traditions of the old government service. How could he carry out the new ideas, demanded Chadwick, this man who was a disciple of Ricardo and Malthus, and who had drafted the report of Sturges Bourne's Committee, which proclaimed him a disbeliever in "compulsory contribution for the indigent"?

They hated and distrusted each other on sight. Chadwick, with good reason, thought it futile to expect the introduction of comprehensive institutional provision for the paupers, or any other aggressive administrative action planned to deal with the wider problems of destitution, from one who felt in his heart that these were matters with which Government should not neddle. (2) Lewis, for his part, at once showed that he intended to give no elevated status to this dangerous, unpractical visionary. There would be no unoficial fourth Commissioners while rankland Lewis ruled at Somerset House. Chadwick, sensitive to every slight, observed that "one of his first acts, for example, was to order for the private room of the Commissioners chairs of a stately sort with leather cushions and mahogany tables, and for the secretary's room common wood 1. Henry Taylor, "The Statesman", ed. H.J. Laski, p. 110. 2. Cf. Nicholls' verdict (op. cit., p.xi) : pankiand Lewis, "although possessing considerable talent and experience, was yet so much of the old school, and so averse to incur the responsibility of any forward movement, that we had great difficulty in dragging him along; and if he had been permitted to have his own way, we should, I think, have remsined almost stationary, instead of masing head as we did against the evils for the putting down of which our board was constituted". 
tables and cane botton chairs". (1)

When Chadwick expressed an opinion at the Board, it was received frigidly as though a clerk had broken in on the discussion. At one of the earliest meetings Frankland Lewis requested him to withdraw while the Comissioners deliberated. By the terms of the Act, Chadwick protested as he left, the Comissioners were bound to keep a record of their proceedings, and the proper recording officer was their secretary. (2) For a subordinate it was an arrogant claim; but it was the only ground on which Chadwiok could assert a right to be present while the Commissioners aiscussed and framed their policies; and he had no intention of surrendering without a struggle into the inactive hands of Prankland Lewis the administrative weapon which be had forged, and with which he had planned to assail so many social evils.

Prom this time onward there poured into the Government a steady stream of protests and remonstrances from the disgruntled secretary, complaints of the way in wich the Comissioners were executing the law, and claims for promotion in recognition of his superior merit and grasp of the subject. He would never have consented to give up his profession for the Civil service, he declared, if he had not been "grossly misinformed and almost imposed upon". (3) By 1837 he was looking for a mesas of escape from a position where he must every day see "the progress or the great good obetructed by the operation of narrow and selfish interests and petty animosities". (4) On the eve of the election which followed Victoria's accession he manoeuvred for a week or two for the Nalton seat, assuring a political abent that if "I were driven to choose between two extremes: between the Tories and the Radicals of the Cobbettite school; I snould certainly choose 1. E.C. - Lord spencer, 3 May $\mathbf{1 8 4 1 .}$

2. ibid.

3. L.C., "Notes of personal paper", is, a.d. probably 1847. 4. E. - Edward Gulson, July 1337. 
the Tories". (1) Iventually, however, the place was utilised for normal party purposes -- in the days when M.P.s were made by their breeches pockets, there was slender chance for a civil servant who was entirely dependent upon his salary. The extension of the Poor Law Act to Ireland in 1839 brought from him "almost a pamphlet instead of a letter" to Lord John Russe11, urging that he be sent as Fourth Comaissioner to Ireland, where a reputation as a Poor Law "purist" could hardly be grounds for objection. (2)

Meanwhile, for good or ill, the new Poor Law was now associated indissolubly in the public mind with the name of Edwin Chadwick. As he complained bitterly to Lord Spencer, while all the Ministers seemed unaware of his services, the agitators against the measure identified the Commission with himself. (3) The favourite phrase of Beaumont, the editor of the "Northern Liberator" was that Chadwick ought to be forthwith gibbeted, (4) while in some parts of Yorkshire the mob vowed their determination not to be "Chadwicked", as they termed being married under the new Registration Act. (5) It became the most hated name in England as the odium of the Poor law Bastilles increased.

"The common conclusion was that the secretary was everything and the Comissioners mere cyphers. One Board of Guardians petitioned in plain terms that the Comisaloners ight be dispensed with and the business left to be conlucted by the "talented secretary". A large proportion of the correspondence was addressed to me personally, in utier disregard of all form, and as if no such persons as Commissioners existed to be consulted. Some of the letters contsined compliments addressed to me personally. Soon after the publication of some evidence

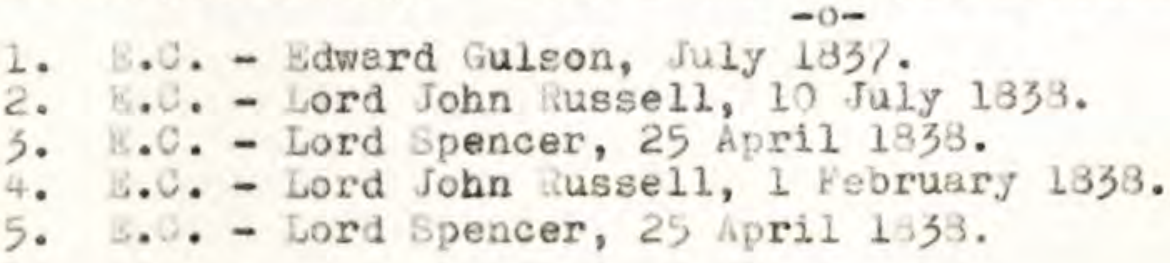


which I had collected on the subject of education, a paper was read which contained some strong praise of myself. I was not present, but it was stated to me that one of the Commissioners on the reading of an eulogistic epithet in the letter, "jumped up as if a pistol had been fired at him", turned pale, and declared that something must be done to put a siop to it. When deputations of the parish officers attended the Comissioners, they would address themselves to me. Such scenes became so difficult to avold and so unpleasant to me that I avoided attending when deputations were present. On some occasions when parties have been heard by the Commissioners, they have insistod on seeing me and stating their case to we before they quitted the office. Parties who have seen the Commissioners have, without informing me of that fact, obtained interviews with me, and in some instances different opinions. I was of late compelled to avold giving interviews to avoid diacrepancies and not being willing to explain why I avolded I have unavoidably given offence to the parties ...." (1)

Such incidents did nothing to lessen the tension between Chadwick and the Comaissioners; and while they imputed to him insubordination, an overbearing ambition, and a rigidity of outlook that no experience could soften, he saw in every departure fron the line he had marked out in the for Law Report jealousy of the Secretary, whose inferior position was a constant reproach to them, and a determination to cripple the measure which was his ereation. (2)

1. "If it had been contrived to blind the judgatent of those appointed to administer the law, and make them hate, evade, alter or destroy it, how betten could it have been done than by rousing their seli-love, excitiog powerfuily their jealousy by placing in op osition to them one who having devised it, was personaliy and indissolubly identified with it, and placing him in such a position as to be a perpetual reproach to them? To admit the law to be above them or their conception was to admit him to be in justice above (Concinued on next page) 
"Seeing the deep hold that such feelings had got, that nothing which I could propose would be adopted for fear it should be its success increase this reproach or thraldom, I was compelled to disguise as much as possible the suggestions which it was requisite in the pressing exigencies of business to make. In this view I bestowed additional care on the private instruction and suggestion to the Assistant Comissioners and founded as much suggestion as I could upon their Reports. On one occasion when I had given some suggestions as to regulations to a young Assistant Commissioner on a subject referred to him, and when he brought them forward and read them at the Board, there was a brightening of countenances, and strong and immediate praise to him for the ability of the suggestion. when he unwittingly and ingeruously declared that the praise was not due to him but to the Secretary sitting at the bottom of the table, there was such a change in the expression of the countenances to sour blank, and the scene was so ludicrous that I could scarcely refrain from laughing outright...."

"On one occasion a Commissioner, as it was reported to me, came from a conference with the linister, bright with an important suggestion which the winister had made; it was that the Owners of Mines or Manufactories should be charged with the consequences of accidents of maiming or death, which usually fell upon the Poor's Rates, in expences of sickness or widowhood or orphange. The comissioner was dilating with

(Continued from previous page) them, and that they were unworthy of their position. But as it was impracticable to sink the measure in order to sins the person, they had a strong motive which was soon displayed, to make alterations and improvenents or qualifications as large as possible, for a capacity to improve or qualify would seem to the publio and themselves to justify superiority of position". B.C., "Notes of personal paper", MS, n.d. probably 1847.

1. ibid. 
admiration at the policy of the suggestion, when Mr. Coode to whom it was communicated with the view to the preparation of clauses, incautiously stated that the suggestion was a favourite 1 dea of mine, which I had advanced as one of the Factory Comissioners. On this unfortunate announcement there was an immediate change of countenance and view of the whole matter, and it was no more heard of. What, or whether any grave practical difficulties were found in its way and told to the Ninister, I have no means of knowing, but a favorable opportunity was lost of advancing the discussion, if not the adoption of the most important principle, which has been recently fully recognised in an able Report of the Committee of Inquiry on the condition of Railway Labourers and partially adopted by the legislature in the Accidents Compensation Act brought forward by Lord Campbell (1)

Meawhile, Chadwick found it hard to credit that so excellent a law was as unpopular as the "ilmes" and the agitators made out. How could the charce of harshness be maintained? Were not wages highest and the condition of the workers most improved where the measure had been most fully carried out, and depression greatest and discontent most widespread where the rates were heaviest and least had been done to abolish the old practices? It was true that disturbing incidents found their way into the newspapess, and some Assistant Comissioners had had slaraiag experiences. Power had been purgued by wild persons dent upon assassinating hin, and had three times been assaulted with serious intent; a party of ruffians bad fallen upon a person they mistook for Stevens, and had Practured his skull, so that it was doubtiul whether he would recover; Edmund Bead bad been shot at, and Gulson and Gilbert had been driven from towns by turnituous mubs. These incidents had been carefully concealed, Chadwick - -

1. E.C., "Notes of personal paper", N5, n.d. probably 1347. 
told Lord John Russell, lest they "incite insane vinds to initation" and even "give a most false impresaion of the unpopularity of the measure". (1) On the other hand, Francis Place, with his close and friendly contacts with the lower classes, wrote to urge Chadwick to greater efforts against lax Guardians. "ray lay your precious paw, in your quiet, smooth way upon them, and compel them to adopt the Workhouse; and do it perfectly --- never mind their howling -.. the more they howl the more you must squeeze them, make them take into the hore all the pauper's family -.- Pather, Mobher, and sue -.don' tlet them take some in and leave some out, and then, but not till then, will the matter approximate even, to what is wholesome".(2)

Complete satisfaction with the Act and - only thinly disguised -.. with himself as the author of it, runs through Chadwick's survey in the "Edinburgh Review" for July 1836 of the first eighteen months' working of the Poor Lam Comission. (3) In the southern districts paupers had been thrown off the rates in droves, and the "surplus" labour had been absorbed as he had predicted; in twenty two counties, comprising 137 Tnions, the expenditure on relief had fallen by $43 \%$ per cent.; on the Boards of Cuardians the chlef occupiers and landowners, yoomancy, gentry, even nobility, were meeting and acting. together for public purposes for the first time in history.

1. E.C. - Lord John Russe11, $1^{-0-}$ Eebruãy 1833. Chadwick hingelf had no fears, as he reveals in a lecter to Lord Normanby in 1841: "Regarding the apprehensions of my personal unpopularity I may state that when I have visited the danufacturing Districts apprehensions have been expressed for my personal safety. But I have gone amongst the working classes; have visited manufactories and gone into the worst seighbourhoods; have been waited on by leaders of the working men who wished to consult me. Hilst staying in Manchester a leader of the Fand ioon exvers applied to me stating that hearing I was in town a deputation was desirous of consul.ting me as a favour on matters unconnected with Poor laws as they colld depend upon me for telling them the truth".

2. Place - ., 21 April 1835.

3. "Ldinburgh Review", July 1336, vol.LXIII, pp. 437 - 537. 
In the winter of 1836, howover, the Comsissioners turned their attention to the industrial districts, and Chadwick's complacency was blown upon by a bleak wind of failure and host1lity from the north. Bad harvests, severe winters, influenza, extensive unemployment in the textile industry, the resistance of the working classes (already organised against the pactory $/$ ct), all combined to rout the Poor Law Comisioners. It had been a serious error in tactics, Chadwick believed, to deal with the southern counties first; the new systew should have been introduced into the northern towns in the first year, while trade was still good and the agitators were otherwise encaged. (1) But not the slightest doubt entered his mind that if the workhouse test bad been introduced before depression hit the industrial workers, and if it had been administered with rigid honesty and efriciency, it would have taken the strain of any burden likely to be cast upon it, and would have withstood even the impact of extensive and prolonged unemployment.

Thus, it was to the administrative weaknessea of the Comission and the local authorities that Chadnick pointed in explanation of the swelling figures for poor rellet. The rates were still collected and dispensed by annually elected, unskilled, snd unpaid soards, "by saall sbopkeepers in the towns who dole out out-door relief to be spent at tueir av shops: by the owners of small tenements who pay their own exorbitant rents in the shape of out-door relief: by farme:s who as Cuardians in the rural districts still under the cover of exceptions to the pronloltory order pay relief in aid of wages to men with families". (2) Buch Boar s were no better than the parish "jobocracies" condemed in the 1334 sport.

Worst blunder of all, in chadwick's view, had been to - 0 -

1. E. - Lord iormanbJ, ? May 1841 .

2. B.C. - S.G. Oaborne, 22 August 1844. 
appoint Comissioners who were half-hearted at best in their adherence to the principles of the Act, and who shaped their policy with a fearful eye on the "limes" and the agitators. Had not Frankland Lewis declared that in his opinion the pure workhouse system was imoracticable in the existing circumstances, though it might be introduced in fifty jears' time? (1) Yrankland lewis had since retired, but his spirit continued to rule in Somerset House, for he was succeeded by his son, George Cornewall. Lewis, who inherited his father's feud. As strong-willed as his father, G.C. Sewis possessed considerably more ability. Over-weighted with emadition, gifted with something of hacaulay's reach of memory but none of his brilliance of style, he was a dry, patient accumulator of facts, from whish by the most exhaustive intellectual processes he pressed out the most common-place of conclusions. (2) He was, says Bagehot, "too prosaic 3 too anxiously safe, too suspicious of everything showy"; but on these qualities he had built up a reputation with the whigs as a practical man of business with aims and motives which any other practical men of business could readily comprehend. Unemotional himself, and distrusteul of feeling in others, he could not understand Ghadwick's Plerce enthusissns; and he turned a cold eye on Chadwick's theories of government action. "The relation betwean himself and the secretary was thatof an ill-assorted marriage of a catholic husband and a protestant wife; the wife somewhat the cleverer of the two, but with no pivilege beyond the use of her tongue". (4)

1. E.C. - Lord Jobn Russell, $7^{-0-}$ Sarch 1340.

2. Reviewing his "Essay on the Influence of Authority in latierg of "pinion", a critic sumed it up as a demonstration that when "you wanted to know anything, you asked someone who knew something about it". (W. Bagehot, "Biographical Altudies", i381, p. 233).

5. ibid, p. 207 . Putronage of Comissions"; "Nestminster Review", October 1846, vol. xvi, p. 229. It is unlikely that this article is by Chadwicis himself, as the Nebbs suggest; it is almost cozvainiy of another hand (pernaps ".... Hickson, proprietor and editor of the "westininter", 1840-1852), working on material supplied by Chadwick. 
So for a dozen years the conflict of wills went on at Somerset House. Chadwick was "unsafe" and "unpractical", the Lewises told their Whig Priends, he wanted to "go too fast" (1), and his proposals we inhuman in their severity. (2) The Commissioners were pusillanimous, retorted Chadwick, they flinched before the thunder of the "Times", they countenanced practices which were flatly opposed to the principles of 1834 , they enployed office methods which were arbitrary and inefficient and, in fact, 1llegal. Over the question of out-door rellef to the able-bodied Chadwick fought innumerable skirmishes and four major battles. In 1835 Shaw-Lefevre advised the

1. "Letter of Edwin Chadwick, $\mathrm{Bsq}$., in vindication of his conduct to the Right Hon. Sir George Grey", 21 June 1847. In answer to the charge of precipitancy, Chadwick observes: "The principle of the change whlch I particularly recommended and, I believe, I alone advocated, was of applying the rules prospectively to new cases and of iiving full, not partial, outdoor relief to the aged or making littie alteration in their cases, except for improvement, and of proceeding wherever it was practicable with alterations singly and separately and gradually, instead of alterations at once with large classes. I advocated as an invariable condition that local inquiries should precede every local application of any important genersl order, and that it should be introduced with such modifications as the local inquiry should prove to be requisite".

2. ibid. Chadwick continues: "To sustain the charge of harshness, an order was adduced before the Committee called the Consolidated Order which two of the Comnissionerg had adopted, which provided for taking, not exceptional cases not temporary cases nor cases of emergency, but the whole of the regular outdoor cases into the workhouse. Now, where and under what circumstances was this order applied? To overcrowded Town Districts, in one of the least ill conditioned of which, out of 1485 families, 929 had only one room and 623 only one Bed for the whole fraily; and in another and by no means the worst conditioned District 382 farilies and 56 single persons had only single rooms, whilst 159 families and 156 single persons occupied, each family, only parts of one room. To those whose impressions of the abodes of the poorer classes in Town Districts or in any others are chiefly derived from Cabinet paintings, which misinform the eye and give no information to the sense of smell, agreeable scenes will be presented of cleanly inmates and cottage comforts, and indoor relief may sound harsh; but let them explore these abodes at times (Continued on next page) 
Guardians of Colne to hire out their paupers to local farmers. The Guardians refused to revive the discredited labour-rate, and Chadwick, with the backing of Nassau Senior, successfully upheld their protest in a letter to Lord Lansdowne, Lord President of the Council. (1) Two years, later the Comissioners proposed to sanction in a General Order outdoor relief to labourers who were reduced to distress by the burden of a large family; Lord John Russell concurred with Chadwick's arfument that the practice was contrary to the intentions of the Act, and there was an unpleasant scene at the Board, Nicholls huffily declaring that he would not consent to work with Chadwick if his views were so opposed. (2) In 1840 they proposed to give statutory force to the various classes of exceptions which had been permitted to their General Order prohibiting outdoor rellef. Forwarding to Lord John Russell a lengthy printed memorandum on the subject, Chadwick assured him that the opinions he was likely to receive from the

Comissioners would be fashioned by what they thought most

(Continued from previous page) when the whole farily is at home, let them see and smell those places and they will concur in the humanity of the General Order for such Districts, as a general order for the relief of the Inmates of every room from which the objects relieved is taken. It was an order in respect of the aged or sick to remove them from a place of filth and personal discomfort -.- fr m bad food taken in unwholesome places -- from bad attendants (for none can be good there) to cleanly and comparatively well ventilated places supplied with water and means of personal

cleanliness, clean linen, wholesome food regularly prepared, with appliances of nurses and medical attendance and a state of things where the health (where any remains) is usually fast improved and life prolonged. Medical officers vindicate the rule on sanatory grounds as well as on grounds of common humanity ...."

I. "Notes of Objections to the proposed measure of recomending to parishes, having unemployed able-bodied paupers, to hire their labour to farners to dig or fork the farmers" land at ploughing prices", WS, n.d.

2. B.C. - Lord Liverpool, 18 October 1841. 
acceptable to him. "If you express a confident opinion in favour of the principle of stopping out door relief in new cases and following out the successful examples and an expectation of exertions and prosress in that direction the expression of that opinion will dissipate impracticabilities and if nothing be done in parliament I have very little doubt that within a year some hundreds of thousands of pounds will be saved and some thousands of families preserved from Pauperism by a clear opinion that that which has been done gradually and pesceably in some places ought to be equally well done in others". (1)

In 1841 matters came to a head. In June of that jear Shaw-Lefevre went to the Board of Trade, and Chadwick promptly asserted his claim to the vacant Commissionership. The new law was in jeopardy, Lord Spencer told him bluntly, and to avoid disaster someone must be appointed who would give the most general satisfaction to the public --- and "from what I collected of the opinions of well informed and judging men when I was in town I should fear your receiving the appointment would $-0-$

1. Chadwick's objections on this occasion are worthy of particular note. In effect, he told Russell, the suggested clause would narrow the discretionary powers of the Commission, and in place of an order or regulation, which could be altered at once to meet the circumstances of different cases, would substitute a statutory provision which must undergo the rigid interpretation of a Court of Law. The power of supervision would thus be transferred from an administrative body, which was fully informed of the public policy of the law, to Judges, who were not possessed of such information and never could be. In the past judicial decigions on the poor laws had invariably been in opposition to the best intentions of the legislature. Fhey could hardly be otherwise; for the opinions of the Judges were governed chiefly by the single case before them (which was irequently an exception), whilst the only safe decisions in this pield were "on large classes of cases, and on general and often renote effects, which cannot be brought to the knowledge of the Judges". (Memorandum, printed, forwarded to Lord John Russell under cover of E.C. - kussell, 7 March 1840). 
not be satisfactory to the public generally".

(1) The post was therefore bestowed on another of the Whigs' bright young men, Edmund Head; he was, in Chadwick's judgment, the least effieient of the Assistant Commissioners, "college friend and companion". (3) The mounting bitterness of the previous seven years was crowned by the preferment of Edmund Head; and about the same time occurred a further clash over outdoor relief. Inquiries, one by the Assistant Commissioners, Mott and Gilbert, a second by Chadwick himself, had uncovered deep-rooted abuses at Bolton and Macclesfield, relaxed discipline in the workhouse, the grant of relief in aid of wages, and subventions in payment of rents. Neither report admitted to any doubt that the workhouse system could cope with the slow agony of the handloom weavers, on their way to the industrial scrap heap, who even in 1834, when bread was cheap, had been described as enduring "sufferings scarcely to be credited or conceived". (4)

1. Lord Spencer - E.C., 13 June 1841.

2. B.C. - Iord John Russe1l, 19 June 1841. Chadwick complained to Russell that more petitions eriticising the actions of Assistant Commissioners had been received from sdmund

Head's district than from any other; it exhibited a large share of relapsed Unions, discontent, badly formed unions, and badly appointed officers. Moreover, Head was known to hold the view that a compulsory system of relief was unnecessary. Chadwick suggested that the same care should be taken in ascertaining the qualifications and opinions of tommigsioners as he himself employed in selecting Assistant Commissioners.

3. B.C. - ?, 13 Uctober 1841 .

4. Cf. Charies Nott - I. ., 14 July 1841: "I have given the officers strict instructions as to the enquiries to be made and I have no doubt but most of them will be found to be in receipt of sufficlent to keep them well .... It will turn out I have no doubt as all previous representations of the kind have that the difficulties of which they complain arise from their own want of care and economy". Mott's "got up" report aroused the indignation of Bdmund Ashworth, the cotton manufacturer of Turton, near Bolton. "Mhen we who live amongst it, see a thousand families, (which we are about to enumerate) brought to poverty by mere want of employment, the poor rates doubled, and parties asking relief or pining in want, who bever asked relief before, we (Continued on next page) 
When Chadwick presented his report to G.C. Lewis, "it was received in such a manner that I should not myself again prefer complaints of the same kind". (1) One Commissioner told Chadwick that "he did not believe the allowance system could be put an end to". (2) He persuaded a Iriendly Tory (Lord Radnor) to ask in the House of Lords for the reports to be produced, but with the end of the session G.C. Lewis managed to shelve the matter, and the reports remained unpublished until they appeared as appendices to the Report on the Andover inquiry in 1346. Chadwick's disgust at the suppression was shared by some, perhaps the majority, of the Assistant Commissioners, a number of whom had seen similar representations received with coldness by their superiors. "That is the feeling in the office", Chadwick told the Andover Committee, "that representations of that sort, importing an obligation to act, are distasteful, and not well received". (3)

The "illegality" of the Comissioners, Chadwick decided, could no longer be tolerated; and be determined on the extraordinary expedient of drafting a "case", in full legal form, against their office methods, which he insisted on laying before the Law fficers of the Crown. Perhaps nothing has contributed more to the unsympathetic portrait of chadwick, rigid in mind, humourless in argument, not a little ridiculous in his self-importance, than this astounding step. Yet his "case" contains a reat deal of hard common sense, a sure grasp (Continued from previous page) cannot stand silently by, or stamp them all as impostors. I wish we could. It then becomes our duty to call the attention of the authorities to these facts .... We are getting worse every day and there will be a loud clamour before the winter is over, if not some outbreak: the patient endurance of the people hitherto is beyond belief, and deserving of all praise". (Edmund Ashworth - E.C., 11 Deceaber 1841).

1. Heport of House of Commons Comittee on Andover Union, August 1846. Chadwick's first examination, Q.19057.

2. ibid, 4. 19065.

3. ibid., 2.19129. 
of certain fundamental principles of office management, and sound insight into the relations of confidence which must be established between a central department and local authorities --- the whole overlaid by legal pedantry and the personalities of which he could never divest his remonstrances. The pecullar merit of adininistration by a central Board, Chadwick contended, lay in the preparation after careful deliberation of resolutions or minutes, which might be circulated for the guldance of local authorities. That advantage was lost by the mode of business introduced by Frankland Lewis, and continued after h1s resignation. The Commissioners, having alvided the country Into three provinces, sat in separate rooms, each dealing with the correspondence of the Unions assigned to $\mathrm{him}$. This is the "sicilful combination of individual and collegiate activity", commended by the Webbs, Which Frankland Lewis defended as the only way to cope with the flood of letters and reports which poured daily into Somerset House. Frankland Lewis did not admit, however, and the Webbs apparently were not aware, of the difficulties to which this arrangement led, and of the advantages of the alternative methods suggested by Chadwick. Three separate establishments of clerks had to be maintained, with varying amounts of business. Letters went out as passed by a Board when none had been held. The tracing of precedents was obstructed. The Commissioners differed in their manner of dealing with the same class of subjects; in their attitude to relief orders, for example, "one Commissioner was fair, another lax, another still more lax"; and Frankland Lewis took nearly twice as long as the other two in the despatch of his correspondence. It was the verdict of James coode, the Assistant Secretary, who after 1839 bandled the bulk of the routine business, that if the Clerk to a Board of Guardians could not keep better minutes than the foor Law Commissioners he would be dismissed. "You should not make the plaister 1. S. add B. Webb, "Old poor taw", vol. 2, . 110. 
larger than the sore" was Frankland Lewis's favourite aphorism, and in his opinion answers to correspondence should be confined to the expression of a dictum applicable only to the particular case. This was directly opposed to Chadwick's view that, instead of short routine replies, well prepared expositions of general principles should be made for each class of case, so that the secretary could then refer correspondents to the minutes of the Commission for information. A Central Board, as be told the Highway Committee in 1833, should be a "reservoir of information", acting on the understanding of local authorities, not browbeating them by lts inere authority. It was essential that there should be an unceasing flow of facts and observations from the localities to the central department, where they $\mathrm{might}$ be digested and put in a form suitable for tbe instruction of local oficisls. "It appeared to me to be the best mode of making authority respectable and respected and obeyed, the obedience being less to individuals or to the mere office and authoritative position, than to the information - o obedience or co-operation rather obtained on the conviction which experience should justify, that the central authority had wade more full and complete collection of the facts and more thoroughly investigated them than any single individuals could or would do".(1)

$$
-0-
$$

1. Chadwick's case against the office methods of the Comissioners is argued in detall in a "Letter to the Right Honourable Sir George Grey, Bart., Her Majesty's Principal Secretary of state for the Home department, on the transaction of the business of the por Law Commission, and on the popular means of exercising a central control", Mis, n.d. 1847.

His main proposal was that only the emergent correspondence should be dealt with on the first day; by deferring the remainder to the second day, he urged, time would be given to search forffomer correspondence on the same subject and prepare suggested answers. The papers would thus be brought berore the Board in a prepared state, after passing through a selective filter of clerks and assistant secretaries who would have reduced its bulk by removing the purely routine matter. But the Comissioners 
One of the Law officers upheld his contention that each instance of separate action by the Commissioners was indictable; some minor changes were made in the conduct of business to meet his criticisms; but the chief result of his protest was that even his infrequent attendances on the netings of his chiefs came to an abrupt end. He thought seriously for a time of

(Continued from previous page) insisted on dealing with even the routine and interlocutory correspondence, and in consequence as they were pressed for time, the tone of their replies became curt and harsh, instead of full and explanatory. And, on the other hand, some matters which were not routine, and should have received the collective attention of a Board -- such as workhouse regulations, instructions to Assistant Cominisioners, and the sale of parish property -- were also conducted by individual Commissioners in their separate rooms. The plan for hiring out pauper labourers in 1835 had been sactioned by a separate letter (by ShawLefevre); and Chadwick maintained that the dismissals of Day and Parker, with all the accompanying scandal, would have been avoided if the Commissioners had taken their decision at a Board meeting and stated in the minutes their publicly defensible reasons for the step.

As an example of the advantages to be derived from the "information-elicitative" and "information-distributive" functions of the central department, he quotes the order for the execution of the Vaccination Act in 1340. "At Pirst the local authorities received the charge as a new Tax and prepared to resist the measure but the instructional letter which I drew up after a laborious consultation of the medical authorities in Scotland as well as in kngland had as I was assured the effect of removing objections and producing extensive voluntary co-operation".

The failure of the Commissioners to enlist such vcluntary co-operation, a failure which he alleged was largely due to their business methods, is the chief burien of his complaint -.. as the title of his "Letter to Sir George Grey" illusirates. "Although I have contended that It was ecessary to lavest the central soard with strong powers yet I have always considered that those powers were only to be used in vehalf of the public in cases of absolute necessity and then used firmly and responsibly. In this view, I objected from the first to the power of maxing orders being delebaced to Assistant comissioners and urged that they should bo compelled to act by sugsestion or persuasion rather than by Order ...." 
accepting an offer from Lord Nornanby to place him in some other Government department -..- as counsel to the Home oifice he could supervise the execution of two other measures he had Pathered, the Factory Act and the County Constabulary Act, and so "obviate the necessity of appointing two if not three chief Inspectors". (1) Since 1339, however, be had been engaged on the sanitary inquiry, and he was beginning to realise that it was the bigsest and most important of his career. He stayed to see it through.

It is fortunate for Chadwick that his reputation does not rest entirely upon this chapter of his career. Had he been in charge at Somerset House Irom 1836 to 1341, that unquestioning confidence of his in the possibility, even the expediency, of cutting off all forms of outdoor relief to the able-bodied might well have orought the whole foor haw edifice crashing about his ears, night perhaps, in the northern towns, have ushered in the Warxist Apocalypse that Engels was prophesying in 1345. The "supineness" of the Comissioners was a policy of caution which averted that danger, their "flinching" sprang from a prudent recognition that the root-and-branch avolition of outdoor relief was inpracticable in the economic circumstances of the time. One unexamined theoretical assumption and one large practical miscalculation had between them made nonsense of Chadwick's foor Law scheme. The assumption was Chadwick's excessive faith in the elasticity of the economic system, and in its capacity to absorb the impact not merely of casual day-to-day unemployment, out even of the "hard core" unemployment which emerges when an industry goes into decline, and of the recurrent mass unemployment which is due to fluctuations in urade and is the heaviest burden of all. Believing that the demand for lavour aight shift but did not fall away in total sum, he seriously overmestimated the lacility with which a labourer thrown out of work in one trade could find 1. E.C. - Lord Normanby, 12 May and 18 june 1841. 
alternative occupation in another. The rest followed logically. If there are jobs for all, then the able-bodied nan who is without one for any length of time must be either unwilling to worik or of such a character that no employer would engage him. In short, he was likely to be a bad lot: an idler, a wastrel, a trickster, an inefficient workor, or a black-listed Trade Unionist. To submit him to the discipline and frugal diet of the worichouse was as much in his own inforests as in those of the community at large. Only by those reformatory influences could his moral pibre be sufficiently strengthened to support the strain of independent existence; only so could the honest labourer be spared the demoralising spectacle of a man who had not worked enjoying the luxuries of white bread, strong ale, and meat every day of the week.

For one whose boast it was that his proposals were based unshakeably on the facts, Chadwick showed a peculiar insensitivity to the evidence when he visisted Bolton and Macclesileld in 1840; and for one who claimed to trace back pauperiam to ltg roots, he remained singularly lncurious about the extent and nature of the various types of unemployment. While his theory was thus insecurely erected on an assumption as uncitical as any made by the "hypothesists" he so despised, his practical recommendations were also vitiated from the start by a fundamental miscalculation --. that, having read his reports, the Government would be stimulated with something of his vision and his entrusiasm for large adninistrative schemes. Where were the teachers, the aurses, the asylum attendants, and all the other specialists demanded by the policy of "aggregate in order to segregate"? To find and train them, and to establish and equip the various residential institutions for instructing the young, tending the old, and curing the sick, made a cail upon the resources and the active good-will of the Government for which there was no precedent. Neither the Poor Law Commissioners aor the Whib winisters had any heart for so 
ambitious a programe. They chose instead to do as little as they dared and as cheaply as they could. On the grounds of economy and siaplicity, they created a hermaphrodite administrative monster, uniting in a single body one institution whose purpose was deterrence, with another institution, or series of institutions, whose professed objects were treatment and instruction. In so doing they made it impossible to divide the "involuntary" sheep from the "voluntary" goabs; all alike, the aged and infirm, the orphans, the widows, the vagrant3, the able-bodied unemployed, bore the same stigan and were subjected to the same discipline.

In justice to Chadwick, therefore, it is essential to realise that his dispute with the Commissioners over their policy of indulgence -- a dispute in which his errors of judgment and obtuseness of feeling reveal him in the worst possible light -- was only one aspect of a wider conflict of principle. The Webbs have made it their major criticism of the Poor Law Commissioners that they did not view pauperism in the context of destitution, and therefore neflected the causes which led to the perpetual recruitment of the pauper host. (1) This criticism, valid as it is against the Commissioners, cannot be levelled with anything like the same force against their Secretary. For, as we have seen, Chadwick in 1834 was already elaborating measures designed to cut at the roots of pauperism. He never believed, with Franikland Lewis, that pauperism was part of a divine or astural ordering of society, and that -.as the Nialthusian revelation ran -.- great numbers of aanind were doomed to live on the margins of misery, only relieved by the casual charity of their betters. To the faith in "God" or "Nature", which issued in a policy of administrative inertia (Meloourne's "letting things shake right") and a conplacent acceptance of things as they are, Chadwick opposed a falth in government as a contrivance of the human will, which might be 1. S. and B. Webb, "OlA Poor Iew", vol. 2, pp. $33-34$. 
used acsressively to minimise the volume of pain and maximise the volume of pleasure. Blinkered as his inteliigence was, Ilmited as be was in the range of his sympathies, inept as he showed himself in the calculation of political expediencies, he was yet one of the very few men in the departments of State of the time, whether as permanent official or political head, who held firmig to the belief that it was the essential business of government to take thought for the welfare of the people ... and, having thought, to act.

As he told S1s George Grey in 1847, he had from the first urged the segregation for specialised institutional treatment of the various classes of paupers, the sick, the blind, the idiots, the Iunatics. But "I could not but regard then as being for the most (part) collections of sores which the best treatment after all could not cure or do more than alleviate."

"The contenplation of these wrecks of humanity continualiy forced upon me the consideration whether nothing effectual could be wrought out for prevention. At every opportunity, I have made exertions to explore the various concributory sources or causes of Pauperisa and the practicable means of prevention, and although persons who have no information on the suoject may imagine on the suggestion of an iaquiry iato "causes" that it was a course or inquiry into original Causes -.- something very remote abstract and iapracticable, it was not so. It was frequently only necessary to go a few links or a few steps back beyond the range of popular discussion and legislation, when we are brought upon causes which upon due investigation are found to be preventible and generally with large pecuniary ecotiony."

With the most notable of these inquiries, the sanitary investigation, we shall doal at length. But there were others, some fruitful, some - - through lack of time, lack of means, and 
the scepticisu of the Commissioners -.- abortive. He had asked himself, for exsmple, how far the traditionel intemperance of army and navy penslonens was due to the practice of paying them quarterly, and, by thus elushing them with unaccustomed wealth, fiving them at once the excuse and the means for celebration. His report on the comection between drunkenness and nodes of pay was set aside by the conmissioners, without reason being given; but he observed with satisfaction that the Governont subsequently decided to pay pensioners at monthly intervals and keep them under inspection. In 1346, despairing of jetting the Comissioners interested, he misde a private investigation into the condition of railmay labcurers: "the sane inquiry and preceding inquiries into cases of chargeability from accidental maiming and of Widowhood and Orphanage from fatal accidents in Mining, Menufacturing and engineering operations led to the development of the principle of making all branches of Industry chargeable with the attendant consequences as the most efficient preventive principle; --preventive of the accidents themselves as well as preventive of the chargeability upon the rates".

"In 1840 I collected vidence as to the difierent value of trained and educated as compared with untrained and uneducated aricnen to shew the consequesces of want of training and education as causes and the imortance of attention to them, as preventives of disorder and destitution.

I had occasion to observe that there were soine persons of peculiarly susceptible mertal constitutions who wight be placed under circumstances to produce Insasity (as we know that there are persons of certain bodily couditions that laay be placed under circumatances to catch fever). I had heard of antecedents to larger proportions of Idiolcy thongst the population of some Districts than others. About 1839 I. proposed that a special. inquiry should be made into the pauper ilinacy and Iulotey not only with the view to the separation and removal of the cases from 
the Union houses and to an improved curative treatment but with the view to more care?ul investigation of coranon antecedents or causes than had yet taken place and for the dissenination of public information and warnings as to the causes which aight appear to be removeable. I had prepared one Assistant Comissioner for such an inquiry but the proposal was not recelved or acted upon at the time and I was unable to press 1.t". (1)

for six wore years after his revolt in 1341 Chadwick rewalned at Somerset Fouse in this anomslous position, not strong enough to overthrom the Comissionexs, too powerful to be dismissed by them. "Your diferences with hr. Lewis were so notorious in the office", comented d. F. Iurnell, one of the Assistant Comissioners, "that I remember oace cuentioing to S. Coode that I wondered why you were not disuissed or could stay at gour post. His reply was, that though you did next to nothing as Poor Law Secretary, that you were so useful to the Government in conducting the sanitary iaquiry and other matters, that you fully earned your salary, and were one of the hardest worked public servants he ever knew". (2) thus, one good result emerged from that unbappy tangie of crobsed wills ...ne was left very much to himself to work out the principles of his preventive administration. "The Comaisgion is thought to be the enemy of the poor", wrote a friendly clergyman, "But when in the History of our country have such researches been carried on for their benefit, or how aanj jesrs, perhaps centuries, wight have elapsed before it would otkerwise have been attempted?". (3) It was fortunate indeed for the public health movement that chadwick iid not make his escape in the sumner of 1841 .

1. "Letter of Edwin Chadwick, Bsq., in vindication of his conduct to the kight Aonourable sir leorge ure.", 21 June 1847.

2. E.C. TufnelI - Z.C., n.d., 1347.

3. Rev. Whitwell Elvia' (of Bath; Later editor of the "Edinourgh Review") - B.C., 15 January 1342. 
CHAPIBR 3.

\section{THE "SANITARY IDEA".}

Canning once observed that there was nothing he so much dreaded as facts and figures; repeating this to Lord Brougham, Chadwick added that in truth there was nothing which ought to have been dreaded more than such figures as were then available -- "wretchedly imperfect figures, giving only half facts, leading to wrong or wild conclusions". (1) At the turn of the century there had been keen debate whether the population of England was increasing or decreasing, and elaborate theories about the future of society had been spun with vast ingenuity from the few known facts. Error and bias were inevitable where judgment and not measurement was the guide. Fear of Roman Catholics wes enhanced because their exact strength was unknown; jealousy of cheap Irish labour increased because its proportions were not clearly seen; and -- to quote one of Chadwick's favourite examples -- the pessimistic school of social moralists were encouraged in their gloom by Patrick Colquhoun's fantastic estinate that there were 50,000 prostitutes in the capital, which meant one for every three or four males in the London of his day. (2) "Political Arithmetic" was making a slow progress, however, triming the outlines of fluffy generalisations, replacing crude guess-work by verifiable information, defining the lineaments of society every year in

L. E.C. - Lord Brougham, 28 February 1356.

2. "First Report of Commissioners appointed to inquire as to the best means of establishing an efficient Constabulary Force in the counties of England and Nales", 1839, p. 15. Even in 1844 Southwood Smith could write to Chadwick: "It is notorious that during the last year fever has been ravaging many localities in the provinces and in the large towns, but no one can form any conjecture as to the real extent of the evil, though this is a matter which the public and the legislature have a deep interest in knowing". (19) January 1844). 
sharper outline. Pinlaison had taken the first Engligh census in 1801 (fifty jears before the ldea had been rejected by Parliament as an infringement of the liberty of the subject, and as likely to lead to some public misfortune or epidemical disorder); actuaries, worried over the validity of their life tables on which the solvency of the insurance companies depended, had begun to work out the theory of vital statistics; in 1832 the Board of Trade had set up a Statistical Department, introducing an outside expert, G.i. Porter, to superintend it; in 1833 the Statistical section of the British Association had been established, to be followed promptly by the foundation of Statistical Societies in London, Manchester, and Bristol. Hore and more the appeal to facts and figures strengthened the hand of the reformers. John Howard, touring the gaols in 1774, had been the first to use the statistical method as an instrument to diagnose the character and assess the gravity of social disease. John Rickman's census of 1831, showing the population and wealth of the manufacturing districts, had its influence on the Reform $B i l l$ debates.

In this development, which before the century was out was to make the central departments vast machines for the ranufacture of blue books, Chadwick played a decisive part. He possessed no mathematical ability, and the subleties of statistical theory were beyond him, (2) but he realised that the 1. J. Rickman - B.C., 5 June 1340 . Rickman's "Statement of Progress", 31 Dec. 1831, showing the comparative populations of every place in Great Britain, was, he says, put in the hands of every M.P. before the Reform Bill debates, "which were mainly founded on this my Volume of 417 pages".

2. He told the Association of Sanitary Inspectors in August 1838 that among the poor in 3righton the deaths of children under five years of age formed 35.17 per cent. of the total deaths, while among the rich they were only 3.9 per cent. "Any conclusion from such premises as to the relative healthiness of the two classes would be misleading. The larger number of children among the poor implies a larger population exposed to children's ailments, and consequently a larger number of deaths under 5 years of age as compared with the total deaths, apart aliogether from any difference in sanitary conditions". (Newsholme, "vital statistics,p.112). 
first step towards controlling social evils was to measure them. Finding his advance everywhere blocked by entrenched interests, he soon perceived the blasting power of fact. His lirst work of note, the essay on "Life Assurances" in the "Westminster Review" (1828), was an exposure of the misleading picture of social conditions presented by the out-of-date life tables of the Insurance Companies, and a plea for Government action to institute a complete registration of births, marriages, and deaths, the "first stages of the process of forming a legitimate theory" being"diligent investigation and the sagacious comparison of a variety of phenomena". (1)

Bight years later the Whig Government introduced a Registration $B i 11$, intended primarily as a measure for the relief of Nonconformists from that remnant of Anglican privilege, the Church registration of births, marriages, and deaths. Chadwick seized upon the Government's pathetic little measure, which lacked any scientific attributes, either medical or economic, and gave it a new power and a new direction. He obtained the provision that besides the fact of death, the name of the fatal disease should also be recorded, so ensuring that registration should not consist merely of a roll-call of the deceased, but should furnish the diagnosis by which the comunal efiobts of preventive medicine might be directed. (2)

In the debate Lord Ellenborough carried a suggestion that the measure should be put into effect by the machinery of the new Poor Law Unions, on the grounds, as he later explained to Chadwick, that the Government's first proposal would have distributed throughout the country "a strong Battalion of ahig Attornies to act as Party Agents at the Public Ixpense". (3) There was "great walling about the lost Battalion", 4 and the $-0-$

1. "On Life Assurances", "Westminster Review", February 1828, p. 417.

2. 6 \& 7 vill. IV cap. 36, 17 August 1836.

3. Lord Ellenborough - .C., 27 October 1841.

4. ibid. 
wailers looked on Chadwick as the cause of their bereavement. He always belleved that Lord Nelbourne's bearing towards himself became less cordial after this lncident. "His private secretary said "they said" that the damage had been done by ae". (1)

Ellenborough's proposal was, in lact, made without consulting Chadwick. (2) Once it was put forward, Chadwick's one concern was that "a llood of jobs intrigues and corruption will be let in upon the Guardians who have hitherto with great difficulty been kept tolerably clear of those vices by the Commissioners"; and at his suggestion the appointment of the local registrars was made subject to the approval of the Registrar General. (3) Nor did the measure increase his popularity with the Church. The poor curate, with his 270 or 2100 a year, looked eagerly for the "Godsends" of the smallest fees; moreover, the clergyman who recorded the marriages of the middle classes was frequently invited to the wedding dinner afterwards, and "to a poor clergyman a feast is something". (4) But it was their baptismal fees which were hit most of all. "The labouring classes have a notion that if their children die without being properly named the proper Angels w111 not know by what names they may be called to heaven by. But if the child be named and registered by any public officer that will do as well; the child is named and that is enough: they dont see why they should go and pay the parson when they can get it done for nothing by going to the Registrar. The inferior clergy have preached various sorts of doctrine against this belief, but still their baptismal fees have diminished and they preach vigorously against the Government from which it emanates". It was a curious episode, and as a result of it chadwick was visited with the double hatred of veing an enemy of the church $-0-$

1. E.C. - Lord K1lenborough, 30 October 1841.

2. The Webbs ("Old Poor Law", vol. 2, p. 113) echo the Whig rank and file in asserting that the idea was due to Chadwick

3. B.C. - Lord John Russe11, 3 July 1336.

4. E.C. - Lord ? (probably tusse11), 3 January 1841.

5. ibid. 
for sponsoring the Bill, and an enemy of the Government for depriving them of some five hundred appointments.

The new department was established at a time when a large proportion of the offices under the Government was directed to the outdoor relief of the upper classes, and granted by 3 inisters to those bearing the family name, or, perhaps, merely the family features. The first Registrar General was T.H. Lister, who was distin uished as a threodecker novelist, but had the additional qualification of being Lord John Russell's brother-in-law. Be was succeeded by a cavalry officer, the brother of Sir Janes Graham. "Neither gentleman understood anything of medical and sanitary statistics and never perhaps wrote a line of the reports on them". (1) But Chadwick succeeded in persuading Lister to appoint as $\mathrm{h}$ is assistant a young doctor, William Farr, who, in the course of an unorthodox and unsystematic medical training, had picked up a knowledge of vital statistics; and Farr set to work, contentedly and profitably, to introduce or er and method into the facts and expound them for professional and public information.

There was no personal friendship between the two, and Chadwick, who at times was as imperious with figures as with men, inevitaoly came into conflict with the quiet clerk at the Register office. Farr ventured to question in the "Lancet" some tables which Chadwick had drawn up to show that in prisons

1. B.C. - Duke of Northumberland, 27 December 1878. Of Major Graham he wrote (MS fragment, n.d.): "The incompetency of the man is notorious. It is not believed that he wrote the reports which bear his name, poor as they are". In justice to the Major, however, Farr's tribute to bis departmental virtues should be guoted: "My name has been a good deal before the public: and the fact is that Lajor Graham's services have not been sufficiently recognized. They will now be appreciated for it will be very difficult to replace him. I know that I shrinik from the task; not that I fear being able to do all the scientific work, and to take the general direction of the elicy of the office; but the daily administration I hold cannot be better performed than it was by wajor Graham". (W.Farr - B. . Richardson, 24 Jan. 
where the diet was richest the amount of sickness wag greatest, tables of which he was very proud, and which tended to demonstrate what was not as obvious as it might be to the queasy stomachs of the working classes -.- that the most economical feeding was also the most humanitarian. This piece of perverseness Chadwick overlooked. But next he found in the Registrar General's returns a number of deaths from starvation. This implied that there were people who preferred to die quietly in the street rather than enter one of the Poor Law Bastilles. Chadwick therefore published an attack on Farr's figures, together with animadversions on his integrity, in the "official Circular", and showed that only 2 or 3 per cent. of the cases registered as deaths from privation were in fact deaths from lack of food, and those were either accidental or suicidal. The coolness continued botween the two men, ${ }^{2}$ so differentiy

1. L.C. - Dr. Laycock, 13 April 1844.

2. When it was rumoured that the census of 1841 was to be put into Farr's hands, Chadwick informed the Commissioners that he would exceedingly dislike having to work on the census in conjunction with the Registrar General's oflice. In the end the census was entrusted once more to Rickman, who wrote to thank Chadwick for his warning about the "machinations of Dr. Farr": "I suppose his Master at the Registrar office sighs to get rid of this disgraceful Incubus, and would gladly do so by recommendation to any other employment, being I suppose too much involved with him for decided dismissal". Rickman goes on to express surprise at the "ridiculous letter of the said Dr. Farr which you have printed with jour excellent Answer to it -.. but it is a serious matter for reflection that such Nonsense should be permitted by Mr. Lister to issue from his office, and if the next Annual Report does not decently but completely disavow the trash appended to the last year's Report, National disgrace will be incurred unless it be duly exposed on the first opportunity, --- which will soon occur" 
constituted and working by so different ways to the same end. He paid no attention to Parr"s "animosities or petty jealousies" Chadwick told a friend in 1844, "but I am sorry to say that it is not the only instance in which on looking into some covert from whence an insidious attack on my labours have proceeded I have found some one behind to whom I have rendered some special service". (1)

The article on Life Assurances, which reveals Chadwick's early interest in statistics, shows also that at twenty eight he had already formulated the principle which underlie nis public health work, the broad but sufficient generalisation that the duration and healthiness of life are determined by the circuastances in which it is lived. He quotes with approval the conclusion of Villermé, the prench inedical statistician, that "the gradations of wealth, or the means of providing comforts, may almost be taken as the scale of mortality", and urges that an investigation into the conditions of the working classes would be an "invaiuable acquisition to science, and would direct the public exertions in removing those circumstances which shorten $11 f e$, and in promoting those under which it is found to attain its greatest duration". (2) A few

1. B.C. - Dr. Laycock, 13 April 1844.

2. "On Iife Assurances", "westminster Review", February 1328, pp. 413, 335. From Finlaison's tables Chadwick shows that the average expectation of life hed beea prolonged by nearly one-third in the course of the previous century, the reason being clearly a beneficial change in the habits and circumstances of the various classes. Thus, "the vice of hard drinking is no longer fashionable; and he who should now seek distinction as 2 six, or even as a four bottle man, would be classed with those persons of humble station and nore limited means, who are occasionally celebrated in the newspapers by the announcement of such exploits as eacing a whole leg of mutton, and a proportionate quantity of candles by way of dessert" (p. 333). As for the labouring classes, "they are more cleanly and regular, their houses are better constructed, they have acquired some notion that fresh air is conducive to health, and the streets where they reside are less filthy and pestilential than formerly" (p. 390). 
Jears later, when he was preparing his report on London and Bericshire for the Royal Commission on the Poor Laws, he observed how some unhealthy neighbourboods were notorious as sources of pauperism. The beadles of Newington, for example, being ordered one very severe winter to pay particular attention to the sick outdoor poor, had gone at once without making any inquiry to a certain group of courts -.. just as a gameiseeper might go to a well-stocked preserve -..- and had returned with two coach-loads of fever victims.

This was the seed which was to bear so plentiful a crop in later years, but it did not germinate until 1838, when Chadwick, now Secretary of the Poor Law Commission, restless with unoccupied energy and unsatisfied ambition, vas permitted to enter upon a course of inquiry which his superiors thought of little importance, save in one respect -.- that it kept him quiet. Throughout the intervening years he had sat in Bomerset House, at the centre of the Poor law web, receiving from day to day the reports of Guardians and relieving officers and workhouse surgeons with their constantly reiterated lesson that disease fed the workhouses and insanitary conditions bred disease. "For some reason, which .... he never understood, the sanitary idea became dominant in his mind, and he became impressed with the coaviction that if sanitation were carried out in its completeness, disease, which was the cause of all death before the appointed time, would itself die."(2)

$$
-0-
$$

1. "kxtracts from the Information received by $4 . M . ' S$ Conmissioners, as to the Administration and Operation of the Poor Laws", $1833, \mathrm{p} .310$.

2. Obibuary of Chadwick, "Lancet", 12 July 1890 (the writer is reporting an actual conversation with (hadwick).

Chadwick, it may be noted, was very critical of an article in the "Bdinburgh Review" which represented the sanitary inquiry "as a consequence following from the new poor law, and naturally following". He told the author (Bamfleld) "that he was wrong in fact and pointed out to him that the circumstance that it had arisen from the accident of a person who had givea early attention to questions of insurance and laws of mortality, having been placed under favourable clrcumstances to direct attention to the subject". (Nacvey Napier Papers, f.629,12 Uct.1844). 
To the relieving officer at the parish pay table and the parish surgeon on his rounds in the lower districts of London the connection between the fever nest $s$ and the mounting poor rates was obvious enough. Ressoning that there could be no end to the outlay of money in relleving individual cases of fever until the cause which produced the malady was removed, the Union authorities in some places indicted the landlords for nuisance, defraying the expense of prosecution from the poorrates. In doing so they came into conflict with the auditors, under orders to strike out and disallow all charges not expressly authoriaed by statute. The disputants took their argument to Chadwick, who saw at once that it offered an opportunity to introduce into the practice of the poor Law Comisgion some of the principles of preventive administration which he had tried unsuccessfully to insert into the Act of 1334. In 1838 the steady anual stream of typhus cases swelled suddenly to flood proportions. In some streets cases occurred in almost every house; in some courts not a house escaped; and in a lew instances there were victimg in every room of every house. Altogether 13,972 cases of fever, 1,281 of them fatal, were reported in London during the year, 9,228 being contributed by certain districts, and in particular Whitechapel, Bethnal Green, Lambeth, St. George the Martyr, Stepney, Folborn, and St. George in the Bast. (1)

Chadwick celled the attention of the commiseioners to the preventible nature of a large proportion of the fever cases, and recommended a special investigation by three well-known medical observers, Drs. Kay, Arnott, and Southwood Smith. No better choice could have been made. Dr. Neil Arnott, a friend of Benthsm and J.S. MiIl, at whose house Chadwick had made his 1. "Yifth Annual Report of the Poor Law Commissioners", 1839. Appendix C. No. 2. "Report on the revalence of Fever in detropolitan Unions during the year ended 20 flarch 1333", by Dr. Southwood Smith, pp. $164-166$. 
acquaintance, had written a celebrated work on physics, and was a recognised authority on the warming and ventilation of houses. Dr. Kay (later Kay-Shuttleworth) brought to the iaquiry the experience of a dispensary physician in the Irish quarter of Wanchester, which, as he says, burned into him the conviction that it was futile to look to charity and medical skill alone to des.l with social evils. (1) With an appetite for work which rivalled that of Chadwick, he possessed also something of his self-confidence and ruthless energy, together with certain crotchets and angularities of his own; and a few years later, as Secretary to the Comittee of Council on Education, he was to drive himself into a breakdown grappling with dificulties not unlike those which surrounded Chadwick at Bomerset House. It is well to remember that Chadwick was not the only permanent official of the time to engage in disputes about his status, to arouse hostility from powerful sections of public opinion, and to encounter the charge that he was making a department of State the instrument of his own views and ambitions. With the third nember of the medical inquiry, Chadwick's career was to be more intimately linked. Southwood smith, physician to the London Fever Hospital, was another Benthamite (Bentham had left him his body for dissection and he had pronounced an oration over the philosopher's corpse at the Webb Street school of Anatomy); and as the suthor of a standard "Treatise on Fever"

1. F. Bmith, "Life of Kay-Shuttleworth", p. 14. In an autobiographical US dated 1377, Kay-Shuttleworth states that about the year 1834 he began to study the dest examples of urban drainage and water supply. "After I found myself likely to be absorbed in the efforts of the Government to establish a system of national education, I recomended $\mathrm{r}$. idwin Chadwick to undertace the prosecution of this investigation into town drainage and water supply, and other connected questions of sanitery improvement .... He possessed singular sagacity and skill to avil himself of a11. the indications in existing arrangements by wich the inost effectual system could be discovered". There is no evidence to support this rather patrondsing description of the genesis of the sanitary inquiry. 
was shortly to become the chief medical theorist of the sanitary reformers. The heart of the gentle Doctor, however, was a great deal sounder than his epidemiological views, and the simplicity and integrity of his character won over for the cause many who were repelled by Chadwick's demoniac reputation. All who met him -- including even the cantanikerous roulmin Smith -- acknowledged his love of his fellow men, which warmed the sympathies more than Chadwick's hard dry passion for efticiency. There was need for both men in the sanitary movement, which must touch the conscience as well as persuade the reason if the Peels and Grahams were to be brought to act.

In May 1838 the three set off on an exploratory tour, Arnott and Kay to Wapping, Ratcliff Highway, and Stepney, Southwood Smith to Whitechapel and Bethnal Green. How far, they inquired, were the conditions in which the poor lived due to the habits of the poor themselves, how far were they "voluntary", to use the favourite word of the Poor Law theorists? Very little, the Union medical officers replied. True, the poor drank too much; they neglected vaccination; they were reluctant to enter a hospital when they were attacked by contagious disease; they did not wash their persons, their clothes or their houses often enough; they crowded noisomely together in dwelling-houses and lodging-houses. But these "personal habits" of the poor, as the investigators termed them, were not the most powerful forces shaping the mould in which their lives were set. They were surrounded by filth, accumulated in cesspools and privies and stagnant surface drains; they breathed the exhalations of undrained marsh land, sraveyards, and slaughter-houses; they had no choice but to live in narrow alleys and close courts. The investigators concluded that there were some evils which could not be avoided by any exercise of prudence on the part of the poor, and which were independent of their personal habits. They were removable, however, by the well directed arrangements of public 
authorities --- by a system of sewers, a plentiful water supply, an effective service of scavengers, / 8 bntrol of building, and regulations segaipt overcrowding and hoxious trades. Powers should, therefore, be given to Poor Law Guardians to cleanse ditches and pools, to inspect lodging-houses, to indict nuisances, and to carry out generslly the functions of a public health authority, for which, as a locsily elected body, charged with duties relating to the poor, and commanding the services of paid officers, they were particularly suitable.

It was not the first time that medical men had investigated the sanitary condition of the towns --- Currie at Liverpool, Ferriar at Manchester, Haygarth at Chester had done valuable pioneer work in this direction at the end of the eighteenth century -.- but it was the first time that such an inquiry had been directed by a Government department with a view to action. The reports were forwarded to the Home Secretary, Lora John Russell, on thay 14th 1838, under cover of an official letter from the Commissioners, recomending as a temporary measure that the Guardians should be empovered to indict the parties responsible for nuisances. addressed a private note to Russell. "It has long appeared to me that it would be worthy of your Lordship to bring in a Bill for an Act of the nature of the Building Act to regulate the 1. "Fourth Annual Report of the Poor Law Coinissioners, 1838. Appendix A, No. 1. "Copy of the Report of the Poor Law Comissioners relative to certain charges which have been disallowed by the Auditors of Unions in England and Wales", 14 Nay 1838, pp. $93-105$.

Supplement No. 1. "Report on the prevslence of certain Physical Causes of Fever in the lietropolis, which might be removed by proper Sanatory easures", by Neil Arnott and James Phillips Kay, 12 may 1838, pp. $103-129$.

Supplement No. 2. "Report on aome of the hysical Causes of sickness and Mortality to which the poor are pacticularly exposed, and which are capable of removal by Sanatory Regulations; exemplified in the present condition of the Bethnal Green and witechapel districts", by Thomas Southwood Smith, Nay 1838, pp. 129-151. 
Puture dwellings of the labouring classes: providing that none should be built without provision being made for proper drainage, the width of streets, etc..... The larger political reforms have only affected the labouring classes indirectly. A reform in the mode of building would affect them directly and most beneficially and would redound greatly to the credit of the Government which procured it."(1)

Thus, within four years of its establishment the new Poor Law Commission was expanding in a way which threatened to burst its statutory limits. The underlying theory of the Act of 1834 , that most pauperism was "voluntary", the result of moral defects such as idleness, intemperance, and improvidence, was breaking down before the logic of the facts; and if the diagnosis was incorrect, it followed that the course of remedy must be altered. A case might be made out for invoking pains and penalties to scourge "voluntary" paupers out of their fecklessness; but once let it appear that the main causes of pauperism were not personal but social, that the pauper was usually the end-product of social processes over which he had no more control than he had over the weather, then a punitive treatment of paupers was no more just and sensible than a punitive treatment/, whom an earlier age had considered in some way responsible for their condition. Deterrence and alleviation, the remedies of 1834 , must give way to an investigation of causes, and the elaboration of wide schemes of reform aimed at prevention. Under Chadwick's influence a department founded to resulate poor relief was assuming, reluctantly, functions which reached out to embrace the duties and interests of all classes. It had already given birth to a Regisiration Act, under which for the rirst time the facts of national ill-health and premature mortality were being assenbled. It was presently (in 1840) to offer to vaccinate 1. E.c. - Lord John Russell, 21 June 1338. Chadwick here suggests that Dr. Kay, who had studied housing for many years, "would at any time supply the materials for a practical and useful bill". 
at the public expense the children, not of paupers only, but of any one who cared to bring them to the Union surgeon. If Chadwick had his way it would also become a department of education and a department of public health, unless the Government should segregate these functions before they swamped the Poor Jaw Commissioners.

The letter to Russell produced no immediate effect. In their next Report the Poor Law Commissioners underlined its argument by publishing a description by Southwood Smith of the fever epidemic in the metropolitan Unions. (1) The Hill coolies that year received from the whigs attention and abundant sympathy, Chadwick observed drily, but nothing was done for the helpless population of the great towns. (2) Eventually, in August 1839, the Bishop of London, who coupled the experience of a tondon parish priest to his episcopal authority and influence, addressed the Lords on the text of Southwood Smith's report, and moved that an inquiry be made into the sanitary condition of the labouring classes. (3) No money was voted, no arrangements made to facilitate the investigation; a curt note communicated the resolution of the House to the Poor Law Comissioners. (4) As Chadwick commented, "the inquiry seens to have been barely tolerated".

The investigation thus begun in 1839 was not completed until 1842, though it was in the hands of a man who, in conducting the Factory and Constabulary inquiries, had shown that he could amass his evidence and present his conclusions in a matter of weeks. Shortage of money, the indifference of his $-0-$

1. "Pifth Annual Report of the Poor Law Commissioners", 1339. Appendix C, No. 2. "Report on the Prevalence of Fever in Metropolitan Unions, during the year ended 20 Harch, 1333", by Thomas Southwood Smith, pp. $160-171$.

2. E.C., "Notes on Iord Normanby's speech", MS, 1844.

3. Ibid. The Bishop's speech seems to have been missed by Hansard's reporter.

4. L.C., "Memoranda of answers to the imputations of blame in respect to alleged delay to adopt sanitary measures", Mis, 13 July 1844.

5. E.C., "Notes on Lord Normanby's speech", iaS, 1344. 
superiors, a change of Government, but most of all the intrinsic complexity of the subject, all combined to drag out the inquiry. "Ho money is allowed the Board for the compensation of professional men of eminence and only Fonorary service can be asiked", he warned Dr. Hodgson, Peel's physician, requesting him to superintend an inquiry in Birmingham. (1) Yet Parliament was considering a proposal to settle an annual allowance of $\$ 30,000$ on the Queen's Consort! "The grant of $\$ 30,000$ for the purposes of a general system of education by which several hundreds of thousands of chlldren in various ways could derive benerit, was flercely resisted", Chadwick wrote in disgust, The grant of the same sum of money for the benefit of this one young man will be granted with adulations of virtues which he has yet had.no opportunity of displaying".

The investigation had been in progress eighteen months when a well-intentioned but impatient fiember of parliament, Robert WXXXXX slaney, obtained a select Comittee on the Health $-0-$

1. E.C. - Dr. Hodgson, 13 November 1839.

2. E.C., "Memoranda. Bor consideration in respect to the young Prince Albert's proposed allowance to be as considerable as that to the old Princes Royal", KS n.d. It is interesting to note to what objects Chadwick himself would have devoted the $\$ 30,000$. The money which would be spent on equerries and gold sticks, chamberlains and grooms of the stole, he calculates would provide six or more normal schools to rescue the children of the labouring classes from juvenile delinquency and give them instruction valuable both to themselves and to society; it would provide twenty stipendiary magistrates to take the administration of justice out of suspected hands, such as those of masters who enforced the law against their own workmen; it would pay the salaries of three or four new Judges to deal with Chancery arrears, it would establish a government depariment to regulate travel by steamships and reilways, or found a school for civil engineers, or provide public walks and gardens, libraries and museums. "Is it better that this sum 230,000 should be given to some few sons of wealthy lords, than that the children of those who toil for our revenue, should go on without education or care from the state"?. 
of Towns! (1) He "must be doing something in 1t", snorted Chadwick, who resented the trespass. (2) The principal witnesses were medical men whose depositions had already been taken by Chadwick, and the valuable portions of the evidence were repetitions of the replies he had elicited. "The remedial measures recommended were chiefly Boards of Health, which had been tried snd/palled, and off hand and easy generalities, which could be reduced to little practice". (3)

The report of Slaney's Comuittee, however, prodded the Government into a show of action. Casting about for popular measures as the Home Secretary of the weak and failing Whig Ministry, Lord Normanby suddenly selzed upon the sanitary question, and in 1841 introduced three Bills, "for the improvement of certain boroughs", "for regulating buildings in large towng", and "for the better drainage of large towns and villages". (4) Chadvicik'g annoyance at this step, though it was sharpened by affronted amour propre, is understandable. The

1. "Report from the Select Comnittee appointed to inquire into the circumstances affecting the Health of the Inhabitants of large towns and populous districts, with a view to improved sanitary regulations for their benefit", 1340 (384) XI.277. Their principal recommendations were ("Report", 17 June 1840, pp. $\mathrm{xv}-\mathrm{xx}$ ):

1. A General Building Act.

2. A General Sewerage Act.

3. A Board of Health in every town of a certain size, to be appointed by the Guardians, Town Council, or ratepayerd.

4. An administrative authority, distinct from the Board of Health, for drainage and sewerage.

5. An Inspector, appointed by the ratepayers or the Guardians, to enforce sanitary regulations.

2. "Notes on Lord Normanby's Speech", MS, n.d. 1344.

3. ibid.

4. Normanby introduced a single 3111 "for the better drainage and improvement of suildings in lerge Towns and Cities" on 29 January 1341 (Hansard, vol. 56, pp. $133-9$ ). In Committee this was split first into two, and later into three separate measures. (1) "For the Improvement of Certain Boroughs", 1341 (300) (338) I.29.55; 1842 (34) I.119; (No.2) 1342 (53)' I.145. (2) "Bor Regulating Bulldings in Large Towns", 1841 (302)(339) I.93.125; 1842 (33) I.287; 1842 (52)(270)(371) I.319.351.367. (3) "For the better Drainage of large Towns and Villages", 1841 (301) II.221; (No. 2) 1841 XX (350) II. 239. 
investigation by the Poor Law Comission was still in progress; the results of the local inquiries were still coning in; and Chadwick's seneral report was as yet a series of massive fragments. The Home Secretary now imposed a ban on the continuance of the inquiry, and when Chadwlek got a friend in the tords to ask for the production of the local reports the request was refused point blank. "A manifest determination was evinced to give the labours in the Poor Law department the go by, on this subject. The government was determined to have the exclusive merit". (i) Chadwick appealed for support to the Tory Lord Liverpool, who agreed that it was an "indecent and improper proceeding" (2), but declared "I cannot suppose that Lord Normanby can mean to hurry a measure such as a general bullding and town draining bill thro but probably his object has been to give himself and his party as much relief as possible by an apparent activity in this matter". (3)

The ill-constructed Bills, concocted, as Chadwick judged, by fiome office lawyers and palace architects, fell to pieces in Committee, and the wreckage was bequeathed to the Tories, in whose hands it remained for three years more an impending threat to the progress of true reform. Chadwick, while pursuing his own inquicies, fought simultaeousfy a muning battle against the principles of these Bills, which were based upon a hasty and superficial view of the subject, embodying technical recomendetions which were out of step with the best contemporary developments, and revealing a timid anxiety to avoid any large scale adminiatrative experinents. (4) They were, -o-

1. "Notes on Lord Normanby's Speech", MS, n. 3. 1344.

2. Lord Liverpool - E.C., 3 September 1341.

3. Lord Liverpool - E.C., 31 August 1841.

4. Cf. a number of fragmentary memoranda, e.e. "Notes on the multiplication of offlcers", n.d.; "Wemoranda on bills for the regulation of buildings, $1844^{\circ}$. The most detailed criticisu is given in his "Draft Report on an Analysis of Le islative Measures for the Sanitary Improvement proposed betore the Issue of the Commission", drawn up for the Lealth of Towns Commission in 1344 . 
he told the Government, Bills "to make orains to run without water"; which prescribed that house drains should be of brick and at least 9 inches in dianeter, though a 3 inch tile pipe at ons quarter the cost was much superior in action; which showed more concern to guard against the remote chance of the labourer's house falling about his ears or catching fire from the house next door than to provide for sanitary fundamentals; which contemplated the payment in fees to surveyors of sums greater than the cost of the drains themselves. They would put the house drainage under one officer and the main drainage under another, and would impose on property owners imediate charges for improvements which in some cases would amount to a confiscation of the entire annual value of their property. "To apply a remedy with the least possible introduction of new machinery" had been Normanby's professed aim. (1) He proposed in fact to utilise for his Drainage Bill the old machinery of Commissions of Sewers, whose ineffieiency in the past had been amply demonstrated, without taking any safeguards that their powers would be better exercised in the future; and for the execution of the Building Bill to permit Borough Councils to appoint surveyors, who would be allowed to retain their private practice and would undergo no scrutiny of their professional competence.

The downfall of the Whigs in September 1841, when Lord Melbourne thankfully surrendered the Government and the deficit to Sir Robert peel, brought a double benefit to the sanitary movement. First, out of a robust belief that the measures he had introduced would have wrought untold good for the lower classes, Lord Normanby discovered in opposition a fervent enthusiasm for sanitary reform, together with an imense indiznation at Tory tardiness; and he proved a valuable ally to Ashley and Southwood Smith in the Health of Towns Association. Secondly, Chadwick was given permission to finish 1. Hansard, 12 Feoruary 1841, vol 56, p. 539. 
his report, which he was ilmly convinced would never have appeared if the Melbourne Government had retained office. Towards the end of 1341 he was instructed to complete it so that it might be put into circulation before the next meeting of Parliament.

Another six months elapsed, however, the 1342 session approached its close, and still the report had not appeared. The Commissioners concurred cautiously with Chadwick's draft, but urged him to prune some of the more offensive passages. "If your report is to suffer mutilation I at least trust it will not be curtailed of any material parts", wrote an indignant friend, "It is necessary in legislation to pay respect to public opinion, but surely the same deference to prejudice and ignorance is not to be maintrined in expository works of which the professed object is to enlighten the people, and prepare the way for wholesome reforms". (2) The report was oritinally printed with the Comissionerg' names appended; but G.C. Lewis opposed its adoption on the ground that it was calculated to give offence to Commissioners of sewers and sinilar authorities. It appeared in its final form only after Nicholls had intervened on its behalf, and Chadwick had undertaken to bear personaliy any responsibility or unpopularity that might attach to it. "It contains a great deal of good matter", G.o. Lewis remarised to George Grote, with an air of giving the devil his due, "and, on the whole, I prefer it to anything else he has written. We shall present it shortiy as his report, without making ourselves responsible for it".

The raw material for the "Savitary Report" falls into

1. Ti. . - J. impson, 25 April 1844: "Hnder his (i.e.

Nomanby"g) ingluence the sanatory report itself was stopped and never probably would have apjeared but for his removal from power".

2. Bev. Whitwell Blvin - E.O., 31 May 1342.

3. G.C. Lewis - G. Grote, 15 irch 1842 ("Letters of Sir George Cornewal1 Lewis", ed. Sir G.1. lewis, 1870, p. 119). 
three main categories. A set of inquiries, based on the conclusions of the "Fever Report" of 1833, was directed to the Assistant Poor Law Comissioners and the Union medical officers in all parts of England, Wales, and Scotiand. (1) The replies to these questions were supplemented by material collected by Chadwick in personal interview or correspondence with surveyors, builders, prison governors, clergymen, lawyers, police officials with anyone whose position brought the facts beneath his constant observation. In addition, in obedience to his own canons of research by which the investigator was adjured not to rest content with the testimony of others, howeven well informed and intelligent they might be, Chadwick himself made a number of excursions to the provinces. (2). There are passages in the "Sanitary Report", as in other reports of his early period, which in their raciness of description, their vividness of detail, and their eye for character remind the reader that Chadwick had served his apprenticeship in Fleet Street. There is humour, too, "that keen sense of the droll and the humourous even in the midst of the horrible and squalid, which, his friends say, Mr. Chadwick possesses in a degree quite remarkable". (3) As the years went by and one bulky report succeeded another, as the ideas lost their newness, and spontaneity was crushed beneath the wheels of the official grind, Chadwick became more and more prolix and pedestrian in his style, and the spark of ironic humour was extinguished by the atmosphere of serious intention; but in the "Sanitary Report" he is still fresh, his strong, plain style is not overweighted by material, and his confidence has not yet degenerated into a querulous assertiveness.

1. The terms of reference were widened to include scotland in January 1840.

2. See, for example, the description of bis inspection, in the company of Neil Arnott, Sheriff Alison, and a police superintendent, of the district of Glasgow lying between Argyll-street and the river ("Sanitary leport", p. 24). 3. Article by Professor Masson, "North British Review", vol. xili, $185, \mathrm{p} .47$. 
The complacency which marks Chadwick's first essay in the "Westminster Review" gives place in the "Sanitary Report" to a note of grim urgent warning. His critics complained that he had become a social hypochondriac, who scanned society with a morbid eye, looking for the symptoms of disease and not observing the general condition of health. He might well have replied in the words of the "Times": "Possibly, there may be progress as compared with a past age, but there is not as compared with a past epoch in the present age. It may be that working men are better housed than at the time of the Great Plague, but such a comparison is merely trivial in presence of the fact that, in spite of all that sanitarians can do, the dwellings of a great part of our population are, in the present age, every day becoming worse".

(1) The age-long balance between birth rate and death rate, between human fecundity and the adversities and accidents of human environment, had been upset decisively between 1780 and 1810 by a steep fall in the death rate. Humanitarian activity, advances in empirical medical knowledge, a more abundant food supply, the rising level of urban wages, the work of Improvement Commissioners and joint stocis companies, all these together had brought down the death rate of Londoners in 1811 to 26 per thousand -- little more than half the figure for 1750. But after 1810 there was no great fall in the death rate till the seventies; and the difference between a crude death rate of 23 per thousand in the niddle decades of the century and one of 16 per thousand at its end is a rough measure of the toll of slum housing, inefficient sewerage, and impure water supplies in the raw industrial towns. Year by year the great towns continued to srow, partly by a natural increase, but even more by the lnflux of immigrant workers whom the expanding industries attracted across the St. George's Channel and from the rural areas of Bngland and Wales, t111 oy 1851 half the population was urban, "a situation that 1. "Times", 5 November 1853. 
had probably not existed before in a great country, at any time in the world's history". (1)

To the administrative difficulties raised by this unprecedented growth and concentration of the population very little hard thinking had been directed by the departments of State before the publication of the "Sanitary Report"; and the engineers who had produced the railway locomotive and the steamship had neglected to apply the same technical sisill to the complex problems of human aggregation. In the building encyclopaedias of the time the word "ventilation" did not once occur from beginning to end. Houses rated at $\$ 1,000$ or more in the newly founded colony of Belgravia reeked with exhalations from faulty house drains. Perhaps not one hogere in a whole street of middle class residences possessed a bath. (2) When Lyon Playfair examined the condition of Buckingham Palace, be found it so bad that the Government did not dare to publish his report.(3) while the middle and upper classes lived in such splendid squalor, the lower classes seemed in danger of being engulfed and poisoned by their own excretions.

The localising of "zymotic" or infectious diseases in the narrow courts and alleys of the poor had been frequently noted by those eighteenth century physicians whose broad sympathies or straitened means drove them to practise in the lower quarters of the towns. This observation -.- that outbreaks of fever were correlated with inganitary conditions -- gave rise to the characteristic medical tbeory of the public health reformers. According to this "pythogenic" theory, disease was caused by an "unknown something in the atmosphere" acting upon the gases from animal and vegetable decomposition, given off, for example, by a midden, a strgnant $-0-$

1. J.H. Clapham, "Economic Eistory of Modern Britain", vol. I,

p. 536 .

2. F.C. - F.O. Ward, 7 October 1849.

3. "Nemoirs and Correspondence of Gyon Playfair", ed. "Reid, p. 94. 
sewer, an overcrowded churchyard, a slaughter house or a tanner's yard. Any of these, in combination with the epidemic influence, might produce, by a kind of spontaneous generation, an outbreak of typhus, or perhaps --- since this promiscuity of filth brought forth an uncertain progeny -.- of typhoid or cholera. Certain corollaries followed from the theory. The transmission of disease by contagion was a fallacy, and quarantine therefore an archaic survival from less enlightened days; Southwood Smith showed his faith in this conclusion by taking his grand-daughter with him when be walked the fever wards. (1) offensive smells were not necessarily injurious to bealth, but the sense of smell was "the sentinel placed at the portsls of $11 f e^{\prime \prime}$. (2) Impure air and the reek of filth, not the privations of poverty, were the predisposing circumstances which favoured the spread of disease, the chief sufferers being not paupers but independent labourers, artisans, and small shopkeepers, who were not destitute of food and clothing. Nor was it chiefly the weak and sickly who fell victims, for a large proportion were in the prime of life, at the height of their productive powers, and with dependent families, who, on the death of their parents, must be cast upon the rates. The confortable belief was thus discredited that the unfit and superfluous, the paupers and the weaklings, were beneficently cut off by nature; and if the economist was wrong, so also was the philanthropist, who thought that fever was caused by destitution, and could be combated by grants of money, ivel, and blankets.

That disease was traceable to specific infections had been demonstrated clearly enough during the eighteenth century, and the pythogenic theory could be sustained only by ignoring some very obstinate facts, to which Chadwick closed his eyes to the end of his life. To assert that fever might be bred in -0-

1. C.L. Lewes, "Dr. Bouthwood Smith", p. 77.

2. General Board of Health, "Report on a General Scheme for Extramural Sepulture", is February 1850, p. 11. 
any cesspool or uncleansed ditch was, as William Budd remarked, "precisely on a par with the philosophy which led the ancients to believe that mushrooms are bred of cow-dung, alligators of the mud of the Nile, and that bees, as Vergil sang, may be engendered in the entrails of a pubrid ox".(1) During the "Great Stink" of 1858, when the stench of the polluted Thames closed the law courts, emptied the river steamers, and assumed the proportions of a national calamity second only to the Indian lutiny, pestilence on an enormous scale was gloomily prophesied; the death rate for the year was, in fact, below the average, and there was a notable diminution in the amount of fever, diarrhoea, and dysentery. (2)

Radically wrong though this theory was, however, it was given plausibility by its demonstrable effectiveness in practice. To counter a disease it is not essential to know the mode of its transmission; and, conversely, a disease is not conquered once it machinery of infection has been discovered. Thus, though the mosquito has been indicted, malaria has not been banished from the tropics; while, on the other hand, leprosy, the "sweating sickness", plague, cholera, typhus, and typhoid were all uprooted from England before their generating bacteria were detected. They retreated because the environmental conditions which favoured their advance were vanishing, for, from the point of view of preventive action, the soil in which a disease flourishes is no less important than the seed from which it springs. For a movement which aimed at clearing up the dark corners of the towns no sounder doctrine could be taught than that immunity from pestilence was to be secured in proportion to the intelligence and energy which were directed towards the removal of its localising conditions. The "pythogenic theory" may well serve as an example of those "fruitful errors" which, 1. William Budd, "Typhoid Fever" (1874), p. 153. 2. Cf. the description of this historic stink by Budd, op. cit., pp. $141-2$. 
as Vaihinger reminds us, have in the history of thought so frequently produced sound practice out of false theory.

\section{In the light of this theory Chadwick turned to the} examination of the returns from the local Registrars which by the end of 1839 were pouring in from 553 districts, giving for the first time in history a reliable and comprehensive picture of the causes of national ill-health and mortality. (2) In the first year, 1338, for which returns were made, he found that the deaths in England and Wales from zymotic diseases numbered 56,461. It was as if the whole county of Westmoreland or Huntingdon "were entirely depopulated annually, and were only occupied again by the growth of a new and feeble population living under the fears of a similar visitation". (3) From typhus alone the yearly slaughter was double the casualties suffered by the allied arinies at Waterloo. The "Fever Bill" footed every year by the nation, in the form of charges for medical attendance, for the support of widows and orphans, for labour lost by sickness, for the shortening of the average working life by premature mortality, was an immense and growing burden. (4)

The lesson of Chadwick's Report was that the great mass of this mortality and sickness was preventible. He demonstrated this by a simple but conclusive device, which came as near as practicable to experimental verification in a field where laboratory methods of control and observation were out of the question. He took the average ago at death for various classes of the conmunity, inhabiting different quarters of the towns, so reverling at a glance the disparities concealed

1. H. Vaiwinger, "The Philosophy of 'As If'", 2nd. ed. 1935, pp. $45-5$.

2. For the deficiencies of the local returns, due partly to the primitive diagnosis and confused nosology of the time, and partiy to the low qualifications of the Registrars and the defective administrative arrangementg for recording the cause of death, see Chadwick's coments in the next chapter. 3. "Sanitary Report", p. 3 .

4. One of Chadwick's correspondents, the Rev. G. Lewis, calculated that the "fever bil1" of Dundee from 1833 to 1839 amounted to 2175,676 12s., or 225,096 13s. per annum. (ibid. p. 209). 
beneath the general averages for the country.

(1)

\begin{tabular}{lccc}
\hline District & $\begin{array}{l}\text { Gentry and } \\
\text { professional } \\
\text { classes. }\end{array}$ & Tradesmen & tabourers \\
\hline Derby & 49 & 38 & 21 \\
Bolton & 34 & 23 & 18 \\
Leeds & 44 & 27 & 19 \\
Truro & 40 & 33 & 28 \\
Bethnal Green & 45 & 26 & 16 \\
Whitechapel & 45 & 27 & 22 \\
Strand Union & 43 & 33 & 24 \\
Kensington & 44 & 29 & 26 \\
\hline
\end{tabular}

The age at death of the individual was thus shown to bear a direct relation to his rank in society. Now the circumstances of the labouring classes differed in two main respects from those of the gentry; they enjoyed a smaller income, and they inhabited dirtier districts, dirtier streets, and dirtier houses. Which of these factors, income or environment, was responsible for the different expectation of life of the two

1. "The slow general improvement, made up by the great improvements of particular classes, is consistent with the positive deterioration of others. The average age of death of the whole of the working classes we have seen is still no more than 22 years in the whole of the metropolis. In large sub-districts, if we could distinguish accurately the classes of deaths, the average would be found to be not more than half that period: a rate of mortality ascribable to increased over-crowding and stationary accomodation, greatly below anything that probably existed at the commencement of the century". (B.C., "Supplementary eport on .... Interment in Towns", App. 11, p. 242). Criticising the statistical methods then in use, Chadwick pointed out that the practice of treating the proportions of deaths to the population and the average ages of death as being equivalent was very misleading and sometines exaggerated the chances of life to an extent double the resl amount. Thus, in St. Margaret's parish, Leicester, the proportion of deaths to the population was 1 in 36.5 ; examining the district street by 3 treet Chadwick found that in streets which were we11 drained the average age at death was 25.5 , in partiy drained streets 21, and in undrained stroets 17 -.- the general average being 2l. (ibid., p. 24l) Masy years later he was still urging that, in franing statistical returns, it should be recognised as a principle (Continued on next page) 
classes? It was proved --- to Chadwick's satisfaction -that the labouring classes received on the average a real incone sufficient to keep them well above the level of starvation(1); the greater mortality from which they suffered must therefore be ascribed to the physical conditions amongst which they lived, and he illustrated this conclusion by "Sanitary Maps" of Bethnal Green and Liverpool, which showed the black crosses of death crowding thickly in the foulest and most overcrowded districts. It followed that if those physical conditions could be improved, there would be a corresponding improvement in the statistics of sickness and death.

Fever, then, was not the result of destitution; on the contrary, destitution usually came on the heels of fever, and

(Continued from previous page) that every place had its own circumstances which governed its mortality, and that the operation of those special circumstances should not be blurred by inclusion in general averages. "One chief objection to the weeisly returns from the Metropolis is that for any practical conclusions they are misleading; all "means" such as these returns only give between extreme divergences of conditions, being virtually misrepresentation ..... And these "means" are particularly injurious in glossing over the different rates of exposure of different classes to preventible diseases". The lower districts of towns were brought under a general average with the well-todo, thus conveying a false impression that their adninistration was unobjectionable. "Particular care ought to be taken to make preventible diseases as little as possible the subject of averages with the other classes of disease or of general averages of any kind, to avoid the apologetic conclusion for inaction by local Boards of small owners, that nothing is required to be done for the cases "are not above the average", it being no consolation to any individual that he died because his death goes to make up a moderate average or a statistical law of mortality, any nore than it is an extenuation of t e administration of the police of a district or any excuse of default of pursuit in any case that "murdyrs and robberies are not above the average", and that indeed the place is well conditioned, for they are below the average of Greece or of Italy". " "Wemorandum on the Returns of Mortality for Cities", MS, n.d. c. $1860-70$.

1. See below, p.123. 
the poor's rolls were the pedigrees of generations of familes thus pauperised. Of the 112,000 orphans and 43,000 widows receiving poor relief in 1840, Chadwick estimated that 100,000 orphans and 27,000 widows had been reduced to dependence by the death of their breadwinner from some sort of zymotic disease, arising from causes which were known and removable. (1) These pauper orphans and widows were a legitimate concern of the Poor Law Commission. Chadwick, however, looking beyond the walls of the workhouge, went on to demonstrate that preventible disease had economic and moral effects upon society at large far more serious than the additional burden cast by them upon the ratepayers. Economically it represented a heavy annual drain upon the country's most valuable capital, its strongest and most experienced worizers. During the Napoleonic Wars Bethnal Green and Spitalfields had raised a regiment of volunteers, but in 1840 the recruiting officers would find it difficult to get together a grenadier company from the same districts; yet the wealth of the nation was ultimately dependent upon the bodily strength of the labouring classes, which in the past had been so superior to that of other nations that English navvies had been imported to carry out railway construction on the continent.

But the moral effects were the gravest of all. It was often alleged that the misery of the poor was chiefly the result of their own intemperate habits. They had few or no pleasures to wean them from intemperance, replied Chadwick, (2)

1. "Sanitary Report", p. 192.

2. He urged the Select Committee on Intemperance (11 June 1334, Q. 325) to consider "whether sober habits may not be efficientiy promoted indirectly by the formation of cricket grounds, of public walks; horticultural gardens in the neighbourhoods of the smaller provincial towns, and by the institution of zoological repositories in the neighbourhood of the larger towns; and by the free admission of persons decently dressed to them on Sunday, after the morning service ..... an over-strict and Judaical observance of the Sabbath (being) equally prejudicial to true religion and temperance". 
and in the depressing conditions of their lives, education ran a losing race with gin. "Seeing the apparent uncertainty of the morrow, the inhabitants really take no heed of $1 t$, and abandon themselves with the recklessness and avidity of comron soldiers in a war to whatever gross enjoyment comes within their reach". (1) Cleanliness and decency were inpossible for the family who occupied a single room in a house unprovided with water or a privy. Overcrowding led to bastardy and incest, and forced the children on to the streets as thieves, beggars, and prostitutes. The evidence was overwhelming "how strongly circumstances that are governable govern the habits of the population"(2), how filth and overcrowding acted as "physical barriers to improvement" against which "moral agencies have but a remote chance of success". (3) "I have often said", the Stipendiary Magistrate of the Thames Pollce Office had once remarked, "that if empty casks were placed along the streets of Whitechapel, in a fow dajs each of them would have a tenant, and these tenants would keep up their kind, and prey upon the rest of the commity. I am sure that if such facilities were offered, there is no concelvable degradation to which portions of the species might not be reduced. Allow these tub-men no education, and you would have so many savages living in the midst of civilisation. If you will bave marshes and stagnant waters you will there have suitable animals, and the only way of getting rid of them is by draining the marshes". (4) The statesman and the employer both had good reason to fear the animals bred in the undrained marshes of the sluns. In abridging the adult years of the labouring classes, wrote Chadwick, "noxious physical agencies ..... substitute for a population that accumulates and preserves instruction, and is itself progressive, a population that is young, inexperienced, ignorant, credulous, irritable, passionete, and dangerous, having a perpetual tendency to moral as well as physical

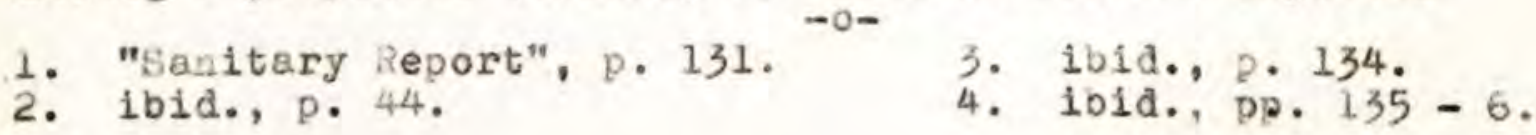


deterioration". (1)

At the Manchester torchlight meetings, amongst the mobs which had gathered under the influence of "anarchical rallacies", observers had noted a striking preponderance of youths. Men of mature age, with sound views on the relationship between capital and labour, were comparatively few in number, and tended to stay away from Trade Union meetings where they found themselves overborne by "mere boys". Thus, as fever sometimes broke from its reservation in the poorer quarters and crept out to ravage the broad squares and airy streets of the West End, so might Irade Unionism and Chartism be born amidst the neglected inhabitants of the slums, and emerge to threaten the established order. Chadwick drew his respectable hearers to the edge of the pit, and bade them observe the monsters they were breeding beneath their feet.

Writing in 1844 Engels castigated the "utter ignorance on the part of the whole middle class of everytbing which concerns the workers", and remarked how in Manchester, where the business and shopping centre was girdled by slumg, the bourgeoisie could yet ride into town without passing through or giving a thought to the "grimy misery that lurks to the right and the left". (2) This sweeping condemnation is a little hard on Chadwick, whose "Sanitary Report", grimmer, more comprehensive and detailed, $-0-$

1. He told an American educational reformer: "The more I go on the more extensive and cogent does the evidence appear to me that the influence of the physical condition on the moral condition has been too much overlooked as an element of education ..... From various sources, from your newspapers and from the proceedings of large masses, from such events as the late hiladelphia riots I gather confirmation of the conclusions I collect from your census and your mortality tables, and of the general conclusion that a joung population must be a passionate and imoral and an untrustworthy one. Strange as it may seem, the better drainage and paving: better construction of your houses and relief from overcrowding, better zkexming internal and external ventilation and cleansing would be essential steps to the moral improvement of your population". (B.C. Horace Mann, 8 June 1844).

2. F. Engels, "Condition of the Working Class in Ingland in $1344^{\prime \prime}$ (1392 ed.), pp. 18, 46 . 
better documented than Engels' own study of the domestic conditions of the English working classes, had been published two years before. (1) But Chadwick would have agreed that the lanes and alleys of the poor, "Little Ireland", the wynds of Edinburgh and Glasgow, the rookeries of St. Giles', Villlers Square, and Golden Square, were as remote from the experience and imagination of the great majority of the middle and upper classes as some Punjab village or South African kraal. (2) After 1842, however, there could be no excuse for ignorance, though interest might continue to find arguments for inaction. In the language of ejewitnesses Chadwick gave descriptions of removable causes of diseese, to be found not only in the industrial cities, but ever in the small country towns and villages, which the sentimental delighted to paint as the homes of rustic comfort and rude agricultural health. The most daming evidence came from the Medical officers of the Poor Law Unions, almost the only members of the professional or middle classes whose duties brought them into close contact with the lower classes in their houses. Thus, the Medical officer to the Liverpool Union reported: "In consequence of finding that not less than 63 cases of fever had occurred in one year in Unioncourt Banastre street (containing 12 houses), I visited the court in order to ascertain, if possible, their origin, and I found the whole court inundated with fluid filth which had oozed through the walls from two adjoining ash-pits or cesspools, and which had no means of escape in consequence of the court being below the level of the street, and having no drain. The court was owned by two different landlords, one of whom had offered to construct a drain provided the other would join him in the expense; but this offer having been refused, the court had remained for two or three years in the stute in which I saw it; and I was informed by one of the inhabitants that the fever 1. Fngels and Chadwick do not appeas to have become familiar at any time with each other's work.

2. Chadwick and Arnott were regarded with astonishment when they visited the Edraburgh wynds. The inhavitants told them tnat uney nad not witnessed for many years the approach of persons of superior condition. ("Sanitary Report", p. 342) 
was constantly recurring there. The house nearest the ash-pit had been untenanted for nearly three years in consequence of the filthy matter oozing up through the floor, and the occuplers of the adjoining houses were unable to take their meals without previously elosing the doors and windows. Another court in North-street, consisting of only four small houses I found in a somewhat similar condition, the air being contaminated by the emanations from two fllthy ruinous privies, a large open ashpit and a stratum of semi-fluid abomination covering the whole surface of the court". (1)

It was true, as Ashley observed, that "one whiff of Cowyard, Blue Anchor, or Baker's Court, outweighs ten pages of letterpress"(2); but what print could do to shock and shame, what the exhaustive cataloguing of horrors could do, what the inescapable testimony of a multiplicity of witnesses could do, was done by Chadwick in the most powerful assault upon the sensibility of the ruling classes that had ever been attempted. All led to the same general conclusions: that the health and comfort of civilised man, urban man, depended upon arrangements for bringing his water supply into the towns and taking his wastes out, and for ensuring that in massing together all individuals should continue to receive their due share of light and air; that in nineteenth century Britain those arrangements were grossly inadequate; and that their inadequacy must be ascribed not so much to lack of knowledge as to s failure to apply such knowledge as was readily available. It was not the intractability of brute physical facts which formed the main obstacle to the cleansing of the town, but the plain human stupidities of indifference, self-satisfaction, lethargy, and stubborn habit; it was not that the problem was too difficult, but that the mental effort directed towards its solution was too puny.

1. "Sanitary Report", p. 31.

2. H. Hodder, "Life and Work of the Seventh Earl of Shaftesbury", vol. I, p. 361. 
In drainage, water supply, ventilation, in all the

essential elements of urban 11Pe, the existing practice was far below the existing science. Methods of drainage exhibited the crudest empiricism, an ignorance of elementery hydraulics, and a conservatism which was blind to the benefits of the simplest improvements. Street sewers were immense bricis caverns, flatbottomed and flat-sided, washed only by a feeble trickle of water. They were built on the hypothesis that they would accumulate deposit, and were made of brick so that they might be the more readily opened; and at intervals of five or ten years the streets would be excavated and men would scoop up the deposit in pails, raise it by windlass to the road surface, and leave it there in noisome beaps to be collected by the scavenger's carts. (1) House drains were also made of brick, and in construction were no better than extended cesspools, Pitted rather to retain deposit than to carry it avay (2); and it was usual to lay down for a single house a drain with capacity sufficient to remove the refuse of a thousand. Rarely in the design of sewers and house drains was there any recognition of the elementary principle of hydraulics, which forms the basis for the modern system of water-carriage, that by concentrating the flow or water in a smooth circular channel its scouring power may be increased. Only in a few middle $-0-$

1. In an undated memorandum Chadwick describes how this offensive process first set him thinking of the possibility of water-carriage: "In passing homewards the Chjef investigator saw a mass of this filth spread upon the surface of the street in a main thoroughrare. A sewer was being cleansed by the deposit being taken out in buckets Por removal by hand labour and cartage. lie turned back to avoid the stench: whon he was arrested, and obliged to turn again by another accumulation, made for the like process. Being thus confronted, the question forced upon him, was this provess realiy necessary? He enquired and was assured by the most eminent engineers and sewers commissioners that it really was the best possible arrangenent, but he was oostinate in his disbelief that it was not: he got it into his head that it might be removed in water, and on enquiry he learned that there was one survejor who had the same notion".

2. "lave you any drains in this house?", one woman was asked. "No, thank God" she replied, "Ne have none of them stinking
things here". ("Noxis "imes", 23 January 1848). 
class houses had the water closet replaced the cesspool or the privy midden; and in London its introduction was obstructed by the Comissions of Sewers, who imposed an illegal fee on any householder who sought permission to drain his house into the public sewer. loreover, there were profits to be made out of filth which would be threatened if it were removed by the expeditious water closet. Vast dumps of ashes, night-soil, rotting vegetables, straw, dung, refuse of $211 \mathrm{kinds}$, in thousands of tons occupying hundreds of cubie yards, the sweepings of the streets, the offal of the slaughter-houses, and the contents of the public privies, were built up in the midst of densely populsted districts as the stock-in-trade of dealers who retailed it to farmers by the cartfull and the barge-load. (1) In London, however, no refuse, except coal ashes, cinders, and dust which were used in the making of bricks, paid half the expense of cartage, and transport costs limited the use and deposit of the refuse within a radius of three miles beyond the line of the district post. (2) The charge for emptying cesspools averaged $i l$, and in metropolitan parishes remote from the agricultural areas the expense, to people who were usually in debt at the end of each week, acted as a complete barrier to clearliness. Thus, as the great towns expanded and their centres grew ever more distant from the country districts, as the numbers of their inhabitants grew and the volume of their wastes increased in proportion, the burden became too heavy for the small scavenging contractors, and the traditional methods of sewage disposal were oreaking down. The result was the steady secretion of filth in basements and backyards.

1. The famous dunghill of Market-gtreet, Greenock, described in the "Sanitary Report", pp. $46-7$, which the Webbs consider "the climax of horrors" (S. and . Webo, "statutory Authorities", p. 339), was rivalled in sany other towns; cf. the "Ash Yard" of Gaywood, Norfolk, which was estimated to contain some 2,025 tons of refuse. (N. Lee, "lieport to the General Board of Gealth on .... Gaywood", April 1850, pp.9 10.)

2. One scavenging contractor confessed, "I have given away thousands of loads of night-soil: we do not know what to do with it". ("Sanitary Keport", p. 46). 
In street paving and the arrangements for surface cleansing, Chadwick found the same waste and the same want of sclence. A road sweeping machine had been invented (by Whitworth), but the parochial suthorities were reluctant to give up the old methods of hand-labour which provided eaployment for their paupers. Paving was coomonly regarded as being required solely for the benefit of cart and carriage trafilc, not ss a means of cleanliness, and it was therefore usually confined to the main streets. OP 687 streets inspected by a voluntary association in Manchester, 248 were unpaved, 112111 ventilated, and 352 contalned stagnant pools and heaps of refuse and ordure. Yet the street cleansing of Manchester cost 25,000 a year; for which sum the first class streets and the large thoroughfares were eleansed once a week, the second class once a fortnight, and the third class once a month -- leaving untouched the courts and alleys where the poor lived, and where the cleansing was required daily. (1) The immediate expense was the objection usually raised to the extension of the street eleansing services. In fondon an annual bill of $\$ 40,000$ was incurred; but, as Chadwick pointed out, two-thicds of this expense was accounted for by the cost of cartage, which would become unnecessary if the sewers were properly adapted to carry away refuse. So far were local authorities from realising that the sewers offered the most rapid, efficient, and economical means for the removal of refuse and rud from the road surface that in some towns the use of the sewers for this purpose was expressly forbidden under penalties in the local Improvement Act.

But the gravest deficiency of all, since it was the key to most sanitary improvements, was the shortage of water, not only for house cleansing and sewerage, but even for drinking, washing, and cooking. The water companies had got into the habit of intermittent supply at a tire when their mains were nade of hollowed out elm-trunks, which were not strong exough 1. "Sanitary Keport", pp. 38, 53 . 
to withstand the pressure of a constant supply. Though cast iron mains were now in use, they still clung to their old practices, and, Peariag the expense of new plant, were prepared to argue that a constant supply was technical1y impossible. In London the companies supplied their tenante for two or three hours on three days of each week. With a show of generosity they had erected public fountains and stand-pipes in the streets and courts, where the poor were allowed to help themselves without charge, and round these, when the water was running, the inhabitants gathered to catch their supply in pails, fishkettles, leaky casks, cans, and even soup-plates. The house wife who had to carry twenty pailsful a day, perhaps to the third or fourth floos, and baing down sa equivalent amount of waste, was certalnly not so srateful as the companies made out; and, as Chadilck remarked, since every house could have a constant supply for twopence a weex, it was a pecuniary extravagance for even the lowest paid labourer to fetch water. "The interposition of the labour of going out and bringing bome water from a distance acts as an obstacle to the formation of better habits", Ian Chadwick's penetrating comment, "and I deem it an important principle to be borne in mind, that in the actual condition of the lower clasces, conveniences of this description must precede and form the habits. It is vain to expect of the Great majority of them that the disposition, still less the habits, will precede or anticipate and create the conveniences". (1) An efficient sand-filter had been introduced by James Simpson, the eagineer to the Chelsea water Works, in 1. "Sanitary Repoxt", p. 69. Even in middle class districts the register of the cistern was vatched with an anxious eye, and the household amenities expanded or narrowed from day to day wilb the Pluctuations in supply. Uf. a letier to the "Times", 14 July 1851: "Ionday - - water six inches. Cook and housemaid on short allowance. aster's bath relinquished. Tuesday -..- water one inch. Boiled vegetables and teas strictly forbidden. Nednesday -.cistern dry; water nowhere. Thursday -.- the water on. Hurrah! fisten to thet rushing sound. We shall drink --we shall wash - we shall bathe! Ah, in five winutes the stream ceases, and all our hopes are blighted". 
1829, but more than half the metropolitan supply still passed untreated from the river to the consumer. It was hardly surprising that during the cholera epidmis of $1831-2$, the poor in sone districts were convinced that the water had been poisoned to destroy them by a Malthusian-minded Government. In genersl, throughout the country, the well, the ditch, the river whic served also as the main sewer of the town, were the sources from which urbon populations drew their water; and few towns had yet had the enterprise to look further afield for more abundant and purer supplies, which the technical advances of the age had made it possible to pipe and pump to them from upland gathering grounds.

Pinally, Chadwick demonstrated how the inmense expansion of the population had offered bounties to the shrewdness of the speculative builder and the "ignorance, cupidity, or negligence of landlords". (1) The census returns gave the impression that the number of houses had kept pace with the size of the population, but in actual fact every occupation under the same roof had been counted as a separate dwellins; and conditions in the growing towns were illustrated by Blackfriars' parish, Glasgon, where in the years between 1831 and 1341, the population had inereased by 40 per cent. While the number of houses had remained the same. (2) The labouring classes, obliged to dwell within convenient distance of their places of work, must take whatever accomodation they could get. In the old districts of the towns they crowded, from celler to garret, the decryea and superannuated mansions abandoned by the rich. In the new suburbs no scrap of land seemed too narrow, too damp, or too close to a public aidden, to be free from the activities of the jerry builder. Cellar dwellings, lacking drains or 1. "Sanitacy Report", 7. - 7 -
3. "ibid. "The dweilings of the workin-classes in london are
3. "The generally houses that have been disused oy the higher classes, and are let out to them". ("Peport from the select Comittee appointed to consider the regulation of Buildings and the Liprovement of Borough", 1342 (372).X.161. Evidence of Richard Kelsey, \&. 1000$)$. 
conveniences of any kind; back-to-back houses, without the sweetening draught of through ventilation; closed courts, with a stand-pipe at one end and a privy at the other -.. every obnoxious ingenuity in the economy of land and materials that the colculated self-interest of bullders and landlords could devise, and the helpless necessity and blunted sensibilities of tenants could be obliged to accept, was to be found in London and the great provincial towns. No attempt had been made by the Government, apart from Lord Normanby's ill-considered Bills, to deal with these evils. Openings for light and air were actually penalised by the iniquitous Findow Duties. (1) The chief concern of the legislature, as revealed in the Metropolitan Bullding Act, had been to prevent the spread of fires by requiriag the construction of party walls of a minimum thicisness; and no legal obstacle existed to bar the speculative builder from runaing up bouses with walls one brick thick on undrained sites outside the jurisdiction of the Comaissioners of Sewers and the District Surveyors appointed under the Netropolitan Building Act. (2) Viewing the choos of London, $-0-$

1. Cf. the evidence of W. Hickson ("Plrst Report of Healti of lowns Commission" 1844, vol. 2, op. $238-240$ ). "The les1slature now saye to the builder, plan your houses with a.s few openings as possible, let every house be 111 ventilated by shuting out the ligbt and air, and as a reward for your ingenuity you shall be subject to a less amount of taxation than your neighbours". On a twelveroomed house with two windows to each room the charge was 2) 5s. 9d.; if there were only one vindow to each room the charge was di2 4s. 9d. -. though, as Hickson pointed out, a difierence of $10 \mathrm{~s}$. was sufficient to influence the poorer buildere. "I spoke but lately to a man in humble circumstances who had put in his privy a single pane of lass; it was discovered by the assessor, and racher than pay the tay (the noney being an object) the pane of slass wa removed, and the opening bricked up". By 4 so 5 will. If o. 54 occulers, if they were duly asscssed to Hindow rax in 1335 , were pernitted to open as nany windows as they pleased. Ihis step was rendered nugatory by the lawyers, who proved that nobody had been dialy assessed to Nindow Tax in 1335 !

2. "Sanitary Report", pp. 281 - 2. Chadwick calculated that such builder' would eain one house in fees slone if they built forty or fifty fourth-rate tenemenis outside the boundarles witnin which tre Act applied. 
sprawling outwards without plan and without control, Chadwick sighed for the "great design"of Bir Christopher Wren, which, as he told a correspondent, "would from its regularity have facilitated and almost necessitated at a very early period a regular system of drainage below the streets and houses as well as have given a regular sweep of air and complete ventilation above them: the plan excluded a.ll burial grounds all slaughterhouses and noxious trades and prevented the accumulation of inhabitants in courts and alleys. From what is now known of the state of health and the proportions of death, in districts similar to that which the whole of the City of London would have been if sir Christopher Wren's plan for rebuilding it had been carried into execution there can be little doubt that its rejection has (entailed) on every succeeding generation an excess of one third of deaths: a proportionate abridgment of the duration of life, and the extensive extinction of families who then lived within the jurisdiction of the Corporation". (1) Christopher Wren and Idwin Chadwick between them would have made a good job of London.

As be thus surveyed the technical deficiencies in the planning and construction of essential public services, and the universal neglect of the lessons of science in solving the problems of the towns, it became obvious to Chadwick that he must become his own engineer. No one had yet taken the prinolples of hydrsulics and the theory of structures out of the text books and applied them to town drainage, nor had any one jet thought of bringing together all the practical improvements in water supp 17 and housing that, the inventive genius of the period was now making readily available. Chadwick boldly annexed to hinself this vast new province. There were, indeed, at the beginning few to contest his title. The Institute of Givil angineers had been founded as long ago as 1. XXXXXXXXX, n. . Inere is a tribute to Mren's plan in the
"Sanitary Report" p. 288 . "Drafts of communication in
answer to Commissions of Sewers". MS, answer to Commissions of Sewers", MS, n.d. (1843). 
1818, but its nembers were stili strugbling to establish recognised standards of professional competence. Before the eyes of the ablest of the profession, the railway projectors dangled the richest prizes that their talents could command. The engineers of the Water Companies were wedded to the restrictive policies of their employers. In rural districts the highway aurveyors were little better that "ditch casters" or colmon labourers, while in the towns they were frequently decayed builders or tradesmen, few of whon were capable even of drawing, and none placed by education, salary, or station above the temptations of bribery. The surveyors of the metropolitan Comissions of sewars were little better. When one Commission advertised for a surveyor able to use a soirit level, the novel demand set surprised candidates to the task of nastering that complicated instrument. (1) Nhose "wretched empirics the modern engineers?" It was a continual lament with Chadwick that thore were "marvellously few" trustworthy men anongst them; "a more ignorant, or a more jobbing set of men, less to be trugted, as the difference of their estirates and their expenditure will shew, than the comron run of men who dub themselves with the title of enfineer and pretiend to science I bave rarely taet with". (2) Nor were the architects any better, he told the students when be distributed the prizes at the Putney College Por Civil Engineers; the proofs of their incompetence were displayed in "spectacle after spectacle of the ruins of fallen bridges, factories, and large buildings, in horrible deaths, and shocking mutilations occurring again and again from the like preventible causes". (3) Altogether, "in no profession, perhaps, is there so large a proportion of bol, rapacious quackery as in the professions of civil engiveering and architecture" (4)

1. "Sanitary keport", p. 332.

2. E.C. - John Shuttieworth, 9 October 1844.

3. "Ihe Builder", vol. CXXX, p. 36c, c Ausust 1045: "Mr. Chadvick on Wánt of Science in our public "orks".

4. "Papers read before the Statistical Society of Manchester on ..... Labourers engaged in the Construction and Working of Railways", (Damphlet). 1846, p. 23. 
But here and there Chadwick found a shining exception, a man of practical common sense and an inventive turn of mind, who had experimented with ideas of his own. Such a man, for example, was John Roe, "perhaps the only officer having the experience and qualifications of a civil engineer", (1) who since his appointment as surveyor in 1820 had succeeded in introducing a number of improvements in the face of the conservatism and obtuseness of his employers on the Holborn and Pinsbury Commission. Roe had devised a systen of flushing the sewers which had saved 50 per cent. on an expenditure of 21,200 a year; he had reduced the size of drsins for short streets and courts from 4" $6^{\prime \prime} \times 2^{\prime} 6^{\prime \prime}$ to 15 inches in diameter; and, finding that the practice of joining sewers at angles (frequently even at right angles) caused eddies and the deposit of sedimert, and obstmucted the current of water, he had persuaded the Comissioners to require that curves should be formed in the sewers with a radius of not less than twenty fent. Chadwick was delighted, and set poe to work on a series of experibents to ascertain the most economical size of pipe for drains and sewer: and the best materials for their construction. Chadwick's "arterial-venous system" of town drainage, which he elaborated in the next two years, owed much to these suggestive experiments by John Roe. (2) Despite the scepticism of engineers and Comissioners of Sewers, Chadwick could not see why -- if the inclinations of house drains were sharpened, if drains and sewers were formed of glazed earthenware 1nstead of rough spongy brick, if the flow of water were mede more regular and were concentrated in a smootb circular tube ---sewers of deposit should not cease to exist, and excreta be conveyed away from the household by the prompt and cleanly water closet.

1. "Sanitary Report", 2. 55. "Thet officer effected the ouly considerable improvements of a scientific character that have been made in the sevage of the metroolis", (ibid., 3. 317 ).

2. S.C. - Fiditor of the "Builder", 25 April 1355; enclosins letier irom Roe of 13 september 1369, in which hoe descibes the experimente he conducted bets en 1843 and 1345 on tubular arains of glazed eartienware, as suggested by B.C. 
The two main objectioas to the use of the water closet, apart from die cost of its installation, were that it must result in the pollution of the rivers, and that, at the same time and by the same process, it mould permit valuable manure to run to waste. The key to the understanding of Chadwick's eagineexing bchemes, which be sicetcined for the first time in the "Sanitary Report", is his effort to show that neither of these results mas inevitable.

The Ilth which caused disease and 3 iscomfort in the town was one of the richest materials of production in the country; its value was such that it would be worth while conducting its by iron pipes, pumpling it by stean power if the levela were inconvenient, to the adjacent farm land. Town and country thus stood in a reciprocal relation. In the country the land was too often poor and thinly clad with vegetation, except rushes and plants favoured by a.

superabundance of moisture, the crops meagre, the population sparse and afflicted with rheumatiom, ague, and other maladies arising from the prevalent damp. In the town the houses and streetg were filthy, the air foetid, zymotic diseases rife; all springing from the shortage of water and the presence of the animal refuse which was needed by the starved land outside. The solution was the "arterial-venous systen", with the public sewers as the arteries pumplag out the rich town guano, and the water pipes retruaing the excess woisture of the countryside to the place where it would do most good. Two aillions aight be added to the revenue oy the simple expedient of removing the sources of ill-health from wonlon's bass-gitreets. If this income were vested in the public authorities, to whom, indeed, by law and custom it properly belonged, it would go far towards footing the bill for the other puolic services wbich were now so much nerlected. The whole schere was iascinating in its simplicity and economy.

1. "Sanitary Report", 2.37 . Chadujck tave as ressons for the neslect of sewarge irrigation in the past -..- the lack of sclence ard skill; the divisions of interests and natural areas betwen different owners; and the want of powers by local authorities. (Wis notes, various dates). 
If he must turn engineer to rescue the towns from filth, Chadwick found also that he must be equally inventive in his adinistrative proposals. No suthorities existed whose functions had for their conscious object the maintenance and improvement of the public beaith. The Lords in Council had been charged, under an het of Jakes I, to keep watch against the dangers of foreign pestilence, and an sunual sum of 22,000 was voted for the National Vaccination Buard. Beyond this the central tovernment recognised no responsibility for the health of the subject. Svery man had a Comon Lan fight to "air for his heslth, light for his profit, prospect for his pleasure", and the legal remedies of indictment night be invoked to suppress any nuisance which endangered the heslth or personal safety or converiences of the citizen. (1) "Annoyance juries", appointed by the Courts leet, stili perambulated some towns in search of public auisanees, an laquest of reluctant ad ignolant tradesmen which retained its value only in the antiquarian affections of a foulmin Saith. (2) The public continued to suffer because no funds existed for prosecution by indictment, while the most offensive of the nuisances were supported by large capital. In every district iadividuals had usurped despotic powers which stood in the way of public healtb, and which they beld with iapunity in face of the expense, delays, and uncerteinty of the legal procedure. (3)

1. e.g. the corruption of wate, the stopping of wholesome air end licht, or the division of a messuage oy which it was rendered pore dangerous at a time of epilemic.

2. Of. the description of the activities of a typlcal jury, "Senitary Report", p. 300. The superiatendent of nuisances at Manchester told the Health of lowns Comsission ("Second Repont", vol. 1, p. 76), "that it has kitherta been found difficult to support the indictment, in consequence of the inhavitants who have cosplained not atvending to give evidence; and that at the court leet, hel in october, 1940, fourteen cases of public nulsances were dismissed from want of evidence".

3. At Birginghat, for example, the river sea, the town sewer, was slugeish and offensive because the water was diverted by a manufacturer to turn his mill "'Sanitary ieport", . 305). 
Apart from the ancient and ineffectual remedies provided by the Common Law, the state of the public health was the unlooked for by-product of the activities of bodies with quite other aims in view; of Town Councils, for example, not yet quickened by a civic conscience and concerned mainly with the preservation of the archaic dignities and privileges of their members; of Commissions of Sewers, whose traditional function was defence against floods and surface waters, and whose works were ill-designed for the additional burden thrown upon them by the introduction of the water closet; of paving trusts, more concerned to ensure a smooth plow of traffic than the cleanliness of the streets. Host of the early Local Acts, though providing for paving, lighting, cleansing, and watching, contained no powers for the drainage of streets or houses, being framed not for sanitary purposes but for the defence of life and property and the improvement of communications. Nore recent Acts, containing drainage provisions, did not extend to courts which were not thorougheares, these being looked upon as private property and so not entitled to beneflt. Though Local Acts contained a multitude of clauses directed against auisances and obstructions, these were often of little effect, since the nost influential merbers of the Corporation or the Improvement Comission might well be the compuny directors whose gas works contaninated the streams or whose cbimey smoke diarcened the ataosphere.

In the new suburos of the frowing towns, lying outside the jurisdiction of the Nown Council or the Improvement Commissioners, erequently the only powers for drainage were afforded by the Highway Act. (1) These powers were permissive; 1. 5 be vill. IV e. 50. By sec. 18 the vestry, in places containing 5,000 inhabitants, was empowered to elect from 5 to 20 householders annualiy, to serve as a board of surveyors for the repair of the highwag. Sec. 67 pernitted the surveyors to make and cleanse ditches, gutters, lrains, and water courses, and to carry them lato and through adjoining lands on payment of compensation to the owner. 
they were clearly intended only to provide means for carrying off surface water which might obstruct the highway; and their enforcement depended upon the energy and public spirit of a body of unwilling householders, annully elected to form a Highway Board, and commanding the services of a single paid surveyor. Yet in many large towns the drains so formed were often the only available channels for conveying refuse from the household. (1)

In the metropolis the aatural drainage area was capriciously sub-divided between the ancient commissions of Sewers, each of which sat within its frontiers, jealously guarding its jurisdiction against the encroachments of the rest, and stubbornly resisting all attempts to saddle it with the sanitary burdens of a new age. (2) When the Holborn and Finsbury sewers were widened and enlarged, the sewers of the City, which. lay on a lower level and with which they comminicated, became insufficient to carry away their contents, with the result that a number of houses in the vicinity of the river were inundaced by sewer water after each fall of rain. Blind to the absurdity of draining a natural area by unconnected and partial schemes, $-0-$

1. Sec. 115 of the Purnpike Act (3 Geo. IV c. 126) also contemplated the use of road drains for the drainage of the adjacent houses, its operation being limited, however, to those parts which were under the superintendence of the turnpike trustees -.- usualiy the principel streets only. 2. By the Statute of sewers ( 23 Hen. VIII c.5, modified by 3 b 4 Will. IV e. 22), Commissions were to be directed as need arose to "such substantial and indifferent persons" as might be named by the Lord Chancellor, Lord Treasurer, and two Chief Justices, empowering them to sit as a Court of Record, to levy rates, and to execute works for the removal of annoyances and the safeguarding and conservation of the sewers. That the drainage of surface waters was their primary function is shown by sec. 2, which recites "the great damages and losses which have happened by the influx of waters upon marsh ksuts grounds and other low places, heretofore through politic wisume won and made profitable .... as also by occasion of land waters, and othor outrageous springs, in and upon meadows, pastures, low rounds adjoining to rivers, lloods, and other watercourses ....." 
the City Surveyor complained in an aggrieved tone that the waters of the "county" ran into the City jurisdiction, oblifing the Comon Council to enlarge their own sewers. The drainage of houses was not a function that the Comissions regarded as falling within the scope of their normal service. Any one who applied to have a drain laid down froin his house to the sewer was charged a guinea; this fee, which was quite illegal, was defended by one surveyor on the ground that "if they were not to resort to that measure, the sewers would be destroyed. Every one would make a hole in the sewer". (1) When the medical observers of the poor Law Comission were conducting their investigation in 1838, the cleris to the Fower Hamlets division told Dr. Arnott that he had heard few reports of fever in his district - - yet Baker's-Arms Alley, a notorious fever nest, was distant only the length of a short street from his office.(2)

While drainage, which offered no prospect of profit, was thus left as an inefficient public service in the fumbling hands of local authorities, water had become an article of trade, and in all but three or four towns was distributed by commercial companies. These had defects of their own. They directed their supplies exclusively to those houses wich could pay water rates, and took no account of the important public objecta of cleansing sireets, flushing sewers, ani fighting fires. long as a majority of the ratepayers rested conteat with bad water, and dividends were not endangered by public clamour, declared Chsdwick, no improve@ents which lavolved the companies in expenditure could be expected. Competition, the economists' panacea for cheap and efficient service, hal jivea no defence to the inhabitsnts of the capital. Ihe London water companies, with whom Chadwiek was presently to be at open war, had soon perceived that it would be more to their proflt if iastead of cutting each other's throsts they got together in a gentleman's 1. "Sanitary Report", p. 311. For further instances of the attitude of the sewers Comissions, see below, 0.168 6f. 2. ibid., p. 313 . 
agreement to cut the throats of their customers. There had been first a period of wild competition, when two or three sets of pipes were driven through the wealthier distriets, and gangs of rival pipelayers fought in the streets. Then followed a reflective interval while the companies licked their wounds. And finally came a compact between the nine companies to partition London, and subject londoners to a nine-headed monopoly.

One primary public service, water supply, therefore, had been abandoned to irresponsible and arbitrary private companies, who confined their functions within the estimated range of easy profit; two more, drainage and paving, were imperfectly executed by torpid, amateur authorities, who, in the acid words of Chadwick's famous indictment, "sit still amidst the pollution, with the resignation of Turkish fatalists, under the supposed destiny of the prevalent ignorance, sloth, and filth". (1) In all three services, a new direction, a new spirit, and a new organisation were urgently required. As a fundamental principle Chadwick laid it down that "it is only when the public health is made a matter of public care by a responsible public agency that what is understood can be expected to be generally and effectively applied for the public protection". (2) The detailed recommendations which followed from that principle took him another two years to elaborate, but we may note briefly here the main pointa of the preliminary sketch given in the "sanitary Report". All structural arrangements, for under drainage and surface drainage, for road construction and road repair, wust for the gake of efficiency and economy be brought together into a olngle public service. These duties should devolve upon the existing machinery of Comissions of eswers, extended from the metropolis to all parts of the country, and re-designed to bring it into line with recent developments. It was true, Chadwick admitted, that there was much legitimate dissatisfaction with 1. "Sanitary keport", p. 44 . 2. ioid., P. 105. 
their present proceedings; but elective vestries were no better, and entirely open vestries were even worse. There might be some infusion of the representative principle by including as ex officio members the Chairman and Vice-chairman of the Board of Guardians, which would have the additional advantage of ensuring close liaison with the body charged with the administration of relief to those who were rendered destitute as a result of preventible diseases.

Similarly the supply of water should be entrusted to the "most eligible local administrative body". (1) Chadwick had been greatly impressed by that most successful of early essays in the alrection of collective regulation and enterprise, the municipal gasworks of Manchester, established under a local Act in 1817, and managed by an elected comittee of ratepayers. They supplied gas as good in quality, and cheapes, than that supplied by companies in neighbouring towns, he pointed out; they had shown themselves more ready to adopt improvements; and their profits, to the amount of $\$ 10,000$ a jear, formed a public fund for the improvement of the town, for such public projects as widening the streets and building a lown Hall. Another notable example of public enterprise came from Bath, where the Corporation supplied more than three-quarters of the town, in competition with four small private companies; their water rents amounted to $23,233 \mathrm{2s.}$, their expenses to no more than 2449 3s. 3d., leaving a proitt of 22,783 138. 9d., which went to the reduction of the borough rate. "The advantages of this system over private companies appear to the great and incontestablen, the chaplain of the Bath Union assured Chadwick, "Here are no expenses for solicitors, or litigation between rival companies, no exorbitant salaries to the variety of officers which every separate establishment demunds, no collusion between coalescing companies to ralse the charges to

1. "Sanitary Report", p. 30 .

2. Bor the history of the lanchester gas works, see 8 . and B. Webi, "Statutory Authorities", pp. $262-2 / 3$. 
the utmost amount that the inhabitants will bear".

As for

the customary objection of the economists that public officials were less efficieat than those in private employment, chadwick saw in it an echo of the old argument he had confronted before, that "government does everything badly", and he dismissed it with the reply that "ordinary service may be obtained for the public, if recourse be had to the ordinary motives by which such service is engaged in private companies". (2) Chadwick had not yet worked out in full his theory of public utilities, but in the "Sanitary Report" he made his first authoritative pronouncement in support of the movement which, before another hundred years were out, was to place in the hands of public authorities four-fifths of the water supply, two-fifths of the gas, four-fifths of the tramways, and two-thirds of the electricity undertakings.

It had been frequently suggested (most recently by the Report of Slaney's Select Committee (3), that/Board of Health should be elected in each locality to supervise the sanitary arrangements. Assuming that such a Board were elected, ouserved Chadwick, its activity would in any case be dependent upon the services of a full time medical officer, charged with the duty of hunting out the physical causes of disease in the houres of the poor. The public medical service, as it existed, was fragmentitious and incomplete, with medical oflicers appointed as inspectors of prisons, asylum visitors, Union surgeons, exalabers of recruits, conductoss of post rortems part time sppointments which brought in only such sums as 240 or 250 a year. Phere was a strong case for putting a wide district under a superior asdical man, with the duty of inspecting schools, places or work, and lodging houses, besides visiting the fever aests pointed out for his attention by the returas of the superintendent registrar. A "Bingle securely1. Rev. Whitwell Elvin - B.C., 11 January 1342.

2. "Sanitary Roport", p. 77.

3. See above, p. 80 . 
qualified and well-appointed responsible officer" of this type would be far more effective than a Board of Health.

Chadwick thus revealed that in local sanitary

administration his ideal was a compact Commission, appointed by the Government, executing or supervising public works through a competent full-time engineer, and working in co-operation with a qualified medieal officer of health. As he had tried to ensure that the relief of the poor should be in the hands, not of elected Guardians, but of a paid permanent official, so he now insisted that the public health was not a matter to be left to local representative bodies. Nearly ten years of day to day contact with the corruption and petty intrigue of vestry politicians had taught Chadwick a profound and bitter contempt for the workings of representative government. From the Poor Law keport down to the latest product of his inquisitive spirit he had been displaying in countless instances the ineptitude, the stupidity, and the greed of the men who were thrown up promiscuously by the process of election. Under this system the public service had come to be regarded principally as the means of rewarding the elector who "voted straight". A tailor woula sell his vote for a legal clerkship, or the volice of an "illiterete tinman, a leading speaker at parish meetings", would be bought for a surveyorship worth $2150 .{ }^{(2)}$ In the open vestries, he once told hord John Russell, "the chief recomnendation to an appointment are that the Candidate has lived all bis life on the Parish, has falled in Trade, and has a Alfe and ten Children dependent upon him for support". (3) This distrust of elective bodies extended to the House of Commons, for the heads of the political executive were the locel party managers writ large, and they thought in political not administrative terms, seeking rather a satisfied supporter in the constituency than an efficient officer in the department of state.

1. "Sanitary Report", p 356.

2. ibid., p. 332 .

3. E.C. - Lord John Russell, 3 July 1330. 
Besides the corruption bred by the elective process, representative government led to a further mischievous error --- the belief that the public business could best be conducted by unpaid amateurs, elected to serve their turn as civic officers, as Highway Surveyors, Paving Trustees, Sewers Commissioners, or Town Councillors. This implied, eirst, that the public business offered no problems which could not be solved by any gentleman who gave to it a eraction of the attention he gave to his own affairs; secondly, that any gentleman who served in such a capacity would look for no reward other than the respect of his fellow citizens and the approval of his own conscience. Both these assumptions were vigorously denled by Chadwick. "The legislature, in making demands for such honorary services", he wrote, "has usually proceeded on the theory which views all those who may be called upon to render them, as persons qualified to understand the whole subject intuitively, and having no other interests or views than to perform the services zealously for the comion weal; whereas, in the locality they are viewed in a totally difierent light, not as public officers, but in their private capacities, as owners or tradesmen, competitors for advantages of various kinds. Howover unjust this impression may erequently be, it is the impression that cosmonly provalls; and since all of one class cannot have a share in the administration of such funds, others of the same class, whether owners or tradesmen, view the persons exercising the power as rivals, and distrust their administration accordingly. As an owner, one nember of a local. Board is stcongly indisposed to any line of operations that will apparentiy improve the property of another; a d as an ane too, he is under the stroneest jeslousy if he proposes or does anytiains which may appear to benefit his own property at the public expease". "(1) Throughout his career Chaduick was combating 1. "Sanitary Report", p. 323. -0- hearins that Dickens was regaring to publish his notes on his American tour, chadwick commented "... I hope he who has so well exposed (Continued on next page) 
this legacy from a leisurely, aristocratic tradition, the belief "that unpaid dilettanti service is cheap service"(1), and opposing to it the principle of administration by salaried experts; for these, being paid, could be held accountable, they possessed special aptitudes for the work, and they stood above local conflicts, viewing the local scene from the impartial aspect of the wider community.

(Continued from previous page) parochial administration will do something better than that inaccurate observer and rash seneraliser de rocquevilie and not countenence the mischievous falsehood of mob flatterers that special qualifications and knowledge for administration is unnecessary: that the capacity for it is intuitive ...." (L.C. - ?, ? September 1842).

Cf. "flotes on paid and unpaid local administration in the poor law service", iss, n.d. (after 1354): "The services of a gentleman of education, or of practical experience when he gives his continued attention to the subject are bejond any price and it is the highest pleasure of a permanent public officer to serve under the most intelligent direction But their services are too frequently transient: the Gusrdians can only attend occasionally: he cannot usually see in their dwelings the condition of the people relieved or know their histories: and it has been the strongly expressed opinion of the public servant whose views have been the most extensively adopted in the lesislation for local administrative organisation, that its puture improverent wust be dependent mainly on the paid officers: on their practical facts and sugsestions, the value of which in general will be in proportion to the constancy of attention and the opportunities of observation. Ihej will be the more valuable and deserving of public suppo t irom their freedom from bias from their freedon from comexions injurious to inoartiality as of employers in respect to their own labourers, owners of houses in respect to their own tenants, tradesmen in respect to their own customers..." 1. L.C. - ? Lord Worpeth, a.d., c. Way 1343. 


\section{CHAPTER 4.}

\section{INTERMENTS REPORT, 1843.}

More copies of the"Sanitary Report" were sold by the Stationery office than of any previous Government publication, (1) to the great satisfaction of the reformers who believed that "its good effect would be (as much almost as by legislation) created by its private influence on society". (2) John Mill, to whom Chadwick had sent the Report in proof, could not find "a single erroneous or questionable position in it, while there is the strength and largeness of practical views which are characteristic of all you do"; the style and arrangement appalled $\mathrm{him}$, however, and be wished that Chadwick would learn "some of the forms of scientific exposition of which my friend Comte makes such superfluous use". (3) The Home Secretary, Sir James Graham, declined to present the Report to Her Majesty, but his vigilance was circumvented by Sir James Clark, the Queen's physician, who gave a copy to Baron Stockmar, "purposely to get him to read the part on Windsor" (5) investigator had described the Royal Borough as incomparably the worst of all the towns he had visited). To many the astounding details came with all the force of a revelation. The medical superintendent of Arkwright's mill at Cromford, for example, despite his opportunities for observation, confessed that he had not previously been aware of the great mortality of the poor as compared with those in more easy circumstances. (6) But others -o-

1. E.C. - Macvey Napier, 11 October 1842 (lacvey Nabiex Papers, f. 175).

2. J. H. Burton - E.C., 29 September 1842.

3. J. . Bill - 8.C., April 1842.

4. B.C. - Col. Phipps (Prince Albert's secretary), n. A.

5. Sir Janes Clark - M. . 21 August 1342. Manners Sutton tola Chadwick ( 5 August 1342) "that Sir James iraham does not find that it has been usual to present Reports of this Mature to Her Majesty".

6. I.Poyson - B.C., 29 March 1843. 
were less impressed, and where they were not openly incredulous greeted the Report with the defensive reactions of disgust or derision. B.C. Iufnell, one of the Assistant Poor Law Commissioners, wrote lightly "your Report reads like one of Ainsworth's novels, and will I think furnish some good hints for deepening the horrors of his next Jack Sheppard production". (1) In Paris a squeamish editor suppressed a review of the Report for the "Siècle" because of its dirty subject. (2) Wany others shrugged their shoulders when it was mentioned to them, Chadwick recalled later, as much to say "it is all very fine but you see the people like dirt and prefer dirt, and you cannot force them to spend money against their will". (3) The hard-headed Dr. Mitchell, asked for his views on one of Chadwick's memoranda, wrote "you have sent me a sheet of matter which to me appears so impracticable so unlike real business that I hardly know how to deal with it. The scheme looks as if made for the whole island but it will bardy suit any one part". He went on to crush detail by detail the absurdity of trying to equip every poor man's cottage with a water closet. Chadwick's estimate of the cost was not nearly high enough. Where was the room for it? If there were room, the people would put it out of order in a very few days. What was to uphold it? where was the tank to be placed? As for saying that the landlord who put in water closets would thereby attract better tenants --- anything like good tenants amongst the working classes were very scarce, and any landlord who thus attracted them would do so only by taking them away from another landlord; so that a scheme which depended upon having good tenants would not be $\mathrm{s}$ scheme on a large scale, and on whatever scale it would be a losing concern. Witchell concluded by imploring bis friend not to let himself down by writing so about bricks and mortar, about which he was clearly so ignorant.

1. E.O. Tufnell - B.C., 27 April 1842.

W.E. Hickson - B.Q., 20 January 1343.

3. E.C. - Sir Fenry de la Beche, 25 December 1343.

4. Dr. James witchell - .. ., 28 February 1842. 
Despite Mitchell's honest doubtg (which nearly cost him his long-standing friendship with (hadwick), the practical value of the Report was instantly recognised by many engineers. At the Putney College Butler Williams began to use it at once as a text book for his classes in civil englneering; and his students, following up Chadwick's suggestions, carried out experimental surveys of Putney and Wandsworth, and prepared the first contour map of the City of London. ( 1 ) When William Lindley was engaged to re-build Hamburg after the disastrous fire of 1842, he proposed to design the city's sewerage on Chadwick's principles of flushing and water carriage. The City Engineer and Architect promptly reported against his plan, basing their objections on passages from the "Sanitary Report", which they were convinced had been writien to indict the evil effects of all sewers upon the health of the population. Not until Chadwick had sent indley written confirmation of his views would the Hamburg Senate allow him to proceed with his scheme.

In political circles some, like Lord Fowick, were now learning with "astonishment and dismay" of the state of the towns, and were beginning to ask themselves whether "we have trusted too much in a case where it does not apply, to the maxim that men should be left to take care of their own interests", whether it would not have been better if "even at the price of some sacrifice of productive power and of national wealth, the state had earlier interfered, and had taken measures which should have opposed some check to so vast an increase of 1. "First Report of Health of Towns Commission", 1344, vol. 2, pp. 447, 454. London "was never surveyed, never had any system of levels, or contours laid down until it was done by the pupils of the college". (B. - Butler illiams, n.d.) 2. William indley - .C., 18 April 1343, 13 june 1843. "Your Report has been to me most valuable and the people of Hamburs will feel the benefit of it in many of their structural arrangewents. any of the Citizens speaks of it, as that "excellent eport" and I have been obliged to send copies to Bremen and to Berlin". (William Gindley - i.d., 25 october 1342). 
population, without some corresponding increase in the machinery for maintaining order and decency, and diffusing the blessings of education and religion". (1) Lord Normanby was already a convert; he had thought the account in the "Vever Report" of 1833 exaggerated, till Southwood Smith conducted him on a tour of Bethral Green and Whitechapel. (2) Ashley also, with the Doctor as guide, had been to see and smell for himself the houses in Cowyard, Blue Anchor, and Baker's Court. (3) But the Government, in the person of Sir James Graham, maintained a wary reserve. Too many interests must be disturbed, too many tenacious preconceptions must be abandoned, too many innovations in the scope and structure of adrinistration must be accepted, for any hasty decision to be made by a Home secretary in 1342 , whether be were a Whig or a Tory. The Health of Towns Comission, described in the next chapter, gave the Government the breathing space and the strengthened arguments that they required. Thus, a fes individuals, like Ashley and Normanby, were already convinced that the State must stretch out its power to avert the yearly doom of disesse and death in the towns; many more, like Howick, were uneasily aware that past indifference and inactivity had produced a problem whose solution could not much longer be postponed, and these awaited only a positive plan and a strong lead; but by a vast inertia the ideas of most legislators continued to move in the deep grooves cut by habit, and confortable thinking, and that unquestionisg acceptance of the questionable that men call faith. The time for legislation was not yet.

Ignorance and interest found a colour of theory for their opposition in the teachings of that complacent achool of philosophers who claimed to see in the operations of misery and disease the workings of beneficent economic laws. "ihat error of Wr. Malthus stands as a wall agalast meagures of sanitary 1. Quoted by J.L. and B. Hammong, "Lord Shaftesbury", pp. 98-9. 1. Quoted by J.L. and B. Hammong, "Lord Shaftesbur
2. C.L. Lewes, "Dr. Southwodd Smith", $69-70$. 3. ibid., and mododer, "Life and ork of the Seventh Barl of Shartesoury", vol. 1, p. 361. 
improvement", cried Chadwiok in exasperation. (1) It met him at the outset of his public health campign as it had met him ten years earlier when he began his Poor Law investigations, that fatalistic view that the pressure of population must in the nature of things lead to a large amount of unavoidable distress, that "undefined optimism" (2) which found ground for inaction in the belief that the ravages of disease formed a natural or positive check, a "terrible corrective"(3), to man's tendency to multiply beyond the means of subsistence. Fars and plagues, thought MacCulloch, tended to place an old country in the situation of a colony; they lessened the number of inhabitants without in most cases lessening the capital which existed for their maintenance. This assertion Chadwick strenucusiy denied, in his Reports and in discussions at the political liconomy club. Such flgures as he had been able to collect, from America and liurope as well as Great Britain, showed that districts where mortality was greatest had also the bighest birth rate, and that the losses due to pestilence were more than made up by new births. "In one of the llldrained and ill cleansed and over crowded courte where there was a heavy mortality I once observed, to one of the women living there: "Why the undertaker is never absent from this place". "No, nor the midwife either, was the reply and it was then crowded with young and puny children". (4) Nor could it be maintained that the "corrective fates" left the capitol of a country unchanged, since they swept away bany workers at the helght of their productive powers, diministins the proportion of adult worcers and increasing the propostion of dependent children and widows. 1. "Sanitary Heport", p. 176 . July 1344.

ibid.

is notes, n.d. Nearly half a century later Chadwick claimed that he had told llalthus at the political tconomy Club, just before his death in 1334, "the fact of the quick reproduction of human life in the bigh rated districts of death. He was quite astonished that this point had escaped his observation". ("Mational Health", ed. B.N. Richardson, (1390), p. 313). 
"The losg of capital from the pestilence might be explained to a farmer .... by asking him, "what would be the effect of the "corrective" on the four footed population of his farm: if of the colts born he could only rear one half, and if the working period of those reared were reduced by pestilence from an average of ten years to an average of five years". (1)

1. "Heass of Answer to J. MacCulloch's positions as to pestilence being corrective of population" (WS notes of a paper read to the Political Economy Club in June 1345). cf. also the detalled discussion in "Sanitary Report", pp. $182-3,193-5,204-5$. The M3 notes are fragmentary, but the direction of the argument may be grithered from the following extracts:

"The proof that pestilence does not ordinarily diminish the humbers of the population is conveyed in masses of statistical evidence proving that wherever the proportion of mortality is the greatest, so also is there the greatest proportion of births .... We notice as examples two at the opposite end of the acale of health. In the county of Hereford in the year 1840: the proportions of deaths were 1 to 64: in the county of Lancaster they were that jear I to 32: in Herefordshire the proportions of births were 1 to 45: in Lancashire they were 1 to 26: in Herelordshire the encrease of the population between 1831 and 1841 had been only 2 per cent. whilst in Lancashire with its double mortality it had been 24 per cent. though a proportion of this encrease is doubtless ascribable to emigration". "To follow Wr. MacGulloch's illustration: the number of the colony will not be reduced: the proportions of widows and children and helpless hands will be encreased by the work of his corrective Pates. The capitsl of the comunity is lessened by the maintenance of upwards of 100,000 orphans, whose orphanage was created by premature, and as is shewn preveatible deaths oscurring to the fathers below 45 years of age: and by upwards of 30,000 destitute widows whose husbands died thirteon years at the least before the natural period and left them dependent on the poors rates...." "The small pox", says Mr. Malthus, "is certainly one of the channels and a very broad and deep one which nature has opened for the last thousand years to seep down the population to the level of subsistence: out had this been closed others would have become wider, or new ones would have been formed". There are large assumptions in such pasegges: as of what are the intentions of providence: and that population is kept down at one level: physicians see ague disapsear but they see rheumatism previl: and for aught they know extend: and in the absence of any proof to the contrary they assume that the proportions of death are (Continued on next page 
Let it be granted then, said Chadwick, that the ratios of Malthus' hypothesis were as well founded as the theory of gravitation; one could adrait the tendency of all stones to fall to the centre of the earth, and yet deny that in actual experience any stones actually did so fall. (1) The truth was that the belief was quite fallacious that the economic condition of the labouring classes was depressed. In that Malthusian stronghold, the Political Economy Club, he was smazed to flad the impression that the wages of cotton workers were continually decreasing under the inexorable competition of excessive numbers. Another unfounded deduction of the "hypothesists"! Actually, he pointed out, an analysis of the purchasing power of the wages now paid as compared with those of an earlier geaeration proved exactiy the contraxy. "The same jarn which cost my father 12d. per 1b. to make in 1792, a.1 by machinery, now costs only $2 \mathrm{~d}$. per $1 \mathrm{~b} . "$, a Lancashire manufacturer told Chadwick in 1841, "paying then only 4/42. per head wages weekly, now 3/3d. or more; yet those wages amounted then to 5/2d. per 1b., and notwithstanding the higher wajes, now to only ld. per 10." And, he continued, the price of provisions was ag high in 1792, and of clothing was 30 or 40 per cent. Higher. (2) In Stockport, Chadwick told peel and Graham in Jecember 1343, wages had recently averaged $11 /$ - per head for man, woman and child, twice the amount gaid in the agricultural dietricts. Guch wages for cotton o eratives were "beyond their capacity of Irugal application". (3) The turbulent welsh minews were also "an example of an uneducated population whose wages had advanced beyond their habits or means of employing toen in the best $-0-$

1. "heads of Answer to J. HacCulloch's positions ...."

2. "Sanitary Report", D. 183.

3. " "iemorandum on present condition of manuiacturing Districts" sent to Peel and Granam in December 1343. Only a tragment, pp. 12 to 25, of this interestins its is to be found amongst Chadwicis's papers.

(Continued from previous page) not diminished. The mortuary registers now consulted yield a difier nt account they shew that the proportions of deaths are dioinished ...." 
manner for theix own advantage, who had no foresight, no gelf control, and no capacity to make reservations in times of prosperity for sessons of depression. They were in that state in which high wages were equivalent to excess of drink or excess of some sort". (1) And the excess was too often divided between the publican, the Dissenting Minister, and the Trades Union agitator. Whenever he heard it objected that the worising classes could not afiord to pay for improved housing and drainage, Chadwick would point to the smount of their "selfimposed taxation" as reflected in the excise returns. On liquor, beer, tobscco, and smuff, they spent $\$ 45$ or 250 millions annually, more than the whole expenditure of the Government on the administration of justice, the civil service, and the army and navy. The town of Bury alone, with a population of 25,000, spent 254,190 each year on beer and spirits, 22 3s. 4d. a head, enough to pay the rent and taxes for 6,770 new cottages at 28 per anrum each. (2)

Fever was born of distress -.. so ran the easy generalisation of the politicians and economists, the corollary being that prosperity was the one cure for epiemics. (3) The

1. K.C. - S1r James Graham, 11 July 1843.

2. "Sanitary Report", p. 227. Also "Draft Memorsnda on the exposition of the Budget", is fragment, $\Delta$. .

3. When Cobden made a statement in the Comons attributing the excessive mortality to unemployment, Chadwick commented: "Employment has increased very wuch of late in the Metropolis but it has not checked mortality. If cobden runs his bead against the universal lacts he will get it broken". (B.C. flon. C.P. Villiers, 6 February 1345). "the reports state that fever everywhere diminished during the distress", he noted in 1843. "In Paisley it was stated to be not one quarter of what it had been during periods of regular work: the mortality certainly diminished in England in the manufacturing distress and has increased conspicuously since the return of work". The docters would ptotably ascribe this "partiy to the fact of the operatives having been, duriag the stoppage of their work, alore in the open air than in their own close unventilated and filthy rooms, and partiy to the clrcumstance of the unusually long continuance of fine dry weather". (E.C. - Dr. N. . Alison, 7 December 1343). 
records of the fever hospitals, Chadwick replied, showed that the pestilential miasma which caused disease was governed more by the weather than by the state of the market. "It has been rife in periods of prosperity, it is there in times when work is full, it is here also when bread is cheap as well as dear, and the plenty is often poisoned by it".(1) Liverpool and Manchester, the two most thriving cities in the country, were also the most unherlthy. It was true, of course, that the districts where the reatest mortality occurred were probably the poorest, but not invariably so. It was the physical circumstances of place which determined the mortality rate, and in the American cities, New York and Philadelphia for example, the mortality was greater even than in Dublin. This fact crushed "the notion propagated here, that disease was evidence of pecuniary distress and that high wages and self government and democratical or dmerican institutions are the best remedies for all social or at least sanitary evils". (2)

The population theory of llalthus was Chadwick's favourite example of the uaverified assumptions on which economists based their recommendations and statesmen built their policies. He was on firm ground when he asserted that the rise in sverage real incomes, and the concurrent increase in both population and wealth, showed that the limits of subsistence had not in lact been reached.

He was right to urge against llalthus that, as Carr-saunders puts it, God lever sends mouths without sending hands, 3 that in the Britain of his day the Nemesis of decreasing retums was held at bay by improvements in agriculture and in the technique of production, that"the labourer goes into the market as a prolucer, rather than as a competitor". (4) He was right to insist, in the race of that loose complacency which, from a dread of over-population

1. E.C., hs Iragment, a.d.

2. B.C. - Lord Francis Geerton, 1 Detooer 1345.

3. See the discussion of population theorles by Carr-saunders in "ilstory of Civilisation", ed. Lyre, vol. 5, pp. $362-75$. $3 i$. 
saw good in a heavy death rate, that "every labourer who, over and above his subsistence, produces a surplus, or a return to make it propitable and worth while to employ biz, is of pecuniary value, and his death a loss, economically considered, as much as the destruction of a machine, with its purchase and maintenance, and that the more there are of such labourers, the better for the community, merely economically considered, just as a comanity is ali the better the more it has of productive machines in actual employment". (1) Unfortunately, however, while deriding the smugness which characterised muny of Malthus' followers, he adopted certain complacent doctrines of his own. Iie was led to argue that there was littlo in the circurstances of the lower classes that good drains and pure watez and improved housing, combined with intelligent administrative arcangements, could not cure. Their diet was ample enough; a working woman, he aaintuined, to lose children and reproduce them again in such rapid succession, aust be robust and wellnourished, and her physique could not be reduced and attenuated by starvation; (2) and, in the comparativ healthiness of the inates of prisons, fed as they were on low-priced diets, he saw evidence that the population was suffering not from insuffleient food but actually from injurious over-feeding. Their hours of work were not excessive; Chadwick, who drove himself hard for anything up to sixteen hours a day, probably never felt the full force of the arjument for a ten hour dey. As for their wajes -.. "such wajes as those now (1343) paid at stockport and lanchester vlewed with relation to the interests of the worisiub classes are deemed excessive uy some of the best informed nanufacturers. paradoxical as it may appear, it may be asserted that the workmen in Manchester would jet more by lower wages; an ap roximation to the country wsiges supposing prices to remain the same would yield to the capitalists profit and the means and inducements to carry on the works

1. "Report from the select Comittee on kailway Labourers",

2. E.C. - john wilson, 5 Januery is44. 
uninterruptediy. On this topic I had occasion to observe to one manufacturer "It being as you describe that you are making no profitg: and that wear and tear are going on without replacement, that is (a) course wibch can have but one end, as injurious to the workmen as to the manufacturer whose capital is destroyed. Considering yourself as the steward for the labouring population of the fund from which their means of subsistence must be obtained are you not acting an inprovident part for them in allowing it to be eating up: and in not enforcing a reserve by a proper reduction of wages?" The reply has been "It rust come to that at last". "Why should it be protracted; since every day it proceeds is in aggravation of future suffering to the workpeople?" "We hope and we do not like to breaic up our establishments".". (1) It is not surprising that between Malthus, who told them they could never be better off, and Chadwick, who told them they were botter off than they thought, the working classes could see little to choose.

The "Sanitary Report" was presented on July 9th 1842, and aearly a jear was to elapse before Chadwick embariced on the extended inquiry under the Roalth of Towns Commission. The Intervening months wore occupied by Chadwiak in preparing a Supplementary Report on Interments in Towns, a subject owitted from the "3anitaxy keport" as "too sreat in its extent, and too specil in its nsture". (2) A finsl chapter, and that the grimest, remained to be added to Chadwick's senitary survey, and without a broak he plunged single-handed into what was to prove the most aisagreeable and thankless of his investiotions.

the overcrowding of the graveyards was only a special aspect of the central roblem of civic police xhich the enomous 1. "Memorandum on oresent condition of Manufacturing Districts", December 1843 .

2. P.P. $1843(509)$, xil. 395 
growth of the population had thrust into the unready hands of nineteenth century administrators. As the housing accommodation of the metropolis was insufficient for the number of the living, so the graveyard space was insufficient for the number of dead Londoners. In earlier times the churchyard had been the resting place of the plous among his forefathers and the refuge of the superstitious from vampires and ghouls. The channels of habit had been cut deep by the centuries; and even when the churchyard was hemmed in on all sides by a forest of brick, and ten parishioners required burial where one had been buried before, the custom maintained its hold of burying in the holy ground within the walls of "God's Acre". "In the metropolis, on spaces of ground which do not exceed 203 acres, closely surrounded by the abodes of the living, layer upon layer, each consisting of a population numerically equivalent to a large army of 20,000 adults, and nearly 30,000 youths and children, is every year imperfectly intereed. Within the period of the existence of the present generation upwards of a million of dead must have been interred in those same spaces". (1) In Gernan cemeteries the number of interments per acre had been fixed by law at 110 each year. In the same area the London gravedigger had to find room for probably twice that number of bodies annully, and perhaps for ten, twenty, or even thirty times as many. (2) Faced by the physical problem of burying more corpses than could be accomodated by the ground at his disposal, he had perforce resorted to sross expedients. It had always been usual for the site of a jrave in the comon

1. "Supplementary Report", p. 27.

2. Chadwick gives the average number of burials per acre as: Parochial Grounds 191; Protestand Dissenters 197; Loman Catholics 1,043; Jews 33; Swedish Chapel 103; Undescribed 294; Private Grounds 405. The average for all intramural grounds was 203. But these averages conceal the great ifferences between the various frounds. Thus, the highest number of burials per acre in any ground Chadwick estimates as: Parochial Grounds 3,073; potestant bissenters 1,210; Boman Catholics 1,613; Jews 52; Undescribed 1,109; Priurte Grounds 2.323. (ibi1., 0. 133). 
churchyard to be used again for the reception of subsequent Benerations, after a decent interval in which the memory of the departed as a person had faded from the thoughts of the survivors and his physical remains had decayed in the earth. But now the body was scarcely laid in the soil before it was rudely disturbed to admit another. Twenty or thirty fresh corpses might be crowded into a grave, the whole festering mass being lightly covered with earth which was stirred continually by dogs, chlldren, and the sexton's spade; and when the close packed earth could hold no more, bodies were broken and hewn into pieces to fit them into a smaller space. In the common graveyards human remains were literally treated as ashes and dust, and bones lay scattered on the surface or were wheeled to a heap in the "bone-house". At the burial ground of the Tottenham Court Road chapel the gravedigger confessed that seven or eight adults and twenty or thirty children were deposited in each grave, the opening being only partially closed after each new interment. The churchyard of St. Olave and St. John in Tooley street had a pit sixteen feet deep and twelve feet square in one corner for the reception of bones thrown up by the gravedigger's spade. Church vaults were never lilled up, because the older coffins mysteriously disappeared, the bones beling wheeled away in cart-loads as farm manure, while the lead was stripped from the colfins and sold by the sexton or gravedigser. (1)

For the sanitary reformers, believing that "mimal matter - $0-$

1. Conaltions in many provincial towns were no better, as the inquiries of the Inspectors of the board of Health revealed. viliam Gee, suming up his impressions of the towns he had visited in 1849 and 1850 , declared "Of these 59 burial grounds, there are only 5 in which uny interment can take place with safty to the living; 30 others ape full of bodies in al1 states of decomposition; 12 are crowded, heaps on hesps, with undecomposed bodies, and the revainias 12 are nothing less than horrible masses of putrid human remains". "Report to the General Board of Realth on Interments in Towns visited đuring 1849 and 1850", 1351). 
In a state of decomposition is injurious to health"(1), the Grand Guignol horrors of the churchyards were deepened by a further fact -- that an epidemic might well be started by exposing a putrid body. In tondon there were upwards of two hundred graveyards, two hundred centres of pollution, each pouring off, day and night, the exhalations of decay, and the morbific matter, whose deadilness was shown if it got into the slightest cut, might be breathed into the lungs when it was diffused into the atmosphere. Plague and typhoid might thus be generated amongst the overcrowded town populations, just as "dissecting-room fever" had been known to sirike down the students and attendants who handled the cadavers in the medical schools. It was on this deduction fxom the crude pythogenic theory that Dr. G.A. Walker, "Walker of the Graveyards", based the attack on the dangers of intramural interment which he launched in 1837. (2) In the Commons the campaign was led by James Mackinnon, another of those parliamentary francs tireurs who from time to time ranged themselves at Chadwick's side, banging away enthusiastically at some well-loved target, the soap duties, quarantine, factory smoke, or the window tax --and more often than not embarrassing him with their half-baked schemes and uncontrollable tendencies to 1 y of 1 at a tangent. When, on Warch 3th 1342, Mackinnon moved for a Select comittee on the burial of the dead, he began with the words "Amongst th. ancient fgytians ...", and there was an immediate burst of laughter. The Home secretary, Sir James Graham, admitted, however, that some legislative interference was "ausolutely necessary", and consented to the appointment of a comittee. By August Mackinnon was ready with the draft of a Bill to

1. Southwood Smith - E.G., 11 Warch 1343.

2. He told Mackinnon's Comittee that he believed that the fever in the Clemeat's Lane district was chlefly due to the atate of the "poor ground" there, which as long ago as 1814 the Hesuinster Improvement Comissioners had ceported to farliament could no longer be used fur interment. (ws. 790 792,321 .

3. Hansard, vol. 61, pp. $231-3,3$ March 1342. 
implement the findings of his Comittee; and Graham, hesitating to move against the religious and customary prejudices and the strong sectional interests with which the subject was hediged, turned for fuller information to Chadwick.

Mackinnon had been concerned only to abate the dangers and indecencies of existing burial practices by ensuring that interment should take place at a distance from the boundaries of the town, the arrangements being controlled by a paroofchial "committee of health" under the general supervision of the diocesan or of a Central Board in London. opened up the attack on a wider front. Chadwick at once remarisable power, he confronted the social conscience of the law-making classes, numbed as it was by indifference, ignorance, and the anodyne of interest, with a picture of the working class family, caught in a web of custom and economic circumstance which could be broken only by the benevolent strength of the central government. The grossness and mudile of the desecrated graveyards seems to have touched something deep in Chadwick. Perhaps in no other report of his is the criticism of unregulated private enterprise so fierce, and the argument so cogent that "habit combined with associations of profit often prevents or blunts the perceptions of the most offensive remains."( $(2)$ We can see him, note-book in hand, probing his 1. See "Report from the select Comittee appointed to consider the expediency of rraming some legislative enactments to remedy the evils arising from the Interment of Bodies within the precincts of large towns and of places densely peopled", $1342(327) \cdot X \cdot 349$. Mackinnon introduced $h$ is Hill "for the Improvement of Health in Towns, by removins the Interment of the Dead Irow their recincts" (1342 (533). II. 603) on 4 August 1842 , its main provisions being:
1. Burials should be removed, say, one mile from the boundaries of the town.

2. Cemeteries formed within the previous ten years were to be exempt from the Act.

3. Prochial committees, formed of the incumbent and churchwardens, were to be empowered to raise funds by a peany rate to purchase land, or to contract with a cemetery.

4. The arrangements wi hit be supervised by the diocesan, or preferably by a Central Board, which might also supervise drainage and ventilation. (Hansard, vol. 65, pp. 1030-33). 2. "Supplementary Report", p. 3. 
witnesses with sharp questioning --- the gravediggers, prematurely aged, with their shrunken figures and cadaverous aspect, solemnly swearing to the bealthiness of their occupation; the robust keeper of a dissecting theatre who had never suffered 111 effects (though, to be sure, his assistants did the most dangerous and dirty work, and eight of them had died, some being dissected in the very theatre in which they were employed) ${ }^{(1)}$; the employers, shrugging away the early deaths of their workmen, with "But they drink -.- they are a druaken set" (2); the cemetery owners adding to their profits by "working the earth close"; the secretaries of the burial clubs revealing the lantastic finances of their societies, the undertakers urging a "respectable funeral", the clergymen pocketing their fees and perquisites, "a silk scarf of three yards and a half, a silk hatband, and black kid gloves". (3) We can feel his toounting impatience with their shifts and equivocations, and share something of the enthusiasm with which he invokes the power of goverment to tidy up the mess.

In a very large proportion of cases in London and the manufacturing districts, one coow was the sole accommodation for the whole family. "In this one room they are born, and live, and sleep, and die amidst the other lnmates". (4) It was their bed-room, their kitchen, their wash-house, their sittingroom, their dining-room; and, if they did not go out to work, it was frequently their work-coom or shop as well. The

secretary of the Statistical Society, conducting an inguiry in the inner ward of St. George's, Hanover Square, discoveredthat out of 1465 families, 929 had a single foom and 403 others had only two; of the same families 623 had a single bed, another 638 only two. Thus, about one family id eleven possessed a third room, and that usually not unoccupied, in which to place a corpse. Yet this district was a favour ble specimen. In Marylebone, out of 608 families, 159 occupied part of a room, 1. "Supplementary Report, p. 3.
2. ibid., p. 9 . 
382 had one room, and 61 had two; only five families had three rooms, and only one had four. (1)

Stretched out on two chairs or a board or shutter, the body must awalt burial, while the normal life of the family went on around it, the family eating, sleeping, working, the children playing, in close proximity to a corpse perhaps still covered with the visible marks of disease. (2) It might remain there anything from five to twelve days, since for the working classes sunday was the one day free on which they could bury their dead, and if a death took place in the middle of the week, the body was irequently kept until the Sunday week, while subscriptions were being collected. Corpses had been retained, according to one undertaker, even after the coffins had been tapped to let out the liquid products of decomposition, till maggots were seen crawling about the floor and over the trestles on which the tapped coffin was supported, till, as the body was borne away, escaping matter ran down the shoulders of the bearers. (3) When the cause of death was an infectious disease, the results could be predicted. The louse, carrier of typhus, deserted its chilliag host, and a vietim of typhus had been known to be followed very shortly to the grave by five of his children and two or three visitors. (4) "If the returns and the statements of witnesses acquainted with the crowded districts be correct, that four out of five families of the labouring classes have each but one room", Chadwick summed up the inescapable conclusion, "then every unit of upwards of 20,000 deaths per annum which occur in the metropolis,

1. "Supplementary Report", pp. $31-2$.

2. The medical officer of Bt. Martin-in-the- ields stated that he had recentiy ordered the removal of a girl to the infirmary, after visiting her room. "I could not remain two minutes in it; the horrible steach arose from a corpse which had died of phthisis twelve days before, und the coffin stood across the loot or the bed, within eighteen inches of it. Inis was in a small room not soove ten feet by twelve feet square, and a fire always in 1t, belng (as in most cases of a like kind) the only one for sleeping, Living, and cooking in". (ibid., p. 33 ).

3. 1bid., p. 38 .

4. Ibid., p. 36. 
every unit of 4,600 deaths of the labouring classes which occur annually at Liverpool, must be taken as representing a horrible scene of the retention of the corpse amidst the family in the manner described in the testimony of those who have witnessed it; -.. and every unit of some 4,000 deaths from epidemics in the metropolis, and every third or fourth recorded death in other towns, and even in crowded villages, represents a distressing scene, and moreover a case of peculiar danger and probable permaneut injury to the survivors amongst whom it taires place". (1)

Why, asiced Chadwick, picking up the next link in the sordid chain, why was burial so long delayed amongst the lower classes? The answer plumbed the depths of human haoit and social custom. In a lew cases -.- one in thirty the secretary of a burial society estimated -- it was due to the widow's reluctance to part with her husband's remains. But in the majority of cases the reason was the high cost of dying, the lack of money to defrsy the expenses of interment. "The desire to secure respectful intement of themselves and their relatives is, perhaps, the strongest and most widely-diffused feeling amongst the labouring classes of the population. Subscriptions may be obtained from large classes of them for their burial when it can be obtsined aeither for their own relief in sickness, nor for the education of their children, nor for any other object". (2) The greatest dread of the poor was a pauper burial, in a bare parish shell, borne by pauper bearers to the "bone-house", the customary receptacle for suicides and those unfortunates who were deserted and without relations, and even "God-forsasen". (3) It was estimated that a fourth or a third of the $424,000,200$ in the savings banks was earmarked for burial expenses, and even workhouse inmates were not infrequently found at heir deaths to have concealed a noard to pay for their ow decent_intement. The enforcenent 1. "Supplementary Report", p. $43 . \quad 3$. ibid., p. 94.

2. 1bid., p. 55. 
of undertakers' bills formed a large part of the buginess of small-debt courts; and one undertaker told Chadwick that if they did not give time for payment to two-thirds of their customers, the poor would not be able to bury their dead at all.

This "pride" of the working classes, rooted in long custom and in the courage of self-respect struggling in adversity, made them the easy victims of the burial club and the undertaker. In Vestminster, Marylebone, Finsbury, Tower Hanlets, and the city, there were about two hundred burial societies, organised usually by one of the small, grubbing undertakers and the publican of the tavern where the meetings were held. Membership ranged from 100 to 800 and deposits from 290 to 21,000 ; contributors usually paid $1 / 2 \mathrm{~d}$. or $2 \mathrm{~d}$., and relatives received a benefit of from 25 to $\$ 10$. (2) Invariably one provision in the rules was that the box should not be removed to any other public house, and the publican counted on receiving the sixpence spending money allowed to each Committee man, besides the patronage of the undertaker's mutes, who were

1. Cf. the complaint of Robert Carr, carpenter and undertaker, to the select Comittee of $1342(Q .679)$ : "In many instances persons say, "we cannot bury under a. week"; that is irom custom. Others have not the means of getting a black gown, and they cannot follow in a coloured one; that is their bit of pride; then it is put off, it may be, two or three days on that account. They will not have their relatives ouried. by the parish; they would rather do anything than that, saying they wish them to buried respectably; and then the end of it is, that myself, and other people like me, often bury for nothing, not intendiag to so it. They cheat us; and if they would do away with their little pride, and let the parish do it, the bodies would be renoved in a reasonable time, and such men as myself would not be imposed on as we frequently are".

2. "Supplementary Report", p. 57. The last London Burial society, for example, wet at the Swan in bethnal Green; its president and founder was Richard Crafer, undertaker. Preston had six clubs with a membership of 30,000 , the chief of them, with 15,164 members, paying out di, 000 a year raised by weekly contrioutions of kd., Id., I/kd. and $2 \mathrm{~d}$. walsall had 90 priendly societies with 5,000 members, who spent a total of 21,239 3s. $4 \mathrm{~d}$. a jear on drink and feasting. ( $p$. 57, 60). 
notoriously heavy drinkers. Thus, the undertaker president had the funeral orders, while the publican treasurer had the members' custom, and in addition the handling of the money, which he usually banked with the brewes at four or ilve per cent. interest.

As a form of insurance, Chadwick demonstrated, this system was completely unsound. Actuaries showed that the premiums were excessive; one Preston society, for example, charged 7s. 10d. for a risk that an assurance colupany would cover for 3s. 9d. --- so that, making every allowance for the cost of management, the members paid at least one-third in excess. (1) Moreover, since the undertaker president had an interest in admitting bad lives, the societies frequently failed. The same rate being charged to members of every age, the younger men perceived that they were paying more than they should; if they were in a majority, they revolted, broise up the club, and so deprived the older men of the benefit for which they had long sacrificed. Ihere was some evidence, too, that multiple insurances on the lives of children, by placing "interests in operation against woral duties"(2), acted as bounties on neglect and infanticide. A child could be buried for 21 or al 103. The clubs allowed from 23 to $\$ 5$ for the purpose; and the child might well be in four or five societies. Hence the common phrase in vanchester: "Aye, aye, that child will not live; it is in the burial club".

By this time Chadwick was far beyond the range of previous explorers of the subject, and was embarked on an uncharted sea that James Mackinnon and " alker of the Graveyards had not dared to penetrate -- and whither 3 ir James Graham made no attempt to follow him. He now turned to make a merciless analysis of the trade in burial. On the mortality returns of 1. "Supplementary Report", p. 62 .

2. MS Iragnent, n.d.

3. "Supplementary Report", p. 64. A case was recorded of a child being entered in nineteen clubs. 
the previous three jears the number of deaths in Iondon averaged 114 a day. Competing for those 114 bodies the Post office Directory for 1843 enumerated 275 persons whose sole business was undertaking. In addition, however, there was a multitude of inferior tradesmen, who retained the undertaker's insignia in their windows for the sake of one or two or lers a year; drapers, tallors, bakers, publicans, even butchers; carpenters almost without exception, and all those engaged in any way on the working of wood, cabinet-makers, upholsterers, packing-case makers; as well as appraisers, auctioneers, sextons, and parish cleriss. (1) All these obtained their funeral supplies from one of the principals in the trade; and in the last analysis it was some sixty of the principal undertakers who performed the real service, the inferior agents merely interposing their unnecessary offices, and stepping up the charges to allow for their own remuneration. The undertakers' trade thus presented the spectacle of increasing numbers of competitors engaged in an increasingly violent competition --- but the result was heightened prices, the very reverse of that which common economic theory dictated. The case was, however, anomalous; for the competition was unreal, and was destitute of the element of free choice on the part of the purchaser of the service. Anxiety, common decency, and the necessity for the immediate performance of some of the last duties, prevented the friends of the deceased from going from tradesman to tradesman, as if they were dealing with an article of commerce. When a death occurred, the funeral benefits were so much "exposed prey" (2) for the undertaker. The experienced tradesman would find out how maxy societies the deceased belonged to, and whether sio, 215, 220 or more was the amount due to the widow, and he would then arrange the funeral accordingly. Once the funeral was over, the widow could not dispute the bill without laying herself open to the charge that proper respect for the dead was begrudged. The estimates were therefore never scrutinised
1. "Supplementary Report", pp. $53-4$.
2. Ibid., p. 52. 
closely. The undertaker was told to provide "what was respectable", and his interpretation of respectability involved a liberal profit to himself. The total cost of funerals in ingland and Wales in one year Chadwick calculated to be about 24,371, 493. In London alone probably nearly a million pounds was annually thrown into the grave. (1)

The Commons Committee of 1342, under the influence of its chief vitness, the Bishop of London, had been strongly in favour of the continuance of parochial control, and Mackinnon in his Bill had provided for the establishment of extramural cemeteries under the management of a parish committee of health. Chadwick brusquely rejected the suggestion that the evils connected with burial should be remedied by the very agency under which they had sprung up, and which had hitherto maintained them in the face of all remonstrances. Fuxtramural ceneteries under parochial management had in fact been tried, he asserted, and had failed. St. Giles'-in-the-Fields, St. George's, Hanover Square, St. James', Westminster, and St. Martin's-in-the-Fields had obtained Local Acts for the purpose forty or fifty jears before. All four grounds were now as closely hemed in by buildings as were the old parish churchyards. In the two acres of the 3t. George's cemetery a thousand corpses a year were being interred, while in the 46 years of its existence the chapel and ground of $5 \mathrm{t}$. James' had cost 250,000 more than the receipts. (2) These examples would be multiplied if each of the 170 parishes of London were empowered to open its own ground, to be managed by ignorant sextons and gravedisgers, under the control of a local board which was exposed to the influence of personal interests and lacked the knowledge to grapple with a subjeci requiring a high degree of science and medical sirill.

In Government circles it was felt that, if the parish adninistration had failed, the solution was to trust to the operation of attural economic forces, to that pursuit of 1. "Supplementary Report", p. 70 .
2. ibid., pp. $97-8$. 
individual profit which, as a by-product, brought about the benefit of society. Already the majority of Dissenters, who could not be admitted into consecrated ground, together with many Anglicans who were appalled by the condition of the churchyards, were burying their dead in cemeteries owned by Individual entrepreneurs or joint stock companies. Unfortunately, Chadwick bluntly revealed, the arrangements of the capitalists showed as little regard for health and decency as those of the sextons and sravediggers. Host crowded of all were the private cemeteries, usually owned by undertakers, where, as one Dissenting minister testified, the heaped soil thrown out from the graves was saturated and blackened with human remains and fragments of the dead, and the splash of water as the coffin descended into the grave sent shudders through the mourners. Churchmen sneered at these "Dissenters' grounds". The Dissenters retorted that they were in fact general cemeteries, and that the majority of those buried in them were not members of Nonconformist congregations, the practice belag for some unqualified, uneducated man to don a surplice and read the Anglican or any other form of service that the mourners desired.

Nor were the joint stock cemeteries, more recently established under rivate Acts, so superior as their shareholders claimed. They calculated on 11,000 interments in common graves for every acre, though well considered regulations allowed no more than 1,452. One company, burylng more than five deep, had made 217,000 gross profit on each acre of its ground. The only effect of the cemetery Acts, in which neither the promoters nor the Commons Comittees had seen flt to insert the improvements sugbested by the best foreign experience, had been to remove burial to better lookins and uaually better situated srounds; which, however, mecely sezved to transfer the evils from the centre to the periphery of the towns, so erecting obstacles to the nealthy growth of the suburbs.

1. Kev. John Blackourn, Secretary to the Union of Congregational Dissenters; "Supplemontary keport", p. 135. 
In the disposal of the desd the casual operations of Inglish capitalists and parochial authorities lagged far behind the achievements of the benevolent absolutisms of the continent. Interments within the walls of Vieana had been forbidden by Maria Theresa; the eight extramural cemeteries of paris had been established as long ago as 1765; in 1794 the Preussisches Landrecht had decreed that no burials should take place in churches or in the inhabited parts of towns. In English political circles, however, the administrative devices of the forelener, if referred to at all, were usually mentioned not as examples to be emulated but as awful warnings to be avoided. It was a prejudice not shared by Chadwick, who based his recommendations for reform on a close study of continental models, and in particular the municipal cemeteries of Frankfort and Munich and the Parisian "gervice des Pompes Funèbres". With a sever logic, which conceded nothing to the interests in burial, he sketched a radical and comprehensive scheme, which met in turn with a well-designed remedy every abuse that he had enumerated. All interments in towns must be prohibited, "without any exception of places, or acceptation of persons". The joint stock ceneteries and the private grounds must be bought out. The churchyards must be closed, their sites being kept as open spaces for the public use. In their place national cemeteries should be established, on ground selected according to scientific principles, with suitable decorations and vegetation chosen on the best artistic advice; and these publicly owned cemeteries should be managed by officers possessing appropriate qualifications. The danger and indecency arising from the prolonged retention of the corpse in the one-roomed homes of the poor should be averted by providing "reception houses" (sc. mortuaries), such as those at Francfort and Munich, to which the body was removed by the mualcipal authorities on the notification of death, and where it was kept under medical inppection for three days before burial. The 1. "Supplementary Report", p. $\mathbf{1 9 8}$. 
public officers in charge of the cemeteries should be empowered to enter into contracts for the supply of funeral services and materials, which might be offered to the public on various scales, such as those lald down by the funeral monopoly in Berlin or by the "gervice des Pompes Funèbres" in Paris, which supplied nine classes of service on a fixed tariff, besides burying free of charge about one-third of all who died each year in the city. While individuals should be free to obtain supplies elsewhere if they chose, the aim must be the gradual extinction of private supplies of funeral materials and services (1)

By such large-scale contracts the funeral expenses of the upper and middle classes might be cut by at least two-thirds, while artisans could be buried at half the present cost; the total saving on burial in London alone would be about $\$ 350,000$ a year. The initial cost of the national cemeteries could be defrajed by a loan, the annual charges being met out of a fund into which all burial dues were paid. Apart from the cemetery owners who were to be dispossessed, the interests of three sroups were affected by the scheme, the clergy, the Dissenters, and the undertakers. The clergy should be compensated for the loss of their burial fees; the Dissenting congregations who lost their graveyards should receive an equivalent space in the public cenetery.

But Chadwick could see no reason to hold out promises to the hundreds of inferior tradesmen who gave themselves the title of andertaker.

It is the most courageous, the most clear-cut, the most coherent of a.l bis schemes; but it bears on 1 ts face the prophecy of the failure, which dogged it for the bight unhappy years of lts history. Chadwick had forgotten nothing. Fe believed that he had answered by anticipation all objections, conciliating those bodies which had legitimate interests, exposing and rebutting those whose claims could not be justified He was soon to find that to answer an ergument was not to 1. "Interment in Towns. Memoranda of the Cnlef Heads", eragment, n.d. 
silence an opponent. He had shown that abroad the various parts of his plan were at that very moment working effectively and to the satisfaction of the people. The problem remained of convincing finglish statesmen that ideas which thrived under German despotism or French centralisation could bear transplanting to the freer soil of kngland. Chadwick concluded his Report with the appeal that the Government "should only set hands to this great work, when invested with full powers to effect it completely: for at present there appears to be no alternative between doing it well or $111 \ldots . .$. (1) A Tory Home Secretary of the eighteen-forties, called upon to interfere with large masses of capital, to arbitrate between the Church and the Dissenters, to lay on Government a delicate and unaccustomed burden, might well hesitate and consider that between the two absolutes of "all or nothing", "well or 111", that Chadwick presented there stretched an infinite possible series of piece-meal improverents.

There remains to be discussed what Chadwick regarded as the pivot of the whole scheme, a proposal, however, which had an independent life of its own, and so may be considered apart Iroin the interments problem with which it was at first inseparably linked by Chadwick. This was his suggestion that local authorities should appoint medical officers of health, to perform certain necessary duties connected with the public burial service, and in addition to carry out other sneasures of medical police. In 1843, in Liverpool alone, engaged in the business of cure or alleviation, Chadwick found 50 physicions and 250 surgeons, apothecaries, and druggists, while not one responsible public officer was emplojed to investigate the causes of disease with a view to prevention. Nor had the
of London, with a population of 125,000 , one such offlcer, L. "Supplementary Report", p. 201. 
though it spent 272,000 a year on hospltals and medical

charities for the alleviation of disease. (1) There were, it was true, scattered over the country, the 2,327 medical officers in the Poor Law service. (2)

But these were cramped and starved

in their activities by the parsimony of Sonerset House; they were subjected to unwholesome influences ${ }^{(3)}$, and their miserable 1. "Supplementary Report", p. 189.

"I Pind that in this county (Lancaster)", Lyon Playfair reported to the Fealth of Towns Commission in 1844, "there are, according to the census, 76 physicians and 1,246 surgeons and apothecaries. To make up prescriptions there are no less than 1,259 cherists and druggists. Here, then, we have a body of 2,581 men connected with the medical prolession; and supposing that each practitioner, on an average, seceives 2300 per annum, we have a sum of $\$ 774,000$ per annum devoted exclusively to the business of the cure and alleviation of disease, and not one single professional man appointed, not one public endowment or provision made to ensure attention to the means of prevention; nothing devoted to ascertain the causes of death; nothing done to remove those causes of disease which are proved to be removable; nothing done to warn against defective drainage and to promote external and internal eleansing; no visits to ensure the due ventilation of schools or workshops, of mines or houses; nothing done to point out the influence of various noxious agencies to the public health, -- cesspools, slaughter-houses, grave-yards, or offensive and injurious trades! In short, at least five million pounds per annum (sc. Playfair's estimate of the value of the adult labour lost by preventible disease) are paid to sustain the attacks of preventible disease against the population of this county and not one pound to remove or weaken the sources from which these attacks gain strength". (Second Report, vol. 2, pp.

2. Chadwickis figure in a letter to Normanby, 3 Bebruary 1841. In December 1846 the Commission employed 2,680 , each of whom averaged 30 visits a week. (Hicholls, "History of the English Poor Law", vol. 2, pp. $405-6)$.

3. Before Ashley's Medical Rellef Comnittee (184.4) some of the witnesses "developed a very maleficent source of adverse interest, the interest of the influence of the landlords of small tenements who are guardians for particular parishes. These men who have little to do but to collect thejr weekly or other small rents are apt to get into parochial office and as members of Boards of Guardians to insist upon outdoor poor relief in money which is in fact payment of their own rents out of the poors rates. In proportion as (Continued on next page) 
pay did not free thef from the necessity of attending private patients, so that, as Chadwick testifled, many of them "hold office merely to keep out rivals or interlopers from their fleld of private practice; they serve very unwilingly and are in perpetual hostility with the Boards of Guardians". (1)

In the England of the eighteen-forties, bowever, the medicsl profession as a whole had great need to put its house in order. Of 1,830 medical men who presented themselves to fill offices under the Poor Law Commission in 1834, 327 had not been examined in surgery, 323 had not been examined in medicine; and 233 had not been examined by any wedical body at all.

The twin oligarchies of the Physicians snd the Surgeons were less conceraed to advance medical acience and caise professional standards, than to essert the superiority of their members in the face of competition from "Scotch doctors", the lowly Apothecaries, and the "Eeneral practitioners" who were now boing turned out in increasing numbers by the Hospital Schools.

(Continued from previous page) they are profuse in this expenditure they are niggard of any other. And the medical officers state they dare not report on the 111 condition of dwellings for fear of offending this class and getting dismissed by them on some collateral complaint against which they have no protection. Hence the argument for making the medical officers irremoveable except at the instance of a aistant an impartial and responsible authority". (E.C. Dr. Layeock, 29 April 1844).

1. "College of Physicians reply to. Controversy with the College of Physicians and its jealousy of the first General Board of Bealth", NiS, n.d. (e. October - December 1843).

2. Speech by Sir Benjamin Hawes on Second Reading of Medical Reform Bill; Hansard, vol. 57, pp. $329-33,17$ Miarch 1341.

3. "The General practitioners have bitherto been in antagonism to the College of Physicians. The College of surgeons has not been more popular with them. Howsoever disguised, the main source of dissatisfaction arises from the fact of it being one class of private practitioners, legislating, regulating, or assuming to determine, gualifications and emoluments of the other classes of private practitioners and by consequence their own position and emoluments in relation to them ....." ("College of Physicians reply to", uh, n.d.; see note 1). 
The profession was expanding rapidl], and in the absence of a public criterion of competency and a recognised course of training it abounded with opportunities for quackery, abuses of practice, and the toleration of the unqualified and the inefficient. It is little to be wondered at that in the social controversies of the time the spoicesmen of medieine sometimes out a very poor figure; that one Select Comittee should severely comment on "the iguorance of some who set up for surgical practitioners" (1); and that a Minister should be able to find, when he wanted them, 43 doctors out of 48 in favour of a measure to enable children over twelve years of age to work a full day in the factories -..- so reversing the findings of a Royal Commission two years earlier, before whom only one doctor out of 31 supported the same proposal. (2) Nevertheless, as Ashley bore witness, in the factory agitation he received more help from the redical men than Irom the clergy, (3) who only too often were "cowed by capital and power". (4) And from the first, when Chadwick sent Arnott, Kay, and Southwood Smith on their tour of investigation in 1838 , the doctors were the strongest supporters of the sanitary movement, from the jueen's physician, Sir James Clark, and the University professor, W.A. Guy, down to the dispensary and hospital physicians, Joseph Toynbee, Thomas Laycock, William Duncan, and the unnamed rank and file of the Union surgeons and general practitioners. "Of all the professions, the members of the medical profession are the shortest lived and the poorest", said Southwood Smith, speaing at a public meeting to raise a subscription for the family of br. J.R. Jynch, a brilliant young surgeon whose life had been cut short by a fever contracted in the slums.

1. Select Committee on Factory Act, P.P. 1841, ix.p. 8.

1. Select Committee on Phomson; Hansard, vol. 32, p. 273, 15 March 1336.

3. F. Hodder, "Life and Work of the Seventh Sarl of Shaftesbury", vol. 2, p. 209.

4. ibid. "Holth of Towns: Report of the speeches of Edwin Chadwick, Bsq., Dr. Southwood Smith, Richard Taylor, Isq., James Anderton, ssq., and otbers", pamphiet, 1347, p. 10. 
Visiting patients in their one-roomed homes, and encountering some of the same hazards and iscomforts, they saw the obverse of that splendid picture of power and wealth which dazzled the eyes of the rajority of the ruling classes. (1)

While welconing these allies, Chadwick was watchful of their pretensions. Nedicine had its part to pley in the defence of the public health, but it was not the pre-eminent rôle that most doctors would clain for it. The doctor's efforts aust be strictly subordinated to those of the engineer and the adninistrator; and in proportion as the sanitarians were successful in rooting out the causes of disease irom the environment, they would render less necessary the traditional ministrations of the medical man. In 1843 the public medical service was represented only by the Union surgeon, whose cheapness and servility were despised and reseated by their fellow practitioners. (2) Yet the publicly employed medical officers, if their status and qualifications were inproved and the scope of their duties widened, could perfom more valuable services to society than the private dealers in physic, concerned as these were with the effects of disease, not its causes.

1. "Often the family doctor minglas in the crowd of millpeople as they leave at night and greets them again in the early moraing as they congregate to their toils without his having, uneanwhile, pressed his pillow. Byd the way it is a curious sight -. the swarming streets at a quarter past five of a cold stormy winter morming. Who but this poor drudge sees it? Host educated people who live on the spot don't know that the labourers, men, women, and children, rise at five, be the weather fine or foul at the sound of the bell to their work ......" (Dr. John Roberton - Mrs. Chadwick, 14 Pebruary 1345).

2. "They are generally considered to be the enemies of the profession, who undersell their Brethren; and rush into danger not from any necessity on the part of the public; but simply for a miserable pittance wich they accept as the full value of their exertions to the great detriment (as it is considered) of the better educated and better qualified part of the profession". (Dr. J. Sutherland E.C., 30 August 1847). 
Already in the "Sanftary Report", as we have seen, Chadwiok had urged that the fragmentary functions executed by part-time medical officers should be combined and entrusted to a single full-time district officer with superior qualifications (1) He nowwent on to argue that, if burial were to become a public service, such an appointaent would be essential. On the occurrence of a death the officer of health would be sumnoned to inspect the corpse, and would note the name, age, occupation, and cause of death. He would urge the relatives to have the body removed to the reception house as soon as possible, and would alsc supply them with a tariff of the prices of burial. If the death had been caused by the insanitiary condition of the premises, he would notify the officers of public works so that they might taike steps to cleanse and whitewash them at the owner's expense. In cases of epidemic disease, he should be empowered to order the removal of other members of the family to the hospital fever ward. (2)

"The ordinary service of such an officer would consist of the verification of the fact und cause of death, and its due civic registration", states Chadwick. (3) This is indeed a very oblique entry upon the duties of a liedical opficer of Heulth, as the term is now understood, but there were strong reasons why Chadwicis should stress this and other functions which in modern society are performed by the general practitioner, the registrar, and the undertaker. For all civic and scientific purposes, declared Chadwick, the existing system of recording deaths was gravely deficient; it was ureless for determining titles to succession, for furnishing data for insurance tables, and for showing the common causes of disease incident to different occupations and localities. During the plague of 1595 the Privy Council had ordered that all bodies should be viewed before burial, and that the minister or churchwarden of 1. See above, p. 113. -o-
3. "Supplementary Report", pp. $160-166$.
3. Lid., p. 159. 
the parish should make weekly returns of deaths to the magistrates, who should forward them to the Privy Council. From that date until the Registration Act of 1836, the parish officers had appointed as "searchers" two old women, frequently pew openers, who merely looked at the body, demanded liquor and a two shilling fee from the ralatives, and certified the fact and cause of death as they were informed of it. No provision was made in the 1836 Act to replace the "searchers" by more efficient machinery. The only qualifications stipulated for the local registrars were that they should be resident in the district, solvent, and without any clashing duties ${ }^{(1)}$; and they were not in any event required to visit the house of the deceased and enter the details on the spot. Popular rumour and the suspicions of neighbours were thus the only securities against foul play. In London inquests were initiated by parish beadles or constables, to whom they were a source of emolument, and Instances were known, and more suspected, where they had been paic to keep silent. Most of the local registrars had encountered cases of prima facie suspicion which had eluded

1. In a letter, addressed probably to Lord John Russell, Chadwick criticises the unsuitable character of many of those appointed as Superintendent Reigistrars under the Act of 1836. Thus, at Manchester a Calvinistic Dissenter had been appointed, so outraging all Churchmen and all Dissenters who were not Calvinists. "Having had occasion to go to Leeds whilst staying at the house of a leading whigg I heard expressions of regret at the impression created amongst persons of respectability by the appointment of the Superintendent Registrar of that town: the first Superintendent one George Rawson was a lecturer on temperance i.e. In beer not politics; an itinerant anti corn law agitator; a non conformist preacher and an agent for the "Reform Interest". His sub registrar Thomas Wilson was an Inn keeper and reform agent. I believe it will be found that it would in a party point of view have been worth while in every case of such an appointme nt to have given each person three or four times the amount not to have their appointment made or to have sent then elsewhere, to have given them expensive outfits and to have sent them for example as justices to Sierra Leone or to the West India Islands, to any part of the Erapire except to the towns where they were known". ( 8 January 1841). 
these flimsy safeguards. Fow many children perished from overdoses of "quietness", Chadwick wondered, or were more slowly and painfully polsoned by it? How many died as a result of incorrect treatment for croup and pneumonia by unqualified practitioners, such as retail druggists, who were in attendance at the death of one infant out of every four? How many were murdered for the burial money? In Scotland, where there was neither coroner nor inquest, the consequences were even more serious. Cases of children overlaid by drunken parents, cases of death from maltreatment in prison, from drinking wagers, from falling into machinery or down pit-shafts -- all went without investigation. Unless a complaint were lodged, the police rarely interefered; nor did the procurator fiscal or the magistrates, for a demand from these judicial officers to inspect a body would be regarded as tantamount to a charge of crime. (1)

Chadwick's first argument for the officer of health, therefore, is grounded on the principle that "all difficulty, all labour interposed in the way of the commission of crime, is so much gained of a practical preventive tendency". (2) At present any one might go to the registrar's office to record a death, and the only check was the registrar's judgment whether or not the statement was consistent. "There may not only be no death nor body, but no such house or no such habitancy. Require that the registration shall be at the spot where the death took place, and the signatures to be there taken of witnesses present, then you impose on the persons wishing to forge the difficulty of finding an appropriate house, and appropriate witnesses: -- require that the registration shall be upon view of the body, and the law interposes another difficulty, and a very formidable one -.- that of finding a 1. "Supplementary Report", pp. 113, 160, 170- 173. 2. "Health of Towns Improvements. Draft Clauses for consideration in respect to the appointment and duties of Officers of Health", MS memorandum, prepared for the Health of Towns Commission, 1844. 
suitable dead body".(1)

The argument is sound, but the problem of preventing Praud and secret murder was to be solved along different lines, when the attendance of the "fanily doctor" ceased to be a luxury out of reach of most working class homes. Greater interest attaches to Chadwick's second main argument. "They may in that position obtain in years, or even in months, indications of the certain means of prevention of disease, for which the medical experience of ages has supplied no means of cure, and only doubtful means of alleviation ...... For the promotion of the new science of prevention, and the knowledge of causes necessary to it, a primary requisite is to bring large classes of cases as may be duly observed, under the eye of one observer". (2) The dry grinders employed by the Sherfield cutlers had long suffered from a characteristic lung disease, which cut them off between the ages of 35 and 45, a fate which they bore without complaint or question. Dr. Calvert Holland, by investigating a large number of cases, had shown that the "grinders' disease" was caused by inhaling grit and metal dust, and this discovery had suggested a simpletpreventive device, a current of air to blow the injurious paricles away from the workmen. (3) The views of the medical officers of the army and navy had long been recognised to be of peculiar value in determining the causes of ill-health and indicating methods of prevention. This, Chadwick pointed out, was explained by the fact that they had under constant observation large bodies of men living under similar circumstances, which could be changed at will and compared for purposes of experiment. In the great towns the same opportunities occurred of observing large and organised populations, living under similar conditions; and those of the local registrars who had medical qualifications declared that their position had given them a knowledge of the effects of 1. Ibid.

2. "Supplementary Report", pp. $178-9$.

3. ibid., p. 180. 
habits and locality in producing disease as no private practitioner possessed. (1) An officer of health, assembling and scrutinising the statistics of mortality and sickness, could furnish the accurate diagnosis on which the preventive action of the administrator must be based.

For such duties very special qualifications would be required; and in Chadwick's opinion the ohly safe proof that a candidate possessed the necessary ability would be evidence that he had successfully investigated some scientific problem in preventive medicine. The freedom of action and opinion of the medical officer must be protected by two essential safeguards. First, he should exercise his functions in independence of the local administrative body, since this would probably contain the chief employers, connection with whom would expose him to suspicion of partiality and diminish his influence with the lower classes. It was necessary, secondly, that he should devote the whole of his time to his public duties. "Of a certainty the attention of every private practitioner, as he gains practice, whilst acting as a public officer, must every hour of the day be from his public duties, and with the means of adding to his emoluments. That the least possible time may be taken from them, the public duties are slurred over, conclusions are snapped from the readisst superficial incidents; extensive and removable, but latent causes of evil, the development of which would require sustained and laborious examination, are perpetuated, by being stamped authoritatively as "accidental" or arbitrarily classed under some general term assigning the evils as the result of some inscrutable cause". (2)

In the Report on Interments the officer of health appears chiefly in the unusual character of a recorder of death and a superintendent of burials. We may look ahead a little, and observe how within less than twelve months Chadwick was submitting to the Health of Towns Commission an interesting 1. ibid., pp. $182-3$. 2. ibid., pp. $125-6$ 
memorandum, worthy of more attention than 1t received, in which the appointment takes on the lineaments with which a later generation became familiar. (1) In this paper the functions of the medical officer are greatly widened and enriched. He should be required to inspect periodically the various parts of his district, looking for any external and physical circumstances likely to be injurious to the public health, and taking proceedings for the abatement of public nuisances and the pollution of the atmosphere by offensive smells. He should visit all schools, factories, workshops, comon lodging-houses, public rooms and places of resort, inspecting the arrangements for ventilation and cleansing, and enforcing the law in cases of aickness from wanton neglect. During such inspections, he should "take note of the children or woricpeople, who appear to be pallid or sickly, or in a peculiarly low condition of health, and inquire as to whether such evident low condition have been produced by overcrowding and defective veatilation, imperfect cleansing, or other removable cause". On the outbreak of any epidemic, endemic, or contagious disease, sll measures of precaution and peevention should be under his control, and he should be empowered to issue instructions to all public officers, including the Union medical and relieving officers, surveyors, scavengers, police, and others. Arrangements for vaccination should be directed by him, and he should have power to direct that children lacking certificates of vaccination should be excluded from schools and places of work until the vaceination had been duly performed. He should undertake the analysis of matters sold as food or drinks, taking measures to stop the sale of dangerous, injurious, and unwholesome adulterations. He should inspect all children who applied for certificates of age, strength, and bodily ability for labour in mines and factories; and also all recruits for military service. - 0 -

1. "Health of Towns Improvements. Draft Clauses for Consideration in respect to the appointment and duties of officers of Health", MS, n.d. (C. December 1844). 
And, finally, he should be required to present an annusl report, giving the statisties of sickness and mortality for his district, comparing it in these respects with other places, analysing the causes of each class of cases, and specifixying those causes which be considered to be removable or preventible for the future.

In all this Chadwick anticipates intelligently the later emergence and development of the Medical officer of Health ${ }^{(1)}$, but it was to take nearly seventy years to establish the conditions in which that most valuable of all local officials could function, as Chadwick desired, as an impartial adviser and guardian of the public, independent of local influences, and defended against the intimidation of threatened interests. When the proposal was first made, the leaders of the medical profession were slow to recognise its importance ${ }^{(2)}$; and the $-0-$

1. Chadwick's list may be compared with the duties of the modern M.O.K. as enumerated by Nimesholme, "Ministry of Health", pp. 40 - 42. The parallels are close, though changing conceptions of public health have led to the growth of new services which Chadwick could hardly be expected to foresee (e.g. for maternity and chdld welfare).

2. The preparation of a $B 111$ to regulate the medical profession was entrusted in 1845 to Sir Benjamin Brodie, an upper class physician of the old school. The Bill provided for a Board of Health to advise the Government on the mode of dealing with epidemics, Chadwick remarked to the luke of Buccleuch, (31 Narch 1845) but "provides no means that I can see of seeping informed and in practical action the agency that is to inform and act practically".

A Board of Fealth without local agents, such as Brodie proposed, Chadwick told Peel's physician, Dr. J. Hodgson, would be like the Poor Law Board without its Assistant Commissioners, a head without eyes or arms or hands. As it stood the title was a misnomer, since the Board was a body constituted to deal solely with the traditional medical functions of curing and alleviating disease, and preventive action was beyond its scope. (22 April 1845). 
politicians at once objected that it would be "unpopular". As one critic wrote, the powers such an officer would wield were "far too vague and arbitrary; and would be considered an infringement of the liberty of the subject, intolerable in a Iree country. A man's home would no longer be his castle, into which no one must penetrate without a special warrant". (1) In the swarming tenements of Whitechapel and Bethnal Green this talk of inviolate "castles" must have sounded strange, but the argument that the poor would resent having "little inquests" held in their homes weighed heavily with the sentimental middle classes, and diverted attention from the less questionable duties of the officer of health. (2) It was indeed unfortunate that the appointment should have first been presented as part of Chadwick's scheme for national cemeteries and a public burial service, and so shared the disfavour with which that scheme was generally regarded in Government circles. Not till 1846 did Chadwick's suggestions bear fruit, when Liverpool appointed the first liedical Officer of Health, William Duncan, under the terms of its new Local Act. And Duncan was employed on conditions which ran completely counter to the principles laid dow $\mathrm{n}$ by Chadwick. The Corporation paid him 2300 a year only, and allowed him to continue in private practice. For a year he acted merely as a weekly registrar of deaths; when it was urged that he might make reports on conditions in the city, the Corporation refused their consent, "and the reason given was

1. Thomas Stewart Traill - Dr. W.P. Alison, 25 April 1345.

2. "Mr. Macaulay told me that the people would not put up with the doniciliacy visits of such an officer. In answer to this ignorant assumption I pointed to the fact that they do put up with domiciliary visits of every sort. lir. Farr of the Registrar General's office in England has been registering on the spot, as a matter of experiment which has justified all anticipations and shewed the groundlessness of the apprehensions of unpopularity: which if real it were a duty to meet. According to these legislators, the darkest ignorance is to supply the norma of legislation". (E.C. Dr. W.P. Alison, 6 May 1847). 
that if Dr. Duncan recomiended any step it would be needful for the Comititee to take $1 t^{\prime \prime}$.

Fearing that this bad example

might be followed by other towns, Chadwick protested

energetically to the Home Secretary, and as a result in 1848 Duncan's salary was ralsed to 2750 and he was employed on fulltime health duties. (2)

The Interments Report, containing in its sombre pages the most powerful of Chadwick's exposures of social evil and the most revolutionary of his adninistrative proposals, was a strange volume to emerge from a Government department in 1843 . Throughout the sumier its fate was in balance. (3) Chadwick continued to amsss evidence, visiting Manchester, Nottingham, Derby, and Leicester, and corresponding with a dozen other places. When be submitted a revised draft to Sir James Grabam in December, he was able to assert with conildence that any investigator who followed the path he had trodden would find his description if anything an understatement of the evil. (4) He sent the Report out at last as a Christmas and New Year gift to his friends. "It was the most difficult and the most painful of the painful investigations which I have been called upon to conduct", he told Ashley, "and unless it be followed by some $-0-$

1. Dr. J. Sutherland - E.C., 17 February 1843.

2. As the Liverpool Local Act subjected the fitness and salary of the medical officer to the approval of the Home Secretary, he declared, it was within the Hinister's power to withhold his approval for a salary of a size that would necessitate the officer giving some of his attention to private practice (14 January 1847). "I trust there will be no more such atterpts again", wrote sutherland after Chadwick's successful protest, "and that the precedent of interference on the part of the Secretary of State, with the doings of our town council, will teach other public bodies what they may expect if they mistake their duty in a similar manner" (18 February 1847)

3. "I am sorry that your report is likely to be stifled, because I think it the best you have ever written" (Rev. Whitwell Elvin - E.C., 13 May 1843).

4. E.C. - Sir James Graham, 4 Decenber 1343. 
better and more complete adoption of the measures than is usual, I intend that so far as I an concerned it shall be the last that I conduct". (1) The published Report did not rise to the full height of his views, but -.. as he told Lord Lovelace -- "I am as jet only a slave of the lamp (by Lord Althorp's breach of engagement with we)". "My report, your Lordship should remember", he continued, "had to undergo a jealous official ordeal before permission to print was obtalned. I rejoice at having obtained leave to print so much". (2)

As Chadwick had foreseen, the Report was unpopular with the Dissenters, the Cemetery Companies, the undertakers, and churchmen like the Rev. Mr. Pyler(3), who looked like losing ¿800 a year il his churchyard were closed. "It warms one into impatience to see the grand plan adopted", Prolessor owen had written, after seeing the first draft. "I hope you will live to see it in Iull operation: yours will then be --- or ought to be -n the most conspicuous Mausoleum in the chief National Cemetery, and a grateful people, who will only know the evils you have remedied by your descriptions in the effort to banish them, will point it out first to their children". (4) But public monuments and a nation's thanks were far from Graham's nind, when he turued over this plan which coolly proposed to 1. B.C. - Lord Ashley, 13 December 1843.
2. E.C. - Lord Lovelace, 1 January 1844.
3. E.C. - Bishop of London, 22 December 1343.

Dissenters' pamphlets, he told Graham (28 February 1843) "are extremely violent, and carry litule other feeling with them than that of owners of grounds who ere likely to lose money by anything tending to a restoration of the Church burials.

The Irish Catholics are the most troublesome and difficult to deal with and the most likely to resist slterations...... (Dr. Gillis, Bishop oi bidinburgh) consulted the vicar General and others and they gave him to understand that inasmuch as their church at Hoorfields was now full they would make no opposition but felt no interest in the natter ...... Considering the deplorable state of the population, I think it must be confessed that the Church has been very backward not to say culpably remiss in this matter, and the State of the Government which undertakes the labour may rairly claim the rull or chler credit for it".

4. EX. Prof. Owen - E.U., 12 February 1843. 
sweep awsy iraportant profit-making interests, which trenched upon the traditional prerogatives of the Church, and threatened to stir up a buzz of sectarian jealousies. It was soon clear that he would take no step except on the beels of a strong public opinion. One important supporter could be counted upon; the Bishop of London favoured a scheme which would rescue the clergy from the competition of the cemetexy companies with their unqualified chaplains (1), and his insluence offered the main hope of stirring the Home Secretary into activity. (2)

1. He told the Lords (Hansard, vol. 57, p. 1063, 25 April 1341) that the Kensal Green Cemetery had caused a diminution of 2200 in the income of the rector of the neighbouring parish. 2. Graham statei (Hansard, vol. 35, p. 458, 2 April 1846) that he wished the Bishop would introduce a Bill himself, which offered the best chance ol avolding trouble with the Church. 


\section{CHAPTER 5.}

\section{HEAITH OF TOWNS COMMISSION, $1843-1845$.}

Sir James Graham, the Tory Home Secretary, had inherited from Lord Normanby three Bills for the drainage of towns, the improvement of boroughs, and the regulation of buildings, but he had not inherited with them also that nobleman's enthusiasm for sanitary reform. The status quo has rarely had a more devoted spokesman nor a more skilful stonewaller than Sir James Graham. Overbearing in his manner, with a hard, limited wind, massively impenetrable to argument, he opposed all the resources of his powerful will to the social reforms of his time. He had done his best to hold back the report on the employment of women and children in the coal mines. He had -.- says Ashley --- so terrified the Factory Inspectors that, though they shared Ashley's views on the Pen Hour Bill, they did not dare to say so. (1) But, if he resisted Ashley's "Jack Cade legislation", it was not out of a perverse obstructionism, but because, when confronted by the great social questions of the age, Graham, lise Peel, was often at a genuiae loss to see a practicable solution. He had, as a deputation from the fancasbire short lime Committees discovered in November 1841, "drunk too deeply at the fount of Malthusian philosophy". (2) For him the iron laws of the economic order -- perpetual and unchaning since they were rooted in the ineradicable concupiscence of man -..- bound the working classes to a life which be sumarised as "but esting, drnklug, working, and dying". He walked in blinkers, seeing everywhere the linits set by his own preconceptions as the inescapable decrees of nature. It is, therefore, a measure of the effect of Chadwick's reports and of the ground gained by the 1. E. Hodder, "Life and Work of the Seventh karl of 
sanitary campaign, that early in 1843 the Home Secretary decided to refer the question to a Royal Commission. For, as Graham told Peel, in opposing a proposal to inquire into the state of education in the manufacturing districts, "a Comission is most useful to pave the way for a measure, which is preconcerted; take, for example, the Poor Law Inquiry; it is often inost embarrassing where it discloses the full extent of evils for which no remedy can be provided, as, for example, the inquiry into the condition of the hand-10om weavers. I might add Lord Ashley's investigations into the sufferings of children employed in factories and mines". (1) Thus, the sanitary question was moving into the arena of practical politics. Reluctantly, impelled more by the pressure of opinion from behind and without than by the drive of inner conviction, a Jory Home Secretary was consenting to explore the ground with a view to ultimate legislation.

Graham's first move was to halt the progress of Normanby's Bills, which had twice passed the Lords and had reached their Second Reading in the Comons. This action, though it dismayed Ashley (2), met with Chadwick's heartiest approval, for the Whig measures, drafted by the experts of the Woods and Forests department without reference to the evidence collected by the sanitary inquiry, seemed more objectionsble to him with every appearance they made. (3) He was equally pleased with Graham's next decision. Prom vestries and Board rooms 1. C.S. Parker, "Peel Papers", vol. 2, p. 548. 2. Hodder, op. cit., vol. i, p. 361: "The remediel Bills for ventilation, drainage, and future construction of the houses of the poor, brought in carefally and anxiously by the late Government, are not to be adopted by this! so I was informed this evening, and I blessed fod that I formed to part of it".

3. It would appear from chadwick's numerous memoranda on the subject (see above, p. 82), that J.L. and B. Hammond's description of the "drastic and $r$ volutionary character" of these Bills "Age of the Chartists", . 293) overvalues their technical and administrative importance. 
in every Sewers division of London the Government had heard rumblings of alarm and anger, and something weightier than the report of a single Civil Servant would be needed to batter down their defences.

The Sewer Commissioners were, therefore, to be given a second hearing before a Royal Commission. Chadwick, having no fears for their verdict, welcomed the idea; an inquiry whether the principles or drainage he had indicated were applicable to the Westminster division of sewers would in effect be an inquiry whether in the westminster division there was any exception to the law of gravity. The Royal Commission, however, should do more than listen to affronted sewers Commissioners and their protesting surveyors. Chadwick was well aware of the limitations of the sanitary inquest on Great Britain he had conducted brilliantly through three laborious years. To those who, like Ashley and llormanby, pressed for immediate action on the conclusions of that report, he replied that, while he had established the general principles which must Guide legislation, he had not indicated the particular measures in which tbey were to be embodied. The "Sanitary Report" had shown the necessity for comined works and an adequate water supply, but it had not laid down the legislative methods by which those objects were to be attained. It bad coscluded that securities must be taken to easure that public works were constructed by men of practical scill and scientific knowledge, but such securities were so far outside the range of the old style Local Acts that no legal draughtsman could lay his hand at once upon a suitable form of elause. (2) Hence, he urged on $-0-$

1. Richard Kelsey, surveyor to the City Comission, for example in a "Report on the Sewers of London", 5 Septenber 1842, maiatained that "without their surveyors presumptuousiy applying to themselves the, often impudently assumed, and much prostituted title of Civil Bngineer; they have conducted their works with judgment, and foresight, and success". Chadwick amplifled his case ageinst the Sewers Comissions in "Drafts of communication in answer to Comms. of S.", Mg, n.d., probably submitted to irabam.

2. "Memorands of answers to the imputati nis of blame in respect to alleged delay jo adopt sanitary measures", Ms, 13 July 1344. 
Graham, the object of the Royal Commission should be to investigate and demonstrate by actual trial the various means for applying the principles he had established. He dwelt with inexorable detail on the syllabus he proposed to set before ther. They might, for instance, test some of the suggested improvements in house construction; the advantages, in particular, of circular drains of tile or stone over square drains of porous brick. These inquiries, which were usually overlooked as matters of detail, would furnish the basic data for public contracts. The Commission could then go on to consider wider questions of municipal engineering; the practicability of a constant water supply; the capacity and flow of sewers; the means of relieving districts lying below any natural outfall by steam power. And linally, what was equally important -.- for it was useless to demonstrate improvements without showing how they could be paid for -.. they could determine "the jurisprudential arrangements for the distribution of the burthens in coincidence with the benefits".

"It is an important impression to extend", he concluded, "that drainage is a matter of Science or its practical application and not of mere common sense or general knowledge: and that science and special qualifications are essential for the paid officers conducting it. For the sake of extending: this impression I would most respectfully urge the necessity of confining the Commission to persons of special qualifications generally recognised, as men of engineering or medical or legal science". (1)

This eathusiasm for sanitary detail was impressive, if not infectious, and Graham followed Gbadwick's recommendations closely. It was not, on peper, an unpromising list of Comissioners. Southwood Smith was not there, though he of all men next to Chadwick had the right to be heard. But there were Neil Arnott, Lyon Playfair, James Smith "of Deanston", the 1. L.C. - Sir James Graham, $15^{-0-}$ Mrch 1343. 
Pamous authority on land drainage, and the zealous Professor Owen, who once declared "I would rather achleve the effectual trapping of the sewer-vents of London than resuscitate graphically in Natural History records the strangest of the old monsters which it has pleased God to blot out of his Creation". (1) The sanitary cause was gafe with these men. Three of the engineers Chadwick had suggested, Captain Denison of the Royal Engineers, Sir Henry de la Beche, and the younger Stephenson, were also included, together with William Cubitt, the leading building contractor in the country. Chadwick had asked for a lawyer or two; these were denied him, but in their stead Graham introduced a leavening of Parliamentary members, a Scottish Duke, Buccleuch, to act as chairman, Lord Lincoln from the Woods and Porests, and the mover of the 1840 Committee, R.A. Slaney. (2)

Chadwick discovered at once that, though his name had been omitted by some strange caprice of Grakam's, the chief burden of the Commission rested on his shoulders. Some of the medical and engineer Commissioners drifted of inco their professional avocations, while the others, willing as they were, lacked his experience and powers of investlgation. "Enquiries into the habits of the population, consideration of public policy, and art and science in their application to them are not things to be had by intuition", he told the chairman, "and I can confidently aver that if I had not attended to the commission

1. Professor Richard Owen - E. 9 , 9 September 1844.

2. Chadwick asked for the following:

(a) Engineers: Sir Henry de la Beche, Gatain Denison, Professor Airy (the Astronomer Royal), Professor Paraday, Robert Stephenson junr., Brunel junt., James Sinith.

(b) Doctors: Sir James Clark, Weil Aroott, Sir Benjamin Brodie, rofessor Owen.

(c) Lawyers: the Master of the Rolls, Mr. Justice Coleridge, Lord Cottenham.

The Comnission was issued to: the Duke of Buccleuch, the Barl of Lincoln, R.A. Slaney, George Graham, Sir Henry de 12 Beche, Lyou Playfair, D.B. Reid, rofessor owen, Castsin Deasion, J.R. Martin, James Smith, Robert Stephenson junr., William Cubitt. 
night and day most sedulously far different and less satisfactory results would have been produced able as the several professional members of the Comission undoubtedly are on the subjects to which they have devoted their special attention." (1) He took full command at Gwydyr House, when the Comission began its meetings on the 1st. June 1343; he marshalled the witnesses, he took the notes of evidence, he prepared the resolutions, and he drafted the reports. And at the same time he was confronting jealousy and mismanagement at the Poor Law Commission, completing his Interments Report, replying to the cross fire of four of the metropolitan Sewers Commissions, and boubarding the Home office with memoranda on a new Builaings Regulationg Bill "most preposterously devised by the palace architects". (2) He was probably never busier nor more happy in his life.

Under Chadwick's directions, the Coumission first despatched a letter with an appendix of 62 questions to the fifty towns with the highest death rates; these included the largest manufacturing towns and the principal ports, comprising a population of three millions. (3) But Chadwick would not let them rest content with paper evidence. The towns were divided into six districts; and in the middle of July 1843 the active Commissioners set off in ones or twos on an itinerary he had drawn up for them, with a paper of his instructions to guide them, to see for themselves the conditions in the most populous areas. (4) Simultaneously, at a number of provincial towns, at 1. E.c. - Duke of Buccleuch, $17^{-0-}$ December 1345.

2. E.G. - A.G. Escher, 24 December 1343.

3. Health of Towns Commission, "Irst Report", vol. 1, p. Xi.

4. "linutes of Proceedings of the Comissioners for Inquicing into the state of lerge Towns", M.H.?, IS, 18 July 1343. The districts were assigned as follows:

Northern District

Yorisshire District

Lancashire District

North idland istrict

Midland District

Welsh District

Miscellaneous Towas
Dr. Reid

James Smith

Iyon layfair

Lord Lincoln, James Martin

R.A. Slaney

Sir Henry de la Beche

ir Henry de la Beche, James kartin 
Liverpool, Preston, Nottingham, York, and Chorlton-upon-Medlock, where he was acquainted with energetic friends of the cause, Chadwick put them to work to report on the state of their districts. (1) Encouraging them with notes of approval, directing their attention to fruitful lines of investigation, occasionally making a sortie himself to inspect some well designed cemetery or the working of a constant supply system, Chadwick drove forward his unequal team of doctors and engineers and politicians. When de la Beche retired discomfited from a sanitary argument at Windsor, he wrote with an unusual sprightliness to ask "into what geological hole have you got to hide your head? Come out and let us hear the rights of it". To Dr. Laycock, who was preparing a report on York, he suggested that an estimate should be made of the number of medical practitioners whose income was derived from attending cases of zymotic disease amongst self-supporting labourers. "Do not flinch", he added, "at estimating how many would be dispensed with from York or enabled to transfer their labours to the colonies or to productive industry if all sanitary measures within view were adopted! It will look impartial and be popular at the same time". (3) of the hazards and horrors of the inquiry he gives a glimpse in a letter to the Registrar General. "My vacation has been absorbed in visitins with Mr. Smith and Dr. Playfair the worst parts of some of the worst towns. Dr. Playfair has been knocked up by it and has been seriously ill. Mr. Snith has had a little dysentery: Sir Henry de la Beche was obliged at Bristol to stand up at the end of alleys and vomit while Dr. Playiair was investigating overflowiag privies. Sir Henry was obliged to give it up .... The people received the comissioners very well". (4) Usually, however, Chadwick remained in London, examining witnesses at $-0-$

1. Dr. W. If. Duncan at Liverpool, the Rev. J. Clay at Preston, Thomas Hawkesley at Nottingham, Dr. T. Laycock at York, Dr. P.H. Holland at Chorlton-upon,- edlock.

2. E.C. - Sir Heary de la Beche, 22 December 1843.

3. B.C.:- Dr. Laycock, 6 June 1344

4. E.C. - Major Gruham, 7 December 1843. 
Gwydyr House, testing street sweeping machines and jets d'eau, collecting specimens of earthenware pipes from Glasgow and Zurich to compare with the products of the Southwark potters, and arranging experiments to determine the engineering formulae for the construction of scientific water and drainage systems. Over the reports of the Comissionerg and other expert correspondents he exercised a watchful censorship, for error crept in by the most unlikely ways. A paper on French cemeterles by W. B. Hickson, the editor of the "Westminster", was quietly discarded after Chadwick had objected to its excessive praise of French municipalities. (1) When the great Robert Stephenson, "who is recognised as the real inventor of the locomotive engine brought forward by his father", submitted a report on water supply, Chadwick condemed it at once for its shocking ignorance of correct principles, and prevalled upon the Commissioners to reject it unanimously. (2)

By the middle of November 1843 the political members of the Comission had seen and smelt enough of the towns, and were talking of laying their recommendations before the Government. The worthy Blaney, in particular, findins himself with the weapon of a koyal Commission in his hands, was tempted to wield it with too much eagerness. In Chadwick's extended inquiries, and his experiments with earthenware drain pipes and egs-shaped sewers, be could see only a waste of time, and he viewed with impatience the maturation of Chadwick's comprehensive administrative proposals. Chadwick had seen too ruch already of such precipitancy. He recalled the perpetual ircitation at the Poor Law Commission because the Government had withheld the powers for the abolition of the Gilbert Act Unions, and his repeated attempts to replace the other omissions, the district schools, district auditors, and diatrict contracts; the ruining of the Pactory Bill of 1833 because of the excision of the sirong schooling clauses the had advised; and Lord Nomanby's $-0-$

1. B.C. - J.A. Burton, 3 Pebruery 1344.

2. E.C. + Morpeth, 18 September 1848 . 
Bills, prepared in ignorance of the evidence in the "Sanitary Report", to make drains run without wates. The debate was prolonged, but eventually Chadwick could tell his friend, Professor Owen, with deep satisfaction, that "Mr. Slaney was in a very different state of mind, and talked less of doing not more than what was practical, i.e. doing what in my sense is not practical, doing any good by halves". "Completeness of execution wherever the Crown or the Goverament does interfere at all is one great point to enforce", he went on, "The certain good and larger popularity from well executed measures and the essential differences of those now proposed from those proposed previously to the issue of the sanitary report and the Commission of inquiry are important topics. I have sustained much injustice by having half measures and the consequent failures imputed to me. In poor law measures I have been placed in the same sort of conflict, as you imagine, one would be if sanitory measures were to be carried out by men who thought that intermittent supplies of water, and separation of the water supply from the drainage, were safe and wise practical courses. I have been stigmatised by such persons as "over hasty", theoretical: visionary a to over colour...."(1)

To Chadwick's imense relief the "pirst Report" of the Comission was through the press in JaLy 1344. "Iwo thirds of that volume will have been written by me, repot, circular letters and queries", he told his rriends(2), and "the continued labour of examining witnesses was becoming very severe". however, the octavo volumes looked very well, and he felt satisfied that his trouble with them had been well expended. The Governent apparently considered that this satisfaction should be his only reward, for he received no acknowledgment of his services and no recompense for the aditional labour which 1. B.C. - rofessor Richard Owen, 14 December 1344.

1. E.C. - rolessor Richard July 1344.

3. B. - Thomas Hawcesley, 9 July 1344.

4. E.0. - Thomas tawkesley, 1 September 1344. 
had increased his hours of work from six to sixteen. If he had employed the same time in writing for reviews, he complained later to the Duke of Buccleuch, as Cabinet Ministers had been known to do while in office, he would have made more money.

The "First Report" was brief, merely outlining in general terms the conclusions suggested by the evidence, and apart from a few striking passages about the state of drainage and water supply in the provincial towns (which have served historians well ever since) it made 11ttle impact upon the public consciousness. "In Bngland", Chadwick told Lord Normanby, "the extensive apathy to the evidence of the removeable nature of the immense mass of sickness and mortality may only be taken as evidence of a low moral condition and almost of co-extensive brutality: and yet whilst the appearance of the first report of the Health of Towns Commission passed almost without notice, the whole of the newspapers were occupied with the case of the flogsing of a boy by an Irish kagistrate". (2) The jolt given by the "Sanitary Report" to the conscience of the ruling classes was not to be repeated. Chadwick had run into the barrier which faced another reformer at the same period. "The House is weary of these narratives of suffering and shame", noted Ashley in his diary in February 1345, "ihe novelty is past, and the difficulty, the apparent difficulty of a remedy remains; it catches, therefore, at any excuse for inattention, and damns the advocate of the toiling thousands, by courteous indifference". (3)

The impression, volced by Normanby in the Loris, was strong that nothing new had been brought out by the inquiry. It was true, Chadwick agreed, that there was lit le bui striking verification in the medical testimony ${ }^{(4)}$; but the evidence on water supply, the sey to all effective sanitary operations, he 1. L.C. - Duke of Buccleuch, $177^{-0-}$ and 19 December 1345. "Nearly two-thirds of these volumes are in my hand writing, for which I ail to get only posthumous credit, if at all". (E. . - Vacvey Napier, 12 october 1344. Nacvery Napier papers, i. 629). 2. E.O. - Normanby, 17 August 1344.

3. B. Hodder, op. cit., vol. 2 , p. 39.

4. B.C. - Southwood Smith, 22 July 1844. 
belleved --- with some justice -.. would revolutionise that branch of engineering, and he counted his examination of Thomas Hawkesley, the engineer of the Trent Water Works, as the most important he had ever taken. (1) Many of the conclusions on technical and administrative matters had in fact been flanced at in the "Sanitary Report"; but these were precisely the parts of the report which had made least impression upon its readers, and where repetition, reinforcement, and a closer discussion were most required. If the main strands of Chadwick's argument are disentangled from the vast mass of the evidence appended to the Comission's "Pirst Report", we can agree with him that the foundations for reform had been laid wore deeply and firmly, and that some of his propositions had advanced from the stage of sugsestion to that of demonstration.

Replying to the protests of the Sewers Commissioners against the charges in the "Sanitary Report", Chadwick had declared that all the evidence showed that their works "were below the existing science applicable to them. That they were a vast monument of wasteful expenditure and defective execution. And moreover it became a serious duty to charge them as lacent causes of disease and death". (2) This three-fold indictment he now proved out of the mouths of the Commissioners and their officers. In Richard Kelsey, surveyor to the City Comission, for example, he found a perfect sposesman for their ignorance and complacency. (3) Asked if he possessed s wan of his district, he replied triumphently that he had; he admilted, however, that it did not show the levels, though be kept a private memocandum of this essential information. "Can you tell, on inspecting the map, which way the water falls in all the drains represented?" Chadwick asked him. "I could tell, because I know", was the reply, "but no stranger could tell". - - -

1. E.C. - Woollett Wilmot, ? October 1844.

2. "Drafts of communication in answer to Com. of S.", IES, n.d. probably intended for 3 ir James Graham.

3. "Pirst Report", vol. 2, pp. $203-231$.

4. ibid., p. 207. 
He confessed indeed that the district might contain some sewers of which he possessed no record. (1) "The maxim of the Comissioners", he declared, "is never to make any sewer so small as that a man canrot get into it easily"(2); so that even for courts and alleys a sewer $3^{\prime} x 2^{\prime} 2^{\prime \prime}$, sometines $4^{\prime} \times 2^{\prime} 4^{\prime \prime}$, with brickwork $14^{\prime \prime}$ thick, was laid down. Sewers of this size, he admitted, presupposed accumulations, which were removed at a contract price of $6 /$ - per yard, the brickwork of the sewer being torn open where no manholes existed. These brickwork caverns, rarely inspected and irregularly cleansed, had sometimes been put to atrange uses. In one parish, kelsey revealed, the beadle had been buried in a sewer. In another a sewer had been surreptitiously used as a burial ground, exploration uncovering two flat tombstones and six or seven coffins. (3) House drains, he considered, should not be less than $15^{\prime \prime}$ in diamcter; for a small house they should be even bigger, as they were more likely to be blocked. Asked his opinion about the possibility of

1. Ce. this report from Edinburgh: "On inquiry at the proper offices I find that there is no means of discovering what houses have and what have not communication with the common sewers unless a survey were tade for the purpose: and further, that not only is there no record of the individual houses connected with the Sewers, but that there is no direct means of knowing what streets are drained by sewers and what are not". (J.H. Burton - . ., 13 December 1341).

2. "Rirst Report", vol. 2, p. 211.

3. But these vast sewers might have better uses, as Chadwick. pointed out to Colonel Rowan of Scotland Yard in April 1343, when the loyal middle class were prepering to deal with a Chartist attempt to selze the metropolis. The chartists might throw up barricades in the streets, from which it would be difiloult to dislodge them. But, suggested Chadwick, a band of two or three hundred sewer men might be sworn in as special constables, to creep unsuspected along the sewers and emerge at mannoles in the rear of the startied revolutionaries. (L.C. - Col. klowan, 8 April 1843). Three months later one of the men engaged on the subterranean survey then being conducted by the Hetropolitan Sewers Commission was lound to be a confederate in a plot to blow up Parilament and the Govern nt filices, the explosive to be laid in the sewers, which were five leet high and oflered easy means of access to the conspirators. (L.C. - Sir henry de la Beche, 23 July 1843). 
replacing the existing brick drains with pipes four or live inches in diameter, he replied scornfully, "half a brick would stop it"; "in poor houses jou can never keep them iree from coals, cinders, bottles, broken pots, and all kinds of old rubbish" -... and if a grating were inserted to prevent the entry of such dejecta, It would of course be wrenched away by the feckless tenants. (1) Main streets in the City were cleansed every day, all others two or three times a week; courts and alleys "ought to be cleansed" twice a week, but kelsey was not certain that this was done. He could only account for the filthy places in his district, he said, by the filthiness of the people. (2)

It was against this background of ignorance and crude empiricism that Chadwick brought forward his technical experts, Dr. Djce Guthrie, \$.0. Foden, the architect, and Jokn Roe, the surveyor of the Holborn and Pinsbury Commission, 3 to show that brick sewers costing $22 / 10 /-$ a yard might be replaced by terra cotta tubes at one-third the cost or by pipes of common clay which were manufactured in Glasgow for no more than 2/- a yard. To put in a cesspool cost about 25 , and to clean it 41 a jear; jet for 44 a house could be fitted with water-closet, sink, water-pipe and improved house-drains. For an addition of 2kd. a week to their rent the working classes could enjoy the combined benelits of a water-closet and a constant supply of water. (4)

water.

1. "First Report", vol. 2, p. 223.

2. Ibid., p. 220 .

3. Ibid., pp. $241-263$ (Dyce Guthrie); pp. $315-324$ (Foden);

4. "It appears then, rom your evidence, that jou put down an apparatus of the nature of a water closet, with water-cock and pipe, sink and drain in the house, in a new district, at an expense of $22 / 5 /-$, or only $3 /$ - more than a suxveyor's fee, for seeing to the erection of a party-well to a twostoey house, in an old district; that at an expense of 24 , or not wuch wore than the surveyor's lee for a irst-class house in an old district, the public may, in a new district, or a provincial town, defray the expense of the complete (Contibued on next page) 
Without a constant supply of water to every house, however, it was useless to think of water-closets and selfcleansing sewers. Could such a constant supply be provided? To Chadwick at Gwydyr House came the engineers of the London water companies to/this lantastic hypothesis. Thomas Wicksteed, engineer of the East London Naterworks Company, (1)as convinced that it was theoretically impossible to keep water at pressure in all the mains and service pipes at the same time, and that the Company's wethod of intermittent supplies on alternate days was therefore the only practicable one. Moreover, "if he (the landlord) was to put a suparate supply to those houses by a lead pipe, the lead plpe would be there in the evening, but it would be gone in the morning". (2) He advised. therefore that the poor should continue to draw their supplieg from cast-iron stand-cocks, which offered less temptation --and of which, in his district, there vas one to every hundred houses. Wicksteed's corpany obtained its water from the river Lea; the supplies were not Illtered, but the more obvious impurities were removed by passing the water through settling (Continued from previous page) apparatus of the nature of a water closet, the sink, and improved house drain, and the proportionate expense of a second-class sewer: -.Unquestionably." (\$.0. Foden, ibid., p. 324). John Roe asserted that if house drains were laid down on a general contract, and were made of glazed or tube tile, the result would be a saving of ovez 50 per ceat. (ibid., . 169). Dr. Dyce Guthrie (ibid., p. 367 ) put ia the pollowing calculation:

Cost of brick-built sewers in the koldora ilvision: Plrst Class $\quad 22 / 10 /$ - per yard 4,400 per mile
Medium Class $21 / 10 /$ - per yard 2,640 per mile cost of tubes of terra cotta or flre-clay, $23^{\prime \prime}$ in diameter:
15/-per yard wi, 20 per mile

Coat of tubes of common brick clay, 12" in diameter: $3 /$ - per yard 24 to per mile Cost of drain tubes in Glasgow, of comon clays $3^{n}$ in diameter 6d. per $\operatorname{jar} d, 6^{\prime \prime} 9 d^{\prime}, 9^{\prime \prime} 1 /-, 1.2^{\prime \prime} 1 / 3 d$, $18^{\prime \prime} \mathrm{e} / \mathrm{C}$.

Cost of esst iron pipes, $1 e^{\prime \prime}$ in dianeter: $14 / 6$ per yard 21,276 per mile

1. Ioid., pp. L1 - 27.

2. ibid., p. 23 . 
reservolrs; and in fourteen years, he claimed, there had not been six complaints of bad water from the Company's 50,000 tenants. The Southwark Water Company, according to its engineer, Joseph Quick (1), supplied 18,000 houses, 2,000 of the lower class tenements being served by 250 stand cocks. In this distriet 5,000 houses with 30,000 inhabitants had no supply at al1, and "they depend for their supplies on pumps or such rainwater as they catch". (2) Water carriers were still to be seen in Clapham and Rotherhithe, charging a halfpenny for two pails, though the Company's pipes ran close to the houses; two objections were raised by the landlords to laying on a supply for their tenants, the lack of drains to carry away the waste, and the imnediate outlay required for the service pipes.

To controvert the evidence of the London engineers Chadwick brought forward Thomas Hawkesley of Nottingham, who had designed and constructed the Trent Water Works fourteen years before. (3) This company supplied 8,000 houses in Nottingham, with 35,000 inhabitants, and charged no more than a penny a week for an unlimited supply to working class tenements. Hawkesley was as firm as Chadwick that such a service should be commercially remunerative, not a form of charity, and he reverled that, despite its low charges, his company paid 5 per cent. on its capital outlay, and its 250 shares sold at 270 to 273. He rejected with scorn the London eagineers' thesis that larger mains would be required for a constant supply, pointing out that in practice he had been using smaller mains and service pipes than was customary. Lead service pipes in his

experience were rarely stolen, the task of cutting them beins highly inconvenient when they were filled with water at high pressure. lenants, who had previously been obliged to pay water carriers a farthing a bucket, cheerfully paid the extra penny a week on their rent for an unlimited and constant supply. 1. "Iirst Report", vol. 2, pp. $114-36$.

2. ibid., p. 116.

3. ibid., pp. $27-97$. 
Hawikesley foresaw a Utopian future -- streets cleansed by jets; constant water supply, water-closets, and Blazed earthenware house-drains in each house at a total cost of less than 25; warm baths in public bath-houses at 3d. a head; even "baths introduced into the houses of labouring men for the use of themselves and families". (1)

Chadwick had an instinct for selecting the right experience and the right advisers, and for combining the partial solutions of the practical men into a working whole, which was at once logical in its theoretical foundations and soundly practical in its technical application. He perceived at once that Hawkesley's evidence was complementary to that of the Holborn surveyor, John Roe. Hawkesley showed the way to cheap domestic supplies of water, as Roe had revealed the possibility of cheap and efficient removal of domestic waste and excreta. If the two were cobined in a unified system, the solution of the main problems of urban sanitation was in sight. There remained the question of the disposal of the town refuse.

william Thorn, a member of the oldest firm of scavenging contractors in London, (2) declared that "the state of prices is such that we should lose money if we disposed of the article". Two years before a contractor had paid the parish authorities in Marylebone 21,850 for the refuse, but the bottom had since dropped out of the market, and in 1344 the parish had been obliged to pay the contractor for his services. Some portions of the refuse paid for the cost of removal; ashef and breeze were in demand for brick-making, "hard cose" was used on the

1. ibid., p. 31. Hawlesley's evidence was supported by Robert Anderton, manager of the Preston llater Norks Jompany, which gave a constant bigh pressure service to 5,300 houses for an annual charge of $5 / 6 \mathrm{~d}$. per house (ibid., pp. 146-151); by the engineer of the Shews Water Works, Greenock (ibid., pp. 1 - 11); and by Wiliam G. Bull, civil engineer of New York, and Willikm Strickland, engineer to the chuslkill Water Works, Philadelphia. (ibid., pp 136 - 143).

2. ibid., pp. $369-332$. 
roads, rags were wanted for paper-making, horse-dung and cowdung were sent out by barge as far as eighty or ninety miles from the capital. But night-soil was almost a complete loss. Cesspools were cleaned out once every twelve or eighteen months, the average contents being five one-horse loads, or five cubic yards. Some of the night-soil was baked and exported to the West Indies; the remainder accumulated in lay-stalls, for which there was increasing difficulty in finding suitable sites.

Now it was precisely in the night-soil, which in London was the least valued portion of the refuse, that Chadwick saw the possibilities of the greatest profits. Captain Vetch when consulted about the improvement of Leeds, hac assured the Town Council that, if his plans were carried out, in ten years the sale of the sewage to local farmers would bring in 210,000 a year. (2) He considered that $5 /$ - a hesd was a low estimate of the annual value of human excreta, and even believed that in many towns the net profit from the sale of sewage manure would be sufficient to pay for the drainage and water supply. (3) Examples were numerous of the profitable utilisation of sewage as manure. At Ashburton liquid sewage had been applied to the land for the last forty years. (4) Three hundred acres near Holyrood Cartle were irrigated by the "Foul Burn", into wich one-third of the sinks, drains and privies of Edinourgh emptied, and the annual value of the land, which produced four or five crops a jear, was estimated to be $\$ 15,000$ or 220,000 .

1. ibid., pp. $432-443$.
2. ibid., p. 439. ibid., p. 442.
5. The "foul surn" was one of chadwick's favourite ex $-0-$

5. The "Foul Burn" was one of Chadwick's Iavourite examples of the obstructive rights acquired iliegitimately by private individuals, -.. In this instance, by the Barl of Moray, Lord Haddington, and others. Lfforts to free the inkgbitants of the nuisance at the time of the Bdinburgh Police Bills of 1832 and 1834 had been defeated, largely by the efforts of Miller, the Member for ewcastle-under-Lyme, who stood at the corner of the Committee room and begged every member who entered to oppose a clause to rob him of his property. They had no contract with the town, observed Chadwick; they bad not been long enough in possession to claim any prescriptive right; yet they demanded 2150,000 compensation. (Wis fragients, n. i.) 
Abroad, Irrigation by 11quid sewage was employed by the farners of New Spain, Barbary, Andalusia, and wilan. Reflecting on these examples, Chadwick asked himself, if a water company, giving the excellent service Hawkesley described at so moderate a cost, could return a profit of 5 per cent., what might be expected of an enterprise which undertook not only the water supply but also the revoval of the town refuse, and drew additional profit from the sale of sewage manure to the neighbouring agriculturists?

In the minutes of evidence of the "iisst Report" Chadwies may thus be seen, selecting his witnesses and pointing his questions with his barrister's skill to confront the defenders of the old order with the authoritative denlals of then who had themseives originated improvements or had seen them in action. Ready to hand, he shows, in the successful experience of Hawkesley, Roe, Foden, Vetch, Dean, were the makings of a scientilic system of municipal engineering, in which the three aspects of urban sanitation, drainage, water supply, and sewage disposal, might be integrated into an organic whole.

It was intended that the "Second Report" should outline the Comissioners' proposals for future legislation. in the 13th December 1344 Chadwick laid before the Duke of Buccleuch the araft of Public Health $B i l^{(1)}$, together with a lengthy memorandum in which he explained and defended bis main recomendations. (2) It is in these papers, and not in the Reports of the Commission nor in the Act of 1343, that Chadwick's views on public health policy are most truly rellected; and they call, therefore, for consideration in some detail.

1. "Health of Towns Improvements. Proposed Outline clauses of a Bill for the issue of Amended Comissions of Sewers, Drainage, water supply, Paving, and Fealth of lowns Improvements", ins, 13 December 1344.

2. "Health of Towns Improvements. Draft Report of Observations and Recomendations on a B111 for the Drainage, Supply of Water, and Improvement by other means of Health of Towns", MS, 13 December 1344. 
He begins by examining the suggestion, sponsored by Lord Normanby, that general enabling powers should be conferred upon the existing local authorities. There was one short and conclusive answer to this proposal; the existing local authorities had in general mismanaged all such powers as they did possess. Of the ilfty towns examined, the Conmissioners were unanimously of the opinion "that in scarcely one place can the drainage or sewerage be pronounced to be complete and good, while in seven it is indifferent, and in 42 decidedly bad as regards the districts inhabited by the poorer classes"(1); as for the supply of water, "only in six instances could the arrangements and the supplies be deemed in any comprehensive sense good; while in thirteen they appear to be indifferent, and in 31 so deflcient as to be pronounced bad, and, so far as yet examined, frequentiy inferior in purity". (2) Chadwick went on tc indicate four main reasons why municipalities were unfitted for the task of administering public health measures.

In the Pirst place, their geographical areas usually did not include the suburbs, which had been built subsequent to the granting of their charters. It was in the suburbs that the best outfalls for the town drainage were comionly to be found, but any attempt to extend the Corporation's jurisdiction over these new districts would be violently resisted by the suburban ratepayers. Yet "the division of a natural district, either for water supply or drainage, would often present mecianical difficulties sometimes insuperable, and always enornousiJ eahance the expense of improvement".

Secondly, the structure of municipal sovernment was slot through with influences opposed to sanitary refort. Many of the corporate towns were so torn by party feuds that the party in opposition would regard with jealousy the grant to the Corporation of any powers of new expenditure, however properly the trust might happen to be executed. At Hull, for example, 1. A quotation from the "kirst Report", vol. l, p. xv. 2. Ibid., p. xvili. 
a very beneficial extension of the water supply was fiercely resisted because the opposition were convinced that patronage in the appointments and jobbery in the expenditure, as well as popularity for election purposes, were the real objects of the measure. "The municipalities are generally composed of occupiers and of persons having short interests, and their interest governs their views. It is not stated invidiously, nevertheless it is the fact, that they are not generally of the most educated class ..... (As a result) the interest in one part of a town has been set in violent opposition to the improvement of another, whilst the best-conditioned districts, having majorities in the governing bodies have gained improvements in preference to the poorer and worst-conditioned districts which stood in the greatest need of them." In London the earliest and ereatest improvements had been carried out in the West Bnd, outside the jurisdiction of the Corporation; they were the work of private individuals with large and permanent interests; and It was only after the effects began to show themselves in the increased trade of the shops in Regent Street and the West End that the City, in self-defence, adopted similar measures of improvement.

Unfitted by their composition and by the partiality of their interest-begotten views to appreciate the need for complete sanitary measures, the municipalities were equally unfitted by their ignorance to understand the engineering problems involved. "Both in leeds and at Deroy the plans proposed by the engineers ..... were not attempted, though indisputably practical and extremely benelicial, and although it was undoubted that they in a very short time would have been also highly proficable .... They fell through muinly, as was avowed at Leeds, because such measures were beyond them". (1)

1. "On similar advice, to obtain a survey and a plan from an engineer, given on an application from Leicester, the parties declared at once that the corporation was incompetent to undertake such works, and adopted a petition, (Continued on next page) 
Without exception all the recent Towns Improvements Acts were vitally defective. The Birkenhead Act, for example, "from the habit of not looking beyond the immediate local experience", recognised and propagated all the old evils of working class housing, blind alleys, eellar dwellings, cesspools, and receptacles for decomposing refuse situated at the entrace to the courts. (1)

Iinally, there was scarcely a town, except those which were too small to afford profit to s separate company, which was not saddled with previous administrative arrangements. Water was supplied, at high prices and to part only of the inhabitants, by a trading company; one mass of houses was imperiectiy drained by the Corporation; another mass, in the suburbs, was drained equally imperfectly by another authority created under a Local Act; while an expensive and extremely defective system of cleansing and paving, which extended only to the main streets, was under the control of a road trust. These separate authorities were usually as much in conflict with each other as were the bodies of parochial watchmen in the metropolis before (Continued from previous page) praying that the Government would send down a competent engineer. The magor of Biraingham made a similar public declaration, that the Corporation was ineligible to undertake such work. And at Derby aome of the chief persons connected with the town have expressed their conviction that the complete works could only be undertaken by a "specially appointed body". ("Draft Report", sec. 12).

1. 6 \& 7 Vict. c. 13 Local. Chadwick had written severely to one of the promoters of the Birsenhead hct: "I shall feel it $\mathrm{my}$ duty to ask the at tention of the Comissioners of enquiry into the circumstances affecting the health of towas, to the regulations set forth in the sanitary feport on Birkenhead, -- in proof of the necessity of some extraneous security other than the builuers' own interests, for the protection (it might be said of those very interests) of the bealth of the population: in other words to ensure that the experience already obtained, as to the causes of disease and the practical means of prevention shall be properly consulted and apolied". (E.C. - John Laird, 22 October 1844). 
they were superseded by the new police. (1)

"For geological and physical reasons in respect to the operations of drainage, which govern those of cleansing the roads, etc., and other woris, you must have special districts for drainage and towns improvement", Chadwick concluded from this survey of the defects of the existing municipal authorities. "If works of drainage for the proper drainage area be attempted to be carried out in sections, you succeed only partially,

1. Chadwick spent a considerable time analysing the Local Acts for Liverpool, the resuit being given in a foot-note, "Second leport", p. 42: "Table shoving want of consolidation and inconsistent powers of various authorities under Local Acts in Liverpool".

1. Health Commiltee. Corporation.

Does not Include the management of cleansing or sewering streets, but interferes with authority No. 5 in paving and sewering courts, and extends for this purpose over the district of Toxteth Park. Does not possess the natural connexion between authorities 2, 5, 6 .

2. Cleansing Committee.

Has no connection with sewerage of with watering the streets, and therefore is ineffective by interfering with, and being interfered by, authorities $1,4,5,6$.

3. Fire Committee.

Possesses charge over fire police, and yet has no charge over the water, brought in at an immense expense, for the extinction of fire. Is dependent, therefore, upon 4 , a distinct and independent authority. Commissloners of Sewers.

4. Water Department.

Water brought in to the town for extinction of fire and watering the streets; interferes, therefore, with authorities 2 and 3 , and, if applied to public fountains, with duties of 1.

5. Sewerage ani Paving.

Confined to streets alone, but not extended to courts, and is, therefore, interfered with by authority No. 1. Poesesses compulsory powers with regard to main

drainage, but not with house-drainage.

Two Aater Companies.

6. Both in opposition, - compelling, rom their supposed inefficiency, the introduction of new water (4) for the extinction of fire; and, from the inalequacy of domestic supply, prevents the proper action of sewers, and hence interferes with authorities $1,2,3,5,7$. Toxteth Paris Comissiones.

7. Causes the expense of separate management for various offices which might be comprised under one or more of the previous authorities by an extension of the existing 
you risk entire fallure, -.- and you certainly incur excessive expense.

For economic, political, and social reasons, you must for these special districts have a special admiaistrative machinery, comprehending within that district the whole of the works to be executed".

He proposed in fact to re-furbish the ancient machinery of Crown-appointed Comissions of Sewers, as he had earlier suggested in the "Sanitary Report"(1), giving them wider powers and a new direction, and putting them under the tutelage of a department of the central government, which would guard against improper appointments and ensure the efficient execution of their duties.

"The powers already possessed, and from time to time exercised, by the crown in relation to the chief work in view, drainage are so extensive, that the new powers hereafter proposed may fairly be proposed as amendments, correctives, safeguards, and as the complement to ensure their more beneficial application ..... It has long been a subject of complaint in respect to the issue of these commissions, that they have been issued on the casual representation of parties interested by an officer, who has no time to inform himself, nor to take securities either as to the works to be executed or the proper exercise of the powers confered, and those powers are proved to be extrenely defective. It has been snown that a very heavy expenditure for delective works has been imposed and maintained by builders, surveyors, and others connected witt contractors, the management of these comissions often falling into the hands of small knots of unqualified persons, who contrive to get their names placed on these comisstons .... It is now proposed that the course of legislation for the removal of the evils in question should follow the ancient track by the appointment of special local agencies for the execution 1. See above, p. 111. 
of such works, i.e., by the issue of local comissions, with extended powers as to the execution of new works, and the extension and improvenent of old works, but with new and efficient security for their better execution".

The nature of that security, and the general character of the central department, Chadwick developed from a consideration of the arrangements he proposed for financing the vast new schemes of public works. Wuch of the outcry against sanitary measures, he observed, was caused by the method which had been employed in the past to defray the cost of improvements. In Lord Normanby's Bills, and in recent Local Acts, the expense of draining, paving, and improving fell on the "owners", defined as the persons in receipt of the rents and profits; and these "owners" were called upon to make immediate payment of the whole charge for which their property was liable. Chadwick commented:

"It may be laid down as a primary and general practical rule of legislation for permanent improvements, that no one has any immediate money to lay out for any purpose not in the usual course of his habits; and in the poorer districts, where there is the most need of improvement, this is literally so.

It may be further advanced, as a Eeneral practical rule, that no persons in the recelpt of the rent or profits of louses or lands, have the fee simple of them, or even a clear and unencurbered life-incerest in them.

In many town districts the great balk of the house property is owned by lessees; and the lower the description of property, comonly the sreater the state of subdivision, of complexity of the ownersipip, and the shorter the terms of interest on which it is held. In several linge districts in the metropolis, in Manchester and other towns, it is stated that the great bulk of the lower description of house property changes owners or rent recelvers within perlods as short as ten years. In tiverpool the expenses of draining, paving, and 
improving extensive house property fell .... upon lessees who had only four or five years of their leases unexpired, and these charges for imperfect works amounted in many instances to $d$ confiscation of the remaining property".

Chadwick recommended, therefore, the abandonment as impracticable and impolitic of the common course of legislation, which laid the cost upon the line of owners, leaving it to them to distribute the charge amongst themselves and to make the arrangements for repayment by the occupiers. (1) Instead of this roundabout method, he proposed to proceed at once to the parties immediately benefited, and to lay the charge upon the occupiers in proportion to their terms of enjoyment ${ }^{(2)}$; and to ensure that they would pay no more than their fair share for the benefit they received, he suggested that the charge, principal and interest, should be spread over a period of thirty years. This recommendation involved two further proposals - - Pirst, that local authorities should be empowered, with the consent of the central government, to raise loans on the security of the rates, and should execute the works under contract, with all the consequeat economies of large-scale business; secondly, that there should be a compulsory rate for drainage purposes, the collection of wich should be consolideted with that of the water rates and other local charges.

In this financial machinery of public loans and compulsory rates Chadwick saw yet another arsument against the grant of self-acting powers to local authorities. For it was

1. "All attempts to give a simple definition of the owner who shall be charged with improvements have failed to prevent great inequalities and injustice" (")raft Report").

2. "Rule: That every improvement subsequent to the letiting of the teneaent not expressly set forth or implied at the time the tenement was let, is an addition lor wich the owner is entitled to charge the occupier an additional rent as for a new or additional benefit enjoyed by him". (ibid.

3. The first outline of these financial proposals is contained in the "Sanitary Report", pp. $224-0$. The consolidation of collection was a means of economy on which Chadwick laid great stress: cf. the evidence of Charles fox, rate collector of scuicoates, "sirst keport", vol. 2, p. 340. 
not only the interests of the present tenants which must be considered, but also the interests of those who would be occupying the premises in thixty jears' time; and there must be some security that the works were of a quality to last so long and be of benefit to these reversioners and absent parties in proportion to the share of the cost which would fall upon them. Chadwick prophesied that, if the distribution of charges were left to the discretion of local authorities, "building speculators would directly or indirectly get possession of Tocal Boards, and would, in consideration of trading advantages to themselves, promote enormous immediate outlays", to be borne mainly by future occupiers. It would amount to offering dangerous bounties to rash speculations and extravagant jobs at the expense of these unprotected classes.

This consideration, therefore, formed the main ground upon which Chadwick based the supervisory powers of the central department. Before granting to the local authority the privilege of distributing charges, the legislature must take steps to guarantee that the interests of reversioners in the efficiency of the works were adequately safeguarded. Evidence must be previously obtained "by a silful, trustworthy and responsible person unconnected with the spot, that the works proposed are fitting, and afterwards that they have been properly executed, and that all the requisite securities have been fulrilled". The procedure should be --- first, a survey of the district conducted by the Board of Ordnance; then an examination by one or more competent engineers, who would produce plans, together with estimates of the outlay involved; and finally the preparation of a report, to be distributed in the locality. The objections of owners and occupiers, the claims for compensation by millowners and others whose interests were affected, the question of alternative employment for displaced officers of superseded Improvement Comissions, "a mass of such difficulties may be removed by any judicious 
officer, which would render any general and merely self-acting measure impracticable"; while at the same time the demonstration by an accredited engineer of the waste and inefficiency of old works, accompanied by a statement in unanswerable pounds, shillings and pence of the gain to be expected from improvements, would secure a favourable local reception for measures of amendment.

After the local examination the next step would be the preparation of a report by a responsible legal officer for the consideration of the Privy Council. The essentially judicial nature of the proceedings --- the object of which was to decide, in the interests of reversioners, whether the works of drainage were of satisfactory quality --- suggested that the Crown should be advised in these cases by a judicial comittee of the privy Council.

"It is apprehended that the judicial character of the proceeding would have many advantages. It would be satisfactory to the owners and rate-payers that every step should be taken, as publicly as may be practicable: as much as possible should be done upon written, accessible, and responsible instructions decided upon in open court. The engineering difficulties would be very early settled, and become subordinate to that which would at times be the paramount trust, -- the legal distribution of the charges, ani the protection of reversioners and the pockets of the absent, the determination of the principles, and the settlement of the amounts of compensation".

The local inquiries should be directed by "one responsible properly qualified legal officer, as standing counsel to the Gomittee of Privy Council". This would have the advantage of belng "in the more ancient and accustomed course, of beiag small, simple, tentative, and easily altered and extended, as circumstances might require, and of being comparatively inexpenslvo". The alternative of a central 
Board Chadwick dismissed out of hand as "troublesome, and for this purpose extremely hazardous, machinery, not easily altered -.- expensive, and probably unpopular". A Board of engineers, he considered would be a particularly dangerous expedient. If, as was only too likely, their doctrines were fixed in the present imperfect state, and reflected the views of the tondon Water Companies and Sewers Comissions, they would inflict upon the country an out-moded system of works. How frequently the cherished opinions of professional judges had been proved wrong in the past! They had derided the first locomotives and steamboats, and dismissed as visionary the proposal to light London with coal gas, and they were now equally sceptical of the new ideas in sanitary engineering. Hence, "whilst such works are in their present progressive state, it is submitted that a Board of officers of Works might have many of the inconveniences which it may be imagined would arise if a Board of

Schooimasters, with fixed techuical opinions, were invested with such powers as those now intrusted to the Privy Council in the distribution of the money for the promotion of elucation by aifferent sects in different places".

The rivy Council, therefore, should act on the advice of the legal counsel appointed for the purpose, and should direct their comaission to persons nominated on his recomendation. Lo satisfy the demand for an infusion of the representative principle, Chadwick sugsested that a proportion of the nominees should be members ex apficio, and should be taken from local bodies already elected by the inhabitant householders or ratepayers, such as tie mayor and one or two Town Councillors, and the chairman and vice-chairman of the Poor law union.

"It need scarcely be pointed out", Chadrick sumed up, "that the machinery proposed is the least obnoxlous to declamation, as a new measure of centralization; it is in truth, a very considerable qualification and protection of the subject 
against an old, a very imperfect, 11 -guarded, and oppressive measure of centralization; the statute of sewers -.- of which it would be the much required amendment". As his draft clauses reveal, indeed, no wholesale powers of initlation were to be wielded by the central government. Public health measures might be orought to bear upon the locality in two ways. The Privy Council might direct an inquiry to be made on receipt of a petition from the Town Council, or the chairman, vicechaiman, or medical officers of any Union in the district, or from any number of the lahabitants. Failing an appeal from the locality, the Privy Council could take action only if it appeared from authenticated returns that the number of deaths from epidemic, endemic, and contagious diseases, or from diseases of the respiratory organs, had on the average of the previous three years exceeded a certain fraction of the total number of deaths; or that the mean ages at death were below the chances of life given in the Carlisle tables. It was clear that many towns would be able to maintain their freedom from incerference by whitehall on the ground that their bad drains and contaminated water did not kill sufficient numbers to justify the intervention of the Privy Council.

There were other advantages in the procedure, however, which Chadwick hoped vould induce local authorities to seek the assistance of the central governinent. "The expenses of obtaining Drainage and Improvement Acts entail more grievous burthens on the ratepayers of the large towns, and operate as bars to the improvement of the smaller towns and the poorer districts. Phus the expense of laying on water in the town of St. Helens, a smal.1 towa near iverpool, was in round numbers 23,000; but it is stated that the expense of obtainiag the act to authorise the works nas upwards of $i l, 000$. Under the proposed arrangements the expense for thus a work would chlefly be that of an enfineer's services during eignt or ten dajs, in examining the spot, and preparing plans, reports, etc., and the 
whole might be brought under one-tenth of the amount paid, and the inhabitants not only obtain the benefit of the privilege conceded, but the value of the plans of a man of science sicilled in such works, and free fron any undue bias, of the usual professional per centage, on the expenditure, as to the character of the works to be recomended. The expenses of obtaining the Corporation B111s, for the supply of water and towns improvements of Liverpool, are set down at 22,600 . Under the proposed arrangement probably a month or six weeks of the time of a competent assistant comissioner or engineer would have been expended in the local examination of the town, and preparation of a plan of works, if his attention had been confined to the one measure proposed; but had such an officer been employed, he would undoubtedly have saved the town from a very erroneous and inefficient measure, and a waste of upwarls of 250,000 . The preparation of a report, and improved plans of supplying water, on the principle of a constant instead of an interwittent supply for the whole town, a principle established by the experience of three (sic) towns in the same county, (Preston, Olaham, Ashton, and Rochdale) would not probably have incurred an expense of more than 22 or 2300 , including the local publication of the report, and of plans for the satisfaction of the owners and occupiers."

Finally, urged, Chadwick, it must be remembered that the evils to be remedied were in equal force in towns which were not incorporated; they lourished in scotland; whilst Ireland contained physicaliy the worst conditioned population in the empire. "Now it is an advantage of the Plexible procedure proposed, that the plaister may (to use a hovely illustration) be cut and fitted to the sore place to which it is applied, that not only the works, but the appropriabe suaff of local officers, whether one or several, to supervise the execution for the large village, for the small (un)incorporated town, for a towa in scotland, or for a town in the colonies, tay be considered and 
provided for in the particular case, and especially authorized by the terms of the comission prepared by a local examination. Whereas on any attempt to fit such powers by generally enabling or compulsory Acts on the existing authorities, elther great labour must be undertaken to examine each class of the local. authorities, and fit the powers to them, or incongruities must be overlooked and proportionate 111 working engendered by giving such powers in the wholesale".

If Town Councils were to find no place in Chadwick's administrative scheme, he was less severe on water companies. Reproved for the restrictive practices and wasteful competition of their unregenerate past, they might yet be integrated into the framework of local government. The motive of private profit and the energy of private enterprise, thought Chadwick, should be harnessed to the public interest by contracts between the local Commission and the local water company, which would protect consumers against commercial rapacity and guarantee universal supplies at constant pressure, while giving the public at the same time the benefit of the superior efficiency of capitalist management.

"The course of legislation established as requisite in the cases of the water companies, and of sas companies hereapter, generally appears to be, the resumption for the public of the fee of the indefinite proprietary rights in the avaliable supplies of water to the population of the towas iadvertently conceded by Parliment to private and irresponsible companies; the conversion of those rights into an express public trust, and the substitution of leases or contracts for service, varying with the demand. In principle, the course of legislation proposed is similar to that sanclioned by iscliament in respect to railways. Nonopolies of water supply, perfect independence and irresponsibility, as to quantity or quality, could not be sustained as a property, as strict monopolies pressing on the increasing vitsl wants of the pubilc, without becoming a 
thraldom so odious as to endanger other property. It is at the same time proved that, under contracts for service, companies may prepare and carry water at a propit to themselves, and at a cheaper rate to the consumer, than ever has been done, or ever probably would be done by a municipality, not having the same motives to economy of the means of supply".

From conversations with the directors of some of the London water companies, Chadwick was convinced that they would be prepared to accept terms for the extension of their supplies in exchange for legal protection against competitors. The companies would gain by the increase in value of their shares, by the freedom from the hazards of competition, by the public security which would make their shares as valuable as public stock; the public would gain by diminished charges, by improved supplies, and by all the economies of consolidation. The contract should provide not only for the construcion but also for the maintenance of the works, so giving the contractors motives for efficient work in the first place. Companies would undertake both maintenance and construction, Chadwlck believed, for a guaranteed profit of 6 per cent. -.. that $13,1 / 2$ to 2 per cent. above the common rate of interest on money borrowed. "Hot 6 per cent. additional interest, nor even 10 per cent. additional interest, would fairly insure the ratepayers for the risks of an additional expenditure by any probable local body, even with the proposed securities of a previous examination of their plans of works".

It has been necessary to consider at some length this memorandum by Chadwick, since it revesls strikingly the strength and weakness of his views on public health policy, and indicates the main points around which the sanitary debate was to revolve for the next few years. What was to be the nature of the executive body in the locality and of the controlling body at the centre? These were the two main administrative questions to be settled; and to both questions, in his advice to 
Buccleuch, Chadwick gave the wrong answers, His suspicion of local representative bodies issued in the recommendation that public health measures should not be entrusted to the inefficient and party-ridden municipalities, but should devolve upon a body of ad hoc Commissioners, appointed for the most part by the Crown on the basis of their fitness for the work. But who is "the Crown" in this context? A committee of the Privy Council -- who are to act on the advice of a single responsible legal officer. There is little doubt whom Chadwick had in mind for the post, for who but Edwin Chadwick possessed the necessary knowledge, experience, and energy to grapple with the problems presented by this vast new field of aduinistration? The whole broad province of sanitary engineering and sanitary legislation Chadwick had now taken for his own, and, surveying whitehall and Downing Street, he could see no one else -.- certainly no Minister of the Crown -.. to whom he was prepared to lease his proprietary rights. Apart from the opportunity it would afford Chadwick to suide and shape public health policy (an argument which stands or lalls by Chadwick's estimate of his own indispensability); apart also from the fact that the privy Council was traditionally charged with the delence of the country against foreign pestilence; there seems little to be said for Chadwick's expressed preference for a Privy Council comittee. At the Pivy Council office the clerks were already finding it difficult to run in double barness their customary function of Praming orders to fill ia the details of legislation, with the novel and quite dissimilar function of inspecting schools and distributing grants-in-aid. As the Treasury Comittee, which Lavestigated a few years later conditions in the Government departments, was to conclude, "to bring together under the charge of a single listablishmeat business of a wholdy incongruous character, tends not to efficiency but to confusion". (1) At this "potting shed for 1. "Reports of Ireasury Comittee of Iaquiry iato the Public offices", 1843 - 53; Report on the rivy Counc11, 1853 , p. 223 . 
administrative plants"(1), in fact, another shoot was in need of transplanting. The confusion right well have deepened into chaos if Chadwick had entered, with a mass of new and specialised duties, the supervision of engineering inspectors, the scrutiny of applications for mortgages, the drafting of sanitary bye-laws --- and bringing with him also bis own decided views on office management, and a personalily which never made for smooth co-pperation. It should be noted that at no time did Chadwick press for a Government Board on the lines of the Poor law Commission. A few days before he presented his memorandum he had told Buccleuch, "Col. Colby (of the Board of Ordnance) who has had much plague with Boards ventures as an axiom that for doing business almost the worst inaividual appointment is better than the best possible Board: I do not go so far but having been the scapegoat of proceedings against which I have remonstrated shall have one day some large revelations on Board management". (2) His model was not the "Three Kings", with their unhappy associations of divided authority and frustrated eflort, but Kay-shutileworth's position of quiet power as secretary to a Privy Council Comittee. It is strange that a man who had helped Bentham to write the "Constitutional Code" should not have seen that only by the establiehment of a separate State department under a ilinister of Health could sanitary measures clalm the attention and attain the prestige as objects of sovernment that they deserved. Chadwick had not learned -... and never would learn -.- the lesson of the Poor Law Comission, and he continued to deplore the system which entrusted the direction of administration to

1. K.B. Smellie, "Hundred Years of Bnglish Government", p. 90. The Treasury Comittee found that the two departments were distinct in object and method; clerks who had gained experience in one were in no respect fitted for service in the other, and there was considerable inconvenience when a man whose offlcial life had been spent in drafting orders believed that he had clains to a vacancy under the Education Comittee. (op. cit., pp. $223-4)$.

2. B.C. - Duke of Buccleuch, $2-5$ Decenber 1844. 
the temporary masters of a shifting Parliamentary majority.

The Royal Commission on the Health of Towns was a continuation of the inquest on municipal government opened in 1835; and Chadwick's team of engineers and doctors probed more deeply than the bright young lawyerg who had drawn up the indictment of the closed corporations. In Chadwick's view the transference of municipal authority from a Tory oligarchy to a ratepaying denocracy of shopikeepers and Dissenters had not made the Town Council in any wise a more fit instrument for government. The investigation had presented him with only too many examples of Town Councils sitting contentedly amidst their ilith, exhibiting neither the desire nor the capacity to introduce improverents. (1) Cramped in their areas, destitute of the most important functions of government or sharing them with intrusive bodies of ad hoc conolssioners, torn by party strife, and dominated by the petty interests of landlords and shopkeepers, the municipalities faced the problems of a society confusediy emerging from an industrial pevolution with the inhibitions of the ratepayer and the conildent ignorance of the "practical" man of business. That was the picture as Chadwick saw it. And, indeed, to foresee that the municipalities were destined to become the chogen instrument of the modern state for realising the good life for its citizens demanded in the eighteen-forties not only a strong dose of optimism and a courageous imagination -..- both of which Chadwick possessed in ample measure -.. but also faith in the democratic process and

1. "It is undoubtediy true that in many places a great part of the evils complained of sise from the insulflelency of the powers given by law for their removal, but we are unwilling to believe that the imperfect mode, and in some cases the absolute neglect of putting into execution those powers that exist, would be allowed to continue, where efficient laws are in force, if the local authorities had a more precise knowledge of' the nature and magaitude of the injuriea consequent upon their nejlect, and were capable of applying the necessary remedies, the execution of wich is too

frequently impeded by the apathy oi those in authority, the contentions of local parties, or thwarted by the poe opposition of interested individuals". "Second Report", vol. $1,0 p \cdot 23-4$ ). 
a sure sense of the direction of social change. Chadwick had no faith whatsoever in political remedies. Parliamentary and municipal reform, he maintained, instead of rooting out corruption had spread it wider and deeper.

(1) It had set false aims before government, and enveloped it in an unhealthy atmosphere of personal and party rivalry. "folitical liberty, personal freedom, are no doubt great advantages, but to the working man what question of political freedon can be compared with the freedom from the inexorable sentence of confinement to twenty days bed lying sickness instead of five (for that is the difference of sickness, preventible by sanitary measures), premature disability to work, and an inexorable sentence of premature death; exemption from ravages worse than the ravages of war, which sweep away before their fifth year nearly half of those bora? Against these the comon stock remedies of political agitators afford no relief".(2) or again: "The freedom of political opinion is no doubt a valuable booin, but a sound body is necessary to the sound and Iree mind necessary Ior the enjoyment of any opinion whatsoever. The freedom of religious opinion, too is a privilege of inestimabie value, but the painful terrors of superstition maintained by a religious slavery can scarcely exceed those which beset the ninds prostrated by filth and disease or low physical condition, accompanied as it sooner or later is with immediate causes of terror in the actual infliction of the pains of sickness, and the perpetual spectacle of the actual infliction on others. Abundant provisions, and constant employment and high wages, as means to their attainment, are no doubt primary objects lor the manual labourer; but good health is essential to that abundance". (3) In Ireland, he declared, "the geat aditator" had for years perverted the attention of the peasantiry irom their own physical condition to questions of political

1. H.C. - Thomas Hawisesley, 19 Septemoer 1844.

2. H.C., kS eragment, n.d.

3. E.C., "Notes on Sanitation", Ma, n.d. 
sentiment, such as the political disabilities of his own class, so perpetrating "one of the most mischievous political frauds of our day and generation". (1) For the Chartists and the "anarchical fallacies" of their Six Points, he bad only suspicion and contempt. The demagogue was no improvement on the borough monger. Corruption for popularity, Indeed, he told Sir George Grey, was worse than corruption for money. "Bad though they may be who pay for their seats, yet as a class they are superior to the Metropolitan members who do not; or than the Mials and the Foxes or the representatives of such places as Oldham or Rochdale or Nottingham where Cam Hobhouse ceasing to pay was ousted by Feargus O'Connor, whose corruption was by popularity". Much of the dread of the ballot was "a dread of the loss of aristocratic influence which prevails by gold, and of the gain of the influence which prevails by popularity; unless learning were expressly represented, and with other arrangements, such as the mode of taking the votes for bringing the less excitable portion of the community to bear, I should fear it too". (2)

On one question, thexefore, the memorandum reveals that Chadwick had changed his mind since 1842. In the "Sanitary Report" he had spoken with approval of public inanagement, and had urged that the example of the Manchester Gas Works might be profltably followed in the supply of water. kow, however, though he insisted vigorously that the unchecked individualism of early buccameering capitalism must cease, te was convinced that only the motive of private gain could ensure efficient and economic service, and that, indeed, "the evidence almost goes so far as to establish this that the worst company would almost be better than the best corporate muaicipality" This was a very crude over-statement of his position, less an induction from the evidence taken before the Gommisston than an 1. MS eragment, n.d.

2. E.e. - \$ir Gorse Grey, 14 October 1352. 
expression of Chadwlck's roseate hopes for his Towns Improvement Company. (1) The testimony of his witnesses were, in fact, more balanced on this point than the conclusions he had drawn from them. Thomas Wroe, manager of the Gas Works in Manchester, had shown that they supplied 1,000 cubic feet for less than $6 /-$, the charge in other towns, where the supply was in the hands of companies, being usually $8 /-$; and the Gas Works bad already returned to the Town a profit of $x 370,000$, which had been spent on the erection of a Town Hall and other improvements. (2) Chudwick asked him: "The chief imputed faults of local public management are carelessness in respect to small savings, redundant and overworked establishments of offlcers appointed and promoted from party or private favouritism, rather than from any proper qualifications, having no interest in snything but the receipt of their salaries with the least trouble, inaptitude to adopt improvements sugsested by the progress of science, jobbing in obtaining supplies; in these respects what advantages are possessed by management by towns' officers as compared with joint stock compenies?" To this blunderbuss question, Wroe replied sturdily: "In these respects joint stock companies have really no advantages over town management; the joint stock directors, after a.ll, are only tradesmen, who have their own separate business to attend to, and generally they have no sclentific knowledge; and joint-stock appointments so as much by favouritism as towns, appointments. A public of icer managing such an establishment for a town has always abundance of inspectors". (3) On the other hand, however, Thomas lawcesley, on whose evidence Chadwick placed so much weight, threw his influence on the side of private enterprise. "As against the ordinary municipal management, which is of a very expensive and variable character, and one which aever assumes a comercial character, I an quite certain that even in theif present shape 1. See next chapter, pp. 220-223.
2. "Rirst Report", vol. 2, p. zk.343.
3. ibid, p. 344. 
supplies by joint stocis companies are better and cheaper. The direction which in companies is thought to require some experience and qualification, is thought in the bodies adverted to to require neither". (1) The brilliant success of Hawkesley's company in Nottingham outshone the few examples of public management which Chadwick discovered in operation at Huddersfield, Brecon, Halifax, Hull, and Bath. (2) He was quite convinced, he told Buccleuch, of the "general utter incompetency of the municipal corporations in ingland to carry out such works ..... I find for example that the corporation of Hull have already expended upwards of 255,000 which may reach 265 or e70,000 for the supply of only 8,000 houses, and giving to them until our evidence appeared only an internitient supply. Now the Nottingham Company, nearly fourteen years aso, and at the then prices of iron, expended only 232,000 of fixed capital in providing for the constant and more complete supply of exactly the same number of houses. The Nottingham Company your irace may remember supply the lower class of tenements at $4 / 4 \mathrm{~d}$. per annum or 1 d. per week and make a remunerating profit out of it. The fiull Corporation must charge double to pay interest and avoid loss. Their charges are in fact double. There appeared to be as it happened no jobbing on the part of the Corporation, and that it is only such a result as must always be expected where people have not an interest in comparing pecuniary results with pecuniary expenditure in the erection and management of works". (3)

1. "Birst Report", vol. 2, p. $94^{-0}$.

2. At Bath, for example, which Chadwick had previously looked upon as a favourable instance of public management, he found that the Gorporation charged 10/ - per annum for 40 gallons a day, as compared wi th the lottingham charge of $4 / 41$. ("second keport", vol. 1, p. B3).

3. E.. C. - Duke of "Buceleuch, 23 kay 1345. "I agree with you entirely that all such works as water and gas ought to be under the control of the public. Sut I apprehend that they will often be the least so when under the lmmediate management and direction of corporate municipalities --- of whatsoever party -- as at present constituted. Of all the extravagant and ineffectual works examined, none has been (Continued on next page) 
There is much to criticise/in which Chadwick has cast his local and central machinery; but in his conception of the proper relationship between the centre and the localities there is much bosides that is admirable. In the prelisinary inquiry --- the prototype of the modern procedure of local inquiry by inspectors of the Ministry of Health and the Ministry of Town and Country planning -.- he had devised an adaptable instrument of infinite flexibility, which, while paying due respect to local idiosyncrasies, would bring the local authority firnly into line with the policy of the central lepartment. It was to prove its value a few years later at the General Board of Health, in the painless grafting of new functions and powers on to the older machinery of local government. An interesting memorandum, in the form of a set of instructions to an Ingineer Inspector, reveals also, however, that Chadwick looked to the local inquiry as a means for planning the future development of the towns. (1) "Everything in the outer appearance of the city attests the individual power of man; nothing the regulating power of society", de Tocqueville had written of Manchester in 1335", "..... Nowhere is apperent the slow and continuous action of Eovernment". Chadwick conceived it the task of his young, brisk engineers to shape the formlessness of the eotechnic town into decency, if not beauty, by "the slow and continuous action of government". Having settled with reference to geological fundamentals the lines of the main sewers, the position of the outfalls, the sources of the water supply, and the dest direction for the irrigation channels, the were instructed next to consider what arrangements were aecessary for the future increase of the population as calculated on the rate of growth (Continued from previous page) found to display such esregious waste and mismanagement, as those carried out by corporations. Even where the corporations woriss have been bona fide they have been dearer to the ratepayers even than the works of companies as now constituted....." (B.C. Samuel Holme, 3 April 1845).

1. ..., "Draught Instructions for an ngineer officer for a Survey and Report on the most advantageous arrangements for the improvement of the general sanitary condition of the population of -..", n.d., c. $1842-3$. 
indicated by the census flgures. Spaces for new building, for public walks and gardens, for children's playgrounds, for cemeteries, were to be noted. The inhabitants should be impressed with the principle that the evil of overcrowding was to be mitigated by suburban dispersal; and the road system should be laid out in anticipation of the trafic to the new suburbs. In every town in the kingdom such a survey would set a target of public works which would provide useful labour for the unemployed for many years to come. Throughout, declared Chadwick, the engineer should proceed as if the entire district belonged to one prudent and well-advised landlord, interested in increasing the agricultural and residential value of the site by introducint all such structural improvements as involved a wise econory and could be justified by the return from the capital expended. There was little in Chadwick's stiff prose to stir the enthusiasm of the statesmen of his day; but behind much dry talk of surveys and sewers and water supplies can be seen some of the earliest imaginatrive gleams of the town planning movement. (1)

The proposal to distribute the cost of new worics over a period coincident with the benefit derived from them wears so simple and comonsense an air that its importance may easiy be 1. Writing to Sir James Graham, 22 June 1844, Cbadwick urged that all common lands in the vicinity of towns "should be dealt with primarily as parts of sanitary measures for improving or relieving the towns", and should be laid out as housing sites to accomodate the incieasing population, gardens and wiks, cemeteries, reservolrs and bathing places, and fields for the application of town refuse as manure. Two Bills were then belore Parliament, one providing for a central Bosrd of lawyers and agricultural engineers for land drainage, the other a central Board for Conmons Enclosures. "I could satisfy the chancellor of the sxchequer that the two other boards might be dispensed with and all their objects better accomplished by the procedure I propose". (i.e. the local inquiry) (L.C. - Duice of Buccleuch, 17 December 1344). But, "in consequence of $\mathrm{k}$. Elasey's impatience", he could not get the Commiesion to consider the bearing of the two Bills on the sanitary question. (B.O. - Thomas Eawkesley, 9 July 1844). 
overlooked. In Chadwick's hands it becomes an argument for the most powerful weapon wielded by the General Board of Health: the scruting by the central department of all local improvement schemes, and the loans by which they were to be financed. It has, however, a further significance, which was presentiy to be exploited to the full by the propaganda of the Health of Towns Association. The bitterest objections to sanitary reform were raised by property owners who feared that drains and water meant heavy aditional burdens upon themselves. Thomas Cubitt, the building contractor, spoke for this class when he declared that "the public" were not prepared to go to the extent of putting a water-closet in every house: "I think that if people were obliged to put them, it would be considered a very severe tax. upon ther". (i) Chadwick's reply was to demonstrate that, if the charge were spread over thirty years, the cost of fitting new house-drains, closets, and water pipes would dwindle to a weekly payment of $1 / 2 d$., which was within the means of even the poorest tenants, and was considerably cheaper than the cost of the existing privies, cesspools, and stand-cocks. It was good arithmetic and good economics; but it fought a slow battie with the "landlord fallacy" that stinks and damp forned part of the tenat's risk, and the equally poweriul ratepayers' lallacy that fever nests were cheaper than public works.

How the Duke of Buccleuch received Chadwick's draft $B i 11$ and the accompanying memorandum we have so means of telling, but Chadwick records that throughout Decenoer and January he was kept busy "endeavouring to stop mischief". (3) It is clear, 1. "irst Report", vol. 2, p. 265 .

2. On 11 January $1845 \mathrm{Chadwick}$ sent buccleuch two further memoranda on the main alterations he wisted to see in the Report -.. (1) a paper showing the necessity of natural areas for drainage, and (2) a paper on the distribution of charges and the securities necessary to prevent jobbing. On 28 Januery he sent some outline clauses and a further paper on the distribution of charges, which he suggested Buccleuch should lay before the Jord Charicelior.

3. E.C. - T. Banlield, 26 Janiary 1845. 
however, that the Commissioners were not willing to act up to the strength of the arguments he directed at them, and the thirty recomendations into which they expanded the general conclusions of the "Tirat Report" departed in several important respects from the advice contained in the papers he had laid before Buccleuch. Nevertheless, "the main propositions are I expect secured", he told a friend, "but very slenderly supported by reasons". (I) He had silenced Slaney; and he had silenced those "others who think it very unsafe to meddle with comisaions of sewers or the "masses of property invested in water companies": (2)

"We therefore recommend", ran the first proposal, "that in all cases the local adininistrative body appointed for the purpose have the special charge and direction of all the woriss required for sanatory purposes, but that the Crown possess a general power of supervision". (3) whethes the "local administrative body appointed for the purpose" should be the Town Council or an ad hoc body estublished under royal commission, whether it should be elective or nominated by the Crown, were/luestions for further debate; and chadwlok's suggestion that the privy Council suould be indicated as the supervisory authority was equally rejected. Bor the aext three years the nature of the local authority and of the controllias department at the centre was to be discussed in parliament, with Chadwick working continually, in lecters and memoranda and personal inter/iews, for his local vomission of Crowa nominees, acting unde the guidance of a judicial comittee of Gouncil. Phere was another sisnificant omission. The keport recomeaded that, upon the representations of the local authority or of a certain number of the inhabitants, the Crown should direct an laquiry inco the sanitary condition of any district, and should be empowered to enforce the execution 1. B.C. - T. Bamfield, 20 January 1345.

2. B.G. - Blshop Blomfield, lo July 1844.

3. "Second keport", vol. 1, p. 25. The leport was signed on 3 Bebruary 1845. 
of the law (1); but Chadwick's proposal that the inquiry should be conducted automatically on the evidence of the excessive mortality as shown in the Registrar General's returns, contemplated the gift of more aggreasive powers to the central government than the Comission were prepared to advise. Similarly they found no place for the flexible, powerful instrument of the local inquiry. A plan and survey must precede any scheme for works of town drainage ${ }^{(2)}$; the Crown should be empowered to define and enlarge from time to time the area for drainage included within the jurisdiction of the local auchority -- these principles were recognised, as they must be in the face of the overwhelining technical evidence. But the local inquiry by a Government inspector, with the scope and intention that chadwick would bave given it, reached beyond this, fumbling towards a conscious perception of social purpose which a Boyal Comission of 1845 could not but regard as"unsale". Even more disappointing to Chadwick's hopes was the casual mention of the Officer of Health. Almost as an after-thought the twenty-ainth recomitendation proposed that the local administrative body should have the power to appoint, subject to 1. Pifth kecomendation, "Second Report", vol. 1, p. 39. 2. Second Recomendation, ibid., p. 29. n 13 way 1344 the Commission had considered evidence "showing the importance of an elficient and complete survey or lowns, with contour lines laid down at equal vertical distances, and proper bench marks, so that the relative altitudes my be found, for Sewerage, drainage, sanatory and other purposes". They concluded that such a survey was an "important preliminary", and went on to consider estimates Purnished by the Board of Ordnance that plans on a scale of 5 feet to the mile could be furnished for 1/0\%d. per acre for a towa of 100,000 , provided that the additions required were inserted at the time the surveys were beins carried out by the Ordnance. They thereupon resolved: "Wth the view of ssiving the additional expense, which must be incurred for future surveys, if the preseat opportunity be Lost, of employing for these purposes the prsctised Corps of Englaeers and Surveyors now actine under the direction of the Board of Ordnance, this Board is desirous of expressing to F. H. 'B Government an earnest hope, that ateps will be taken immediately to enable the Surveying lepartment of the Board of Ordnance to make the necessary arrangements for promoting this service". (Wwinutes, h.H.?). 
the approval of the Crown, a properly qualifled medical officer to inspect and report upon the sanitary condition of the district. (1) a few lines dealt with the functions of an official to whose importance Chadwick had devoted elghteen months of afitation and thousands of words of argument.

On the other main points Chadwick carried the Commission with him. Ihe local authority should have ider powers in sanitary matters than had hitherto jeen granted either under Iocal Acts or by the statute of Sewers. It should be responsible for the paving of all streets, courts, and alleys, and for the construction not only of the sewers but also of the house drains. (2) It should be invested with the rights to all the dust, ashes and street refuse. (3) It should have powers, subject to approval, to buy out mill-owners and others whose property rights were an obstruction to proper drainage ${ }^{(4)}$, and to purchase property for the purpose of opening thorougheras, improving ventilation, and increasing the general convenience of traffic. (5) But of the greatest importance were the resolutions on water supply. The Commission recommended that it be "rendered imperative" on the local administrative body to procure a supply of water in sufficient quantity not only for the domestic needs of the inhabitants, but also for cleansing the streets, scouring the sewers and drains, and extinguishing fires; that, with this end in view, "where any independent body has the management of the supply of water, it be liade to comply with the demand of the local administrative oody on equitable terms; and that, further, the locsl administrative body be empowered to purchase the interest in water-woriss, subject to the control of the Crown, whereves the proprietors are willing to dispose of them". (6) "we further recommend", 1. "Second Report", vol. 1, p. 122 .

2. Bighth and Iwelve Hecomnteadations, ibid., pp. $52,65$.

3. lhirteenth lecommendation, 1bid., p. 72.

4. Seventh Becomendation, ibid., 44.

5. Twenty-Second Recommendation, p. 107. 
the Commissioners continued, "that on the establishment of new Companies it be made a condition, that the local administrative body be enabled to purchase the works after the lapse of a certain number of years, upon certain terms, and upon a rate of interest to be fixed; and that, with a view to economy, competition between Water Companies be discouraged as far as practicable". The three recommendations which followed made it clear that the service should be extended to all dwelling-houses, and that the supply in all cases should be constant and at as high a pressure as circumstances permitted. (1) Unqualified approval was given to Chadwick's proposal that the water works should be executed, maintained, and kept in good repair by public companies,"as lessees or contractors for terms of years, with liberty of redemption by the public upon terms previously settled". (2) In phrases which echoed Chadwick's memorandum to Buccleuch the Report declared that companies would consider a return of 6 per cent. an adequate inducement, this being 1 to $1 / 2$ per cent. above the usual market rate for such investments. "An addition of $1 \frac{1}{2}$ per cent., for which a company would often undertake the maintenance and execution of such work, would be cheap, as compared with the risk of mismanagement by local boards, composed of persons having no professional skill, and liable to be misled as to the materials and magnitude of the proposed works, as well as to the aumbers of of icers requisite to maintain them. It might be difficult to easure that a local body should be so constituted as to give the same constant attention to economy in the expenditure of other people's money that contractors would do in the expendituce and management of their own". (3)

The financial machinery outlined by the Comission was also substantially that proposed by Chadwick. Loans for 1. Nineteenth, Twentieth, and Twenty-first recomendations, "Second Report", vol. 1, pp. 100, 101, 103.

2. ibid., p. 104 .

3. ibid., p. 104. 
constructing public works might be raised by the local administrative body on the security of the rates, the approval of the Crown being ilrst obtained. The expense of the works would then be charged upon the properties benefited, "to be levied by a special rate upon the occupiers, and recovered with interest by annual instaluents within a certain number of years? (1)

With the publication of the Reports of the Health of Towns Commission, the second phase of the public health movement was concluded. The first Phase, to expose the evil, had been the primary task of the "Sanitary leport". That report had also contained a sketch of Chadwick's ideas on the course leguislation should take. But it was the revelations, not the recommendations, of the "Sanitary Report", which had attracted attention. Now the technical and administrative remedies had been explored by an authoritative body of Commissioners, whose advice came with more weight than that of a single civil servant of equivocal reputation. The third phase, to translate those recommendationa into legislation, was now opened.

1. ibid., pp. $60-1$. 


\section{CHAPTER 6.}

\section{SAIITARY PROFITS AND PROPAGANDA.}

Throughout these busy months of 1843 and 1844, while Chadwick had borne at Gwydyr House the main burden of the Health of Towns investigation, two further anxieties had weighed upon bim. First was the behaviour of the Marquis of Normanby. As Lord Lieutenant in Ireland Nornanby had antagonised the AngloIrish community by his friendship with Catholics and his clemency in political cases, thus revealing that beneath a somewhat flippant and flamboyant exterior he concealed an unexpected strength of principle. As Home Secretary he had been converted to the cause of sanitary reform in the backstreets of Whitechapel; with the best of intentions he had sponsored a set of remedial measures which Chadwick, from a fuller knowledge, could only adjudge as incomplete and illdesigned; and now from the opposition benches he directed a jealous eye upon Sir James Graham's leisurely handiling of public health questions. At the beginning of the 1344 session Lord Normanby rose to inquire what the Lories had done with bis three sanitary Bills. When the Whig Government Pell, Grabam had promised to take the Drainage $B i l l$ under his own special care; nothing more had been heard of it. After an unaccountable delay of twelve months, Graham had appointed a Commission of Inquiry, though Cbadwick's Report of 1342 proved the necessity for imediate legislation, and "the result of its perusal mist be to convince any one that nore information nas not what was required upon the aubject". The remedies were simple enough. "Centralization" was not necessary; it would bave been suficient as in his own Bills, to confer more powers upon existing local authorities. (1) In May Normanby resumed his attack, presenting 1. Hansard, vol. 72, pp. 220 - 228, 5 February 1844. 
a petition from a public meeting of 3,000 Bdinburgh working men, the first petition on such a subject that had ever been received from the lower classes. Four years had passed since the need for a general measure had been consldered, said Normanby, two years since the "Sanitary Report" had appeared, and "another year was elapsing without anything being done". (1)

Chadwick resented the imputation that the months which had been devoted to maturing his technical and administrative plans for the HeaIth of Towns Commission constituted a quite unjustified delay. To avoid superficial legislation, time was well spent in designing measures, and, what was equally important, in cultivating opinion for their reception. As he told R.A. Slaney, who shared Normanby's impatience, "the cause is progressing, the evidence is telling, and in due time a fullness of opinion will be manifested to carry the measures which can only be carried with the strength of a strong opinion. What I am most afraid of is separate and inefiectual measures". (2) In the virtuous indignation of a Winister out of office with the tardiness of his rivals in power, Chadwick saw a further danger -- that sanitary measures might be dragged into the aresa of party politics, where they would lose the cool detachment of a ecientific investigation in the heated atmosphere of a faction fight; and where, moreover, they were likeiy to escape from his control. Thus, he vrote to James simpson, who at his suggestion had drawn up the petition from the Edinburgh workers which Normanby presented in the Lords: "I should have deprecated the giving the proposed petition to Lord Normanby or doing anything which would give the proceeding a party complexion as I fear that will do. The fact is Lord Normanby's measures against which or. Southwood Smith and others were strongly remonstrant would, if they could have been carried $\rightarrow 0-$

1. Hansard, vol. 74, pp. $541-547,2$ May 1844.

2. B.C. - R.A.Slaney, 23 November 1344.

3. In a letter of 25 December 1343 Chadwick had suggested that Simpson should give a lecture to the workers of Edinburgh, and draft a petition for their signature. 
out have spread bad drains throughout the country at an enormous expense, and not have mitigated and in all probability have aggravated the evils intended to be remedied. He stopped all proceedings in the getting up of local sanatory reports and under his influence the sanatory report itself was stopped and never probably would have appeared but for his removal from power. Now that it has appeared he is very complimentary. Still however the objection to such a presentation is its party complexion. Why could not Lord Dunfermline who may be said to be the natural representative of Edinburgh attend and present the petition?"(1)

In a long and effective speech Normanby closed his 1344 campaign on 26th July with an address to the Crown, hoping that in the coming session the specific attention of parliament would be called to the sanitary question. There was much of value in the "Iirst Report" of the Health of Towns Commission, which had just appeared, but "I think it is overloaded with much as to cause and extent which was unnecessary, except for nen men, who if they required this information, should not have been appointed on this Commission .... This strikes me as one of those subjects on which there has already been too much consideration and too little action". In the past few days he had revisited the eastern districts of London, and had come away with the impression that no such misery existed in any other civilised country. He warned the House that there was danger 1. E.C. - James Simpson, 25 April 1844. To Normanby on 1? August 1344 he wrote: "Pray accept my thanks for the kind expression of your spproval of the sactiary report, which is the more Bratifying at this time when notwithstunding I can prove that everything of a substantially popular character that has issued from the Poor Law Comission has been written oy myself, I am charged with habitually writing "hastily and harshly" and having made the whole law uapopular, the fact being that of all the papers attacked in the House of Commons (I think unjustig) only one happened to have been vritten by myseli, the others having been written by gentiemen who ride away with the credit of having "mitigated the severity of the law"...." 
In further delay; "the sick bed is the place in which there is most time to brood over neglect, or to feel gratitude for sympathy". (1) The Duke of Buccleuch, armed with a memorandum from Chadwick (2), had no difficulty in demonstrating that when they were in offlce the Whigs had been as dilatory as the Tories, and he suggested that a large part of Normanby's enthusiasm for sanitary reform sprang from a desire to score off the Government.

Chadwick's second great anxiety at this period was the apathy of the public at large on the sanitary question. "I am crying out Pestilence! and for the relief of the masses", he wrote to Thomas Carlyle, "but can get no one to hear of means which will affect the pockets of small owners in small corporations who have votes for the election of members of parliament and who set up the cry of self government, as against any regulations which may lead to immediate expenditure for puting in better condition the houses for which they exact exorbitant rents". (3) In particular, he was keenly disappointed with the reception of his Report on Interments.

1. Hansard, vol. 76 , pp. $1460-1430,26$ July 1344. 2. "Confidential. Viemoranda of answers to the imputations of blame in respect to alleged delay to sdopt sanitary measures", hS, 13 July 1844. He also wrote to the Bishop of London ( 16 July 1344), urging him to "do further good by speairing upon the subject by urging the adoption of the practical conclusions which science has developedi taking the whole subject out of the hands of local ignorance and prejudice (on which see the evidence of Hr. Butler Williams and his exposition of the consequences of both in the rejection of Sir Christopher Wren's plan), not sacrificing water companies, but not handing over the population to them as monopolies and sources of future profits and deprecating the obtrusion of party feelings into the consideration of remedies".

3. E. - Thomas Carlyle, 20 June 1844. In an attempt to enlist another powerful ally, he esclosed some of the evidence on ventilation in a letter to Charles uickens, "for the value of its impression on yourself in getting you to at lend to the means of ensuring frest air in your own rooms and the public importance of keeping yourself in good health and spirits". (21 June 1844). 
While he was writing 1t, feeling had risen to a pitch of healthy indignation; the officer of Health, the most important proposition, had been welcomed by all the clergy he had met; "and yet soon after the appearance of the report that which had previously been a storm, almost, of agitation subsided". (1) In a stream of letters in December 1843 and January 1844 Chadwick had urged his friends --- Dr. Holland at Manchester, Dr. Laycock at York, James Simpson in Edinburgh, Southwood Smith in London -- to get petitions signed by the working men in all large factories. If Scotland did not agltate, he warned his Scottish friends, Scotland would go without the officer of Health, as it had gone without the Vaccination Acts ${ }^{(2)}$; while Dr. Laycock was exhorted to sound the alarm in the "Lancet" against the practice of leaving the cause of death to be verified by the present registrars instead of by a qualified medical practitioner. (3) "I can get petitions pretty smartly poured in from Lancashire", Lyon Playfair bad promised, ading that Bury was about to send a memorial calling for officers of Health, and he would see that Preston and Ashton did the same. (4) But six months later Chadwick had to confess to Dr. Holland, "I have heard of two or three petitions, your own is the only one I have seen". (5)

"I must own my disgust at the carelessness and selfishness of our puolic men", he confided to a German economist, "An excess of selfishness or of what Bentham calls the "self regarding virtues" without any compensating power of the "extra regarding virtues" is perhaps characteristic of our people. It is however to this excess, to strong stomachs and appetites that our manufacturing and comercial energy is to be ascribed". (6) The problem was that if the pour were to stop

\begin{tabular}{|c|c|}
\hline $\begin{array}{l}\text { B.C. } \\
\text { B.C. } \\
\text { B.C. } \\
\text { Lyon } \\
\text { B.C. } \\
\text { B.C. }\end{array}$ & 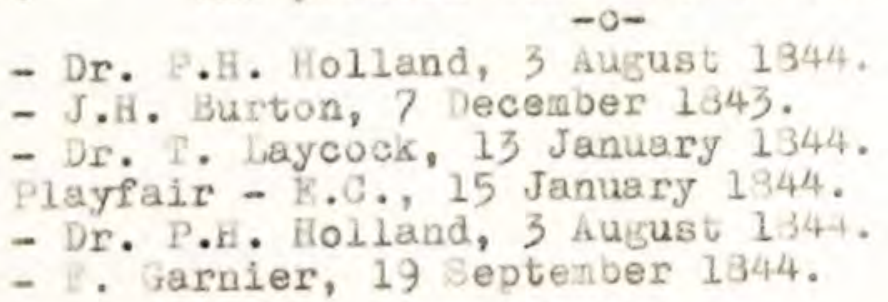 \\
\hline
\end{tabular}


using the streets as middens and to cease dipping their water from wells and ditches, hard-headed business men in the Commons --- fully endowed with the "self-regarding virtues" and the un-self-conscious possessors of those "strong stomachs and appetites" -- had first to be convinced that they were not being stampeded into rash and expensive action by the exaggerations of cranks and sentimentalists. Gentleinen, walking round their milis or their estates, had spoken to sturdy workmen, who had lived half a century and raised a numerous progeny in districts which were now (surely extravagantly) described as "fever nests". Lhey felt it was being overdone, this danger from stiniks and the propinquity of filth. After a11, many themselves lived in houses of fashionable but insanitary design, with cesspool odours rising dankly from the servants' basements, and crawling nameless things in the water. At the Westminster School, where some educated their sons, cesspools were strategically sited on either side of the entrance to the dormitory. The drains beneath the very building in which they sat, deliberating the welfare of their humbler countrymen, were so bad that a daring surveyor, who had once ventured into them, had declared that it was a relief to get back into the public sewer. So, only too often, Chadwick's political friends listened to him and seemed impressed; they went away vowing that something must and should be done; but once they were beyond the range of that earnest and importunite eye, the warning lost its urgency, and the firm outilnes of their resolve softened into polite generalities of goolwill. His keenest arguments were turned by the tough, intertwined. fibre of the opposition -- the 1nertia of the localities, "the laissez falre of evil people:(1), the indifference of Ministers, the ignorance and com lacency of powerful men about the uncleanliness of the towns.

Hence, in May 1844, we find Chadwick writing to Lord 1. E.C. - Rev. Theobald Matthew, 26 April 1845. 
Ashley:

"There is certainly a very large class of questions affecting the condition of the labouring classes on which external aid will be of much service if it be powerful and not merely a small buzz that goes on unheeded. There are many small interests adverse to the condition of the labouring classes that might by such aid be usefully kept in check by the representations of a body that would be properly attended to if well directed $\ldots$...

Your Lordship has seen how frequently interested parties are seated at Boards of Guardians, who are ready to stop anything which may lead to expenditure for the proper repair of the dwellings of the labouring classes.

where measures of arainage are proposed, and the works carried out by Commissioners of Sewers are found to be defective a cry is raised nothing must be done for fear of offending the Commissioners, and the active Commissioners in several instances are found to be precisely the same sort of persons as those of whom you have heard as Guardians.

When additional supplies of water are called for, for the salubrity and cleanliness of the dwellings of the working class population one cry raised is "On the interest of the companies is too powerful to be touched". side".

An associated voice should surely be raised on the other (1)

What was needed was some hearty and persistent campaighing, with public meetings to pass unandmous resolutions, lectures and pamplets and letters to the "limes", and deputations to the llome secretary headed oy noble well-wishers to copviace dinisters that, if only for their own peace of mind, sowething must be done. But a civil servant could hardiy appear as the leader of a movement to briag the external pressure of opinion to bear upon Her Majesty's Government; and, 1. E.C. - Lord Ashley, 11 May $\mathbf{1 8 4 4 .}$ 
even if he had not been disqualified by reason of his office, this was work for which he was constitutionally unfitted. When James S1mpson, in an adaress to a meeting of İinburgh workmen, told them that Edwin Chadwick had counselled the labouring classes to join in petitions to the authowities, he was annojed at this indiscreet mention of his name in connection with a public agitation. (1) He preferred to exert his influence from the official anonymity of Somerset kouse. Chadwick, indeed, was no platform agitator. In private conversation he could bring to bear his vast stores of information, his close argument, bis intimacy with detail, the authority of his personal knowledge, which caused men to listen to him with respect. But a public speaker required other qualities besides a thorough acquaintance with his subject, qualities which, as his unsuccessful Parliamentary candidatures in later life showed conclusively, Chadwick consplcuously lacked. His public utterances were lame and dull, tied down to notes, bristling with statistical minutiae, and sounding like excracts from one of his own blue books.

So the formation of a "Health of Towns Association" was left to other men, to Askley, Nornanby, Bbrington, and above all to Dr. Southwood Smith, who had revealed a flair for propaganda in the illustrations he bad arawn for the Report of the Children's Impioyment Commission. (2) When, in December 1844, Chadwick heard that Southwood Smith was organising a meeting at Wxeter Ha11, he expressed bis hearty approval; but he wrote warningly to the Doctor, "I must bef of you to be careful not to mix me up with the meeting. It will do no good and may hinder much my power of being usefui".

The meeting, which took place on lith December 1344, was presided over by Lord Nornanby; and it may be supposed that not 1. E.C. - J. Simpson, 3 February $18 \overrightarrow{4} 4$.
3. C. Lewes, "Dr. Southwood Smith", 9.73.
3. E.C. - Southwood Smith, 9 December 1344. 
the least of the benefits Chadwick expected from the campaign was that it diverted his Lordship's energies into the safer channels of a non-political agitation. He had visited the huts of hundreds of negro slaves in the West Indies and the cabins of Irish cottiers, he told his audience, but "he would rather pass his life in any one of the first, or in most of the last, than he would inhabit one of those dens or cellars too often used as dwellings of the industrious poor of this country". Dismissing the Health of Towns Commission as "but a bad substitute for action", he hoped that "they would separate this day vith a firm deternination to do all that in then lay to prevent the seasons again revolving still to find so dreadful a contrast existing between an increasing national prosperity and a deepening misery of the masses". (1) As a result of the meeting a Health of Towns Association was founded, with Southwood Smith and Professor .A. Guy as secretaries; and in the following months branches were established in Edinburgh, Liverpool, Manchester, York, Falifax, Derby, Bath, Rugby, Narlborough, Walsall, Plymouth, and worcester. (2)

In the next few years the Association, in lectures and pamphlets and petitions, hammered away at Southwood Saith's proposition that "the heaviest municipal tax is the fever tax". Its lecturers, the doctors W.A. Guy, R.D. Gralnger, J. Poynbee, the lawyer James simpon, the Rev. C. Girdiestone, and Lord Ebrington, instructed audiezces of both the working and the midale classes in the elenentary principles of ventilatioa, drainage, and civic aad domestic cleanliness. (3) It liverpool 1. "Abstract of roceedings of fublic Weeting at Exeter fiall, December 11 1344" (pamphlet), pp. 12, 5, i3.

2. "Health of Towns As ociation: Report February $241347 "$ (pamphlet), pp. 7, 9.

3. Under the titie, "Unhealthiness of lowns, its dauses and Remedies", for example, lectures vere given by W.A. Guy at Crosby Hail, Bishopsgate Street (1345), by R.D. Grainger at the Royel Institution, Liverpool, and the Athenaeum, Nanchester $(1345)$, and by Viscount Lriagton at the Nechanics' Institute, Pymouth (1346). 
a "Health of Towns Advocate" was started by Dr. John Sutherland, 1,500 copies of the first number being distributed gratuitously. (1) In January 1847, on the eve of the introduction of Lord Morpeth's first Health of Towns Bill, the Ketropolitan Association began the publication of a "Weekly Sheet of Facts and Pigures". (2) Joseph Toynbee organised in London an ancillary "Metropolitan Working Classes' Association for Improving the Public Health", which adopted the motto, "We can be useful no longer than we are well"; (3) the example was followed at Newcastle and Gateshead where a "Working Men's Association", which included thirty"foremen and other influential workers", was formed in friendly alliance with the local Sanitary Association. (4) In many other towns the working classes, under middle class guidance, set up associations, which were prolific in advice to their fellow workers and in memorials to the Government. (5) But not everywhere was there this docile acceptance of middle class tutorship; and Chadwick heard that at Glasgow "some noisy, brawling, turbulent Chartists had got mixed up with the agitation", and that "their way of doing business had disgusted the more discreet".

It was all a bit vulgar and demagogic, thought some of Chadwick's friends. He was rather apologetic himself. "I confess it seems to me in respect to outdoor agitation in this subject that needs must", he told the Bishop of London, "where the opposing interests are so strong as they are, of paving bosrds and local trusts for cleansing, and so influential with

1. Dated 1 September 1845.

2. "Health of Towns Association: Report February 24 1847", p. 10.

3. "Wetropolitan Norking Classes' Association for Improving the Public liealth" (pamphlet), 1847.

4. "lirst Annual Report of the Newcastie and sateshead sanitary Association", 1843, p. 14 - 15 .

5. The Wigan orking Classes' Public Health Association, for example, publisbed a pamphlet "On the ecuniary Lconomy of Sanitary improvements, as applicable to the lanufacturing Districts", 1849 .

6. Thomas Beggs - E.U., 11 April 1846. 
Members of Parliament". (1)

But though Chadwick refused to have his name connected openly with the Association, he took full advantage of this powerful instrument of propaganda which lay so ready to his hand, and, by a kind of ventriloquism, its publications incorporated the memoranda he supplied to them, and its deputations spoke arguments he had sugsested. Thus, on the 3rd November 1846, he sent Ashley a review of progress since 1837, together with the mortality bill for the quarter, which showed some 15,000 deaths above the average, proving that "if we are idle death is not". "If in the union workhouses, in our prisons", he went on, "such epidemics or such increases of mortality were to occur as occur without inquiry or care in closely crowded courts and alleys, investigations would be properly instituted with the perfect certainty that some one would as a result have to be dismissed for the neglect". (2) Ashley replied that the paper was "singularly important". "I made use of it today at a meeting of the "liealth of Towns Association", which I hope may at last produce some movement on the part of the Government. It is almost the boldest document ever published by a subordinate department". (3)

It was, taking the country as a whole, a sprawling, loosely-knit campaign, wuch less a pitched battle fought to a general's plan than an affair of local skirmishes under guerrilla leaders. In the years of the cholera especially. little agitations, auxiliary to the national movement though often quite independent in their origin and development, were ignited in many places by the energy of some public-spirited. individual or group, to blaze fiercely for a few months or a year or two, perhaps, and then to flicker out as the enthusiasm or the wholesome fear departed. In 1849, for instance, the Christian Socialists were busy in the slums of Bermondsey, and had a wild scheme for waylaying the prince Consort with a

1. B.C. - Bishop Blomfield, 18 November 134\%.

2. B.C. - Lord Ashley, 3 November 1846.

3. Lord Ashley - E. ., 6 November 1346. 
memorial against the sanitary condition of the district(1); Chadwick seems to have known nothing of their activity --- or, it may be, he studiously ignored "Parson Lot" and his Chartist Iriends. There must have been many enlightened clergymen, like Charles Kingsley, who asked their parishioners "Who Causes Pestilence?", and whose sermons attacked "the Deus ex Machina theory of judgments and visitations". (2) There were even more sturdy doctors like Tom Thurnall, pitting their science and blunt common-sense against the dirt and prejudice which surrounded them, devoted allies of Chadwick and the General Board of Health against "that "local governinent", which signifies, in plain English, the leaving the few to destroy themselves and the many, by the unchecked exercise of the virtues of pride and ignorance, stupidity and stinginess".

As a propagandist movement, however, the public health agitation did not approach the power of the Ant1-Corn Law League. Middle class opinion never organised itself so formidably behind Asbley and Normanby and Southwood Smith as it organised itself behind Cobden and Bright, and the "Weekly Sheet of Facts and Figures" never exerted the influence of the "Anti-Bread-iax Circular". The Anti-Corn Law League set before the public a single, easily comprehended ain, the repeal of a set of laws which possessed the ideal quality for the propagandists' purposes that they could be shown to be taxes on the people's food. The Health of Towns Association faced a complex of problems, often of a technical nature, about whose solution there was frequently a division of opinion even in their own ranks. Both professed to be dealing with the same disease, the "Condition of England Question"; but the Leaguers prescribed a specific, while the sanitarians could recommend only a prolonged and exacting course of therapeutics. The extraordinary success of Cobden and $-0-$

1. G. Kendall, "Charles Kingsley and His Ideas", p. 76.

2. ibid., pp.'75, 77. "Who causes Pestilence?" was the title of a series of sermons delivred by kingsley at the end of 1843.

3. C. Kingsley, "Iwo Years Ago" (3rd Bd., 1360), p. 213. 
Bright was won because they combined the appeal ad misericordian of the farm labourer's "I be protected and I be starving" with a cogent economic exposition that kepeal would bring increased trade, higher wages, and even a better market for the farmer. The weapons of the Anti-Corn Law League, though they were sharpened and given their cutting edge by the misery of the lower classes, were forged out of the solid core of middle class interests. But was there any profit in sanitation? Maybe there was, if jou cared to go into the figures of Chadwick's Towns Improvement Company, of if you accepted his thesis that the labourer, as much as any productive machinery, repaid care and money spent. But how could sewers compete with railways as fields for investment? Projects for bringing drains and water into the homes of the people were looked upon as too "philanthropic", "humanitarian", and "patriotic" to be good business. The capitalist contributed to schemes for improving the condition of the labouring classes in much the same spicit as he put money on the plate at church, expecting to draw his return not in bard cash but in the transcendental Butler's "liusical Banks".

It was this feeling that Chadwick had set bimself to coubat since the earliest of his social investigations. Nothing disgusted him more than the attitude of those who looked complacently on the poor as objects of charity, and who found an easy discharge from the labour and responsibility of seeking a solution to the problem of human misery by neans which sapped the independence of the worker. He believed that "the freat mass of charities which have for their object the distribution of the means of maintenance create a large proportion of the misery which they are intended to relieve and cannot relieve all which they create". (1) It might almost be said, he thought, that if the trustee of a fund for the distribution of alms ate and drank the money hinself, or if the man appointed to 1. E.C. - Lord ?, n.d. 
administer a charity for the sustenance of foundlings kept a mistress instead with the proceeds, they would have performed a work of public benefit; the corruption being confined to one instead of being diffused amongst a multitude. Moreover, charity of this kind was directed only towards the visible and pitiful effects, and failed to come to grips with the physical causes which produced them. Lady Bountiful was well meaning but muddle-headed; she was touched by the sight of the sick labourer, lying untended in his damp, cold room, surrounded by the circle of his pale, ill-fed children; but she sent him medicines, blankets, and fuel, instead of removing by drainage the dampness and pestilential miasma which caused the disease, and also money and food, instead of eliminating the depressing factors in his environment which led him to spend at the beershop the wages which would have sufficed to feed and clothe his family. She would have done better to have fullowed the example of the benevolent lady of St. Margaret's parish, who, instead of distributing alms amongst her tenants, spent a hundred pounds on the drainage of their houses. "This was the greatest and most comprehensive charity, a dry house instead of a damp one was better than the extra fuel and blankets to ward off the effects of the damp, the removal of the offensive cesspools and the filth which are the causes of the disease was surely better than the medicine the expensive and doubtful palliatives of disease, a cleanly and healthy and industrious and independent tenantry better than one which is filthy and squalid, and weakly and exciting compassion from its abject misery".

Chadwick regarded mistrustfully, thereloce, the activity of those whom the world called "philanthropists". - - Dr. Southwood Suith, for example, "who is a man of benevolence merely and who has miananaged the Sanatorium". (2) Not

1. B.C., "Notes for a speech at Lelcester", MS, August 1843. 2. E.C.' - Lord Lansdowne, 31 July 1344. A forerunner of the modern llurging Home, "The sanatorium" was opened in 1842 at (Continued on next page) 
benevolence but self-interest was the motive which should be invoked by the social reformer.

The logic of Chadwick's argument runs simply enough. More and more he looked to the great capitalists, whose crude ereative energy was equipping Britain with an expensive, 11l-planned, but modern system of communications, to furnish the brains and the money to re-build the towns. Such men would move only if they were guaranteed a safe six or seven per cent. on their outlay. Now all Chadwick's inquiries and experiments tended to prove that propits as high as this could be made on the construction of sanitary works; and that the capitalists were overlooking a vast, untapped mariket right under thelx noses --- the millions of the have-nots, dirty, ill-clad and miserably housed, the supply of whose needs would form the basis of a score of new industries. It followed, if this were a true picture of the situation, that it was a grave exror in tactics to let it be put about that model houses and reconstructed sewers could return no more than four per cent. Thus, when Southwood Smith outlined to him in July 1844, the plans of the Society for Improving the Dwellings of the Labouring Classes, he was ready with his advice and sympathy, but he plrmly declined to allow his name to appear as one of the Committee. He was confident, he explained, that if large capital were engaged a profit of six or seven per cent. could be obtained from a superior dwelling let at the same rents now charged for wretched hovels; but the Doctor based the institution on charity and benevolence and proposed to restrict the profits to four per cent., so discarding the powerful stimulus of comercial success. fie urged on Southwood Smith, therefore, that the Board of Prade should be asked to reconsider the limitetion of interest wish had been inserted in the Society's charter, and "to place the proceedings on a commercial principle simply, as being really proceedings on a comnercial principle

(Continued from previous page) Devonshire House, Regent's Park, as a "home in sickness" for aembers of the middle classes. (C.L. Lewes, op. cit., pp. 30 - 34). 
the most benevolent in its ultimate operation to the working classes". (1) The same logic runs through the advice he gave to James Matheson, who was about to spend some of the fortune he had made in India on improving the town of Stornoway. "You express your readiness to adopt any improvement, which may not be of disproportionate expense", Chadwick told him, "I hope you will deem no plan sound that will not be in the end remunerative. I shall one day or other have a chapter to promulgate, as a warning of the mischiefs done by the late Duke of Bedford, and others, in their notions of "doing good to the poor" making work for the sake of employing the poor --- when they have only, so far as their labours went, in nine cases out of ten, gone to make paupers, burthensome to others, as well as themselves. Depend upon it that you serve the population in the best manner, when your proceedings have a thoroughly commercial basis, and you make them answer comercially to yourself. You take the best course for improving the population, when you conduct remunerative works, whlch make it to your own interest, to get skilful, intelligent labourers, foremen and others of various grades to carry them out. The improvement of agricultural processes, and encreased requirements of skill, I bave everywhere observed is equivalent to an improvement of the population".

By the end of 1844, therefore, Chadwlok was telling his friends that there was little chance of effectual measures of sanitary improvement being carried out early, visorously, or comprehensively, unless they were carried out comercially. "Administration seems not likely to attain that reach of improvement, when a vital interest in success will be given to the administrators, or the same motives to vigilance and economy in the expenditure of the public money that capitalists have in spending their own", he observed to one.

To another be 1. B.C. - Southwood Smith, 1 July 1844.

2. B.O. - James Matheson, 18 harch 1345.

3. B.C. - Raikes Currie, 26 Detober 1344. 
defined his position in detail:

"You ask me whether I think the water supply of the town may be best carried out by a Company or by the municipality. All the evidence collected under the Comission of Inquiry would I think establish the fact that it will everywhere be best carried out by a private Company on proper conditions and with new securities for the public: making the Company lessees instead of proprietors....... In the sanitary report I held up the instance of the supply of gas to Manchester by the municipality but I have since been led to believe that the Manchester people would get more if they let the works out than now when they are conducted by the corporation officers ..... Very recently the corporation of the town of lill undertook to provide an extended supply of water for the inhabitants. For the supply of 3,000 houses, they have without any jobbing incurred an expense of 855,000 : and that too for a very imperfect supply and they nay charge 6 per cent. on the rental for it. The Nottingham Company jives a superios and constant supply for not more than 3 per cent. on the rental: and having expended no more than $\$ 32,000$, notwithstandin; much exira expense, they make a return of 6 per cent. to the ratepayers. In most of such puolic works the expense of management is not less than 20 per cent. on the outlay. They are wasteful from ignorance as well as from jobbing".

lhis excessive enthusiasm for private enterprise (but, be it noted, under strong securities for the public interest) was out of character, and was soon to wilt. It had its origins in a complex of considerations: his scora for local administrative ability, his auxiety to geu saditary reform under way without walting on the slow pace of a reluctant liovernment, the influence of the englneer, Homas Hawsestey, wose Nottingham Hater Company seemed a model of elficlency and economy. (2) Possibly his marriage in 1339 to kacnel Dawson 1. E.C. - J. Hodson, 10 April 1345. 2. "Wottingham is a pattera place for the supply of water". (E.C. - J. Booth, 12 Feoruary 1845) 
Kennedy, flfth daughter of John Kennedy, the cotton manufacturer, had left him more open to the arguments of Manchester. Certainly he had lately made the personal acquaintance of some of the great railway capitalists, and had imbibed from them something of the romantic theory of capitalism, the hero of which was the self-made man, who by energy, thrift, and a strict attention to "sound economic principles of trade", forged upwards from the bottom of the social pyramid to become the chairman of a company. There was James horrison, for example, the railway director, who had come up to London with all his worldiy goods in a cotton pocket handicerchief, had prospered, married a partner's daughter, and was now wor in three millions. "His cardinal maxims", Chadwick told Colonel Phipps, Prince Albert's secretary, "were on all occasions to tell the truth, always to consult the interests of the consumer; and always share profits with him". His rule was not that of the vulgar noney-grubber, "to buy cheap and sell dear", but "to buy cheap and sell cheap", not vaxying his prices according to his supposition of what the customer could afford to pay. Keeping the same excelleat rules, his eldest son had already made a quarter of a million. (1) There seemed no reason why Bdwin Chadwick also, if he turned his abilities to comerce, should not in due time become a millionaire.

On these twin postulates, therefore, -- that municipalities were incompetent to aanage such services as gas and water supply; and that, of all inotives to appeal to, seliinterest was the steadiest and most powerful -- was based Chadwick's grand scheme for a lowns Improvemeat Company. His interrogation of witnesses before the llealth of rowns Comission had.left him, as we have seen, with the conviction that there was money to be made not only out of the supply of wate also out of the disposal of sewage. (2) The fisures of practical engineers and farmers could be shown to prove it. For a penny

1. S.o. - Col. pipps, n.d. 
a week supplies of water, constant and at high pressure, could be extended to lower class houses; for another penny those houses could be drained; for another pavements and roadways could be washed and swept. A company could safely contract to perform these services at a fair rate of profit, and in adation it could count on an immense return from the sale of rich town manure to progressive farmers. Three points were essential to the scheme. The company must have a monopoly of the fleld of supply. It must contract for all three of the interdependent services of water supply, drainage, and sewage disposal. And, ilnally, the service must be universal, to all classes of the community, and paid for by a compulsory rate. For, as he explained to Thomas Hawikesley, "the best securities for a fair and liberal and permanent profit, will be in the close consultation of the wants conveniences comforts and means of the greatest numer of the poorest classes of the consumers and in moderate profits on extended supplies, rather than very high profits on aarrow supplies". (1)

The field of operations open to such a company was immense. In Britain, in the colonies, in every country in surope, there were scores or towns which needed water and sewers. Carlisle, Durham, Frome, Kidderninster, Salisbury, Werthyr Pydvil, Stourbridge, Walsall, Wednesbury, West Bromwich, Wrexham, Wolverhampton -.- these were only a few of the places without an adequate water supply. (2) Berlin had already asked Chadwick's advice, and he had heard that he was a greater prophet in Germany than in England. (3) Paris, again, would make the best enterprise in Europe; if only Guizot would take his mind off Algiers and draw his head for a moment out of the elouds of high politics, Chadwick could show him how the highest rooms in paris could be supplied with filtered water for three sous a ton, as compared with the nine francs ta present paid 1. B.O. - T. Hawkesley, 25 November 1844.
2. B.C. - T. Hawkesley, 7 March 1345.
3. B.C. - T. Hawkesley, 11 August 1344. 
to the "porteurs d'eau". (1) Turning over these possibilities, Chadwick was flushed with the vision of himself a.s managing director of a vast public utility company with ramifications in every country, which would be the instrument for carrying out his sanitary schemes and would serve at the same time as a "golden bridge for escape" from the insults to which he felt himself exposed at Somerset House. (2)

The schere began promisingly. Sir John Easthope, the first chairman of the London and Southampton line, gave his "very hearty concurrence", and declared his willingness to embarik 250,000 or more. (3) Other capitalists of European reputation, among them kaikes Currie, Sir George de Larpent, James Matheson, James Morrison, John Moss. Edward and Anthony Strutt, J.L. Ricardo, Rowland Hill, sassau Senior, fell under the spell of Chadwick's tale of gold from sewage. "Such a conjunction, such an Assembly of Eagles on the same perch had perhaps never before been seen", he exclaimed in delight. (4) The company was resistered on the 7th Auguist 1345, with Lord Francis Bgerton as its chairman, three millionalres amongst its backers, and a team of technical consultants chosen by Chadwick for their known sympatiny with the most advanced ideas in sanitary enjineering -- Thomas Hawisesley and Chadwell Mylne Por water supply, John koe and Butler williams for drainage, Smith of Deanston and Captain Vetch for sewage disposal. It was proposed to raise $21,000,000$, on which a return of at least six per cent., and perhaps nine or tea per ceat., was promised. (5) In a tour of the provinces Chadwick expounded to local capitalists the advantages of investing in a venture which

I. E.C. - Sir John Easthope, 23 November and 31 Uctober 1344 .

2. H.C. - 'P. Hawkesley, 8 August 1345.

3. E.C. - T. Hawkesley, 22 October 1344.

4. E.C. - Sir John Easthope, 2 October 1345.

5. Chadwick arafted the prospectus in Marcl 1345, entitling it "Prospectus of a Public Company to be called the British, Colonial, and Foreign Drainage, Water Supply, and Towns Improvement Company". 
offered double the return of the average railway speculation, and combated everywhere the heresy of a water supply divorced from drainage and sewage disposal. At Bristol the Merchant Venturers showed a disposition to co-operate ${ }^{(1)}$; at Leicester, Lancaster, and Exeter strong parties were converted ${ }^{(2)}$; at Nanchester he addressed members of the Corporation for an hour, and made an impression on Cobden. (3) to London with engagements to the extent of 2700,000 . (4) From Lyons, too, came an attractive ofier, which seemed to promise a brilliant commercial result; there was hope of paris; and inquiries were received from Athens, Berlin, Frankfort, and Munich.

But good will and promises and five competent engineering reports remained the extent of the company's achlevement. Chadwick's prospectus was swamped in a sea of railway advertisements; his engineers were lured away by offers of seven 1. E.G. - T. Hawisesley, 18 July 1845 . A letter to Lord

Ebrington (2 August 1345) is typical of Chadwick's optimistic correspondence of this period: "At Bristol a local scheme was on foot to supply the town with water. This scheme was to take it from the Avon which is polluted with the sewage of Bath and other districts. Their expenditure was to be for this supply $t 200$, 000 , or the same sum for supply from a spriag which we found would only have Given one fourth the quantity required. Ne were fortunate in finding a pure source from which a double supoly may be obtained at half the price. The facilities for the application of refuse, though great naturally, were not great in the intelifigence of the owsers of the lands adjacent to the town. Exeter we found was supplied with about balf the quantity of water it ought to have, oy a joint stock company conducted on erroneous orinciples. in. Terrell a solicitor who is one of the town's improvement comissioners had brought the subject of the applicstion of the refuse before that body, but they declined to have anything to do with it, and we found the field left open to the proposed company. Mr. Smith and in. Hawkesley saw at once that the facilities for its applicstion there are peculiarly good: the land adjacent is very poor for the situation, and held by intelilgent owers, and occupied by farmers who are very sensible of the value of liquid manure"

2. E.C. - R.A. Slaney, 6 September 1845.

3. S.C. - kaikes Currie, 25 september 1345.

4. B.C. - Vapt. veten, 25 september 1345. 
and a half guineas a day as railway surveyors; and his millionaires succumbed one by one to the madness of the great rallway boom. (1) At leicester, after six months of negotiation with local capitalists, who were reluctant to see the control of the town's water supply pass to a London company, only \&7,000 of the $\$ 70,000$ required could be raised. (2)

At Manchester and Bristol Chadwick's company found itself opposed by separate water schemes, which drew away suppori because their offers seemed less speculative. (3) The optinistic prospectus was founded largely on the experience of Thomas Hawkesley, and it was a severe blow to Chadwick when this expert of his own choice began to exhibit heretical tendencies.

He was bewildered when Hawkesley accepted a retainer from the Lancashire Water Company in september 1345. (4) How could hawiseslej square advocacy of a new company with his published views which condemned the intrusion of second capitals into the same field? Such a scene would rejoice the old-style water eagineers, the simpsons and the Wicksteeds, exceedingly! (5) When Hawkesley began to cast doubts on the accuracy of Chadwick's figures for the returns from sewage irrigation, the break became complete. (6) It was certainly strange, if Hawkesley was so dubious of the soundness of the schame, that be waited eighteen months, and until Chadwick was having difficulty in raiging crpital, to reveal it.

But the most fundamental weakness of all was the impression which had spread in business circles that the company bad philanthropic objects. "One of our capitalists had objected to me! as tending to taint the list with benevolence and philanthropy", Chadwick ouserved with uneasy heartiness.

1. T. Hawkesley - E.C., 16 October 1345; 8.O. - Dr. P.H. Holland, 22 October 1345.

2. E.C. - Dr. P.H. Bolland, 26 January 1846.

3. E.C. - R. Reynolds, 19 April 1846; Dr. P. F. Holland - B.C., 3 JuIy 1846.

4. 2.C. - Dr. P.H. Holland, 16 September 1345.

5. B.C. - T. Hawkesley, 31 August 1845.

6. B.C. - T. Hawsesley, 26 Detober 1345.

7. B.0. - Lord Francis Bgerton, I November 1345. 
"So good a commercial man as Mr. Bates", he wrote urgently to Nassau Senior, "should not be allowed to labour under the delusion that there is any more patriotism in the objects of the proposed Company than there is in the every day operations of his own counting house in supplying the wants of the needy in all parts se the world with goods, or money, and receiving in tale, and measure, in a solid and tangible shape the expression of their sense of gratitude for the amount of service rendered to them ..... He owes some apology to the gentlemen whose names are on the prospectus for so injurious a supposition". (1) But it was in vain that Chadwick pointed to the adhesion of John Hoss, the chairman of the Grand Junction Company, "a firm minded man who would not let his feelings get the better of his pecuniary judgment" (2) in valn that he declared that for the sake of humanity the percentage should be looked to with the eye of a shylock. (3) It was whispered that a company to furnish the houses of the poor with water and drains must be humanitarian and patriotic, and as such offensive to the business conscience.

Some 2600 had been spent on the prospectuses, advertisements, and reports of the Towns Improvement Company, of which nearly 2500 had cone out of Chadwick's pocket. The money had not been entirely wasted. For a moderate outlay the company had examined seven towns, Manchester, Salford, Bolton, Leicester, Bristol, Exeter, and Derby, and had produced exploratory reports on the ilrst five of these, Indicating how between two and three million pounds might be profitably spent on their improvement. (4) A surgeon of Manchester, Dr. P.F.

1. B.C.- Nassau Senior, 11 April 1345.

2. H.C. - Lord Prancis Egerton, I November 1345.

3. E.C. - Barl of Lovelace, 8 harch 1345.

4. "The expositions promulgated by the cowns Improvement Company did great good in paving the way and it is much to be regretted that the money market has never so recovered as to enable it to be carried forward ...." (E.C. - Earl of Ellesmere, 20 Pebruary 1847). He comended the reports to Lord Morpetb "as aiding the consideration of the Pacienda, in respect to the Inspectors work". (23 October 1343). 
Holland, had produced a report on that city which was adjudged by Chadwick to be the best of its kind that had yet appeared. Altogether this fleld-work in the service of the company undoubtedly stood Chadwick in good stead when he came to direct the activities of his Inspectors at the Board of Health.

After 1846 the Towns Improvement Company fell into a state of suspended animation from which Chadwick never succeeded in awakening it. (2) But to its curious history there was a still more curious appendix. By a flash of characteristic ingenuity, Chadwick had conceived the idea of distributing sewer manure by pumps mounted on canal boats, and now, with three other optimistic spirits, Dr. P.H. Holland, Robert Rawlinson the engineer, and Joseph whitworth the inventor, he forned an association to conduct an experiment on the Bridgewater canal. His hopes -- as usual -- were high. Farmers were shaking their heads over the shortage of manure, yet the sewers of the towns were veritable guano mines. The rich refuse of the towns might be ferried down in boats to the barren and starving farm land, and the produce would float back to feed the workers in the factories. "Chadwick's Blixir" would make the banks of every canal green and fertile.

The ldea found little favour, however, with the rugged 1. B.C. - Dr. H. Holland, $23^{-0-}$ Dacember 1345

2. He wrote to Holland, 6 January 1347: "You are to bear in mind that I by no means consider the lowns Improvement Company defunct. Every day brings some new case of a demand". To the Earl of Bllesmere (the former Lord Francis Egerton, chaiman of the company), he lameated in a letter of 28 varch 1347 that railway demands on the money marset still handicapped the company. "Manchester is however shlfting for itself, and is going on i.e. the corporation, in a good direction. Into this they have been led by our report. The Leicester people have dotermined not to wait for a complete measure, and some of our allies there are getting a bill to bring to the town, the water from the new source which we found for them .... Lxeter, Rugby, Worcester are offered. But the Bates and Barings who have never been known to fuil beiore, have very recently failed to raise money for undertaisings in which they took especial interest!" 
farmers of South Lancashire, and they listened with a canny scepticism to these plausible strangers, with their pumps and jets and miles of canvas hose, who promised them agricultural miracles, and offered to manure their fields in return for half the extra crop obtained. Where Dr. Holland, who had been put in charge of the experiment, did find employment for his floating pump, few of his hopeful clients noticed that remarkable transformation of their produce which he had led them to expect.

Part of the misfortune Chadwick attributed to the unhappy Dr. Holland, who was not the man to cope with "this plaguy irrigation". But the failure was due chiefly, he felt, to the farmers of the old "round frock" school, who could not be convinced that they might pay an additional reat by saving the manure which they now wasted. It was a psychological phenomenon, this bucolic resistance to new ideas. As an example of "agricultural logic", Chadwick would tell how the Duke of bedford attempted to prove to one of his tenants that a certain piece of ploughing could be done as well by two horses as by the four at present used by the farmer. Words failing to carry conviction, the Duke gave an sctual demonstration. "We only response which his Grace obtained was that way might be all very well to be worked by a luke but he as a farmer could not afford it". (I)

Chadwick continued the experiment till the end of 1849 , paying expenses out of his ow a pocset, despite Holland's continually more depressing reports and the prudent secession of his allies. (2) It was a courageous act of faith, and when - 0 -

1. E.C., "Notes on Agricultural Logic", w, a.d.

2. Writing after the abandonment of the scheme, Holland told Chadwick ( 8 January 1850) that, althoug) it would be publicly deemed a total fallure, he believed the effect of liquid manure on the crops had been shown to be decisive. "The reason of our losses is because so few of the farms are properly drained and cultivated, and so few of the farmers have enterprise enough to try anything new so that we have had nothing like occupation for our engine and man". 
defeat could no longer be hidden, he was keenly disappointed. The successful application of sewer manure to agriculture, he belleved, would do more than anything else to encourage the adoption of a better system of drainage and water supply and the universal introduction of the water closet. And to the end of his life the productive powers of liquid sewage remained his "King Charles" Head", the fascination of a fortune from town guano drawing him back time and again to the idea of a Towns Improvement Company.

1. In 1872, for example, he attempted to float a "German Towns Improvement Company". Writing to a Berlin correspondent (probably the Mayor), he reviewed recent plans for improving "the most stinking capital in Europe". "Ten years, it is stated to me, have been occupied in consulting experience and preparing plans for messures of relief; and ten years more, it has been stated, are contemplated for their execution. It might indeed be so, if they are set about, without the available experience in such work. But we might undertake, that with a body of German workmen, under the guidance of practical knowledge, a contract shall be Given for the completion of the works in question, in three years, and that by the fourth year, a zone of agricultural has never yet been beheld in Gesmany".

His son, Osbert, wrote to him severely (5 May ? 1885) that he thought he had convinced him that the drainage of towns was not proper work for a syndicate, no contract being possible on such vague terms. "It is quite unsuitable to your age and position to become the tool of a gang of financiers". 
CHAPTER ?.

\section{STRUGGUE ITE THE SPECULATORS.}

The queen's Speech at the opening of the 1345 session referred to the Fiealth of Towns Report, and volced the hope that it would form the basis of a measure for "promoting the Health and Comfort of the poorer Classes of My Subjects". (1) So, for the first time in history, a British Government announced that its legislative programme included a Public Healtb Bill. The period of inquiry, begun in 1838, was finished; and Chadwick's seven years of ceaseless investigation and argument had brought the Government to the point of action. The question remained whether that action would be as bold and as comprehensive as he had planned. He had wished --- as the memoranda he had laid before Buccleuch show clearly -- that the Comissioners would embody their recomendations in the actual clauses of a Bill, dictated by himself, and so strongly buttressed by the evidence and the authority of a Royal Commission that it must pass without substantial alteration by the legislature. The Government had other intentions, however, and the preparation of a Public Health Bill was entrusted to the Earl of Lincoln, Chief Commissioner of Woods and Forests, a couple of months before the kealth of Towns Comission presented their Second Report. The decision made two things plain: that the Government looked upon the B111 as the minor measure of a toinor department, and that they felt themselves in no wise bound by the conclusions of an inquiry dominated by Bdwin Chadwick.

Lord Lincoln immediately turned his back on the Health of Towns Commigsion, and sought bis authorities among the $-0-$

1. Hansard, vol. 77, p. 4, 4 Feoruary 1345. 
builders and architects of the Woods and Forests. "Their working men are entirely of the old school", Chadwick told Lyon Playfair (1); and a day or two later, "I know of no reason to distrust him: but the men about his office are exceedingly to be distrusted who fix the flues of chimneys twice the size that is necessary. There is indeed an impropriety which ought to strike every one in his proceeding to prepare a separate measure without the slightest consultation with the Comission .... The Chelsea water works offered to give them a constant supply of water for large fountains in Irafalgar Square for $\$ 400$ per annum. That may be an overcharge: but only think of people who spend $\$ 7,000$ at once to erect engine houses: steam engines and sink artiesian wells for those two fountains!"(2)

The success or fallure of the Towns Improvement Company depended very largely upon the provisions of Lincoln's Bill; and It was the future of his "Golden bridge for escape" which was Chadwick's chief anxiety throughout 1845. If the recommendations of the Health of Towns Commission were adopted, companies of the old style, with their separate water schemes and restrictive policies, would be handicapped, and facllities would be granted to a company prepared to carry out combined works by a contract under public regulation. As the 1845 session advanced his hopes rose that Lincoln might be persuaded to ignore the "prejudices of various pestilential interests"(3) and that out of the woods and Forests might yet emerge a well designed B111; in which event the Towns Iaprovenent Company 1. B.C. - Lyon Playfair, 14 December 1344. "I have much dread of the advice which will be given to lord lincoln by the Woods and Forests builders, who have been advising him for the retention of the old brick drains 9 inch for houses and the retention of cesspools and the provision of parish fire engines for the prevention of fires. If that office have anything to do with the execution of the measure it will certainly be destroyed ...." (ibid.)

2. B.C. - Lyon Playfair, 16 December 1844.

3. B.C. - Lord Ibrington, 25 June 1845. 
might immediately take the field, examining places and recruiting local capitalists, in readiness for a sweeping campaign on the collapse of the railway boom.

Lincoln's Bill made a momentary appearance in July 1345 , and was then withdrawn for consideration and amendrent during the recess. (1)

"Your annoyance at the announcement of today, that the bill will not be pressed this session will not exceed mine that another year's delay is to take place", Chadwick wrote to R.A. slaney. "But it is to be noted, that if the bill is to be presented in its present shape, as the shape in which it is to be brought forward next session then the whole of the Metropolis, all Scotland and all Ireland is omitted for snother year, beyond that session for 1847 !

I despair now of doing anything anywhere that is effectual except commercially, and the bill puts all such projects in a very awkward shape so as to prevent instead of facilitating the formation of companies. The new Commissioners are to borrow money at 5 per cent., and the whole machinery is such as will present the aspect of their spending the money so raised: of their executing and maintaining the works instead of the works being maintained, as well as executed by contract as the report recommends. I fear that the large capitalists who have been persuaded to look at the sanitary improvement of towns, will not look at it in the shape proposed in the bill a shape to hold out inducements only to the petty tradesmen of a country towa, who done will serve under the orders or humour the caprices of the other petty tradesmen of country towns, even though they should be presided over by local Donaldsons".

hile Chadwick thus watched anxiously the delaying and

1. Hansard, vol. 82, p. 1077,25 July 1.5.5.

2. L.C. - R.A. Blaney, 3 July 1345 . Thomas Leverton Donaldson, chairman of the estminster Comission of Bewers, had defended the old order before the liealth of Towns Comission ("Irst Report", vol. 2, pp. 13- 202 ). 
possible crippling of his main measure, on the interments question he faced complete deadlock. Throughout 1845 Sir James Graham maintained an imperturbable front. When a newspaper report was brought to his attention, describing the practice in the clerkenwell churchyard of disinterring bodies after a few days, chopping them with a spade, and burning the pieces in a bonehouse, he consented to make inquiries --- "though he thought there would be some difficulty in removing the cause of the evil". (1) A week later he observed that he "feared that any prohibition of interment within the walls of a city would not be in harmony with the feelings of a great body of the people". (2) Chadwick exploded into protest. Who were these people who were so attached to the practice? Was it the working classes, the poor, the uneasy, the heavily laden, who dwelt with complacency upon burials in the over-gorged charnels of the metropolis, where new ly buried corpses wre hacked and hewn by the sexton's shovel to make way for others? Was it the middle and higher clasaes, who were abandoning family vaults in the graveyards, preferring to pay heavily for interment in kensal Green cemetery? Since it was clearly none of these, then who constituted this "great body"? A portion of the clerby! "Are we to endure to have it held up before this country and before all Europe, that respect for the dead and the health of the living are to be prostrated for the maintenance of clerical domination, or rapacity for fees or for the lowest traders" pelf? The legislature seeing the evils fully displayed, and the course of remedy demonstrated, by the example of civilised nations, is it to be allowed to go forth that the moral courage of our leading public men is so low, or their perceptions so obtuse, or their capacity so feeble that administrative neasures which have been carried out in Austria, Prussia, Russia, Meimar, nay even in Spain, and are seen to elevate the feelings of the population are beyond the capacity of our parliement or our 1. Hansard, vol. 77, p. 1234, 26 February 1345.

2. ibid., vol. 73, p. 325, 5 Jareh 1845. 
Government ! (1)

On the 8th April 1845 James Mackinnon confronted the Government with a resolution condeming intramural interment. Faced with an inescapable decision, Graham came out openly in support of the existing system. aving aside the "exaggerated views entertained on the subject", he declared that it would not be easy to stop people being buried in the places where their kindred lay. He refused to admit that the public health was endangered; there was no metropolis in the world where hesltb was so well preserved. If they adopted Chadwick's suggestion, and prohibited absolutely interments in cities and towns, public feeling would be greatly excited, if not grossly violated. Were the Government to undertake the arrangements for burial, it would be intruding in a field where private companies were beginning to enter; so they should take care "lest, by a compulsory enactment, they interrupted that course of feeling, which, if left to itself, would remedy the evil". Graham was decisively routed in the debate, and tackinnon's resolution was carried by 66 votes to 49 . (2) Chadwick, who judged that the vested interests in burial fees had prevailed with the fome Secretary, (3)as delighted, but the victory brought no change in the attitude of the Goverment, which was clearly unwilling to believe in the nuisance because of the trouble it would be put to in finding a remedy.

Corn dominated the arliamentary scene in 1346 , and it was soon evident that until the manufacturer and the landord had played out their parts in the drama of the session, the public health reformers must content themselves in patieace. But the year showed some notable advances, and the fact that not all of them orisinated directly with Chadwick proved that the "sanitary idea" was pushing out roots into many influential

I. S.C., Mis Pragment, n.d.

2. Hansard, vol. $79, \mathrm{pp} \cdot 330-359,3$ April 1345.

3. B.C. - J.H. Burton, 12 April 1345. 
quarters. An Act was passed to authorise Town Councils to establish public baths and washhouses, defraying the cost out of the rates.

\section{(1) A Nuisances Removal Act empowered Boards of} Guardians in the rural areas to indict nuisances before the Justices of the Peace, and, where the order for removal was met by recalcitrance or continued neglect, to take steps to execute it at the expense of the person reaponsible. (2) Sanitary legislation thus made its first tentative step into the rural areas; and for the narrow purposes of the Act the parish was replaced as the responsible authority by the Poor law Union, with its superior efficiency, its paid medical staff, and its responsiveness to control and instruction from the centre. Another clause of the same Act authorised the rivy Council to issue emergency Orders if any place should be threatened by "formidable contagious or epidemic viseases". This measure was in fact, the first payment made by fear on an insurance policy against the cholera, which even then was advancias on the southtastern frontiers of Europe.

To balance these small gains there was unother check on the interments question, and a further delay in the introduction of a Public Heaith Bill. In April James Meckinnon brought in a Bill drafted by Chadwick on the conclusions of the Interments Report. (3) "Sir James Graham has become so unpopular", $-0-$

1. "An Act to encourage the establishment of gublic Baths and Washhouses", 9 and 10 Vict. c. 74, 26 August 1846.

2. "An Act for the more speedy removal of certain Nuisancen, and to enable the rivy Council to take Regulations for the Prevention of conta ious and epidemic Diseases until the 3lat Day of August 1347, and to the end of the then next Session of parliament", 9 and 10 Vict. c. 90, 23 August 1346. Amended by 11 and 12 Vict. c. 123 and 12 and 13 Vict. e. 111 .

3. "For providing Cemeteries, and promoting the Public fieatith in Towns and Populous Districts", 1346 (516).1. 255. The Bill provided for:

1. A Burial Comission under the supervision of the Privy Council.

2. A local inquiry by a Governeat Inspector, his report being subitited for the approval of the Privy louncil, the 
Chadwick wrote hopefully to the Bishop of London, "that it is more than probable that his opposition would contribute to the success of Mr. Mackinnon who will receive support from both sides of the house". (1) Graham unbent so far as to allow him to circulate privately amongst the Bishops the provisions of the $B i 11^{(2)}$; but with the collapse of the Tory Government, it disappeared once more from view. Not until the General Board of flealth was installed at Gwydyr Rouse did Chadwick get the opportunity to carry out his interments scheme.

Lord Lincoln's Public fealth Bill (3e-appeared, unchanged, at the beginning of the session, and Chadwick promptly joined with Southwood Smith to draw up a detailed report on its provisions for publication by the London branch of the Fealth of Towns Association. (4) This interesting pamphlet illuminates not only the defects of the Goverament measure, but also certain peculiar limitations in the view-point of the sanitary reformers themselves. On the whole the Bill was a iseat improvement on (Oontinued from previous page) Bishop, and the district concerned.

3. A local committee of clergy, members of elected bodies, and a number of the residents to manage the cemetery A separate committee of Dissenters might be appointed to manage the unconsecrated portion.

4. An officer of Health, appointed by the local comittee, subject to the approval of the Privy Council

5. Contracts with undertakers to furniah funeral materials, according to specifications prepared by the officer of Health.

5. Compensation for clersy, clerks, sextons, companies and private owners dispossessed by the Act.

7. Thirty-year loans, secured on the burial dues, to defray the cost of the ceretery.

1. B.C. - Bishop Blomfield, 9 Warch 1846

2. J. Hackinnon - E.J., 10 June 1846. The draft was sent to the bishops of worwich and Chester on 22 June 1846.

3. "For the Improvement of the Sewerage and Drainage of lowns and opulous Districts, and for making Provision for an ample supply of later, and for otberwise promoting the Healtb and Convenience of the Inhabltante", 1345 (574). V. 363.

4. "Report of the Committee to the wembers of the Association on Lord Lincoln's Sewerage, Drainage, ete. of Powns Bill", Charles knight and Co., 1346. 
earlier attempts, the report conceded, and might form an excellent basis for a comprehensive sanitary measure. It recognised the principle that the whole of the natural drainage area, together with all the works for water supply, sewerage, drainage, cleansing and paving, should be under a single authority. It protected the interests of the community by the supervision of an impartial Government Inspector. It provided for surveys by competent engineers, for the examination of plans oy responsible public officers, for the publication of expository reports to be circulated localiy. It permitted local authorities to enter into contracts for the maintenance and execution of the combined works, under the supervision of a competent, paid, and responsible Surveyor. It stipulated that an Inspector of Nuisances and a Medical officer of Healih should be appointed. All these things were new, all were steps in the right direction, and they were by themselves suflicient to effect a highly beneficial change in the sanitarg condition of the people.

The tone changed sharply from satisfaction to criticisti, however, when the report went on to consider the administrative machinery. A novel and complicated field of administration was to be entrusted to a man whose avery moment of timo mas already in incessant denand from the va:t and undifferenciated functions of an unwieldy department: the Home secrebary --- Cabinet unister and party leader, head of the metropolitan police and of the unpald and stipendiary magistracy, regulator of prisons, protector of young persons in factories, supervisor of the poor Law, superintendent of Ixish affairs, and judge of appeal in the last resort -.. was now expected to add to his labours the smeling out of nuisances, the planning of drainage and water systems, and the perusal of the multitudinous reports of Nuisance Inspectors and DPPlcers of Health. bven Sir James Graham, wlth his "athletic strength and powerful intellect", 1. ibid., pp. $4-5$. 
exhibited plain signs of overwork, and --- Southwood Smith charitably suggested -.- the failure of measure after measure in his hands was due in large part to the inadequate attention he could afford to give them. (1) The practical result would be to abandon sanitary measures to the chance zeal of a clerk or some other unknown and irresponsible subordinate; who would be (to quote a parallel not given in the report) the Home office equivalent of Charles Buller'g harassed Mr. Mothercountry in the Colonial ofice, so imorged in his departientel duties that he had no time to obtain sound and Plrst-hand snowledige of the colonies over. which he exerclsed his obscure and dictatorial authority. It would be far better, declared the report, to charge the duties of supervision on the erivy council, who might delegate one or more of their number to pay special, constant, and public attention to sanitary afrairs ${ }^{(2)}$; and where, the report omitted to add, sdwin chadwick might secure in public health the key position that kay Shuttleworth now occupied in education.

The sanitary reformers were no better pleased with the propoeal to establish elective local Boards, which comitted the cardinal error, illustrated time after time in the shady bistory of the sewers Comissions, of making a numerous local authority an executlve instead of a supervisory body. (3) The

responsibility of preparing plans and estimaies lor puolic works should be concentrated on the local surveyor, who should be a qualified civil engineer; and, while the local. Board should determine the expediency, efilciuncy, and completeness of the works, they should not be given powers to interfere in technical matters on which they were incompetent to forn a sound judgwent. Moreover, the Board shoula be entirely barred from executing works by themselves or even by their ofricers, and should be obliged to carry them all out by contract under the supervision 1. ibid., pp. 9- -11
2. ibid., p. 14.
3. ibid., p. 16. 
of their surveyor The merely permissive authority under the $B 111$ to enter into contracts for the construction and maintenance of works should be made perenptory. In this connection, and considering that "the object of the Legislature should be to engage and regulate the spirit of comercial enterprise in the execution of the measures of sanitary iaprovement", the report regretted that ao facilities were offered oy the $B 111$ to induce joint stock companies to make tenders for contracts. (1) Nor was this the only serious departure from the recommendations of the Eeaith of Towns Commission. The Bill was limited to figland and wales, and Iondor was onitted, although the specific proposals in the Comission's Second Report applied directly to metropolitan evils. The essential point had been missed that the loan for defraying the cost of the local works should be spread over a period coincident with the benefit derived from them; while the old practice was continued of looking to the owaer to pay the charges and to execute the domestic works by arrangement with his own plumber and brieklayer. (2)

There was no stipulation that every water company seeking legislative aid and protection should be compelled to furnish a constant supply of filtered water at high service. Furthermore, phrases in the Bill clearly recogaised the existence and envisaged the extension of the cesspool and the privy, despite the accuralated evidence proving their expense, noxiousness, and inepiciency. "If intermittent suppliess of unliltered and filing water, if expensive tanks and cisterns in which this water may stagnate and acquire silil rurther iapurities, if cesspools and orivies,

1. ibid., pp. $21-27$

2. "On this principle the main difficuliy of carfyias out sanatory improvements, namely, the dificulty of meeting the immediate outlay, is retained in its full force; while the interests of the landlord being always materialiy injured, and in sorne cases his property bein confiscated, \& combination of this whole class against the bill, and, if it should pass into an act, against the due execution of the law, is certain" (ibid., p. 33). 
if "nightmen to carry avay night-soil" -.. if all this is still to be perpetuated and encouraged, perpetuated and encouraged by being legelised, then indeed witnesses will have testified and comissioners will have reporced in vain against a system which al1 classes concur in stating to be the most costly, and under which all declare that it is impossible that "any population can be healthy" (1)

Great advance though the Bill was, therefore, on Lord Normanby's measures of four years earlier, its provisions showed unmistakably that, as the report put it, it had been produced not by James Graham but by some ignorant legal draftsman. (2) Soon after the Bill re-appeared, however, it became clear that there was no chance of its passing into Law in the 1846 session. Chadwick resigaed himself to another twelve month's delay, until the new whig Government should recast the measure bequeathed to them by Iord Lincoln. Peraaps the change of Government might justify a year's postponement; Lord Morpeth, who succeeded at the woods and Forests, was certainly more amenable than Lord Isincoln, and no Home Bucretary could be less sympathetic than Sir James Graham. When Jord John Russell made an address to his constituents in Juiy 1846, he announced his intention of taking up this grievously neglected field of legislation. Chadwick was delighted; public opinion was advancing on sanftary questions, he felt, and they were being officially thought of at last ${ }^{(4)}$. Meanwile the London and provincial branches of the Health of Towns Association passed their resolutions and circulated their leaflets; Southwood Smith and Dr. liolland wrote their acticles; and chadwick dreamed and planned stili for the conquests of bis joint stack company.

1846 is the year of the Andover Comittee, and of Chadwick's flal 1 break with the foor Law domiasionerg, which 1. ibid., p. 7i.

2. ibid., p. Il.

3. B.C. - D. P.H. Holland, 4 July 1346.

4. J.C. - J. Nhitworth, 28 Septenber 1846. 
will be described in the next chapter. And the defence of his reputation against his official superiors was not the only heavy burden which the events of the session threw upon hili. During the lull in the main battle for a Public Fealth Bill, he engaged in two brisk campaigns against the over-mighty capitalists of water and railways. For to Chadwick the selpgovernment of capitalists was no better than the self-governiment of local authorities. Great though his faith was in selfinterest, it was as the spring of individual vigour and efficiency that it met with his approval, and as the most persistent and calculable element in human character that it ifgured so prominently in his thought. He saw no evidence at all that social benefits resulted of necessity from its pursuit, and much which persuaded him that without the barriers erected by the law its undirected enecgies uight disrupt society. He put his trust, therefoce, not in the rule of gome "invisible hand", blending the interests of the individual and society in a mystic reconciliation, but in the secular authority of the State which, abandoning the superstitions of laissez-faire, should intervene to guide the activities of individuals towards the desirable goals of comunal welfare.

The publication in the previous year of the Second Report of the liealth of Towns Commission, foreshadowing public control of water supplies in the not too distant future, bad been followed by a sudden mush of water compries to seize the most eligible sources for the supply of towns. In this Chadwicts saw a double danger. At the very moment when le islation was under consideration for combining water and drainage estaolishments in every town, and for extending to all classes constant supplies of pure water, separate water companies on the old model, with their intermittent service and restrictive policies, were establishing themeelves in positions of vantage; in some places, indeed, rival companies were being formed, threatening to develop a type of competition condemned by the 
Royal Commisaion only a few weeics before. Once established, such companies would be obstacles to the introduction of the new principles; they would be able to demand large compensation if they were disturbed; and Chadwick had no doubt that their promoters were, in fact, speculating on "forcing the inhabitants to pay heavily when comprehensive measures are adopted".

In the second place, these separate schemes endangered the Towns Improvement Company, Chadwick's chosen instrument for the execution of sanitary improvements. As he told the chairman, Lord Francis Egerton, they would deprive "all comprehensive measures of the commercial force, which is so salutary in overcoming the vis inertiae of the towns themselves. The people are accustomed to consider water works as a proper subject for the investment of capital: the instances of companies formed for carrying out drainage work's are very few and may be said to be unknown. The first point of conflict at Leicester was to join the scheme of drainage with the scheme of water works: the next to prevent them separating the water scheme, on which (comercially) they "saw their way clear", --to a dividend: but the drainage they had never considered. All the commercial motive, contained in the water bills, will by allowing them to be passed separately, be lost to complete works, as it would have been lost in the case of Leicester". (2)

Hence Chadwick condemned "this hurrying and graboing of water sources" as "most improvident and unbugsinessilike"(3), and he instructed his friends that the press should open fire st once on all separate water schemes, for "all those which gain Ground will take it from us, from better measures". (4) Barly in 1345 he had drawn up a set of conditions, and had urged on 1. B. . - R. Monckton Ilnes, 23 February 1346
2. - Lord Francis Egerton, 2 April 1346. E. - - Phomas liawkesley, 3 November 1345. "The Water-ioriks and Sewer-iater application questions seem to be making considerable stir. The London Ingineers are already chasing about the country for jous". (T. Hawkesley - M.0., 16 Septenber 1844).

4. E.U. - Dr. P.I. Holland, l Sovember 1845. 
the Government that the promoters of Private Bills for water supply should be informed that they must insert them or lose their measures. In this document benefits to the consumer were nicely balanced against privileges to the company. (1) The franchise should be granted for a term of years, renewable by the crown only if it were satisfied after an examination of the needs of the district that the company was still competent to supply them. The works should be repurchaseable, on conditions settled at the time of the concession, by any local administrative body wich might thereafter be appointed on behalf of the population. A constant supply at high pressure Iust be furnished by the contractor, who should also be required to adopt all improvements introduced from time to time in the storage, filtration, and care of the water. The company should be bound to provide the poorest class of tenements with a constant supply of forty gallons daily of filtered water, at a charge not exceeding $1 d$. per week, and to shaintain the distributary apparatus and house drains for another $1 \frac{1}{2}$. In return the company should enjoy the protection of limited liablilty, and should be guaranteed against the intrusion of a competitor into the same district. The charges of the service should be repayable by a rate, assessed on the value of the rental of all the tenements rated to the relief of the poos. Ihese proposals, however, had proved too strong for the Government to accept. The only reault of Chadwick's representations was the insertion into some Bills of a Government clause to subject the promoters to any general regulations that might later be approved; and tois, as Chadwick complained, was too feeble a safeguard to doter the speculators. Falling to secure allies amongst the fory linisters, he declared a private war against the wates companies in the summer of 1345, $-0-$

1. E.C., "Hesith of Towns. points for considerstion in respect to Contracts for the execution and maintenance of Works of Water Supply, Drsinage and Clesnsing by Companies, under Private, Local, or General Acts", lis, N. 
employing Thomas Hawkesley as his champion before the select Committees. A few incidents of this obscure struggle may be pieced together from the fugitive notes and memoranda he directed to his friends on the Cormittees, and to supporters who were conducting parallel campaigns in the localities. There was a keen Plght over the janchester Vaterworks B111, which proposed to raise $\$ 600,000$ for extension of plant which Hawkesley calculated could be laid down de novo for k250,000. old companies, Chadwick informed a member of the Comittee, habituated as they were to the practice of high charges for lixited supplies, always preferred them to extensive supplies at low rates and fixed charges; or rather, their officers did, who saw double trouble without double salaries. (1)

The company put forward James Simpson, a London engineer of the old school, as their expert to testify that a constant and universal supply would cost them asother 2100,000 ; Hawkesley in rebuttal stated that if the Manchester company was not prepared to Bive a constant supply of filtered watex at a pena a week to labouring class tenements, the Iowns Improvement Company would?' and he weat on to combat the company's assertion that filtration was unecessary, and their demand that they should be paid extra for the supply to water closets.

Little return could be shown for chadwicis's elforts to convince the irivate sill Comittees that proceedings for water supply alone, in the face of the conclusions of the Royal Comission, must be "mere extorney's jobs for the saice of the

i. H.C. - J. Milner Gibson, 24 May 1345. Hawkesley wrote to Chadwick, 25 Kay 1345: "I an perfectly astouished at the course taken by the danchester Water Company and at the very fallacious arguments adduced by Mr. Simpson in support of his own intermitcent systen. The fact is the tondon ingineers have so long kept the population on short comans for the purpose of spinning out their own inadequate means that they do not dare to recomend the natural system of supply upon Iull comans elsewhere 1 st they should be called upon to give it in the etropolis.

2. B.G. - J. Siliaes Gibson, 24 tha 1345.

3. S.C. - Dr. P.H. Holland, 29 May 1345. 
Bi11". (1) Chadwick had the unusual humiliation of being routed by James Simpson, when he appeared in person to protest against a Bill promoted by the Sheffleld Waterworiss Company for leave to raise fresh capital, twice as much as he estimated the company should require to give a superior supply.

(2) But he and

Eawkesley scored one notable success. The enlightened provisions of the Nottingham Inclosure Act (3) owed much to their strenuous intervention, in the teeth of bitter opposition from the Corporation. The truth was, Chadwick heurd from Hawicesley, the Corporation was in fear of the "Cowocracy", the Freemen's Rights Comittee, "an interest I am sorry to say of the most ignorant corrupt and degraded kind - - an interest which has been the curse of llottingham as rempectis its Social Sanatory and Commerclal prosperity for many years past". (4) The assertion of the Nottiagham Councillors, despite the statistics, that Nottinghan was the healthiest of all the large towas, their corruption (Bawiresley told him that since 1300 a quarter of a aillion had beea spent in direct bribery in the city (5), and theif opposition to the proposal to replace cesepools by water closets -... all confirned chadwick in his view that the defence of the public health could not safely be entrusted to municipal authorities. (6)

In 134645 drainage and water works Bills were introduced, twice the number for a normal year. Ito rival companies were racing to secure water sources for Bristol, both of which the engineers of the Towns Inprovement Company had

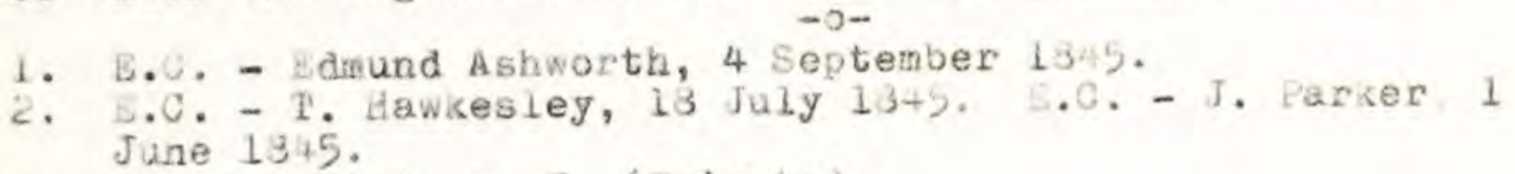

3. 3 and 9 vict. c. 7. (Pivate)

4. Hawkesley - H.C., y Bebruary 1345.

5. T. Fawkesiey - 1.., 22 September 1844.

6. "ine corporation of "lottingham I learn today resisted the clause of the improvement bill which puts an end to cesspools and substitutes boil pans! .... Phe more I see the nore $L$ am convinced that no otner element than the commercial element can or ought to be relied upon" James Bmith, ? Nareh 1845). 
examined and rejected as too hard. For Manchester, Liverpool, and Edinburgh also there were two competing water bills. (1) wile the Health of Towns Association debated with Lord Lincoln, and the Government moved slow-looted in the direction of control the speculators were strengthening their grip on the necessities of the public. Chadwick had now lost his chamion, for Hawsesley had been seduced from the cause by an offer from the Lancashire waterworks Company, one of the companies whose principles he had been engaged in attacking. To fill his place Chadwic chose Joseph Hume, the leading Radical advocate of retrenchment, whose voice had recently been raised against the exorbitant fees charged by Parliamentary agents for the draiting of rivate Bills. On the 7th April 1846 tiume woved, in the terms of a resolution which CLadwick had put into his hands (2), for a Belect Comittee to examine how far the principles of the Health of lowns Commission could be carried out in the Bills now oefore the House for the erection of new water works and the execution of drainage, paving, and other improvements. There were more water works Bills this year than had ever before been known, he observed, and none of them should be sanctioned until a Government Commissioner had been sent down to see that the works were in fact required. Instead of metoers having to decide upon the rerits of bills running counter to each other, they should be asked to determine what actually was the best mode of watering such places as Liverpool and Bristol. phere seesed no reason why a general $3 i l l$ should not be passed, under which any town wishing to have water works might establish them without coming to Parliament at all. Sis James Grahem in reply adnitted that the announcement of Lincoln's B111 had stimulated speculation, and that a great aumer of sills had been promoted in consequence to take possession of mater sources. Ist "the jealousy of Parliament ought to be exercised"; and he intended 1. ..., "Menoranda on the codes of passing lucal acts", ws iragment, n.4. (c. April. 1346 ).

2. ibid. The memorandum ends in the actual words of Hume's votion. 
to insert a clause in each of them, so that the companies would not have an indefeasible title, but only a dependent title contingent on any general measure that wight subsequently be passed.

The witnesses before Eume's Committee were marshalled and briefed by Chadwick(2); he east himself for the chief part, however, and in his evidence replied to questions which he had earlier suggested to liume. Before the Comittee, and even more forcibly in a series of private memoranda, he subjected the whole system of rivate Bill legislation to searching criticism, demonstrating at every point the superiority of his own administrative device of local inquiry. He described how, under the forms or a legal contict between private interests watters of vital concern to the comminity at large, arfecting its cleanliness, health, law and police, trade and cominucations, were debated and decided. A glance over a Private Act would soon reveal by whom of for whom it was drawn. In a Waierworks Bill, for example, "this is apparent in sumary and stringent remedies by the companies against the consumers and the absence of such renedies by the coasuer, or the public agalnst the seller, the company. The tenant whose water supply is stopped or intermoted from any cause, or deteriorated in qualiby, must pay nevertheless or be deprived of the water. In the Locel inprovement acts where the property in the dust or night soll is given to the scavenger penalties are provided 1. Hansard, vol. 35, pp. 670 - - b/3, 7 April i340.

2. See, for example, the following letter to Wr. H. Holland, 27 April 1846:

"I was with Mr. Hume last night who talks of sum oning you before his comitiee. I shall then have the opportunity of seeing you and talking over our general views.

che points to which you will be examined ace

Phe necessity of local invesulgation by an snglineer or competent offlcer before ?arliamentary sanction is obtalced: The combination of works:

the necessity of an inexpensive procedure for small Dlaces:

the necessity of postponing all the works in question". 
againgt any person who may remove it, but there are no corresponding sumary remedies or penaltieg against the aervants of the companies who neglect to remove it, though dreadiul injury as well as painful offensiveness wight be inflicted by the netlect. In the earlier ralway bills there were sumary penalties: rights to take in custody on the loss of tickets or negligences by pasengers, but no summary remedy by the passengers or travellers against the companies or the companies' servants ....." (1)

This exaltation of sectional interests above those of the general public was the natural result of the procedure adopted by the Pivate Bill Comittees in the collection of their evidence. While those interested parties, who were wealthy enough to fee professional advocates and send witnesses to London, were powerfully represented, the lubouring classes and the inhabitants at large were usually unable to obtain a heurlng; and, in any event, they lacked Iunds to make the investigations on which an informed opposition could be based. "I taj clain to have had some experience in public iavestigation and + certainly should deem it a prievarce to be called upon to prodounce on the Pirst impression, or on a few hours sitting as we bers of comitiees are. It takes on any aew subject andivided tige and zore attention to prepare, to investigate, dal to judge than Comittees are allowed to bave for judging. Iney determine therefore upon the opinions of persons of profegional name rather than upon the facts which they carely can xampue for themselves. It is only under this state of things that the extremely defective nature of the norks and arrangenents carried gut can be accounted for .... his sale of unexabinod upinion evidence has led to a most pemicious syster of trading in propessional evidence. svideace given in scientific questions has been inserted on cards. Wen of science receive retainers: and the past experience will snew 1. E.C., "Local. Acts. How and for whom composed", hS fragment,
H.d. 
Give evidence according to the retainers on one side or the other as may serve with the interests of the party retaining them. Ihis is an evil which I would submit calls for some strong check. The imputation on lawyers of the indiscriminate defence of right or wrong by the indiscriminate use of truth and falsehood, adrits of palliation, if not of defence.

A11. the world knows upon what conditions the lawyer speaks: that what he gives as facts are the facts of bis client: the advocate's cited cases and not his assertions are relied upon. But the science of the scientific man is taken to be his own science and not the sclence of his client, made up for the cause". ( 1 ) Comittees on water Bills, for instance, could not be expected to be conversant with hydraulics; hence while one Comittee listened to one school of engineers and dsclared in favour of constant supply, another leaned to the experts of the old companies and pronounced it to be impracticable. "Wotwithgtanding the clearly ascertained scientific principles on which the constant supply is founded the weight of the professional testimong as it may be called would have prevailed against it, and deprived the labouring classes and the whole of the public of its advantages had it not been for the fortuitous development of cases where it had occurred".

If the important classes of legislation now dealt with by Private Bills were to be renoved from the atmosphere of partiality and ignorance in which they had bitherto been considered, Chadwick urged, prelininary investigations ust be made on the spot by a competent officer, unconnected with the locality and deputed by a Department of State -- a known and responsible infornant, instead of the unisnown and irresponsible persons who were at present professionally retained to give "opinion evidence" before Comittees. He would hear parties who were not now neard; and those who were now heard would be $-0-$

1. B.U., his eragment, n.d.

2. ibid. 
heard more conveniently, and at greatly reduced expense. (1) "The facts and information are paramount: and those can only be obtained quickly, completely, economically, and satisfactorily in situ". (2) Many places in need of lighting, paving, and water -- especially the smaller country towns -- were deterred by the cost of a Private Bill, which even if unopposed inight amount to $\$ 500$. "In the town of $\mathrm{st}$. Helen's, which required a Water Bill, I think the expense of the works was $\& 3,000$, and the expense of obtaining the pernission of parliament to erect those works was 21,000 ; consequently, one-fourth of the money upon which the inhabitants will have to pay interest went for the Parliamentary expenses. In fact, the expense of obtaining works for drainage of many villages, and rather important small towns, would equal the expense of laying down the house drains; and the expense of a Water Bill would equal the expense of laying down the tenants' water pipes."(3)

Not the least evil of the Private Bill system was that the drafting of the Bills was left to the interested parties and the legal agents retained by them. "By draughtsmanship, powers are obtained, and responsibilities evaded by words which require great vigilance to detect .... The instance will be within recollection where by skilful draughtsmanship and by omitting the word lottery, lotteries having been suppressed as immoral by the legislature a private act was obtained for the creation of a lottery at Glasgow". (4) Into the Campbelltown Harbour

1. "Mr. Chadwick's Suggestions relative to Private Bills. Previous Bxamination", MS, 13 kay 1846.

2. "Local Acts. How and' for whom composed", as frament, a.d. He told the select Comittee: "I think it important to state, that I have comonly felt very great difficulty in coming to conclusions upon mere documentary representations (Q. 255 ): "i have seldom been engaged in any public inquiry in which I could have got on with any degree of satisfaction, but by an examination on the spot" $(6.327)$. 3. "Report Irom the Select Comittee appointed to examine the applications for Local Acts ...", Evidence,

4. "Gocal Acts. How and for whom comosed", is fragment, n.d. 
B111 had crept unnoticed a provision which empowered the provost and baillies to award sentences of hard labour or solitary confinement up to thirty days in duration. (1) "The lower class of attorney will not unfrequently derive emoluments from obscurities or disputes that arise out of the imperfect draughtsmanship or gain an act for the amendment of the first bill in consequence of the imperfect provisions of the first .. ... Parliamentary orders have constituted a strong interest in favour of separate bills for separating works which are connected. Thus in an instance brought beiore the House of Lords by Lord Hardwicke, a private act having been applied for, for the drainage of a district by the improvement of a aavigable river, that river having three different outialls into the sea it was held that the powers could not be given without three different acts one for each outfall. In like manner it has been held that, if a town is to be improved by the introduction of water that must be done by one bill: but to authorise the construction of drains or sewers to remove the waste water, that must be done by another bill: the paving by a third the scavenging by another and the fees if not the bills suitiplied. These interests in the multiplication of bills and expense ought to be abated: with the eucreasing wants of the country there will certainly be an eacr asing demand for legitimate, that is to say really beneficial professional service".(2) Hence suggested Chadwick, all future Bills of this nature should be drafted by responsible puolic ofticers attacied to one of the Government Depertments. "It appears to me to be objectionable In principle that legislative expression should be in uniknown and irresponsible hands exclusively subservient to the interest of those who retain them. It appears to me that the nane of the professional draughtsman or the counsel approving the draught should be upon every bill introduced into the house, and that this would be more lmportant than the names of the 1. "Report from the select Committee appointed to examine the applicutions for Irocal Acts...", vidence, . 345.

2. "Local Acts. How and for whom composed", as fragment, n.d. 
nembers who give a general approval of the objects of the measure but who are not responsible for the professional provisions. The official nomination of the profeseional draughtsman would it appears to me be the best step to obtain coherence of expression, which may place the Laws eventualiy within the perception of those by whom it is expected they should be obeyed."(1) Amongst other advantages of this method, "the draughtsmanship of classes of bills could not without much misarrangement $f s i l$ to fall to particular persons who would acquire information in respect to the class of subject, as well as some skill in expression upon it".(2)

Though Chadwick's criticisas of the Water Bills were toned down, and he failed in bis attempt to halt them completely, his hand is evident throughout the Committee's Report. (3) The great mass of the so-called rivate $3111 \mathrm{~s}$, they declared, were essentially public in character, yet the public were not represented before the Comittees by any competent or duly qualified person. They recommended, therefore, that in future, where only ordinary powers were sought, means should be made available for executing projects under the authority and supervision of a Government Board or Department, without the necessity of applying to Parliament; and that for this purpose

1. "Local Acts. How and for whor composed", as fragment, n.d.

2. ibid.

3. "Report from the Select Committee appointed to examine the applications for Local Acts during this Session of Parliament, especially in respect to the Bills for the erection of new water works, Drainage and Paving, and Improvements, according to the recomendations made by the Commissioners of Inquiry into the means of improving the Fealth of Towns and densely populated Districts, and to ascertain how far the principle of their recomendation nay be carried out in relation to the Bills proposed, and whether any and what measures may be recomended for the adoption of the House", 1846 (556). XII. 1.

One of Chadwick's memorandu, "Local Acts. in respect of expenses and means of reducing them", is drafted in the form of a Report from the comittee. Report actually presented coatains many of the same points, put more succintiy, and phrased less strongly. 
Fublic General Acts should be passed for all classes of Private Bills, except those which, like Divorce and Bstate Bilis, were personal in their nature. (1)

The procedure under such fublic General Acts should be on the lines indicated by Chadwick: a memorial from the promoters to the Department concerned, a local inquiry conducted by an Inspector sent down by the Department, a written report from the Inspector to the Department, which would then decide whether or not to grant the required authority. (2) If it appeared likely, however, that private property would be seriously interfered with, the parties should be left to the ordinary mode of proceeding by application to Parlianent; with this important difference -- there should be a preliminary investigation on the spot by a Government Inspector, so diminishing the great expense for the attendance of agents and witnesses in London, saving the time of $U_{\text {. }} .3$ now consumed in Comittees on Private Bills, and furnishing those Committees with the local and trustworthy information which was now wanting. (3) Binally, the keport advised that, to obviate the evils resulting from the lack of uniformity in the construction of Pivate Bills, a series of clauses Consolidation Acts should be passed, covering Pollce and Fatching; Haterworks and Sewage; Lighting; the Improvement of Towns and Regulation of Buildings, Streets, and koads; Warkets and Hairs; Ceneteries; Bridges and Ferries; Harbours, Docks, Ports, lers, and quays; Canals, Rivers, and Navigation.

ithin little more than three weeks of its appearance, the Report bore its first fruit in "An Act for making preliminary Inquiries in certain cases of Application for Local $-\mathrm{O}-$

1. Report, p.iv.

2. ibid., v.

3. ibid., p. v- vi.

4. Lid., vi lhree Acts of this type had been passed the previous session, viz., the Companies Clauses Consolidation Act, 1845, 3 and 9 Vict. c. 16; the Lands Clauses Act, 1345, 3 and 9 Vict. c. 18; and the Railways Clauses Act, 1345,.

3 and 9 Vict. c. 20. 
Acts", (1) Ihis provided that notice in writing, together with copies of the plans, should be submitted to the Comissioners of Woods and Forests, "In any case where it is intended to make an Application to Parliament for an Act for the Establishment of any Waterworks, or for draining, paving, cleansing, lighting, or otherwise improving any Town, District, or Place, or for making, maintaining, or altering any Burial Ground or Cemetery, or for continuing, altering, or enlarging any of the Powers or Provisions contuined in any Act or Acts relating to the Purposes aforesaid". The Commissioners would then appoint one or more persons "of competent skill to be a surveying officer for that Purpose", who would make a local survey, exame the promoters and their plans, and hear the evidence of local officials and other witnesses. (2) In this way, through Chadwick's efforts, another wide province of administration was brought under the jurisdiction of the Government Inspector. Chadwick saw him, detached, capable, incorruptible, impersonally surveying the welter of individual and sectional interests; arbitrating between them, encouraging some, suppressing others, shaping all to the service of the community; bringing the superior science of the centre to solve the technical problems of the locality. and correcting the narrowness of local politics by a broader vision of social aims. He was the channel through which information and guidance flowed out to the local suthorities, and facts and opinions flowed back to the Government Department; the agent of the "information-elicitative" and "inforationdistributive" functions of the State. And, presently, as the Factory Inspectors had become the powerful advocates of a State-controlled education, so the Inspectors of the Woods and Forests and the General Board of llealth were to become the advocates, in the field of public utilities, of the principles.

1. 9 and $10 \mathrm{Vict}$. c. 106

2. In the case of Acts relating to a Port, Harbour, Tidal Water, or navigable River, similar inquiries vere to be conducted by the Admirelty. 
of territorial monopoly and municipal ownership.

In the following year a further recomendation of the Comittee was acted upon, and a batch of eight clauses Consolidation Acts passed into law. (1) In Chadwick's eyes these were of far less importance than the local inquiry. "It appears to me that you have laid too much stress on model Bills", he had told flume. "We must carefully distinguish between mere legislative style and form, which there is a great dificulty in improving and the matter which can only be improved by laborious investigations of partlcular subjects in different localities, to which mere lawyers accustomed to deal with evidence brought before them are most unapt ..... A.II the models I have seen upon subjects with which I have been conversant are very poor and delusive things .... It will be the local examination and report by competent and really responsible men that will be the improvement". (2) But there was, in fact, something more than "mere legislacive style and form" in the Model Acts of 1847, and their provisions bear witness to the influence of the public health reformers. Thus, the Powns Improvement Clauses Act obliged the Comissioners to appoint a "duly qualified" Local Surveyor and an Inspector of Nuisances; it prohibited the ouilding or any house without adequate drainage: it permitited the Comissioners to appoint an officer of Health; it permitted them to contract for a supply of water, and to construct house drains, charging the cost on the

1. derkets and fairs Clauses Act, 1347, 10 and 11 vict. c. 14; Gasworks Clauses Act, 1847, 10 and il Vict. c. 15; Comissioners Clauses Act, 1847, 10 and 11 Vict. c. 10; Waterworks Clauses Act, 1847, 10 and 11 Vict. c. 17; Harbours, Ducks, and Plers Ciauses Act, 1347, c. 2?: Towns Improvement Clauses Act, 1347,1 and 11 Vict. c. 34; Cemeteries clauses Act, 1347, 10 and 11 Vict. c. 65; Iown Police Clauses Act, 1847,10 and 11 Vict. c. 39.

2. E.C. - J. Hume, 12 April 1346. "The form of legislative expression, the draughtsmanship of bills is subordinate to the question whether the works ox things to be sanctioned are deserving of the sanction, and that can only be determined by enquiries by a competent officer on the spot" ("wr. Chalwick's Suggestions rel tive to Private Bills. Previous Examination", 13 May 1346). 
owner. The Waterworiks Clauses Act limited the profits of the company to ten per cent.; it imposed penalties on the company which neglected to comply with a legitimate demand for a supply to be laid on ${ }^{(1)}$; it obliged the company to furnish water for such public services as cleansing the sewers, watering the streets, and supplying baths and wash houses; and it required the undertakers to "provide and keep in the plpes to be laid. down by them a Supply of pure and wholesome Water, sufficient for the donestic Use of all the Inhabltants of the Town or District ..... and such Supply shall be constantly laid on at such a Pressure as will make the Water reach the top story of the highest flouses...."(2) By the Model Acts, therefore, a litile was done to elip the independence of the water capitalists, to raise the technical standard of local works, to widen the obligatory functions of local authorities, and to put atill wider powers within their reach if they should choose to take advantage of the offer.

It is unfortunate for Chadwick's reputation that his Pight on behalf of the railway labourers in 1346 has not deen better knowa. The episode exhibits his best qualities as a man and a reformer -.. his sense of public duty, his courage, his contempt for the power of wealth, his sympathy for an exploited class, his powe: of forceful argument, and of perceiving for social ills their bold, inevitable remedies.

His quarrel with the railway capitalists was on many counts and dated back many years. ver since the success of 1. By clsuse 55 pipes were to be laid wherever they were required by a certain number of owners or occuriers, who should sign an agrement to take the water for three years. by clause 53 every owner and occupier, once the plpes were laid and the rate had been tendered to the company, was entitled to demand and receive a suificient supply for donestic purposes.

2. But tho saving clause was added, ".... unless it be permitted by the special Act that the water to be supplied by the Undertakers need not be constantily laid on under Pressure" (clause 35). 
the Liverpool and Manchester railway, be "had ever the notion that these Iron ways skould have been peculiarly the King's Highways and carried out by the government". (1) The Government should deternine where the lines should be laid, and should put up for competition the contracts for their construction and maintenance. This did not imply an abaridonment of the principle of competition, he pointed out; it offered opportunity for coapetition on the largest scale, for the whole field of service, not for such part only as could be grabbec from other competitors. Instead be saw that uncontrollod private enterprise was saddling the country vitb a "disjointed, jarring, conflicting system" ${ }^{(2)}$; recistess financlering was threatening to tie and clog in perpetuity the main arteries of communication; and a vital public service was being strangled by ignorant Directors, such as those of the Leeds and Manchester Iine, who, with the false economy of vulger traders, imposed churges for the conveyance of fish according to their estimate of its value and the customer's necessicy --- so raising its cost above the means of the lower classes, and prohibiting its sale in the widest and most remunerative market. (3) During the liealth of Towns inquixy, he had discovered how those same Directors tossed carelessly aside all interests, individual and

1. L.C. - Garl of Bllesmere (Lord Francis Lgerton), n.a.

2. E.C., "Address on Railway Reform" (pamphiet), 1865, . 46.

3. "I enclose you a copy of my notes in relation to the experiment on Fish at Manchester, wich I made about a year ago. The encrease was very early from $3 / 2$ tons to 30 weekly: but great quantities vere brought in irom other directions of which no account could be got, to meet the new denand. In consequence of the reduction of the charge of transit for milk, from Cheshire to Wanchester, I am informed aome cheese fams have been converted into dairy farms ..." (k.C. - J. liorrison, 18 Warch 1345). The illustration was used by worison in the Common, and Chadwick wrote to bim after the debate: "You served up the fish well, but, not as would seem from the report with quite the right sauce which was ... that the improvement was shut out from liverpool because the Liverpool Managers dil not choose to adopt the same low though fesunerative rates". 
social, which did not offer a promise of immedate profit. When a railway coinpany wished to build a new terminus, it would buy up the houses on the desired site and tear them down, ejecting thelr swarms of working class lahabitants, who were oblised to crowd into the already over-populated tenements in the neighbourhood. Writing to S.I. Laing of the Board of Frade, Chadwick urged that in the two Bills for the establishment of termini in London and flanchester, which were soon to come before his department, some provision ahould be inserted for the protection of the dispossessed tenants. "No loss, no other hardship than that of being prevented by headlons proceedings entailing much disease and demoralization and aggravations of existing evils which already press so heavily on the ignorant and unprotected, and entailing heavy future charges on the Poor's Rates, would be imposed upon the Railway speculators, aor would any legitimate speculation be impeded"( 1 ) Against such activities the legislature -... uneasily conscious of the growth of these overbearing corporations, but recoiling from the idea that any curb should be placed on private enterprise -. had so far erected ony the flimgy powers of supervision exercised by the board of trede under the Acts of 1842 and 1844 .

When the second railway boom began in 1345, Chadwick perceived that it would place the virectors, whose irresponaibility and lack of public conscience had so appalled Lim, in charge of an aray of 200,000 labourers, who for the next few years would be enployed in constructing the network of new

1. S.C. - 3.H. Teing, 25 November 1344.

2. by the 1342 Act previous notice frust ve given to the soard of rade before any new railway were opened. The board could not interfere with the mangement of the railway, out it could postpone its opening if it were not setisfied with the conditions for safety. By the 1344 Act parlisment provided that there might be a revision of tolls and fares if the dividend of any railway exceeded 10 per cent., and empowered the "reasury to purchase all new lines laid down after 1344 . 
1ines. Before the Private Bill Comittees of the Bouse of Commons, where Directors and landowners and occupiers met to adjust their claims, no one spoke for the railway labourers or gave a thought that their interests were also at atake. The Hudsons and their lawyers seemed incapsble of realising that the health and skill of the nuvvies were a national asset which should be conserved. The best and stroagest navvies in the world came from Lancashire and Yorkahire, and their services were Irequentiy sought for the construction of forelga lines; yet they averaged only fiorty years of life, instead of the sixty they inight reasonably expect if they were given fair treatment. The railway labourer had the bad repute of the nomad with none of the romance; he had the hard work and hard living of the pioneer with none of the credit. Torn from his home and viliage, and removed frow the moral control of a recognised and respected place in the comunity, he was siven double wages and was encouraged in driak and devauchery, both by the conditions of his work and by the neglect or active inducements of his employers; and on his dischurge, at the end of his two or three years of employment, be was, 11ke dany a demobilised soldier, penniless, discontented and recisless. It was a roaring, violent, Glpsy lile. on the fuirkirk and Ayr kailway the contractor was a "vall powerful Highlander, a man of mere brute passions, who drinks dances and righte with the men ..... He often incites the men to drink, and provokes then in that state to fight ia whlch amusement he seems to taice an interse delight". (2) The lubouress had names, Laws, and custums of their own. Whey called each other ancy Bob Bellexophon, figherman, Fizhtiag Jack, sumager, Long Sam. At theis weddings the couple jumped over a boourstick in a room 1. "papers read before the Statistical society of wanchester on the Deroralization and Injuries occasioned oy the want of propes resulations of lubourens en 3 jed in the construetion and iveriag of railways gamphieti, 1346,

2. Howas jeges - . . . 11 April 1346. 
full of men, and were put to bed at once in the same rools. (1) Altogether the impact of a railway encampment on a rural commity was like that of a rarauding srm. When rioting broke out in Zebruary 1846 between Inglish and. Irish navvies on the northera lines, the yeoriary were called out, and the press unlted to condem these "savsge" and "Lawless" men. Robert Rawlinson, the enginoer of the Bridgwater Prust, commented that It would be strange if, in the clicumstances, they were anythins else, and he was echoed by many of the engineers who had lived for years aroungst them. (2) The nsvies "on the whole are fine, independent, honest fellows, declared Butler williams, "really will weli repay any fine fellows, care and atbation paid to their physical and moral well-being". (3) "sany of the men are reckless, but what is the cause?" demanded Ruwlinson. "Wo man cares for them; they labour like degraded brutes; they leed and lodge like savases; they are enveloped in vice as with an atmosphere; the sersusl anly is present".

Here, in fact, was an outstanding exemple of Uhadwick's thesis trat the circumstances of men shaped their morais; and be prompty set out to confute the confortsible middie-class beiler that the condition of the railway lavourers was due to an excessive dose of original sin. As a test case he took the works in profress at the Sumit lunnel on the sheffield, Ashtonunder-byme and Manchester dailway, which bad been recently visited by a friend of his, Dr. John Robercon, a benevolent

1. "papers read before the statisticsl Soclety of Manchester .....", p. 49 (Rawlinson's evidence).

2. Robert Ramlinso. - I. ., 14 Fintua y 1346.

3. J. Butler Villiams - . . 26 Dec mber 1345. He sdded:

"Those who are bad characters are the local labourers picked ug ia each parish as the work proceedz, and who, suddenly elated by couble or troble wages, take to drinking, paching, sheesstesiling and the perpetration of other aischief's laid wauliy to the doors of the "navigators by profession"; but generally unjustly".

4. "avers read before the Statistical society of Manchester ...." 
mewber of the Manchester Btatistical Soclety. (1) The work had been let for $\$ 5 ?, 000$ to a contractor, who two days later had sub-let it for 447,000 , and it had since been parcelled out amonjst a number of minor contractors, Now, Dr. Roberton described to Chadwick in a long letter of 13 liovember 1345, a colony of 900 or 1 , 000 workers with their wonen, housed in tworoomed huts holdins as meny as fourteen or fifteen, was clustered round the Iunnel. Lore than half of both sexes were infected with some form of venereal disease. (2) while the railway Directors merely ignored the welfape of the labourers, responoibility for which they considered they had sold with the contract, the sub-contractor had an active interest in defrauding them by truck and enfeebling them by overwork. He brove them without rest, by night and Sundsy shlfts, 30 that the line might be opened a few weeks sooner, and he obliged them to buy their beer and provisions at his shop at prices 20 to 50 per cent. above the market rates. "hey five us great wages, sir", one labourer renarked rusfully, "but they bake it all. from us ugain". They were paid at intervals of a month or longer, usualiy at a puolic house, and in the lean weeks between paydays they were driven to seek advances frow their employer is the form of printed tickets or ordeers on his shop. The contractor in some insinces probably courtied on "plundering by truck", and to meet the iseen competition op his rivals made bis prolit "out of the bowels of his workwen" (3); in one notorious case a contractor who stuod to lose by the work itself had made a prolit of 27,00 from bis tomy-shop. (4) and yec, noted the 1. ibid., pp. 9-17. forwarding a copy of the pamphlet to a inlend, Chadrick wrote: "rag read the exclosed just to see the practicality of the sanchester Statintical sooiety Puey are good wen those: they have no nonsense about confining thair inforants to pure stavietides, unconseguential and unexplained, and uninteresting columns of ligures ..." (B. - - Col. Sykes, 23 feoruary 1846).

2. loborton states "sone form of ayphilis", wat it seems most probabls that this tern is intendod $t$ sover venoreal diseases in general.

3. ibil., pp. $16-17$.

4. ioid., 35 
good Roberton with a tinge of surprise, the labourerg' "natural feelings" remained. They had not yet been permeated, like the workers in the large towns, by socialism, "or any other vulgar speculation"; and some of them had even purchased, "at somewhat reduced prices", a total of 22 Bibles, 70 lestaments, and 36 Prayer Books. (1)

Using Dr. Roberton's letter as a text, Chadwick drew up a paper in which he outlined the remedies which were within the reach of enlightened administration. Surely, he asked, the grant of privileges involving the aggregation of large masses of labourers should be accompanied by conditions ensuring their proper accommodation and regulation under public inspection? These assemblages of railway labourers were encampments, and should at least have the order of a canp maintained in them The men could be lodged for small rents in portable, wooden, weather-tight houses; food could be supplied from temporary kitchens; deposits in savings banks might be encouraged; and a school, a small hospital, even a temporary church with a bell, night be erected. There was nothing impracticable in all this. A manufacturer was making just such wooden buildings for export to the coloaies, and there seemed no reason why they should not be used nearer home. Nor could continuous work for seven days without a break be defended on the grounds of economy and efficiency. "Merely considering the labourer as a machine, it is as improvident a waste of power, as runing post-horses every day in the week is found to be"(2); and if the contractor himself were careless of the waste, the rest of the community was bound to intervene. The "principle of superintendence on behalf of the public (3), already sanctioned in the case of Pactories and mines, was applicable a fortiori to railways.

Agalast truck, however, he could see to valid objection,

1. Ibid., p. 17

2. Lbid., p. 36 .

3. ibid., p. 36 . 
provided that it were surrounded by adequate safeguards against abuse. Leglslative incerference with truck had failed, he asseried, and in the case of the railway labourers would forbid payment in kind when this was the most beneficial mode. Railway encampments being often some distance from a town, provisions must be taken out to them, and large-scale purchases by the contractor would be more economical then individual arraagements by the men. The law should, therefore, authorise contacto of hiring and service, which would provide for the payment of stipulated portions of a man's wages in provisions or supplies on terms settled by a writien agreement between the labourers and their employer. (1)

32 fatal accidents, and an incredible number of minor injuries, fractures, burns, lacerations, and dislocations, had been the cost of the Sumit Tunnel in human suffering. Invariably it was proved at the inquest that "it was the man's own fault"; but though coroner's juries might be deceived, experienced engineers were convinced that the majority of the accidents could be traced to the lack of foresight or the cupidity of the contractor. Excavations were worked by vertical falls of earth, "knocking its legs from under it", as the men called it; (2) while iron stemers were used in churging

1. Lbid., pp. $34-5$. "If I were setting to work as a capitalist to improve the condition of the workpeople I would insist upon payments in kind, or the truck nucb more extensively. I would supply them not only with food but with clothes and with houses and would beat every other improver. Depend upon it, that it is to the interest of the labouring classes that the profits of retall distribution should go to those who provide them with capital and labour rather than to that ignorant and mischievous set, the beer shop keepers and the smell village shop keepers. These last must be superseded and it will be a good result, by the improvement of distribution, by the extension of the principle of large sales for small prolits" (G.C. - S. Trewenheere, 4 sept.1844).

2. Ibid., p. 46. As long ago as eptember 1340 Butier 1lliams had suggested to the Board of l'rade a simple contrivance which would have prevented numerous accidents caused by the method then in use of detaching the horse from the wagon as it approached the tip; but his suggestion had been ignored. (u. Dutler williams - D.U., 20 Necember 1845). 
blasts, although it was well known that copper would have averted the danger of a sudden explosion set off by a spark. bien working under the directions of a fanger might have as little discretion as the soldier in the ranks; they must use the tools their employer provided, they must act as he ordered, they must work with the fellow labourers he had selected yet if there were a mishap, the charge of carelessness or neglect of due precautions was levelled only at the workman who was buried when the undercut face of the cutting collapsed or whose head was blown off when a spark from his iron stemer ignited the explosive. The Directors and the bigger contractors were remote from the accidents, and thought them none of their business; while the sub-contractors, who were on the spot and could take the necessary steps to prevent the accidents, were sensitive to the smallest outlay for precautionary measures. Responsibility somehow leaked away in the gap between the Directors who furnished the capital and the sub-contractors who marshalled the labour. That gap Chadwick proposed to bridge by his doctrine of "pecuniary responsibility", which he had first put forward under the Factory Commission (1) and had aired again in the Constabulsry and Sanitary Reports. What if the Directors and shareholders had to bear the expense of the arintenance and education of the orphaned children up to the age of working ability, and the compensation of the widows for the loss of their huabands' aid and support - - what if they had to bear the expense now faling on the ratepayers or on the individual families, who at present had to bear both the cost and the sorrow of bereavement -- what if each life lost in an accident involved them in an expense of 2300 or 2400 ? The Directors would then concentrate responsibility on the subconteactor, and make sure that he did everything possiole to avert such an expenditure. As a general principle, then, Chadwick decised, it should be recognised that "those who erect 1. See Appendix, pp. $649-651$. 
machines, or conduct large and dangerous works, or undertake public conveyance, should be pecuniarily responsible for all their unavoidable, as well as for their avoldable consequences". (1) The strength of the principle was that it was based on self-interest. An appeal to the highest sentiments would call out only a weak and intermittent response. "self-interest is the most constant -- the most uniform -- most lasting, and most general feeling; and it appears, when traced in its ultimate actions, to be really one of the most beneficent. at once arrests the attention; and the shrinking from pecuniary responsibility when it is proposed -- the objections that it will be "too serious", and the efforts to evade it, all attest its efficiency". (2) Moreover, the pcinciple was self-acting. "It dispenses with agencies of inspection -.- and a priori regulations; it reaches where they could not reach, and renders arbitrary and troublesome interferences unnecessary - - it is awake and active when authority and public attention, and benevolence and humanlty are asleep, or powerless".

On the 16th January 1846 or. Philip Folland, the secretary of the Manchester branch of the Health of Towns Association, read Chadwick's paper to the Manchester Statistical Society, and Robert kawlinson followed with a strong letter in support. (4) The Manchester railway Directors had been particularly invited, but not one attended the meeting. various indications, which it would be needless to specify" Dr. Roberton reported to Chadwick, "I infer that the subject is distasteful -- they don't like it at all. and no wonder: many of our most respectable influential men have beeu inţthe habit of speechifying at the yearly and other meetings of the proprietors of some of the largest Manchester Reilways -- as the Leeds, Manchester and Birmingham, Sheffield, etc., in which 1. "papers read before the statistical society of Wanchester 2. ibid., p. 26.
3. ibid.; p. 27.
4. Dr. Kobertion - E.U., lo January 1846 
they have glorifled themselves as directors; and, when the lines were in the making, often boasted of the rapid progress they were securing by their efforts and the wonderful dificulties that were being/overcoine: -.- And, of course, now they don't relish to have it said that there were enormous evils connected with their system of proceeding which they either falled to see or shut their eyes to; and that humanity revolts at the effects, on the labourers, of such triumphs of engineering energy". (1) Dr. Holland also, when he talked with railway Directors, discovered "none of them would admit that they had found time to read the pamphlet -- they had got it, and would read it, but as jet they had not found time!"(2) One of them, indeed, did Iind tiane, and Chadwick was approached one day by an excited and truculent liember of Parliament, a former chairman of the Sumit Tunnel line, who declared that he knew nothing of the scandals described in the paper.

"You know what a reckless set of men they are who are employed", he said. "It would be impossible to prevent accidents in such a work".

"But you might diminish them?" suggested Chadwick.

"That I do not deny", he replied.

"And the point of my staterent", went on Chadwick, "is why do you employ reckless men on dangerous works?"

There was no reply to this, snd a deflated M. . departed with the adnission that it was right to publish the facts for the sake of the example.

Chadwick had 2,000 copies of the pamphlet strucis off at his own expense (G.O. Lewis could not be persuaded that the inquiry fell within the scope of the foor Law Commission, and spent 230 in "billing" both Houses of Parliament and the country papers with copies. (4) He gained some notable support.

1. Dr. J. Roberton - E.T., 16 January 1846.

2. Dr. J. Roberton - 8.G., 11 March 1846.

3. E.C. - Dr. J. Robertion, 28 Eebruary 1846. (the In. . was Parker, the nember for Shefileld).

4. S.C. - Plejdell Bouverie, 16 September 1346; D.U. - Col. Sykes, 28 rebruary 1846. 
Dickens, he heard, was greatly impressed; J.R. Porter drew the subject to the attention of his chlef at the Board of Irade (1) Lord Campbell assured him that legislation could not be long delayed, but at the moment Corn only was attended to. (2) But from Sir Robert Peel there came only polite acknowledgment "He fears that the accounts sent by Mr. Chadwick as to the demoralisation which is the Result of such Employment have but too much foundation --- but no satisfactory solution of the great difficulties which would attend Legislation on such a Subject has at present occurred to Sir Robert Peel". (3) It was the old familiar do-nothing note; a frigid recognition of the evil coupled with a much warmer appreciation of the obstacies in the way of doing anything to remove $1 \mathrm{t}$.

"The poor Surgeon who furnished the Tables is in a sad plight", Roberton reported, "having been written to, called upon and threatened with every kind of punishment for having, as they say, shamefully betrayed his employers in having given the Statistical Society rables of accidents. I had such a letter yesterday from poor Pomfret the Surgeon in question, that I was constrained (thougk I bad been out professionaliy in the night) to go over to Hollingworth early this morning on purpose to console him. I found things even worse than I supposed -.his wife's uncle is one of the Directors of the shefield railway, his father-in-law a large proprietor, and many of his friends besides interested parties". (4) Nicholson, the contracto for the Sumit Tunnel, a "crafty, enersetic, and plausible" zan, published a pamphlet in its defence, the chief argument of which was that there had been only 26 fatal accidenta, not 32; and that a far greater number had been killed on other works of similar magnitude, at kilstey Box, for example, Clay Cross, and the leeds Summit l'unnel. (5) Advocacy 1. F.C. - Dr. J. Roberton, 27 January 1346.

2. Lord Campiell - ..., 26 Pebruary 1346.

3. Sir Robert Peel - 1..., 16 December 1345.

4. Dr. J. Roberton - E.U., 30 xarch 1346.

5. Dr. S. Roberton - S.C., 20 April 1346. 
or this nature was double-edged, and Chadwick welcomed an opponent who, in making his own face white, threw a strong light on the blackness of his fellows. He was delighted also when Directors, with an air of frankness, admitted that his account was largely true, but cast the whole blame on the contractors, "who were such a difficult set to deal with". (1) Phus, a friend of his was told by the Directors of the sheffield Railway how "two of the contractors, I presume they must mean sub-contractors had been killed by their own carelessness. One of these men had stuck a candle in some loose gunpowder; it blew up and killed him: the other had doubted whether a block of stone which they were hoisting was securely fastened, when he, being possibly in liquor, stood under it to see, and it fell upon him and crushed him", Chadwick commented: "It would be worth while to have enquiries made into these cases. It would shew to what sort of men lives had been comitted". (2)

1. B.C. - Dr. J. Roberton, I April 1346.

2. Ibid. The more usual view among the railway Directors was expressed by Samuel Holie (- B.C., 19 Pebruary, 1846):

"There can be no doubt whatever, but that the majority of accidents which occur, are the result of the recklessness and carelessness of the men themselves; and so far as my knowledge extends, I think no legislative measures will materially decrease them". Another line of criticism is illustrated by a review in the "nilway Chronicle", 21 Harch 1846: "Mr. Chadwick, whilst he must be allowed to possess great cleverness, and oftentimes to be on the right side of a question, is one of the least cautious of our most aseful public servants .... Carried away by his crotchets, he deals in assumptions, oftentimes crude, and sometimes absolutely contradicted by facts .... Evils attendant on the condition of railway labourers are ststed, and remedies proposed, for the accompilighent of which we must look, in a great aeasure, to directors, engineers, and contractors of railways; yet so little is $3 r$. Chadwick's prudence, that he treats these classes with unaflerable offence and misrepresentation. Speasing of civil engineers, be politely says, . 23, "In no profession perhaps, is there so large a proportion of bold, rapacious quackery as in the prolessions oi civil engineering and architecture". A pleasant way truly of insuring the co-operation of the civil engineer, and engaging his ear to listen to one's suggestions! ...." 
The pamphlet had created so great a stir that even the unwilling Peel Government could not avert the demand for a further investigation. When Pleydell Bouverie moved on 30 th April 1846 for a Select Committee, Sir James Graham raised no objection, though, as he sald, be anticipated nothing very important would result from its deliberations. Joseph Hume must have voiced the private thoughts of the Government and the majority of the members when he ceclared that he expected that the inquiry would "lead to the conviction that the less they interfered between employers and the employed, it would be so much the better for both". (1)

It was a most satisfactory Committee. Poor little Ponfret, the surgeon of the Summit Tunnel, defied his embatiled relatives, and gave his evidence with great spirit. (2) The engineers, most of whom had been suggested by Chadwick, were strong for Government intervention; except Brunel, who objected to putting British workmen in leading strings --- to which Chadwick retorted that they were already in strings, pulled st the hazard of their lives, by irresponsible persons. (3) In his own evidence he made out a vigorous case for the doctrine of pecuniary responsibility. "As eminent gas engineer", he told the Comittee, "was consulted as to a melhod of removing gas from a coal mine, so as to render the formation of an explosive nixture impossible The plan was not adopted, because the expense was thought too much in proportion to the risk to the proprietor; the risk to the men was not recioned. If the proprietor had been responsiole, as I contend ha ought to be, for all the nany losses occasioned oy bis works, for the support 1. Hansard, yol. 85, pp. $1323-5,30$ th horil 1346.

2. Dr. J. koberton - G.C., 26 ay 1346.

3. "heport from the select Comittee sppointed to inquire into the condition of the habourers employed in the Congtruction of kailways, and other fublic forks, and into the Remedies which may be calculated to lessen the pecullar evils, if any, of that condition", Evidence, 2. 2203. P.P. 1846 $\left(530^{3}\right)$, xiii. 411. 
of the maimed, and of the familles of the killed, it would bave been food economy to have incurred the expense. And suppose it had added a penny per ton to the price of coal, and suppose it had somewhat lessened the rent of the coal mine; it would have diminished nisery and destitution, it would have saved lives and linbs, it woul have lowered poor mates, and probably rendered mine work leas dangexous; and by sheltering the men and theix famllies from the destitution caused by accilents, it would have lowered wages without producing the 111 effects of lowered wages; for lt would diminish the want which wages have to meet, and wo should haye all the benefit without the sacrifice". (I)

The recomeadations were well up to the strength of the evidence. The Comitiee departed prufitubly fror Chadwick's views ia adviging that the ruck hct should be extended to cover the railway labouress, und that hears shoula bo providod to eneule tien to recover all their wages without any set-off for goods received. There waș nothing in the kct, they pointed out, to prevent employers furnishiag supplies, as chadwick had urged, and giving their worken the benefit of large-scale purchases; but the wen should have their duo in coin, aud should be allowed to choose for themselves whether or not to tase divantuge of tine eaployer's offer. (2) They considered, aoreover, that $i f$ wages were paia in sinal sum at more frequent intervila occasions los riot and intenperance would be rscer. Next the jombthee recomended that oeliore a raliway company should be permitied to proceed with Lts plans, trere should be an inquixy oy an laspector from a publie soard into the extent of accomadation for the labourers in the districu, and the steps tae company intended to take to supplement it: and the Inspector suouid be empowered to visti the loditige of the ren and mare such santiary regulautons as he deemed necessary. It was, they coniessed, a novel proposat, but hey feit thut the L. ibid.

2. Ioid., p. v.

3. Loil., pp. vi - vil. 
State might fairly ask such a guarantee in return for the powers granted to the companies. Indeed, for the protection of those interests of health and welfare which lay outside a shareholder's perspective, the Inspector might beneficially be given further powers: to make regulations for the provision of relief to the sick and injured, for example, or to examine the facilities for education and religious instruction.

Finally, the Committee adopted in full Chadwick's proposal that the companies should be made prima facie civilly responsible in all cases of injury to life or limb incurred in constructing their works. This meant changing the law in two respects: first, it would remove the anomaly by which, under the existing law, liability to make redress ceased if the injury resulted in death, the claims of dependent relatives not being recognised; and, secondly, it laid the liability, not on the ganger or contractor, but on the companies, the party with the greatest power to prevent the injury and the greatest means to repair it. (2)

That the House of Commons, in which one railway company alone was said to muster 80 votes, should take action on the Comittee's Report was not to be expected. "I am somewhat disappointed", wrote Chadwick to Alexander Bain a month after the appearance of the Report, "that the scope of my view in respect to the question of responsibility for accidents is not taken up in any wise by the press, or apparently conceived by the nowspaper writers". (3) Another generation was to pass before opinion would be ripe for the principles of employers liability and workmen's compensation. But the session was marked by one small advance. Chadwick's friend, Lord Campbell, obtained an Accident Compensations Act which smoothed out one harshness of the existing law: the dependents of a workman tortiously killed were empowered to recover damages, from which 1. lbid., p. vil, xil 2. ibid., p. x. ¿3. F. - Alexander Bain, 7 September 1346. 
they had previously been barred by the maxim 'actio personalis moritur cum persona'. (1)

In some quarters too the thought

great Mr. Peto belleved that he was well repaid for his outlay on chaplains and schools, and for his attention to the condition of his labourers, perhaps after all the idea was not just another of Chadwick's crotchets. Some companies set aside sums for the welfare of their workers, and sought Chadwick's advice on the best use to which the money could be put ${ }^{(2)}$;

1. 9 \& 10 vict. c. 93,26 August 1846 .

2. The Directors of the Liverpool and Bury Railway, for example, asked him to suggest how they could best lay out $\Sigma 1,000$ for the benefit of their labourers. He replied characteristically: "I think you would render a most important service by setting an example of what might be done, an important moral example but that it may be effectual it should as I concelve be executed at no great pecuniary expense, or that it may be done, as I believe it may be done to a profit, considering the efficiency and speed of the execution of the work by respectable woricmen attracted as I expect they would be from other parts, or what is equivalent by respectable workmen prevented leaving by irritation caused by discomfort" (B.C. - William Stuart, 31 March 1346). He advised that a notification should be circulated amongst the workers, announcing that -.-

1. The Directors were willing to provide a place where cooked and uncooked provisions might be bought. A comittee of workers might examine the prices to see if they were fair and those who chose might deal elsewhere.

2. Temporary lodgings would be erected, with beds and dining-roons, properly warmed and supplied with hot water. A sleeping-room for a single man could be rented for halia-crown. If the men could find accommodation elsewhere, they were at liberty to do so.

3. Wages would be paid weekly, and if the workers wished the Company would save a part for him at an interest of 5 per cent.

4. The Directors would provide:

a schoolroom and schoolmaster; and every parent would be expected to send his child at a cost of id. \& week.

a reading-room and a minister; and every workman would be expected to attend church on Sunday and pay his 1 d.

a temporary hospital and medical attendant, towards which the men would contribute 2 d. a week.

5. Nen found on the works in a drunken state would be discharged. Beer was not forbidden; but no conveniences (Continued on next page) 
others began to introduce into their agreements with the

contractors clauses giving more protection to the labourers, compelling payment of wages in money and at short intervals, and prohibiting truck in drink and work on Sundays.

(1)

Meanwhile, the logic of events had been driving some of the more intelligent railway directors to admit the necessity of a measure of central control. The expense of competition in the construction of duplicate lines and the struggle between rival companies for neutral territory, the controversy between broad and narrow guages, the need to determine through-rates for goods and passenger traffic -- all these were arguments for consolidation, a revision of charges, and a degree of regulation. Thus, Chadwick now found an influential ally in James Morrison, the railway millionaire and Chaiman of the Select Committee on Railway Acts Enactments, and the two men worked together for the establishment of a Railway Board to control the construction of new lines and to supervise the condition of the railway labourers. (2) Morrison carried his

(Continued from previous page) for its sale would be offered, as they would for the gale of tea, coffee, and soups.

6. There would be no Sunday or night woris unless it were absolutely necessary.

A note among Chadwick's papers shows that he was Iully aware of the linited effect of such company regulations. "iluch we hope will be done in the spirit of the Committee of the Liveroool and Bury Railway. But the continued accounts of latal accidents from the falling of earthwork, of disorder and riots, preclude any reasonable expectation, that so much can or will be done voluntarily, as to supersede the necessity and duty of legislative interferenc ${ }^{\prime \prime}$.

1. "Mr. Hilditch, the barrister told me last night that in consequence of reading your pamphlet he had introduced clauses in the railway contracts he had since drawn more protective of the men than usual" (R.H. Holland - E.C., 25 March 1846).

2. J. Morrison - B.C., 29 June 1846: "I wish I could induce you to look over confidentially, the Evidence and papers and advise me upon them. I expect the Evidence will be found deficient". Another, n.d.: "All the old lines go strongly for a Board now and they want a strong one". 
Railway Board after a close fight, but in the subsequent legisiation(1) it issued as an emasculated body, with generous stipends and vague powers, which in five years "died of too much pay and too little work". (2) Chadwick wrote in disgust to Morrison: "I saw a member of the Government, but one not in the Cabinet who speaking to me apologetically for the new railway board having no powers in respect to rallway labourers, or the conduct of existing works, said oh but they will get powers for that or any other work, only let us get the board, and then the rest will come. This is only the usual cry of expectants. "Only let us get the places and we care not what wi11 come" $(3)$

1.20 0 (8) 10 Victo

1. 9 \& 10 Vict. c. 105.

2. Hadley, "Railroad Transportation", p. 172.

3. B.C. - J. Morrison, 27 August 1846. With his employment as Poor Law Secretary clearly approaching its end, he considered for a while the possibility of transfering to the new Rallway Board

"You will have seen enough in the newspapers to show why I have not been able to continue assistance for your railway comittee and report. I am sorry to have been driven away from the subject in which I have taken an interest, and believe that great work may be done. As the bill is at present shaped, it (is) such an one as the existing companies might have proposed; to keep clear of them and act against new and interloping schemes.

In the present unsettled state of things I am placed in a very awkward position. If the Government determine not to carry out the new poor law, or what, whether they know it or not, will be next to the same thing, continue me in a position of subordination in which I cannot act, or act efficiently, then I shall be desirous of removing. I should desire to remove to a Board for carrying out sanitary measures. But they are now giving the functions of superintending such measures to the old Board of Works and the formation of any new board is a matter of uncertainty. I am averse to leaving unfinished work. I should make some sacrifices, if there were any chance of completing the poor law organisation, but failing that which a few days will shew, I should then be willing and desirous to act in carrying out your railway work, if the places be not as they usually are filled up". (E.C. - J. Morrison, 24 August, 1846). 


\section{CHAPTER 8.}

\section{RETREAT FROM SOMERSEP HOUS.}

In 1845 the "disgustingly voracious habits"(I) of two paupers in the Andover Workhouse, who attempted to supplement the meagre bread ration by scrapings from the green bones they were employed in crushing, led to a violent outcry in the press. The Poor Law Commissioners ordered an investigation by Parker, one of the Assistant Commissioners, and seized an early opportunity to dismiss him and make him a scapegoat for public dissatisfaction. This action brought to the surface all the submerged antipathies in that unhappy office. kallying to his standard all the Poor Law malcontents -.- Parker, Day, Coode, Tufnel1 -.. Chadwick led an attack on the opinions and business methods of his chiefs; and the Select Comittee appointed in July 1846 to investigate the Andover scandals found that an inquiry into bone crushing and the morals of workhouse masters had widened into a discussion of the whole constitution and working of the Poor Law Commission.

In the course of his nine examinations before the Comittee, Chadwick skilfully planted one barb after another in the flanks of the Comissioners. The scepticism they had openly avowed of the fundamental principles of the Act it was their duty to execute; their displeasure when abuses were brought to their atiention which would require action on their part; their conduct of business by conversations at casual meetings, by private letters from single Comissioners, by unrecorded transactions in their separate offices; their toleration of the allowance system, their attempt to revive the labour rate, their suppression of the Boltor and vacclesfleld report -.. all the accusations which had been fementing in 1. G. Hicholls, op. cit., vol. 2, p. 394. 
Chadwick's mind for the past twelve years seethed over before the Committee. The Commissioners, aided by the Poor Iaw critics on the Committee, retorted in kind. An attempt was made to fix on Chadwick the full responsibility for the inadequate dietary scale in use at Andover $(1)$ and for other rigorous and unpopular measures, such as the order which disallowed fees for tolling church bells at the funeral of a pauper. (2) "Well, then, if you will have it you must", cried

1. "Report of Select Committee on .... Andover Union", Evidence, Q2. 19635 - 19643, 19376 - 19901. It was a "libellous expression", Chadwick replied, to say that he recommended "coarse food" for the paupers (Q. 19880). What he had advised was "coarser food", in view of the anomaly that paupers were getting meat and white bread, while independent labourers were living on brown bread. (Q. 19393). "I have got labourers' dietaries, labourers' expenditure for their families, mechanics' expenditure for their families, and information on various points touching their own domestic economy, on which persons who undertake to legislate are often the very worst informed. I believe I was the first person endaged in any official investigation of that description; I am aware of no one who had ever inquired of labourers themselves, or visited their houses, or inquired of them to anything like the extent I have done from time to time" (Q. 19312). "Of this I am quite certain, from my knowledge of the labourers, that if a dietary were settled by them on the principle of making an allowance to the members of benefit societies, to persons who are on the box of benefit clubs, they would not exceed, and I think generally would certainly be below the allowancesfiven in worichouses" ( 2 . 19644). The dietaries had been drawn up on the principle that the supply of food should be sufficient to maintain health and strength, and that plain food, such as potatoes or oatmeal, should be given ad lib. (Q. 19876). Wuch of the outcry against the workhouse dietaries, he believed, was due to sheer ignorance of what the lower classes were in fact obliged to eat. Thus, when John Walter alleged that it was the intention of the oor law Comission to reduce the diet of the working classes, Chadwick replied by quoting reports to the effect that the dietary scales of workhouses were more generous than tiose budgeted for by independent labourers. "One or two bundred pounds would be well expended in geting the scale of expenditure of difierent portions of the labouring classes in diflerent parts of the empire" (..U. - J. McGregor, 12 Narch 1345 ). 2. ibid., 8. 22334 (T.F. Lewis). 
Frankland Lewis, "Mr. Chadwick was an able man, but I thought him as ungcrupulous and as dangerous an officer as I ever saw within the walls of an office". (1) It was the petulant rage of a little man; but it served to add one more touch to the picture of Chadwick as a kind of Poor Law Inquisitor, Disraeli'g "monster in human shape", who sat in his torture den in the recesses of Somerset House, devising fiendish new plans for separating old men from their wives, spaying the daughters of the poor, and slowly starving paupers to death on a diet of bread and gruel. Chadwick, it would appear, imuediately challenged Frankland Lewis as to the truth of his wild outburst, and he received sufficient amends for the two to part with a friendly handshake. The Comissioners could not really have it both ways: if they kept the business firmly in their own hands, as Frankland Lewis claimed, allowing their officers to make no suggestions (2), then Chadwick could hardly be beld responsible

1. 1bid., Q. 2260. He made it clear later that he did not intend "unscrupulous" as a general stricture on Chadwick's conduct, but only as a description of his actions with reference to two documents: - (1) Instructions to overseers and churchwardens in March 1336, relating to the legality of certain charges on the poor rates, wbich contained the disallowance of fees for tolling at pauper funerals; (2) a Consolidated order issued to the metropolitan Unions, in Detober 1835, which, Lewis asserted, led to a rebellion in the parish of $\mathrm{St}$. George-the-fartyr, "almost the first thing which excited vehement dislike to our proceedings". $(2.22335)$

of the former document the Hammonds write "Chadwick trod on this universal sentiment as if all life had gone from it" ("Age of the Chartists", P. 75). Chere seems no reason, however, to doubt Chadwick's statement that the regulation was inserted by Coode into his draft; and that he had urged the Commissioners to obtain statutory authorisation for this and other charges ( 2.24999$)$. On plain issues of fact, such as dates and the report of evidence, he was as punctilious as $\mathrm{h}$ is legal training could make him -..- and this remains true, even if it be adnitted that at times he also showed the lawyer's sisill of advocacy in his manipulation of those same facts.

2. ".... out of whose hands, I may almost say, I was instructed (but at all events I expressly undertook) to seep it". (2. 22323). 
for the harshness of Poor Law administration. Indeed, as Chadwick pointed out, of all the papers attacked in the House of Commons only one was by him; he had therefore complained to G.C. Lewis how unjust it was that all the unpopularity fell upon himself -.. to which lewis had replied that he would get no redress if he applied for it. (1)

The report of the Committee was a severe condemnation of the Commissioners' part in the Andover affair. (2) Chadwick read it with a triumph he made no attempt to conceal. He had been the principal actor before the Comittee, he reflected, and had repulsed all his assallants in turn; and yet he had brought up none of his reserves, "which are heavier than my adversaries or the public suppose". (3) His momentary elation at the rout of the Commissioners, however, soon gave way to dark conjecture about the future of the Poor Law Act -.- and the

1. Ibid., 4Q. 20021, 20024, 20030. Echoing the Parliamentary crilics, historlans have in general much exagerated Chadwick's power to influence the course of Poor law administration. Thus, it has been asserted that "the history of the poov Law between 1334 and 1847 is the history of an experiment in centralised administration, and of what that experiment produced in the hard and energetic bands of Chadwick, checked from time to time, by wiser colleagues" (J. L. and 3. Hamond, "Age of the Chartists", p. 60). It seems sufficient to comment that this cives a totally unfounded impression that the "experiment" was under his control; that the "colleagues" were, in fact, his superiors; and that they may be acclaimed as "wiser" than he only if their sceptical attitude to his preventive policies is ignored.

2. The Comittee reported that the Comissioners had not given excouragement to their subordinates in the detection and removal of abuses; that Parker had carried out his inquiry with ability and promptitude, and that the manner of his dismissal gave him just cause for complaint, and was inconsistent with the discreet exercise of the Comissioners power of dismissing their officers; that they had altogethe failed to justify the removal of Day (who had been earlier dismissed by them); and that the proceedings with regard to both Day and Parker were irregular and arbitrary, were not in accordance with the statute, and were such as to shake public confidence. (Report, pp. vili- $\mathrm{x}$ ) 3. B.C. - Sir Charles Shaw, 4 September 1346. 
future of 1 ts author -- when the Bill for the continuance of the Comission should come under discussion in the following session. "The anti poor law members of the Flouse of Commons have expressed reluctance to have the Commissioners immediately removed, for say they if we delay their removal we may get rid of the law and themselves together at the next session of Parliament", he wrote anxiously to the Earl of Liverpool. "You may observe that the Times is taking the course of declaring that the fault is not with the Commissioners but with the law: that it is a law which it is impossible for any one to execute". (1) Nor, looking more closely at the printed evidence of the Andover inquiry, was he satisfied that it conveyed the right impression. If it blackened the reputation of the Lewises, the character and opinions of Rdwin Chadwick did not in contrast shine forth so brightly as he had hoped. But Sir George Grey, the new Whig Home Secretary, remained deal to Chadwick's/lea he should be permitted to make a full public statement in selfvindication. (2) His fears increased. Was not Cornewall Lewis

1. E.C. - Earl of Iiverpool, 24 August 1846.

2. In a Letter to Sir George Grey, 17 January 1847, Chadwick pointed out that the Report omitted to mention the a imission that separate action by the Commissioners was legally indefensible, and falled to emphasize the inportance of the documents printed in the Appendix, which Chadwics had put ir as evidence -.- his report on Bolton and Macclespleld; his paper on the ineligibility of bone crushing as a workhouse lest; the condemnation by the Treasury of modes of business similar to those enployed by the Comissioners. His chief complaint, however, was that no opportunity had beea given to him to answer the aspersions cast upon him during the examination.

"Before the Andover Committee I was examined, or cross examined, by a member of the late Government, as it I were a crininal for having as a rember of the Commission of inquiry prepared for the information of the Government the draft outline of the remedial measures which the Comission had adooted and also for having had a principal share of the exposition of principles and measures in the general report placed before the public and the Legislature and which were adopted as the basis of the poor Law Amendment Act .... The libellous tone of aspersion cait upon me before the Andover comittee has been publicly renewed since the comittee has (Continued on next page) 
married to Lady Teresa Lister, one of the Villiers, sister of Lord Clarendon and sister-in-law of Lord John Russell, "a lady who invites Senior to the most fashionable parties"?(1)

"In such a country as this, with a position to maintain amongst public men of aristocratical connexions, it is not easy to contend without pecuniary resources to fall back upon", he confided to an American cousin. "And my family drains and various pecuniary losses other than the American have given me more anxiety than the conflict itself. The Government have to decide upon the case, but my chief opponent is the brother-inlaw of Lord John Russell, and Lord Clarendon two Cabinet Ministers and two others. Lord John Russell I have cause most to distrust because he has dealt unjustly towards me, and to condem the comissioners will be to condemn the arrangements to which he was a principal party. The public however are I belleve with me ....."(2) To another friend, Edmund Ashworth, the cotton manufactures, he wrote, "Though unassailed or unshaken and victorious upon every point of atteck, yet defeat is by no means without producing its effect on powerful memoers of the Cabinet, the friends of the defeated parties: and it is by no means improbable that I may be driven to make an appeal to the country ......(3)

Relations at Somerset House were now extremely strained, with Chadwick muttering in his office and the Commissioners caballing against him with the Wige.

A chance encounter in the street with Prankland Lewis led to a scene as violent as that before the Andover Comittee; and one, moreover, which did $-0-$

(Continued from previous page) closed. Your predecessor had led the way by an imputation directed against me in Parliament of having made the law unpopulas by "harsh writing" in th $\Leftrightarrow$ correspondence of the office which was entirely under the control of the comissionecs which was not drafted by me and in the preparation of which I had fros the first remongtrated"

1. B.C. - H. Hickgon, n.d.

2. B.C. - Lndrew Boardman, 3 October 1340.

3. 2.U. - Ldmund Ashwosth, 26 January 1847. 
not end in a handshake.

(1)

Russell and Clarendon, he was told, had a majority with them in the Cabinet determined to uphold the Commissioners against the report of the Andover Committee (2); and "Lady leresa was in good spiritg". (3) "If I an not put down", he reflected bitterly, "three carriages must be put down which have been kept up on my labourg whilst I have walked". (4) Restlessly be fingered the strands of that dirty little tangle: "the obligations to truthfulness on the part of official superiors; the unscrupulous mendacity of Sir James Graham; the demoralising effect of the disregard of law by officers specially charged with its execution; the contemptuous setting aside of the author of the measure; the violation of the old rule that he who devises shall execute". (5) It was, he felt, quite another Rowland Hill case -- but sdwin Chadwick had had three Colonel Maberlys to deal with. (6) ihe difficulty was (though Chadwick was scarcely the man to realise it) that in producing evidence of the laxity of the Comissioners he was only strengthening them in public esteen; and in proving that they had not executed the Poor Law Act, he was inviting the retort that that was all to the good.

Looking at the new year with rheumy eyes (he was "unwell and very dear" (7), Chadwick considered the political prospects anything but bright. "Nothing is known of the intentions of the Government", he bold the barl of liverpool as the 134? session opened. "Wy own position is nost anious and unpleasant, and if the session does not make sn end of it some how I shall be driven to do it myself". (3) sir George crey and Lord Morpeth had not consulted him sbout the instructions

$$
\begin{aligned}
& \text { 1. E.C. - W. Christie, n.d. } \\
& \text { 2. E.O. - B. Gulson, t.d. } \\
& \text { 3. E.c. - W. Christie, } 7 \text { Pebruary } 1847 . \\
& \text { 4. B.U. - N.E. Hickson, n.d. } \\
& \text { 5. H.C. - H. Hickson, n.d. } \\
& \text { 6. ibid. } \\
& \text { 7. B.C. - Dr. P. Holland, } 2 \text { January } 1347 . \\
& \text { 3. E.C. - Earl of Liverpool, } 13 \text { Eebruary } 1347 .
\end{aligned}
$$


just put out by the Woods and Yorets on the conduct of inquiries into local improvement schemes. it were not intended, and an insuit if it were; in either case, it boded ill, especially when considered in connection with the attitude the Government was likely to take in Poor Law matters. (2)

"I now get no acknowledgment of saything I send: and yet outward deference is expressed to my opinion, and jet I am complimented in the opening speech of the session by the Hon. Charles Howard!"(3) Eis feurs seemed justifled when, in the debates on the Poor La: Amendment Bill, Lord Joht Russell came out strongly in support of "the Lewis interest", and piled all the discredit which hung around that unpopular measure upon the shoulders of their intriguing Secretary. Vainly Chadwick tried to awasen in his Parliamentary eriends a sense of their responsibility towards himself and the reformed foor Law. They retained un admant and cheorful confidence that right views would prevail and justice would be done to Bdwin Chadwick without any necessity for putting themselves out to assist that desirabie consumation (4) "This Government is renowned for its facility in abandoning all measures and all men", Lord srougham agreed heartily. (5) "You may see that J'Isreali bantered Lord John about jou, but it was all lone in a good humoured jocose tone, and can do you no hax"m", poulett scrope reassured him. (6) Pleydell Bouverie would have pointed out to Russell the absurdity of blaming Chadwick for irregularities over which as Secretary he had no control -.. if only be had thought of it at the time. (?) George Nicholls wrote a testimonial to his exemplary conduct during the lourteen years

1. Under 9 and 10 vict. c. 106; see above, p.255.

2. E.C. - Ur. P.I. Holland, 2 January 1347.

3. H. - Charies Clark, 20 Jamuary 1847

4. "I a at the mercy of accidents and of friends who certainly are as I feel under a false confldense which I cannot dispe I" (B.C. - W.D. Christie, 1 ? June 1347).

5. Lord Brougham - B.C., n.d.

6. J. Poulett scrope - B.,., n.d.

7. Eleydell Bouverie - .C., 23 May 1847. 
they had worked together, and when it was read in the Commons several other gentlemen were moved to add their mite of approbation. (1) "Altogether, at the close of the discussion your name stood clear from reproach, and most honourable testimony was borne to your public servicen (2)

All this was highly gratifying, but the Lewis interest remained firmly entrenched, and the Government seemed in no mood to make a public profession of error. They gave ear instead to the speech of Charles Villiers, who, though a brother-in-law of Cornewall Lewig, "has the indelicacy to come forward in the guise of disinterested advocacy", and decry Chadwick's "wrongheadedress". (3) This was the pliant politician, Chadwick recalled, who had expressed protectionist views in his report as Assistant Comissioner during the poor Law inguiry of 1834, and had stood as a free trader at Nolverhampton in the following year. (4) "Haviog been induced to withhold all reoresentations", he told Grey severely, "I have been extrenely surprised to find myself treated as an accuser who has failed in his proofs and blaned amongst other things for not preferring authentic representations". (5) And again, with a note of deepening indignation: "I regret that I must not accept gratifying praise and testimony for the performance of other duties not in question, as compensation for seriously unjust blame leading to erroneous measures on proceedings on the question of Poor Law administration".

In this truculent mood he began to draw up bis Grand Remonstrance. The "Letter of Edwin Chadwicis Bsq. in vindication of his conduct to the Bight Bonourable Sir George Grey" was a wordy, argumentative, and execrably written paper, $-\mathrm{C}-$

A. G. Nicholls - B.C., 27 wey 1847.

2. J.G. Denison - E.C., 17 June 1847.

3. B.O. - Lord Bllesmere, 15 JuIg 1847.

4. Hbid.

5. E.C. - Sir George Grey, 16 June 1847

E. B.C. - Sir George Grey, 24 June 1847. 
with seven appendices, and a mass of facts carefully verified by the evidence of the Assiatant Commissioners. (1)

It recited the history of his protests against the Comissioners, and outlined the course of preventive administration which he had designed and they had done their best to frustrate. Lord John Russell bad told the House that Chadwick had diccouraged the Assistant Commissioners from revealing the abuses in their districts; the truth was, Chadwick replied, that it wag the Assistant Commissioners who had complained to him of the coolness with which the Commissioners had received their representations. (2) Dissatisfaction, he alleged, was "at various times almost general" amongst the officers of the Commission. (3) And he himself had certainly not been remiss in the duty of aaking formal representations to the Home secretary. He had addressed complaints to Russell and Lord Normanby; and, through Lord Liverpool, he had attempted to get an interview with Graham -n who had declined to see him.

Chadwick backed up his own case against the Commissioners with a long and lively letter from a former Asaistant Commissioners, B.C. Tufnell, who confirned the correctness of the iapression Chadwick had given to the Andover Committee. Botb Cornewall Lewis and bimund Hesd, fufnell asserted, were "Literally without a particle of noral courase. A depreciatory baragraph in the newspaner seemed to fill them with the direst

1. 21 sune 134 ?

2. Sut the recollection of one Assistant Commissioner, to whom he appealed for support, did not agree with his own. He reminded the Hon. Charles Clements how he had come to Lancashire Irom Ireland to find it "one vast hugean stable of abuses"; "and you subsequently were compelled in consequence of the discouragement you had received to leave it $80^{* 1}$ ( 2 June 1847). He received a very frigid reply. lements could not recall what he had gaid, but he was sure that it did no justify Chudwicis usinis his name as he had before the Andover Comittee ( 7 June).

3. "You have seen it represented that I was the only discontented person in the Commission. The ract is that there was not any person who had any anxiety lor its success and any understanding of principle who was not discontented ...... (E...- Dishop of London, su june $134 \%$ ). 
alarm, and they were ready to sacrifice any subordinate officer, or any principle of the Law it was their duty to enforce, to appease a newspaper clamour or the demands of an anti-poor law agitator". Though be considered Chadwick went "too far and too rapidly", he paid a handsome tribute to Chadwick's method of careful personal investigation as compared with the "tortuous" modes adopted by the commissioners. "whatever jou proposed, jou never seemed willing to have your proposals put in inal execution, without hearing and discussing every objection that the Assistant Coramissioners could bring against them. I could rarely get kiessrs. Lewis or head to pay the slightest attention to my representations of what I deemed the impropriety of any course they were pursuing. Hy objections were generally poohpoohed in not the most courteous manner". (1) Edmund Fead's idea was to get things done by finesse and indirect ways. "I remember being excessively disgusted at his sending we a long paper to show the advantage of attending to aronywous communieations which I think ought to be put in the fire without being read ..... I have geen the foulest slander circulated by the Comissioners on anonymous authority". And, in fact, he belleved that Day had been dismissed on the strength of a letter from a person who desired that his name should not be divulged.

1. E.O. Tufne11 - B.O., 28 May 1947. "My chief objection to the Comnissioners" public conduct", wrote tufinel, "arises from their neglect of the law they were apointed to enforce, Their sole object for the last few years seems to have been to ende vour to cuII popularity by acting the "poor man's friend" .... It was perfectly clear to me, that what was always uppermost in their minds was not how they should best perform their duty, but how they should appease the Times Newspaper, and nollify by concession all the objections of the ant1-poor law agitatorg". About the Poor Law hot itsele, he observed: "I was for nearly eleven years engaged in superintending its operation in the faost pauperised parts of sn bland -- in districts wher the change made by it was most violent, and ail familiarly acqualnted witn its action in 130 unions. I think I may, Nitiout vasity, lay clain to as much practical acquainuance with its working an any mo in England; and 1 urhesitatingly affirn, that it did produce, whenever lairly puo in 
Chadwick's friends --- among them the Bishop of London, the Duke of Richmond, Lord Liverpool, Lord Fortescue, Lord Lansdowne, Lord Ellenborough, Lord Radnor -.- read the draft of his letter; they read Iufnell's letter with its corroborative evidence; they assured hin that he had an excellent case -.- but no two of them were agreed as to the steps be should take to obtain rodress. "Such a letter ought to satigfy any statesman of his good fortune in having the writer of it st his disposal", said John Mill, "-.. but whether any of these men have sufficient brains to appreciate brains in another, remains questionable". (1) It was now quite clear, however, that the jury had pronounced its verdict, though it was in cool defiance of the judge's sumbing up. The Government had made up its mind, and decided on its course, and no representations, however autientic, could now change Russell's attitude. The debates on the Poor law Bill had closed without any reiraction of the slurs on Chadwick's notives and conduct, and that "mass of exror and delusion", frankland lewis, was still disseminating the statements which he thought he had refuted once and for all before the Andover Committee, (2) Whoever was to form the

(Continued from previous page) operation ail the good its authors promised -.. that the condition of the labourer was imensely improved by it, that his earnings were increased, that the amount of work provided for bim was largely augmented, and that in innumerable cases it was the direct cause of proviling constant exployment to workpeople who were previously turned adrift on the parist on every shower of rain". Le bad been aware some time before he resinged that the Comissioners regarded him as a "dangerous character", and he had retained his post for one reason only -.- so that he might devote bis salary to maintaining the Normal School he had established. "Had I resi ned, I should have been compelled to break up that school, as well as faitb with many of the students who had entered it, and persons who had contriouted to its support.... ihe only person connected with the office, who when asked to subscribe in support of that school, positively refused wo give a farthing, was ir Bdmund Head".

1. J.3. Uill - E.C., H.d.

2. B.U. - Lord?, n. 1 . 
reconstructed Poor Law Board, it seemed that Kdwin Chadwick was not to be of their number, though a friendly Lord might wonder "who upon earth is to rule at Somerset House to be St. Sebasilan (who was martyred by being shot at with Pagan arrows) in each house of parliament?"(1) had even declared that he had no claim to be considered for the grant of a pension. To Lord Bllenborough he wrote bitterly, $" A g$ the bill at present stands it might be inticuled "An act to enable the Government to dismiss without reasons assigned, those who otherwise canat be removed without justiflcation or compeasation. If during fifteen jears $I$ had held a sinecure offlce, or an office of ordinay routine, a removal without compensation would not be thought of or tolerated". (2) A few days before bbe fiealth of Towns Bill, his life-boat, had foundered in the Commons. The future looked rim that ruly

It was time, he felt, to unmask his batteries. "I shall 1. Lord Lovelace - R.C., 2 October 1347.

2. E.C. - Lord Rllecborough, 12 July 184 ?.

3. His uncertainty about the future a this period is illustrated by a couple of notes: (1) to John Walter (n.d. mariced "Writien before the Phird Reading of the Poor Law Adninistration Bill.") -... "The last night in the House of Lords saw at the least the close of the present poor Law goard and possibly of ny public services.... Whether I shall return to public service may be doubtiul". (2) An undated and unadiressed note .... "y condexion with the poor law and public office may now however be sald to have ceased: whether it is to be renewed which will be by no change on ny part or I return to my professionel endeavour is yet to be seern".

At this crisis In his fortunes, as in 1837 and 1341 , his thoughts tirned ageidis to the possibility of a seat in arlisment. "T should for the sanitary pessures and on other rounds be glad to get in but I camnot spend money", he rote to J.H. Burtor, $24 \mathrm{Ju} 1 \mathrm{y} 134 \%$. "I was offered 5 place in epland some days ggo but I co ld not iacur the expenge". For a time, though not too seriousiy, he seems to have toyed with the idea of contesting inbucgh, where the scholarly kacaulag should have as sn opponent "not a mere comiron place shopkeeper" but someboly "intellectually respectable", such as John ill ... or ridin Caadwick. 
certainly not consent to removal however without reasons assigned and an opportunity of vindicating myself. It is not to be endured that the tried, and upon their own hearing the convicted are to be maintained and the person whose measure bas been frustrated, diggraced and set aside". (1) Hicherto his "Vindication" had circulated only amongst his personal friends, but now he began to prepure it for publication. He even contemplated legal action againgt the Poor Law Commisioners, and drew up "Heads of kepresentations or Artioles of Charge against George Cornewal.1 Levis Esquire and Sir Eidrund Head Baronet for acts of Walfeasance of Nonfeasance and Hisfeasance in the performance of the duties of their ofilce $a s$ Comissioners under the 4 th and Sth Wili. IV. c. 70 and other Acts for the relief of the poor" (2) At once he ran into the difflculties vhich must confront any civil servat who proposes to oreak the triple vow which binds his order to silence, anonymity, and obedience. S.C. Iufnell declined the honour of eppearing as a leading witness in any public scendal, and imposed a ban on the publication of his letter. Hewwas too late, however, to prevent Lord srougham reading exoracts from it in the House of Lords. There was an indediate outcry that this was a breach of offlcial confidence. "Gan any one help leep disgust", wiove chadwick to sroughem, "that there should be no feeling of concern, for imense mal administration affecting large nasses, positive brecches of law and disastrous misconduct, which ought to nave been the subject of judicial inquiry and impeachment, and to feeling for the sscrifice of an able officer like wr. Parker, but aifected horcor at an accidental revelation of one part of the risconduct, by the removal of a barrier of privacy or confidentiality wich is a misprision and public offence ever to have imposed. The official confidentiality and honour I have only found to come within Dean Swift's simile of conscience as being like a pair of 1. E.C. - Lord?. 3 July 134 ?.

2. n.d. 
breeches, a garment made to conceal lewdness and nastiness and readily let down for the convenience of either". (1)

Reviewing Chadwick's correspondence relating to this period, one is struck at once by a remarkable omission. Nowhere is there any hint of his views on the decision to put the Poor Law offlce under a Parliamentary head. He appears to have seen the whole problem of Foor Law administration in 1847 as a personal, not a constitutional crisis; the principles of 1834, personified in their author, Ldwin Chadwick, wre arraigned against the pernicious policies of the Commissioners; the Lewises, from the powerful shelter of Winisterial friendship, were plotting to hurl him from his Secretarysbip. Chadwick would undoubtodly have agreed with Bagehot that year by year the central deparbment was getting more and more feeble, that the corrupt interests in the localities, with their spokesmen in press and farliament, were gradually wresting the control of Poor Law administration from its impotent srasp; it is equally certain, however, that he would have denied Bagehot's assertion that this was due to the intrinslc weakness of the machinery he had devised, a weakness which could be removed only be putting the department under an "opflcial and party protector in the House of Commons". "If Sir George Lewis and Mr. Chadwick could not maintain as outlying department in the face of parliament, how unlikely that an inferior compound of discretion and activity will ever wantein 1t!", wrote Bagehot at the conclusion of his classic analysis. (2) the weakness of the poor Law bastion, Chadwick would probably bave replied, lay in the fact that its garrison was $i 11$ chosen; it vas nanad by then who had doubts of the position they were supposed to defend, and who treated as a sutioeer the most powertul chamion ol the reformed Poor law. The remedy, the only remedy, was to give cdwin Chadwick a free hand: "1f I had had proper support I vould have reversed the picture and by this time have had the law popular, 1. 1.0. - Lord Brougham, $13 \mathrm{Ju} 18 \mathrm{y} 1347$

2. Bagehot, "English'Constitution", world'B Classics, p. 167. 
district industrial schools established and the rates full one million lower". (1)

A truculent Civil Servant, with a grievance, the makings of a case, and a following in the country, could not have been too pleasant a thought for the Whig Government. He would be a nuisance and a bore, if he were not a danger. in more than one serise when the Prime minister decided that Chadwick might proitably occupy himself with an inquiry into the sanitary condition of London. To the reasons for that inquiry, and to Chadwick's other activities in 1847, we must now turn.

Chadwick's great hope at the beginning of the 1847 session was that his ten years of investigation and inquiry would at last bear legislative fruit. But the Public fiealth Bill, which Lord Morpeth introduced on the 30 th arch, was not Chadwick's Bill, though it displayed extensive evidence of the influence of his tieports and memoranda and of the criticism which the sanitary reformers had directed at Lord Lincoln's abortive measure. It was understood -.. though by no means was it promised by the Government --- that he would be offered a place in the new administrative arrangementa; and it was mainly with an eye to his own freedom and power of action that he looked over the clauses of Morpeth's Bill. The central authority was to be a "Board of Realth and Pubilic oriss", composed of five nembers, three of whom would be paid, with the first Commissioner of wods and Forests as president. (2) Phus, $-0-$

L. B.C. - Duke of Richmond, o Novenber 134\%. His views on later developments under the Poor Law bost may De illustrated by his slatement that "since the change was made from an undivided atiention of real Boards to the divided attention of changing political chiefs and to boards of members whose atieution is and can be only formal and nominal, the administration has retrograded; in poor laws most disastrously..." (

2. Aansard, vol. $91,9.624,30$ arch 1347. 
Lord Lincoln's proposal to bring the public health under the aegis of the Home Secretary was abandoned in favour of machinery modelled on the recently established Railway Board. The lesson of the discredited Poor Law Commission had not yet been digested; the new Board would have a Parliamentary spokesman, (even two, as the other unpaid member might well be a Nember of Parliament) but the Pirst Comissioner of Woods and Forests. though situing as president, was in no sense a ministerial head, since he shouldered no more responsibility for poliey than any other meaber of the Board. The weakness and inadequcy of this arrangement were to be sharply revealed when the General Board of liealth later came under the presidency of Lord Seymour. (1) It meant, moreover, the end of Chadwick's visions of himseif working the public Health Act as standing counsel or secretary to a Comittee of the Privy Council, and with considerable misgivings he looked forward to a Board on which he might find himself in the company of uncongenial fellows. In the local machinery, too, the 13111 turned its back on Chadwick's recommendations. In corporate towns the town councli would exercise sanitary powers; in non-corporate towns the members of the local authority would be elected by the ratepayers, with the exception of a certain proportion, not to exceed one-third, who would be nominated by the central Board. the local authority - $0-$

1. S.H. Gael, a Parliamentary counsel, sent Chedwick some acute criticisms of the Bill in a paper entitled "Obeervations on the Health of Towns Bill 1847 and the lowns Improvement $3 i 11$ incorporated therewith".

"If the President of the Hoods and forests can attend to this", he asks, "why not his Brethrea without having new Commisgioners? If he can't attend to it why is he made a member of the new Commission? If a President be required why should the Comissioners go to the Woods and Forests for him?

But what is the resident above his fellows? of this the bill tells us nothing and we cannot guess. Perhaps as an organ in Parliament. But then none of the Comissioners are prevented from siting in Parliament, and if one gets in he would be much better qualified to defend the acts of his Commission than the Commissioner of the Hoods and Forests.." 
would be set up by the central Board after a local inquiry, in which the district coming within its jurisdiction would be defined; and should it be considered necessary for the purposes of the Act, the central Board might extend the existing boundarles of the towns. Powers over drainage, street cleansiag, building construction, and nuisances were to be exercised by the local authorities through the agency of a surveyor and an inspector of nuisances. They could construct water works and gas works -.. a notable deviation from Chadwicis's recomendation that these services should be carried out by contract with private enterprise. (1) On the financial arrangements, however, his arguments had had more effect. "It is this question of rates which has hitherto been the direct, and for some time to come must be, I fear, the indirect obstacle to the inhabitants taking up sanatory measures with vigour and good heart themselves", Morpeth declared. "There is something in the very sound of "rates", which weighs fearfully in the balance against health, industry, content, and all the virtues". As Chadwick had urged, the burden wo ld be eased and the obstacle lowered by granting powers to the local authorities to raise loans on the security of the rates, the principal to be recovered from the occupiers by instalments spread over thirty years.

In the ensuing debate Lord Lincoln objected that the Bill introduced too strong an element of centralisation and that the title of the Board seemed to foreshadow Iunctions more extensive than tbose described by zorpeth. He repeated the suspicion of town councils voiced in the Health of l'owns Report: the suburos of the great manufacturing towns were so wide that the aunicipal 1. "Not a tittle of the facility recommended by the commisioners (sc. Health of Fowns) to be fiven is by the 111 given. The framers do not seem to comprehen: that part of the subject at a $11 \ldots$ Unlike Mr. Hawkesley and other experienced judges and the Health of l'owns Comissioners the Pramers of the Bill seem to be unfavourable to the agency of Companies" (S.E. Gael, op. cit.) 
jurisdiction did not cover their whole area (two-thirds of Nottingham, for example, lsy outside the existing municipal boundaries); moreover, the corporations were strongly political in composition, and an opposition party would look with distrust on powers of taxation in the hands of the majority.

The measure was pushed through its Becond Reading and the motion for Committee, however, by coufortable Government majorities; and then the critics took command of the field. It was a very valnerable Bill. Critics could bang away with the cheering certainty of doing damage to one or other of its rambling outworis. A provision which incorporated the $B i 11$ with the Comissioners Clauses Act involved the consideration of some seven hundred clauses, and six other Acts were also brought in by this sumary but exasperating method of cross reference. Presently korpeth found himsell engaged in a brisk contest over every clause, occasionally rising to a more extended strugele on the broader ground of general principle, such as the inalienable rights of every middle-class Eaglishman and the tendency of all Governments to job. From the first the Bill was "the object of singular Protectionist aversion"(2), and in comittee spokesmen of the landowners strongly opposed a measure which might burden them with taxation for tunicipal improvemeats (5) "The country 1. Hanserd, vol. 91, pp. $633-\overline{642}, 30$ Nurch 1347 . "It would puzzle a person to give any satisfactory reason why

Corporations the fiembers of which are all elected should be thought competent bo manage the affairs of Health while bie elected Compissioners of a town are not to be trusted without the association of crown Compissioners .... What is there in unicipal machinery to render it decessary or sultabie for the purposes of the sill? ... There is no advantage it is apprehended in having a soard of auove sever or ten lembers; and mat rials for this inay be evergwere had without new slections or extension of Corporation authority .... Their unfitness is not merely owing to isporance but to ibe bias etc. of their position, and of the two Corporations have more of this untoward tend ncy than the lown comissioners would be likely to bave" (... Gael, op. cit.) 2. "Iimes", 3 July 1847.

3. Hansard, vol. $93,2.710$ (Uivett), pa 717 (buck), 728 
was sick of centralisation, of commissions, of preliminary inquiries -. of all sorts of jobs", cried Hudson, the Railway sing. "The people wanted to be left to manage their own affairs; they did not want Parliament to be so paternal as it wished to be -. Interfering in everybody's business, and, like all who so interfered, not doing itg own well". (1) It was the crude "Hands off!" of the seli-sufficient capitalist; and it was strensthened by an older argument from the elghteenth century whea Colonel Sibthorp exclaimed against the appointment of Commissioners under Government patronage. "he objected also to their being salaried, entertaining a strong feeling that if they had not patriotism enough to give their services for the good of their country, they were utterly umortby of so importsnt a trust. He objected also to the appointment of three inspectors. These things led to a great deal of bribery of a peculiar kind; and he had served long enough in that House to be extremely jealous of all Governments, whether Whig or Tory. They all could, and did, do a great deal behind the scenes; and there was a great deal of secret service money spent". (2)

In the country at large the bill caused litile noise. frue, 32,000 signed petitions inilts support, and 237 sent resolutions against it; but apart from this vinority the public did not seem greatiy concerned about the defence of its own health. Chadwick sent some notes on the Bill by southwood Bmith to a friendly editor ${ }^{(3)}$, and added the tart coment "Adnitting the justice of of the Rajah of suttaras claim and of (Continued from previous page) (Newdegate). In answer Brotherton pointed out: "Honourable meabers connected with those districts were very sensitive; but he could bell them that in the suburbs of large towns, landowners had derived great advantages from the industry of their neighbours, and he knew cases where landowners had bnelr incomes advanced from 45,00 to 820,000 a year, without doing a single thing to promote the welface of the inhauitants oy whom the were so much benefited".

1. Hassard, vol. 93, p. 743,18 June 1347.

2. ibid., p. 727

3. B.C. - ?xxproxay the "ines"), 7 July 1347. 
the Portuguese and of delinquents, I must say that the condition of the population would seem to have a right of precedence". There was a thin crop of pamphlets, bearing on the title page the trend of their argument, and in their contents plain evidence of their origin. "A Townsman" of Worcester wrote \& "Letter to Lord Morpeth on the Health of Powns Bill; involving an outlay of 50 to 100 milifions -- an snaual charge of 10 to 20 millions, with a countless host of Government creatures and dependants -- showing that it ought to be withdrawn, and an entirely new sanatory measure introduced, omitting its violent and arbitrary powers, especiaily the power of taking in suburbs and creating new districts -- that the local powers should be given to bodies distinct from the Town Councils -.- and that strict accounts should be kept of returns from the sale of sewerage, and their application be subjected to the controul of the central authority"; while another writer, whose interest is not difficult to divine, put forward his "keasons against the Legislature granting to the Crown an extraorilnary Power, discordant with the Principles of the Constitution, of coercively ordering the Population of Places and parishes in Counties at large to be incorporated with the adjoining Borough: or to be included in the enlarged boundaries of any lown (or District) "for all purposes" s. $19-23 \ldots$ and so subjecting County Parishes to all funicipal Jurisdiction, Deots and Corporste burthens, and seriously affecting the laterests of Owners of roperty and Ratepayers in County Di tricts by an alteration and disturbance of the ancient and cnown arochial Boundaries and consequent new distribution of hates etc."

In the hope of etting the bill through before the end of the session, the Hetropolitan Sanitary Association urged llorpeth to make concessions. (1)

London was aroped from the bill (2) i

1. Hansard, vol. 93, p. 1177, 2 July 1347

2. H.G. - horpeth, 3 June 1347: "In reapect to the omission o1 the petropolis $I$ have stated to leading embers of 
the element of nomination in the local Comisaions also disappeared; it was agreed, to pacify the vater interests, that local authorities should contract for their supplies with existing companies. The number of Comissioners on the central Board was cut to four, of whom only one was to be paid. (1) "If defective at all", observed Morpeth on the lst July, "he believed the Bill contained too little of stringent or compulsory power to effect what was desirable. The principle of the Bill was to leave all to local agency, advised and encouraged by central superintendence". (2) But by the 3th July it was clear that Morpeth's concessions had not gained their object of securing an easy passage for the Bill. Nobody was grestly surprised when Lord John Russell announced that the measure could not be proceeded with during the present sessioni and nobody could disagree with his verdict that this was partly due to the inportance of the subject, partly to the defective framing of the Bill -.. but "another cause may be, that unnecessary opposition has been made for the purpose of delay". (3) In lact, whatever had boen gained in postponing the clash with metropolitan interests was lost in the feeling which the exemption aroused in the press and the provincial representatives, who saw in it one more instance of the influence of the City Corporation and the solid block of sixteen metropolitan M. . .

1. Raneard, vol. 93, p. 1100, $\overline{1}$ July 1347

2. ibid., p. 1103 .

3. ibia., vol. 94, p. 25 .

(Continued from previous page) Associations and to all purties I have met with, thet I realig believe it will not be of much moment if full powers of inquiry be siven to the new Board to prepare for the next session, because if full powers of execulion were given, the new Board, if they know what they are about must eaquire and urve.y very cautiousiy and would not 1 aporehend get beyond iaquiry by the midsle of the next ession; when very probably bey might not ind the best a priori powers of execution sufliclent or applicable and wo ld then recomend a nen bill with speclal provisions. All I should be anxious about (and I should say it publicly) would be full powers of enquiry and preparation for the next Session". 
Une point above all impressed Chadwick as he read the B11l after it had passed the Committee stage. Only one paid Commissioner, and that one at 21,000 a year! Was this the value the Government set upon the execution or the new messure? Even the extreme kalical papers, such as the "weekly Dispatch, scoffed at the cry of patronage in this connection. (1) The influence of Southwood Smith's name with the press would bave been worth double the cost of a second commissioner. (2) In 1. B.C. - Joseph Iume, 5 July $\mathbf{1 3 4 7}$. In anotier note to Hume, undated, Chadwick observes: "The reduced salary for increased duties carries with the appearance of a public affront, a public contumely of intellectual labour applied to the field of legislation .... Now would it not be becoming your position as an econonist to insist on some security for good appointments, and vindicate yourself from a participation in the wasteful parsinoney".

2. "This cuts of $\mathrm{f}$ the chance of the undivided aid of $\mathrm{br}$. Southwood Smith whose assistance in the medical portions of the measure, I should have deemed essential; whose writing is of a high order and whose popularity with the Press which it is important to carry with us, and with the medical profession would be worth several salaries, and whose labours entitle him to a paid place at the Board even if it were to be a sinecure." (E.C. - Nassau Senior, 7 July 1847). He added: "hree members of the Government (not in the Cabinet) ured me to withhold personal remonstrances on the assurance that my position for the future must be changed for the better. You know that wy salacy at present is 1,200 per annum. The extraordinary roduction proposed is Lts own commentary".

In a note, probabiy addressed to Lord Norpeth, 7 July 1347 , he reported that as a result of the decision concerning the number of paid comissioners, southwood smith "feels himself in a painful position .... As he is now as he considers excluded from acting as a pald. Comissioner, he is desirous in bis antety of acting as one of the unpaid members of the Board, and the only consideration with hir at present is as to the time and mode of sending in his appliction .... He has g friendly and an affectionate desire to continue in cooperation with me upon the measure and I reciprocate the feeling". 
accepting the post, he must himself sacrifice sicoo a year of his present salary; yet, when he reflected on the dangers of a less suitable appointment, he lelt that "if the salary were one half that proposed, there would seem to be (regard being had to consequences) an obligation to take it". (1)

"Look at my present position!" he wrote hestedly to Nassau Senior. "After every appeal of mine has been affirmed: every remonstrance made sustained against adverse inclinations: I who have had no charges preferred against me, no hearing and no public condemnation by impartial members, $I$ am proposed to be in efiect removed axbitrar $1 \mathrm{y}$ to a lower place in emolunent which all who believe ayself to be contemplated regard as a public and intentional slight". And he could draw no comfort Irom the hope that the position offered would improve in time. mas I not told on the word of a pritue minister and a gentleman as the condition on whlch 1 took the office of secretary to the Poor Law Comission that I should have "the position of a fourth Comissioner" assured to me; a position which a regard to the public service not to speak of gentlemanly leelings of propriety and a regard to the naturally inalienable supertority of him who has devised superior measures, would have assured to me even if there had been no promise whatsoever". He would decline the paid Comissionership with its derogatory salary, he told senior, but he would put in a claim for an unpaid seat at the new Board, at which he would continue to give such eratuitous service as he had all along given to sanitaxy measures. At the same time he noind clalm to be retained at the poor law soard, on the rounds that his remoustrances had been upheld by the Government and the Law officers, and that his was the best experience and information available (2) Chadwics liked to think that the management of the two Bills, the Poor law and the lleaith of Iowns, did Russell some damage in his constituency in the 134 ? 1. B.C. - Lord Bbriagton, n.d. 2. H. - Nasgau Senior, 7 July 1847. 
election. Even Richard Lambert Jones, an old adversary on the City Conmission of Sewers, stopped him in the street one day to tell him that the Corporation considered that he was being sacrificed for having performed his duty to the public. (1)

On the 8th July the Public Health Bill was thrown out, and Chadwick with it. Somerset House had closed its doors behind him. He faced a period of twelve lean months before Worpeth's revised $3 i l l$ could be passed. Already he had warned his American dependacts that they could expect no help in the coming year, when he was sumnoned to an interview with the Prime vinister. He was to be put in charge of a comission of

Inquiry, Bussell told bim, not into the evils, which had been sufficiently proved, but into the specific remedies available for the sanitary 111 s of the capital.

Possibly the thought of Chadwick, with his indiscreet pen, at a loose end for twelve months was too much for a Cabinet whose part in the Andover affair could nót be too kinaly scrutinised. But in any event the problem of metropolitan government, at the sight of which Jorpeth had "glruck his flag and cut his stick"(2), loomed olackly on the legislative horizon of the coming session; and Chadwicis, with his zest for investigation and his uarivalled grasp of sanitary and administrative principles, was the only isan who, in the space of a few months, could draw up the indictment of the present régime and indicate the lines of future reform.

But there were more powerful reasons. In the last few month 3 the knowledge of the sanitary reformer had taken on a beistened value. Cholera had broken out in kabul in the hot season of 1345. Spreading from the north west provinces of India, as from a centre, it swept ovor Apganistan, Persia, and the south eastern portion of Asiatic Iurkey, unil it was arrested by the winter of $1346-1347$. In the spring of 1347 1. E.U. - Lord Eorington, $20 \mathrm{July} 1847$. 2. Roebuck: Hersard, vol. 93, p. 75e, 18 june 184 . 
it recomenced its advance, striking south into Persia, Arabia, and ligypt, north through Georgia and Circassia into the southern provinces of dussia. The northern wing of the microbic invasion divided, one branch thrusting through European Rugsia into 8 inland and Sweden, the other decimating the towns of the lower Danube, and advancing through Augtria into Germany. In september 1348 the cholera was at Hamburg, whence it took ship to bdiaburgh, appearing unmi takeably in the scottish capital at the beginning of gctober 1343. More than twelve montis before that date cages of iadigenous fever were being scrutinised enxiously in england for the characteristic symptoms of this exotic disease. What put a wholesome fear of filch into the governiag classes was the spectacle of the unhastening, unchecsed advance of a microbe on the march, traversing thousands of miles at the heels of the overland caravans and spreading westwards slong the great interior waterways of Russia. For this was the second time ia one generation that cholera had swept through Jurope; and not since the English Sweat landed with Henry Tudor at Ailford Faven in August 1435 and, as Poljdore describes, journeyed to London as his camp Pollower, had Britain experienced go novel and so terrifying an epidemic as the Astacic Cholers, which struck down its first vict $\mathrm{Lm}$ in suaderland in crober 1331. A few rooths of cholers in 1331 - 1332 caused more alarn than centusies of home-ored typhus, wich silled its thousands yearly in the slums of the industrial towns. It was the dramatic sudenness of the choleralattack which spread terror. In the space of a few aours the sufterer might be lying pulseless and olue, his body shaken by repeated vaiting and purgias, his linbs twisted with cramp; and in the existing state of medical knowledge one nalf of those who passed into the olue, or collapse, stage of the disease were doomed. "bleeding, brandy, opium, calomel, amonja, quinine, croton-oil, cold water, the wam bats, the cold effusion, sil varieties and contrarieties of treatment possible, have been enployed alise in vain". . or this reasn, though the 1. hetro. sanitsry Uubission, second keport, p. ce. P.P. 1847 - 48 (911), xxxi1. 253. 
influenza epldemic of 1847 killed more of the middle and upper classes than the cholera of 1848 - 1849, it aroused nothing like the same amount of apprehension. Nor was this all. "Difference of social grade less exenpts the individual from the attacis of cholera than of fever, and cholera more often, and apparently more capriciously, bursts its usual boundaries, and attacks the inhabitants of comparatively healthier districts, amongst whom it proves little less mortal than when it ravages its accustomed haunts". (1) The louse was no longer seen in polite society, and typhus in consequence was a poor man's disease. At the end of the eighteenth century a respectable middle-class physician was noting complacently that fever was rare in Liverpool; though, to be sure, Dr. Currie was treating a steady average of three thousand typhus cases a year at his dispensary. But the coma bacillus was a social climber; excreted by some lowly sufferer in Fore street, Lambeth, or Hair-brain Court, it might penetrate the halihearted filter defences of the Water Companies to poison his betters in the orod squares of the west ind. When the obituary columns of the "Times" began to lengthen, the law-making classes were stirred rore deeply than by the pigures in the reports of the Registrar General, which referred chiefly to poor men's losses.

Assured of the backing of an epprehensive Government, (2) therefore, Chadwick cast an imperial eye over the vast, -0-

1. Metro. Sanitary Comission, First Report, p. 27.

2. Returning from the interview with Russeli, Chadwick wrote to the Bishop of London ( 24 July 1847): "I could not out accept, believing that there was no one else who had bestowed so much labour on the subject, or would be likely to arrive at conclusions quicker tho" I cannot but feel that the treatment of such labour has heretofore been far from encouraging. I shall part with the Poor law administration, where so much renains to be done with much regret. I am firmly convinced that two thirds of the unpopularity which attaches to it, or the ereater proportion of it, is due to simple mismanagement. Aoove all, I regret being impeded in the preventive course of administration, all of which might be made popular in the best sense". 
disorderly province of the metropolis. Outside the square mile of the City, London in 1847 was a tangled jungle of overlapping jurisdictions and conflicting authorities. Some three hundred local bodies -- including seven Comissions of Sewers, nearly a hundred paving, lighting, and cleansing boards, and about 170 vestries and Boards of Guardians --- jostled and frustrated each other, each clinging with determination to its minute segment of power and dignity, with the object, it would seem, rather of keeping out other authorities than of conferring benefit on the population beneath its care. For the densest parts of the capital there were 120 Local Acts, under which were established 80 distinct local jurisdictions, many of which coincided with neither parish nor Union nor police district. In the parish of St. Pancras alone there were sixteen separate Paving Boards acting under 29 Acts of Parliament. (1) And while the drainage and surface cleansing of London was thus minutely sub-divided between a host of pubilc authorities, other vital sanitary services were shared by eight joint stock cemeteries and nine Water Companies. The Royal Comission on liunicipal Reform, which had devoted the whole of its second report to the capital, had concluded that London must have a unified government, but it had not ventured to decide whether it should take the form of a Government Comission, of a newly created municipality, or of an expansion of the City Council. If the Government ever really intended to take action on this report, the edge of their resolve was turned by the hard core of vested interests in the city. The chaos remained, and grew worse year by year, a challenge to all Chadwick's principles of administrative consolidation. For the remaining years of his official career the problems of London'g drainage, water supply and burial services were to occupy a major part of bis energies.

There was liftle attempt by the Government to conceal the real purpose of the investigation on which he was now engaged. $-0-$

1. "Report on the Epidemic Cholera of 1343 and 1849", pp. $y-$ 10. 
It was to convict the works and administration of the Sewers Commissioners, and to furnish arguments which might be used to justify to the public the resumption by the crown of the sanitary powers they had so ineffectively wielded. Lord Lincoln and Sir James Graham had earlier taken tentative steps towards superseding the Commissions, but had drawn back --apparently, Chadwick observed, for fear of offending the Comissioners. "Something must be said publicly", he wrote sharply to Lord Morpeth, "of the state of mind which inflicts disease and death extensively on thousands out of deference to conventional feelings of individuals, which feelings are most improper for those individuals to entertain". (1) For the Sewers Commissions stood plainly condemned by the Commons Committee of 1834, by Chadwick's Sanitary Report of 1842, by the Health of Towns Commission of 1844; and Chadwick fretted at the needless delay which the Government's caution imposed upon him. Within a fortnight of the interview with Russell, he submitted to Morpeth some "Menoranda of results in relation to the Metropolis, promised by E. Chadwick"(2), a paper which, in its reckoning of sanitary profits and economies, struck the confident note of the comercial prospectus. Three districts might in future be drained for the cost of two, two courts and two houses at the cost of one hitherto drained by private builders -- provided that sound adrinistrative arrangements were adopted. The secret lay in the consolidation of the whole of the natural drainage area of London under a single Commission of Sewers. Over 260,000 a year might thereby be saved on establishment charges, on the expense of rate collecting, and on the outlay for Comissioners' dinaers. Consolidate at once, without waiting for the results of the new inquiry, Chadwick urged on Russell and Morpeth. If the Sewers Commissions remained in their present hads, the doomed Comissioners would resist the investigation to the utmost of their power. The 1.
2. 4 Aigust 1847 . Lord Morpeth, 5 August 1347. 
more enlightened of the surveyors had already come into conflict with their reactionary masters; John Roe, for example, whose flushing machine had been coldly received by the Holborn and Finsbury Comissioners, and that "extraordinary man", John Phillips, the self-educated journeyman bricklayer who had risen to the surveyorship of the Vestminster division and who had pointed out the defects of the system of sewerage pronounced perfect by the President of the Association of Civil Engineers. These experienced officers were agreed that it would be well worth suspending all the drainage works now under construction for the sake of a complete survey, and they assured Chadwick that if they were given emancipation and security they would willingly co-operate with the Commission of Inquiry in the preparation of remedial measures.

Morpeth approved highly of Chadwick's papers (2); but Russell was luke-warn $(3)$; and a strong letter from the Lord Chancellor, which Morpeth would show to Chadwick only in abstract, put an end to Chadwick's hopes of a coup d'état. (4) Consolidation was postponed until the investigation was completed, and Chadwick sighed that whilst the Sewers Comalssioners would not obstruct the inquiry so openly as to expose themselves to a supersedeas, there would be "no work with a wi11". (5)

Besides Chadwick and Southwood Smith, the Commission of Inquiry included Lord Robert Grosvenor, who was Russell's choice, and Richard Lambert Jones, representing the interests of the City of London; while Chadwick had made sure of a majority in favour of progressive measures by insisting on the nomination of Professor Owen, "the Cuvier of our day"

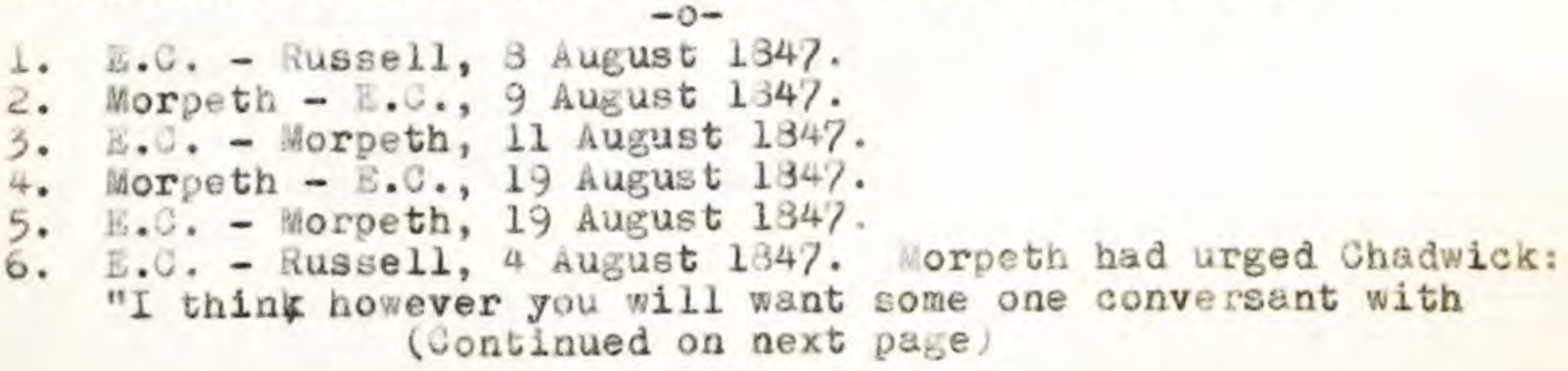


Russell had wanted to appoint the son of Sir John Bowring as assistant secretary to the Commission. Chadwick retorted bluntly that it would look like a political job, and instead he secured the post for Henry Austin, a young engineer who had carried out some pioneer sanitary work of considerable promise (1)

Early in September 1847 the Commission moved into the rooms in Gwydyr House where the Health of Towns inquiry had met two years before. "I have seen enough and supped enough of horrors not to avoid more except where it may be absolutely necessary", Chadwick confided to Worpeth at the outset of his third sanitary expedition. "A man who has had two fevers in the sanitary cause, may be placed on the footing of an officer in the Arny who has led two forlorn hopes and excused a third. I certainly shall put forward younger men for the enterprise". (2) Within a few days, however, he was revisiting the lower districts of Bernondsey in Professor Owen's company.

As early as possible Chadwick withdrew, with his two allies, Owen and Southwood Smith, into the seclusion of a subcommittee on the cholera, and the main propositions of the reports were hammered out in this congenial atmosphere, removed from the "Parliamentary influences, fidgets, and groundless alarms" of Lord Robert Grosvenor(4), and Jones' continual insistence on the rights and dignity of the sewers commissions. To save time, and to gain the support of the representative of the City, they confined their attention to the seven districts for which the Crown was responsible, and the attack on the City $-0-$

(Continued from previous page) Parliamentary feasibilities, and with what is likely to go down with the general detropolitan feeling". (25 July 1347). To which Chadwick had replied by expressing his suspicion of the metropolitan Merbers: "I doubt whether the service would not bring a disagreeable pressure upon thenselves; and impede the inquiry by their becoming the means of hearings of parties out of the regular course of the investigation". (26 July 1847)

1. E.C. - Horpeth, 24 July 1847; 8.0. - Sir George Grey, 25 August 1847 .

2. E.C. - Horpeth, 11 September 1847.

3. 5.C. - John Forster, 4 November 1347.

4. E.C. - Morpeth, 18 November 1847. 
sewers, which were no better than those under the other Commissions, was postponed. The first Report of the Comission: of Inquiry was signed on 20th November. (1) At their opening meeting Professor Owen had informed them that in the medical schools it was strongly believed that a cholera epidemic was impending. (2) On that grim note of waraing the Report opened. If the cholera came, were the defences of London any stronger now than in 1831? A few of the old open sewers had been arched over, some additional lines of common sewer laid down; but most of the new sewers were not supplied with a suficlent sweep of water to carry off their contents. (3) The improvements made in the past sixteen years were, in fact, neglifible. As Chadwick had already written to Russell: We have compared the state of all the districts most severely visited by the cholera, and shewn that there has been no material improvement in their sanitary condition. It is as I think, proved, that in the majority of the districts the Comissions are positively not to be entrusted with the cleansing of a ditch, and woreover that the districts, even for that purpose, interfere with each other" (4) London was wide open to the cholere in 1847 as in 1831.

But, thought the Commission, the men of 1347 had one great advantage over those of 1331. It was now known how the cholera was generated, and how it might be prevented. Reports of medical observers on the progress of the epidemic in bondon during its last visitation showed that in general it had followed the track of rivers and water-courses; but the most deadly explosions had taken place near some notable accumulation of filth, the nouth of a sewer, a "bone vessel" laden with anure, a fever-nest like Three Iuns-court. (5) such

1. "Pirst Report of Comissioners appointed to inquire whether any and what specisl means may be requisite for the improvement of the health of the metropolis", $1347-43$ (883) (395) XXX11. 1.57.

2. E.C. - Russeli, 6 October 1347 .

3. Metro. Sanitary Comission, First

5. Metro. Sanitary Comission, First Beport, pp. $17-19$. 
accumulations wre usually to be found in the lower districts of the towns; but impure air could not be fenced in, and the great numbers of respectable artisans and shopkeepers who had perished proved that a contaninated atmosphere was an "incomparably more powerful predisponent" to the disease than extreme poverty and the lack of adequate food. "In the present state of most towns and cities, the number of persons whose constitution is enieebled by want of food, compared with the number whose vital energy is depressed by want of pure air, is found to be an exceedingly small minority. We have little power to deal with the former class of predisposing causea, but we have complete power by arrangements which are known, and which involve large and manifold economies, to remove from the metropolis, and from every lane, court, and alley of every town, the sources that poison the air. Here then is the true field for exertion". The lesson was plain. There was only one safeguard: "that safeguard consists in sanitary arrangements". (2)

Could the cleansing of London be safely left, however, in the hands of the existing Commissions of Sewers? The chief preventive measure must be the flushing of the sewers, and of the several districts, though the advantages had been set before them years ago, only one, the folborn and Finsbury Commission, had flushing machinery in systematic use. It would be necessary to divert upper streams under one Commission to cleanse the sewers of lower levels lying under a different jurisdiction; such collective action the present Commissioners had shown themselves incepable of understanding or executing. Their existing works were a standing memorial to their ignorance and incompetence. Private acts had been obtained by the Commissions for westminster and for Surrey and kent, and bills were in agitation by the Tower Hamlets and the Holborn and Finsbury divisions -.. and not one of them contained provisions $-0-$

1. ibid., p. 17.

2. ibid., p. 33 .

3. 1oid., p. 37. 
for the supplies of water which were needed to make the sewers act properly.

The clerk to the Surrey and Kent Commission, after confessing that few house drains were joined to their new main sewers because of the offensive effluvium which was thrown back through the privies and water closets, went on to state that his Commission now proposed to spend $\$ 100,000$ on extending the same system.

Strong though the condemnation was of the works and administration of the sewers Comissions, it is clear that the harsh phrases of Chadwick's original draft must have been smoothed down in deference to Limbert Jones. (3) "she sewers estabilahments were mere "Castles of Indolence" "Chadwick wrote later. "I scarcely know of any old Government offices which were worse or so bsd. Now and then a Court with sbout the degree of business to give the excitement of Sessions work for the relief of a Country Squire; now and then a new sewer to be considered, on the report of the surveyor; Chief clerks with good salaries, going there in the middle of the dey, hearing a complaint or two, reading a newspaper for an hour or two, and then going home to his Country house, or to some other place of emolument; clerks of the works seeing to the performance of half labour by labourers with extra pay; the surveyor now and then seeing to the work, and hearing the reports of the clerk of the Works; but leaving early to amuse himself with a farm or to attend to uny private professional engagement which might offer itself". (4) In a confidential report to Lora Robert Grosvenor, he comented: "No sane person would go on, so expending their own money es these comissioners are now going on spending the money of others ..... Had sustained attention been biven to the 1. Ioid., pp. $38-39$.

2. ibid., pp. $65-66$.

3. Chadwicz told Owen, 11 Novewber 1847: "Dr. Smith agrees with me that it will never do to go on, on the principle of not stating anything that may give offence to any one and that we should hear the whole of the alterations proposed before we agreed to sny one".

4. E.C. - Hon. Wrederick Byng, 11 Beptember 1848. 
works by persons qualified by educabion giving close and earnest attention to them, it may be confidently averred that it is impossible such works should have gone on as they are now soing on, and money have been so wasted: - it is impossible that they should go on with work piecemeal, without any common system of levels, without knowing whether the plecemeal work would ever combine as parts of one system: it were impossjble that they should go on building sewers without any guages of the quantities of flood water, or the house or street drainage; that they should carry expensive sewers through streets without duly considering and representing the necessity of facilities, and adaptations of the house drainage to the main drainage; that they should have gone on as they do now, draining some districts at the expense of others which for years have paid sewerage rates without any particle of benefit whatsoever, levying so large an expenditure, so unequally oppressively and often 1llegally levied. And lastly it is impossible that they should have gone on, as they have done, and are now doing without perceiving and representing the necessity of having supplies of water adjusted to the proper and wholesome action of the works under their management". (1)

The cholera and Chadwick's revelations were too much for the waw officers, and within a few days of the signing of the Report they concurred in his proposal to recell the Commissions of Sewers and re-issue them to the same individuals for each district. Chadwick had asked for a small. Commission, fitted "through their known attention to sanitary improvement" (2) to supervise the paid officers in the execution of a comprehensive drainage scheme. All that was really wanted, be thought, was a suficient number of Comissioners to supply a working quorum of six; and the public should see from the character of the appointments that scientific and medical skill was being

1. "Metropolitan Special Comission. Notes on the Evidence examined", MS, 7 October 134 ?.

2. Metro. Sanitary Comission, First Report, p. 33. 
brought to bear on the problems of metropolitan drainage. No more influential names could be found than those of Dr. Southwood Smith; Dr. Nell Arnott, the expert on ventilation; Bir James Clark, the queen's physician; Dr. Toynbee, that very successful young surgeon -... "all of whom would I believe work with me". (1) Ihe nomination of every half-infomed person, he told Russell, would be an additional obsbruction to business; but for a time - rather inconsistently - he was taken with the idea of asking some of the larger property owners, such as the Duise of Bedford and Lord Vestminster, to sit on the Commission. Their interests certainly lay in "having complete woxks, in preventing dilapidations, in a healthy well conditioned and prosperous population, in avolding the chargeability of a wretched and unhealthy, an irritable, short lived and dangerous population".

There was a long history of Goverment intervention in the administration of London, owing to the absence of organs of municipal government. Metropolitan police, вs, roads, cemeteries, markets, had all in turn received apecial attention from Parliament, while Seleet Comittees had considered plans for the improvement of the capital in 1838 and 1844 . Chadwick's

1. 1.0. - Russe11, 4 August 1347.

2. ibid. "Another cless is specified as having large and permanent interests in the improvement of the habitations of the population: this appears to me to involve a principle which ought to be asserted. The createst obstructions to proper outlay are commonly created in towns by the smaller class of owners who are lessees and have only short and temporany interests. I have stated that the worst conditioned habitations will comonly be found to belong to them. The spreading of the charge for permanent works over long periods of time, will hold out to this class temptations to waste; which forms one ground for the appointment of a central control to act as the court of Cnancery acts judicially, for the prevention of waste and for the protection of reversioners...."

Morpeth rejected the suggestion, pointing out ( 9 August 1847 ) that "it is quite obvious that inen lixe Lords Westainster and Portman could not be expected to attend; would not therefore the insertion of their names be open to much the same sort of objection as the present composition ur we vummissions!" 
plans for London were in the direct line of this tradition. The model of goverament he advised was the one he had recominended consistently for local sanitary adninistration since 1842: government by Commission, efficient because it was composed of selected bralaz, responsible vecause its powers were defined by Act of Parliament and its conduct was under the jealous serutiny of the legislature. Sanitary works, which called for technical knowledge and specialised sisills, could not be entrusted to an elected assembly, composed of vestry politicians and jobling builders. "The more the investigation advances, the more is it apparent that the progressive improvement and proper execution of this class of public works, together with the apoliances of hydraulic engineering, cannot reasonably be expected to be dealt with incidentally, or collaterally to ordinaxy occupation, or even to connected professional pursuits, but requires a degree of special study which not only places them beyond the sphere of the discussion of popular administrative bodies but beyond that of ordinary professional and architectural practice" (1) $-0-$

1. Metro.Sanitary Comission, irst Report, p. Bo. In the memorandum quoted above, "lotes on the Evidence examined", Chadwick combats the idea that sanitary adninistration should be entrusted to parcenial bodies.

"The parishes are entrusted with some powers of house drainage and cleansing:

The powers themselves are more extensively ueglected, and when exercised are exercised even more inefficientiy than by the combissioners of sewers. The powers entrusted to parishes are not in their nature powers of such large expenditure, but in respect to the business of paving and cleansing which they exercise powers as large the waste is as great as by the comissions of sewers.

The perishes have complained of the Comissions of sewers: but the object of the complaints have been to get a ahare of the rates expended in their own parishes: -.- or to obtain power in the direction of the expenditure. There is no evidence that if the power sought were conferred upon then; the expenditure wolld be itproved; these is indeed strong presumptive evidence that it would not

In the rirst place with all the motives which opposition gives to search out the defects of the parties opposed; the pariahes bave perceived none of the glaring defects of the (Continued on next page) 
Over a thousand Commissioners were superseded by the writs of November and December 1847? (1) and their powers were transforred to a select body of 23, which included seven Members of Parliament, three doctors, two clergymen, two lawyers, the proprietor of the "Times", a geologist, a physiologist -- and, despite all chadwlck had written, four of the discredited sewers Comwissioners. (2) A dozen or more of these were personal friends of Chadwick; but the new Commission, small as it was in comparison with its predecessors, was larger than he would have wished. And he soon made it plain that he considered it was too large by just the number of those who opposed his views.

(Continued from previous page) works of the Comissions of Sewers: in to one instance has any suggestion for the inprovement of the works; or indeed any well considered plans of adninistration arisen from the parishes or from the parochial leaders.

Nor can it be expected from the nature of the works that It should be otherwise ..... of their very essence they are as peculiarly unfitted for discussion in popular assemblies, and voting on them as are questions of chemistry or surgery. The merits of the officers equally with the plans are out of the reach of discussion of such asserublies ....."

1. The numbers wre as follows:

$\begin{array}{lr}\text { Hestminster and part of Middlesex } & 240 \\ \text { Holborn and Finsbury } & 150 \\ \text { Tower Hamlets } & 179 \\ \text { Poplar and Blackwell } & 67 \\ \text { Surrey and Kent } & 280 \\ \text { Greenwich } & 116 \\ \text { St. Ketheriae's-by-the-Nower } & 33\end{array}$

The first six of these were superseded on 50 November 1847, the last on 4 December. The names on the Cornissions includea those of the Duke of liellington, the Lord Chancellor, and the Prime Minister.

2. The following were appointed to the Comission:

Lord iorpeth, Lord Ashley, ford Ebln ton, the Hon. Frederick byng, the Dean of ontminster, Sir James Clark, Sir Bdward North Buxtor, Sir Eenry de la Beche, Joseph fune, John Waltex, h.A. Slaney, William John Broderip, John Buller, rofessor Owen, Dr. Neil Arnott, Dr. Southwood Sith, the Rev. William Stone, Jobn Bidwell, Robert fiutton, lhomas Puckle, R.L. Jones, John Lesile, and Edwin Chadwicis. 
Horeover, the jurisdiction of the Comission halted at the wails or the city. It was indeed no more than an interim soiution, into which the Government had been driven wore by the transient threat of the cholera than by any consideration of the enduring problems of London's senitary aduinistration. Chadwick was pwesentiy manoeuving to replace this temporary body by a germanent executtve mocelled closer to his $11 \mathrm{king}$. Unsabispactory thoush be thought it, kowever, he had good reason to congratulate himself that in the consolidated comission of Sewers London for the first time in its history had an administretive body charged with the responsibility of planing and constructing public works for the whole netropolitan area outside the City. 


\section{CHARPER 9.}

\section{PUBLIC HEAITH ACT, 1848.}

Lord Morpeth introduced his revised Bill on February 10th, 1848. Once again Chadwick's hopes were at the mercy of the "winds and waves of speech in the house". ( 1 ) Would their lumbering craft, with its 150 elauses, go to pieces again, as in the previous jear, and be stranded, an abandoned wreck, when the session came to an end? The Bill was, he knew, in the hands of a man who wished it well. As a Howard, the heir to the sixth Earl of Carlisle, Lord Morpeth was a power amoug the Whigs. (2) He had shown himself a sincere and courageous friend to progressive movements ... as Chief Secretary in Ireland encouraging agrarian reform, as a visitor to the United States startlins Bostonians by attending an Anti-Slavery Pair, as a Whig grandee in Bagland giving lead to men of rank in supportins mechanics' institutes and the Eealth of Towns Association. To the Public Kealth movement Morpeth brought the prestige of his family name, and the personal popularity earned by his characteristic charm and transparent goodness of heart. He was, says Harriet Martineau, "the best and most beloved man in the company of statesmen of his day and generation". (3) All this vas vell enough; but in his heart Chadwick wondered whether Lord rorpeth's resolution was firm 1. E.C. - ?, i.d.

2. George William Frederick Howard, 1802 - 1864. Chief Secretary for Ireland during Lord-lieutenancies of Lord Normanby and Lord Bbrington. Weraber for West Riding February 1846, and again in August 1847. Chief Commissioner of Woods and Forests, JulJ 1846. Seventh Earl of Carlisle, October 1348, taking his seat in the Lords February 1849. Chancellor of the Duchy of Lancaster, Harch 1850. 3. "Biographical Sketches", 4th edition 1876, p. 142. 
enough, whether his temper was not too equable. Was it sufficient in the Parliamentary leader of the sanitary agitation to possess moral idealism, a gracious sympathy of manner, an exquisite politeness? One could be too polite to the entrenched interests which cast their shadows over the health of millions; one could be too sccommodating to slum landlords, and listen too patiently to the defenders of local self-government. Perhaps Morpeth easned at too great a price Disraeli's commendation that he was one of the most popular wen in the House and in the country. (1) Por his part Morpeth, the politician, found Chadwick, the administrative theorist, too punctilious and unbending in his views. "You must not suspect me of any disposition to undervalue your advice or to slight your counsels", he assured Chadwick, "but as I have to make things go down with Senates, Boards, and Bodies of men, there must/often a want of the identity of proceedings which

otherwise I might be glad to exhibit ...... I hope we shall keep all things smooth, which is not only pleasanter, but at the present constitutes our highest prudence". (2)

As in 1847, the Bill provided for a central Board of Health with five members, two of whom were to be paid, "presided over bj a responsible member of the Executive Government". On the petition of one-riftieth of the rated inhabitants the General Boerd would have powers to introduce the machinery of local sanitary administration into a district, and to influence its working by the advice and survelllance of a number of Superintending Inspectors. The amount of central interference, explained Morpeth, "was really at present conilned to a very lew itens": it "was intended to operate with regard to advising the original formation of the district, without which the Bill could hardig be applied; to considering disputed questions, which inight be referred by local Boards, and arbitrating upon them; to 1 Hansard, vol. 101, p. $-\overline{68}, 30$ August 1843. 2. Morpeth - E.C., 7 'June 1343. 
retaining some power of interference upon points on which it was considered desirable to enforce a uniform procedure; and to deciding upon some works of great magnitude -.- which he considered was a powar that afforded a fair protection to the ratepayers, and which he should have thought the local Boards themselves would not have been unwlling to reier to an independent, an impartial, and a competent tribunal. Another power which would be given to the central authority was the auditing of the accounts, which he thought would impose a very necessary and salutary check". (1) A local public health Board would be established of an order in Council or Provisional Order, which would prescribe the number of wembers the Board should have; in a corporate town this inglied that the municipal councll would select the Board from amongst its members, thus obviating the criticism that town councils were too numerous and cumbrous for such duties. Where the boundaries of the newly established sanitary district extended beyond the former municipsl jurisdiction, the eress thus adopted would be permitted to elect a number of represertatives to sit with the town council for public hesith purposes. In non-corporate towns the Board of Health would be elected by a system of plural voting similar to that in uge for the election of Poor law Guardians. The powers of local Boarde fell into two classes: 1t was irperative upon then to compel ownerg or occupiers to provide house drains, to ensure a constant water supply (by the compulsory purchuse of existiag water works if necessary), and to appoint a surveyor and an inspector of nuisances; they vould also exercise permissive powers to appoint an officer of health, to re-congtruct ine sewerg, to pave streots, to meke regulations for the disposal of filth and refuse, to provide places for public secreation. Neither scotland nor Ireland was covered by the Bill; and the problem of London and its hundred Local Acts was reserved for a separate measure.

1. Hansard, vol. 93, p. 737,5 May 1343 
It was by no means the best Bill that could be devised, thought Chadwick as he looked over its provigions, --- but it was the best they were likely to get. (1) The machinery of ceatral control was certeinly not of Chadwicik's planning. "I fiust do the best I can and how I can", he told his friends resignedily, "-- the board is an exceedingiy hazardous affair but there seems to be no other chance". (2) Presently, however, Morpeth was wavering before the critics who condemed the Bill as a Goverament job, to ereute nen Comissionere and a numberless host of Inspectors in the face of a Budget deficiency of two or three millions, and there was talk of entrusting the measure to a Bosrd of unpaid Commissioners. "That of course excludes those who eannot live on air, or who like myself have no private fortune". (3) obviously the proposal was aimed at himself, probably out of jealousy at the $\mathrm{g} .3$. with which the Prince Consort had recently honcured him. (4) It reflected the iguorance of men like that talkative eccentric, Colonel Sibthorg, who had once declared that the whole sanitary service was unnecessary, and taat hulf a crown per dien would be sufficient remuneration for an Inspector, who would be expected to superintend a noval type of englneering woriss, three to ten guineas a day being the usual paynent to engineers in private $\rightarrow-$

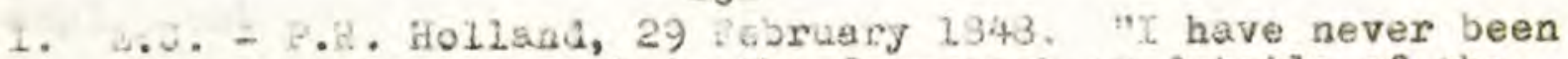
able to take any part in the framework or details of the Bill since the first meeting at ford orpeth's: I do not feel myatif respoasible for 1t, and do not peel confident as to its working other than as s commenemeti". ( . C. - tord Campiel1, 26 June 1848).

2. I.C. - .B. Bj.ckson, 4 March 1843.

3. E.C. - ? , n.d. The letter continues: "There may be questions as to what should be done: as to the degree of gower that should be conferced: as to the number of Comissioners: but is the House reduced so low in sense, as to refuse pagment for what is done, or to thinic that unpaid dilettanti service is cheap service

4. "I do believe it has tended to sirr up a mass of jealousy against me in the House of Comons which has furnished the Government with the pretext for abandoning the Board of paid Comissioners, and promising that it shall be carried out by Commissioners who are unpaid". (B. - . . Hickson, 9 May 1848). 
employment. (1) Once again Chadwick began to fear that his proposals would be accepted but their author rejected. "For the sake of sound principles of administration, and against cant and humbug, do what you can", he appealed to Joseph Hume, ading that if it were consistent with public policy he would be glad to be paid piece work to execute the Act, on to receive a small percentage on the savings -- or no cure, no pay. (2) The following day lume obtained the conseat of the fouse to the appointment of a single paid Commissioner, but Chadwick still rotained 2. Lorbldaing vision of bimself sitising as a resented and unhonoured figure at the botsom of a Board of titled amateurs. Te aust be assursd a position where he could inlibate measures and defend them, he told R.A. Slasoy. (3) A Cabinet inister or a recognised oficial chiof, he would not mind; but he had strong and decided objections to seting under any howurary Cowissioners whatsoever. (4) What honorary Commissioners could be found whose special qualffications would give public confldosce? Apert frou Viscoust Bbrington, who was there in Parliament who could assist the measure? "All experlence shows that the unpsid pay taenselves in some other wey for their service which is alweys the moet extravagant ... Their services are adritted to be necessary, tise people of England are the lest who are ludisposed to pay for them -.. the very Chartists ccknowledgo the principle, that pay and responsibility go together". (5) An honorary Board, moreover, would be lise a screen before the real dovisers and draughtsmen of schemes, shieldirg them when they were et fault and eclipsing them when their work doserved praise. "We do not want the real movers of measurea placed bekind crreens: we want to see and know the real authors: we want to attack face to face Mr. Chadwick or whosoever is the resl author of any exceptional

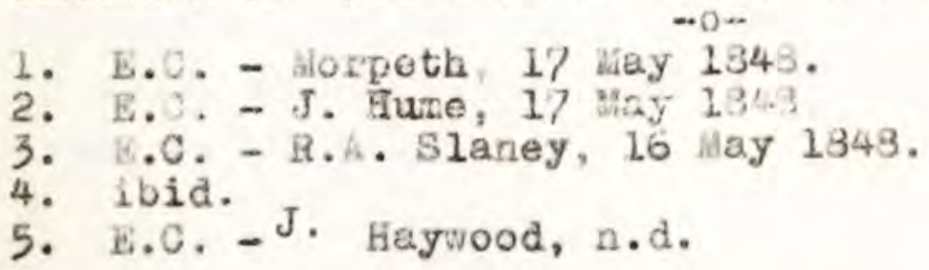


measure". (1) To cut the Bill eree of the dead wood of patronage appointments, he urged Russeli and Murpeth to consider whether even now the messure might not be reshaped, and the dangerous expedient of a Board aropped in favour of the machinery he had outlined in 1844.

"My orlginal proposition was to carry out the work, to some extent in a manxer similar, to the measures of education, as a secretary to a Conmittee of the Privy Council. But I proposed that the Committee should be a quasi judicial commitiee; for their functions would in lact be judiclal. I believe it would be satisfactory to the local authorities, to bave the determination of their cases, in open public sittings such as are given upon applications for auniclpal charters. It would be for the advantage of the cause that false or futile objections should be puolicly shewn to be so. The public officer who brought forward the case, in the way of a relator, would take care that it was so good a one as to be in no danger of fallure with the local or general public, as well as with the judjcial committee.

This errangement would follow in a beaten course. The Privy Council by old es well as by recent provisions are invested vith functions in relution to the public health: and have special powers in relaticn to contrgious clierses. The functions of the rivy Council in matters of quarantine extend over the whole empire. If the measure succeed, as it will succeed, if Iuis play be given to it, the expansion of powers and extension to othex parts of the couniry wight, I apprehend, be most readily given to it under such suspices ....

1. you took the President of the Council listead of the dhief Comnissioner of Woods and Vorests, and one paid Secretary, you might I apprehend shape the $B 111$ to carry out the measure in still closer connection with the Privy Council than is now given by the bill". (2)

1. B.C. - J. Haywood, n.d.
2. E.C. - Lord John Risseil, 14 May 1343. He sent Morpeth (Qmentinued on next page) 
In Comittee Morpeth's original proposal was eventually whittled down to a Commission of three, one only of whom was to be paid, under the presidency of the Firgt Commissioner of Woods and Forests. Though he regretted that "the principle of single seatedness" (1) had not been adopted, Chadwick found some satisfaction in the amall size of the Board; unless there were very special qualifications of knowledge and zeal, he had told Morpeth, every additional member of a Board was an additional trouble to inform and keep right. (2) It is noteworthy that once again, as in the debates of 1847, the principle of ministerial responsibility for the policy of the new department was not clearly envisaged by the Government, nor by any of the critics, friendly or hostile, in the House, with the exception of Lord tincoln, who continued to urge that public health

1. E.C. - W. E. Hiekson, $4^{-0-}$ March 1343.

2. B.C. - Morpeth, n.d.

(Continued from previous page) (31 May) a "Memorandum: on the plan of working Sanitary Measures under the Secretary of State for the Home Department", in which he remarked:

"Besides the objections urged by the Health of Towns Association in their report on Lord Lincoln's bill, there is another.

The local authorities and the public at large desire to have persons to look to in such positions, of whose attention to the business they may be confident and whom they may deal with directly. But on this scheme they would be deprived of the advantages of the information of the proceedings upon the measures in question given in regular reports from the responsible officers. of the appreciation of these reports there can be no doubt. The sale of them to the public, has been on the average ten times greater than the average sale of Parliamentary reporis and state papers; plus a wide gratuitous distribution. They promote voluntary local exertions in places not provided for by law. They have been found to be of use in the colonies. Fiong Kong has been surveyed on the plan recommended in the Sanitary Report and works of drainage are in progress there. It may be asserted that these reports are contributory to the advancement of sclence and are so referred to auroad, as well as at home by Fingineers and by men of medical science. The issue of such expositions would be incompatible with the functions of the Secretary of State for the Home Department or the custon of that ancient office". 
measures should be put under the jurisdiction of the Home Secretary. This solution was rejected by Chadwick, partly because in his view sanitary administration should be kept free from the party influences of a changing political head, partiy because public health measures were too important to receive merely the fractional attention of an already overburdened. Minister -- but chiefly, it is clear, because he judged the question by one sovereign test, the amount of authority it would ensure to himself.

In its scheme for local administration, also, the Government Bill departed from Chadwick's original recommendations. "I have already remonstrated on the new powers to be given to the town councils which I entirely distrust", be told the Bishop of London, "..... What I apprehend is, that they will go into a.l kinds of waste, and then lt will be said, how much has been spent for Sanitary measures, and how ineffective they have been". (1) The main bulwark in the Bill against a flood of local jobbery was the provision that the General Board should be required to give its sanction to any proposal by the locul authorities to spread sanitary charges over a period of time. This safeguard, "so important a key point for the central control"(2), was struck. out, without discussion, by the Comons, so "allowing the Corporations to pull down what premises they please, pay what they please, and spread the charges as they please" (3), without 1. E.C. - Bishop of London, 16 June 1843.

2. E.C. - Morpeth, 3 June 1848.

3. E.C. - Lord Lincoln, 2 June 1848. To forpeth he wrote (3) June 1343):

"Really the concession of the privilege to the Local Bodies, of spreading charges over periods of time is fraught with so much mischief, and is in itself so large a dereliction of principle, it forms so important a key point for the central control; --- the opposing perties are themselves aware of its importance, and they could make so slight a fight for it, that the provision should be in some way or other replaced, or the privilege of spreading the charges struak out.

It may be said "Oh it may be (Continued on next set right, -- it may be page 
the prior examination of an Inspector of the Central Board. The local officers, the surveyor and officer of health, were guaranteed some security of tenure by the provision that the approval of the General Board must be given for their dismissal; but, since their emoluments and conditions of service were left to the local authority, their independence of view and action was far from being secured. Central control over the officers and Pinances of the local Boards was in fact clipped so close by the Common, that at one stage Colonel Sibthorp was under the gratified illusion that the Government had abandoned altogether its plan of "centralization". (1) Chadwick pinned his hopes on the Lords to save the Bill from complete futility.

In an interesting letter of this period, Chadwick throws light on his views of the relationship between the central departinent and the local authorities.

"Your respected father was always distrustel of the

middle class Boards when they had to deal with the interests of the labouring Classes. He distrusted Boards of Guardians and justly: so did I. He regarded the Central Board, as the agency of the middle or higher Classes; at least I so understood him. I was always of opinion that it should occupy a judicial, an impartially judicial position; with however a strong leaning 1. Hansard, vol. 93, p. 872,11 May 1848.

(Continued from previous page) provided for in the provisional order". But the provision will create jobs; men seeing it in the Act will lay down ell sorts of schemes, on the presumption that the expences may be spread, and will fight with the rage of men, who are about to have a money loss inflicted upon them, against the privation. It will create conflicts which the Central Board uay not be inclined to undertake, to be unkind and to save the money of indefinite persons. The expenses thus incurred will act as barriers or in reproach of measures of sanitary improvement. The doctrines of the necessary saleguards have been so widely preached and are now so well understood by those out of the house who take an interest in the question, that the whole responsibility of the consequences will be thrown upon you, unless you protest ....." 
for those who were unrepresented; namely, the labouring classes. I can conscientiously say that any failure in that respect was no fault of mine.

Here in Sanitary matters, which it is necessary to carry out by Local Boards they will unavoldably be of one Class: that Class the well to do Class, who do not look into the Districts Inhabited by the labouring classes, and who will not believe anything stated about them. Here we have the Sewers Commissions of the City of London: with representations from each Ward: on the theory that they will know the wants of all the inhabitants. Yet we are developing sources of disease, fever nests, which the Aldermen and the Deputy have never seen, and know as little of as they do of any foreign Country.

Instead of impairing Local Government, the new measure proposes to found it where none exists, and consolidate it where it does. But inasmuch as it is the Local Government of a Class, I think it requires the securities of appeal and protection, for thoee who are not of that class". (1)

He lays a finger here on the source of much of the opposition which the Public Health $B i l l$ encountered in 1847 and 1343. Wany Members refused to recogaise in Chadwick's sombre picture the visage of their own towns. They deplored the "anonymous slanders" on one place after another, put out by the Health of Towns Association, and rejected indignantiy the unsavoury details of the home life of the poor as "an unfounded calumny upon the meritorious classes to which those statements referred". (2) Urquhart could not believe that Stafford was unhealthy. (3) Divett declared that the Commissioners in Exeter had laid out $\$ 100,000$ in the improvement of the city, and the place had never had less sickness. (4) Hudson, who had I. E.C. - I.P., 24 March $\mathbf{1 8 4 9}$.

2. Hansard, vol. 98, p. 773,8 March 1848 (Charles Pearson). 3. ibid., p. 716, 5 tay 1848. 4. ibid., 0 . 1174, 18 May 1343. 
Iived thirty three years in York, had canvassed the electors' houses six times, and had gone among the lower classes as a Methodist exhorter, had seen nothing approaching the scenes described in the report put out by the York Sanitary Committee. (1)

Yet -- Morpeth cited a petition from stafford, referring to the high mortality in the town, and signed by all but one of the medical men, all the clergy and ministers of the different denominations, the late mayor, a majority of the aldermen, and a large proportion of the town council (2); Lord Ebrington, recently returned from Exeter, had attended a meeting, under the chaimanship of the mayor, where citizens had spoken warmly of the lack of drains and good water ${ }^{(3)}$; and not a medical man in York impugned the report which Hudson so contemptuously rejected. (4) So, in the Commons, Members asserted and denied as their limited observation and emotional premossessions taught them. Sanitary science, in fact, lacked as yet the well-knit logic of established knowledge, and in that unfenced country of the half-known and the merely surmised, opinion could canter on a free rein. Nothing caused so much confusion, for example, as the reformers' well-meant actempt to demonstrate a firm correlation between disease and the offensive exhalations of organic decay; for, as the bacteriologists were later to show, the nexus of cause and effect did not lie bere. The connection between noxious emanations and the itch was much more pronounced, as Bnow pointed out, but, because men knew what caused the itch, they did not fall into the error of laying it to 1. Hansard, vol. 93, p. 1284, 6 July 1847.

2. Hansard, vol. 93, p.734, 5 may 1348. "Such answers as have been given from Stafford may be obtained irom other places if there be further delay which is to be deprecated. If I could be provided with a moderate sum for personal expenses -- I have already incurred much personal expense, answers might be obtained from within the City of London from merchants and traders and the larger parishes of Marylebone" (E.C. - Lord John Russe11, 14 ilay 1343). 4. Hansara, vol. 93, p. 1283, 6 July 1847 (Wakley). 
the account of every unpleasing smell. While some Members, therefore, could appeal to the awful warning of undrained districts where the inhabitants had been decimated by an explosion of fever, others could show cheerfully insanitary populations who for generations had been driniking unfiltered water and piling ordure round their doors without any catastrophic retribution. (1) Chadwick, who had been twice attacked, and Southwood Smith, who had had three bouts of typhus, wre convinced of the danger; and when he heard remarks that the danger was exaggerated, Chadwick would recall the honourable list of casualties in the service -.. the Roman Cetholic priests who had visited the Liverpool Irish; the doctors, Lynch and Mitchell and Dyce Guthrie; and the Health of Towns Commlssioners who had retched on the corners of dark back streets, Playfair, Smith of Deanston, and Sir Henry de la Beche. (2) Here, he felt, in the deaths and physical discomfort of healthy, well-fed nembers of the middle classes was ovidence to satisfy all who were not blinded by self-interest.

Openly, or under cover of such arguments, the voices of affected interests were raised against the Bill. The smoke clause roused the manufacturers; the proposal to extend municipal boundaries to take in country districts stirred up the representatives of the agricultural districts. Divett objected to the transfer to the local Boards of private undertakings for the supply of gas and water; if parliament fixed the charges, these matters were better in the hands of private bodies. He detected in the Bill the hand of Chadwick, who would obtain under it an important and powerful position, $-0-$

1. See, for example, a letter on sanitary statistics in the "Morning Chronicie", 3 April 1848. In 1832 Shoreditch "a district sacred to cloacina", was most exempt from cholers, having one case per 1203 inhabitants; while the City, the best drained district, had one in 155. If this were a fact, it was an argument for abolishing sewerage altogether.

2. B.C. - Morpeth, 30 June 1347. 
such as he had already secured for himself at the Commission of Sewers. (1) This was not the only personal attack endured by Chadwick in the course of the debates. (2) He believed that old Poor Law scores were being paid off, by Tatton Bgerton, for example, whose practice, as owner of a close parish, of pulling down cottages and drawing labour from other parishes, had been condemned in Chadwick's evidence before the Bettlement Committee in 1846, and who now declared that the appointment of "a certain individual" would be distasteful to the manufacturing districts. (3)

1. Hansard, vol. 93, p. 725,5 tay 1843.

2. He wrote to Lord Lincoln, 8 May 1843:

"May I ask as a favour that you will use your influence, in the discussion on the Bealth of Towns Bill, to discountenance the prectice commenced by ifr. Divett, and likely in the discussion on the central Board to be renewed of attacking subordinate ofilicers, who are not responsible. The Morning Chronicle has been attraking the bill on the supposition that it is mine. Lord Morpeth, in a way, relieved me lrom that responsibility. You were in possession of my individual opinions which Sir James Graham requested me to dram up five years ago. Except those members of Government who have that statement, I do not know any one who would be entitled to discuss anything on the assumption of what were my views. Except the report on the practice of interment there has been scarcely a report which I have signed that has been entirely as I wished. As a public officer it has been my juby to carry out measures very different to those I would have recommended. For years Mir. Stephen was attacked for Colonial measures; latterly Nr. Trevelyan for Irish measures, and from the comencement of the Poor Law Amendment Act, I for neasures which were the work of another Department.

I would offer my protest against the continuance of this system of attack upon the absent, and really defenceless ..." Lincoln replied, 9 May 1848:

"You may rely upon my doing all in my power to aiscountenance the attacks upon you in the Rouse of comons of which you complain. I consider attacks upon any Gentleman employed by a Responsible Minister of the Crown unjustifiable. If the Bill be yours, it bas been adopted by Lord Morpeth -- he will reap all the merit if it succeed and upon him must $f$ al the blame if it feils -.. this in my opinion is the only safe Parliamentary view of any question"

3. "My answer is that the acts of the manufacturing districts will speak for themselves", Chadwick told Russell, 14 May 1343. "The Major of Leeds applied to me to recomnend to (Continued on next page) 
Provincial jealousy flared up when it was seen that Iondon was escaping again, as it had escaped the Municipal Reform Act. Why should London be exempt, demanded Colonel Sibthorp, in preference to his own constituency, Uincoln, which was clean enough, and had not a poor man in it? (1) "It was in London, in stinking London, in filthy London, that sanitary measures should begin", cried Wakley, the editor of the "Lancet", adding his grumble against the "soup influence" of that "nasty turtle-eating corporation". (2) "Help I pray you against Banks!", wrote Chadwick to the "Times" correspondent, the kev. S.G. Osborne (6 May 1848). "He wishes to do nothing in sanitary measures until the bitropolis is included but he is most zealous he says for them. Cannot you now press forward the claims of the Dorsetshire villages, and of his own cottages to his sanitary zeal. Pray give him a sermon on the times from psalm 74. v. 21 prayer book version; "All the earth is full of 1. Hansard, vol. 98, p. 711, 5 May 1843. 2. ibid., vol. 96, p. 414, 10 February 1348.

(Continued from previous page) them an engineer to survey the town for drainage. Captain Vetch of the Royal kingineers made them the survey which I recommended. The towns improvenent committee for Liverpool applied to me for advice. They took the engineer whom I reconsiended for a water supply; and have taken his plan. One of the Mayors of Manchester and some of the town council applied to me for advice, on which preparatory action has taken place; some time ago when I was in lancashire a deputation of persons from Bolton applied to me for advice. The paving board at Lancaster applied to me to recomend them an engineer to make them a preparatory survey: and the person whom I recomended is now at work there. The hayor of Varrington applied to me, to make a similar reconmendation, and the preparatory survey is now in progress there, by the bingineer whom I recommended. From bton, Rug y, and other places in the west of Bngland, I have received sinilar applications. Now it is on the practical experience thus obtained, from comanication with engineers specially qualified and so engaged, that I am enabled to make confident statements of the compulsory powers wanted for carrying out combined works, -- even in the places where such voluntary comencements are nade". 
cruel habitations", but let your volce of exhortation be raised soon".

Most significant, becaure it was a direct confrontation of the fundamental principle of the Bill, most powerful, because it was backed by many of the municipalities, was the attack on "that mode of forelgn government which was known by the name of centralization". (1) It had long been the pride of the country that the Government had little to do in the management of internal affairs, declared urquhart, the member for stafford. He disputed both the diagnosis and the remedy of the sanitarians. If the country was in a sink of filth, it was because the House had passed laws affecting the labour and industry of the population. The Common law provided ample means for putting down all nuisances; if anything more were required, it should not be in the form of this "clumsy, encumbered, and almost unintelligible Bill" which superseded the functions of Parliament by enabliag another body to set aside laws and impose taxation, but should be a simple and facile nessure grenting to nunicipel authorities the powers they needed and subjecting them to penalties if tbey neglected to put them into operation. (2)

Many of those who kicked at any measure of coatrol of their owa activities, however, were ready to take a iair-minded view of regulations directed at sopebody else, and were even prepared to sugsest bow such regulations could be profitably 1. Hansard, vol. 96, p. 10202,21 iebraury 1843 (Urquhart). 2. ibid., vol 93, p. 711, 5 kay 1343, and p. 1175, 13 May 1348. Ashley in reply (ibid., p. 779,8 May) pointed out that there certainly were Acts on the Statute Book which were drected sgainst the abuses complained of -.. if somebody was prepared to pay the costs of legal action. "The old laws leight be equal to the reaoval of abuses, but they were by no means equal to the institution of imporements: there was a law for removing masses of filth or noxious stenches, but there was none by which you could furnish to the working classes a pure, ample, and constant supply of water" 
extended. Viscount Duncan wanted to know why lorpeth had avoided the window-tax ${ }^{(1)}$ : Horsman wondered what were the "mysterious difficulties" preventing the Government from tackilng the interments question (2); Reynolds regretted the exclusion of Scotland and Ireland. (3) These fractions of support added up to a quite considerable total, and besides the clamour of energetic interests there went up a counter cry of satisfaction that the Lealth of Fowns Bill went so far as it did and regret that it did not go a little further.

Outside the House public attention was distracted by the exciting continental news, by the spectacle of thrones toppling and Metiernich packing his bags for London. (4) As in 1847 and earlier jears it was a vociferoug minority on either side which Pought over the principles of sanitary government. The doctors and clergyaen of the Eealth of Towns Association conducted a vigorous campeign of lecturing, letterwriting and lobbying, and drafted petitions for signature by the working classes; and Chadwick found time to supply amcunition to local leaders in strategic points. (5) From the strongholds of local selfgovernment, the City and the metropolitan parishes, rose an angry hum of disapproval. The Common Council resolved unaninously to condemn the Bill. (6) No place in the world had so complete a system of drainage as London, said the city Remembrancer. (7) "It would turn out to be notining but mere 1. Hansard, vol. 96, p. 474, 10 February 1345. 2. ibid., p. 406. 3. ibid., p. 42 4. Or, as George Combe wrote Prom lidinburgh (10 Mareh 1843): "here, we are more occupled with petitions against holding intercourse with the Pope and against runnins railway trains on sundays, and in denounclirg education in natural knowledge without the catechism of Calvinism as infidelity than in studying the conditions of health".

5. See, for example, his letter to Dr. P. fl. Holland (29) February 1843), erumerating the points which should be iacluded in a petition from haschester.

6. 19 Hay 1343; "Times", 22 May 1343.

7. "Sanitary Condition of the City of london: letter to Lord Ashley from the City Remembrancer" (Panphlet, 1343), p. 4. 
humbug", a Builder Comissioner forecast of the sanitary movement. (1) "ikead "Morpeth" as "Metternlch", cried one Tower Hamlets ratepayer. (2) The "Morning Chrouicle" was the chief velicle for these protests; and the most active pen in the service of local self-governent was that of Toulmin Srith, whose writings gave to the opposition such shape and philosophy as it possessed. A legal antiquary of $a$ deeply encrusted Torylsa, he saw in the Public Fealth act one further episode of the Whig plot by which the Anglo-Saxon institutions of the kingdom were sradually being replaced by the government of whig Comissioners, and the ancient Common Iaw defences of person and property were being overthrown by "lnk and paper law-making" (3) "If this act, or anybhing like it, passes into a law, it will have to be recorded in history that the court of star Chamber was abolished in 17 Car. I, A. D. 1641, but was reestablished, with greatly increased powers, in 11 Victoria, A.D. $1843^{\prime \prime}$. (4) His solution to the sanitary problem was admirably simple -... a closed cesspool should be provided for every house and the Highway Surveyors stirred to activity in laying down new road drains ${ }^{(5)}$; and to enforce public health regulations the courts leet, vestry, hundred, and county courts should be restored to their originul dignity (6) ghere was no need for $-0-$

1. "Sanitary Gondition of the City of London: letier to Lord Ashley Prom the City Renembrancer", 12

2. "Morning Chronicle", 29 March 1848.

3. "The People and the Parish: the Comon haw and its Breaicers", 1353 , p. 14 .

4. Wetter to the "Jurist", 26 February 1345.

5. "The Parish. Its obligations and powers: its officers and their duties", 1354. "The making of a lined, covered, and closed cesspool, at a distance of twenty or thlsby feet from the dwelling (though the farther off the better), and provided with a pump for the garden use, or for otherwise regulariy emptying, of the contents of such cesspool, -or with comunication to some tank in adjoingng land, if ary arrungenent of that kind is nore convenient, -. is the simple, cheap, and effectual remedy for the nuisance now caused in very many cases by delective house drainage". ( $p$. 6. Leter to "Dally News", 30 tarch 1343. 
a central department "to tell the People of England, from a closet at whitehall, how each an is to make his arains and water-closets, to build his ash-pit!" (1)

From teeds, Kanchester, Bradford, Biruingham, delegates frow the town councils were sent to London to protest against the Bill; but in every place where such opposition manifested Itself Chadwick could count upon the support of an influential section of the inheibitsints. The Health of Towns Association circulated a questionnaire to 69 of the principal towns of England and Wales, and sumarised the returns in a pamphlet which breathed local suspicion of the existing authorities, and contempt for the icea that, unalded and uncontrolled, they could lift themselves out of their present squalor. (2) Nor was it true, Chadwick believed, that the town councils would offer the universal resistance to e central department that was prophesied by Divett and other disciples of Toulmin Smith. As he assured Lord aroeth:

"When he (Divett) taliss of bis confidence that the towns would not submit to our dictation, the fact is as regards myself that the people of his town hearing of ay being in the neighbourhood sent for me to attend a towns-meeting and also for Dr. Southwood Smith. We found our names placarded as intending to address them. Ihe mayor gave us a dinner. I found it extremely difficult to get away and avoid the applications to see places, and I have since oeen in correspondence with parties in the town who are anxious that steps should be taken.

I have been applied to for advice from leading members of the Liverpool lowa Council. In Lancaster, Warrington, Rugby and other towns proceedinge have been teicen for surveys and plans at ay instance. 1 was also applied to from Linburgh, 1. "Centralization or Representetion?", 1843, P. ix.

2. "Report of the sub-comitiee on the answers returned to euestions aciressed to the rincipal Towns of Bneland and Walss, and on the objections from corporate bodies to the Public kealth B111", 1843. 
St. Andrews and other Scotch towns: Prom Belfast and Dublin Prom Gateshead and Brighton from Fton and other places. I have a.so frequent applications from town survejors and several engineers. Leeds was on my recomendation to the Mayor surveyed by Captain Vetch .....

The spplications to the Metropolitan Sanitary Comission on the supposition (from confusion with the letropolitan sewers Comission) that they have some executive powers are nunerous and pressing.

I think it would be well to state that such applications had already been nade, and proceedings teken in anticipation that the Health of Towns b111 would pass and that kowever indisposed any towns might be to the measure, others who uridexstand it better might be permitted to sopt it, or in respect to self government to be allowed a cholce ...." (1)

There were, as the "rimes" wisely remarked, just and prudent limits in the capacity of a Bill as there were in the tonnage of an last Indiaman. (2) The loss of come of the subjects which were omitted from the original draft, or were later jettisoned in Comittee, was not regretted by Chadwick. The exemption of london, he considered, would not be serious if the General Board were Eiven full powers of inquiry in preparetion for a separate measure. (3) Colse and iron manufacturers had risen in protiest against the smoke clause, and its excision was judicious. (4) The limitetion of the durstion of the Poor liaw Commission had not worked vell (it had

encouraged some local authortties to go slow in the hope that in five years' time the Act would be repesied and the comissioners hanged), but Chadwick was prepared to accept a term of five 1. B.C. - inord worpeth, n.d., c. 10 kety 143.

2. "Times", 11 Rebmary 1843

3. E.C. - Lord Motpeth, 30 June 1847.

4. E.C. - Lord Morpeth, 8 August 1848. 
years to the Board's life as one of the least injurious concessions. (1)

But, looking over the Bill as it emerged from the Commons at the end of June, he sighed that it was a mere wreck of what had been intended. (2) "As it stands it will only enable the commencment of legislation to be made", he told his friends. "Great administrative wisdom and experience in the General Board and Inspectors might still extract some good from its practical operation; but that if it be put inbo other than the most competent hands, more evil than good may arise from it. I never could have thought that any Government would have conceded so extensively the power and authority of a central controlling Board either to pitiless self-interest or sonseless clamour". (3) It was clear that if the General Board were to exercise any real powers of initiation and supervision in the localities, those powers must be inserted in the Lords, where fortunately the friends of Chadwick mustered strongly. He wrote at once to brief the Bishop of London, Lord Ellenborough, Lord Campbe11, Lord Lansdowne, and the Duke of Buccleuch, assuring them that "I have distinctly stated that I must hold myself at ikberty to express my opinions on the provisions of the bill". (4)

How was the machinery of public health administration to be introduced into the localities? Ithis was the fulcrum whose position deterwined the leverage the General Board could exert against recalcitrant districts, and much of Chadwick's dissatisfaction arose from the inadequacy of the clause to which the commons had assented. If one-tenth of the inhabitrant householders rated to the relief of the poor signed a petition the General Board could set to work. (ihe Comions had rejected $-0-$

1. B.C. - Norpeth, n.d.

2. B.C. - Sir George Larpent, 20 June 1843.

3. L.C. - William Lee, 10 July 1843.

4. E. - Bishop of London, 16 June 1343. 
on sight the original optimistic suggestion that one householder in fifty, whether he was a ratepeyer or not --- he "might really be of the working classes", Chadwick told Lord Lansdowne should have the power to bring all the apparatus of sanitary inquisition to bear upon the obdurate forty-nine). "It is well to get the smallest wedge", declared Chadwick, his metaphors becoming hopelessly mixed in his annoyance, "but we should be sure that it is really a wedge, and not a rotten staff. For opening the worst conditioned districts the provision as it now stands will I fear be a mere rush".(2)

"As it stands I see no probability whatsoever of the introduction of the measure into the most important places. It would require three or four thousand rate-payers in Liverpool or Manchester to be moved and to sign for the introduction of the act. Some of the trades unions and some of the Chartists have begun to notice the measure. It has been called, as it is properly a poor man's measure, and it will not escape them, that the initiation of it is given to another class, the rate payers who will not feel themselves aggrieved, or have any particular interest in it, and are yet biassed against it from a dread of the increase of the rates.

I do not see how any one could get up in the Commons and contend that where there was a heavy infantile slaughter, or where the labouring classes are exievously ravaged by epidemics there shall be no intervention except on the initiation of the midale classes". (3)

1. B.C. - Lord Lansdowne, 13 July 1348. "As it stood, if any fifty of the inhabitants of Yorkshire petitioned the Comission, down came the inspector, and upon his report the whole kingdom might be included, under the Bill, in one district" (Henley; Hansard, vol. 93, p. 123, 5 May 1848).

2. E.C. - Lord Lansdowne, 13 July 1843.

3. E.C. - Lord Lansdowne, 13 July 1848. The letter concludes: "I think it would be well that the provision as it now stands, which I believe came from Mr. Henley and the protectionists should be distinctly placed to their account, as in a new position, as protectionists of epidemics and excessive mortality". 
There must then be some formula for intervention, which, once recited, would bring the Board's Inspector posting down from London, whether the local tradesmen were ready to give him a welcome or not. The possible formulae were canvassed in turn by Chadwick and the Bishop of London, who had expressed his willingness to introduce the "Poor Man's Clause" in the Lords. The excess of deaths from zymotic diseases above the general average for the towns of the whole kingdom might be taken, suggested Chadwick, or --- which would be more acceptable to the squires -- above the average for the towns in a county. ("They could not say that there should not be interference in behalf of their worst conditioned towns in the county"). In 1841 the deaths from epidemic diseases formed 21 per cent. of the total; he would propose intervention in any place where the proportion rose above 20 per cent. But in the past the registration of the causes of death had Prequently been tampxered with, and to check any ratepayers' trickery, therefore, they should have at least one further test. Farr's advice was that it would be best to take the deaths of children under five, which in 1841 averaged 38 per cent. of the whole. "Surely", cried Chadwick, "38 per cent. of infantile deaths and 20 per cent. of deaths from epidemics to be protected against authoritative intervention ought if not the Commons to satisfy Moloch himself! What a piece of evidence of our barbarism must not this hereafter appear to be". He would like also to have "some direct reference to the poor man as a class", on the basis of the expectation of life given in the Northampton table.

1)

When the question came to be discussed in the Lords' Select Committee, however, the Bishop was not present, and --with the best will in the world, as his friends assured Chadwicis --- they strucis out the "Poor Man's Clause", 2to which they 1. E.C. - Bishop of London, 12 July 1843.

2. E. - Bishop of London, 20 July 1848. "What their objections may be, I cannot conceive -.. except that the Bill which before would have been ineffieient and a nullity as to the worst places would have been with the amendment workable". 
thought the Commons might object, and inserted a smoke abatement clause, to which the Commons certainly would not consent. "The whole of the alterations in the Lords will, with the present mode of initiation, make bad worse", Chadwick told Morpeth with justifiable irriatation. "I have always confined myself to the matter within public cognizance already, Sewerage, Cleansing, Fater Supply, in the first instance. I have never suggested meddling with trades and if I had been in the way I should have advised their omission, well knowing how potent they are. The smoke clauses will now bring into the field all the manufacturers against general sanitary measures. I know places in the North where two or three Manufacturers may by their influence with the ratepayers, almost the whole of whom are under their influence, effectually prevent any application whatsoever. Then all the butchers, all the Plshmongers, all the poulterers, who are to be subjected to inspection, all the lodging-house keepers, all the owners of the classes of houses having cellar tenements, and persons carrying on trades which are nuisances, must be in array against the Bill, -- all these are ratepayers; and the others of the midale classes, who will be frightened with stories of the increase of rates, and yet we are to expect unheard of combinations amongst them for the introduction of measures which are to benefit chiefly the working classes!"(1) - $0-$ (21 July 1848)

1. The same argument figures in a petition to the Lords from the Working Men's Association ("Times", ? August 1348): "Your petitioners would pray your right honourable houss to consider the powerful nature of the interests interfered with by the proposed measure; of which we need only name to your lordships the owners of manufactories and steam furnaces;

the owners of slaughterhouses, and many persons connected with offensive trades; the shareholders of water works, and the tradesmen who might be influenced by these parties; and to reflect upon the little probability that there is of any large number of ratepayers being induced to come forward in opposition to such interests to take a step in behalf of the class represented by jour petitioners, who are almost entirely precluded, as the bill now stands, from applying in their an $\mathrm{n}$ behalf, however severely they or their families may be visited with sickness or death in consequence of the defectiveness of the existing sanitary arrangements". 
Despite Chadwick's protests the Lords insisted on retaining their smoke prevention clause; but in other respects the Bill was improved before it was returned to the Commons. The Bishop of London appeared in the House to press the importance of his "Poor Man's Clause", and it was re-inserted without opposition. The hands of the General Board were strengthened by providing that the local authority must seek their sanction before mortgaging the rates, and that the local surveyor should be irremoveable except with their consent. As a further precaution agalnst jobbery, an individual ratepayer was given the right to appeal to the General Board against any exceptionable expenditure by the local Board. Altogether, as Chadwick told Joseph Hume, "the Health of Towns 3111 as amended by the Lords is to some extent a working measure". (1) But would the Commons accept such large alterations in the original Bil1? "I understand from the Speaker", Morpeth informed Chadwick, "that the entire interference with the Bill is rigidy considered, so irregular, that a general condonation must cover a.11n, (2)

Chadwick's fears in this instance proved groundless, however. John Bright rose imediately to attack the smoke clause, and, as Chadwick expected and hoped, it was dropped without further discussion. (3) There was an anxious moment when Morpeth deleted the Bishop's version of the "poor Man's clause", but he replaced it at once with a clause susgested by the Registrar General, which empowered the General Board to apply the Act to any place where the deaths from any cause exceeded 23 per thougand on the average of the previous seven years. It was not so good a test as the infantile mortality, Chadwick told him; but, he added with satisfaction, "I have had it tried over, and I believe it will give more places". (4) The 1. B.C. - Joseph Hume, 5 August 1843.

2. Morpeth - E.C., 26 July 1343.

3. Hanserd, vol. 100, p. 1.173, ? August 1848.

4. E.C. - Morpeth, 8 August 1848. 
sanction of the General Board to the mortgaging of local rates was preserved "as by fire", and also the appeal from aggrieved owners or occupiers. (1) "In other respects it was lamed; it was very badly supported; many friends were absent, and parties directly interested against the Bill mustered strong $1 y^{\prime \prime}$. (2)

The Public Health Act of 1843 established a Central Commission, terminable in five years, and consisting of three members, with the First Commissioner of Woods and Forests as President. (3) Their powers of initiating sanitary measures were strictly defined: their aid must be invoked by a petition signed by one-tenth of the ratepayers; failing a petition, they could take action only where the death rate from all causes had reached the figure of 23 per thousand. (4) In either case, a preliminary inquiry would be conducted by a Superintending Inspector, who would submit a report to the General Board. (5) The Act would then be applied by Order in Council; or, in districts where a Local Act was already in force or where the boundaries were to be altered, by a Provisional Order, which would not become effective until approved by parliament. $(6)$

In districts possessing municipal institutions, the Town Council was to be the public health authority. (7) Non-corporate districts were to be given an entirely new authority, a Local Board of health, the size of which would be specified in the constituent Order. ( 8 ) viddle class influence in these Boards was jealously guarded, members being elected by plural voting, ranging from one vote for persons with property to the annual value of 250 , and rising by one vote for every additional $\$ 50$ to a limit of six votes for those possessing over 4250 . officers the local Board were to appoint a clerk, a treasurer, $-0-$

1. Morpeth - E.C., 8 August 1848.

2. E. - Bishop of London, 8 August 1343.

3. Ii \& 12 Vict. c. 63 .

4. Ibid., o. 3

6. Ibid., c. 10.

8. ibid., c. 14 .

5. ibid., c. 9.
7. ibid., c. 12.
$9 . \quad$ ioid., c. 20. 
an inspector of nuisances, and a surveyor; for the removal of the last of these the approval of the General Board was necessary. (1) If they thought fit, they might also appoint a medical Officer of Health; the appointment and dismissal of such an officer were subject to the approval of the General Board, but his remuneration was to be determined by the local. authority. (2) Chadwick had thus falled to make obligatory the appointrent of the most valuable of the local officials; and though both surveyor and Officer of kiealth were secured from summary dismissal, their independence of view was threatened by the fact that their salaries were fixed by the local Board.

Over forty clauses dealt with the powers to be exercised by the new local authorities (3), the effect being, as Chadwick. pointed out, that for the reasonable expenses of an Inspector's survey, a district would be invested with all the advantages of a costly Local Act. In their detalls the provisions showed. that six years' campaifining by Chadwick and the Health of Towns Association had not been wasted. Thus, it was provided that no new house might be built without drains of the size, materials, level, and fall which appeared necessary on the report of the local surveyor, nor without a sufficient water-closet or privy or ash-pit; a house within a hundred feet of a sewer might be required to communicate with it; otherwise it should discharge Its refuse into a cesspool at a distance directed by the local Board. In the default of the owner, the lockl Board were empowered to construct such communicating drains, and recover the costs so incurred. (4) The local Board - - to take a further exumple -.- were given powers to provide a water supply, either under public management or on contract with a private company; the supply to be pure and wholesome, and at "such Pressure as will carry the same to the top Story of the highest Dwelling House within the District supplied". But it

1. ibid., c. 37 .

3. ibid., c. $41-85$.

$$
\text { - }-
$$

2. ibid., e. 40 .

4. Ibid., c. 49, 50. 
was not lawful for the local Board to supply water if there were already a water company in the district able and willing to do it adequately, on terms fixed by an Inspector or an arbitrator. A householder might be required to obtain a water supply, if it could be furnished for a sum not exceeding $2 d$. a week. (1)

A General District Rate for the purposes of the Act would be levied on the occupiers of property rated to the rellef of the poor, and Private Improvement Rates imposed for works beneriting individual occupiers. (2) To raise money for woriks of a permanent nature, the rates might be mortgaged by the local Board. Such mortgage could be made only with the consent of the General Board.

Tenuous as was the element of "Centralisation" in the Act, the Lords, responding to Chadwick's concealed guidance, had left the General Board with more aggressive functions than the Commons had been prepared to permit. The central department conducted the preliminary inquiry; it recommended that a sanitary district be formed; it gave its approval for the removal of the surveyor and the officer of Health, and for the appointment of the latter; it sanctioned mortgages for public works; it heard appeals by parties aggrieved by the proceedings of the local board. That in sum was the amount of its legal powers. By stretching these powers to the utmost, by extending the imponderable authority which superior information and capable officers lent to a Government department, by employing persuasion where imperatives were barred, Chadwick hoped even yet that the new Board would not fail in its appointed task. The original Bill was not his, as he pointed out to the critics who saddled all its imperfections upon him ${ }^{(4)}$; and the Act which

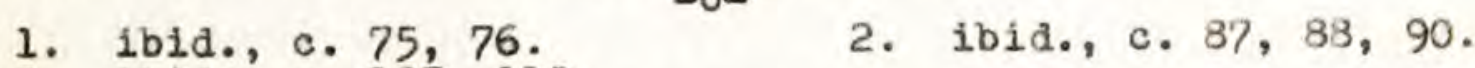

3. ibid., c. 107,119 .

4. He had foreseen that he would be used as a whipping boy. Writing to Edmund Ashworth (26 January 1847), he had observed: "Sanitary measures we shall carry by halves: i.e. imperfectly and as usual I expect abuse for the imperfections on which I have remonstrated". 
had eventually emerged represented no more than what his adroitness and tenacity had panaged to preserve after Morpeth's draft had been shot to pieces in the Commons. It was a continual lament of Chadwiak's that the schemes of his conception had to be put into the clumsy hands of politicians, and that, after a Parliamentary mauling, the resultant patchwork of compromise and amendment was passed back to him to make into

a practical working measure. (1)

1. Criticism of the Public Health Act usually develops into criticism of Chadwick, to whom its parentage is attributed. The most stinging of these attacks is probably that by J.L. and B. Hammond in their "Lord Shaftesbury" (p. 159): "Parliament might have set up local authorities, given them wide powers, called on them to prepare plans for drainage, water supply, streets, buildings, open spaces, destruction of slums and cellar dwellings, and the future developinent of the towns. A central body might have been established at the same time to give guidance, to enforce a minimum standard, and to stimulate local action by grants in aid. This method would have put the relations of the local and the central authority on a good basis, and it would have kept to the front the main character of the problem, as a problem in the organisation of town life and growth. If, at the same time, Parliament had applied Adam Smith's teaching about taxation to the new land values created by the rapid conversion of country into town, these towns might have been made attractive and healthy without any ruinous cost ....."

There is an air of unreality about all this. It is easy to see that the scheme outlined in the paragraph quoted would have provided a better solution to the sanitary problem than the Act of 1843; but it is easy to see this because we stand so far from the event, and have the lessons of past experience, including the revealed weaknesses of the first Board of Health, to guide us to a balanced judgment. The scheme described, in other words, isco guite artificial alternative, constructed by a twentiethphistorian in the light of three-quarters of a century of administrative experience. Who, in 1848, was making proposals of this nature? Whence, in 1848, would the support have come for any such scheme? (except from Chadwick himself, who would particularly have approved of the suggestion that the new land values should be taxed). How many towns possessed the vision and commanded the technical skill to execute such plans? What chance was there of grants-in-aid from a Government which at the time was nervously slashing expenditure? In general, it seems that the hammonds make too little allowance for the necessarily experimental nature

(Continued on next page) 
He might with reason deny the paternity of this mongrel measure; but sufficient remained of a recognisable structure for it to be acknowledged as at any rate a family connection of the Poor Law Act of 1834. Such strength and purpose as the Act exhibited, it owed chiefly to Chadwick. This is evident in the ground plan it lays down for the relationship between the local authorities and the central Government. In the attitude towards this problem of the Poor Law Act of 1834 and the Nunicipal Corporations Act of 1835 there was a sharp antithesis, the resolution of which supplies the key to half a century of administrative history. Apart from requiring Treasury sanction for the raising of loans by a Corporation and for the alienation of its property, the Municipal Corporations Act did little to trin the traditional autonomy of the local authorities. On the other hand, apart from the control of police, it gave them no new powers. It left then, diverse in their customs and powers, unequal in their areas and reserves of skill, to meet the thrust of the industrial age as best they could, with no Minister or State department charged to guide and teach them, and if necessary to admonish and correct. Against this conception, Chadwick had opposed the principles of the Poor Law Act, those (Continued from previous page) of this first essay in sanitary legislation. Furthermore, in seeing in its defects a reflection of Chadwick's limitations of mind and character, they give insufficient weight to the fact that the measure (for the drafting of which he was not responsible, in any case) had to run the gauntlet of the House of Commons --that in its final form it represented not what Chadwick wanted but what he could get. They dismiss the Act scornfuily as a "small scheme". Small as it was, it was as much as the Commons could swallow; and very muck bigger, in fact, than the sadly botched measure which had been passed from the lower House to the Lords, where Chadwick's friends managed to repair some of the damage done by the Commons critics.

Throughout their treatment of the General Board, the Hammonds appear to have placed too much reliance on the evidence of Lord Seymour. The value of that evidence will become apparent later. (see below, pp. 470-7, 562-5, $(617-24)$. 
adminlstrative ideas which in the jargon of the time were known as "Centralisation" -- the beneficent tutelage of a specialised. central department, exercised through the media of the departmental circular and an expert inspectorate; areas cut to a pattern drawn by the technical demands of administration; a uniform system of ad hoc bodies in the localities to serve as the instrument of central policy, entrusted with a minimum scope of function and expected to attain a mimimum standard of performance. Nothing so clear cut as this can be seen, of course, in the Act of 1848. But it was a great step forward that a central Board should have been established, an embryo Ministry of Health, with aggressive powers, however slight at first, to make head against sanitary evils; and that a beginning should have been made towards imposing a code of public bealth on the country, defining legal minimum standards for drainage and water supply. It was a great point gained that under the Act considerable powers for the defence of the public health and the construction of public works could be readily and cheaply extended to authorities which had formerly lacked then. (1)

1. Par from restricting the functions of local authorities, Morpeth explsined in reply to the anti-centralisation party, the Act would confer powers of drainage, cleansing, and paving on 92 corporate towns which were at present without them, and on 158 more which did not possess such powers undivided. "ihere were at present only 29 Bnglish municipal corporations which had local Acts under the Hayor and Corporation exclusively; there were 66 corporations exercising powers jointly with the Comissioners; there were 30 towns in which the corporations had no powers at all, but where the powers were exercised independently by comissioners; and there were 62 corporate towns which had no local Acts whatever within the boundaries of the municipalities. Of the other towns in England, not being corporate towns, to which this Act might apply, there were 107 having local Acts; and there were 276 towns or populous districts, containing above 5000 inhabitants, without either corporations or local Acts. Upon these towns this Bill would confer powers which they had never yet enjoyed in any way. He vight also mention that there were in England 175 (Continued on aext page) 
The cholera marched from Moscow to the Danube as the Commons began to discuss the Public Health Bill; scattered cases were reported from Berlin as it passed the Lords. The dread shadow overcast the debates, and frou time to tine leguslators cast uneasy glances over their shoulders at its steady advance. It was not specifically the cholera at which the Bill was aimed, Morpeth had told the Commons, but "the abiding host of disease, the endemic and not the epidemic pestilence, the permanent overhanging mist of infection, the annual slaughter doubling in its ravages our bloodiest field of conflict". (i) However, many members entertained the impression that in voting for the public Health Bill they were raising defences against the cholera, that "it was absolutely necessary for the safety of all". (2) The subsequent discovery that it was designed to provide large permanent works for drainage and water distribution, works which could not be ready anywhere in time to affect or nitigate the epidemic, was not without its influence in drawing off support for the later measures of the General Board. To meet the cholera the Board had only the exiguous powers of the Nuisances Removal and Diseases Prevention Act, as amended in 1848(3); and these powers were to be granted only when the Privy Council deemed the danger sufficiently acute, and their duration was limited to the six months of the Order in Council which put them into force. During the period of such order a medical member might be added to the General Board of Health; and the Board were authorised to issue directions and regulations for the cleansing of streets and dwelling houses, the execution of which (Continued from previous page) towns, containing above 5000
inhabitants, which had local Acts, and 296 which had no local Acts at all; and it was upon these 2.96 towns which had no local Acts, and upon the 158 corporate towns which had at present either no powers at all, or divided powers, that his Bill would, for the first time, confer the exclusive power within their boundaries of cleansing, sewering, paving, and providing a supply of water. 1. ibid., vol. 96, p. 392,10 Februaty 1848. 2. ibid., vol. $98, p .770,8$ may 1848 (R.A. Slaney). 3. 11 \&2 Vict. c. 123, 4 september 1848. 
was to be superintended by the Guardiens of the Poor (in Scotland the Parochlal Boards). (1) Another year elapsed, and the epidemic was nearing its height, before powers were granted to the Board or the Poor Law Guardians to institute prosecutions for violation or neglect of the Board's regulations. (2) From the first, then, in this important field of their activity, the one which for twelve months bulked largest in the public eye, the Board's authority was circunscribed by an ancient jurisdiction stubbornly maintalned by the Privy Council office. Ostensibly, from their title, charged to protect the health of the kingdom, they must await the sanction of another department, which lacked both their knowledge and their responsibility, before they could strengthen thelr membership by the addition of a medical expert, and before they could take preparatory measures to deal with a threatening epidenic.

Throughout the 1849 session Chadwick had been pressing forward with another important sanitary measure, a Metropolitan Sewers Bill, to give statutory recognition to the consolidated Comission set upiin the previous December. By this Bill he hoped to recast the Commission more to his liking, and to rid it of the weaknesses which had aiready made therselves apparent in its structure and personnel. He had wanted, ss we have seen, a small sanitary executive for Iondon, composed of men carefully selected for their knowledge and enthusiasm for the work, to give close day-to-day supervision to the technical details. The Comission of 23 he considered was too numerous and rissiparous for the task ${ }_{-0-}^{(3)}$ It included a strong contingent 1. ibid., secs. $x i, x$.

2. $12 \& 13$ Vict. c: Iil, secs. iil, iv.

3. "At the best I for one never conceived an administrative board, acting at monthly meetings, and at special meetings fortaightly even where sut the members were all competent, and all unanimous, the best possible or the only possible (Continued on next page) 
Prom the Metropoliten Sanitary Assoolation, Lord Ashley, Lord Ebrington, R.A. Slaney and Dr. Southwood Smith; the physiologist, professor Richard Owen, one of Chadwick's closest friends; the geologist, Sir Henry de 1a Beche; and two distinguished physicians, Neil Arnott and Sir James Clark. These could certainly be expected to follow Chadwick's lead; and in addition he could count upon the support of the chairman, Lord horpeth, the First Comissioner of hoods and Forests, so long as he did not race too far ahead of the policy of the Whig Government. But four of the old district Commissioners had also been nominated, and with one of them, John Leslie, a vestry poitician from the parish of St. George' 6 , Chadwick at once found himself engaged in the bitterest of controversies. (1)

To Chadwick's consternation he found that Morpeth was contemplating a step which would add strength to this dissident minority led by John Leslie. Fearing an outcry if the Bill did not embrace the principle of representation, he was leaning to the view that each union and select vestry should elect a member to a Metropolitan Board of Sewers, the right of the City to nominate its due proportion being of course reserved. (2) Chadwick rejected with scorn the idea of such a "Sewers Parliament", where the ignorant delegates of Marylebone and St. Pancras would debate scientific principles of drainage which were "as peculiarly unfitted for discussion in popular assemblies, and voting on them as are questions of chemistry or surgery". (3) Bad as the works of the superseded sewers Commissions had been, he told Morpeth, they were better than $-0-$

(Continued from previous page) contrivance for carrying out such a work. For if any work be of importance enough, involve pecuniary loss enough, apart from sickness, the infliction of ill health, detaralisation enough, to render it econonical to have measures carried out by dgily, hourly uninterrupted sittinge it is surely this". (HS memorandum, n.d.)

1. See below, chap. 11

2. Horpeth - B.C., n.d.

3. "Metropolitan Special Commission. Notes on the Evidence examined", MS, 7 October 1347. 
those of the parishes. (1) His own preference was indicated by the approval he gave to a suggestion of the Lord Chancellor's, that the Commission should be confined "as much as possible to Government subordinates". "At this time", he urged, "we might with such subordinates give evidence of political importance: that it was possible for such subordinates to carry out a reform such as local representative bodies had never dreamed of: to beat commercial companies in efficiency, and even private builders in respect to the economy of works, and win the approbation of the public to the extension of new power without the ordinary cumbersome machinery". (2) In the event, however, neither Morpeth's parliament of parochialists nor Chadwick's select Board of civil servants found favour with the Government, and it was decided that the Metropolitan Sewers Commission should remain substantially unaltered, apart from the introduction of five representatives of the Common Council.

Chadwick failed also in his efforts to bring the enclave of the City within the jurisdiction of the consolidated Commission. "There is a natural desire to carry out measures and to postpone conflicts", he told Delane, "but the fact is that the feeling in the House of Commons against the exemption of the Corporation is so strong, that it is believed that it would not permit separate legislation. In the case of drainage nature determines what shall be the area of jurisdiction, and the city could not be drained separately except on an enormous cost". (3) To Lord John Russell be wrote: "The retention of the nuisance of a Cattle Market in the centre of the Metropolis, and the obstinate conflicts of the Corporation against various proposals of amendment, have brought out in strong light its undue powers in questions affecting the whole metropolis, of which it is only about one fifteenth part in houses, and one tenth in rental ....... They stated that they

1. E.C. - Morpeth, 4 August 1848.

2. E.C. - Morpeth, 11 September 1848.

3. H.C. - J.T. Delane, 24 February 1848. 
had done much. What they have done has been examined, and found to be very little and very bad, and the condition of the population in the poorer districts to be much worse than had been before demonstrated; at every step the declarations of the Corporation witnesses have been falsifled". (1) The Health of Towns Association published a sensational report on the state of the City, basedoon lacts supplied by Chadwick. Both sides circulated petitions for signature among the parishes. Pamphlets and articles in the "Morning Chronicle" were addressed by City aldermen to other local authotities in the provinces to stir opinion against sanitary centralisation. Toulmin Smith appeared before the Metropolitan Sanitary Commission, and Chadwick put him through a "stout cross-examination"(2); a few weeks later the irascible antiquarian was accusing Chadwick of refusing him the opportunity to revise the notes of his evidence, and Morpeth implored his colleague not to give him the opportunity of "kicking up a dust". (3)

The Corporation were worsted in the public controversy, but in the lobbies the "soup interest" prevailed. The Health of Towns Association, believing that their agitation had stopped the separate Sewers Bill promoted by the City, were amazed when they found that somehow it had got into the Lords. The Metropolitan Sewers Act of September 1848 was thus obliged to recognise the conjoint authority of the Metropolitan and the City Commissions of Sewers. ${ }^{(4)}$ The defences of the City garrison were still proof against the drive towards consolidation.

One day in May 1848, in the middle of the struggle for the Public Health Bill, a clerk waited on Chadwick at Gwydyr 1. E.C. - Lord John Russell, I May 1348.

2. E.C. - Morpeth, 29 April 1843.

3. Morpeth - E.C., 29 May 1348.

4. 11 \& 12 Vict. c. 112 . 
House with a request for unexpected information -.- how his name should be entered for the Companionship of the Bath.

"All things and Lord John's previous displeasure considered, I was not a little surprised at the honour ....", he confided to a friend.

"The Prince had made the recommendation as an observer. He had, I found, taken an interest in Sanitary questions and had read the reports.

I have had one interview with him on the subject of the improvement of labourers dwellings. (1) I do not remember that I was ever better questioned. I must be strongly biased towards him, but from all I hear of him he appears to be a person who divested of his rank must take a very high position". (2)

The C.B., of which this was one of the first awards for civil services, was the only official recognition that Chadwick's labours were to get until the last few months of his long life. It was well-timed. At the end of the 1848 session Chadwick could look back on a decade of continuous agitation and inquiry in the cause of public health. At last, crowning the ten years of drudgery, a Public Fealth Act was on the statute book. The machinery for its execution at the centre and in the localities was in process of construction. In London a single authority was at work under his guidance, planning the drainage and water supply of the whole capital. Slowly, but with gathering momentum, the new values which the "Sanitary Idea" set before society were permeating the minds of law-makers and administrators.

1. See below, p. 589 .

2. E.C. - W. D. Christie, 29 May 1848. He told W.H. Hickson: "It was an unexpected and to me a strange affair not initiated by the Government". ( 9 May 1848). To Sir George Stephen he wrote (19 May 1848): "The newspapers have knighted me, but I am only honoured as a companion of Knaghts - - a civil companion of the Order of the Bath which on the whole is quite as well as I have no private fortune to sustain the additional expense which a higher honour might require". 
PART THO.

THE CENBRAL BOARD OE HBALTH,

1848 - 1854. 


\section{CEAPPER 10}

\section{CHOLERA, $1348-1849$}

The six years Chadwick spent at Gwydyr House were the happiest in his official career. He lost for a time the sense of frustration which at the Poor Law Comission, "where all was going back under the evil influence of the Lewis's" (1), had weighed down the natural buoyant optimism of his spirit. Working twelve or fourteen hours a day; taking up with zest the burdens which fell from the fatigued hands of colleagues and subordinates; sitting at his desk in Gwydyr Fouse, snd feeling an intricate administrative machine respond to the thrust of his will; sending his scouts posting to some foul place to root out nuisances and bad smells, and put chastened local authorities on the cleanly peth of tubular severage and constant supply; drafting reports and memoranda on evils yet unconfronted, and Bills and resulations that would set them to rights; -- so occupied Chadrick was nore content than at any time since the Government had put the Poor law inquirg into his bands.

That self-esteem of his which at times degenerated into arrogance, his inflexibility of thought, his irritability in the face of criticism, combined to nake him an uncomfortable colleague. At the Poor Law Board he had shown that he expected to be first in autiority as be was first in knowledge; and that if he could not rule, he would be leader of the opposition. By good fortune, rather than by conscious intention on the part of the Cabinet, he now found himself associ ted with two men wh were fundamentaly in agreement with his views, an who in consequence eithe could see no objection to bis proposals, or curbed their opposition for the sake of a smooth-running unarimity.

1. H.U. - W. Ohcistie, 29 May 1843. 
The reformers had indeed been put in office: Chadwick, the brains of the public health agltation, Bouthwood Smith, its chief organiser, Lord Ashley, the chairman of the London Health of Towns Association. Chadwick, waiting in trepidation for the name of the colleague whom the unpredictable workings party politics would thrust upon him, was delighted at Ashley's appointment. "It afforded to the country a guarantee of earnestness, sympathy for suffering, singleness of purpose in labouring for its relief", he assured Ashley. "I shall labour under a deep feeling that I have no time to lose", he went on. "You I hope may look to more years, and to see more of success". (1)

They presented a strong contrast, the eupeptic Chadwick, who had his disappointsents but never his doubts, who entered on every task with such unolouded confidence; and the selfquestioning Ashley, with his "prolonged fits of despondency"(2), "whose views are usually the reverse of sanguine". (3) One characteristic they had in commont they both liked their own way; and it is a remarkable fact that in six years of colluboration these two masterful men never clashed. partiy, perhaps, it was because there was a natural division of function between them. For Chadwick un isputed authority at Gwydyr House, the shaping of measures, the delighta of power wielded behind the scenes; for Ashley the Parliamentary limeli ht, the influencing of audiences, the satifaction of doing good conspicuously. Ia this way the clauses that chadwick had had in mind since the time of the Sanitary Report sppeared before the public in 1851, and went down to history as "Lord Bhattesbury's Lodging Houses Bill". (4) Their agreement was based, however, on something deeper than complenentary

$$
-\mathrm{Or}
$$

1. 1. . - Lord asi ley, 28 September 1343. He told orpeth that Astiley's topointment "will promote the lmpression that the measure is regarded as a poor man's theasuro" (15 eptember $1843)$.

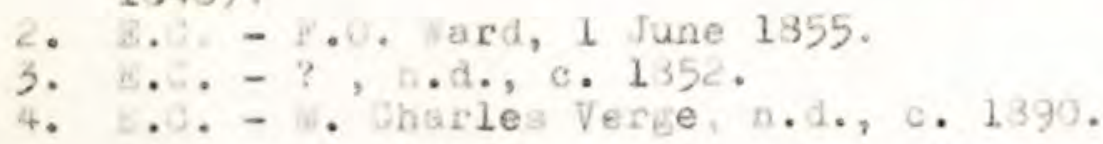


capacities and spheres of action. Lord Ashley, the Evaagelical of the svangelicals, and dwin Chadwick, who probably sever felt any religious emotion in bis life, had a body of beliels in common, and the currents of their thought -... springing from sources so widely separated -..- yet ran in parallel channels. They dreaded that the savage indocility of the neglected workers wight organise itself behind the frade Union leaders and the Six Points men. They maintained that if a Chartist millennium were to be averied, the governing classes must free the goveraed of their "too quick sease of constant infelicity", by improving the physical conditions of their lives, and by brining them under the influence of that judicious education whose conservative powex had been known to the privileged since the days of plato. Thoy saw the remedy in the intervention of the impartial power of goverument to check the more obvious crudities of exploitation, and to raise a bulwark for the unprotected agsinst organised economic laterests and locs goveraing cliques.

liar from colliding, therefore, these two strong wills supported and encouraged each other, giving to the activity or the Board a multiplied energy. There was fimess, too, in the unobtrusive Southwood Snith, who at the age of seventeen had thrown up a setolarship for conscientious reasons, and who was fond of saying that "life is not loag enough for us to reconsider our decisions". (1) But he was slow -... "deliberate", Ohadwick phrased it, to avold the less kindly adjectives eaployed by others -- and at times of pressure Chadwick fretted to see papers accumalating in the D ctor's unlurrying hads. ben southwood smith susgested that he might act as Becretary to the new Board, Chadnick was firm in his relusal. The post was inconsistent with the Doctor's business habits. (2) Eventually he eateres the soard oy a 1. O.L. Lewes, "Dr. Bouthwood smith", . 4. 2. "I must say that in pressing you ás I hav done from time to time for puolic empl yment 1 have had much to bear up (Contirued on next page. 
side-door … the clause of the Nuisances Act which permitted the appointment of a medical member. ( 1 ) It was not a gracious entrance for a man whose name was linked with Chadwick's as a pioneer of sanitary reform, nor was it a propitious introduction of medical science to the counsels of the Board. There was alvays a hint of supercilious amusement, not untouched with jealousy, in Chadwick's attitude to the Doctor, whose heart was bigger than his head.

The easy-golng Lord Morpeth was never quite at home at Gwydyr House, with the ebullient Chadwick and the sombre, moody Shaftesbury, both in their different ways so earcest in their sanitary labours. Chadwick he sincerely respected, but found him, with his strong-minded views about every subject that arose, a constant source of embarrassment. He thought it wise to warn at once this formidable colleague of his, who was entering office with expectations shurpened by a series of disappointments, and who over a decsde had been maturing large scale plans of reform. "henever I may be inclined upon any occasion, such as I hope and believe will be rare, not fully to go along with you, it will probably arise from s wish to temper too suddea a strain after perfection by what I may feel to be the most practicable modes of lealing succes fully with

(Continued from previous page) against. One point which I would allude to, has been slowness, or as it has been expressed dilatoriness in the dispossl of business. You re spoken of as slow and dilatory at the Health of lowns Association, at knights; an? I must say that at times and in emergencies as I have considered them, I have been fretted at the pace in the execution of the work. I un convinced that it would excite out door surprise, to see you connected. with the new work as "Becretary" ... (a position) ... inconsistent with habits which 1 will call of deliberateness rather than by the dialogistic terms applied to them" (... - soutkwood Smith, 11 August 1348).

1. "London Gazette", 5 nctober 1343, p. 3615.

2. "I will pass over for the present quch of whet I must sa'y of what your frieods have been allowed to arite in respect to your position in relation to the prosecution of the princlples of Sanitary measures which are now carried, but wich writing I must take an opportunity of noticing". (L.u. - Southwood smith, 11 Aujust Li43) 
Parliaments and Bodies of men". (1)

There was no question who was master. The volce of the Board was the volce of Chadwick. The majority of the documents they issued came from his pen; the remainder were revised by him, frequently to the extent of being almost rewritten. When Ashley and Horpeth spoke in the House, they were briefed by Chadwick. The poor Law mutineer had at last a comand of his own, and he was fortunate to have it manned by men who were ready to ifive a proper deference to his massive knowledge, amp would not dissipate time and energy in untidy dissensions.

The first task was to get a staff together. The Government were unesily awaiting an attack on their expenditure which was threatened from all sides in the coming session. hen Chadwick called at the Preasury, Sir Charies Irevelyan, the permanent secretary, assumed an expression "almost of fright at the idea of being asiced for any money; and bofore I could enter into any explanations with him he began to exhort that expense might be spared. But when Chadwick outined his modest demsads, he "relaxed, and highly approved". (2) A secretary (lienry Austin) at $\$ 400$ a year, an Assiotant Secretary

(pofessor bala) at 2300 , one copying cleris, the messengers and housekeepers already on duty in Gwydyr House (3) not even the most apprehensive of reasury officials could charge the soard with extravagance in staffing an offlce which was to have control of a new and complicsted field of administration, and to conduct corres ondence with local. authorities in all parts of 1. Lord Morpeth - ..., 4 September 1348.

2. - - Lord orpeth, 15 September 1343. Gf. G. . Lewls 1 rancis llead, 23 September 1343: "Economy is now the order of the day, as Charles Wood was at last compelled to propose a loan of two rillions. All establishments are now to be reduced to the lowest footing compatible with efliciency". G.C. Lewis - rancis Bead, 24 Novomber 1343 "The "reasury thinks a grant of $\$ 100$ is now a grest concession to anybody. All estimates are undergoing a severe revision". " "Letter or G.C. Lewis", pp. 134, 133).

3. Board of Fiealth - Treasury, 26 september 1343. 
England, Wales and Scotland. Chadwick, who had cut his requirements to the bone to avert ireasury opposition, told Uorpeth that "when we have occasion, however, we must protest against their economising the means of economy in these times of public pressure". (1) When, a week later, his own salary was publicly announced at 21,200 instead of the 21,500 he had expected, he felt that the time for protest had arrived. It was "lower than that of an Bnclosure Commissioner, lower than that of an Under Secretary in the Poor taw Commission, lower thar that of an Usber of the Black Rod, or than that of a Pown Clerk of Manchester and Liverpool, not to speak of the secretaries of railway and trading companies". (2) He got his 21,500 .

1. E.0. - Worpeth, 15 September 1843. "lo begin with half legislative powers is bad enough, but the present pressure on the revenue is pleaded for restricting us to quarter measures of staff". (1.,. - Ashley, 28 september 1343).

2. B. - Worpeth, 30 September 1343. On 7 overber he told lorpeth, "If the salary of 21,000 had been kept as at ilrst announced, I tell you frankly should have accepted it under protest and taken the chance for the sake of the measure .... I had given directions for a search for a suburban dwelliag and made inquiries myself beiag deberwine to reduce my expenditure to a still narrower compass. The trouble of this change would have interrupted important public business; and after your gecond acouncement which as you must weil kuow was made at no instance of mine, and in compliance with what appeared to be the feeling of the flouse, I countermanded the directions I had given .... It is exiremely disagrceable to speak of myself; and I believe I bave never done so except when some measure of injustice or agression was in question nor indeed unless the personel injustice involved a public principle as I believe lis the case here, whless it be intended to reduce all old salaries in which case, I shall cheerfully bear ny oart with all others".

In some ws notes of this period, headed "l syments for superior service", he cites the example of 5.4 . Laing, who had bee paid no more than 2600 at the buerd of crade for protecting the puolic against the raiway co punies, but in private practice had made 420,000 in two yeara.

"Comerce adhereg to the rule that ho who devises snall execuse: and that he who contributes to the profitable $\boldsymbol{r}$ asults shall share in the profit, which la its owa hoour. Comerce animates its hands with a warm interest in enterprize and in execution. Goverament or puolic ministers (Continued on vext pige 
The Treasury objected even to the Board's estimate for the price of a seal, and Chadwick was obliged to send Austin out to see what could be bought cheap and second-hand. (1) Such $-0-$

(Continued from previous page) in this country apparently understand the application of the common motives only to one class of enterprize, that is to say to war, and there it is successful

A project is presented to the Govenment, lavolving extensive saving by more efficient applications of existing works, to the extent of several hundred thousand pounds per annum and of achieving an eventual national saving of lost labour, of the expenses of sickness and the expenses of funerals to the extent of no less than 14 millions per annum for kngland and Wales alone. Now how would Commerce receive such a project? As it has received and dealt with a project for the improvement of the trade in corn of not half the amount. How would commerce set about the execution of such a work? To him who had devised it, they would give the main direction, and would secure his services at any price. It would not stop till it had obtained a staff of officers of the highest aptitudes, whom it would pay well for their full time, and excite their zeal by participation in the results ..... kow has the Government set about its appointed work? Six years urging and $r e$ urging have taken place, during which time the condition of the whole population question was postponed to the condition of convicts, of juvenile delinquents, to questions of the liayooth sant, and when proposed for execution, it is with a staff of unpaid officers who canaot give their whole time to it, who canot have acquired, and, in all probability will not acquire the detailed knowledge necessary to successful direction, and only one paid Comissioner to whom it is proposed to give for this new and extraordinary work, a salary not more but positively less by one half than that ordinarily given to ordinary and co paratively routine comissioners, such as the comission for the comratation of tithes. This one Commissioner will be required to act in dislodging from the field of public service, comercial bodies who will oppose him with professional aid and officers each paid one half more, or double his salary

1. Chadwick turned the tables by conducting an inquiry into the cost of manufacturing seals. He found that the contract price lor seals was 40; yet equally good seals had been obtalned for the ewers Comission for 5 and with a little $t$ ought he himself devised a rwas method of making superior seals for dic. He received no thanks for his pains. "The subs quent conversations with the Ireacury on minor subjects had been curt and disobliging and in a tone open to the inference that the inevitable explangtions ceferred to had by no means promoted cordiality". (hotes, "Administrative Relations of General Board with Preasury".) 
cheese-paring would be mexely comic if it did not reveal that the Government conceived of the scope of the new department as being no more than a subordinate function of a subordiaate Minister. At Chadwick's suggestion, horpeth urged that two medical observers should be sent to the continent as in 1331 to watch the advance of the cholera and report on the steps which foreign Governments were taking to meet it. What was the use, replied Sir Charles wood, when no one mode of treatment had been found to answer in all places. (1) It would take more than an impending epideaic to stampede the Chancellor of the Exchequer into incurring a bill for a medical wild goose chase over half surope. (2)

In ministerial circles a new Board meant places to be distributed, friends to be obliged, and supporters to be placated. Chadwick, recruiting his stape, had never known the pressure of applications so heavy; but he had been siven a free hand, and he dropped no crumbs for the hungry crowd o: expectants who waited at the door of the Patronage Secretary. He warned Lord lorpeth, who had a kindly man's easiness and a Whig's sensibility to the claims of family and partys "If I were a nember of your tordship's household, it would be a duty to withstand your kind impressions in favour of applicants when I knew they were founded upon imperfect information. tor myself I was early disposed to accept and act upon lavourable representations of men, until the contraxy was pooved, and I have paid nost bitterly for it. I have veea coavinced sainst my own will that a reverse rule is the sound one for ordinary cases; but in our peculiar work, I cannot but feel that it is a strong necessity. To take for granted, to presume taut all will be we11, that error may be easily rectified; that to use tord Heloourne's expression, "things will shake cight" and as we wiah them is the most easy and pleasurable course: to scrutinize, to 1. Morpeth - .,., 18 september 1343

2. One Kedlcal Inspector (Grainger) was eventually sent to Hambur for a ferp weeks. 
cross-examine, and to refuse: to watch and remove or reprove for partial failures, is disagreeable to me; but not other people's money, but literally extensive life and death, others' pain and misery depend upon the performance of this duty". (1) 80 candidates who brought to Gwydyr House a chit from the Treasury or a powerful friend were told bluntly that he had an "entire distrust of testimonials from persons however eninent, who undertook to recommend persons for the periormance of very special duties of which the parties recommending knew nothing". (2) In selecting the Board's Superintendent Inspectors he looked for men who were not blinded by indurated professlonal habits, and who had the "proximate practical experience" to understand and to execute the novel combination of works which was the heart of his sanitary scheme. Ihere was Robert Rawlinson, for example, the young Mancheeter engineer, who had startled the Liverpool Council by his brilliant plan for bringing water to the city from the Bala lake in llales, 72 miles away; William Ranger, a former lecturex at the College of Civil sngineering at utiney, who had drained the Pevensey and Worthing district of the Pens; George Thomas Clarke, later to make a name - 0 -

1. H.C. - Hometh, 13 September 1348. He continues:

"ve must strive to searoh out talent and not comit ourselves to insufficient hands. In this entirely new and untried work, I could scurcely say that we heve any that must not be regarded as unsste bands. They will ail require watching and training, and we must propare for failures....

It mey be asked, 'are we to trust no one, not even men of the most eminent practical science'.

in such new and untrodden ground I believe the $r$ ply mat be still in the negative. .e must trust solely to

ascertiained Pacts .....

$I$ work now at high pressure. I cannot well bear more strain. I shall however have to make bool more or less sny failures from defective appointments: have to give nore instructions, and exercise more cere. very inept or useless person is an additional inconvenience".

Ci. also, B.C. - Worpeth, 4 septembor 1343 : "You will think in some instances nave to guard yourself against being nisled by what they call in the Navy "pye service" -.. gervice rendered only where it is seen".

2. B.C. - Morpeth, 14 September 1381343. 
as the master of the Dowlais ironworks, and as one of the first to assist Bessemer; Edward Cresy, the author of a standard "incyclopaedia of Civil Engineering", and an expert on hydraulics as applied to house and main drainage; James Smith, "Smith of Deanston", the authority on agricultural drainage, an old ally from the Health of Towns Commission. As Secretary he had named another young engineer, Henry Austin, brother-in-law of Charles Dickens, who had earned Chadwick's special esteem by his plan for draining the low districts of towns by steam power, and who was Pightint Chadwick's battles before the Metropolitan Sewers Commission. ( 1 The selection of such men as these did not make for easier relations with the Treasury subalterns, but it put under Chadwick's command a small corps of competent investigstors, most of them young and Illexible in outlook, all of them possessed of enthusiasm for the new principles of sanitary engineering and of practical capacity to carry them out on the spot.

By September 1848 Chadwick already had news of applications in agitation at York, Plymouth, Rotherham, Llanelly, and Barnstaple; while"a Candidate for employment is getting up a movement from lewcastle". (2) In December he was able to report to lord John Russell that "75 Towns or places have applied to have the Public Health Act put in force. In the gmallex Towns the application has been by petition from one tenth of the Ratepayers, in the larger lowas by petitions - -

1. Wh notes, "Names and descriptions of eagineers to serve as superinténdent inspectors" c. September 1348. In a lecter to llorpeth, 14 Septeraber 1843, he describes nis nethod of siaing up the candidates. "I have sail to them, "since you can give no evidence of completing some previous successful work, the next best evideace would be for jou to take some ill conditioned place, badly drined and batiy cleansed, and shew in what way you would recommend that it should be amended, and in what time and at what expense you would undertake that it might be done'. To some I have described particular cases, and asiced them the treatment they would recomend, which has been comonly some exploded peactice". 2. B.C. - Wompeth, 20 September 1343. 
chiefly of the Town Councils. Amongst the applicants are York, Derby, Wolverhampton, Dover, Portsmouth, Gloucester, Worcester, Preston and Leicester ..... This body of applications puts an end to the talis of universal resistance." "We are proceeding tentatively", he went on, "by a small staff of the best engineers who could be found with the special requirements for the service. We do not believe that six can with all aids, get through the work of 66 towns in any otherwise reasonable time, and for the sake of feeling our way, we incur the certainties of outcries at delays. Nevertheless but for the delay in constituting the Comission, we should I conceive have been ready with complete measures for several Towas at the opeaing of the Session". Concluding a rapid sketch of the Board's work to date, he remarks: "I. am sanguine, that wich due support, the general results achieved will be satisfactory to you, and that while the Continent is convulsed with questions of privilege and sentiment affecting the labouring classes, which will comoniy wake bad worse, we, by avoiding the metaphysical, and by pursuing a quiet but strong course of physical improvement (in which I would submit that it is most important that the Government, and the natural leaders should take and keep the lead) sure and atriking results will be achieved". (1) Eachew politicul metaphysics; atm at the practical in social reform; put your trust in government -.- no better illustration than this rucipe for anglish statesmen could be fiven of Chadmick's position in tiat current of thought thich arises in zenthemisu and flows into Fabianism

Vor the next fifteen months, however, though the engineering inspectors pushed on steadily with their local inquiries, the main energles of the Board were directed towards the task of fighting, with linited powers and a tiny ovecworked staff, the epidenic which for the last year had been leisurely traversing the continent. 1. E.O. - Lord John Russelit, 5 December 1843. 


\section{2}

"The accounts of the new cases of Cholera at Berlin begin to wear a serious aspect", Chadwick had written to Morpeth in the middle of August. short holldays". (1)

"You must make up your mind to very held their first meeting together as a Board, and recorded in the minutes their fear that the country was threatened by a dangerous epidenic. (2)

There was universal unwillingness to acknowledge the presence of the disease. The earliest cases were busked up or recorded under a lalse name. By the end of September 1848 , however, the cholera had begun its work in figland; and, as the Metropolitan Sanitary Comission had predicted, it appeared by a kind of hereditary succession in those neglected districts where plagues and fevers were bred anew for each generation. The first case in Leith was in the same house as in 1332. In Bernondsey it was near the same ditch. In Pollockshaws cholera snatched its first victila from the same roora and the very bed in which it had broken out ajxteen years before. (3) Amongst the earliest places attacised in tondon was Fore street, tambeth, where "the miserable inhebitants look more like ghouls and. maniacs than buman belngs", where the doorways at high tide were blocked with boards and plaster to prevent the river getting in, and the surgeon made his way to bis patients along planks la1d over two feet of water. (4)

The two sailors from the Hamburg vessel at Horsleydown had undoubtedly died of Asiatic Cholera, chadwick informed Delane on the 6 th october. There had been two more undeniable cases in Lambeth, two in Sunderland, flve in Bdinourgh. (5) The ripples of the epidemic were beginning to widen. Sitting in the midst of their cesspools and dungheaps, the local

1. L.O. - Horpeth, 20 August 1848.

2. "Minutes", vol. 1, 26 Beptember 1343.

3. "Report ó the Epidetic Cholera of 1343 and 1349 ", p. 18. P.P. 1850 (1273), xxi. 3.

4. "Times", 28 octooer 1343.

5. A.C. - J.T. Delane, 6 October 1343. 
authorities were fluttering in apprehension. The Sheerness Guardians were in a panic, reported the "Times". They had
reason to be. "The offal of a population of eight thousand
lies upon the surface of the streets and alleys in its most
disgusting form. The only resemblance to a drain is a ditch
which surrounds the town, full of black and stagnant matter, and
forms the last receptacte for all the carrion that is too bulky
and ffensive to Guardians were in a panic, reported the "Times". They had
reason to be. "The offal of a population of eight thousand
lies upon the surface of the streets and alleys in its most
disgusting form. The only resemblance to a drain is a ditch
which surrounds the town, full of black and stagnant matter, and
forms the last receptacie for all the carrion that is too bulky
and ffensive to Guardians were in a panic, reported the "Times". They had
reason to be. "The offal of a population of eight thousand
lies upon the surface of the streets and alleys in its most
disgusting form. The only resemblance to a drain is a ditch
which surrounds the town, full of black and stagnant matter, and
forms the last receptacie for all the carrion that is too bulky Guardians were in a panic, reported the "Times". They had
reason to be. "The offal of a population of eight thousand
lies upon the surface of the streets and alleys in its most
disgusting form. The only resemblance to a drain is a ditch
which surrounds the town, full of black and stagnant matter, and
forms the last receptacie for all the carrion that is too bulky
and ffensive to Guardians were in a panic, reported the "Times". They had
reason to be. "The offal of a population of eight thousand
lies upon the surface of. the streets and alleys in its most
disgusting form. The only resemblance to a drain is a ditch
which surrounds the town, full of black and stagnant matter, and
forms the last receptacie for all the carrion that is too bulky Guardians were in a panic, reported the "Times". They had
reason to be. "The offal of a population of eight thousand
lies upon the surface of the streets and alleys in its most
disgusting form. The only resemblance to a drain is a ditch
which surrounds the town, full of black and stagnant matter, and
forms the last receptacie for all the carrion that is too bulky
and ffensive to Guardians were in a panic, reported the "Times". They had
reason to be. "The offal of a population of eight thousand
lies upon the surface of the streets and alleys in its most
disgusting form. The only resemblance to a jrain is a ditch
which surrounds the town, full of black and stagnant matter, and
forms the last receptacie for all the carrion that is too bulky
and offensive to wither in the streets". (1)

on the 2nd netober an Order in Council gave the Board powers for six months under the Nuisances Removal Act, and three days later they published their first Notification in the "Londoa jazette". To understand the admindstrative measures that it prescribed it nust be remembered that the Board bad no concepion that the causal agent of cholers was a selfpropagatiag micro-ofganism, discharged in the evacuations of the sufferer, and borne to the next victin in contaminated water or on the feet of that ilithy feeder, the hosse-fly. They were not even aware that cholera was a specific infection, as distinct in ite aature from plague and oyphus as the elephant from the giraffe and camel. The plezue of lexandria, in their view, was the wphus of thitechapel; yellow fover as not sui Beneris, but was s.n ordidary lever diflering on ly in its

intoasity; and the cholers also was no move thon a virulent form of those familiar crowd diseases which killed thousand every yeareplathe slums of the sxeat towns. (2) The loctrine bis ond differed essentially from anothor boublood sith wote uff as an eighteenth century errox to was now agreed, he

waintained, that there was a general reseablance bew ween these wiseases. "Thej are all fevers; they are certian atwospheric conditions; the $J$ al obey sibilar lews of diffusion; they all infest the same sort of Loculities; they all attack chiefly the same classes, and, for the wost part. 1. "rines", 24 october 1343. 2. p.Pepgrt 1350 on 1273$), x \times 1.3$. "second teport on quaratine", p. 4. P.P. 1852 holera of 1343 and $1349^{\prime \prime}$, passim. 
persons of the like ages; and their intensity is increased or diminished by the same sanitary and social conditions". (1)

Under the influence of the "epidemic atmosphere" it was possible for mild indigenous fever to develop into the most deadly of plagues; and, in support of this, Southwood snith claimed that, six moaths before the cholera epidenis broike out in 1332, he had observed that cases of typhus in fondon were taking on characteristics approximating to cholera. (2) The Board were convinced, therefore, that every case of diarrhoea -..- which could not be distinguished by pathological sigas from the epidemic itself (3) -... was potentially a case of cholera. There is a consequent confusion, both in the aethods of treatment they advised and in their account $s$ of the prosress of the esidemic. The medicines prescribed ia their Notifications were directed at the symptoms of diarchoea, and the medical visitors were instructed to seek out all cases of looseness of the bowels. If any such cases did not pass into developed cholera, they were acclaimed as victories of medical science. Hence, since they found 60 cases of diarrhoea, the great ajajority of which were amensble to treatient, to every cholera death, the soard had a highly inflated opiuion of tbe efficacy of their methods. (4)

1. "Report on quarantine", p. 5. 1849 (1070), xxiv. 137.

2. "Report on the Hoidenic Cholera of 1343 and 1349", P. L2. ef." "uarsntine Report", 1.349, 0. 61: "confinenent in foul atmosphere can convert comon Pevec into pestilence".

3. "heport on the pisemie Cholera of 1343 and 134 ", p. 91.

4. Loid., pp. Lio - ill. In eight weeks the board's visitors Aiscovered and trested in tondon
"Cases of premonitory diarrboea
Cases approaching to cholera
Cases of developed cholera
Cholera corpes, cases in which death
took place without any medical
attendance shatever
Cases which passed into cholers after
treatment

From this return is appears that the cases of prenonitory diar hoea were to those of developed cholera nearly as 60 to 1 ; and that of these premonitory cases, evea including the 78 which were on the verge of cholesa, not 1 in $3 \%$ passed into the developed form of the disease". 
Opposed to the Board's theory was that of a large minority of the medicsl profession who retained the traditional belief in specific contagion. But if it were true, declared the Board, that anyone who touched a patient night himself develop the disesse or transmit its"contagium vivum" to the next person with whom he shook hands, then the general practitioner on his rounds would leave a trail of death behind him; and every member of the General Board of Health must have fallen victin to cholera or typhus, since from morning to night they were receiving visits from medical inspectors just returned from the worst localities. Indeed, it was difficult to see how the human race had managed to survive so long, if every epidemic disease could thus propagate itself in all directions.

Rejecting such absurdities, the Board directed attention towards those physical factors in the eavironinent with which they believed disease to be associated. In the Report puolished in August 1850, in wich they described their sctivity during the epidemic, they gave a list of ten of these "localising" or "predisposing" causes: - overcrowding; filth; walaria from putrescent sud; dampness; want of drains and bud drains; graveyards; anwholesome water; food; fatigue; a d purgatives. ( Ihe one"csuse" on which the modern epidemiologist would fasten, unwholesome water, ranks seventh in the list, and is regerded, not as the vehicle for infection, ut merely as a predisposing agent.

In the Loadon of 1343 it was only too easy to point to some adjacent nastiness or of ence to the nose to wich a lucal oatbreak could be uttributed. "The epidemic was no respecter of classes, but was a great respecter of localities", wrote pr. sutheriand, one of the Board's medical insoectors. "Hich and poor suffered alike or escape alike, according as they lived in the observance or violation of the laws of their physical well-being". (2) They were atbacked when they lived near the i. ibid., pp. $37-67$.

2. ibid.,, 73 . 
Regent's Canal, which had not been cleaned out for twenty-live years, or near the two acres of refuse accumulated in a suburb of Hill; when they lived in the Potteries with their three thousand pigs and their fat-boiling plant, or in the Taunton girls' school, where 67 girls were crowded into one sleeping room, with an average of 68 cubic feet of breathing space each. (1) On the other hand, there were remaricable instances where the avoidance of filth had preserved lives as by a kind of providence. Hector Gavin reported the case of a well supplyin a dozen houses, which vas surrounded by four cesspools within a radius of twelve yords. The water was as thick as soup with feculent matter, and the landlord's agent was obliged to spend an hour every morning in pumping until it ran fit for use. the 35 inhsbitants of the houses, 22 did not use the well, and ali escaped, while 46 of the remaining 63 were sttacked by choleraic diarrhoea. (2)

1. ibid., pp. $49,45-6,43,37-8$.

2. Seventh Notification, "London Gazette", . 2633. The theoretical weakness and practical strength of the Board's epidemiology are well illustrated by the report of ur. Gavin Milroy on the twenty deaths which occurred in Albion Perrace, wandsworth Road, in the first two weeks of August 1349. ilroy attributed the outbreak to three causes: (1) an open sewer in Battersea Fields, 400 feet to the north of the lerrace, from which the inhabitants perceived a disagreesble odour when the wind was in certain directions; (2) smells from the sinks in the back kitchens, which grew noticeably worse after a storm two days before the first cases; (3) an accumulation of rubbish in the cellar of the house where the first case occurred.

Comenting on this explanation, bnow observes: "With respect to the open sewer, there sre several atreets and lines of houses as much exposed to ang emanations there might be from it, as those in which the cholera prevailed; and jet they were quite free from the malady, as were also 19 houses situated between the sewer and Albion Terrace. As regards the bad smelis from the sinks in the kitcken, their existence is of such every-day and almost universal. prevalence, that they do not help to explain an irruption of cholera like that under consideration; indeed, offensive odours were created in thousands of houses in london by the same storm of rain on July $26 \mathrm{th}$; and the two bouses in which the offeasive sme 11 was greatest, viz. Nos. 3 and 9 -those which were flooled with the contents of the drain (Continued on next page) 
Southwood smith had been working for a month on detailed regulations for the guidance of local authorities. They would not do, reported Chadwick in disgust to Morpeth, as he picked up his own pen. (1)

Morpeth and the Law officers later softened the harsh imperatives of Chadwick's regulations, but, as events proved, they were still too emphatic for the tender ears of the believers in local self-governinent. Under the terns of the Act they were directed to the Guardians of the Poor, but, realising that the rapidity of the cholera's advance would not permit time to be wasted in waiting for the Guardians to hold their weekly meetings, Chadwick framed then avowedly with the object of concentrating power and responsibility in the hands of the Union medical officers. All places which the Union surgeons certifled to be dangerous to health were to be cleansed at least once every twenty-four hours; ditches were to be cleansed under their superintendence, and solid and liquid filth of every description was to be removed from beneath and about houses. They were to inspect lodgining-houses, and require the landlord to ventilate them; where a family intabited a single room, they were empowered to order the removal of either the patient or as many as they deemed necessary of the other occupants. Dispensaries were to be established at convenient stations, to supply remedies and advice on bowel complaints; and also "Houses of Refuge", to which endangered families aight be removed. Believing as they did, that while the "epidemic

(Continued from previous page) were less severely visited with cholera than tbe rest; the inuabitaats having only had. diarshoea, or mild attacks of cholera. The accumulation in the house No. 13 could not affect the bouses at a distance from it .....". The only special and peculiar cause, he concludes, was the state of the water supplied to the Cerrace, which was followed by cholera in aloost every house to which the supply extended. ("On the mode of communication of cholera". 2nd. edition 1354, reprinted New York 1936, pp. 29 - 30)

ilroy's account of the genesis of the outbreak is thus obviously untenable; yet bis reconmendations -.- efficient sewersge and house drainage and a superior water supply -..were adnirably designed to prevent a repetition. 
atmosphere" prevailed, any case of diarrhoea might develop into cholera, the Board instructed the Guardians to have the infected districts combed out daily by a small squad of qualified officers armed with the appropriate remedies for arresting the diarrhoea. vor the same reason they advised that all foods which tended to irritate the bowels should be avoided, every variety of sreen vegetables, for example, and all kinds of fruit. The diet should be solid rather than Pluid, and "those who have the means of choosing should live principally on animal food as affording the most concentrated and invigorating diet". In particular, the Board combated the notion, popular among seafarers, that spirits were a good protection. (1) The advice was sound enough, but many thousands of those who were in the greatest danger were in no position to pick and choose their daily dietary. The same criticism applies to the Soard's maternal insistence on the importance of wara ciothing, and their

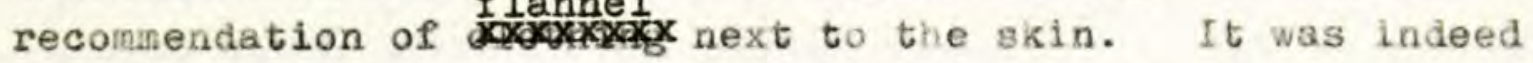
fortunate that it was impossible, as the Board well knew, to avert cholera by scorning cabbage, esting meat, and wearing flannel belts round the belly; otherwise the poor might have been left, with the economists' blessing, to their own individual efforts

Outside Gwydyr House, with its confidence and calm certainty, schism and dissension split the ranks of the fredical profession. Cholera bewildered the doctors. "quot medici. tot sententiae", opserved the "Times". (2) Meories as to its cause poured in to the "Lancet" and the "Limes", ranging from Budd's "Fungus Theory" and snow's rearable anticipations to hypotheses thin spun by vast ingenuity from a handful of

1. Notification in respect to Nuisances Removal and iseases revestion Act, "London Gazette", 6 october 1348, pp. 3616 - 3620. Second Notification, ibid., 31 October 1843, pp. 3875 - 3334. Special Notiflcation to Captiins of Merchant Ships, steaners and Colliers, 1 December 1343, pp. 4336 4399.

2. "ines", 1 september 1343. 
selected facts. Lea urged his "Geological Theory" that cholera miasm became toxic only when acted on by the calcareous and magnesium salts in water; while a Mr. Baggs lectured at the Polytechnic on "its dependence on the electric state of the atmosphere", stating that "this view of the subject is original" (1) One physician recommended a nostrum from an aneient Arabian manuscript; algebraic principles (2)

(3) another outined how to treat a case on (3) "In our profession", commented Dr. Sutherland drily, "every new occurrence, an epidemic, or a new remedy, or an extraordinary case of disease, is attended by violent literary symptoms". (4)

The College of Physicians said little, and criticised the Board of Health for saying too much. Chadwick bad wanted his new department to be called "The General Board of Works and Health", or some such name, which would make it clear that its functions were chiefly in relation to those environmental factors which affected the public health. (5) But it emerged as a Board of Health, administering a public lealth Act, and preseatly its advice and arbitration were being sought in the solution of medical problems. The muttering of the medical corporations grew louder. A Board of Health, which occupied itself mainly with brick and mortar arrangements, and to which a medical member had been added as a kind of afterthought, was 1. "Times", 25 August 1843. 2 2. ibid., 14 september 1343. 3. ibid.

4. Dr. J. Sutheriand - E.C., n.d.

5. Cr. "iem. on reports as to the constitution of local Boards", is, n.d.

"query. The expediency of altering the style and title of the Board.

..... Strictly the main Punctions of the Board will be the superintendance and direction of those works which are specially conducive to the public health; and the former title seems to have been well chosen. The name "Board of Health" alone, will tend to the notion of a medical Board, and to functions more widely extended in that direction than it is ever likely to possess or exercise. It would be repugnant to the popular understanding to call local Boards which the eeneral soard will have to superintend Boards of Eealth". 
not worthy of the title. (1) A lay board, composed of two noblemen and a lawyer, was prescribing treatment, civil engineers were discussing mortality rates, and a farmer, Smith of Deanston, who was no doubt an excellent judge of turnips, was inquiring into the sources of disease. Chadwick, with his oftexpressed desire to put doctors out of business, was singled out for attack, and. when the Treasury cut the allowance of the Board's medical inspectors to two suineas a day, there was an outcry againgt Chadwick's "poor law Parsimony" and ennity to the profession". (2) The cholera notifications led to open bostility

between the Board and the two Royal Colleges. The "Lancet" sneered st the "extempore doctors" and the "zymotic gibuerish of or. Southwood suith"(3), designed to prove the omipotence or stenches to produce cholera, plague, or any other epidenic. The college of Physicians put out a counter notilication, recomending an almost eatire freedom in the use of vegetables

1. The "Lancet" greeted with "deep regret" the announcement of the constitution of the Bosrd of Health. (30 September 1348) It professed a high opinion of Chadwlek as a lawyer: "but as the high priest of Hygeia, we confess we have no faith in him whatever ..... For a lawyer to attempt the adrinistration of the Health $B 111$ is about as bsurd as for a lawyer to attempt the editorship of a medical journal ..... Nr. Chadwick, with the belp of certain medical sanitary reformers, printed some very good sunitary reports, and making use of the facts furnished him by medical observers, he has taken a prominent lead in the agitation for sanitary reforn. Very true; we admit these arguments, and such second-hand material may do very well for agitation, but it will hardly serve for good legislation. Direct, positive, and personal knowledge will be required in the counsel. chamber of the board of Health; such knowledge as can be obtained from no subordinate officials, whether they be, or be not, superintending inspectors or officers of healtb. It will not work well to have medical men of unknown or second-rate reputation as advisers at the Board of Health; if medicine appear there at all, either with credit to herself, or for the public advantage, her just $r$ ank must be acknowledged, and her repreaentative must take equal place with the noblemen who are to preside and assist at the Board". (23 September 1348).

2. E. - Sir George Grey, 18 October 1348.

3. "Lancet", 7 July 1849 and 9 August 1849. 
in contrast to the Board's "wild dietetic cordon", and there was a brisk exchange on the subject of the cabbage as a predisponent to cholera. Though Morpeth congratulated Chadwick on having "cabbaged" the physicians ${ }^{(1)}$, the dispute did nothing to dissipate the view that the Board was dominated by an unprofessional meddler. $(2)$

It had been a mistake not to consult the medical corporations before issuing the cholera notification, a mistake which the Board tried to correct when an epidemic again threatened the country in 1853. Chadwick endeavoured to make his peace with the College of Physicians by a studously courteous letter which he drafted for Norpeth's gignature ${ }^{(3)}$, but he did not do so with a single mind. He was in no wise repentent. He had been criticised for intruding lay decisions into technical questions; but his private (and far from silent) opinion was that the physicians wre now seeking to annex as a medical province a field of investigution which he himself had opened up, and that the "College of private practitioners in physic" was presuming to set itself up as the supreme authority on a subject about which the majority of its nembers were grossly ignorant until the appearance of his "Sanitary keport". (4)

i. Horpeth - B.C, 17 Oetober 1843.

2. "We were toid that Edwin Chadwick would be a doctor in full oloom in less than ten days from the date of his ap ointment, but we hardly expected such a wedical Crichton as we have found. It is a sin ular lHet, in this, the early history of public medicine and sanitary measures, that whenever prescriptions are issued by the Board, they are sure to be countersigned by "Henry Austin", a civil engineer, we believe; while, owing to the left-handed manner in which a physician has suffered binself to be cadded to the Board, all the regulations for street-sweeping, emptying privies, and the removal of dirt and nuisuncos, are signed "Southwood Bmith, 4. -- no very flattering fact for our profession, and for this physician in particular". ("Lancet", 11 November 1843).

3. B.C. - Morpeth, 16 october 1843. The letter, deted 17 October, was published in the "Lancet" on 16 December 1843. 4. U. - Morpeth, 5 December 1843: "Sir beajamin Brodie told me that until my report appeared, the whol profession were grossly ignorant of the subject some Nembers of the college isnorantly think they ought to be consulted upon". 
"These bodies may be challenged as somewhat unreusonable in expectine to have in the whole or part, execution of that which they had no share in devising. The work of sanitary improvement was developed in a lay administrative department of the Government. It may be held up and ought to be cherished as evidence and an example of the possibility that large and most important popular improvement may orisinate in a Department of Government and from no agitation from without; that instead of waiting to receive instructions frow without, a Government Department may give it". (1) He always doubted the "success of mere medicine" $(\hat{2})$, and tended to minimise the importance of the medical practitioner, whose training was to cure ratber than to prevent. Medical men, he told Morpeth, "are much divided amongst themselves, and they distrust each other, and the schools that distrust medicine altogetier are large and increasing". (3) When Southwood Smith suggested the formation of a medical department of the Bosrd of Health, Chadwick replied that "the immediate and the principal work would undoubtedly be the engineering work: the medical work would follow at a distance". (4) Clearly he conceived that the engineer, oringing abundant pure water to the poor and flushing away their refuse cleanly and expeditiously, and the architect, designing for them dry and airy dwellings, would between them put out of employneat a large proportion of the profession which lived on the ills of mankind.

Chadwick's scorn, it should be rermemered, was directed at a profession which had yet to set its house in order by the Medical Act of 1353. It should be remember further that bis narrow conception of the part the medical man was to play in public health administration was rooted in the theory that disease was a product of a deleterious environment. But

1. "Wotes on the hostile attibude of the college of hysicisns to the proventive work of the Board of Health", Wi, n.d.

3. B. - Norpeth, 16 October 1348.

4. E.C. - Southrood Smith, 11 August 1343. 
whatever the reasons -.. and to those just noted, we should undoubtedily add Chadwick's own superb self-confidence --- his attitude crystallised into the principle that the professional medical expert should be subject to lay administrative control. For this be advances two main arguments. First, he asserts that "the preventive remedies are not found in the pharmacopia of any University. They are not those which can be administered by the Apothecary; but must for the most part be devised, perfected and applied by the Engineer, or the Architect, or the professors of mechanical science.

rescriptions indeed in the shape of Acts, Administrative orders, and resulations gust be written out by the Legal practitioner". (1) Secondly, "it is of great importance to the public interest that the General Board of Health should be free to adopt at once whitsoever new views by whomsoever they are made out. The obstacles to the progress of medical science by fixed professional opinion is notorious. New views have their Greatest enenies in medical practitioners. They ruined Harvey; they were the most powerful obstructions to Jenner. Bxcept a practitioner have attained a towering position in fortune as well as reputation, he will if he consuit his own interest propound any new views stealthily. The lay Board have no cause to be afraid of injuring their practice or professional position --- private practitioners have no professional jealousy towards them: and communicate more ireely with them, than they usually will with one another. Unfortunately professional jealousy is more powerful than professional zeal: as they well know, and will commony prefer non professional arbitrators .... It is a well known fact that in the church the brightest ornaments owe their elevation not to Episcopal but to lay patronage. Nelson would never have got forward with a Board of old Adnirals ...." (2) The subordination of medical officers to the administrative civil servants, taus urged oy Chadwick, was to prove a point of contention for more than half a century after - 0 -

1. "Wotes on the hostile attitude of the Coliege of physicians to the preventive wors of the bosrd of lealth", Hs, n.d. 2. Iuid. 
the fall of the Generul Board of Health; and it was not finally resolved unt 11 by a Minute of August 1919 the Chief lledical Officer of the Ministry of Health was Given the pay and status of a Permanent Secretary without administrative functions, and was permitted direct access to the Minister in order to subeit proposals and discuss matters falling within his responsibility.

Meanwile, leaving Morpeth to soothe the outraged physicians, Chadwick was deploying his slender forces to meet the attack of tho cholera. The appointment of two medical inspectors, Dr. John Sutherland and Dr. R.D. Grainger, had been sanctioned by the Treasury, and of these one, sutherland, was ordered to sdinburgh to take the scottish towns in hand immediately, with instructions to set Boards of Bealth in action at Gateshead and sunderland as he pessed through. (1) The police and the Poor Law Commission were warned. A circular to the Bishops suggested that the clergy take the lead in calling the attention of the parochial authorities to the need for preventive reasures. Chadwick was engaged in preparing regulations for the medical inspection and purifying of suspected vessels (he had already been to the Board of Irade to "beat them up about shipoing"(2), when without warning sir wiliam Pyn, the arch-contagionist at the rivy Council office, clamped down a quarantine. "h new department is instiluted", fumed Chadwick, "it is ofgreat importance that it should be well ushered forth, ag its influence will be moral vather than legal, yet before it is fairly constituted, one of the first public acts towards it, is one of direct disregard, and binost of puolic contempt, of one of its fundamental propositions". (3) She quarantine was so much ink on paper -.. as in 1831, then alnost the only ships put under restraint by the cordon on the Wear had sailed from Dutch ports where no cholera cases had occurred. Lven if it weee not so casual in its adwinistration, it was too late. Ihe shipping interests appealed to the board

1. E.C. - Horueth, 5 Qctober 1343 .

2. Norpeth - i.C., 10 Oetober 1843.

3. B.U. - Jord ?, a.d. 
to intervene, and the medical officer of the Customs called on Chadwick to confide his own private opinion of "the flagrant absurdity of the whole thing". (1) But no answer cane from the Privy Council to the Board's remonstrance; (2) though in the end, when it was clear that cholera was already at work in both England and Scotland, Pym agreed to lift his quarantine.

The Poor law Unions, with their surgeons and fever wards, were better equipped to fight an epldemic than the vestry comittees and volunteer bodies of sixteen years belore.

But Chadwick, who a month before the appearance of the chulera had complacently reassured Lord Lansdowne of the strength of this new machinery of his designing (3), soon perceived that the legislature had comitted a grave error in entrusting the execution of the Diseases Prevention Act to the Guardians. Frorn their Board Rooms the Guardians viewed the needs of one class only, the destitute; they were now called upon to meet $y$ collective edergency which threatened all clisses, the ratepayex as much as the pauper, without any consideration for that important if indistinct line which marked of the respectable and self-supportiag from the disreputable and dependeat. They were designed as a breakwater to protect property againgt the rising rlood of pauperisa, and the master orinciple of their

administration was "to do nothing except on application, Bnd then only upon proof given of the urgency of the casen. (4) They were now akzed to forget their rate-books, and to take the initiative in seeking out opportunities for the exercise of their new powers.

i. E.C. - Morpeth, 17 October 1843.

2. inute, undiated, of October 1343. See also "Notes on the Privy Council administration on uaragtine end other Laws", lis. n. d.

3. B.6. - Jord lansdowne, 29 August 1843 "The new poor law Unions in England and rreland: the Union houses with fever wards; the union medicsl officers present the conveniences of a strong and improved local adninistrative machinery for meeting such calamities, which the public misht be reainded they did not possess when the cholera attacked the Country in 1331 and which they owe to the "his Jovernment".

4. "Report on the Epidemic Cholerg of 1848 and 1849 ", ए. 138. 
Most of them stuck in their poor law rut. "They could not comprehend the duty of searching for objects of relief". (1) Preveative measures were treated as common medical relief, to be given only upon the order of the medical officer, issued after inquiry and adjudication. where a portion of the workhouse was set apart as a "House of Reruge", the workhouse test was applied to those who sought adisision. "The majority of the Guardians" Dr. Sutherland reported after a visit to the Sculcoates union, "consists of couatry people who mould meet as often as you like, discuss for ever, and agree to nothiag". (2) In the towns the Guardisas wee usually too fully occupied with their existing functions to find time to master aew and extraordinary duties. when they did act, they dis so on the narrowest view or the situation. Not lintil cholera had unaistakeably appeared in a district would they order whitewashing and cesspool cleansing, and strengthen the hands of their mediesi officers. The execution of the Goneral Board's orders was generally postponed until the Guardisns hold their regular weekly meetiags, the only motive for delay that the inspectors could discover being "the hope on the part of the Guardians that the epicaic would have pessed before the orders were executed, and that therefore the expense might possibly be saved". (3) wen, lor example, the Board ordered the Guardians of st. George the Martyr, southwaris, (where the mortality from cholera was highe than in any aistrict except Larath) to uppoint three extra wedical sssistants, congideration of the order was put off from one weekly meeting to another; twelve days elapsed; and then the luardians resolved not to eomply. (4) It was in vain that the Board urged that expense could not be avoided in time of public calamity. "isoney must be spent either in saving life or in the naintenance of pauperisn, widowhood, and orphanage. In this case, economy is on the side of humanity, end the nost expensive fi all inings 1. Seventh Hotification, "Fendon Gazetce", 13 Gepteaber 1849 P. 2863.

2. J. Sutherland - E.C., 2 ctober 1343.

3. Seventh Hotification, p. 2636.

4. ibid. 
Is to do nothing ..... The parish of Lambeth, for example, was up to August the $27 \mathrm{th}$, already burthened with 61 cholera widows and 226 cholera orphans, who must for years remain a costly burtien on the parish. From a small court in Bishopsgatestreet, Peahen-court, the parish of st. Wthelourga had already received up to August 29th, one widow and twelve cholera orphans, whose malatenaace, untll they are able to provide for thaxiselves, will cost the parish, according to the estinate of a competent authority, not less than 2420 ; while a timely expenditure of 230 in putting the court in a proper sanitory condition would prooably have prevented the occurrence of a single case of cholera. The funerals of persons who have died of cholera in the metropolis alone have already incurred an expenditure of not leas than $650,000 "$. ( 1 ) Rigures, however, the Guardians of the foor continued to regard theaseives as the Guardians of the rates.

\section{As asrly as December 1847 Chadwick had sugsested that} temporary boards or comittees of Health should be organised in the localities to prepare preventive measures against the cholera. (2) Four months before the epidemis broke out he renswed his plea that the terms of the Nuisances kemoval and Diseases Pevention Act would surely permit the General Board to set up special Boards as had been done in 1332 - 1333. (3) The Law OPficers refused, however, to sanction this "large remedial interpretation". (4) the first and most obvious necessity was unity of action, cried Cbadwick, and the first and most obvious delect of the law was that such unity of action was impossible. At Edinburgk there were flve organisations doing the work of one, with alit the resultant delay, expense, and loss of life. At Hull two Boards of Guardian, a Cleansing $-0=$

1. Seventh Notification, p. 2363.

2. $x \times x \times x \times x \times x x x \times x \times x x x$ fonpeth tolz Ghadwick that "it is hardly opportune to organise and extensive temporacy uachinery, on the eve (let us hope) of subulting to Paridamenc a scheme of permanent le islation". (9 Jan. 1343). 3. "Memorandum as to provisions for the cholera", ks, 24 May 
Board and two bodies of Sewage Commissioners existed to do the work which eould be efficiently carried out only by one representative Board, or perhaps better by a selected Board specially appointed for the purpose. At Bristol "part of the Borough is under Local Act -.... part is in Olieton Union .... part in the Bedmiaster Union, and the whole is under a kayor and corporation". "ho are the authorities in such a case, who are responable for carryias out jour resulations?", the General Board was agked, "-.. and to vihom am I to apply and urge forward in the good work". (1) In aany places Town Councils and Improvement Comissioners pressed forward to take over duties from the paralysed hands of Guardians and parochial boards. isequently, however, such bodies wre unwilling to receive directions from the poor law offlcers. Where some arrangement for eo-operation was reacked, a divided power was created, and consequentiy a divided responsibility; and cholera sufferers died while their cases wery being referred from one authority to another.

A Purther weakness was that the Board's regulations were issued to $10 c a l$ bodies who were accustomed to look for orders to another department of the central Government. At Bunderland Dr. Sutherland's advice was passed over in the belief that he would not know so well as the Poor law Inspector what might and should be done. Chadwick at once wrote a letier of protest to Viscount Rbrington, sharp but "not undegervelly so", Norpeth agreed. (2) "In strict duty and in cases of emerisens there ought to be no waiting for consultations of internadate authorities who have and ought to have on such extrsorainary occasions any intermedite discretion. People sust not die that offlcial forms nay be gone through which are of no use".

In scotisnd there were neither Boards of Guardians nor a General Buard of Health. Chadwick proposed thot for the $\rightarrow-$

1. D. Guison - E.S., 4 Detober 1848.

2. Morpetr - 8.6., 13 Dotober 1848.

3. L.W. - Viscount Borington, 13 Oetober 1843. 
duration of the epidemic the administration of health measures should be centralised in Edinburgh -.. and promptly brought down upon his head a storm of local jealousies. "Glasgow positively refused: they would not be placed below Bdinburgh - - not they! Aberdeen refused subjection to it in terms of violent abuse: if they communiceted at a.11 it should be direct with London". A quaking deputation from Dumfries, where there had been 219 cases of cholera and 78 deaths, in the previous three weeks, waited on the Board in London to ask for the assistance of a medical inspector (2); yet, returning home, they promptly fell to bickering with the medical men of the town over the fees to be paid for their extraordinary cholera services. Ashley was for sending a sharp letter and a pereaptory demand that medical assistants should be appointed without too close a scrutiny of the bill. Chadwick decided on a more conciliatory course, and gent his best man, John Sutherland to talk some sense into the benighted parochialists. "Hy very spirit is crushed at the want of action of the people", he wrote to Chadwick after his first day in the town. "In all my experience $I$ have met nothing like it. Fair to look at and full of promises but no talk can be more empty. Anything but doing. The regulations of the Board appear to be so much waste paper". (3) He summoned a meeting of the parochial board "to insist on the immediate adoption of measures for extended house to house visitation. There is only a population of ten thousand, and it ought to be well done. I shall also insist on a large provision of medicines being placed in convenient situations, for the applicants by day and night. These are the great apparent ineans to be used: but in addition we must have a House of Refuge, which I an sorry to say has not yet been provided, although numerous instances have happened of more attacks than one in the same family". (4) After a week of sutberland's drive 1. E.C. - Andrew Boardman, $\mathrm{A}$. A.

2. Minutes, vol. 1, 5 December 1343.

3. Dr. J. Sutherland - E.C., 7 December 1348.

4. Dr. J. Sutberland - E.C., 6 December 1843. 
and force of character, the parochial board, deflated but thankful, saw the cholera retreating from the town. "At the first effort everything looks well. Our cleansing is going on and our cholera cases are diminishing. The committee of the Parochial Board will now do anything and I believe that both the General Board and I have their entire confidence and approval (with the exception of a recusant or two)". (1)

For fifteen months the tale of local inadequacy and shortsightedness went on. The medical officer of Cumnock complained that the parochial board refused to pay his charges for attendance on cholera cases.

The Kingston Union declined pointblank to appoint medical assistants or to publish notices of the provisions of the Public Health Act. (3) The medical officer of Culross, who had urged the parochial board to take steps to carry out the Nuisances Removal Act and the regulations of the General Board, was dismissed for his pains. (4) The Guardians of Redruth refused to reimburse their Treasurer for paying District Visitors during the outbreak. (5) Suming up his experience in fighting cholera and ignorance in a score of towns in England and Scotlend, Dr. Sutherland declared that the Sanitary Committee of Sheffield was "the only body in the country which had the enlighterment to perceive the full extent of their duty, and the courage and energy to perform it. This, I believe, was done without regard to expense, and in the firm conviction that apart altogether from the humanity of the course they had taken, the ratepayers would be large gainers in the ultimate saving of widowhood and orphanage which was, without doubt, effected". (6) The committee began preparations as soon as cholera was reported in the country; taking the Board's publications as their suide, they embarked on 1. Dr. J. Sutherland - B.C., 14 December 1343.

2. Minutes, 23 January 1849.

3. 1bid., 3 February 1349.

4. ibid., 12 January 185.

5. ibid., 25 Vebruary 1850.

6. "Report on the Ipidemic Cholera of 1348 and 1849 ", p. 107. 
a campaign of public cleansing, and consulted their medical officers about the preventive measures desirable. To this Sutherland attributes the fact that only 76 cases of cholera occurred in the town, though 5,319 cases of "premonitory diarrhoea" were discovered.

As the epidemic developed Chadwick became, as one friend described him, "the busyest and necessarily most inaccessible man in the empire". (1) Hardly a day passed without a meeting with Southwood Smith and Ashley at Gwydyr Bouse. There were deputations to be cajoled and hectored, notifications to be drafted for the official Circular, instructions to be telegraphed to Sutberland and Grainger, the Poor Law Board to be spurred to further exertions, the pretensions of Sir william Pym to be combated, another fat Report to be prepared to condemn root and branch that relic of pre-Chadwickian superstition, the Quarantine system. And when he had finished at Gwydys House, he hurried round to the offices of the Metropolitan Sewers Comission in Greek Street, and there plunged into the great debate on the sewerage of Jondon. On the 22nd Noverber 1848 Austin, the Secretary, told the Board, in explanation of a gap of a month in the minutes, that the pressure of business in preparing instructions, issuing forms, and attending to personal applications, "which had been as numerous and more pressing than the written applications", had made it impracticable to keep the Board's records in order. In January 1849 Chadwiek informed Lord John Russell that Austin was "overdone with woric" and Bain was "knocked up"; one Inspector had the premonitory syuptoms of cholera and another was down with fever; Lord Ashley was away to recruit; "and Lord Carilsle excepted, it nay be said the Board of Bealth is very unwell".(2)

But the most severe test was yet to cone. During the winter of 1348 - 1849 the most violent outbreaks had occurred 1. J.H. Burton - E.C., $23^{\text {O- Oetober } 1843 .}$

2. E.C. - Lord John Russell, January 1849. 
in Scotland, England escapine comparatively lightly --- perhaps, as Snow ingeniously argued, because the English did not drink much unboiled water in cold weather, while the scots used it freely at all seasons to mix with spirits. (1) As the weather grew warmer, however, the figures for cholera deaths in London began to mount. Between Westminster Bridge and Teddington Lock the river lay like a prolonged lake, into which poured each day the excrement of two million or more inhabitants; and with the ebb and flow of the tide, the stale water passed to and fro through london as the river regurgitated its filth. To protect the londoner from this poisonous mass no defence was raised except the half-hearted filter systems adopted by some of the Water Companies. The situation was not improved when the Setropolitan Sewers Comission, acting on Chadwick's belief that filth in the river was less dangerous than filth in the sewers, recomended that the sewers be flushed regularly into the Thames, so driving the cholera evacuations into the river at a spot just opposite the intake of the main water supply. The low districts of the capital might have been constructed by design to serve as a culture medium for the fostering and nourishing of the germs of the epidemic.

The cholera broke over London in two waves. In the first six months, from the end of september 1343 to the end of March 1849, there was a progressive but irregular advance, with 988 deaths, the highest weekly mortality being 94 in the week ending 13th January 1349. Throughout April and Alay the epidenic was dormant, but no. week passed without its deaths. In june it gathered strength, and the figures began to rise, reaching their highest point with 2,293 deaths in the week ending 3 th September 1849. (2)

Early in the spring of 1848 the Whitechapel Guartians had warned the landlords of their district in letters and personal 1. "On the Mode of Communication of Cholera", (1849), pp. 117-8 2. "keport on the Ipidemic Cholera of 1343 and 1349", pp. 12 -13 . 
interviews of the precautions which stould be taken to meet the advancing cholera. The landlords weighed the cost against their tenants' risk, and decided to let the tenants take their chance. In December cholera crept into a tiny dungeon of a cul de sac, called Hair-brain Court, which lodged 157 people in the 32 rooms of its thirteen houses. "In one house on the right side", reported the Union Medical officer, "a grandmother and grandchild were lald out with the funeral paraphernalia of Roman Catholies, while a husband, wife, and two chlldren lay side by side in the same room suffering from cholera. In the next house a woman was lying in the last stage of the disease, who died a few hours after .... There is a common privy at the end, and a channel runs down the middle of the court, under which is a drain, with branches right and left to the doors of the houses; but these, not commulcating with any sinis, serve as receptacles for the filth which flows over from the privy, as appeared by one of these branches then lald open for the purpose of being cleaned out. Many of the children were dancing about on the heaps of filth taken out of $1 \mathrm{t}$. There is no supply of water for any of the houses in this court, and the inbabitants have none but what they can "beg, borrow, and steal" from the neighbouring courts belonging to other landlords. It lies considerably lower than the level of the streets". (1) Seven years before the New River Company had driven a min through the court, but the landlords had ignored repeated pleas from the inhabitants to lay down house connections. "In another court, where the houses are in better condition and are supplied with water, were found -- a man lying dead in one house, a firl dead in the next, and a man dying in the cellar. This last poor creature was lying on a heap of chips and dirt in one corner, close to the foot of the steps leading down into it from the court, and his wife sat by his side or leaned over him. He bad been taken, last night, from a wretched lodging house in Hairbrain-court to St. Thomas's Hospital. There he was refused 1. "Times", 16 December 1348 . 
admission, and being unwilling to go to the workhouse could find no place but a cellar, without door or window. No persuasion could prevail upon his wife to suffer him to be removed. She said, while leaning over the body of her husband, "Give me some relief to-day and a coffin for him to-morrow". (1)

A fortnight later John Liddle, the medical officer who made these revelations, wrote frankly to the "imes": "under the present arrangement, it is almost impossible for a union medical officer, subject as he is to an annual election, faithfully to discharge his duties as an officer of health, in endeavouring to prevent disease by urging the adoption of sanitary measures, and at the same time maintain his independence. He must either be silent upon the subject of the physical sufferings of the poor, and allow the most disgusting and degrading state of thimgs to continue, without raising his voice to ameliorate them, or he must resign his appoiatment".(2) In making the Union surgeon the key to their administrative arrangements, the Board of Health had rightly turned to the one local officer with the necessary knowledge and skill, thereby earning for their decision the rare commendation of the "Lancet". But the Union surge on took his orders from the men who paid his salary, and his usefulness was limited by the intelligence wath which they directed his activities and the willingness witb which they provided additional assistance during the period of emergency. Between the intentions of the Board and the will of the locul authorities lay a chasm which was not bridged either by the slender powers which the Board exercised under the wisances Act or by the good sense and public spirit of the Guardians. In the worst districts the Union surgeon strugiled to stem the mounting flood of cholera and diarrhoes cases, and was lucky if be could get his masters to appoint an assistant or two to dose the sufferers. After eighteen years of service the medical officer of Lambeth sent in his resignation in disgust, and then 1. "Times", 16 December 1348 .

2. ibid,, 29 December 1848 
sat down at two o'clock in the morning to write to the "Times": "During the week ending July 31, I and my two assistants, appointed under direction of the Board of Guardians, from an order received from the Board of Health, have attended 322 cases of illness among the poor of my district, requiring 1,023 attendances to be given at the houses of the poor, and at my own surgery; 59 of the cases wre cases of Asiatic cholera in its different stages, and 141 were cases of diarrhoea and ordinary cholera: for this duty my salary amounts to $39 /-$, or 8100 a year, which is not quite three halfpence for the medicines required by each case and ny own services. (1)

House to house visitation, Houses of Refuge, home nursing, remained luxurious refinements, which, since the Guardians refused to vote the necessary money and assistance, were introduced into a few districts only. With few exceptions, the London Guardians neglected to make a list of the localities in their pariskes which had been attacked by epidenic and endemic disease. On the very evening that cholera broke out in whitechapel, the Guardians resolved that the Board's order "need not be acted on in this Union"(2); and three days later, when their cleris laid before them a list of the places where zymotic disease was then prevalent, they resolved further, "That the clerk forward such particulars to the various local boards in the Union, but that the medical officers be notcalled xupon to visit the places in question". When the Board ordered the St. Pancras Guardians to appoint four medical visitors, they were met by a flat refusal, the Chairman observing that house to house visitation "was calculated to do more harm than sood, from the alarm it created". (3) Brom Bethnal Green they received the following weekly returns of deaths: - August 11th 35, August 18th 125, August 25th 127. They prompty issued a special order directing the provision of suitable hospital accomodation 1. "rimes", 4 August 1849 .

2. "Report on ..... the Hisances Removal and Diseases "revention Act", p. 28. P.P. 1849 (1115), xxiv. 1.

3. "Times", 26 September 1349. 
and a dispensary to be kept open day and night in each infected locality, and the immediate appointment of four medical

visitors, one additional medical officer to aid in treating cholera cases in the infirmary, a sufficient number of nurses to take charge of the persons attacked, two inspectors of nuisances, and a staff of lime washers. Dsepite the emergency, the Board of Guardians appointed no medical visitor for five days; they provided no nurses; they established no hospital; they opened no dispensary; they appointed one inspector of nuisances instead of two; and they took no steps for extensive and effectual lime-washing. (1)

Nothing showed up moxe grimly the crass negligence of the Poor Law authorities than the outbreak at the Tooting child farm. Here 1,395 children wre housed in a building 700 would have filled. Cholera went though the close pacised pauper children like fire across a dried prairie. 300 had been attacked, and 130 were dead, before the Guardians listened to the Board and withdrew their children from the plague spot. Eight days after the epidemic had broken out there were still no separation of the sick from the healthy, no sufficient medicine or medical attendance, no nurses, and scarcely enough assistance to remove the dead; while the survivors still tossed and gasped three or four in a bed, infection spreading from one to the other by the involuntary dischargesof the cholera sufferers. Chadwick sent one of the medical Inspectors (Grainger) to investigate; and, as soon as it was reported to him that the cottages used as the boys' dormitories were built over a stagnant ditch which served as a sewer for the whole establishment, he despatched an expeditionary force of fifty navvies armed with pick-axes and scoops. (2) Wakley, the Finsbury Radical and proprietor of the "Lancet", conducted an able and exhaustive inquest, which lasted three weeks, and laid 1. "Report on the Epidemic Cholera of 1343 and $1849 "$, pp. 111 2. "Times", 8 January 1849. 
bare a soandal which did almost as much as the green bones of Andover to discredit the Poor Law administration. A pathetic procession of child witnesses testified that they wore the same scanty clothing in summer and winter alike; that there was sometimes not enough bread to eat, and such meat as was provided went to those who were strong enough to fight for it; that the hungry climbed over the palings to pick broken victuals out of the hog-tub. (1) The medical inquirers found that many of the children were big-bellied with scrofula, and covered with the eruptions of scabies and the itch. The verdict declared that the victims were "suffering from the effects of insufficient diet, deficient warmth of clothing, and impure air". It was a verdict less against the cholera than against the poor Law authorities, and in contrast the Board of Health, with its energetic and prompt action and its recommendation of a generous animal diet, came well out of the affair.

In the City of London itself, with its devoted garrison sworn to the defence of local self-government, the Board were fortunate to find one powerful ally. In January 1349 the recently elected Medical Officer of Health, John Simon, read his first report to the City Comission of Sewers, assuring them that their. new Act gave them "as good an antidote for the spread of fever as vaccination is for the infection of smallpox". (2) When the city of London Union refused to obey the Board's order to appoint nine additional oflicerg, Simon persuaded the flealth Comittee of the Corporation to set up a board of inspectors to conduct house to bouse visitations. In their first round they discovered the bodies of six cholera victims who had died without any medical aid watever. But opposition was strong on the Court of Common Council, and the "wimes" believed that portions of Simon's reports were suppressed. The City should be proclained safe, declared Alderman sidney, because all this talk about cholera had caused 1. "Times", 20 January 1349 .

2. Ibid., 24 January 2849. 
thousands of families to flee in panic, and in consequence shopiseepers were "paying hundreds a year for their premises, and only earning 6d. per diem by their trade". (1) One member of the City Comission of sewers objected to the "spicy, unctuous articles" in the "Times", while another was snnoyed by the practice of "handing over a heap of complaints to the press". Lacking the co-operation of the metropolitan Guardians, the Board of Health, with two medical inspectors to cover the whole of England snd Scotland, were helpless. Without the power to originate prosecutions for neglect or violation of their orders, the Board had no direct control over the Guardians and it was only through the indirect and uncertain result of a coroner's inquest, such as that conducted by Waisley at the rooting institution, that they could brine pressure to bear on the poor Law authorities. In vain the Board lectured the Guardians on their responsibilities under the Common Law, warning them that they were legally accountable for neglect involving injury to health and life. They debated the advisability of instituting proceedings against the more flagrant offenders. The powers of the Board of Health, argued Chadwick, were in fact a continuation of the authority of the Privy Council to take all necessary precautions in times of public darger. The authorities, from Blackstone to professor lang, were clear that the Poor Law Guardians as a corporation were not immune from punishment for infractions of the law. (3) But Lord Carlisle advocated caution. "As to prosecution, I think we ought to bear this in mind", he told Chadwick, "Boards of Guardians are rather impsipable bodies, not paid, and I think there would be a risk, if they were proceeded acainst actually, that they would throw up their appointmentis. Their liability might remain, but would not great confusion be the consequence?" (4) -0-

1. "imes", 8 October 1849.

2. ibid., 10 October 1849 .

3. Minutes, 24 August 1349.

4. Carlisle - B.C., 25 August 1849. 
Sventually, however, they determined to test their strength before the courts, taking a stand on their decision to close the worst of the overcrowded graveyards. The amended Nuisances Act of August 1349 empowered the Board to laquire into the atate of the inetropolitan burial grounds and to direct the managers to take such measures of precaution as were necessary for the public safety. (1) The Board at once sent the medical inspectors on their rounds, and by the second week of September burial had been interdicted in half a dozen of the worst erounds. The orders roused violent opposition. (2) A tumultuous vestry meeting in St. Saviour's, Southwark, resolved that the closing of their churchyard would be a hardship to the poor, who would have to pay double the fees to be buried in a distant cemeterg. "Why did they not comence at the right end, and before closiag one place point out another in which these poor people could be buried?", asked the Chairman, while another speaker "deprecated the meddling of a whig Government, and inceed of any Covernment, in their local affirs". (3) The Chairman of the Board of Guardians of st. George the Martyr, Southwark, declared "they might as vell send an order that no more people should die in the parish as atten to close these grounds. During the last two months the burisls had greatly increased in number, and if these grounds were suddenly closed before any arrangements were made elsewhere, what would they do? All the poor people would then come to the parish to bury their friends, as they would be unable to bear the expense of removing them any distance from town. (4) The vestries, in fact, were 1. 12 \& 13 Vict. c. 111, sec. ix.

2. Conditions in the parochial grounds may be illustrated by the figures for burials in the churchyard of St. George the Martyr, Bouthwark, (one-third of an acre in area) in the previous twelve months ("Times", 21 september 1849): -

1848: Sept. 12, Oet. 23, Nov. 23, Dec. 25.

1349: Jan. 33, Heb. 22, Har. 23, April 20, llay 16, Juae 23, July 65, Aug. 141.

3. "Times", 12 September 1849.

4. 1bid., 21 September 1349. 
moved less by commiserstion for the poor than for the poorrates, and by the fear that the wealthy parishioners would lose the fees they had paid for burial vaults in the parish church. themselves

The Board of Fealth stiffened Xkaxx to meet the protests of outraged parochialists. "we must refuse at once to receive any Deputations, or Committees, or any form of kesistance to our Grave-yard Orders", Ashley told Chadwick. "he must not parley; the necessity of action is immediate, urgent, paramount to all law, right or interest. At once refuse to receive Deputations, and direct Lav to act instantly. I will take any amount of responsibility". (1) a general hinute on Interments recorded the soard's inteation "to act solely upor the Report of a qualified laspector". "They cannot consent to aubject the Public fiealth to the mischief that would arise from the delays of a recewed discussion. It is their duty not oniy to lay down gesersil rules, but also to give sumacy decisions, which to sccomplish their object must be delivered with promptitude". (2) "I am amazin ly pleased with our Resolution. I chuck.le over its stile", Ashleg told chadwick. (3) Proceedings were taken $-0-$

1. Ashley - E.C., 12 Septenber 1849.

2. inutes, 13 September 1349. Chadwick wrote to Delane (15 September 1349) to explain the reasons for the resolution. "had they heard the parochial deputations, the closings which have been effected in two days would have required several weess or perhaps two months. On each wase the question would have been opened and the whole of the evidence taken and exhibited in the report on the practise of interments put forvard again. Thoy would have brought forward chemists and medical men who would have declare that they did not believe tiat exanations from human remains were injurious. They would have brought forward a ruddy sexton as the Rev. Dr. Ryler did, in proof of the salubrity of their particular round, the curate also would bave been orought forward, to say that he bad received no harin. In cross examination it might be got out, thet the curate read the service not over the grave out at a respectable distance from it. I myself the other day observed a poor man's burial, the poor people standing at the edge of the grave, and the ruddy clergytan reading the service at such a distance that I am sure the mourners could not have heard one word of it, or only confused sounds".

3. Ashley - 8.C., 14 September 1849. 
immediately against the rebellioug parish of St. Saviour's, but the magistrates upheld the churchwardens' contention that the Act did not empower the Board to close their burial ground. "Nevertheless we have acted rightly, boldiy, wisely, "Ashley maintained. "I never thought that out interpretation of the Law would stand before a Magistrate. But public opinion and feeling demanded such an act of Heroism on our part. We can and must urge very strongly the public overruling necessity of our course." (1)

A becoad time the Board went to law, sumaning the managers of the Whiterield Chapel burlal srownd before the Bow Street majistrate. The sumons was again alsmiesed, the magistrate giving his opiniva that the measures of precaution contemplated oy the Act must be such as "buxyiag leeper in the ground, abstaining from puttiag one cofin upon another, using lead coppins"; "at any rate, they could not be held to imply the destruction of the property altogether, which would be the effect of enforcing the order". Ihe two counsel and the magistrate united in denounciag the new Act "as one of the most lamentadle instances of legislative buagling that they had ever met with". (2) In this way the local authorities wrisfied through the wide meshes of an Act whose inderiniteness of phrasing had been intended to broaden the discretion of the Board. "This is intolerable", cried Ashley, after reading the magistrate's decision, "-- private property must not be turned to public injury". (3)

The Board were now driven to issue xugulations prescribing the use of quickline at each intermeat. It was the 1. Asniey - b.C., 13 september 1349. "t canot concur in not pressing for a decision. It is, I talnk, our cuty to do so, that we ary show to the couatry, the leebleness of the waw, and the obstacles opposed to ow progress. e shall otherwise be misundersiood and misrepresented. I feel very strongig on this; and I am convinced that it is necessary for cur case belore the Bouse of Conmons"

2. "Times", 28 fieptember 1849.

3. Ashley - h., I Detober 1849 . 
only disinfectant avallable, and it had objectionable associations, Cbadwick confided to an unusually sympathetic Delane. "At this time the populstion we know are peculiarly excitable the poor Irish especially. The belief has not gone out, that the doctors sre poisoniag the wells. At St. Andrews the other day there was a disposition to riot on this ground; that the doctors were poisoning them to diminish the population, and that the Goverament had sent down an Inspector with the beneficent object of preventing the victims being carelessly or wantonly chosen". The parish gravediggers and sextons, who felt that their livelihood was in jeopardy, Were not likely to restrain this feeling; but the Board, having only a handful of overburdened ofricers, were oblised to work through these ignorant and unwilling agents.

"Our arfairs are eomine to a crisis", xrote Ashley in the second week of september, "The Wabistrates against us, no Courts sitting, the preasury backward ..... It will be necessary to report to the Goverament that the Board has no power equal to the terrible ixigency of the times". (2) In the middle of a long vacation, the only effective suthority left in Iondon was fighting a pestilence with an ill-written Act s.nd a scenty, inadequate staff. Under the burden of that heavy and anxious time, the secretary, the assistant secretary, and southwood Soith fell ill in turn, and finally even Chadwick weot down with suspected cholera. (3) for a wees or two at the height of the epidenic Asaley continued the fisht siagle-manded, wresting in prayer with God and the Goverment. "Labour and anxiety at Board of llealth very grest", be noted ia his diary on 7 th september. "wo axe now ia the dity of the lague, and still by God's love under his shield and bucklet. Fe hears our prajers, and defends against the "lestilence that walketh in darkness". Disorder increasing; close of last week showed a mortality 1. E.C. - S.I. Delane, 15 September 1849.

2. Ashley- 13 september 1349.

3. B.C. - Coi. Phipps, 1 Tebruary 1850. 
trebling the average of London; 1,381 victims of this awful scourge! Yesterday showed for the metropolis alone, a return of 345 in one day ....."(1) "Iondon is emptiea", he wrote two days later. "Cholesa worse than ever; returns of yesterday quite appaling, and yet marifest that we do not receive more than two-thirds of the truth". (2)

The inactivity of the clergy dismayed Astaley.

Thitewashing and opiates and strict temperance were well enough, but surely this was a time when the pious example of the Ninevites in proclaiming a fast and putting on sackcloth -.which had such excellent results -- might be profitably followed. In the Bishops' professional judgment, however, the emergency, grave as it was, did not call for measures of this drastic nature. A special prayer was read on the l6th September, and the clergy of London, with hardiy an exception, gave a practical turn to their djscourse on cholera, exhorting their congregations to assist in deljvering their fellow-men from the bondage of dirt. It was"a poor substitute for a day of repentance and humiliation", Brumbled Ashley (5); but there was a gratifying decline in the mortality in the ensuing weeks. It was a curious survival of the ancient belief that epiderics were the direct action of deity, visicing the wicked with misfortune and disesse. Sinful man could siways think of some perfectiy good reason why be should be 30 punished.

If ever a Government department was in need of prayer it was the Treasury in the grim weeiss of that sentember when the cholera score in the capital was mounting daily by hundreds. Sir Charles hood was a timid Chancellor of the Gxchequer, whose dread of expenditure was almost pathological. The oaralysis of 1. I. Eodder, op. cit., vil. 2, 2. 225.

2. ibid., p. 296 . "Irom many places we receive no returns. There is the greatest elfort made to suppress all reports from watering-places on any places of trade or public resort" (Ashiey - Bir George Grey, I Septeaber 1349, 1bid., p. 239).

3. ibia., 300 . 
his Inhibition spread downwards to the permanent officiais who conducted Treasury diplomacy with the minor depariments, and the wide vision of an ingland elean and healthy soon coniracted in the tortuous chancels of Treasury accountancy. At Solnerset House Ghadwick had already had experience of the obstructive tactics of the Ireasury, but he was startied by the extent and nature of the obstacles which were now thrown in the path of the new department. Ihis was the moment, when the staff was depleted and ongrossed in the public emergency, that the Treasury chose to demand that the Board send in its accounts, adding that until they were made up the quarterly payment of their earliamentery grant would be suspended. Chadwick and Southwood smith were obliged to pool tbeir salaries to pay office expenses; (1) while Ashley was furious that the reward for all their labous was "to be treated as Swindlers and Vagabonds". (2)

When an urgent appeal for a inedical inspector was received from sewton, Hontgomeryshire, the Board replied that they had so many demands Ior aid that they were obliged to take them in rotation accordiag to the prlority of application. (3) Yet a fortnight later the rreasury refused to sanction the appointment of additional inspectors. The proposal should first be subitted to the Home Secretary, said Sir Charles Trevelyan. The Board replied firmly that "the statute under which the Board is constituted sives no jurisdiction over its proceedings to the Home secretary".

"Should it bappen that the secretary of 3tate for the Home Department was of opinion that certain measures recommended by the board and coming within their proviace, were inexpedient; and, if the Board ia deferenve to that opinion, were to refrain from executine those measures, and loss of life or other calamity were to engue, the quesiton would arise, --- would the opinion $\dot{0}$ the Hone secretary exonerate the board irom

1. S.C., "Administrative.

Relations of the

General Board of

Health with the rreasury. inutes for a paper on", Ms, n.d. 2. Astiley - . . 2. 25 dotober 1849.

3. Minutes, 6 August 1849. 
responsibility?

On the other hand if the Board were to adopt the views of the Home Office in opposition to their own opinion and injurious results followed, they do not consider that they would be exempted from the responsibility of such results.

In cases of emergency such as the Boarc have to deal with, it is necessary for the sake of promptitude that multiplied references whould be avolded; in adition to which, division or confusion of responsibility is detriantal to the puolic service, and more especially, if references are thade from a body specially iaformed, to one that has no special information whateoever on the subjectu. (1)

The Ireasury reply was to sanetion the appolntment of one medical inspector and four assig fants in london -.- for a fortaight. (2) on 7 th september Bain had an interview with Hayter, the secretary to the iressury, in an attempt to secure approval for the employment of additional District Medical Superintendents in Loxdon; Hayter expressed dowbts whether the soard had the power under the Nuisances Act to make such appointments, and declined to give any answer until he had consulted the Chancellor of the fxchequer. Ihe deaths in London were then approahing 500 a day. Aabley, the only nember of the soard of Health still on his feet, went over to the Ireasury to request an immediate consent to the appointaents, but ne covid find no one there. Returning to Gwydyr Eouse, he recorded. In the kinutes, "that ax the smallest delay in making the aecessary appointwents in the present emergency must be prodictive of serious injurg and loss of life, the appointments be now rade, in the hope that the lireasury would see lit to sanction them". (3) He notified the Ireasury imediately by letter of his action, but no reply care - - ili six months Latex, when the Board were reproved in frong terms 1. Ninutes, 23 August 1849.
2. ibid., 24 August 1849.
3. ibi3., 7 Se terber 1349. 
Poz making sppoincmentg hot only without the consont of the Ireasury but without previousiy informing then. (1)

Shus, eleven months afver the cholera kad appeared in London, the Bosrd of Health in exasperation threw of the reins of Ireasury restraint, and on their own responsioility engaged the services of a surficient nuber of medical men to comb out the stricken distriets. Al length, with a stafl of eight superintendents, wad such medical visitors acting uader them as the Guardians could be laduced to pay for, the system of visitition was brought finto operation in the first week of septenber ij49, when the weeirig deaths smounted to 2,026. In the first noek the four visitors in Bethral. Green discovered 1,571 cases of dlarrhoea and 69 of cholera -... everg one of which had been without any inedical assistance orevious to the visitation. Altogether, in the elght weaks the system was in operation, the Board's oflicers discovered and treated over 45,000 ceges of diarthoea and cholers. (2)

With the diminution of cholerd in London, the starf of medicel assistants was ceduced, and the duily agenda of the Board gradually lost lts sinosphore of fearoul urgeagy. It had been a sharper lesson then that of sixtecn years before. Ia tondon it 1831 - 1332, out of a population of 1,031,64t, 14,144 had been attacsed an 16,129 had died; is 1343 - 1849, out of a population of $2,200,076$, the attacks nimoered 30,000 and the deaths 14,601. Dver the whole sountry 1 in 250 had been attacred in the first epidenic, 1 ia 151 in the gecond. In tngland and wales in 1331 - 1332 the attaoks had aumered 71,606, the destins 3.6,437; in 1343 - 1349 the deaths alone from cholera and dismpees were 72,180 , and scotland contributed a further seven or efint thousand

1. B.C., "Ininistrative. Relations of the General Board of Gealibir with the Profusury. Minutes for a paper on", is, a.d.

2. See foot-note, p. 364 .

3. "Report on the Bpiaenic cholere of 1343 and $1849^{\prime \prime}$, pp. 11 12. The Report estimates the deaths from cholera alone in 1943 - 1349 at 60,000 20r the whole of Great Britain. 
The hand of man had done little to stay or divert the course of the epidemic. Hippocrates ilattered himself that he had brought the plague of Athens under control by burning fires in the streets. Phere is the same confurion of 'post' and 'proptex' in the Ceneral Board's appraisal of the methods they adopted against the cholera. Iine-washing, cesspool cleansing, all the Board's earnest exhortations to shun filth, did not deny access to a waler-borne wicrobe. In the perspective of later knowledge, It is easy to see that the Board, instead of prosecuting reluctant churchwardeas and Guardians beiore unhelplul ragistrates, woula have been beiter employed in cireularisine the public on the noed to boil their water, and in elsuring thet the companied filtered their supplies. Not until their seventh and last notipication, puolished on 13 th September 1349, did they suggest that water suspected of contuining impurities should be boiled. In wudon they did prubably more ham than good by thein advocacy of regular liushing of the sewers into the Themes. Belief in tire spontiveous generation of epidanice feora ilct, ani in tre funa entai laenity of the diseases so fenenated -- these twh tedical hesester were propasated by the soard ticough the selium of its Reports and its energetic laspectors, heaviaz an inpession on propessional pracilea whica was atil 3twar forty jears later. John Gimon refised to accer toch's garm theory till 1390. Blorence lightingale thought that conthaued Pever aight levolog into small-pos. Ghadwiok Listioged with scocn the possibility of tre"existence of diseased germs, a rere hyotresis"(l); and a few nonths before his deut cannot tell you how etrongly I believa ha sodp and dater as a prevenuive of epidenies. If gu epitegic were to gocur, I nould proctelas and enforco the active applicution of sus, and water as a preventive. "(2) There are plenty of texta here for a sermon $-0-$

1. kn memoransum, n. A.

2. "ieakjy Dispatco", 13 Julj 1390. Chadvick continued: "I do so believe in fresh air. Vy pet project, at which a correspondent in the paper laughed some tine ago, is to bulld great towers in our citios, and pump down the ozone Irom above". 
on the unwisdon of our ancestors in their generation; but in recognising the wrong-headedness of the public health reformers, we must not under-value the empirical sanitation which they championed. Unable to confront an enemy they could not see, whose existence indeed they did not suspect, Chadwick and his eagineers were well occupied in cutting his lines of communtcetion.

Ilithin the linits of their power the General Board did what they could in 1343 - 1349, and they vould have done much more if the preasury had let them. In many of the dark places of the capital, in Haicbrain Court, and slater's court, and Rosenary Leno, jets of water from the parish fire entine, or fros a hose attached to the nearest stand-pipe, played on walls and pavearent, anl purged divay their scurs of $\mathrm{lilth}$. Grainger and sutheshand, the aedias. Inspectons, were enthusiastic over the results of the house to house visitation, which they considered hal proved so effective a safegurd of the poor that "Beveral lamentable justances occurred in which the wealthier classes perished vihile the poor vere saved". (1) whe Government urdoubtealy gr.ve the problom $a p$, and its nembers revired to the country until the epidemic was spent. The 3oard stayed in wondon to fight; and at the least their activity did gomething to spread the belief that opidenics coul be halted if energy and knowledge were applied to the task. It vas the first General effort that had been made to fivestigate and put right, by the direct agency of medical men, the senitery evils affilcting the borking cliases, and the peosle reveiled a touching sratitude, not uningled with astonishment, at receiving visits of succour from the busting, officient officers of the boara.

"The boaxd of llealth they hope littie, tad periaps desire Iittle, for the epplause of men", wrote Ashley in Lis diary, after reading an epprovine erticle in the "swervor", "but I do $-0-$

1. "keport on the Lpidewio Cholets or 1343 und 134y", p. 103. 
much deplore that our anxieties and labours should be thrown away, and we be told that we have done nothing, atterpted nothing, imagined nothing, wished nothing. Our diligence and zeal are mentioned in the aricie; yet it is less than justice. We have indeed tolled uncessingly, and not as mare officials, but with earnestness and feeling. Chadwick and Snith are men who may feel, but who show not fatigue or satiety in business, when necessitg urges, or ducy calls. As for the staff of the Board, cisersbly paid as they are, with scanty hopes or preiernent, or even of continued employment, I am unable to spear with adequate praise. Shey have laboured even to olikness, and ween biruck down by the disease, have hastened back to theif work, not for molument (for they receive rixed salaries), but for coasclence sake. Aad such are the mea whose scanty reconpense certain geatry would roduce oj 10 per cent. out upon this disgugting econoxy!" (I)

The crisis had revealed sharply the weaknesses and anomalies of the Board's position. For all that their enemies protested, they were no Inquisition with supreme powers to reclaim the sanitary beathen. Ihey did not possess the aggressive veapons needed to combat local privileges and property rignts. It was unrorsunate for the Board that the pestilence was in full retreat lons before parlimeat reassemoled. "We uust, if we can, keep up the spirit of physical reform", Ashley told Chadrics. "he cnolera, thaak tod, has passed -. is not the naolesome fear passing also...(2) The transicory lesrs of the majority had deer the force which drove the sanstary measur s through partianent; the steady and permaneat inceresis of minorities now opposed their applicetion and extension. In the days of security men forgor their irenors and the old errors which had brought disarter upon them, and few rememoered the exertions of a hach-pressed coard save the srateful dwellers in the bacs atreets, who vere inarticulate and the outroged parochialists, who were sar too vocal.

L. E. Hodder, ov. cit., vol. 2, 0.296.

2. Asnley - E.0., $2 y$ october 1043. 


\section{CHAPPER 11.}

\section{GREEK STREET, $1948-1949$.}

Here in London, Chadwick Pelt, at the very doorstep of Gwydyr House, was the tough contre of the sandtary problem. If life in the towns of tha industrial North was even more squalid, and health, as the mortality rates showed, suffered even nore, 1.t was in Iondon that the evils which he had indicted were massed and concentrated on the largest scale in the physical discomfort of a population of two millions; and the greatest strength of the opposition, the alliance of property and particularism, of shareholders and vestry politicians, was here entrenched. Before the end of 1849 the General Board of liealth had in hand two major measures, for regulating the interments and the water supply of the capital, the story of which will be told in later chapters. From his other base, at the ofrice of the Netropolitan Comission of Sewers in Greek Street, Chadwick since 1847 had been attacking a further aspect of the metropolitan problem -- the main sewerage of London's 170 parishes and the donestic drainage of its 300,000 houses.

The first recessity wae a general surveg, wlthout which the main erteries of Jondon's drainage could not safely be laid down. No asteriale for such a survey were to be found in the offices of the old Sewers Comissions, and the surveyors' deep ignorance of the subtemmean geography of their districts was perhaps the most daming indictment of their casual, piecemeal methods. As Chadwick bad informed sir James crahum in 1343 , they had "only longitudinal sections and heigkts of their lines of sewers and if they deviate from them, they know not whether it be into a pit or upon a hil.1"; in fact, the westminster Comission had granted a license for laying down a sewer "in a direction in which it was found when the builder came to examine 
the spot, the water would have to run uphill". (1) When Chadwick's men, probing the cause of a violent outbreak of fever in Westminster School, opened up a great sewer running beneath the Abbey Precinct, the Clerk of the Works was astounded. "It is all a mystery", he murmured, "drains being things he never troubled himself with, so long as the water went off". (2) It was less than five years before that Chadwick had been asiked by Butler Willlams, Professor of Geodesy at the Putney College of Civil sngineers, to describe what special requirements would be called for in a sanitary survey. The idea was as new as that; and it was with some misgiviags that he now put the survey of London into the hands of the Board of Ordnance, which was then engaged on a survey of all towns with a population of 4,000 or more on a scale of five feet to the mile. The Ordnance, whose officers had been busy over a period of years in the work of self-reform, was a department of which Gregory Hardlines, the Civil Service Pharisee, might well approve, but its pace was too leisurely and its departmental habits too rigid for the task now demanded of it. Patiently Chadwick and Sir Henry de la Beche explained their views on sanitary cartography to Colonel Hall, the Superintendent of the survey. All that was immediately wanted was the triangulation and the levelling, which need occupy six N.C.0.s no more than eight months. There was no need to delay drainage woriks while the ordnance, intent on making a plan which would be "a credit to them", marised gardens and flower beds, trees and lamp posts -.. and even the number of steps before every house door -- as they had in their recent map of Dublin. A block plan, at a cost of 237,000 , of london and its suburbs for eight wiles around St. Paul's would be quite sufficient. (3)

Chadwick had good reason for his delight, when the

1. E.6. - Sir James Graham, 27 Warch 1843.

2. Metro. Sanitary Commssion, Third Report, p. 14.

3. E.6. - Morpeth, 4 January 1349. Also "Report on Proposed Ordnance Survey of the Metropolis and Suburbs", by B.C. and Sir Henry de la Beche, 10 January 1348; "Orders of Court",
vol. 1 , pp. $24-26$, I'3 January 1848. 
military surveyors hung up their "cat's cradle" on St. Paul's in January 1848, and people turned in astonishment to see common soldiers using theodolites in the street. (1) But in two months the work came to an abrupt halt. Why should the whole country bear the expense of a survey of London, the Commons were asking, a survey which was quite unnecessary in any case? (2) Faced by a combination of provincial jealousy and metropolitan bostility, the Government declined to sanction any further advance from the Treasury. Lord Morpeth, who had assured the Sewers Commission of the Government's support, offered to resign from all his official positions (3), but was talked out of it by Chadwick; and eventually it was agreed that the cost should be borne on the metropolitan sewers rates. (4)

Three months had been wasted by the political manoeuvring of the Whigs, and it now seemed likely that the survey, stripped though it was to bare essentials, must take at least another year. (5) How was the Sewers Commission to occupy itself in the 1. "The Ordnance men are on the ground, some of the Sergeants in uniform have been seen looking out at steeples, and Sappers and Miners are in the Streets": E.C. - Morpeth, 20 January 1848.

2. Hansard, vol. 97, pp. 1014 - 17, 2 March 1848.

3. Morpeth - E.C., 28 March 1843.

4. "Orders of Court", vol. 1, pp. 49 - 51, 1 April 1848.

5. E.C. - Morpeth, 2'June 1848. In a speech to the Sewers Comission ("Tímes", 3 April 1848), Chadwick declared: "There are no public procedaings more discouraging to those who would labour for systematized and economical administration, whether local or general, than the whole proceedings in Parliament in relation to the general survey. It is a work which as the security for the identification of properties must be the foundation of fair valuations, equal assessments, and collections of local rates and taxes upon them ....." He revealed that he had urged the importance of a general survey for the more guat fair and equal assessment of the poor-rates, but his proposals had failed, with the result that both charge and collection continued to be oppressive. At the time of the tithe commutation, he had supported Captain Dawson in again urging the value of a Beneral survey, but the idea had been rejected by the landed gentry in the commons. He believed that if a survey had been carried out before the railways had been constructed, fifteen millions would have been saved. 
meantime? In two ways, thought Chadwick: lirst, in experiment, for in sanitary works there were no authorities who could safely be followed; secondly, in creating house drainage where it did not exist, and in reorganising it where it did. The lines and outfall of the main drainage could not be settled until the survey was complete, but, after all, the combined area of the smaller conduits of the system of sewerage was greater than that of the trunks, as the area of the capillaries of the body was greater than that of the main arteries. The cesspools and the house-drains formed three-fourths of the evaporating surface, the sewers only one-fourth. If the Sewers Commission busied itself in abolishing cesspools and replacing them with waterclosets, in taking up the badly levelled brick drains and laying down in their atead earthenware pipes, cleansed by adequate supplies of water, the mephitic exhalations which offended the noses and depressed the health of Londoners would largely disappear. In short, they should aim first at "the complete drainge and purification of the dwelling-house, next of the street, and lastly of the river". (1)

What this meant in concrete terms of human comfort may be illustrated frow the example of the cleansing of Church-lane and Carrier-street, a part of the former "Rookery" of St. Giles', where 2,850 people were crammed into 95 houses on a space of little more than an acre. Amongst the genteel correspondence of the "Times" there appeared one morning a erude, misspelt note:

"The Bditur of the Times Paper.

Sur,

May we beg and beseach your proteckshion and power, We are sur, as it may be, livin in a wilderniss, so far as the rest of London knows anything of us, or as the rich and great people care about. We live in muck and filthe. He aint got no priviz, no dust bins, no drains, no water splies, and no 1. "Times", 4 October 1849 . 
drain or suer in the whole place. The Suer Company, in Greek Street, Soho Square, all great, rich and powerfool men, take no notice watsomedever of our cumplaints. The Stenche of a Gullyhole is disgustin. We al of us suffur, and numbers are 111 , and if the Colera comes Iord help us.

Some gentlemans comed yesterday, and we thought they was comishoners from the Suer Company, but they was complaining of the noosance and stenche our lanes and corts was to them in New Oxforde Street. They was much surprized to see the seller in Number 12, Carrier Btreet, in our lane, where child was dyin from fever, and would not beleave that Sixty persons sleep in it every night. This here seller you couldent swing a cat in, and the rent is five shilling a week; but theare are freate many sich deare sellars. Sur, we hope you will let us have our cumplaints put into your hinfluenshall paper, and make these landlords of our houses and these comishoners (the freinds we spose of the landlords) make our houses decent for Christians to live in.

Preaye sir com and see us, for we are livin like piggs, and it aint faire we shoulde be so ill treted.

We are your respeckfull servents in Church Lane, Carrier Street, and the other corts.

Teusday, Juley 3, $1849^{\prime \prime}$.

The "Times" did go and see them; and as its reporter, at the protective elbow of a police sergeant, made his way from one human warren to another, his note-book filled with grimly pathetic details. The landlord of one of the better houses "pointed in triumph to a clock and some crockery in one of the rooms". One woman told him "they seldom tasted meat -- hardly ever. They did not expect 1t. They were slad to get bread, and they had not often enough of that." (2)

1. "Times", 5 July 1849. The letter bore 54 signatures.

2. ibid., 9 July 1849. 
"The houses are underlet to a lessee for a term of years at about 220 per annum", reported the assistant surveyor who was sent to inspect the area. "These were again underlet, house by house, at 235 per annum; these were let in rooms at a highly resunerative rent; and, lastly, the separate beds in rooms are underlet to vagrants, tramps, and the refuse of society, at about $3 \mathrm{~d}$. per night, produciag, after deducting rates, expenses, losses, elc., about $\$ 70$ per house per annum". Yet in many of these houses, with their average of thirty or forty tenants each, the necessary conveniences had been abolished, "in consequence of an occasional charge upon the landlords for the relief of them"; and their inhaditants wre obliged to beg their supply of water from shopkeepers in the neighbourhood.

The report of the assistant surveyor revealed that the emptying of cesspools in these lanes and courts involved an average outlay of $21 / 10 /$ - per house per annum, that the water supply, miserably inadequate as it was, cost $c 1 / 10 /-$ more, and that the scavengers' charge, occasioned by the want of dustbins, amounted to fully another poind -.- in all $t 4$ per house per annum. For an improvement rate of $81 / 15 /-$, he estimated that the streets might be paved, tanks erected to furnish a constant water supply in every room, privies and cesspools replaced by water-closets and drains, and a dustbing fixed in each yard and a common urinal in each court. (1)

In this and in similar reports by assistant surveyors of the Sewers Comission, Chadwick worked out his interim plans for metropolitan drainage. A block of buildings, such as Goulston-street, Whitechapel, or Jennings' Buildings, Kensington, would be chosen, and would be examined by an officer of the Comission. He would then produce a report, indicating the measures needed, and proving that "the annual money-cost of loathsome squalor largely execeeds that of decent cleanliness". (2)

1. "Report on Church tane and Carrier Street, St. Giles'", by E. Gotto, 7 July 1849. "Orders of Court", vol. 2, p. 135, 2. "Times", 22 October 1849.

12 July 1849. 
At the same time, to check jobbery, and to determine the details of domestic drainage, Chadwick set going a series of experiments and trial works. In his various reports he had condemned the woris of engineers of the highest reputation, of Rendel and Wicketeed and even of the great Robert Stephenson. Gwilt, the author of the standard Bncyclopaedia of Architecture, advised for a moderate sized country mansion a drain of an area of five square feet, with a capacity large enough to discharge 2,000 eubic peet of water a minute. In this sphere of disputed principles and contradictory practice, the public were at the mercy of the jobber, with his discounts and trade allowances. Chadwick once reproached a well known architect for putting in bricik house-drains at half-a-crown a foot when for sixpence a foot he might have laid down superior earthenware pipes. "Oh, but you know, Mr. Chadwick", he was told, "we architects must live". (1)

"The most efricient if not the only mode of checking these pernicious influences appeared to be to analyse carefully the cost of production, ascertain what the arificles might be produced for, and either acturlly manufacture the goods or to promote their production by contracts on a large scale, at such a rate of profit, as whilst ensuring the production would preclude the payments of the several stages of percentages or the allowances designated in France pour payer les influences". (2) To the opposition on the Sewers Commission, when they questioned. the value of his experiments, he declared that the disputed problems of drainage were "a matter of guaging and measurements, and as those were carefully and fairly proceeded with differences of opinion would disappear ..... Great was gravitation -- it would not be diverted by passion or ignorance, and would prevail". (3) Barthenware pipes were brought from Switzerland and their prices and quality were 1. E.C. - Morpeth, 14 October 1848.

2. "Sewage: Supply of pipes: reasons for trial works", is, n.d. 3. "Times",24 July 1849. 
compared with home products. The production cost of bricks was enalysed and the prices charged by contractors shown to be 60 per cent. higher; whilst a subterranean survey revealed that the ruinous state of so much of the sewers was caused by the fact that the bricks supplied had been far inferior to the qualities contracted for at that very high rate of propit. The flow in the sewers was guaged, and it was demonetrated to the astonishment of the old officers that house drains need not be larger than four inches in diameter, a pipe that size being sufficient to carry off the sewage from a thousand people or more. Tests were made to determine the quantity of water actually consumed in the metropolis, and the quantity which would be requj.red for the new system of drainage. Trial surveys were made of suburban districts such as Richmond and Sydenham, and plans and estimates drawn up to show the practical advantages of the combination of water supply and drainage. Barges took out sewer water to enterprising farmers, and encouraging reports came in of double crops of grass and wheat.

He pushed on quietly at the sane time with preparations to dispossess the Water Companies. Bxplorers were sent out to test the quality of the surface and drainage water at Epping, Vindsor and Richmond. The specimens so far examined, he told Lord iorpeth in June 1848, showed only six degrees of hardness, as compared with the twelve or fourteen degrees of Thames water; this would mean a saving in soap of 2200,000 a year - - and he

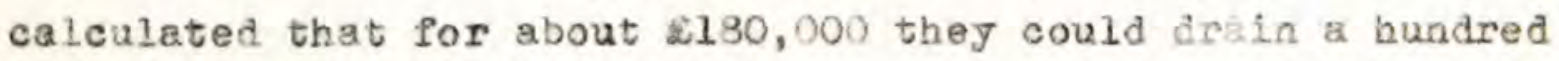
square miles of land to give a corapletely new supply of up to a hundred gallons a day to each of the 300,000 houses of the capital. (1) If confirmed, these results apelled the doom of the Companies, with their restricted supplies of dirty water. It was not surprising that he warned lorpeth that "our course of research should if practicable be kept quiet froin the Water Companies". (2) What he feared most of all was that the 1. E.C. - Worpeth, 14 June 1848.
2. E.C. - Morpeth, 31 July 1843. 
Companies, getting wind of his activities, would press for a Government pronouncement on "pre-appointed terms of compensation" which would reflect their own inflated ideas of the value of their works. "Such pre appointed terms of purchase nefther could, nor ought to be carried out", he told Morpeth. "If they were, you would have purchased peace for the present, w1th the certalnty of enduring unpopularity and hostility hereafter. The more we proceed with the investigation in the Metropolis, the clearer it is, that the pipes of some of these companies, for which they claim compensation, will not be worth triking out of the ground, and that their supplies ought not to be endured for a day. Compensation for some of them will hereafter appear to the people, like compensation for the capital invested in the old sewers (which are extended cesspools) had they been laid down by trading companies. On principle I am for liberal compensation, but I see no chance of the water companies own terms being enđured". (1)

It was valuable work; it was necessary work; and in the Interval until the completion of the general survey the officers of the Cornission could hardly have been better employed than in conducting experinents and putting London's domestic drainage in order by blocks and districts. But the policy lacked that appeal to the interest and imagination of the ratepayers which a grand engineering feat like the main drainage of London would have provided. It was dullness unrelieved. Chadwick was a bad publicity agent both for hinself and for the works of the Sewers Comission. In his speeches at Greek Street the generous design of a capital freed from the burden 1. H.C. - Morpeth, 30 Way 1843 . Worpetin replied (12 June 1343) "I do not understand you as intending to incorporate these precise observations in your Report, because I think it would be more judicious for you to indicate what ought to be done, and what can be done, without telling the existing companies that their claims to compensation will. turn out to be worth nothing at all, or we shall have their hostility with a vengeance". 
of dirt and disease was obscured by chatter of dustbins and siphon traps and the flow of water through a sewer. The "Times", which had smiled upon the Commission in its early months, fumed to see it dribbling away its own time and the public money in measuring house drains and offering prizes to plumbers for patent comodes. (1) The "pimes", and the public, had lost patience.

Prom the beginning Chadwick was convinced that the survey and the experimental works could not be supervised by an unwieldy body of 23 Commissioners, one section of whom never attended the monthly meetings at the rooms in Greek street, while another swction sat in permanent implacable opposition. In January 1849 he used his command over the majority of the active Commissioners to secure the appointment of a numberoof committees, for Pinance and Bye-Laws, and, most important of a11, a Works Comittee, from which there branched sub-committees for the Ordnance Survey, the Trial Works, the Disposal of Refuse, and the Construction of Roads.

One object of this step was to carry on business in the intervals between the meetings of the full Commission; but 1t was Chadwick's aim also to ensure that scientific questions should be discussed in an atmosphere free from the friction, the delay, and the untidiness of aissension. He sought to"put a stop to the thirst for debates"(3) by withdrawing with companions of his own choice behind the doors of a comnittee room, where the merits of gulley traps and hollow bricks could be given the same calm

1. "Times", 2 July 1849. "M.C.S. Minutes of the General Purposes Conmittee", vol. 4, pp. 48 - 49, 28 February 1849.

2. "Orders of Court", vol. 2, p. 3, 16 January 1849. The Committees were composed as follows:

(1) General Comittee, open to all members;

(2) Finance (7 members);

(3) Bye-Laws ( 6 members);

(4) Works ( 13 members), with sub-comittees for Ordnance Survey (4), Trial Works (3), Disposal of Refuse (3), Construction of Roads (2)

3. "Times", 3 August 1849. 
deliberation as questions of surgery or physics. When he emerged from the comittee room, however, he found himself in the less equable climate of an open asserably, where unfriendly Comissioners could attack him in 1ll-inforined speeches half an hour in length, and where even friendly Commissioners in their ignorance could cause snnoying delay. At his ease when making an exposition of principles to a symathetic audience, Chadwick's temprature rose when he encountered the obstinate pressure of a hostile mind. The anti-Chadwick panty never numbered more than half a dozen, and its golid indissoluble aucleus was the little group of old Commissioners, Byng, Leslie, Jones, Bidwe11. Chadwick left them in no doubt that he resented their presence. In their leader, John Ieslie, a former member of the Westminster Commission, he discovered a man whose jaw was as Pirn as his own, and whose determination to expose error and point out true courses was just as great -with this difference: that Leslie was as set in the old ways as Chadwick in the new. Chadwick saw in Leslie the incarnation of that parochialism against which he had always contended, with its pis-headedness, its petty horizons, and its clinging to exploded practices.

There seemed no end to Leslie's perversity and obstructiveness. When he was told that a number of the old Comissioners were to be transferred to the new body, Chadwick had sent thers copies of the reports of the lletropolitian Sanitary Commission, and had received from them hearty expressionsoof assent to the principles he had laid down. Yet, hardly a week after the writs of supersedeas had been issued in November 1847, the old Commissioners, led by Leslie, were volcing views in plain matradiction of the new methods and in support of the practices which were to be abandoned. (2) "Presuming that they were not dishonest", Chadwick commented, "it follows that they did not understand the measures; and 1. "Nemoranda in respect to the proceedings in the sewers Commission", MS, n.d.

2. E.C. - Morpeth, 30 December 1847. 
having previously been engaged in a party antagonism, what they really were impressed with was, that their adversaries were to be superseded, and themselves put in a position of greater power". (1) At the very first meeting Leslie revealed how little he had grasped of the proposal to consolidate the worise, when he contended that the two surveyors, Phillips and Roe, should be placed on an equal station in separate districts. A week or two later, he stood alone, in defiance of the lawyers on the Comission, in questioning the legality of a general survey; and when, with much expense and delay, the opinion of the Law orficers was obtained, he treated it with "equally ignorant and insolent contempt". (2) In medaline with house drainage, declared Leslie, the Comission was stepping beyond its proper function. It should conteat itself with a simple declaration that cesspools ought to be abolished, leaving it to the parties themalves to find out how to do it; sewers should be driven up the streets, and the occupiers left to break through the fronts of their houses and form the junction as best they could. On the mysterious doings of the Trial Works sub-comittee Leslie directed an angrily inquisitive gaze. Bourteen thousand warrants of distress for the non-payment of rates had already been issued, and the Commission should be more careful with the ratepayers' noney than to spend it on guaging the run of the sewers and other profitless inquiries.

But the innovation which Leslie nost detested was Chadwick's comittee system. He saw no reason why the old method should be changed of dealing with a miscellaneous assortment of business in open Court, where all questions affecting the sewers administration could be discussed under the critical gaze of the ratepaying public. Had this been the only point at issue in the dispute over the committee system, 1. Memoranda in respect to the proceedings in the Sewers Commission", MS, n.d.

2. E.C. - Eon. Frederick Byng, 11 Septemberr1848. "Mi.c.s. Minutes of the General. Purposes Committee", vol. 2, p. 55, 23 May 1348. 
Chadwick's case would have been incontrovertible. In so intricate a task as the administration of London's sewers, involving such diverse technical matters as the assessment and collection of rates, the supervision of a large clerical and engineering establishment, the preparation of surveys and estimates for local improvements, the trial of new meterials and new devices, a subdivision into specialised comittees was the only way to come to close grips with the detalls on which policy must be iramed. It was in the comittees, with their fingers on the pulse of business, that policy must be initiated; the open Court, though it might influence its comittees by criticism or encouragement, must in the main be content to ratify their decisions. (1) But this was not all. No idea of composing the committees on representative lines seems to have entered Chadwick's head. From the all-important Works Comittee, with its off-shoots Arazkgg controlling the survey and the experiments in drainage, irrigation, and road construction, the old Comissioners without exception were shut out. (2) He did not listen when Lord Carlisle, sensing the

1. See MS fragment (apparently araft resolutions) in which Chadvicis defends the comittee system:

what the greatest security against waste by any board composed of numerous nembers is the thorough examination of the business brought before it.

That the only practicable mode of effecting this in such bodies is by a subdivision of labour and delegation.

That responsibility is increased by the fewer hands into which the business is divided;

That executive aispatch is increased by the fewer competent hands into which business is confided.

That the greatest waste delay and mismanagement has arisen amongst numerous and fluctuating bodies of persons.

That the presence of every Comissioner, at every Comittee and sub Committee is incoasistent with the principle of the proper examination of buslness by means of division of labour ......"

2. See Protest signed by Byag, Leslie, Lawes, Bidwell, and Jones ("Orders of Court", vol. 2, pp: $33-35,22$ March 1849: ".... out of the seven Comittees constituted or Confirmed by these orders namely --- the Ordnance Survey Comittee; the Trial orks Comittee; the Construction of Roads Committee; and the Sewage Manure Committee exclusively (Continued on next page) 
danger of an excluded, embittered minority, suggested that it might be prudent to utilize and occupy Leslie by putting him on a committee with three or four others of superior knowledge to report on the poliution of the Thames. (1) What could Leslie contribute to a scientific investigation beyond an ignorant obstructiveness? You might as well expect a vestry politician to design and construct a locomotive as to plan a complex and scientific system of dreinage.

It was hardly to be wondered at, therefore, that the decisions of the comititees came in for a hotly jealous scrutiny when they were brought before the whole body of Commissioners in Court or Geners l Committee. John Bullar, one of the lawyers on the Comiseion, whose good humour frequently cushioned the shock of the contending factions, urged that it would tend much more to the harmokious woring of the Commission if both parties were represented on the comittees, so that "their differences of opinion should be called out and reconciled at the outset of any proceeding rather than nooted for the first time in the Ceneral Committee". "If", he went on, "there is to be a repetition in the General Committee of the investigations which have been arde in the Committee of works, the members of that Comittee will very soon save themselves the logs of time of attending its meetings, or leave itg duties to

$$
-0-
$$

(Continued from previous page) consist (with one single exception) of twelve of the Comisgicmers nominated upon the Horks Committee ....."

Larlier, before the General Committee ("W.0.S. Ninutes of the Geners.l Furposes Committee", vol. 4, pp. $33-40,22$ February 1849), Leslie had argued that it was illegal to aiford lacilities for the performance of the ordinary business of the Commission by committees. The authority to delegate was not to be found in the Sewers ActB; indeed, every facility was given by the Act of 1343 to the Commission as a Court of Record to carry out its objects most advantageously "by making the public fully acquainted with ail its proceedings". A case was prepared for the Law officers (ibid., po. 59-60, 1 March 1349), as a result of which some silght adjistment was made in the arrangenents. ("Orders of Court", vol. 2, pp. 29-31, 15 karch 1849). 1. Carlisle - B.C., 16 April 1949. 
be perforned by a small minority." (1) Chadwicis proposed instead to meet the truculence of the opposition with the equalig truculent resolution: "That if the court did not support the cormittee it had appointed, consisting of gentlemen whose intention it was to do their duty, it was inpossible for the buginess of the Coramission to go on". (2)

Inevitaoly the others fell undsr his domination. It was a benevolent despotism, working through the machinery of half a dozen consittees, whose head and heart wore Chadwick. As the "ines" objected, if the comititees were nominatad by Chadwiok, and the Court ass bound to support the cosaltites, it was only too slear that the Comaision represented and registered the opinions of ons maa alons(3) The combittee systan, in the eyes of its eneries, was a screen for the dictatorship of one anditious mind. "Asy comissioner who did not belong to the Worikz Comittee was perfectly useless", cried one. "Mr. Chadwiak asked bin why he did not attend; and he answered that the works Comittee governed the conmission. All the rest were aere cyphers, and wre treated with a degres of intemperance if, as congissioners, they came to the court to Hischarga their dut $J$ and do what they considerod right. They were considered excessively inpertinent if thoy askod a quostion, or alluded to any explanation that might do food to the corrission". (4)

The gulf betweon Ghadwick and Leslie could not be bridged. The uahappy Carlisle found himself in the desperate dilenma of a taan with one foot on each gide of an ever widening crevasse. Chadwicis's last word was that there aust be no "self indulgence in kindy feeling at the expense of the public and of 1. Tohn Bullar - Lord Carlisle, 2 Feoruary 1849.

2. MS Pragment, n.d.

3. "Iimes", I October 1849. "The Cormitsston has been made a Parliament to register Mr. Chadwick's acts; the sujcoanittees conduct his experme iss, ddopt his projects, and reflect bis opintons; and general courts s se but so many packed tribunals for silencing any contumacious opposition". 4. Hon. Fredesick syng; speech reported in "Pimes", 3 August 1349. 
duty: that is to say by jobbery in urbanity. It is laid down by an eminent member of the Government that the essence of statesmanship is compromise. Be this as it may with matters of Government, it is totally misapplied in respect to sewers administration. Between good and bad sewers there can be no compromise." (1) Carlisle was sympathetic when Chadwick, reporting another "dreadfully annoying day at Greek Street", cried that "the present state of things cannot, ought not to go on". (2) But not infrequently Chadwick, with his continual alarums, his protests and his fretting, strained the patience of the peace-loving nobleman. He could not endure bad blood and squabbles between the nembers of the Commission, he warned Chadwick, and "if they go on I shall run away from both Boards". (3)

When the time came in September 1848 for the reappointment of the consolidated Commission under the terms of the recently approved Sewers Act, Chadwick moved ponderously to shake off hls old Man of the Sea. It had been agreed that the original 23 Commissioners should continue in office unless they signified their own desire to be relieved, and when he found that Chadwick was trying to edge Leslie out of the Commission Carlisle sent him a stiff note. "Now I am entirely convinced of the thoroughly public-motived spirit of all you do, and I can quite understand how particular people may thwart, annoy, offend, obstruct; but where is the work we can expect to do without a mixture of these elements? I sometimes think that people who have not been in Parliament are more intolerant of this species of opposition and obstruction than we who are more seasoned to it. We have enough of opposition and jealousy to deal with from without, to make it very unseasonable to excite and create them in fresh quarters ..... So pray let there not be any more bad blood raised about it". (4) Earlier a sensible,

1. MS fragment, n.d.

2. E.C. - Carlisle, 2 July 1849.

3. Carlisle - E.C., 26 January 1849.

4. Carlisle - E.C., 18 October Hats 1348. 
good-humoured letter from John Bullar had urged the same point. There must be some opposition, and none was likely to be less effective than Leslie's. "You intimated that you would retire Prom the Commission to avold Mr. Leslie. That would be to abandon projects in the success of which you take great interest, and to allow the apprehension of a little occasional annoyance to be your master. If you had not had force of determination enough to master circumstances of annoying character, you ought to have been quietly buried in a cesspool some years ago, with a train of Assistant Commissioners following your funeral, and the pall borne by broken-hearted Plushers!: (1)

If the cantanikerous Leslie was the most irritating, he was not the most serious obstacle to the inauguration of the new order. By June 1848 Chadwick was sighing that the establishment at Greek Street was not well in hand. The cleriss and surveyors who had been inherited from the extinguished district Commissions were sensitive about their rights of precedence, and worked together with a bad grace; and they were appalled when Chadwick introduced a regular working day of six hours from ten to four, in place of the carefree sloth of the $\rightarrow 0-$

1. Byng, the most approachable member of the opposition group, admitted that Leslie's manner was very bad. But, he went on on, "Does not this occasional difference of opinion lead the Publick to suppose that matters are discussed and that we are not a packed Jury under such an able Foreman as yourself? It will be very difficult to persuade the Metropolitan Rate Payers to be highly taxed by any but a representative Commission. If they are passive it will be owing to their fancied security in certain names and therefore should I be glad to see them repeated tho' they have not given hitherto any assistance. Ieslie's is an influential one as a security to the great body of St. George's. Even I, am the means of keeping St. James' quiet. ..... I may be permitted to remark that your manner has all the appearance (I speak of committees of impatience and anger at the smallest opposition from him --. and as no doubt he is quick of sight, he may have observed what has struck me, a certain aristocratical bearing among his Colleagues to the Tailor. That I should not wonder with his very independent spirit has raised rather than diminished his spirit of contradiction ....." ( 14 September 1848) 
old régime. (1) Urgently needed was an engineer of commanding personality and advanced views to be put in charge of the works. On a proposal of John Leslie's the Commission had committed a cardinal error in dividing the metropolitan area into two districts, each under an engineer of equal status, with the result that the two engineers, Roe and Phillips, pushed on with their separate programmes without consulting each other, just as if no consolidation had taken place. "I believe them both to be good well disposed men; both capable of good work, if not put out of their proper positions and if properly directed", wrote Chadwick. "But it is a new system which is required to be carried out; a system very different from their own recent practises, which they must be led to alter. To say that they shall not be interfered with where necessary, is to say that there shall be no relief, and that the health and lives of the population shall be subordinate to the feelings and interests and knowledge of the officers brought up under the old establishments. The new consolidation of works required, as compared with anything which Mr. Leslie appears to have been prepared for, is as widely different as a locomotive is from a common dung cart". (2) As worning after morning Chadwick was $-0-$

1. "Every morning nearly I have to give an attendance at Greek Street to give instructions to the Officers: no single officer being there up to the general views, or having influence: Mr. Stables, not recognising $\mathrm{Mr}$. Hertslet, as Chief, and Mr. Hertslet not liking to instruct or give orders to Mr. Stables: Mr. Roe not liking to interfere with Mr. Phillips or Mr. Phillips with Mr. Roe, and neither advancing readily out of their separate district habits, and all waiting or standing still for orders unless seen to" (B.C. - Morpeth, 9 September 1848).

2. E.C. - Hon. Frederick Byng, 11 September 1843.

"Neither Roe nor Phillips have advanced with their position. The latter sent in a Report in respect to liarylebone, which would have exposed us seriously and I was obliged to stop it and have it altered, and the former gave in a report, the other morning which appeared to be almost insane, and the committee at once decided upon its entire suppression.

We cannot supersede either, both have considerable merit, but they require an excessive amount of watching".

(E.C. - Morpeth, 30 May 1848). 
called to Greek Street to reprove the absurdities of the engineers and to smooth over their jealousies and disagreements, he recalled that Roe had been a reluctant witness in support of consolidation, and that Phlllips' evidence before the Metropolitan Sanitary Commission had been given its edge by his resentment against his employers. Sir Henry de la Beche had been right, he began to think: the break with the old order should have been sharp and complete.(1) The old officers could not adjust their mental habits, formed under the district commissions, to the wider outlook of the consolidated area, nor could they readily accept the new knowledge quarried by the Trial Works Committee which went against their professional practice for a quarter of a century. It was a fact, they agreed, when the demonstration took place before their ejes, that four inch pipes kept clear whilst larger ones accumulated deposit; yet both continued to put down house drains of double the size they admitted to be necessary. They had too much to unlearn, and though when pressed they might concur in the value of the new 1deas, they were too blinkered by old and

accustomed practice to catch more than a fractional glimpse of Chadwick's grand design. (2)

"In respect to the Metropolitan Commission of Sewers I am exceedingly anxious", Chadwick confessed to Lord Morweth in October 1843. "There is much to be done requiring steadiness science and zeal and so little available force there to do it. The officers have falled more than I had expected, and my expectations were not $h i g h$. They have failed in suggestions as to details. They do nothing without instructions. Everything 1. "Sir Henry de la Beche has a stronger impression than myself of the looseness and uncertalnty of the old machinery for carrying out new work". (B.C. - Morpeth, 9 September 1848).

2. Forwarding a copy of the Metropolitan Sanitary Report to sir John Burgoyne (26 December 1851), Chadwick observed: "You will see that in respect to Mr. Phillips the main propositions were put to him not by him and I found that having deliberately assented to the propositions put to him he afterwards set himself in opposition to them, as indeed he had previously carried out works, which themselves were full of what he admitted when questioned to be errors in 
has to be reorganized. All their former habits have to be changed; all their "practical" experience, 1.e. routine, inapplicable to new conditions, is wrong, it is a delusion and a snare". (1)

In his perplexity Chadwick turned to the rellab Austin, now the secretary to the General Board of Health, wh the was acting as Consulting Engine r to the Commissionly ruptured the nominal agreement between the engineering officers of the Commission. Austin was uniknown; he was quiet and modest, and had little presence. He lacked the authority which would have enabled him to dominate his two professional colleagues, and to silence the clamorous minority in the Court roon. Roe remained faithrul to Chadwick, but Phillips seceded to the side of leslie and Byng.

The clash came in June 1849, when Austin and Phillips produced rival schemes for the disposal of London sewage. Instead of limiting the attention of the Court to minor matters and piecemeal work, said Phillips sharply, -.. such as the drainage of a detached and separate district, the advantages of a three inch over a four inch pipe, or the shape of a water closet pan - - the energy of the Cormission and its officers should have been concentrated in the first instance on the selection of a sound plan for providing an outfall independent of the Thames. Phillips' proposal, in its essentials, was the construction of about twenty miles of intercepting sewers from Vingston in the west to the Kent or Assex marohes ia the East, following the course of the thames and acting as a substitute for it, at a bepth of soine hundred feet below the bed of the river. (2) The idea was not new. It had been exsmined and rejected several times since Martin's original scheme was turned down in 1842; and in a modified form it was later to form the basis of Bazalgette's plans for metropolitan main drainage. 1. E.C. - Morpeth, October 1848.

2. "Letter to the Commission of Sewers on the Drainage of the Metropolis", 21 June 1849. Printed. 
Chadwick, his eyes still lovingly fixed on the mirage of gold from sewage, found it totally unacceptable. Far better was Austin's "converging syster". By this plan London would be divided into distriets, eack having a sump, into which the refuse would be collected; from these reservoirs steam engines would eventually pump it out to the farmers through subterranean pipes. In ang event, said Chadwick crushingly, whatever plan was adopted, tunnels or sumps, it must wait on the completion of the survey; and in the meantime the comission must continue with its programe of experiment and preparation, remedying the domestic arainage wherever possible, and flushing the sewers regularly into the Thames.

In this policy be inevitabiy came into collision with those who held that the Thames was London's greatest nuirance and Londoners' greatest danger. As the summer stinks from the river were wafted through the windows of the office in Printing House Square, the editor of the "Iimes", with handkerchief to his nose, poured out columns of protest. "Not a single cesspool to be found in the city, -..- except one, reaching from Richmond to Gravesend, with an exposed surface averaging a quarter of a mile in breadth! No filth in the sewers, -- all in the river!"(1) The Sewers Comission relieved Church Lane and Carrier Street, but only by polsoning the water supply of the whole capital, a piece of devilry forbidden even by the rules of war. (2) It mas only a choice of evils, Chadwick replied; the evil of sanding the refuse down into the thames was utterly lacongiaerable with the evil of keeping accumulations of noxlous natter in densely inhabited localities or of removing it to laystalls(3) The flushing of the severs he regarded as the greatest contribution which the Commission could make to the defeat of the cholera. In their first month they had flushed 22,400 feet of the Westminster sewers, with a deposit ranging 1. "Times", 7 October 1348 .

2. ibia., 14 September 1943.

3. ibid., 14 January 1348. 
from six inches to 3 feet 6 inches, amounting to 3,386 double loads of solil ${ }^{(1)}$; their activity was intensified when the epidemic broke out; and in July 1849 one of the assistant surveyors reported that "for the last $3 i x$ weaks the Commission had spent 2150 per week, and each sixpence of that sum represented a load of filth carted away from some locality in the metropolis."(2) The intention, and the energy displayed in its execution, were admirable; the results were not -.. for the hoorded refuse, lncluding the fresh infected faeces of the cholera victims, was flushed lato the Thanes at a point opposite the main intake of Iondon's water supply.

Judging the policy of the Commission from one aspect only -- its effect upon the cleanliness of the river -- the "rimes" presently passed from occasional criticism to open and permanent hostility. John Walter began to suspect that he had been chosen as a Commissioner less on account of bis interest in the sewers than of his influence with the "Tines"(3); which was only too true. His technical opinions he took from an aged engineer, Stewart, an old-Pashioned empiric, who scorned the notion of waiting for the completion of the survey before beginning a general scheme of drainage, and who was in favour of Phillips' plan of deep intercepting tunnels to divert sewage from the Thames. In a series of letters Chadwick attempted to turn the "Iimes" from its chanpionship of Phillips. The intercepting sewer, he argued, was a reckless and uneconomical method of handling so valueble a comodity as town refuse; the plan anounted to throwing the sewage of London a hundred feet deep in order to pump it up again and send it back several miles in the direction whence it had come to be used as farm manure; it would occupy two or three years, cost two millions, and leave St. Giles', Whitechapel, and Rotherhithe in much the same condition as at present. All this Chadwick explained to Walter 1. "Orders of Court", vol. 1, pp. 20 - 21, 13 January 1848. 2. "Times", 20 July 1849.

3. John walter - E.C., 22 July 1849. 
and Delane, exuding a breezy confidence that after this exposure no one could possibly continue to countenance such nonsense; but the "Times" still cheered for Phillips and intercepting sewers. (1)

Thus, in the summer of 1849 affairs at Greek Street came to a climax, and the Metropolitan Sewers Comissionsrushed with increasing velocity on its own destruction. Ph1111ps and Austin exchanged broadsides, each deriding the other's scheme. (2) Simultaneously the chief clerk, Levis C. Hettslet, after sternly reproving his employers for not laying down a definite course of action for their works, sent in his resignation and promptiy began to manufacture hollow bricks, \$150,000 worth of which would be required for Phillips' tunnel. (4) little note reached Chadwick from one of the cleras: "phillips says, and thinks that the Gentlemen comprising the Commission (useing hiss own words) are a lot of old women or Muffs, and that the Comissioners will not get much out of him unless the Commissioners adopt his plans, for he w111 not be put down". In the following month, the debate begun by Phillips and Austin was thrown open to the whole profession, and engineers were invited to submit their plans for the sewerage of London. (6) It was a victory of the "Times" over Chadwick, who held that no comprehensive scheme could be laid wur down until the survey of the capital was completed, and who was continually pointing out that, since the Sewers Commission was already engaged in undoing the work of civil engineers and architects of the highest eminence, it was futile to seek in their ranks for the designer $-0-$

1. B.C. - John Walter, J.T. Delane, n.d.

2. "Orders of Court", vol. 2, pp. $105-108,21$ June 1849. "M.C.S. Minutes of the General Purposes Comittee", vol. 4, pp. 72 - 91, 28 June 1849). "Letter to Commission of Sewers on Drainage of the Metropolis", 21 June 1849, J. Phillips (printed). "Ooservations on Phillips" Letter", June 1349, H. Austin (printed).

3. "Orders of Court", vol. 2, pp. 103 - 104, 21 June 1849.

4. "Notes of Information to Lord Palmerston on the foundations of hostility to sanitary measures". MS, c. August 1853.

5. T.F. Greene - E.C.. ? July 1849.

6. "Orders of Court", vol. 2, p. 157, 23 July 1849. 
of London's main drainage. When the Court opened on 20 August to receive the plans of the competitors, the room was immediate imediately thronged with aspiring civil engineers. It was a tumultuous meeting, the competitors listening to the Commissioners and each other with great excitement, and the Comissioners present were clearly taken aback by the numbers and rivalry of the competitors. (1) that morning, and another 75 before the competition was declared closed. All were useless, as Chadwick had predicted, being drawn up in ignorance of the findings of the surface and subterranean surveys.

Bvery resolution was now becoming a battle ground for the opposing parties, and at times the Court was "nothing better than a beargarden". (3) Should the Commission appoint two additional assistant surveyors? "Mr. Phillips, wheh appealed to, denied that more assistant surveyors were wanted; Mr. Austin as confidently asserted that they were indispensable. Mr. Chadwick spoke at some length on the point, seasoning his observations with further hits at the old comissioners". (4) When Chadwick remarked complacently that under the old Westminster Commission the cost of removing soil by hand labour had been seven shillings a cubic yard, while now it was plushed away for only sixpence, Leslie rose in a fury of denial and demanded a speoial meeting to go into the figures. On the appointed day only three members were present in the comittee room to support Leslie. In an adjoining room Chadwick waited with a strong contingent of his friends, ready to enter and swamp the meeting if a quorum were formed; while a beadle was set at the door to intercept Commissionerg who looked like

1. "Orders of Court", vol. 2, pp. 220 - 223, 20 August 1849. "Times", 22 August 1849.

2. "Report on Plans for the Drainage of London. By J.F. Burgoyne, James Vetch, J.M. Rendel, H.D. Harness, Robert Stephenson", 8 March 1850; in "Reports and Communications of Board of Health to Home Secretary on Drainage of the Metropolis", P.P. 1854, 1xi, pp. 104 - 111. 
strayling into the rebels' camp.

It was a ludicrous situation which lost nothing in the telling in the "Times" , report.

As a gesture of appeasement the Woriss Comittee was thrown open to all members in August 1849. (2) The move was a failure. The committee was now in difficulties, cried Byng, and wished to involve others; (3) while Leslie pressed on his attack with a motion that the Trial Works sub-committee, "on account of the expenditure and small results", should be abolished. (4)

In such wranglings and personalities the Sewers Commission was gasping out its life. "Mr. Leslie complained that other Commissioners were allowed to say what they pleased, but so soon as he spoke he was told that he was personal". (5) "Mr. Buliar .... complained that the time which should be given to business was wasted by Mr. Leslie in fruitless discussions". (6)

It could not continue. At the end of september 1849 Chadwick appealed to the Government to recast the Commission, in the hope of eliminating Leslie and his friends. The reply, conveyed in a letter from Lowrd Carlisle "under feelings of very great pain", gave him a severe jolt. Lord John Russell and the Lord Chancellor agreed to supersede the Commission --- "but they make it a condition that neither of the prominent parties in the late disputes and differences should re-appear in the new one". Carlisle continued: "I am upon the calmest consideration I can give to the subject, inclined to think that the course decided upon is under present circumstances the most prudent for the Government, for the Board of Health, and for yourself. From whatever causes, or by whose-ever fault it has happened, the present Commission has lamentably broken down, and there is not at present sufficient

1. "Orders of Court", vol. 2,pp. 225 - 226, 21 August 1849. "Times", 22 August 1849.

2. "Orders of Court", vol. 2, p. 204, 9 August 1849.

3. "Times", 10 August 1849.

4. "Orders of Court", vol. 2, p. 281.

5. "imes", 30 August 1849. 6. ibid. 
confidence in the public mind at lerge towards any portion of it to make people wait with patience for the inevitable delay and gradur d developrent of the requisite measures. In the present conflict of opinton which prevalls upon many of the main points at issue, and anidst the disgraceful squaboles and mutual accusations of our own ofilcers and surveyors, it is clear that even although we could feel sure that the course which you and those who would be most likely to follow your guidance might adopt would be invariably in the right, still the Government and the public will require the sanction of the highest engineering authority that can be procured. I an aware that jou have been disposed to entertain a different opinion, but the times and circunstances rake it imperative. I thibk it at least questionable, allow the to bay this, hov far you would work smoothly with those by whor you were liable to be over-ruled, and I even feel persuaded that you are more likely to see your own views curried into effect, 1 r you are yourself not one of the executive body -- if you would act more as an dielcus, than as an acturl tember of the "curdae" ....."(1)

Chadwick was furious that this undiscerning Government had classed him with Lesile as great and equal nuisances. For the second time in his career he felt that he was being made a scapegoat by the Russell Goverabent, mile the real culprits escaped uncensured. "I cannot see the justice or the policy of the assumption of there veing two parties, or of shaping the procedure so as by implication to divide blame", he replied to Carlisle. "..... I can quite siate, that I have opten expressed ny desire to see the arrangements rade, of the time come when I might entirely leave the severs Comission. I have felt the anonalous position, but assuredly there was no helo for 1 ti; lothing would have been done, noae of the more essential points would have been pressed, oy any ouner members of the Conaission. Not one of them I aa sory to say appears to be awaxe of the bearing of what has been done as a whole, 1. Carlisie - B.v., 29 september 1849. 
which yet remains to be shewn; still less can they be aware of the bearing of what has been done on the Public Health Act".

But the sentence could not be averted, and, despite the polite words of Russell( $(2)$ and Carlisle, Chadwick felt it to be another rebuff. The Board of Health put the best gloss they could on the affair, and in their Minutes passed off the defeat as a strategic withdrawal. Experience had shown, they declared, that membership of the Commission of Sewers was not compotible with their duties at the General Board. They had therefore resolved that in future they should have no personal connection with any local Board:

"Because as members of a local board, in which they can form only a minority, an undue weigkt and responsibility may be, and the believe has been, ascribed to their individual or personal influence with the majority; ---

And because as members of a local board they may be in a minority with reference to measures on which, from more enlarged information, they may not only take a different view, but with regard to which it may be their puolic duty to enforce on their $\rightarrow 0-$

1. E.C.- Carlisle, 29 september 1849. He wrote again the following dey:

"There are I think very strong and serious reasons why the new Commission should not be issued as proposed until a statement of what has been done and what cemains to be done is made and issued.

I cannot understand how arrangements are to be made for the work until some connected view is had of what is to be done. I should doubt whether that can have been given to you. I know that Sir Heary de la beche who knows most of the suoject ooly knows part of it.

Unless the statement is made before the commission is issued it cannot be made after without inconvenience. I myself shall be exposed to more libels which I must not put up with. Moreover I submit that there is no necessity for cudely and abruptly breaking in before the important reports which are understood to be nearly ready are given ....."

2. Russeli - Carlisle, 24 September 1849: "The chief inconvenience of this course would be that vir. Chadwick would be omitted. But his abilities are so fully employed in the Board of Eealth, and are so freely recognised by the Government that I trust he would not see in this omission any mark of want of appreciation of his valuable services". 
responsibility an opposite course". (1)

It would have been well for Chadwick if this resolution, the argument of which is unexceptionable, had been passed a year earlier, and if he had severed his connection with the

Metropolitan Commission of Sewers the moment he was appointed to the General Board of Health. By September 1848 the large-scale survey, the essential preliminary to the sanitary regeneration of London, was well in hand, and Chadwick might have left to other men the task of building upon the foundation he had laid. There is a limit to the amount of work one man, whatever his resoirces of energy and will-power, can profitably undertake. To establish a great new department of the central government, and to nurse it through the dangerous years of its infancy, was a labour in which he snould have found ample room for the exercise of his abilities. The trouble with Chadwick was that he felt himself to be indispensable. In this field of sanitary reforn, where he had been the pioneer, he placed no trust in the judgment of others, however well-intentioned he knew them to be. Sir heary de la Beche, the geologist, Simon and Southwood Smith, the physicians, Roe, Austin, Ravlinson, the engineers -.- ali these, and many other friends of the cause, saw clearly some fraction of the whole; but none of them, Chadwick believed, saw saw the problem in all its bearings so clearly as hinself. hated to delegate his power, because he could aot at the same time delegate his knowledge and his vision. It is a dilemma 1. Minutes, 17 october 1849. In a letter Irom Carlisle, also recorded in the same minute, he concurs in the resolution: "He would have felt most unwilling to single out any individual name among the members of the Commission, but as one of his colleagues at the Board of Aealth, Mr. Chadwick, has sustained a prominent share both of labour and of attack, he would think it neither just nor generous to a public servant, where even health has been out too much affected by his unremitting exertions for the good of the public, if he neglected this opportunity of expressing the simse which the Government entertain of his past services, and the hope which they cherish that many more vill yet be reserved to him for the general advantage". 
known to all benevolent despots.

What had Chadwick to show for his two jears at Greek Street? In the severe view of the "Tines" -.. and the "Times" in this reflected the opinions of the great mass of tondon ratepayers -- his dictatorship by comittee had accomplished practically nothing. It had left unsettled the principles on which London's main drainage was to be lald out. It had not decided whether the Thames was to cease to be a common sewer, or whetier London was in future to be dralnaed by sump or by tunnel. Its activity had not extended beyond the flushing of old sewers, the advocacy of four-inch capillaries, and the cleansing of blocks of forty or fifty houses. For that lame and units unimaginative policy, concluded the "Iimes", the responsibility must fall on the man who had manoeuvred himself into the monopoly of power.

It was a heavy judgment, which hung around Chadwick's neck to the end of his official career, and helped to drag him down at the lest. And it was an ill-informed and partial judgment. The critics cried for immediate works, as if it were merely a matter of sending out a fang of labourers with shovels and pickaxes to trench and tunnel a passage for london's sevage. The problen of metropolitan main drainage was not so simple as it appeared in Printing House Square. The Commision of engineerine experts appointed in 1856 to consider the question took three years to settle the principles, and a further seven years elapsed before Bazalgette's schere, with its 83 miles of interepting sewers at a cost of $84,600,000$, was final1y executed. Cbadwick hireself had not foreseen how long and how expersive a business it would be (ho alweys insisted that he could have done it more quickly and at less cost)(1). But in 1. He told Lord Hersche11 (July 1838 ) that bis plans night have
been completed for the whole of the hetropolis "in lour
years, or by 1356 , and the death rates reduced to 12 in a
thousend". 
two important respects he saw further than his detractors. Until a survey had been completed, however long it might take, no general scheme of wain dralnage could be undertaken. Bazalgette planned his sewers according to Chadwick's lerge scale survey. Secondly, in the experiments of his Trial Works Comittee chadwick showed himself to be a generation or more ahead of his crities in recognising the importance of domestic drainage. Iven today the designing of the arrangements for renovins refuse from the individual household 1 s too often left to the architect or builder, with the result that it is an exception to find anything like a scientific system of house drainage. 


\section{CHA PTER 12.}

\section{A NEW PRESIDIANT.}

The epidemic, which had put a severe additional strain upon the overcrowded burial grounds during the terrible months of 1849, had raised in an acute form the question of the accommodation for London's dead. (1) By the amended Nuisances Removal Act of August 1849 the General Board Had been empowered to inquire into the state of the metropolitan graveyards, and to prepare remedial measures for the next session of Parliament.

The scheme which Chadwick laid before the Government in December 1849 followed closely the recommendations of his great Report of 1843. Under it the burial of the dead, which was "a most unfit subject for commercial speculation"(2), would become a public service, controlled by a small Board of qualified and responsible Commissioners, at least one of whom was to be paid. Parish churchyards, private burial grounds and joint stock cemeteries would all be closed, and replaced by national cemeteries managed by the Burial Commission. All interments - 0 -

1. It should be remembered that the Board urged the regulation of the churchyards, not simply on aesthetic and moral grounds, but primarily as a matter of life and death. Iyon Playfair had calculated that the 52,000 metropolitan corpses annually evolved no less than 2,572,580 cubic feet of gas; and it was an article of faith with the Board that putrescent animal matter, in suspension in these gases, was capable of communicating its own state to similar organic matter ("Report on a General Scheme for Extramural Sepulture", 1850, pp. 6 - 7, 9). For this reason the Board opposed the idea of cremation, believing that the atmosphere would be more injured by the burning of 150 bodies a day than by the gradual process of decomposition under a properly regulated system (ibid., p. 118).

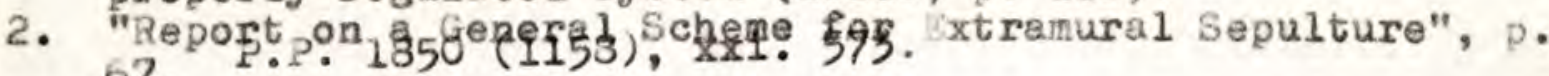
67. 
without exception were to take place in the National Cemeteries; this monopoly of burial enabling the Commission to enter into advantageous contracts for the 52,000 funerals annually occurring in the capital. The cost of funerals would be regulated according to a series of scales or classes; and Chadwick estimated that the consolidation of the services, together with the economy of large-scale contracts, would reduce the present bills of gentry and tradesmen by two-thirds and of artisans by one-half. To supervise the arrantzements, to ensure that burial should be sanitary and decent and cheap, and to perform the other duties which Chadwicl had sketched out in the papers submitted to the Health of Towns Commission, there was to be a paid permanent staff composed of one chief officer of Health and eleven assistants.

Such a scheme touched the interests of three main groups, the Church, the Dissenters, and the cemetery shareholders. Parish incumbents would be paid compensation for the loss of their burial fees. Each of the National Cemeteries would have a consecrated portion with a church for conducting the Anglican burial service, and an unconsecrated portion with a chapel for the use of Dissenters. The consecrated portions of the National Cemeteries would remain under the same ecclesiastical jurisdiction as the parochial churchyards which they replaced. whe eight joint stock cemeteries (2) must be compulsorily purchased, the award in each case being rixed by a jury. Only one of them, Rensal Green, possessed a site suitable for the purposes of the scheme, and this would be enlarged to form one of the National Cemeteries. At least one additional cemetery would be required, and this should preierably be situated near the river. An average of 96 bodies a day would ploat along this "Silent Highway" from ellght houses of reception established on either bank. Chadwick knew the ideal site --- Abbey wood, 1. ibid., pp. $87-89,113 \overline{3}, 115$.

2. Kensal Green, Nunhead, Highgate, Norwood, Brampton, Abney Park, Tower Hamlets, and Victoria Park. 
part of an ancient monastic domain, a dry tract of gravel and firm sand rising gradually from the river's edge.

2700,000 was the sum immediately required for the construction of the new cemetery in the east, the enlargement of Kensal Green in the west, and the purchase of the rest of the joint stock burial grounds; and the annual expenditure on interest, establishment charges and compensation woufd amount to 2112,000. (1) The money was to be raised by a loan, payments on which were to be defrayed from the recelpts of the cemeteries. The Act would provide for a rate to make good any deficiency, but Chadwick was confident that, even with the burden of compensation and the reduction of the existing fees, no deficiency was to be expected.

In a series of extraordinary papers, addressed to the Government and the Bishops, Chadwick gave his imagination full rein to fill in and colour the outlines of his scheme. Bentham, planning his Funopticon or working out to the last detail the equipment of a Government office, could not have been more patientiy thorough than Chadwick as he described the layout of his National Cemetery, the style of the church, the materials of its construction, the arrangements for the chaplain, the choir, the bearers, and the corpse. "From the architecture, from the decorations, everything belonging to pagan structures or periods should be strictly excluded. The style and decoration should be christian. If it can be so it should be of the present period. If nothing characteristic, solemn, and jet cheerfully impressive can be devised of the present period, which will give satisfaction, then a selection may be made of the older styles in use which appear to give the greatest satisfaction to the largest body of the members of the Church of Bngland." Lord Carlisle was staggered at the inventive

ingenuity of his colleague as he described the Crystal Palace grandeur of the church, with its dome of stained glass ribbed with Iron, and its floor of encaustic tiles; with its stalls for the mourners, walled with hollow bricks and hung with rich cloth, each distinguished by the arms of one of the metropolitan parishes or the terra cotta effigy of one of the apostles; with 1. Keport, pp. $115-116$. 
Its approaches which might be covered with glass panels in wet weather, and its surrounding avenues lined with full size or colossal statues. (1) It was a remarkable effort of ordered lmagining -- andwithal a grave imprudence. As Carlisle hastend to warn him, such papers were "apt to ooze out"; and if that happened he foresaw that they "would give rise to a storm of controversy, or at all events be exposed to much cavil and ridicule". (2)

The thoroughness of Chadwick's plans delighted Ashley. "Should Sir George exhibit a comprehension and a relish for grand and efficient Schemes, we shall have the noblest system of Extranural interment the world ever knew", he told Chadwick. (3) The scheme was considered by the Cabinet on the 12th December 1849. "There was a general impression that much needless offence was given to large classes and bodies in the mode of statement", Carlisle reported. ${ }^{(4)}$ The next day Carlisle and Ashley were summoned to the Home OPfice, when Sir George Grey apparently intimated that if the scheme was to have any chance of public support it must lose the peculiarly rigid cast in whic Chadwick had shaped it. (5) Carlisle therefore re-drafted the 1. "Memoranda of draft instructions for consideration for designs in respect to the construction of a church for the celebration of Divine Service at the National Cemetery", MS, n. d.

2. Carlisle - S.0., 26 October 1849.

3. Ashley - E.C., 21 December 1849. He had written on 27 October: "I shall positively refuse to undertake or support any half measure. The thing shall be complete or not at all We have, besides, the best of Parliament with us. If any limit be assigned ..... I shall decline any inquiry whatever".

4. Carlisle - E.C., 12 December 1949. The scheme was outlined in a Minute of 4 December 1849.

5. Carlisle - E.C., 13 December 1849. "I hope with great care and discretion we may get through all opposing obstacles, but it will be rather a tough job. You must let me act very dictatorially. I must go into the country on Saturday, but I shall take the Draft with me and study its arrangement and mode of expression. I have not I hope a high opinion of my general qualifications for such a task, except the single one of prudence ....." (ibid). 
Report, and under his tactiul pen Chadwick's attack on the undertakers and cemetery owners lost much of its rude directness. In February 1850 the Report was published(1), and -- most surprisingly, in view of the attitude they were soon to adopt -- the Government introduced a Metropolitan Interments Bill two months later. "You have bestowed infinite trouble and most praiseworthy attention to the preparation of a matured plan", wrote Sir James Graham. "I shall consider it very attentively with a disposition to cooperate in promoting it as far as $I$ am able: but panie has supsided; and rejudices and selfish iaterests yield only to fiear in cases of this kind. Wuch will depend on the state of Public opinion with respect to your Proposal. When you first made it, the Public lind was not ripe for the Change. In the midst of the Cholera it might have been carried; I am not unwilling to hope, that with some modifications it may jet be found feasible". (2) It was something gained, st any rate, that the man who, as Home Secretary, had set his face against the scheme should now consider that it fell within the range of legislative Peasibility.

A Crown appointed Comission, with the power to levy rates, exercising functions which were now possessed by influential if siugoish vestries, threatening the existence of eight cemetery companies and three thousand undertakers, and treading the debatable ground between the Church and the sects, offered a very broad taret in the comons. The Bill was met by the unanimous opposition of the metropolitan members, who coupled Chadwlck and the Blshop of Iondon as objects of their boundless distrust; Chadwick for foisting upon the capital a huge job -- " "a board attended with 1 ts usual accompaniments of clerks, treasurers, secretaries, chaplains, and God knows

1. 15 iebruary. The descriptive portions of the Report, which added Iittle to Chadwick's Report of 1343, were written by Southwood Sinth; the recommendations, from p.

2. Sir James Grahara - E.C., 3 April 1850. 
what"(1) -- which would put some scores of appointments within the gift of the Whigs; the Bishop for having brow-beaten the Government into promising the clergy fees in perpetuity for services they would cease to render once their intramural churchyards were closed. The political economists argued against any interference with the machinery of supply and demand, but were blind to Chadwick's demonstration of the superior economy of large-scale fovernment contracts. The constitutionalists wre shocked at the weddling with local selfgovernment, but kept silent about the working of that admirable principle during the cholera epidemic. Dissenters were indignant at the introduction of distinctions between dead Christians which were not recognised between live ones, and protested that every living man, whether Dissenter or Anglican, would be mortgaged for a certain sum to pay compensation to generations of clergy yet unborn. (2)

Outside, in the press, and in the lobbies of the House, the undertakers were raising an outcry, just as in 1331 the chiffoniers of Paris had threatened to riot if their vested interest in street garbage were attacked by the French

Government. But the Bill had won one powerful and unexpected a.1y. The "Times", a little troubled at the condemnation of private enterprise as vicious and detrimental, a little dubious of the proposal to control individual choice by Government officers, hed yet decided that "the bodies of the dead and the tears of the living are subjects which may be withdrawn from tradiag speculations without violence to the maxims of political economy". (3) Londoners had reason to be grateful to the Commons for passing this measure, the "Times" told them; adding that it could perceive no compulsion except to deposit the corpse in a place where it would be safe from desecration, 1. T. Duncombe: Hansard, vol. 111, p. 693, 3 June 1350.

2. Hansard, vol. 11, pp. 677 - 710, 3 June 1850; pp. 856 - 870, 6 June; pp. $903-31,7$ June; pp. 1068 - 78, 11 June; pp. 1286 - 92, 14 June. Vol. 112, pp. 122 - 124, 20 June.

3. "Times", 17 April 1850. 
instead of in a foul reeking churchyard. (1)

\section{Chadwick's scheme emerged from Parliament with} substantially little change --- save in one respect, and that, as It proved, a disastrous one both to the schene itself and to the reputation of the General Board. Chadwick had recommended a special Burial Comission with four pald aembers appointed by the Home Secretary; the Government had decided instead that this new duty should be laid upon the General Board of Health, with the adition of one paid meraber for the purposes of the Act. It was a further burden which Chadwicis confidently assumed, but it added one more touch to the legend of his ambition and love of power. If the measure had been bedded out under a separate Comission, the General Board, its time alresdy sufficiently occupied with the tutelage of the Local Boards which its Inspectorz were calling into existence throughout the country, would have been saved two years of fruitless labour and anxiety, and the discredit of the eventual failure.

In Warch 1350, at this delicate stage in the Board's history, when one intricate measure was about to be introduced into the Commons and another (the Bill for motropolitan water supply) was well advanced in preparation, the Barl of Garlisle was appointed Chancellor of the Duchy of Lancaster, and retired frox the presldency. Iver since he had succeeded to his fatber's title, he explained to Chadwick, he had wanted more leisure for his ow afpars. Bu the easy-eolng carlisle turned his bsck without rouch real regret on Gwydyr House, with its earnest sanitary labours and its unsetiled atmosplere of continual controversy. Vore than once he had threatened to "cut and run". (2) had supported Chadwick loyally, but with $-0-$

1. "rimes", 21 June 1350.

2. "fiot water -.. hot water -.. hot water!", he wrote to Chadwick on 18 January 1850. "Here I have a remonstrance from some of the Comaission of sewers, and some of the best too, about the tone of soine of your communications to them. They will give you any informstion you wish that they can supply, but they cannot have their officers imperiously (Continued on next page) 
a sense of increasing strain, and though he remained friendly and helpful in the difficulties of the following years, he showed no willingness to take a full share of the "odium sanitatum".

Chadwick could not conceal his alarm that the presidency was again at the disposal of the political chiefs. It had been a miracle that Lord Ashley and Lord Carlisle had been appoknted to the Board in the first place, two noblemen both of whom were syapathetic to the sanitary cause and willing to accept Chadwick's leaderghip with a good grace -- a miracle unlikely to be repeated.

"I cannot help expressing anxiety, at the appointment of any stranger in our peculiar position", he wrote to Carlisle, "particularly of any one with whom Lord Ashley may not cordially co-operate, and he is not likely to cooperste with any one who has not hitherto manifested zeal for our common objects.

Ary material change of the Board would at this time be peculiarly hazardous pending the discussion of the interment question, when it is jmportant that the confidence of both the Church and the Dissenters should be maintained undivided as I believe it is in the present Board, particularly in Lord Ashley. I cannot but perceive, that he is discomposed and anxious on the subject of a change.

With an old Board, and with settled courses of action, there may be little danger from changes in the personel but with this where all is new, where there has been so much anxiously prepared and agreed upon, where we see many of our chief

difflculties and have all I believe a perfect understanding, and reciprocity of feeling, and where the public bave confidence, as - 0 -

(Continued from previous page) sumaned. I think they are quite right in this, and you may depend upon it no coordinate body will bear it". When Chadwick wished to take up the point, and uphold the authority of Comissions of Inquiry (the information was required for the Metropolitan Sanitary Commission, the warrant for which had not yet expired), Carlisle implored him, "Pray do not be blowing sparks into llames, or I shall cut and run". 
is most unequivocally shown by the extent of applications to us any large change will at this time I am convinced be unsatisfactory to them hasardous to our measures and damaging to the Government. It must present the appearance of dealing 1ightly and perfunctorily with a business, which they regard every day more seriously.

The extreme zeal and labour which lord Ashley has

bestowed in mastering the subject, will I hope be considered with his reeling upon it". (1)

1. B.C.-Carlisle, 6 Merch 1850. He mrote about the same time to Russe11:

"For the introcuction of a new department, a more fortunate cholce could not have been abe, than of two noblemen of the highest standing in the country with all parties and of knownzeal for the objects in question, menifested before they were in offlce.

There was also an obvious fitness in having as an ex officio President of the Board a Cabinet hinister, and it tended to the public confidence, that the Government by this arrangement, regarded specially the proceedings of the new department.

The public confidence is shewn uneguivocally by the unexpected extent of applications to the Board for its interforence.

Will it not shake confidence to alter the arrangements and introcuce, at this time a new wember of lower office and station, with whom lord Ashley may not be able to act cordialiy.

The interment ineasure is one in which the public feeling is involved more tban may readily be estimated. Up to this point confidence is evidently with the measure and with the Board. But it is most important that, on this neasure, it should heve the confidence of the Church and the Dissenters. The Board has now this confidence particularly in tord Ashley.

With an old established department changes in the personnel may be made with comparatively little danger. I hope that in the course of another year or so that we shall have got out of the provisional state, and so far established that the changes may be made in this, but at present when there is so much in preparetion that is agreed upon, with perfect unanimity of feoling, the introduction of a stranger, or of any person lower in position, or of less public estimation, excites much apprehension.

Would your lordship allow ne to submit for consideration whether the ex officio presidency of the General Board of Healti might not be attached provisionally so at the least (Gontinued on next page) 
"Whenever I have been deeply troubled in spirit and have received a note from you", he wrote again a week or two later, when it was clear that the loss of Carilsle could not be averted, "it has produced a calning soothing effect, and helped me on in the course of duty; and so it is now, but it is the promise that tho' somewhat separated officially, you wili be present and aiding us in our snubs which will be many. I have said amongst my friends that I have never served with any one, whose notives I felt to be more pure and elevated and therefore icindly. I observed only that at times it soemed to me the kindilness was in excess for the rudeness, bad passion and sinister interests which were opposed to us ....."(I)

An even more serious blow to the Board of Health than the witharawal of Carlisle was narrowly averted. Lord Ashley had counted upon having the honour of introducing the Interments Bill Into the Gommons, and when the measure was entrusted to other hands he sent in his resignation. He was given all the tedious details of the Provisional Orders to steer through the House, he grumbled, but any important measure the Government reserved for therselves; he was to be"reduced to the station of a senior oleris in the Home Office". (2) Fardly had he been talked out of his sulks when he heard that another was to be appointed over his head as fresident of the soard of Health. Again his resignation went in; and he was persuaded to remain

(Continued erom previous oage) with the lighter office of the Duchy of Lancaster, and whether if the Presidency of the Board of woris be not held oy a neuber of the Crisiat, the General Board of Health may not be left, as it is provisiona $11 \mathrm{y}^{\prime \prime}$.

1. E.C. - Gaslisie, 27 Harel 1350.

2. H. Hodder, op. eit., vol. 2, p. 318. mhey expect me, I perceive, to devote my time, thoughts, alwost life, to the business of the Board of Health; to prepare the plans and Bills, but then to have no volce or discretion in the proposal or conduct of then, nor any little honour that may accrue from the scheme and the industry bestowed upon it. (Honour, in these metters, becones influence and power to do more) ..... I cannot bide to mysele my own disappointment; partly, I had hoped that my name (is this an illogitimate desire?) would be inseparably connected with these reforms; and, partis, i noped that intense labour and anxiety would not be without their fruits". (Diary, April 1850). 
only by a promise from Russell that he should have the Blll for metropolitan water supply. (1)

If not Ashley, who was to take Carlisle's place at the head of the Board? Looking round for men of good will, Chadwick picked out Lord Bbrington, a member of the Poor Law Board, who had taken part in the early sanitary compaigns and knew something about the subject; moreover, he assured Russell, employing a characteristic argument, the Poor Law Board could be worked just as well by three members as by four, and by transferring Ebrington the Government would save 21,500 a year. (2)

Considerations of economy and aptitude, however, exerted no influence on the political dispositions of the Russell Government. Amongst the members of a deputation which had waited on Chadwick a few weeks earlier to oppose the application of the Public Health Act to Totnes was one who confessed franikly that he knew nothing about the measure and had never read the Act. (3) It was Lord Seymour, heir to the Duke of Somerset -.. who now took his seat as First Commissioner of Woods and Forests and ex officio president of the Board of Health.

\section{chilling blast}

Seymour's coming fell like a $\mathbf{x} \times \mathbf{x} \mathbf{x} \mathbf{x} \times \mathbf{x} \times \mathbf{x}$ of scepticism and hostility on the devoted company of Gwydyr House. At their first meeting he informed Chadwick and Southwood Smith that his rule of action in office was"never to act until he was obliged and then to do as little as he could". This remark, observed Chadwick, "was addressed to men who had explored the seats of fever and had each suffered by it, in a new department appointed to promote measures, for the reduction of preventible sickness and death by the wholesale, which they, from study knew to be practicable". Seymour, they heard, "was averse to all such interferences and his saying was that there must be poor" -..- "a pretty theory", commented Chadwick in disgust, "that physical degradation and misery was not only an irretrievable, 1. E. Hodder, op. cit., vol. 2, p. 319.

2. He. Russel, 7 March 1850 .

3. "Adrinistrattve. Notes of objections to the course taken by Lord Seynour in respect to the Public Health Act", MS, n.d. 
but a proper necessity for the great mass of the population". (1)

Seymour's shocked colleagues did not immediately confront his statement of faith, "the policy of which for these times might be questioned for older departments" and which was particularly repugnant to the principle of the Public Health Act, "which is to do with the means granted to us, all the good in our power". (2) But the inevitable clash between Chadwick and Seymour could not be long delayed. The new President left no doubt of the value he set upon the activities of the Board, and complaints presently reached Chadwick that his whole bearing was one of hostility to ganitary measures. He openly declared that he wished to stop as much as he could. Deputations from local authorities and sanitary associations were received curtly and their cases listened to with evident ill-humour. Nearly every officer of the Board was given marks of his disapproval. (3)

On three occasions only during the two years of his presidency did seymour attend meetings of the General Board, and since his colleagues were so rarely honoured by his presence dificulties soon arose over business which had been conducted in his absence. Not long after his appointment, Chadwick was requested to wait on him at the Woods and Forests. Beymour then produced a paper he had received from the Treasury, and asked "in a very unusual and unpleasant manner" why he had not

1. E.C. - Russell, n.d.

2. E.C. - Carlisle, n.d.

3. Chadwick describes how Lord Seywour attended a meeting of the Board when a minute was passed to recomend the appointment of Sutherland and Holland for three months to make preparatory inquiries for the execution of the Interments Act. Although he had agreed to the minute, he called in sutherland a short time later, and "in a most offensive manner" informed him that if the present appointment were sanctioned, its renewal would not. Sutherland, a most valuable officer, had been much hurt by Seymour's manner.

Shembers of a depuation from the Town Council of Birmingham told Chadwick that Seymour's reception of them indicated decided hostility to the Public Health Act. This was undoubtedly a factor, Chadwick judged, in deciding them to apply instead for a Local Act. 
been made acqualnted with 1t, and with the Board's proceedings in general. Chadwick retorted that there was every disposition to advise him of their doings, but that, with a Board which sat dally to deal with such a variety of subjects, it was impossible to keep a person who never came near supplied with information which could be acted upon satisfactorily, unless be could listen for a period in proportion to the time which the Board took in transacting its affairs. "I ventured to represent to him that action upon such a business, otherwise than at the Board, and as a member of 1t, or upon the hearsay of any individual members in the absence of the others, was not what was contemplated in the act, or understood by the legislature or the public, and was I apprehended not only questionable in law and practise, but led to misunderstandings and unsatisfactory results .... He told me that he knew all I said as to the practise but inasmuch as he was held responsible by the Ireasury be must be informed at all events, of all matters which involved expense. I repeated to him, that there was no other disposition than to give him every information but that if any of the members of the Board were required to act irregularly they should be exonerated from whatever responsibility might be incurred by it. I stated my apprehensions, that for a new Board, jealously watched, sarrounded by enemies it was impolitic and unsale to have any irregularities even in formal practise".

(1)

On August 5th 1850 the Metropolitan Interments Act received the royal assent, $(2)$ and the General Board (with the exception of their President) held a special meeting the same day to decide on the steps necessary to execute its provisions. Southwood Smilh, who had ceased to have official standing on the Board when the Nuisances Removal Act lapsed at the end of the epidemic, had been appointed aditional member for the purposes of the Interinents Act, and Charles Macaulay, nephew of Sir Charles Trevelyan, chief secretary to the Treasury, became 2. E.C. $\overline{1}^{2}$ ? (Carlisle), n.d. 
assistant secretary. Alexander Bain, the assistant secretary appointed under the Public Health Act, had resiened six months before, worn out by the heavy pressure of business which the cholera had put upon the office. His place, in deference to the Treasury, had not been filled; and now Austin, "poor Austin" as Carlisle called him, who had struggled to cope single-handed with the ever-growing correspondence of the Board, threw up the task out of sheer exhaustion and became a Superintending

Inspector. He was replaced by Tom Taylor, barrister at law and Fellow of Irinity College, but best known as a contributor to "Punch" and the author of numerous farces. (1)

In September Chadwick and Southwood Smith visited Paris and spent ten busy days accompanying the medical inspectors of the prefecture on their daily rounds and seeing at first hand the successful working of an interment scheme similar in its essentials to the one they were now preparing to carry out. (2)

1. Minutes, 18 March 1850 . The legal business was soon suffering from his cheerfuliy offhand attention. The Inspectors complained of the loose manner in which be replied to their inquiries; and Chadwick, who had referred Taylor to his own Poor Law orders as a model, had frequently to go over his drafts of bye-laws and weed them of technicalities. Most alarming of all, Taylor presented to the Board, almost as a matter of course, proposals for sanctionling the mortgage of the rates of Great Yarmouth for the very works which had been condemned in the Inspector's report as wasteful and useless. Sending bim a lengthy reprimand, Chadwick observed that it was almost publicly notorious that he attended, within the hours of official business, to matters nct in accordance with the very serious work in which the Board was engaged. He came late and left early, was frequently absent in the middle of the day, and had now stopped signing the attendance book. One messenger was chiefly employed in taking papers to the printers, the offices of "Punch", or the theatres. Actors and editors had been received in the office, and on one occasion Taylor had absented himself to attend the rehearsal of one of his Parces. (E.C. - T. Taylor, 12 April 1852).

2. "Report of Preliminary Proceedings under the Metropolitan Interment Act. Prom the 5th August to the 31 st December $1850^{*}, 3$ July 1851 , pp. $5-6$. 
In the first five months the Board received 5,000 communications on business under the new Act, and sent out nearly five times as many. (1) It must be remembered that, simultaneously with their activity under the Interments Act, the three colleagues were engaged in preparing a scheme for the water supply of the capital, and in introducing sanitary works into over a hundred towns which by now had been brought under their jurisdiction. In their Minutes the analysis of water samples, the choice of gathering grounds, the examination of engineering estimates, the appointment of survejors and officers of health, the reception of deputations friendly and hostile from the locelities, all jostle for attention with questions of cemetery sites, the design of reception houses, and compensation to vestry clerks and churchwardens. It will be convenient, however, to unravel one thread at a time from this tangle, and to follow to its end the story of the Hetropolitan Interments Act before turning to other aspects of the Board's work.

Was the scheme workable? Was it practlcable for a public board to manage cemeteries, to monopolise burial, and to regulate the cost of funerals by large-scale contracts? To this question Chadwicik's reply was to point out that in Frankfort, Munich, Berlin and elsewhere publicly owned cemeteries were in operation, while in Paris the "Service des Pompes Funèbres" worked with general satisfaction; in short, that the measures which his critics declared to be impracticable were practised abroad with great advantage to the community. The only difference, in Chadwick's view, was that his plan, which aroused the appreciative envy of Parisian administrators, was more thorough, showed a clearer recognition of the social objects involved, and provided a superior machinery for public control and instruction. Only the event could show whether or not he was right, and it might vell have furnished nim with a conclusive reply to his critics. As it turned out, however, his scheme did not succeed; neither did it fail; it was merely $-0-$ 1. ibid., Appendix A, P. 14. 
not attempted. The General Board, in eighteen months, never got further than the preliminary skirmishing with the cemetery companies and the Treasury.

From the first it was made clear to the Board that the Treasury disliked the Interments Act, and distrusted the men who were to administer it. A week or two after it had been given the royal sssent, Chadwick received an emphatic warning that the measure "would never be allowed to work". (1) The Chancellor of the Exchequer, Sir Charles Wood, had for years been dragged reluctantly at the rear of his party along the dangeroug paths of social anci economic reform. He had not accepted the necessity for the repeal of the Corn Laws until 1844; he had fought against Ashley's Bill to restrict the hours of women and children; and the only remedy he could see for Ireland in 1847 1848 was to wait with Malthusian resignation until fanine and hunger had cut off the excessive numbers of Irishmen. Put in charge of the invalid Whig finances in 1846, he directed himself with single-minded devotion to the one object of cutting public expenditure. He had obliged the General Board to begin its work with a staff too small for efficiency, and he never forgot that during the epidemic they had defied the Treasury and appointed five temporary medical inspectors. His views were shared to the full by Willian Goodenough Hayter, who, as Parliamentary Secretary to the Treasury, was chief whip and paymaster to the Whigs, maintaining discipline and good humour in the party by the judicious dispensation of the loaves and ilshes of patronage. He told Chadwick that he considered him and Lord Shaftesbury "no better than a pair of socialists", and frankly declared that he intended to do what he could to hinder them. (2) "Mr. Hayter has been sufficiently explicit to me on the subject", Chsdvick remarked to Carlisle, as the Interments Act faltered to a standstill in the Treasury bog. "He has told me in so many words that he thought the whole measure entirely 2. E.C. - Lord John Russeli, n.d. (185l).
ibid. 
wrong; that he was opposed to our whole proceedings, that he thought it wrong to interfere with trading companies, that we were wrong in our measure as to water supply, that Government ought to have nothing to do with these things: for Government did everything badly, or worse than other people. Certainly his own office has done nothing to reverse that dictum". When the Russell Government $\mathrm{fell}$ in 1852, Hayter told Chadwick that he regretted quitting office since he would thus lose the opportunity of "working" the Board of Health. (2) Finally, Chadwicis thought it was not without significance that the Treasury letters to the General Board bore the signature of G.C. Lewis, who had nearly succeeded in stopping the publication of the Sanitary Report in 1842.

It would be interesting to know how many legislative projects have been killed in embryo by over-cautious Chancellors and unco-operative Financial Secretaries; but there are no mortality statistics for the unborn. The peculiar value of the Minutes of the General Board and of Chadwick's memoranda and letters relatiag to the Interments Act, and to the Metropolitan Water Supply Bill which we shall consider later, lies in the fact that they reveal in detall how such an abortion was carried out, and 1ight up the motives of those responsibie.

The first step must be the immediate purchase of the eight metropolitan cemeteries, the soll of only one of which was suitable for interment, and the simultaneous closure of the overcrowded sraveyards, which could be divided "only into such as are bad, and such as are extremely bad". The General Board must take possession at once of every cemetery and graveyard. If only one district were selected for the introduction of the new scheme, bodies would merely be taken outside its uoundaries to other grounds in just as bad a condition.

1. B.C. - Carlisle, n.d.

2. E.C. - Lord John Russe11, n.d. (1851).

3. Minutes, 21 November 1850. "Of the eight existing cemeteries, five consist almost entirely of a stiff retentive clay soil, quite ansuitable for the purposes of (Continued on next page) 
On November 25th 1850, after a careful examination of the sites by their Inspectors, the Board submitted an estimate of the value of the cemeteries to the Treasury, and requested permission to negotiate for their purchase. Two months elapsed before the Ireasury replied. The Board's estimates, showing a valuation of $6251,000^{(1)}$, must have been framed on insufficient data, wrote G.C. Lewis at last; the Treasury's own expert was of the opinion that the cemeteries could not be acquired for less than their original cost, which might be as much as 2750,000 . The Ireasury wre not prepared to permit the Board to enter into negotiations of such magnitude, which might commit them to any indifinite amount that a jury might award. They suggested an alternative policy. The Board should buy up one or two of the cemeteries as a start, which would enable them to close the worst of the graveyards, and also give them some idea of the exact figure of the compensation which would have to be found; at the same time they might at once take steps to acquire land for a public cemetery, which would show evidence of their intention and ability to carry out the requirements of the Act,

(Continued from previous page) interment. This soil could only be rendered fit for interment at a cost between two and three times as great as would be requisite for the purchase of new sites where the soil is unobjectionable. Of the remaining three cemeteries, the soil of one is so porous and dry as necessarily to impede decay; of another the soll could not be used without an expensive process of drainage, and out of the whole eight there is only one the soil of which can be considered in its present state as fit for interment".

1. The valuations of Austin and Ravlinson (ibid.), based on estimates of the land, works and buildings, and the laying out of the site, were as follows:

Kensal Green
Nunhead
Highgate
Norwood
Brampton
Abney Park
Tower Hamlets
Victoria Park

553,453

$839,371 \quad 13$

cic, 378

240,927

243,836

224,236

$223,131$.

\& 8,990

$\begin{array}{rr}12 & 5 \\ 13 & 0 \\ 4 & 0 \\ 0 & 4 \\ 15 & 3 \\ 16 & 4 \\ 19 & 8 \\ 7 & 11\end{array}$

2251,326

$8 \quad 11$ 
independently of the cemetery companies, and so strengthen their hand in the negotiations.

The whole question of a burial monopoly, and of its administration by a public authority, was thus re-opened, and Chadwick found himself repeating once again his familiar arguments against leaving the interment of the dead to the anarchic, irresponsible competition of comercial companies. On January 30th 1851 Lord. Seymour made one of his rare appearances at the Board. The reason was soon evident. He moved that the Board of Health was ready to act on the Treasury sugsestion, and would open a cemetery of its own to go into competition with the joint stock grounds. When his colleagues refused to adopt the Treasury's "absurd and destructive scheme", Seyuour declared their attitude was "most unwarrantable insubordination", and warned them "this would never be forgotten or forgiven by the Treasury". (2) The Board ignored his

threats, and re-defined their position in two uncompromising Minutes, the substance of which was embodied in letters to the Preasury. (3) The Board did not feel it their duty to treat for the cemeteries on the principle of their alleged cost to the proprietors, which might burden all future burials with compensation for works of little public use, on which extravagant and wasteful expenditure had been lavished. But $-0-$

1. G.C. Lewis - Hoard of Health: 22 January 1851 and 13

Februery 1851 ("Second Annual Report of the General Bosrd of Health, under sec. 73 of the Metropolitan Interments Act",

2. P.e. - Iogard John Russeli, n.d. (1851).

3. Minutes, 30 January and 14 February 1851. Boerd - Treasury, 31 January and 15 February 1851 ("Second Annual Report", pp. 111 - 116). The Matute of 14 Peoruary states "that the principle of unlimited competition as to price without security for the due performance of the services paid for had zalled of every object in respect to burial; that, as applied to the provision of sepulture, it was repugnant to the feelings of large classes, and that instead of this system of competition, funerals should in ruture be performed by contractors, under the Board of Health, engaged to perform stated services at rates of charge to be definitely fixed". 
even if the juiles mere to award the full sum claimed by the companies, it would atill be necessary to make the purchase and 1t would still be consistent with the estimates laid before Parliament, which were based on the proprietors' own valuations of 2400,000 . If the Board attempted to carry out the Act without first securing possession of all the cemeteries, they would find thenselves involved in a competition with the companies, "most unseemly and repugnant in itself, ..... and aubject to all the disorder and loss necessarily incident to the introduction of a number of capitals in the same field, rendering it impracticable to make tho desired reduction of charges to the public". (1) In such a contest the Board would be handicapped by having tc rind 240,000 of compensation per annun, and by having the further burden of a ilxed interest of $4 / \varepsilon$ per cent. on their capital; while their competitors would have the advantage of cluser proximity to the metropolis, and would undoubiedly continue to make unscrupulous use of such insanitary but profitable practices as pit burial and the re-opening of graves after recent interwents.

(2)

"I wish to record $m y$ disapproval of that answer", wrote Lord Seymour after the Board had despatched their second letter. 1. The lreasury scheme " competition on the largest scale, and from the trading interests involved, with a degree of virulence and desperation which has not hitherto been witnessed, and such as must be offensive to decorum and public feeling, preventive of economy, incompstible with systematic nanagenest and accompanied with risk to the public health". (Minutes, 14 February 1851).

2. "It appears to have been overlooked that the Board have no power to direct the corpses from any district where the grave yards may be closed, shall be interred in the paricicalar cemeteries, or new sites which maj be opened; neitiner have the Bosrd any power to regulate the existing cemeteries, and consequently no power to prevent pit burial or the re-opening of graves after recent interments, or ang other practices at variance with sanitary principles which lessen the cost of funerals to the Companies; which practices could not be adopted or allowed in any cemerery opened by the Board". (ibid.) 
"The Treasury have refused to sanction the scheme proposed by the Board; and since upon this point authority is given to the Treasury by Act of Parliament, it appears to me that the Board or Health, after having fully stated their opinion, should submil to the decision of the Preasury. The course now proposed to be adopted by the Board of Health, in again arguing with the rreasury, instead of acting as they are required, would, if it were copied by other departments which are similarly subordinate to the Fressury, obviously render all the machinery of the Executive Governuent inoperative ....."(1)

Chadwick's answer was to point out that the rreasury's proposition amounted to a suggestion that the setropolitan Interments Act should be dispensed with, and another principle of action be introduced, at variance with that laid down in the statute. By the Act the lreasury were invested only with the responsibility of approving the appointrents and the financial arrangements; and if the Bourd carried out the Treasury's scheme, end became involved in disaster in consequence, it would be no defence to plead that they were acting on the advice of a body which had no legal standiag in the matter. "Supposing the plan of competition had failed, as it must, might not the members of the Board have been held to be responsible for the failure, for the delay of the remedy, flatiy opposed to their recommendations? .... Parliament might sey .... what

justification have you who had the most inforastion for adopting against jour own convictions, a course which you believe to be illegal, as well as impolitic, at the suggestion of persons who have paid only incidental attention to the measure and who are not resporisible for it? ${ }^{n}(2)$

"I feel myself in a position of some delicacy as to being at all an wapire or point of appeal in your unhappy differences", wrote Lord Curlisle, when Chadwick appealed to him, "nor do I think ny representations to my colleagues come 1. 17 Vebruary 1851 ("Second Aarual Report", pp. 132 - 133). 2. Wh prament, n.d. 
with so much effect, as I am always rather considered to be still acting under your spel1". (1) And it was the influence of Sir George Grey rather than of Lord Carlisle, Chadwick believed, which prevalled with the Chancellor of the Bxchequer, and induced him to consent that the Board should be allowed to proceed with the scheme sanctioned by Parliament. (2) 1851, four months after the Board had made its original application, the Treasury authorised them to buy out the cemeteries. (3) Fromptiy they issued notices for the compulsory purchase of the Brompton and Nunhead grounds, und made an offer for the Abbey wood estate at Krith, on which Chadwick planned to build his National Cemetery. (4)

Now came further delays and embarrassments, as the Board encountered the shareholders' invincible bolief that their property was worth far more than the surl they were offered. Chadvick urged on lord seymour that the Board should be given the powere they had requested in the Interments Report to compel a decision by the findings of a jury, pointing out to him that the experience of his own department, the woods and Forests, showed how vain it was to expect to purchase land or property for public purposes by private agreement with the owners. The Treasury insisted, however, that the purchase should be made by a series of separate bargains; and the cemetery companies, unwilling to hasten their own undoing, claimed the right to submit their csises to the dilatory procedure of arbitration. Before the Board could enter into possession of the cemeteries they must await the adjudication of aine claims for compensaiton. By July 1851 the arbitration proceedings for the first two cemeterles had been in progress three months, and were still not complete. At this rate, their solicitors warned them, they vould not get possession of all eight in less than a year.

1. Carlible - 2.0., 1 Tebruary 1851.

2. E.C. - Russe11, n.2.

3. Minutes, $19 \mathrm{March} 1851$.

4. ibid., 21 March, 21 April, 8 May 1851.

5. 1bid., 1 July 1851. 
"The delays to which we have been already subjected have been most disastrous", Chadwh.ck told Carlisle in May, "They have enhanced expense; they bave given rise to extreme inpatience; we have done our woris In one third the time, the other two thirds has been the Treasury, and in part Lord Seymour, all the delays have resulted in differences, and those differences we are confident, it must be said deviations in exror.

The appointment of a president who cannot preside augnents by one third our delays even if he agcee in our views: it could never have been worked if you lad not come bo the Board". (1)

Chadmick now went lnto the City to raise money for the purchaze. To his consternation the Guardian Assurance Company declined the loun on the legal ground that the Board's life was limited by the Public Health Act to five years, and that it might not therefore be in existence at the expiration of the loan. The Directors of the Royal Lxchange Assurance Company, who were next approached, exarined the estinates of the smount to be expected from fees. They discovered that there was no provision to secure the whole of the interments to the Board; that bodies right be taken to new and unconsecrated grounds outside the jurisdiction of the Metropolitas Interments Act; and that in consequence there was no guarantee that the Board would have power over the whole of the burial fees. (2) A powerful 1. B.C. - Carlisle, 19 Hay 1851.

2. Winutes, 22 April, 2 Kay, 24 day, 10 June, 17 June 1851. "Gecoad Aanual Report", po. 7 - 3.

"It is said that as the law now stands, there is nothing to prevent the formation of new cemetery Companies beyond the Metropolitan district to compete with the Board, and that as such Companies would be free from the havy charges imposod on the soard for conpensation, etc., the Board would be unable to support the competition. Ihis objection goes to the root of all the calculations upon which the Board rest their estimates of a revenue, and can be removed by nothing else but reileving the Board from the possibility of competition". (Memoradum on the loan difficulties in uinutes, 14 July 1851). 
reason for their doubts, Chadwick believed, was that the delay in executing the Ast had encouraged speculators, and a $B 111$ to establish a Metropolitan Necropolis at Woking was nov being canvassed; its promoters clalmed that they had the approval of the Goverament, and Ghadwick discovered that the Sollcitor General, SIr Richard Bethel, was a large shareholder, and his brother-in-law was the architect.

The board turned now for help to the Treasury, suggesting that the measure should be Rinanced with Bxchequer Bills, and pointing out that this would save 217,500 a year on the estimated outlay of 2700,000 , since money-lending corporations would require a profit of from 2 to $2 \%$ per cent. more than the Government. (2) mhen I weat to the Bank (of England) Pariour, and explained our application for a loan to the Directors, "See, exclaimed the Governor to the Directors, the way in which the Government manages these works, in placing the public at the mercy of money corporations like ours: putting the public at such an expense when it thay upon a dixect security, obtain the money by Lxchequer Bj11s at so much less". Such Government assistance, argued Chadwick, was granted freely enough for other public purposes -... the anaual retura listed advances "For Canals and Drainage", "For Farbours and Dockg", "For Railways", "For waterworks", "Yor Collieries and Mines", "For inlerging Workhouses", "For Lunatic ksylums and other Public Buildings", "For the Relief of Parishes", "lor the Improvenent of Cities and Iowns". Why not an issue of Ekchequer Bills for "ketropolitan Internents"? (3)

This solution did not recomend itself to the Treasury, however, and thus in July 1851 the Interments Act Ilokndered to a halt. Despite the erequent, earnest meetings in Gwydyx House, the reports, the thousands of letters, the busting: energy of the Inspectors, the Board now found themselves hemmed 1. I.C. - Russe 11 (?), n. 3 .

2. Minutes, l July 1851 .

3. B.C. - Russo11, 21 July 1851. 
in by a closed circle of perplexities. They could not close the parochial graveyards without gubstituting alternative places of interment; they could neither ख out the ceutery companies nor provide new burial sites without raising money; they could not raise money because of the defect in their constitution; and when they approached the Governuent with a view to removing this defect, they encountered a disposition to curtail rather than to expand their powers. Chadwick was on edge with annoyance and anxiety and the irritatins sense of labour thrown away. Shaftesbury was on the point of resigning out of pique. (1) Lord Carlisle seemed reluctant to come out in support of the Board and the Report to which his name was attached -.- that amiable nobleman too easily took on the colour of the company he was in.

All that the Board reeded, in Chadwick's judgment, to make the Interments Act workable was the goodwill of the Ireasury and the addition of two clauses: one pcoviding for some other body to sssume the lisbilities and duties under the Act if the Bosrd of flealth were discontiuued, the other empowering the Board to levy its fees and impose its regulations on the burial of every person dying within the metropolitan area. Hopefully Chadwick prepared a 3111 exbodying the two clauses ${ }^{(2)}$, and obtained the approval of the Assurance Companies to its terms. (3) After all, he thought, the "insuperable difficulties" of Sir Charles food were the merest oversights, which the Comons -.. who, in approvize the purclase of the metropolitian

ceneterios, must have intended that the board should have the 1. B.A. - Carlisle, 21 Jüly 1851.

2. "Bocond Anmual Keport", pp. 9 - 10. "Metropoliten Interments Act Amendment. Uraft of a 131.12 to amend mine Metropolitan Interments Act 1850", and to provide for the Regulation of Hon-parochial Burial Grounds hereafter to be provided", 23 July 1851.

3. The Board have yet the assurance of persons conversant with the advance of large loans of money; that if what it must be concluded was intended by parliement, V1z. : a good legal security be Biver, the money may be obtained by loan, with as littie dificulty as it is now raised for other local and general oublic works where the security is satisfactory". (Minutes, 21 July 1851). 
means to do it -... would rectify at once if the case were fairly put to them. Shaftesbury showed the two clauses to Sir Charles Wood, who said he had no objection to them but he did not think the House would pass them.

The Board's clauses, however, never went before the House. "Jnstead of doing so", Chadwick compleined to Carlisle, "Sir Oharles is reported to have represented that the Board had made some propositions which the Government could not assent to, as if it were something new and enormous that they required: whereas all they requested is comprehended in the scope of the act as it stends". (2) The Chancellor then introduced a Bill providing for the advance of $\$ 137,000$ from the consolidated. fund for the purchase of the Nunhead and Brompton cemeteries, and announced that in the next session the board might be deprivea of lts executive powers and reduced to a Boara of Control, the duty of providing the means of burial being charged "either on the parishes or on districts, or or parties". (3) It was clear that the rreasury had written of the Interments Act as a dead $10 s 8$, and were now preparing to wind up its affairs. And worse was yet to be leared. wood was openly coquetting with the wild men of the Marylebone and St. Pancras vestries. Late one night in an emptying souse he announced the"intention of the Government to renew the sewers Comission only temporarily and next session to briag forward a aeasure, to put the water supply and also the intermeats act, under the oarochial representatives. Sir Charles made this statenent, bowing to Lord Dudley Stuart who forthwith thaniced the Goverrment". (4) Yothing could bave been more insolent than his maner when Shaftesbury saw him for a few minutes and conveyel the Board's protest at his sudden change of front. (5)

\section{For some months loager the laternants act liagered on in}

1. 3.C. - Carlisle, 22 Julg 1351.

2. B. - Carlisle, 21 July 2351.

3. Hansard, vol. 1is, p. 1552, 25 July 1351.

4. 2.0. - Lord? , 23 julg 1351.

5. Shaftesbury - L.Q. 23 July 1351. 
its state of suspended anination. In October, after nine montins of haggling, the awards for the two coneteries were promileated at last. The conpanies had falled so utterly to make out tieir case, ad the Board's offer was thought so liberal, that the unpire declined to call evidence. The companies had clalmed \$2.68, 111; the Board bad offered tien 283,707; they were awarded 2117,105 . (1) Jubilantly Chadwick pointed out to Delane that, though the rate of compensetion was one-third bigher than the Boerd had intended to offer, 1t would not make the totsl purchage price for the oight cereteries more than 2350,000 , insteac of the 2750,000 which the Treasury expert had estimated. (2) On November 24 th 1851 the Bishop of Loncon heades a deputation to the Prime Minister and the Chancellor of the sixchequer from the Letropolitan Sanitsry Associetion, and spoke to a brief which chadwick had put in his hends a few days before. Lie was convinced, be deciared, that the intergents question could never be effecturily dealt with except by a Government Board composed of men who, like sinfitesbury and Chadwlek, hed full clalms on the confidence of the church and public by reason of their mastery of the subject. The proposal, which had been ruaoured, to put ourial in the charge of some new body which ofmould also be entrusted with the sewerage and water supply would disgust public opinion. In reply, sir charles wood declared that he wos satisfied that the Board's estiaties for the purchase of the cemeteries would be exceeded three or four trimes; he added "that in Sainburgh no one was suried within the city, but the whole was managed by cexetery companies; thexefore it did not seem so absolutely impossible to be done by private partics" (3) The deputation lelt with the impression that Lord John did not know much about the hatter and 3 ir cbarles wood knew very little more. (4)

In December the ireasury adrainistered the coup do grâce. -o-

1. Minutes, 18 october $135 \%$.

2. E.C. - j.I. Delane, n.d.

3. "Pimes", 25 November 1851.

4. E.C. - Lord? , c. 25 Novomber 1851. 
The Board were instructed to abandon the awards for the Brompton and Nunhead cemeteries, and were informed at the same time that a new interments measure would be submitted to Parliament early in the coming session, framed on principles essentially different from the existing Act. (1) "There is no use, I am sure, in lighting against power, unless we have something on our Side to appeal to", wrote Shaftesbury resignedly. "You particularly and the Doctor cannot $\underline{10 n g}$ resist, and retain your positions; and we shall then lose all by endeavouring to save half". (2) A word from the Treasury, an additional clause or two, Chadwick reflected bitterly, would have saved the Interments Act and the Board of Health from the reproach of failure. Convinced as he was that "measures for the relief of pain and physical suffering should have the precedence over all others" (3), he was perplexed and bewildered by this absence of goodwill. The more he thought of it the more incredible it seemed to him that "a matter of the most solemn moment, the horrors of a thousand agonising scenes to the population" (4), should be so lightly dismissed by the Government. Nothing had happened to show that his scheme was unworkable and based on wrong principles, jet official encouragement was now being given to everything that had been condemed in evidence, trading in burial, joint stock cemeteries, and parochial management.

Surveying the unhappy history of the Act, we can see that by the end of 1850 the Government had got over its cholera panic and had had time to think twice about metropolitan interments; and its second thoughts, coloured by a general suspicion of central Boards and of interference with private enterprise, were against Chadwick's National Cemeteries. While still anxious to be rid of the indecencies of burial within the capital, and to find a remedy for a nuisance which thrust itself on the eyes and noses of Nembers of Farliament every time they went by St.

1. Minutes, 15 December 1851 .

2. Shaftesbury - E.C., 7 Decenber 1351.

3. E.c. - Lord ? , n.d.

4. E.C. - Lord?, c. 25 November 1851. 
Margaret's churchyard on their way to the House, it was not prepared to sanction the peremptory intervention of the Board of Health. In the rreasury view the Board were comitting the Governinent to a vast undefined expenditure for a dubious object. Hayter told Chadwick in conversation that the cemeteries would never be bought for less than a million; to which Chadwick roundly returned that, if Hayter were not a shareholder himself, he was speaking in the interests of shareholders. (1) Certainly the Treasury produced no evidence to support Sir Charles Wood's assertion that the purchase price would be three or four times the amount stated by the Board; the arbitration awards in the case of the Brompton and Nunhead grounds, indeed, showed that Chadwick's figures were far more reliable, and that the total cost of buying out the companies would be well within the estimates which Parliament had before it when approval was given to the scheme. Behind the curtain of financial scruples, in fact, the Treasury concealed a more powerful motive for its opposition. Seymour, (a former Secretary to the Treasury), Wood, Hayter, Lewis, had all been trained in the negative traditions of the old administrative service, and all took the narrowest views of the functions of government. Their faith was in the efficiency of private enterprise, and their principle of action was to leave to the capitalist anything out of which he could make a profit. They doubted the strength of government to shoulder any further burdens; and with good enough reason --- Hayter, the Patronage Secretary and "brokergeneral in offices", was well aware of the quality of the placemen who were nominated by him, at the instance of party supporters, to the departments of state. They sighed with relief when they found that oversights in drafting had rendered the Iinterments Act so imperfect as to be promptly reversiole.

Thus, the Board of Health, turning from their absentee president at the Woods and Forests to the Ireasury and back 1. E.O. - Russe11, n.d. 
again, were, as Chadwick described it, very much in the position of a person engaged in litigation connected with those two ancient jurisdictions, the Court of Chancery and the Court of Exchequer, who could take no step except with their approval and at their pace. (1) Now both of these channels of communication with the Cabinet -- the President who was the interpreter of their views, the Treasury who acted as the financial censor of their conduct --- were openly hostile to the persons and measures of the Board. Disaster came, in Chadwick's view, when no minister high in responsible office could be induced to find the tine to enter into the subject with a sincere desire to surmount the difficulties. The Board's activities lay at the very periphery of ministerial attention. Their scheme had been read and studied in detail by no member of the Cabinet, except the Earl of Carlisle, and perhaps Sir George Grey, who took no interest in the measure once it was passed. As Chadwick foresaw, when he implored Carlisle not to leave the Board in 1850, "half-knowledge would be continually finding imaginary false difficulties and finding real ones insuperable". (2)

The Metropolitan Interments Act, which had started on its way with such bright hope some eighteen months before, had now returned to lay its burden of discredit at the door of Gwydyr House. The Board had failed to close the overcrowded churchyards. The Board, it was said, had made the measure unpopular. The Board had threatened the Dissenters with intolerance and the parishes with tyranny. The Board had frittered away its time in protests and appeals and reclamations. All this was the fault of the Board -.- but in particular of $\mathbb{E d w i n}$ Chadwicis. "That gentleman was no doubt very ingenious", cried John Bright, when Parliament was asked to vote the money for the purchase of the two cerleteries, "and whenever he had a board with such persons as Lord Shaftesbury sitting at it, he would be sure to pull the wire. And he did 1. MS Pragment, n.d. 
pull the wire, for if they granted the sum now asked for, Mr. Chadwlck would become the arbitrary dispenser of more patronage than was in the gift of officers filling the highest situations In the Government". (1) In every clash of the Board of Health with hostile interests, the public now saw further evidence of the uncompromising harshness of his mind; in every suggested addition to the Board's functions, evidence of his ambition and love of power.

1. Hansard, vol. 118, p. $\overline{367}, 22$ July 1851. 


\section{CHAPTER 13.}

\section{LONDON'S WATER AND LONDON'S GOVERTMAENT.}

Throughout 1850 and 1851, while the Board were making their iruitless effort to put into effect the provisions of the Interments Act, a greater project for improving the health of the capital was pursuing a parallel course to disaster. In May 1850 Chadwick produced another bulky report, the Report on the water supply of the metropolis, in which he once again trod that well worn path of argument first blazed eight years before. He had succeeded in consolidating seven of the Sewers Commissions; he now aimed to unify the nine companies which shared the supply of London; and the final step he contemplated would be to bring water supply and drainage together in a combined service, admimistered by a single body for the whole of the metropolitan area. In short, he could see no reason why his principle of sanitary consolidation, the principle of the Public Health Act, should not be applied to the capital as much as to any provincial town.

The foulness of the dilute sewage which was pumped to the average Londoner as his domestic water supply was by now so clearly demonstrated that even a witness from one of the companies was prepared to admit that offensive matter made the water "not so pleasant" --- though, Chadwick noted, he spoke as if "the water-drinikers are regarded as a small or eccentric set in the City, and that such pollutions of their beverage are things of no moment, calling for no remedy, and treated as a joise rather than otherwise". (1) But even if the Thames could

1. "Report on the supply of water to the metropolis", p. 45. P. 1850 (1218), xxi1. 1. 
be protected from contamination by sewage and be purifled of animal and vegetable matter, asserted Chadwick, it would still remain an unsuitable source for London's water supply. It was too hard, twice as hard as the average for 150 rivers examined by the Inspectors of the Board of Health. Bvery day 26 tons of lime passed through the pipes of the water companies, coating the inside the kettles, baths, and boilers, and using up excessive quantities of tea and soap. "The washerwomen's interest" (which in the aggregate was larger than that of all the cotton and linen manufacturers) demanded that the Thames, the Lea, the New River, the Colne, the Wandle, and other tributaries of a similar degree of hardness should all be abandoned as early as practicable. (1) From 150 square miles of gathering grounds, from Richmond and the heaths of Bagshot and Farnham, London could derive a supply double that now furnished by the companies, and only a third or even a tenth as hard as the water of the Thames. The evidence was conclusive in favour of "the principle of soft water supply by means of gathering grounds". (2) An entirely new supply of the softest water, pure, filtered, and alsated, could be delivered on the constant system in unlimited quantity for drinking, cooking, washing, and 211 domestic purposes at an inclusive weekly rent-charge of twopence a house. At the same time, since it was axiomatic that drainage and water supply were two inseparable aspects of a single problem, he sketched out a plan for the main drainage of London. Soil water should be sent out of the capital through pipes, skirting the cultivated lands where much could be let out as manure, and the surplus discharged so far down the river that no portion could be brought back by the return tide. (3) The gross outlay for water supply and drainage, Chadwick estimated, would be $22,142,000$, necessitating an average weekly charge per house of $5 \mathrm{~d}$. -.- less than the present charge for a defective water supply alone:
1. ibid., p. 82 .
3. Ibid., p. 280.
2. ibid., p. 113 . 
In this scheme there was no place for the water

companies. (1) No consideration of profit should enter into the supply of a commodity which was absolutely essential to the health, physical and moral, of the people. Xet the companies proceeded on the principle of charging the consumer not merely the cost of the service, but according to their estimate of his necessities and his presumed capacity to pay. The promises made by the companies when they were first established made ironic reading now. Sir William Clay, chairman of the Southwark and Vauxhall Company, had once observed indeed that they could not have kept their promises, and would have been. fools if thoy had. (2) The Grand Junction Company had gone before the puolic forty years before with a programine of pure water, a constant supply, a high service free of extra charge, and lowered rates. Once its pipes were laid it had purped its water from a point opposite the Ranelagh sewer; it had withdrawn its constant supply, and obliged its tenants to spend $\$ 50,000$ on cisterns: and it had made its high service subject to a rate twenty times its actual cost. (3) Chadwick did not conceal his disgust at the bland inefficiency of the water companies, the costly inadequacy of their works, and their frankly predatory attitude to the public. He protested againgt the abandonment of a public service to private enterprise. The supply of water to a town had been looked on as a municipal duty from aarliest times, and it was only during a low state of public administration and ill-informed public opinion that the concessions had been granted to joint stock companies. "There is no reason to conclude that the maintenance of companies, based on such concessions, and supplying water fcr purposes of exacting profit, is necescary, wherever there is the requisite -0-

1. There were nine of these, viz. the New River, Hampstead, Cheisea, Rast London, Grand Junction, Neet Middlesex, Lambeth, Southwark and Vauxhall, and Kent.

2. "Notes of heads of remonstrance on the Metropolitan water B1.1", MS, n.d. (c. 1852).

3. "Promises held out in the prospectus of the Grand Junction Company", ab, n.a. 
knowledge or public spirit on the part of the authorities to provide for an object eminently of public concern, with no other consideration than public interests". (1) Nor was there any need for the state to be gentle in resuning the rights which had fallen from 1ts grasp in a period of debility, and which the companies were now so flagrantly abusing. Water flowing in a strear was "publici juris", a commodity which as property belonged to no individual, but the use to all. Since the companies could not claim the Thames and its tributaries as their property, all the property they really possessed was their distributary apparatus - most of which, Chadwick privately declared, was scarcely worth more than the old iron of which the pipes were composed. (2) "Water Companies, however they may have been originated and conducted, have, we apprehend, no more claim to be protected against improvements, than have the owners of stage coaches, or posting-houses, or the shareholders of canals and turnpike trusts agalnst railways, or railways therselves against each other in the case of competing lines". (3) The Government should therefore take steps to acquire the water works, the amount of compensation being fixed by arbitration or by the award of a jury.

But who was to inherit the works and functions of the water companies, and combine them with the administration of the sewers for the execution of Chadwick's grand plan for the sanitary redemption of London? He dismissed brusquely the idea. of a municipality, for reasons which he developed later in greater detail. (4) The metropolis had a national importance as the seat of parliment, the centre of law and comerce, and the occasional residence of the population of the whole empire. The administrative machinery suitable for a provincial town would be inadequate for London, and any attempt to introduce it must open up new and large political questions the settlement of 1. Report on Water Supply, p. 288.

2. E.C. - F.O.Ward, 6 october 1849.

3. Report on Water Supply, p. 272.

4. Below, p. 485 - 489 . 
which would delay the remedies so urgently needed. (1) The tendency of recent legislation had been to consolidate administrative bodies and to extend administrative areas; to ensure the individual attention of competent and responsible paid officers; to protect minorities and give them rights of appeal; to raise new securities for guarding the public interests against the narrow selfishness which was apt to predominate in small communities. Hence the water supply and drainage of London should be entrusted to a small Board of paid and skilled officials. Three competent officers, meeting dally and giving undivided attention to the subject, could push through business at six times the speed of the present thirteen Sewers Commissioners, who met only once a week or fortnight in comittees of varying composition; "while a pecuniary saving would be effected even after the payment of these officers, which would show the present practice of honorary service (implying intermittent service and delay) to be the most grievous public and private waste". (2) Such a Board would be responsible to the Government, and through Parliament to the ratepayers; and in addition it would be surrounded with the additional guarantees set out in the provisions of the Public Health Act for explanatory reports and estimates, for public audit and the publication of accounts, and for the execution and maintenance of works on contract by open tender.

It was a bold, simple plan, argued with great power and at times with passion as Chadwick confronted the interests which barred the way to a cleaner, healthier Iondon. The Report, it must be emphasized, contains three distinct proposals: - first, that the water supply of London should be derived from new sources; secondly, that the water companies should be bought out by the public, and their works consolidated; and thirdly, that an executive commission should be appointed to administer the combined service of water supply and drainage.

By Chadwick i. ibid., pp. $285-286$.

2. ibid., p. 301. 
these

three proposals were regarded as inseparable elements in a single scheme; but, in fact, each of them --- a soft water supply, public ownership, an executive commission --- was supported by an Independent body of reasons, and might have been isolated for consideration on 1ts own merits. A public monopoly of the water supply was the great object to be achieved. It would be better to dispossess the companies even if London continued to draw its supplies from the hard water of the Thames; it would be better to dispossess the companies even if their functions fell to some other form of authority than the executive commission that Chadwick desired. We may, at the outset, lay a finger on one reason for Chadwick's fallure in this, as in so many other projects. Once he had arrived at a solution, after an exhaustive examination of the evidence, he committed himself to it wholeheartedly, harnessing to it all the energy of his emotions and his intellect. In that sinfleness of mind there was too little room left for manoeuvre, for modification, for compromise. He was incapable of cutting and moulding his schemes to fit the resistant pattern of other minds, suppressing criticlsms in detail so long as the main principle were established, sacrificing with good will a lesser good that a greater might be achieved. He had, as the Earl of Carlisle told him, "possibly too ardent a strain after perfection which necessarily becomes one-sided in a world of so many mixed considerations". (1) It is to be regretted that Chadwick did not concentrate his attention upon the primary task of buying out the companies and consolidating the supply under a public authority. Instead he wandered off into the wilds of Surrey in search of the perfect source, and the clear-cut administrative scheme of the Board became entangled with disputed questions of chemical analysis and hydraulic engineering. He was thus driven to extend his lines to defend positions which were not vital, and to press arguments which later scientific developments rendered largely irrelevant. 1. Carlisle - I.C., 4 October 1848. 
"I have patiently endured the misrepresentations and obstructions of the Treasury", Chadwick wrote to Carlisle on May 4th 1850. "I have postponed any counter representations to Sir Charles Wood or to Lord John Russell; I have repressed all complaints; I have forborne writing to you at all in order to get through this draft report on the Water Supply". (1) Now that the scheme was before the public, he hoped to get the Government's sanction before the end of the 1850 session to take the preparatory steps for the consolidation of the water works. Once again, however, he had fallen into the error of assuming that the hearty assent he heard in Gwydyr House would find an echo in Downing Street; and that the Government, in admitting the cogency of his arguments, were prepared to shape their policy on his recomendations. The Treasury would be very restive on the question, Carlisle warned him ${ }^{(2)}$; and two days later Ashley added, "We must be very circumspect. I see clearly that the parties are anytining but friendly. Go forward very gradually". (3) When Parliament went into recess, the Board had secured their Interments Act, but the Government were still avoiding a decision on the water supply scheme. The Board must get ready for an arduous November campaign, wrote Asnley, when "we must pipe all hands, God belping us, for the water-supply". (4)

The interval, as we saw in the previous chapter, was largely spent in preparations for implementing the Interments Act; but from ten o'clock to ten $0^{\prime}$ clock one late summer day the members of the Board wandered over the wild heaths of Surrey, round Farnham, in search of gethering grounds. This preliminary survey promised well, and Chadwick took immediate steps to have the results checked. For once be made an unfortunate choice of agent. The Honourable William Japier was a high-minded young man, who bore a burden of debt with the 1. E.C. - Carlisle, 4 May 1850.
2. Carlisle - E.C., 12 Auqust 1850.
3. Ashley - E.C., 14 Ausust 1850.
4. Ashley-E.C., 18 September 1850. 
careless charm of good breeding and an aristocratic name. The combination of charm and family probably had its effect on Chadwick, who, for all his scorn of the intellectual qualities of the upper classes, had something of the snobbery of the man who has clambered several rungs up the social ladder. It is difficult to understand otherwise why he should have accepted so readily Napier's offer to make (for expenses only) a closer examination of the Farnham gathering srounds. Chadwick could have laid his hand on a dozen men better qualified for the task, whose reports would not have been so vulnerable to attack. (1) Napier spent some six months in Parnham, but beyond underlining Chadwick's superlatives and feeding his faith in the soft sand springs, his researches did not amount to much. The water was undoubtedly there. "Gushes of water as big as one's waist", cried the enthusiastic John Simon, when he checked over the results, "with scarcely perceptible alteration by any reagent!". (2) A few weeks ' exploration Into every hill and copse of the district revealed forty-four streams, with a yield sufficient to supply half a million bouses; "the water being of its primitive purity; perfect as to apration; brilliant in colour; soft almost as distilled water; of a grateful temperature, about $50^{\circ}$; and alnost free from all mineral, animal, and vegetable impregnation ". (3) The great fact dtermined by Napier's $-0-$

1. "I find tat a great deal of the existing hesitation depends on those unlucky reports -- so startlingly loose and contradictory. However, what is done, is done; ... and we must fight from our position such as it is. But it should be a lesson for the future, to be excessively cautians how reports, carrying the seni-sanction of the Board, go forth in a form calculated to excite mistrust of the entire case". (F.0. Ward - B.C., 21 January 1851). "Napier's errors (with the grossness of which I an more astounded the more I observe the ground here for myself) have damaged us so much that we can't afford any more random reporting". (F.O. Ward - E.C., 30 July 1851).

2. J. Simon - E.C., 21 October 1850.

3. "Further Examination of the "Gathering Grounds" dor the proposed Government Water Supply to the metropolis, as contained in a Report to the General Board of Health, ... by the Hon. William Napier", D. 6 . 
investigations was that the minimum quantity in a period of unusual drought, such as the summer of 1850 , would suffice to give an increased suppiy to the whole of the metropolis. More and more rosy grew Chadwick's view of the possibility of collecting the threads of the Surrey springs, and bringing them -- forty million gallons at $1^{\circ}$ of hardness -. in one continuous stream from the Hindhead to the attic of the highest house in London. With this amended supply, he assured Prince Albert's secretary, they could wash the streets and houses of London in readiness for the Great Exhibition.

When Ashley returned to London at the end of October, invigorated by a three months' holiday which had saved him from a breakdown, he was delighted to hear the results of Napier's researches. He would write at once to Grey, he said, for authority to prepare the water Bill. (3) A week later he had been in touch with members of the cabinet, and doubt was beginning to creep in. W1.11 our Government have courage and principle to carry the plan into effect?" he was wondering. (4) One day Lord Seynour came to the office, and to Chadwick's amazement demanded to know upon what suthority the Board had investigated the water supply of London, and objected to any further proceedings upon the matter. For answer Chadwick directed his attention to the recital at the opening of the Report itself. (5) With heavy foreboding, Ashley noted in bis Diary, "The Water Supply, for which alone I remained at the Board of Health will be set aside or emasculated by the Government; and jet I made this measure a condition of my stay there. The situation is painful, because it is become that of a clerk, and I am raade, by Seymour and Grey, to seel it hourly. The Board has no free action, no power to effect any of its decisions, for the Treasury and the Home Office refuse, or

1. "Memorandum. The plan of improved Water Supply of the Netropolis", printed, 9 December 1850.

2. E.C. - Col. Phipps, 19 October 1850.

3. Ashiey - E.C., 25 October 1850.

4. Ashley - E.C., 2 November 1850.

5. E.6. - Varlisie, n.d., c. January 1851. 
thwart, every proposition".(1)

On December 19th G.C. Lewis Informed the Board that the Treasury did not deem it expedient at present to incur the expense of a plan and levels of the district which Chadvi cik had indicated as the future gathering grounds for the capital. (2) And in the first month of 1851 the friction between the imperious Seymour and his imperious colleagues struck into flame. A curt note to the Secretary demanded to know who had authorised Napier to continue his inquiries into the Farnham gathering grounds beyond the period sanctioned by the Ireasury. The challenge was taken up by Ashley as the champion of the Board, and there was a sharp exchange of letters.

"It appears to me", wrote Ashley, "that if you conceived there was ground to censure your Colleagues for any course they had pursued you would have done better to have called them together and heard their explanations. You might then while you listened to their explanations have ascertained who they were who had concurred in the Resolution. But to write in such terms to the Secretary, and make such a demand without one word to those who were associated with you at the Board, is, I am sure, a mode of action which, on reflection, you will, yourself disapprove." (3)

Seymour replied the following day. "It appears to me that I should have been informed of this proceeding on the part of the Board of Health. Bxplicit directions were sent from the Treasury to the Board of Health that they should submit to me any proposal involving expenditure". He would certainly have objected to a further investigation by Napier if he had been made aware of the proposal. "A Scientific enquiry should in my opinion be conducted by Scientific Men: whereas now instead of a Satisfactory opinion, we have received a paper suited only for a Monthly Lagazine. The practice of the $-0-$

1. 12 December 1850: E. Hodder, op. cit., vol. 2, p. 320.

2. Minutes, 19 December 1850.

3. Ashley - Seymour, 6 January 1851. 
Ancient Peruvians, and the Canals made by the Moors, the Water courses of Mesopotamia, and extracts from Sale's Koran, are surely not the materials which should be presented to the Government and to Parlianent by the directions of the Board of Health.

I object to this sort of Report because it wants Scientific precision. I object to it still more because it is deficient in that spirit of impartiality which it is the duty of Goverment to maintain in all inquiries, and which is more particularly requisite in reference to a question, where it may hereafter be necessary that private interests should be sacrificed to the attainment of a great public benefit."

He concluded: "It is still my intention, if ever the Board of Health initiate proceedings involving new expenditure in contravention of the Treasury directions, to remonstrate against such a course. I am aware of the Severe animadversions which this received from the preasury before my accession to orfice, and I wish to act in such a way that I at least may not be liable to such censure". (1)

This was the first he had heard of "orders from the Treasury", replied Ashley. "I do not presume to question jour right to find fault with your Colleagues, to restrain expenditure, and insist on the most minute and scientific statements, in every case, great or small that can be brought under the notice of the Boarad. I remonstrated with jou, and I am sure in a very dispassionate manner, on your mode of action towards us; I suggested simply that it would be more agreeable to us, and certainly in consistency with the proper and necessary rules of Board operations, that you should personally convey your differences of opinion, hear the explanations we could offer, and ascertain not by copy of Minutes and lists by the Secretary, but from our own avowal, who were or were not, parties to the Resolution. I have sat 1. Seymour - Ashley, 7 January 1851. 
during many jears on various Commissions, but $I$ have never before been subjected to that form of control; certainly your predecessor, Lord Carlisle, who was very seldom able to attend, did nothing of the sort. He came personally whenever he had any doubt or difficulty and the result was a nost friendly and comfortable unanimity". (1)

Seymour, hearing of Carlisle's virtues, must have experienced something of the disagreeable feeling of a second husband whose wife continually ings the praises of his predecessor. He could have derived little more satisfaction from Ashley's next letter:

"On my arrival in London this Morning I directed a Search into all our records, and I questioned my Colleagues and the other Functionaries of this office to ascertain the correctness of the Statement in your Letter. You say "Explicit directions were sent from the Treasury to the Board of Health that they should submit to me any proposal involving expenditure". May I ask you when and how? I never heard of this regulation before. Ve can find nothing, we can remember nothing of the Sort. I must therefore deny the accuracy of your assertion, and indeed the ease is clear, for surely the Treasury would never have issued an Order wh1ch, in fact, would have been 1llegal, that, on a Board consisting of four Commissioners, three should be compelled to submit their proceedings to the fourth, who did not intend to take any share in the business, or even $t \mathbb{0}$ be present at their deliberations. As a matter of courtesy and convenience we would have acquiesced, as far as it was practicable, in such sn arrangement (as indeed we did acquiesce) but if it be denended by an sct of authority, and the Board thereby be deprived of all independent action, I, for one, shell refuse to be subject to the order.

Next Mr. Chadwick inforxs me that he stated to you, by word of mouth, the clreumstances of the acceptance by the Board 1. Ashley - Seyinour, 8 January 1851. 
of Mr. Napier's gratuitous services (gratuitous excepting the payment of his personal expenses) for the purpose of raking further inquiries as to the resources of Water Supply. Ur. Napier was not sent out a second tine but being actually on the Service he was requested somewhat to extend his operations. rou did not at that time record nor have you since recorded any objection, either to the measure or to the Repost, tho' many opportunities to do 30 have been offered.

I am sorry that you endeavour to throw such conten pt on hix. Naplex's report; 1 t is to my mind of great value and emineatly practical, out of 34 folio pages, less than two are devoted to the system of Peruvians and Moors in these Sanitary matters, and I cannot see that he is reducing his Report to the level of a "Monthly Magazine" because he avails himself of the experience of other ages and Nations.

You say further "I an aware of the severe animadversions which they (the Board of Health) received from the treasury before my accession to office". I regret that you have revived this charge, becaue it must revive a discussion that I had hoped was at an end. The chief part of the case is this. During the fury of the Cholera in 1849 the labours of the Board were excessive; the mortality in September had, in london alone, reached searly 500 a day; the most urgent and terrific appeals were made by euthorities of all kinds for further assistance; our Inspectors supported them, and required the Services of six additional thedicsl. Men for house to houge visitation. We applied to the Ireasury but no answer was received; I then went oven ryself but I found that no one was in Iondon, neither the First Irord, the Chancellor of the jochequer, nor either of the Secretaries; all had guitted the Town; wat could be done? The affeir was too serious for delay; we appointed the Medical officers, and notified the esct to the Treasury. Severe coments were no doubt mede, but with the eretest injustice. 31r Charles Nood afterwards cominichted to me that, tho' there 
was a defect in form, he had no doubt of the necessity of our arrangenents

exceed \&500". (1)

P.S. The whole expense of the six Medical Men did not

Seyriour's reply came the same day.

"It seems to me from your letter that you have not

received correct information upon the matters to which you refer.

We need not however argue about thein, because as regards the future I will ascertain from the Chancellor of the Exchequer what my duties and responsibilities are, if I am not responsible for any proceedings of the Board of Health I shall be quite satisfied, but if I am to be held responsible, it seems to me reasonable that I should not be left in ignorance of the proceedings. Either decision will satisfy me".(2)

Ashley's answer was blunt.

"I am sorry to repeat that we have keot you duly informed of all our proceedings.

I are, and I have been, most anxious to study your comfort and convenience, but I cannot consent that the Treasury should Eive, what, in fact, it has no power to give, and what it has not yet attenpted to Bive, authority to one, and that an absent Heraber, to control at his will the deliberations of three others.

In laying the case, as you intend, before the Choncellor of the exchequer. I nust request that you will lay before him the whole of this Correspondence". (3)

"I never thought of taking up bis time with it", was Seymour's lame response. "I have no copies of my letters and coula not therefore do it". (4)

"It is a very sad thing that the time of the Chancellor of the Exchequer should be taken up by reading the

1. Ashley - Seymour, 10 January 1851.
2. Seymour - Ashley, 10 January 1351.
3. Ashley - Seymour, 10 January 1851.
4. Seymour - Ashley, 10 January 1851.


Gorrespondence between Jou and me," san Ashloy's justifiable retort, "but your deternination to reeer the case to his decision has made the perusal of it necessary. He canzot give a judgment unless he shall have heard both sides of the question Now the question is, not what the areasury wil1 say, but what it has aald. You charge the Board and me among the rest wth neglect of duty and disobedience to "explicit directions". I asiced jou before, and I now ark you again when wais the Order given. What was it; was it be vord of mouth or in writing, where is it now to be found?"

Remenber that this is a sorious affeir. I have requestied jou with sreat couctesy, and I nost respectilully request gou again, to give me answers to these queries

You canzot surelJ, as the Head of the Board, or as a private individual, persist in repusing me". (1)

Pinned down at last, Seymour asserted that he "understood" such directions had been given to the Board by the Preasury or by the Chancellor of the Bxchequer.

"I was confirmed in this view because in August I wrote to the Board of health requesting to be informed bofore any proceedings involving outlay of money was sanctioned by the Board, and I recelved a reply dated the 27th August stating that no proceedings involving any expense was about to be proposed only formal matters and adding that if anything should present itself of more importance I should be informed before anz declation was come to.

With this Declaration I was satisiled that the Board of Health would not oj anj paoceedings Involve me in responsibility without giving me an opportunity of giving an opinion on the matter. In this expectaiton I have been decelved, and must therefore take further procautions to giard nyself in future"(2) "An undergtardiage", Ashley pointed out, "lis a weak. $-0-$

1. Ashley - Seymour, 10 Janiary 1851 ,

2. Seynour - Ashley, 11 January 1851. 
foundation on which to reprimand three Gentlemen who are associated with you in the Public Service". (1) The same day he wrote again to sweep away the last excuse for Seyrour's querulous complaint. He forwarded copies of two letters, one dated the 10th August 1850 informing Seymour of Napier's engagement, the second dated 12th August, from Sejmour himself, recording "no objection". Napier's engagement did not begin till five days afterwards. "Such is the haste and want of considerafion with which you attack your Colleagues", Ashley eoncluded. (2)

Lord Seymour had retreated discomited behind the skirts of the Chancellor of the Exchequer; but in Gwydyr House there was consternation and a feeling that the Board had reached a crisis in their career. (3) It would have been serious enough if the incldent had merely revealed that the manners of their President were bad, his memory feeble, and his attention to the business of the Board neither regular nor sympathetic. The correspondence -- taken in conjunction with the attitude which in this same month he adopted towards the Interments Act -.1. Ashley - Seymour, 14 January 1851.

2. Ashley - Seymour, 14 Janusry 1851. There is no record of Seymour's reply to this. On 18 January Ashley told Chadwick "Lord Seymour's reply is a becoming one. I hope for peace", which may indicate that he sent a note of apology. The correspondence was laid before Carlisle, who returned it with a brief injunction to Chadwick, "Pray keep them all at peace as long as it is possible". (18 January 1851).

3. Ashley embodied the Board's position in a resolution

(Minutes, 16 January 1851): "That while the Board consent to the proposition made by Lord Beymour, and agree that copies shall be sent to him of all their Minutes, and express, in addition, their desire to consult his convenience on all occasions, their conduct must not be construed as recogaizing in a single member of the Board, and one too who is constantly absent, the right to reverse or control the proceedings of the other three. That if the President of the Board question in any way the acts of his colleagues, and express in consequence an intention to alter their decisions, he be requested to take his place at the Board, hear the evidence on which those decisions have been founded, and the explanations that can be offered. thereupon". 
showed inaddition that he intended, in his own words, "to stop as much as he could" of the work of the sanitary reformers, and that in this policy of obstruction he was supported and incited by a powerful section of the Cabinet. Clearly he felt no loyalty either to the members or to the duties of the Board of Health. His allegiance was given wholeheartedly to the Lords of the Treasury, and he agreed with them that sanitary legislation meant feeing busybodies to meddle with things which were best left to Providence and private enterprise. To Ashley he was obliged to be outwardly polite; but Southwood Smith, Dr. Sutherland, Austin, all were treated to marks of his contempt; and Chadwick he loathed.

One point was clearly illustrated by the Seymour-Ashley correspondence -- the anbiguous nature of the President's status. Was he simply the first among his equals, or did he sit at the Board as a departmental chief with his subordinate advisers? By the Public Health Act he was on the same footing as the other three members of the Board; yet, as a Minister of the Crown, his shoulders carried added responsibility and his opinion had more weight. There was another aspect to the question. While the critics objected that the Board was independent and uncontrolled, Chadwick complained on the other hand that no Winister gave his full attention to the subject of public health. The Board shared with the woods and Forests the time and labour of a minor Minister. Corlisle had attended carefully to his duties at Gwydyr House; with the result, since he could not be in two places at once, that he aroused dissatisfaction at the Woods and Forests. Even before his clash with Chadwick and Ashley, Seymour had declared, in conversation with Carlisle, that he would take little part in the Board's proceedings. It was obvious that, unlike his predecessor, he looked on the duties of the new department as of a very subordinate order indeed, and found the routine and atmosphere of the older office more congenial. 
In consequence, the whole business of the Public Health Act, as Chadwick complained, was subjected to a double or even a threefold procedure. After being passed at the Board, it was submitted to a President, who never presided; and it was also transmitted at the same time to the Treasury, whose officials had no resources of information to guide them in making decisions on sanitary policy. In the older departments the subject matter was familiar to the public, and persons of general intelligence could undertake the duties without incurring any serious dangers of failure; but the Board's business was new, and hedged with technicalities. A mastery of the new principles, Chadwick maintained, together with attention at the Board to discussion of the details of their application, was really necessary to safe conclusions upon the Act. (1) If this proposition were accepted, the intrusion of the uninformed Seymour stood condemned for its arrogant impertinence. Moreover, Chadwick argued, the Public Health Act had directed the Treasury to make its decisions only upon the advice prepared by joint deliberation at a Board. It was not legally competent for them to substitute for the joint responsibility of the Board action upon the responsibility of a single member of it -.. not even if he had taken part in the deliberations, and much less if he were absent and never heard of them.

In January 1851 Chadwick sent a long letter to Lord Carlisle on these "internal obstructions" to the Public Health Act.

"Unless some relief be given from this double stage of procedure, the increase of public dissatisfaction is certain and disgraceful failure imminent.

It is rather hard in itself: after having bestowed great labour in convincing the public, then the Government: then the 1. "Administrative. Notes of Objections to the Course taken by Lord Seymour in respect to the Public Health Act", MS, n.d. 
parliament, and getting a measure passed, and then to have the whole measure subjected to gentlemen, who say that all are wrong and that they are hostile to the principles of the measure.

Seeing the losses which delay occasions, and the necessity for prompt execution; conceding that they who have necessarily the best information from having prepared it, and who are the most deeply interested in its success, and who w111 be made responsible for 1ts fallure, are the last to be entrusted with 1t, and that some control should be exercised over 1t, then it may be submitted that it should not be subjected to two stages of appeal: to have to wait its turn for attention that 1ts every step, unimportant or important should be subjected to have to wait its turn for the fragmentitious attention in departments already overburdened with business; where, if there be not positive hostility there is sure to be impatience of the detailed statements requisite to form a judgment on a new measure, now in its principles as well as in its details.

An old department may be left to take its course under the guidance of precedents; but surely if any branch of adrinistration requires sustained and special attention for continued support against the obstructions which 1t must necessarily encounter; for aid in cases of checks, reverses and mistakes where there is no previous information for guidance, in (a) new and difficult position, surely it is this.

If the agents, as well as the measure are doubted, the more important it would seem to be that the attention to both should be undivided, constant and from the freedom of the means responsible; but $1 \mathrm{t}$ is due to the measure itself that the attention should be unprejudiced and fair and for support as well as checks.

The expense here to the publle as well as the horrors against which the measure provides would repay the undivided attention of the cabinet, at the lesst ...." (1)

1. B.C. - Carlisle, n.d., c. January 1851. 
He wrote again the following month:

"Our hopes for the measure you have promoted are that the constitution of the new Government nay be such that you may be enabled to take part in it.

I venture to suggest the importance of Lord John Russell being informed of the impracticability of any person being enabled to attend properly to the business of two Boards, in the position of the Board of Health and that of the Woods and Forests with so much new work going on, not to speak of the serious personal causes for future lnharmonlous working in manifest adverse or uncongenial vlews.

The jars and interruptions to the messures required, under the Fublic Health Act, and the Metropolitan Interwents Act, will be sooner or later felt in the hundred towns nearly, to which it will soon be applied, as well as in the hundred more to which it will quickly follow.

Should the couble procedure be maintained, of an appeal from those who have laboured most and who know most and who are the most responsible to those who know the least who have neither time nor interest to obtain the requisite information, or to give attention to the particulars and bearings which it is requisite to master in order to arrive at a safe judgment? More than half the time since the passing of the Metropolitan Interments Act has been consumed and much putlic discontent engendered in re-opening the discussion of principles, settled in the Board's reports and remonstrating against conclusions at variance with the whole scope and intention of the measure as sanctioned by Parliament". (1)

The Board's position was further weakened in May 1851 when Ashley succeeded to his father's title. It was true, as Chadwick pointed out, that in the less sustained debates of the upper House, his health would not have to bear the strain of late night sittings; and he would encounter less opposition from $-0-$ 1. E.C. - Carlisle, 25 February 1851. 
sinister interests than in the Commons.

(1)

Nevertheless, the removal of Ashley left the Board with Seymour as their only official spokesman in the lower House -.. a champion unreliable in his loyalty, and more inclined to turn his weapons against the cause he was defending.

Despite Iord John Russell's promise to Ashley --- which alone had persuaded him not to resign in March 1850 -.- the Bill for metropolitan water supply was put in the hands of the Home office. Not one member of the Board was consulted about the measure, except Iord Seymour, their fainéant President. The Government Bill, introduced on April 29th by the Home Secretary, Sir George Grey, (2) proposed that the stock of the existing companies should be valued, and that they should then be consolidated and placed under the supervision of Her Majesty's Principal Secretary of State. The dividends of the consolidated company would be limited to 5 per cent., any excess income being applied by the Treasury to the reduction of rates. As a sanction to ensure that the proprietors complied with the provisions of the Act, the Home Secretary would be empowered to stop the dividends. Constant supply, regulations for filtrabion and purification, the provision of new sources, were left open questions to be decided at some indefinite future date by the Home Secretary.

Looking over the Bill. with a discouraged eye, Chadwick must have felt that his Report might just as well have remained unwritten, Napier might have stayed in Jondon, and the Board $-0-$

1. E.C. - Ashley, 9 June 1851. "From the conversations I have had with one or two persons, I am led to believe that your power of initiation will be by no means diminished to the extent which we might at first have apprehended from the change. At all events you will be in a better position to influence public opinion which influences the House of Commons ....."

2. Hansard, vol. 116, p. 340 . 
might have saved themselves the laborious inquiries and preparations of the previous fifteen months. Not only Chadwick himaelf, however, but the whole trend of sanitary inveatigation since 1842 was slighted by Grey's B111. The comblnation of water supply and dralnage under a single authority, which had been urged by three Comissions of Inquiry, found no mention at all. Some 700,000 Londoners were still to be left without any supply beyond what they could beg or steal or catch from a public etand cock. Above all, the companies would remain, their virtual nonopoly, based on a tacit agreement, now converted into a legal monopcly; their proprietors guaranteed against competition and assured of a dividend of 5 per cent. in perpetuity on a fictitious capital of $\$ 4,800,000$, a sum more than double the amount they had actually laid out.

The origin of the Government Bill was an open secret. Twolve months before sir बilliam Clay, chairman of the Southwark and Vauxhall water Company, had adressed himself to Chadwick, declaring his hearty concurrence in the proposition that the water works should be consolidated and acquired by the public. The radical defect of the present system, ile observed, was that the companies had no protection against the incursion of fresh competitors. Few years passed without new schemes being canvassed; the public were easily led astray by projectors who professed to be able to defeat the oppressive water monopoly; and the compantes were thereby caused continual trouble, anxiety, and expense. For this reason, he believed, the proprietors would welcome a "water works annuity fund", created under the guarantee of Parliament, the amount of the fund to be determined by the actual net income of the companies. "These annuities to be always a Iirst charge on the water rates and to be transferable at the Bank as othor Governnent annuities. For such consideration the whole of their property and the works to be vested in the public". Both parties would gain by the chansege, the public by the economies of a unified administration, the companies by the increased value and 
security of their shares.

Clay's schene was, In lact, an ingenious method of exchanging the precarious benefits of comercial freedom for the financial stability of a Government rentier. It sprang from an intelligent appreciation that the old order was passing, that -- as the columns of the "Times" unequivocally revealed -- the weight of public opinion was against the companies, and that if they continued to resist they would exaceroate that opinion and open the way for a settlement on the ruthless lines indicated by Chadwick. But Clay, who wrote heartily that if the companies and the Board of Health got together, they could come to an agreement in five minutes ${ }^{(2)}$, could have had no inkling of the depths of Chadwick's scorn for the claims of the water traders. (3) Presently, finding Chadwick unresponsive, Sir william lay diverted his stream of memoranda to the Home Office, where they were given a aore sympathetic bearing.

In his acceptance of the principles of consolidation and public ownership, however, Clay -- who confessed, in his own words, to be "tired of presiding over Directors' meetings"(3) -- was far from typical of his class. There were others who retained their raith in private enterprise, who would rather keep their independent existence than be merged either into a single company or a unified public service, and who were unwilling to exchange for a safe percentage the risks of the old order with its possibilities of greater profit. The majority of the directors were resolved to fight a delaying action as long as they could. A barrister friend of Chadwick's, engaged in auditing the accounts of the Chelsea Nater company, found a good round sum set down as a subscription to the opposition to the Fublic Health Act. (4) But when the Water Works Clauses 1. "Memorands on the supply of water to the metropolis. Sir W. Clay's paper", Wh, D.d.

2. Sir W. Clay - E.C., 8 April 1850.

3. Sir W. Clay - E.C., 23 July 1.850.

4. I.C. - B.0. Ward, 6 Cotober 1849. In enother note, probably to Delane (28 July 1851), he gives the figure as $\$ 200$ or 
Act of 1847 for the first time applied the curb of a sanitary survelllance to the trade in water, they realised that it was no longer sufficient to subsidise journalists and lecturers to talk darkly of French Centralization and the invasion of property rights. They must make a show of accepting gracefully some part of the sanitary findings; and they calculated that if they did so, they might be enabled, by virtue of their strength in the Commons and the respect accorded to them by the Government as great nucleations of capital, to survive into the brave new world of Chadwick and the Health of Towns Associetion.

Each of the three solutions so far described -.. the Government-appointed Commission urged by Chadwick, the statutory Company proposed by the Home Ofice Bill, the independent Companies under certain minimum restrictions desired by most of the proprietors -- had its spokesmen in the debates of 1851. There was a fourth party, however, inore vocal than these, and commanding outside the House a wider measure of popular support. If Sir William Clay, and behind him the less accomodating Directors of the water companies, formed the right wing of the opposition to Chadwick's scheme, the left wing was represented by the advocates of parochial control. It was a confused, disunited, clamorous group, drawing its theoretical arguments from Toulmin Smith, its members diverse in their aims and in the quality of the motives which impelled them; a loose alliance of the metropolitan M.P.S and the Common Council, of Guardians, overseers and churchwardens, the projectors of a dozen water supply schemes, and a dubious tail of contractors and jobbers; some shouting for a municipality for the whole of London, others hoping to give the separate parishes of the capital the essential organs of urban government. The chief movers,

(Continued erom previous page) 3,240. "Now I apprehend that the Chelsea water Works company did not take this step gingly; where could this money, or such a purse as rust have been made up from such a contribution, have been spent? and that too for the mere defence of an outpost against the principle of consolidation, for the Public Health Act expressly exempted the Metropolis". 
Chadwicik was convineed, were a set of engineers and promoters who felt that they had iittle or no ehance with anything higher than a parish vestry. (1) There was Mr. Taberner, for example, the attorney's managlag cleris who acted as spokesman for the Metropolitan Water Supply Association, and who was connected with a scheme for supplying each parish separately by artesian wells. He had the effrontery to call one day at Gwydyr House with an offer to direct the agitation according to the instructions of the Board, provided only that they reiroursed him for the time and money he had sacrificed. Similar overtures had been made to the Board by the solicitor of another scheme, which proposed to draw water from Henley at an outley of two millions and appoint a saiaried Board of Management costing 26,000 a year. mphese overtures were made on the most vulgar conception of the notives and desire of the members of the General Board to obtain mere power and patrinage; in which on the implied conditions that it was to be glven to the promoters, unreserved support was promised, and hostility intinated if it were withheld". (2) But the scheme which was acclaimed in vestry after vestry from June to September 1851, and which enlisted the support of Delane of the "Times", was a proposal by a metropolitan member, Mowat, to vest the ownership and managenent of Tondon's water supply in a representative body, comprising four members elected by the ratepayers for each of seventeen districts, together with four from the Comon Council, and four nominated by the Government.

In a series of lengthy letters and memoranda Chadwick combated the notion of creating a municipality for London, which 1. "Water Supply: Central Establishment versus Parochial Hatablishments in the metropolis", MS, n.d.

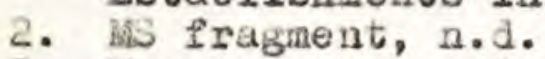

3. Mowst attempted to introduce his Netropolitan Water Supply (Control of Representative Body) Bill on 24 June 1851 (Hansard, vol. 117, pp. 1140-1149), and again on 6 February 1852 (Hansard, vol. 119, pg. $220-231$ ). 
stood condemned by all his experience of the corruption and interest-begotten prejudices of local representative bodies. He described in broad outline this vast new local authority, with a jurisdiction over two and a quarter million people, disposing of millions of pounds of rates, and burdened with a complex of technical problems. Then, with a note of irony, be pointed to the products of vestry politics, and asked if men of this callbre could possibly grapple with the enormous task. "Is there any reasonable expectation or any evidence from Works done", he asked, "that out of the greater number, namely the smaller shopkeepers who form the bulk of the Ratepayers in the Metropolis a municipal body could be created of a higher degree of intelligence, and with a better disposition to execute works of improvement than the Corporation of the City of London?" --- a body whose ignorance, callousness, and susceptibility to sinister interests, was clearly shown by its defence of the cruelties and abominations of Smithfield Market, from which it raised 45,600 a year in fees, tolls, and dues. The peculiar difficulties of metropolitan government arose out of the very magnitude of the works required for drainage and water supply, involving an expenditure which Chadwick estimated at two millions. This sum, he maintained, might easily be doubled, and without obtaining the desired result, by errors of which ordinary representative bodies would be wholly unable to judge, but which they might be readily influenced to commit. Bodies shot through with local intrigues and pecuniary interests had an unsavoury reputation in the handling of public money. In the days when the Lord Chancellor inserted names in the Commissions of Sewers at the instance of the metropolitan llembers, the Members were moved by electors, the electors by friends of contractors - with the result thet relatives of contractors were appointed as Commissioners, and were fiven the power of deciding upon contiacts. Many of the active managers of the vestries were owners of houme property, with interests opposed to sanitary improvements. Aloreover, works of this nature could 
not be conducted by intermittent Board meetings, nor even by the incidental attention of professional engineers and men of science. On the Metropolitan Gomission of Sewers the popular representatives had swamped the scientific rembers, and had hindered progress by their jealousy when it was proposed to delegate powers to comittees and paid officers.

Shifting his ground, and aimiag his argument at the selfimportance of national legislators, Chadwiok urged that a unified municipality for the whole of bondon would be a formidable and independent power in the state, which would always be able, by the magnitude of its political influence, to procure the exerption of the capital from the operation of the laws passed by the legislature. In the most democratic constitutions there had always been a reluctance to create co-ordinate authorities within the seat of the central government, and it was, for example, a fundamental article of the American Inion that no wunicipality should be set up in Columbia. (1)

"The proposition, then, involves the constitution of a new representative body for two millions and a quarter of population, equal to one-eightth of the population of England and Wales, and more than the population of scotiand, having jurisdiction over 12,186,000 of assessed property, equivalent to one-eightth of the assessed property of Great Britain, oneseventh of the assessed taxes of Great Britain and wales, nearly one-third more than the assessed property of all scotland, nearly four tiaes that of all Wales, and not less than the assessed property or fourteen caflish counties.

Now the mismanagenent and Jobbing proved to exist in the local administration of one rate -- the poor's rate -- where the sums administered amounted to thousands and teas of thousands of pounds, were suck as to require, in the metropolitan as in other parochial districts, parliamentary intervention and the control of Government; jet it is now 1. E.C. - J.T. Delane, 27 November 1850. 
claimed to entrust, without control the raising and managenent of rates, emounting to teng and hundreds of thousands, and even of willions of pounds, to persons who, ladividually or collectively, are entirely unaccustomed to the management of any such expenditure.

The direct outlay for the works of arainage and water supply now in question ...... is estimated at about two illions for new existing works, and the purchase and consolidation of works, from which an income of $\$ 430,030$ per anoun is derlved, and for which claims for six millions of compensation axe spoiren of.

The future anaual amount of water rates and sewer rates for the metropolis will, however reduced in amount, probably Breatiy exceed the expenditure on the Civil List.

It is to be borne in roind, however, that the question is not one of expenditure without representation and without responsibility. Ihe adainistrative position stated in the Board's Report, and which they believe has ceen accepted by the public, is, that the interests of the isetropolis, as the seat of Governinent, are national, and that the representation in respect to those interests should be national, and that the present responsioility of puolic gdrinistrative podies to parlianent, as It now exists, with 811 defects, gives a more real protection, than is afforded by such a representative and administrative body as the court of Common Council of the fity of london, and one in every way nore elficacious than could be arforded by the proposed aew represantative bodj, whlch wust cepresent rated property twelve tines zreater than is reuresented by the Corporation; connected mith fifteen times as mang houses, and seventeen tines as nuresous a population.

If farlianent be asked to reliaquish or to delegate any portion of takt direct and special contsol which it has heretofore been accustomed to exercise through the Government in relation to questions alpecting the seat of empire, it is 
submitted that 1t car oaly be asked to do so, on the ground either that the subject matter is too little for it, and that all the other watters with which it is occupied are of larger public consideration or that it is too large, new, and difficult for it; in which case 1t must not be concealed that the proposition for the creation of a new local representative body for such a purpose implios that this body is to possess an administrative capacity for large woxks, beyond those of the Goveriment and of Parliament itsolf.

The puilic at largo certainly, and Purliament probably, are unprepered for the application of the proposed principle to the metropolis.

On the contrary it inay be averred that they are prepared by continued practice for an opposite course, that is for the adoption of a special agency directly responsible to Parliament. It would be deersed an extraordinary course if a special Governuent Comnission were issued to deal with any matter of local administration for a provincial town, or a city such as ifanchester or Yorik, yet for the Metropolis Covernment Commissions and Government intervention have been popularly demanded. There is a natural reluctsnce, not to say repugnasce on the part of the piblic to undertake the execution of works of thlo description; and a desire to devolve the responsibillty of their management upon whatsoever body might be got together for the purpose; arising probably from a feeling of the very special nature of such works, and of the scientific requiraments requisite to julge of them. It is this speciality which creates the difficulty of getting proper peraons to manage them, and which renders apparent at the same time the inconvenience and danger of placing them under the control of any popular representative assembly". (1)

$$
-0-
$$

1. "Memosendun as to tho Constitution of the Administrative Machinery for the erection of dew public orks", printed, 24 January 1851. Ashley told Chadwick: "I fully concur with the Memorandun; and we must stand to it" (28 January 1851). 
If the Home Secretary read these nemoranda, he did not allow himself to be swayed by their. argunents, Yet it was iursediatuls evident that the Governheat's Bill stood no chance of success. Si.r George Grey himself seemed to have no great confldence in the measure. The best plan, if it were only practicablo, de declared, would be "to place the administration of water supply in the hands of a nunicipal corporation I(if it existod) or some body analogous to it (i.f it could be created)". (1) Again, he oonfessed, "he did not doubt that if they were deslias with this subject as a now one, irrespectively of the rachinery estublighed for a long series of jears .... Lrespectively also of the habits which now existed, and of the aversion to the interference of covernient in matters of daily and domestic concem -- the proposal made by the Board of Heaith nlght be the best in litself, and one which Parliament would do well to sdopt". (2) Thus, by the Home Becretary's own admission, his solution was only a bad third, and he laid biraself open to attack on the one hand bJ all those who were not so easily persuaded that a rauicipality was inpracticable, and on the other by those who belleved that water supply was properiy a subject for Government interierence. The B11l was enfligded on sll sides by a suspicious House, which felt that "there rust be sometring in the background to cause this $3 i 11$ to be brought forward contrary to the universally expressed opinion of the labobitsnte of the metropolis". (3) Why should Iondoners pey $\$ 400,000$ or $\$ 450,000$ a year when a conpletely new sad inproved supply could be obtained for $\mathrm{A} 2,000,000$, demanded Viscount Bbriagton, whose speech owed mich to Cwyogr House. (4) Sir Benjamin Hall, the member for Marylobone, declared that the Bill would boom the 3 per cent. water shares to 2130 ; "he was Informed, that no lese than 70 Members of Perliament held shares in these companies, and it was not very likely, if they voted, 1. Hangaxd, vo1. $110,9.340,29$ April 1851. 2. ibid.

3. ibid., vol. 117, p. 478, 5 June 1851 (W. Williams). 4. Lbid., p. 306. 
they would vote for any competition". (1) In his belief that the water companies were bohind the Bill, however, Hall had misjudged their temper. They were far from willing, as we have seen, to forfeit their freedom of action to the extent contemplated by Sir William Clay, and the opinton of the majority of them was expressed by Sir John Johnstone, a former director of the New River Company, who "really did not see what there was to prevent the House from passing a Bill which would tie down each company to certain rules and regulations relative to supply, in a manner similar to that in which it was proposed to deal with the companies when amalgamated in one body". (2)

The Bill was given its Second Reading by 95 votes to 79; but only two had risen to speak in its favour, Sir George Grey himself, and Sir William Clay. ${ }^{(3)}$ On June 5 th it was referred to a Select Committee, its defence being entrusted to three eminent counsel, while a phalanx of lawgers and engineers was arrayed against it by the Companies and the parochial party. The Board of Health were allowed no locus standi before the Committee; their inspectors were not called as witnesses; and the most Chadwick could do was to send copies of the Report on Water Supply to members of the Comittee. "The reference of the whole water question of the Metropolis, to a cominittee of private and irresponsible members, is really a very fearful thing; and should not they be reminded of their duties to those who are unrepresented; the vast mass of two millions of the population, and of the poorest ........ The private bill legislation is really in general the legjislation of those who can pay for it. Where Hudson was unopposed he did as he liked, through these comittees, with the legislature; and for railway purposes the committees, and through them Parliament itself, 1. Ibld., vol. 117, p. 472 .

2. ibid., vol. 116, p. 322. "It was a matter of perfect notoriety that not only the New River Company, but other companies, and he believed he might say the majority of the companies, were strongly opposed to the measure" (Sir W. Clay, 1bid., vol. 117, p. 497).

3. ibid., vol. 117, p. 511. 
was the agency of the parllamentary agents ........ There will be perhaps as much as three millions sterling in issue against the public for which there will be counsel. But the power of money in procuring the Bvidence of scientific witnesses is the most disgusting feature to be anticipated. Before the railway committees, men of science were got to swear against a rival line which had a tunnel, that the air of the tunnel would be dangerous to human iffe. Before the private committee of the River Lea Trust Bill, an eminent Chemist, who had given a certificate in favour of soft water for Liverpool, was got to express his horror at the proposal to supply (people) with soft water, as one for poisoning them ........ In favour of the Thames water as it now is, the Companies obtained the strong certificates of men of science who had denounced it before the Board of Health ....... Could not the inhabitants of Church Lane, St. Giles, or of Jacob's Island be advised to come in forma pauperis, and ask the cominittee to assign counsel to them?"(1)

Helplessly Chadwick looked on at the day to day clashes of the contending parties. He was cheered when Sir James Graham, who was strongly disposed against the Government Bill, showed signs also of being impressed by the constitutional inconveniences of Mowatt's parish parliament. (2) But Graham had vagaries of his own, Chadwick noted disgustedly, --- "of supplying the North side from Watford and the South side from Farnham and erecting on each bank a distinct Municipality to whom it should be given ....... This would be (like) saying an organisation in which there would be two hearts in one body"(3) Under cross-examination the parochialists made revealing admissions. But what was the use, he asked Ward, of bringing out the fact that the agitation was conducted by a few interested individuals acting on small minorities in the 1. I.C. - ? (probably Delane), 20 June 1851. 2. F.O. Ward - E.C., 19 June and 27 June 1851. 3. E.C. Xaxd - Y.O. Ward, 3 July 1851. 
parishes, when the papers printed none of the proceedings? "With very slight efforts, the narrow and sordid base of the parochial agitation is displayed in the committee room, but not in the papers. The Times ceases to report the proceedings. S1r James Graham has an evident leaning, it is said, to the parochialists. He is suspected, of wishing to get into a Metropolitan seat himself as he has no chance of being returned for Ripon". (1)

In one vestry after another from June to September 1851 Grey's Bill was condemed, and resolutions were passed in favour of parochial control. Seven hundred ratepayers in Southwark signed the requisition for a public meeting against the Bill, the largest roquisition ever known in the borough. (2) But, with the exception of the "rimes", Chadwick observed, the trading interests seemed to have got very complete possession of the papers. (3) The secretary of one water company told him that "they had got the Economist"(4); but opposition was only to be expected from a journal which had looked upon the Public Health Act as an unjustiflable meddiing with natural law. More perturbing was the defection of the "Chronicle" and the "Daily News", two newspapers which had hitherto been distinguished for their advocacy of sanitary measures. Napier called on the editor of the "Chrontcle" to complain of the way his views had been misrepresented, and discovered that the writer of the offending articles was Venables, the counsel for the Kent Water Works before the Salect Committee. Chadwick was oapecially pained by the scurrility of the "Dally News", which "has been introduced as a reformed newspaper and has been held up I believe by Bright and Cobden as an example of what a cheap Newspaper should be". Crowe, the editor, was most respectable, and "it is most likely to be the affair of some mere capitalist" $-0-$

1. E.8. - F.O. Ward, 5 July 1851.

2. Minutes of Evidence taken before the Select Committee on the Metropolitan Water Bill", 1851. XV. 1; Q. 4982, evidence of $\mathrm{B}$. Collinson.

3. E.C. - F.o. Ward, 28 July 1851. (1851). 
And so it turned out to be. "Smith the manager of the Daily News appears as the solicitor for the Hampstead water works and it is stated is largely interested in them". (1) The "Daily News", he recalled, had also been strongly opposed to the removal of Smithfield Market --- the articles beinc written by one of the counsel engaged on its behalf. Chadwick wrote a public letter (which apparently remained in draft) to protest against a practice which must be conducive to the corruption of the press, arguing that the retainer of a barrister who was an influential writer in a newspaper, perhaps even its proprietor or manager, was in effect the retainer of the newspaper itself. He thought also of mentioning to the Attorney General this new kind of Huggery, which led to the employment of barristers not for their legal qualifications but for their secret services as writers in a newspaper.

The "Times" alone seemed not to speak with the voice of the hired hack. "Whatever bias I have heard imputed to the Times I have never heard it accused of a pecuniary bias. Indeed, although I largely differed from the late Mr. Walter, I always said that his integrity against every sort of sinister influence appeared to me to be most remarkable". (2) shut out from the Select Committee on Grey's Water Bill, with the Government increasingly cold and unresponsive and the threatened interests ever more active and menacing, Chadwick made an attempt to secure the alliance of the most powerful leader of opinion in the London press, Delane of the "Times". In Printing House Square unfortunately the name of Chadwick carried with it the odour of the polluted Thames; and he was driven therefore to make use of a stalking horse, an eloquent and forceful journalist, F.O. Ward, who could put a more attractive colour on the sanitary case than could Chadwick with his desiccated Inglish. (3) Delane had made it plain that he found 1. E.C. - F. . Ward, 30 June 1851.

2. E.C. - ? (probabiy Delane), 28 July 1851.

3. Ward made Chadw1ck's acquaintance towards the end of 1849. (Continued on next page) 
more to recommend Chadwick's Government Board than Clay's statutory company; but in preference to ither of these solutions he wanted to see Iondon's water supply in the hands of a municipality. To mature tha municipal institutions demanded by the "ines", argued Ward, would take a life-time. The interval would best be bridged by a terminable Comission, small, poid, and removable, going on from three jears to three jears as an ad interim administrative expedient until the municipal reconstruction of London had been carried out. (1) Ward addressed his letters to Chadwick, who forwarded them without comment to Delane; but the "Times" showed no sign of abandoning its campaign for the irmediate establishment of representative government for London. Nor was Chadwick's assent ungrudging to the form in whlch Ward had put the Board's plan. He cartsinly did not concur with Ward's thesis that government by comission was no more than a temporary administrative device, to be replaced within a generation by a municipality. The feeling abroad in favour of representative control might be regretted, Ward urged on Chadwick, but it must be admitted, and their policy should be to modify it or mitigate it as best they could. All Chadwick's evidence that the parish agitators were interested men, and the vestry meetings but thinly attended, would not deter the "Times" and other journals from advocating ratepayers' control, whlch, "whether demanded by large meetings or small, is at all events the only principle that has in its favour any popular meetings at all".(2) This, Chadwick must have felt, was giving hostages to the enemy. Ward's letters ascribed too much reason to the schemes of the opposition for a controversialist of Chadwick's rigid cast.

1. P.0. Ward - B.C., 31 July 1351.

2. F. Ward - E.C., 14 July 1851 .

(Continued from previous page) He had explained the Board's scheme in two articles in the "Quarterly Review": (1) September 1850, vol. LXXXVII, po. 468 - 502, "Metropolitan Water Supply"; (2) March 1851, vol. LXXXVIII, pp. 435-492, "Sanitary Consolidation -..- Centralization --. Local SelfGovernment". 
After one or two of his letters had been held up by the censorious Chadwick, Ward ventured on a postscript of expostulation. It would weigh with Delane, he said, if all the letters were sent, "as this will show that independent views are taken and discussed, and that I am not a nere puppet reflecting your views and playing into your hands. (And, by the bye, let me mention that you are much weakened by the prevalence of a belief of this kind in aany quarters -.- it is thought that the Fingineers Inspectors and those who serve you, give in many cases opinions modelled in conformity with yours --. which deprives the evidence, etc., of its cogency. Bven I have been openly said to be "In Chadwicis's pay!" It is worth while to adopt all reasonable means of mitigating the intensity of the dislike and opposition and mistrust occasioned by these unfounded ideas. Let my various letters, etc., go for what they are worth, for example -.- and be assured that, so far as they are wrong, they will not prevail, while the candour of giving fair play to opinions not entirely identical with gours will be appreciated". (1)

Chadwick's irritability increased as the Select Committee ambled on through ten inconclusive weeks. Ward wrote to encourage him: "Above all keep our soldiers in good cheer -.don't for heaven's sake talk about "disasters" in the camp. I for one have not the slightest misgivings --. and I promise you a bowl of Funch made with soft Gathering ground water delivered through my water-tap in Cork Street before two sumners are over our heads". (2)

The Committee closed the hearing of evidence at the beginning of August. No report was made. None was necessary. The case for consolidation was proved, but that was the one point on which agreement was reached by the unhappy Committee, bevildered by a confusion of issues -..- hard water against soft, constant supply against intermittent, Watford chalk against 1. F.O. Ward - E.C., 7 August 1851

2. F.०. Ward - I.C., 30 July 1851. 
Surrey sand, Mowatt against Clay --- and ealled upon to deal with a complexity of topies, administrative, chemical, and engineering, like a juggler with five balls in the air at once. "The impresssion was, of our own inspectors, that every party had broken down", Chadwicis reported exultantly to Ward, "The Government or Sir Tilliam Clay's bill had broken down and the preamble will be declared not to be proved: the Vestry people have broken down and damaged themselves: the water companies so far as they went broke down and damaged thenselves: for the money they spent, they had I an told a most pitiful result: no such knowledge as ours being applied to meet the case or direct the cross examinations to produce it".

Russell had already announced that the Government did not intend to legislate on water supply during the present session. The water question had been put off for another year, as it was clear it must be the moment Grey introduced his ill-concocted Bill. The Treasury, which had refused to grant the Board $\$ 500$ for a survey of the new sources, had spent $\$ 5,000$ on the rejected measure. (2)

1. E.c. - P.o. Vard, 2 August 1851.
2. E.C. - Lord John Russell, n.d. 


\section{GHAPT: 14.}

\section{THE INSPECTORS AT WORK.}

The jealousy of the locsilties and the caution of the legislature had circumscribed the powers of the General Board of Health by the narrowest of boundaries. Their Inspectors could be summoned by a petition slgned by one-tenth of the ratepayers; alternatively, the Board could institute an inquiry into the sanitary condition of any place with a death rate over 23 in the thousand, whether the inhabitants welcomed the investigation or not. But that was the sum total of what may be texmed their initiatory or aggressive powers; and, as a rule of practice, they laid it down at the beginning that they would not conduct any local inquiry unless they were assured of substantial local co-operation. phey proceeded upon the authority of a return from the Registrar General only after they had received solid evidence in the shape of some form of local representation, a resolution of the rown Council or a ratepayerg' meeting, that their. Inspectors vould be kindly received by influential elements in the listrict. Bonetimes they over-estinated the strength of the feeling in their favour; sometimes the swing of local politics put their iriends out and their enemies in; sometimes a district which had at first seemed recoptive was swept into opposition by the speeches and handbills of water Company agents, Local Act attornejs, or the Adti-Centralisation beague. Inis was only to be expected. Nhe Inspectors' probe was bound at tines to press on a teader spot. But the Board took up no intransigent attitude towards the localities, and they withdrew with adrirable cautlon when the opposition seemed preponderant, regreting privately at the same time that they had no power to clean sway such well defended dirt.

Reseatrent was aroused by the novelty not the extent of their 
control, which was of course far less than that of a modern department. The bit was galling because it was new, not because it was excessively sharp.

Nothing annoyed Chadwick more than the charge that the Board of Health forced its way into a place and rode roughshod over the feelings and interests of its inhabitants. He would point in answer to the securities he had so carefully provided. for sounding local opinion, consulting the wishes of the population, and preparing their minds for the responsibilities and benefits of the Public Health Act. A local examination was conducted by a specially qualified engineer, escorted by leading eitizens of the district; a public interrogation of witnesses was held before the ratepayers; the Inspector expleined the objects aimed at and the methods by which it was intended to achieve them; a report on the present state of the town was published locally, together with a description of the new public works proposed, sad an estimate of their probable expense; and ifnally, in Iondon, a responsible Public Board sat to review the contemplated measures, and to serve as a court of appeal to private parties. What more painless method could be devised of grafting the functions and powers of the public Health Act on to the older machinexy of local government?

How admirably on occasion the nethod worked is

illustrated by an entertaining sccount by Robert Rawlinson.

"On my arrival in Hexham, I found the town in a state of ferment as to the inquiry, the bell-man was perambulating the streets summonsing the ratepayers to a meeting to oppose the inquiry. This wes repeated during the evening, one of the meetings being for the evening, the other for the morning. Several of the promoters called in upon me during the eveming, evidently fearing the monning's meeting. I explained the Act to them, as the most absurd statements had been published and were believed. I learned that the leader of the opponents was a Local solfcitor. The promoters were most anxious to learn 
what courge I should take, as they suscia feared to come forward and support the measure in public. That j.s they would attend the meeting but wished to avold taking an active purt in the proceedings. I toid them this was exactly the course I desired they should take -.. namely -..- let the ogposition nave all the talking to themselves, and so leave thera to me as I was quite sure out of their ow evidence I could convict, if not convince them. The laquiry had to be adjourned to a large room as there was a Iull and rather formidable attendance. The day being wet many workmen were there. I commenced the inquiry by a short slatement of the proceedings which had brought me down -- and then glanced rapidly over the powers contrined in the sct -taring up one by one the objections which I had been informed the promoters of the opposition had made. I then requested any persons bavins evidence to offer either for or against to come forward and tender it. The opponents entered most resolutely into the arena, declaring that Hexhem was well supplied with water; and was, in all other respects, a perfect town. I inquired for the return of the mortality, and found that, for the last seven years, it was actually some $29 \%$ in the thousand, but with 'cooked' returns it was $24 \%$ in the thousand. I then called the Medical officers and the Relieving officers and soon got amongst causes of fever, mall-pox, and excessive money relief. I then traced disease to crowded room tenements, undrained streets, lanez, courts and crowded ysrds, foul middens, privies, and cesspools. The water I lound was deficlent in quantity and arost objectionable in quality, dead dogs having to be lifted out of the reservoir. And though the opposition fought stcutly they were obliged publicly to acknowledge that improvement was needed -.. they, however, dreaded the General Board, and the sxpense. I then explained the constitution of the Board and stated that their powers would be used to instruct, protect and to check extravagant expenditure. By this time the eagerness of the opponents had 
somewhat subsided, the body of the meeting had come partially round, and so I entered into an examination of the promoters who came willingly forward. At the termination of the inquiry several of the opponents came forward and stated that I had removed their objections and they wished the Act could be applied immediately.

Today I have inspected the town --. and have found it as bad as any place I ever saw. I have had at least twenty gentlemen with me all day although it has rained most of the time. The town is old, and is in as bad a condition as Whitehaven, and I dont know that I can say anything worse of 1. I am stajing at the best Hotel in the town, but there is no watercloset, only a fllthy privy at some distance, --- the way to it being past the kitchen. I have just been out in the dark and rain blundering and found some one in the place.

I have inspected the sources of the present water supply, and find that the water is taken from an open brook, filthy and muddy in wet weather, and filthy and bright in dry weather. In the same districts I have found; or rather, been shown, springs -- pure and soft -- and at a sufficient elevation, to Give 150 foot pressure in the town -- and in abundance for the whole population. The existing springs will be added to if requisite by deep drainage. Most complete water works might be formed at a cheap cost. And the town may be sewered and drained for nothing, as a Nursery Man adjoining has stated that he will give 2100 a year for the refuse, if it is all collected by drains. There are many acres of market gardens and nursery grounds within reach of the outlet sewer and more than $2100 \mathrm{a}$ Jear w1ll be obtained.

Since the inspection today I have had parties from both sides with me, the opponents trylng to explain away their opposition; the promoters to furnish information; and, at times, I have had nine or ten gentlemen at once, belonging to both 
parties. The leader of the opposition has made me a present of some Anglo-Saxon colns -- called Stycus which were found in Hexham Church Yard (1)

The deft and tactful handling of a truculent opposition, leaving no scars of controversy, is an example of the sanitary diplomatist at his best. But not all inquiries were thus concluded by a peace offering from the leader of the critics. When T.W. Rammell Invited the Corporation of Chipplng Wycombe to accompany him on a tour of inspection, they refused point blank, "they having determined to give all attempts to saddle the town with the Act the bitterest opposition in their power". (2) Pressure was not infrequently brought to bear on witnesses to prevent inconvenient revelations. During the inquiry at High Wycombe, for example, the vicar produced a letter from one of his parishioners:

"Sir -- If you send for me when you hare redy in the town hall, 1 will give a true statement of the newcence of the pigsties against my house belonging to Mr. Hunt. Mr. g. Hunt told Mr. J. Hunt that 1 told you about the sties. Mr. Jo Hunt asked Mr. g. Hunt if I hoed him any money, if I did he would demand it, and if $i$ dint pay it he would have a warrant of distress and take my goods, that was the reson that 1 was afraid to say the complaint, the Lord delievered daniel from the Lion paw, and that same god is my god and he will deliever me from my henemys.

i am your obdiet servent, John Pippin. the rev, Mr. Paddon, Wickham, Bucks. ${ }^{n}(3)$

Many in the localities looked with suspicion on the tables of mortality rates concocted in a distant London office, and called on the evidence of "popular repute" or the "oldest living resident" to prove the healthiness of the district. 1. R. Rawlinson - E.C., $30^{-0}$ September 1852.

2. Report on Chipping Wycombe, p. 8. (March 1850).

3. Report on High wycombe, p. II. 
At Merthyr Tydfil Rammell found a "very general indisposition" to the application of the Act -.- and, in particular, from the iron miners. They argued that the high rate of mortality was caused by their dangerous work underground and by lack of food. "What they wanted was more meat", not sanitary regulations. (1) One miner put the point forcibly: "My reason is, that people have not enough to buy food, and have nothing to spare for water. The wives of many being barefoot, there is no expense of shoe-leather". (2) Rammell in reply demonstrated that, even if full credit were given to pit accidents, 27,6 deaths out of each thousand were still due to natural causes. The workers eventually agreed to send eight delegates, four against and four in favour of the Act, from each of five districts, to accompany the Inspector on his round of inspection, and they broke up with an evident disposition to treat the matter on its merits.

As we turn the pages of the Inspectors' reports, we become familiar with a local drana, repeated in a hundred places, played sometimes as a comedy and sometimes as a tragedy, with innumerable variations of plot and circumstance, but marked by a few constantly recurring themes. We come to recognise the characters -- the landlords, who "would do that their neighbours did" and refused to be "at the expense of making a drain"(B); the farmer, frankly admitting "I prefer cesspools to drains, and I should like to stop drainage altogether" ${ }^{(4)}$; the Improvement Commissioners, defending their inactivity in the - 0 -

1. Report on Merthyr Tydeil, p. 4 (1850).

2. ibid., p. 47. Similarly the Highway Boards of Hanley and Shelton maintained that "considering the debilitating occupations of many branches in the pottery trade, these Towaships, generally, are not unhealthy. Neither do the intelligent part of the medical profession think them so. Those of the greatest practice, consequently of the greatest experience, are bold enough to say, that the mortality will be much the same, whatever steps may be taken with respect to sewerage". (Report on Stoke-upon-Irent, April 1350, pp. $45-6$ ).

3. Report on Wakefleld, pp. 11 - 12 (W. Ranger, December 1851). 4. Report on Bangor, p. 5 (T.W. Ramme11, September 1852). 
past with the argument, "Powers are apt to go to sleep unless attention is called to them sometimes; we don't claim perfection"(1); the local solicitor scornfully rejecting the Inspector's statistics with the comment "the excess is but sixtenths, which is but half a man"(2); the Justice of the Peace, well-intentioned but ignorant of the provisions of the Public Fealth Act, demanding suspiclously, "Have not the Board of Health power to order what they please to be done? and can the inhabitants control the expenditure?"(3). Against this mass of interest, 1gnorance, and apathy, the Inspector's strongest weapon was a general perambulation of the town. As he made his way through the courts and back streets, accompanied by a train of clergy, doctors, solicitors, Guardians, and Commissioners, the inhabitants crowded out of their wretched dwellings, crying out their complaints, on the supposition that he was armed with power to give them inmediate relief. One fact which these frox surveys revealed was that not only the higher but most of the middle classes knew very little of the conditions in which the lower classes lived. The delegates of respectability often expressed astonishment and horror at what they saw, declaring that it was utterly strange to them and beyond their belief if they had not seen it with their own eyes. The plea of

ignorance could no longer be maintained, however, after they had watched the Inspector put his questions and take down his notes in their uncomfortable presence. Here, for example, are the minutes made on such a tour by William Lee at Dudley:

$$
\text { "Patchett's-buildings. -.. All Irish. A court about }
$$

eight feet wide, ...... with only surface drainage. No

ventilation. A foul well used for cleaning the yard; most filthy privies are placed at the top, and as fast as the pots are emptied into the open receptacle, the fluid runs down the yard; the seats and passage covered with ordure, and the privies 1. Report on Chipping Wycombe, p. 40.

2. ibid., p. 6 .

3. Report on King's Lyan, p. 31 (W. Lee, September 1852) 
cannot be used. One case of cholera. The houses have water; the landlord would not lay it to them, but the water company did. One of the tenants says, "He will not put a brick in, but if he is asked to do anything at the property, d--- and b-- us, and is often drunk". Rent for house and chamber, 2/4d. The whole of the medical evidence shows these yards to be among the worst localities of disease in the town.

Mr. Richard Fellows' property, and Thomas Williams, four houses. -- Oaly one privy, without door, roof, or seat, and part of the wall down. The tenant, Richard Roberts' wife, says "I cannot get him to even come and look at it. We pay 2/6d. per week. The back door is nearly down, and I am sure I expect it lalling on the children. My husband is lame, or 1t would not be as it is. We cannot go into the privy. We have no water but the cellax water, which we use for slopping; we cannot get any other without sither buying or stealing. The landlords ought to lay water on for all the houses".

William Cox's property. -- Nine houses; no water; have to go half a mile for water. One of them says, "We may as well talk to that", stamping her foot on one of the bricks of the footpath, "as talk to the landlord about having any water. He looks after the rent".

Badger-square. -- Twenty-five houses. Very shocking privies. No water but from a draw-well. One of the tenants, who lent a rope and a bucket, said, "We have to steal water or do anything we can, and to drink the well water. There are dogs and cats in it, and sometimes we wind a cat up and cannot stomach it ......"

The New Dock. - A street witich is a perfoct quagmire, even at this dry season, for want of pavement and drainage. The property is almost new, and yet everything connected with health is in the most wretched state.

Birmingham-street, Vanes's-yard. -.. .... The Inspector 
of Nulsances caused the owner of some property below this to erect a privy for some houses that were without; but the tenants pulled it down, because they sald they should have all the people in the district coming to it if they did not. He then erected three others, and had locks put on, and they now stand.

Bond-street, John Owen's property. -.. I asked, "Where do jou get water?" Answer -.- "We steal 1t ....."

All the nelghbours about this part of the town were calling my attention to the 111 s connected with arainage, privies, want of good water, and stench, etc., to such an extent, that I was compelled to refuse to take them down in my minutes, because I should have had to mention almost every house, and could never have used my remarias". (1)

In town after town, against the advocates of laisser faire and local self-government, the Inspectors argued $C$ Chadwick's thesis that in matters of public health an impartial central authority must intervene to adjust the balance between the powerless masses and those of their betters who wanted privilege without responsibility. "Is sanitary reform a thing to be accepted or rejected at will by individuals, or even by comurities?", asked one of them. "Is it a subject for a show of hands, when the persons whose lives depend on the decision are nostly either igacrant, misled, or coerced? Can it be left to the ordinary principles of supply and demand? Is there any parallellsm between those public arrangements that are necessary to existence, and private dealings with the butcher or baiker, --- although these may be equally nocessery?"(2)

\section{Report on Dudley, App. A, Minutes of Inspection, pp. 77 - 85 (W. Lee, 29 December 1851). \\ 2. W.Lee, "Summary of Exporience on Disease", 1851.}

Lee, after the tour of Dudley described above, concludes: "It is'an axiom that property has its duties and its responsibilities, as well as its privileges and influence. The above are illustrations of the manner in which those duties are too Prequently performed; they are also 1llustrations of the belplessness of a large proportion of the poorer classes in towns, and of the working of the (continued on next page) 
All the anxiety of decisions which they believed involved life and death to thousands crowded upon the Board as the time came round each session for the preparation of the Bills in which their Provislonal Orders were confirmed by the legislature Whitstable and Newton Abbott must be strucis out of the schedule because strong local opposition had developed. (1) A deputation from the Leamington Commissioners asked that the application should be postponed for a session. Did they represent the real wishes of the ratepayers? wondered the Board; and their doubt was confirmed a few days later when they were informed that the resolution of protest had been passed at a vestry meeting not open to the public. (2) Ryde took a poll on the Act, and twothirds of the ratepayers voted against its application; a fortnight later the medical men of the town sent a deputation in favour of the Act, but the Board reluctantly refused to move against the majority of the inhabitants. (3) The Meraber for Brighton secured the omission of the town from the schedule, and Chadwiok drafted an ironic speech, "Thanks of Sir William Pechell for withdrawing the Public Health Act from Brighton" -- "I thank you for having struck out Brighton from the provisions for the promotion of cleanliness. I am deoply impressed with the obligations due to you for having stayed a weasure for the saving of Eome hundreds of people from the ravages of typhus and other preventible disease. As a friend of the population I an delighted that you have refused measures for the introduction of water into the houses of the poorest classes". (4)

Deputations, friendly and hostile, waited upon the $-0-$

(Continued $\rho$ rom previous page) voluntary principle in a matter no less momentous in its consequences than life and death". (Report on Dudley, g. 53).

1. Minutes, 21 June, 27 July 1850.

2. 1bid., 12 and 27 July 1850 .

3. Ibid., 26 Mareh, 12 A pril 1853.

4. "The Thanks of Sir William Pechell for withdrawing the Public Health Act from Brighton and notes on his attack", $M$ M. n. 
Board, and petitions and counter-petitions poured into Grydyr House, Irom administrative bodies whose powers would pass to the Local Boards, from ratepajers who areaded the expense of water and drainage schemes, from landlords who disliked regulation and office-holders who feared disturbance. Attempts were made to discredit the testimony of the Inspectors. A letter from the Commander of the Royal Engineers at Portsmouth attacked the reports of Grainger and kawlinson as a "tissue of wilful misrepresentation", and declared they aust have been imposed upon by interested persons. (1) Babbage's report on Bronyard was stated to be full of absurditles and 1ies; he had remarked, for example, that three funerals had taren place there on one day -.. but not that they were of three old women, aged 72, 92, and 95 respectively. (2)

Irom Alfreton came a typical petition, signed by the Nayor and the largest ratepayers, and maintaining that the town had","to the knowledge of the oldest inhabitant, been notoriously remarikable for the bealth and longevity of the Inhabitants". It went on to plead/had chse of thners of lands and premises, and the greater occupiers and ratepayers within the town, colpared with the inhabitants generally, who are chiefly employed in the manufacture of stockings and in coalrinling and agricultural labour, and unable to bear additional imposta, whereby the liability of such owners and occupiers, in case of the sald Act of 1848 being adopted, would greatly enhance and become burdensome to them, and induce many to remove Irom the town to avoid such additional imposts; whereby the property within the town would be greatiy reduced in value". The "gigantic machinery" and "numerous officers" were quite unnecessary, as the parts complained of had now been improved under the Nuisances Act. Those who signed the original petition had been deluded by the belief that the Act would 1. Minutes, 21 August $1849^{-0}$.

2. Hansard, vol. 124, p. 1351, 9 March 1353 (Col. Pechell). 
Involve an expense of no more than twopence a week. (1)

At the subsequent inquiry at Alfreton a local clergyman informed the Inspector that he had been asked to "direct" his tenants to sign the counter-petition. (2) The Board had abundant reason to believe that agitations against the Public Health Act in other places were only too often moulded by pressure from landlords or other interested parties; and that where such tactics failed, counter-petitions were cooked up and signed with flctitious or forged names. The clash of local jealousies and interests may be illustrated by the case of Macolesfield, from which the Board received four memorials, one in favour originating from the Wayor and Corporation, three opposing the Act, promoted by the Police Commissioners of the town and the highwey Boards of Sutton and Furdseield. The memorial from Iurdsfield declared that "the petition of onetenth of the ratepayers, forming a very small portion of the whole inhabitants, had, in the case of Macelesfield, no reforence whatever in its orifin or promotion to the lingrovement of the sanitarg condition of the town, but for the avowed purpose of enforcing the jlelding up bJ all the othex public bodies in the borough of their functions and powers to the one body with whom that petition originated and by whom it was promoted". (3) A letter from the Town Clerk of Macclesfield later informed the Board that out of the 4,132 signatures appended to the counter-petitions, only 1,421 could be identified as those of ratepayers; "that sevarsl of the signatures are not those of the persons they purport to be; that a great number of the names are in the same handwriting; and that some appear fictitious; that there are also frequent repetitions of the same name, of persons not resident at all, and after the signature of the father in several cases, those of the children are appended". (4) The Inspectors were later $-0-$

1. Report on Further Inquiry at Alfreton, p. 5 (December 1850). 2. ibid., p. 10 .

3. Report on Macclesfield, p. 8 (Rawlinson, Bebruary 1851).

4. Uinutes, 9 June 1851. 
instructed to verify the genuineness of sisnatures by personal visits or by reference to the rate books ${ }^{(1)}$; and ultimately, in May 1353, the Board decided to request that in future the Clerk to the Guardians should attach to each petition a certificate showing the number of ratepayers and attesting the qualifications of those who had signed. (2)

From Great Yarmouth came an octavo pamphlet of 58 pages, inputing that the evidence berore the Inspector had been mutilated, falsified, and fabricated, advocating an alternative scheme of sewerage which would leave nearly 25,000 out of the 23,000 houses undrained, and propounding reasons why the existing supply of hard impure water was superior to the suggested proviaion from a soft and unpolluted source. The application of the Act, "firstly, would destroy a large proporition of the value of real property; secondis, ruin whole farilles who ars living upon the surplus fino me of mortgaged property; tilidiy, drive prom the town those owners of shipping property who, having no interest in the real property of the town, will be ladueed to roside where local taxation will be less oppressive; fourthly, by which means bundreds of poor will be thrown out of employ, and become chargeable upon the parochial rates; and fifthly, largely contribute towards the decay of a town once among the rost plourishing seaports in the expire of Great Britain". (3) The objections from Great Yamouth were supported by Joseph Fume; but the case afgainst the town was so overwhelming that the Board felt strong enough to defy the opposition.

1. Minutes, 24 vetober 1851. $\quad 2$ ibid., 26 May 1353.

3. Report on Hemorial from Great Yarmouth, p. 27 (V. Lee, October 1850).

4. Hinutes, 15 Apri 1 1851. According to a letter from the Inspector, Nilliam Lee, to Chadwick, 4 August 1351, the death rate was 24 in the thousund. There wes nearly half an ounce of saline and mineral saker matter to every gallon of the town water suppiy. With the exception of the barracks, sll the houses recently built hed so means of drainage whatsoever; and all their privies and middens (Continued on next page) 
From the hamlet of last Stockwith came a memorial against being included within the district assigned to the Gainsborough Local Board:

$$
\text { "Worthy Sir, }
$$

We the undersignea Being princeable Rate Payers of the hanlett of Elast Stockwith do feel our Selves agrieved By your Saniture measure concerning the Plans Laid down of us haveing any thing to Do with gainsboro waterworks or any Part of the Dreaniage it Doth Require as we have a good Dreaniage of our own about 6 feet fole in 20 chean, wich falls Down into the Carr wich that Dresniage is Verry good and hath Been greatly Iaproved at a Serious Expence by the Erection of a large Steam ingene at Ravensfleet which will Continually Bring Large Rates upon us for the Management and Repairs of the same we have good Dreaniage and three Hrustees Regularly Chosen to Enspect any Defisunces that may occor in our Dreans will not Lett any stagnated water become a wuolsance to hinger any thing and as to haveing any more Expence with New woriss it will be a burden more than we Can Bear as our kates his bxceedingly heavy. Now we Sinceerly Beg of you to withdrav any Such

(Continued from previous page) opened into dead wells, the infiltration from which daily poisoned the water used by the nearby Military Lunatic Asylum. The powers of local

improvement were in the hands of a body of 113

Comissioners appointed under an sct passed forty jears before and altogether unsuited to the existing requirements of the borough. "A flagrant instance of taxation without representation", concluded bee, "... a majority of the Commissioners are self-elected for life; ... for a great number of years, until within the last few months, they had never published any accounts; ... the Abstracts now published, with the Public Health Act impending, are so mystified that their Lordships (the select Comittee of the Lords investigating the petition) could not understand them". The select Committee had decided that the mortality was so excessive that the General Board would have been justified in applying the Act without any potition from the locality. One witness admitted that in order to obtain signatures against the Act he had told ratepayers that they would be compelled to pas 7/6d. to 10/- in the pound as rates. 
mesure from us as it w111 be of No use what Ever to our Place with gratitude we are you obt. Servants
(Signed) Robert Wildboar
(and 50 others) ${ }^{n(1)}$

The indifference of the fuinesant Presidents, who shared none of the enthusiasin of the Board and had no desire to share $-0-$

1. Report on Purther Inquiry at Gainsborough, p. 6 (May 1851). The ratepayers of East stockwith were later assured that inclusion under the Gainsborough Local Board would not mean beling burdened with the cost of the works, unless they received benefit erom them.

A few roore exaraples will serve to show the kind of objectioas raised in the localities and the Board's attitude towards them.

The Comalssioners of Sewers, Paviag, Cleansing, and Lighting of Bristol; protesting that the Act was not needed in the town, declared that the anrual mortality was not 23 in the thousand. The Board replied that their action had been taken on a return from the Registrar General, which in fact showed a death rate of 20 per thousand. Ho representation bad beea received from ary public meeting that a majority of the ratepayers opposed the Act; "all the representations received by the Board againet the application of the Act are erom bodies whom it will. displace". The Board concluded firmly: "there is great necessity in Bristol as eisewhere, Por consolidacins Wunieipal powers in the hands of the Yunicipal body, and for thus escaping from the delay, expense, and ineficiency inseparabie from the existence within the sale city of several concurrent jurisdictions, no less than the evil of dividing anong various bodies, duties, which to be eflectualiy and economicuily discharged, ought to be in the hande of one". (Winites, 15 Maj, 13 June 1951).

After bearing a deputation which included John Bright, the board decided to take no further proceedings on the petition from Sacup. (Minutes, 7 Pebruary 1850).

A deputation from figh Wycombe to protest against a prelininary inquiry being conducted there included the Nember, Martin Tucker Smith, and the Vestry Clerk. But a week later another deputation, including the wayor and the Vicar, asked for the intervention of the Board. They decided to hold an inquiry. (Minutes, 18 and $25 \mathrm{Apri1}, 1849$

\& Salisbury protest declared that the drainage recently lald down was the best a town could have. The Local Board would have only nominal self-government as it would be guided by the generai principles of the Central isoard. There was the expense of five paid officers to consider. And altogether the application of the Act would involve an outlay of 40,000 . (Report on Salisbury, p. 115: T... Remme 11, Oetober 1851). 
any of its labours, was another cause for anxiety. In June 1852, to take a notable 1nstance, ford John flanners told the Board that he fearea he would not be able to undertake the introduction of a second Confiming B1ll that session. No reason was given for this decision, which would have thrown away months of preparatory labour in investigation and the conclilation of local sentinent. The Board protested strongly. "The powers of the Act are urgently required in the case of the towns included in this Schedule, eapecially Woolwi ch, Wisbech, and Salisbury. In woolwich, the nortality in the lower parts of the tow amounts to 27.3 in the 1000 , though in Woolwich Comion it does not exceed the septennial average of 14 in the 1000, while in some particular parts of the town it rises to 38 and even 40 in the 1000. In 1 isbech the septennial average is 30 in the 1000 and in Salisbury a fraction higher. In all These cases the Board feel that a very serlous responsibility vill weigh upon tham if any dalay that ean properly be avoided takes place in applying the Act, as they congcientiously believe that such delay ray occasion the loss of nany lives". (1) Lord John then consented to introduce the Bill, "on the understanding that it is the deliberate opinion of the Board that no delay or discussion is likely to arise in Parliament in respect of such Bill". (2) Eow the Board could be held answerable for the $B 1.1 l^{\prime} \mathrm{g}$ smooth passage through Parliament he did not make clear.

By February 1850 the Board had received applications from 192 places, with a total population of $1,969,915$, ranging from Birmingham with its 182,922 to the Northamptoushire parish of Little Bowden with 439. The Fublic Heslth Act had then been introduced into 32 places. (3) Aiter the initial inpetus of 1. Minutes, 9 June 1852 . $^{-0 m}$ 2. ibid.

3. "Return of the Number, Names, and Population, of Towns and Districts which have asked for Inspection under the public Health Act, and of those which have Embraced and are placed under its Provisions", 6 March 1850 (Commons). H.P. 1850 (110), xxxili. 591. 
the first eighteen months, however, the number of new applications slackened off to an average of just over twenty a year. In July 1853 a return of the Boaxd showed that petitions had reached them from 255 places, 164 of wleh had been brought under the Act, 36 by Provisional Crdes and 78 by Order in Counc11. (1) The power to act on the authority of a return from the Registrar General had buen exercised witt the greatest caution. In the first five years the Board directed inquiries into oniy 28 places from which they had not received a petition signed by at least one-tenth of the inhabitant ratepayers; and even in these places, as we have seen, they moved only after they had seen good evidence in the shape of influential local representations that their Inspector would be siven strong support. (2) In one place only had they instituted an inquiry without any form of local application. A petition had been received from the parish of filsoiren, a suburb of Wisbech, and the Inspector, William Lee, had expressed the opinion that no effective sanitary works could be constructed without taking in the rest of the town. His report bad subsequently gained the unaninous approval of the inhabitants of wisbech, the death rate of which was 30 per thousand. In other places, Alawick, for exanple, the Board had reluctantly decided not to incorporate within the jurisdiction of the Local Board certain districts where hostility to the Act was manifest, although their inclusion would have rounded of the atural area for dreinage. (3) The drafting of a sanitary scheae was determined by paysical facts, the line of a water shed and the delimitation of a natural drainage area. Jut across the physical face of $-0-$

1. "Betura of all places which have petitioned the General Board of Health for the application of the Public Health Act, otc.:P'. 1852 - 53, xcvi'. Ir George Pechell, 1 July 1853).

2. Ibid., P. 15.

3. "As the expression of opinion against the suggested consitution of the Alluwick district seens wide and general, the auzsestion of ins. Rawlinson will not be acted upon". (ivinutes, 20 April 1850). 
the countryside, its rivers and hills and geological strata, eariler generations had traced the lines of their civil adninistration, eutting it into units which frequentiy bore little relation to the area within which the objects of the Public Health Act could be most economically and conveniently accomplished. Chadwick, much as he would no doubt have liked the tasik, could not sit down like Napoleon in council and redraw the adniniscrative map of Great Britain. Some redrawing there must be: but the Inspectors were instructed to go beyond the exiating civil boundaries only where there was a physical necessity for doing so, or where there would be manifest advantage to the occupiers and owaers of the district included in the new jurisdietion. (1) Comanding as they did a stafe of Inspectors which was never more than seven in number, and for most of the period was onlJ flve, they had no gtrength to spare for protracted batties in the localities; and, as Chadwick confessed, "bitherto the aupber of bad glaces compeing for the services of our very small stapl has been so considerable, that we have asually only been inoved in favoux of any particular place by a strong representation." (2)

The crities in parlianent and the press, who uried to make out that the Board's intervention was everywere resented and that sanitary works reant enormous expense for a doubiful benefit, were anply rebutted by the evidence, The average cost of applying the Puolic Realth Aet by Provisional Order was little more than s336, by order in Council still less, only 238. Co obtain a grant of similar powers by Local, Improvement, or ta.jerworks Acts would invoive legal charges amounting to over 21,600 ; the average expense of even an unopposed Improvement A.t was $\$ 600$. The comparative costs of 1. "tet our Inspectors understand, that things being tolerably equal, it is an object to keep existing divisions"

(Carlisle - E.C., 11 November 1349).

2. S.C. - Edwin Edalson, 9 October 1852. 
the two procedures were strikingly illustrated in the case of Reading, where a Local Act was promoted for the sanitary improvement of the town. A preliminary inquiry by the Department of Woods and Forests cost $£ 900$; and the expenses ran up to a total of 28,000 -- yet in the end the $B 111$ was defeated by the opposition of the local Water Company. Subsequently a petition was sent to the Board of Health; their Inspector conducted his inquiry and survey for $\$ 140 / 19 / 3$; and the woriss for which 260,000 had been estimated under the unsuccessful Local Act were executed for 225,000 , (1)

In most places the Inspector of the General Board was the first to give serious and informed attention to the preparation of a comprehensive scheme for supplying the inhabitants with water and relieving them of their refuse. He was ordered, in the set of instructions drawn up by Chadwick, to consider the three-fold aspect of the problem: how water, pure and wholesome, from springs or rivers or upland gathering grounds, could be brought to the population; how it could be carried away ggain after use, bearing human wastes with it; and, finally, how the product of the sewers could be utilised to manure the neighbouring farm land. (2) The attention of local authorities was directed to sources of water which they had never suspected. At Ely William Lee suggested that the polluted Ouse should be abandoned, and the land-drainage water be collected instead from the table-land above the city. (3) At Alnwick Rawlinson proposed to get water from the moors, "not by impounding reservoirs, as would most certainly have been done by any Engineer not educated in your school, but by deep drainage. $\rightarrow 0-$

1. "Return of all places which have petitioned the General Board of Health for the application of the Public Health Act, etc.", pp. 23 - 24 (Commons, 1 July 1353). P.P. 1852 53, xcvi. 1. "Report on the administration of the Public Health Act .... from 1848 to 1854", p. 39. 1854, xxxv. 1. 2. "Report on ..... the Nuisances Removal and Diseases Prevention Act", July 1849: App. X, pp. $129-135$.

3. Report on E1y, pp. 36 - 38 (11 January 1350). 
The Idea was of course new in the district, and the Local Board requested to see some of the water that they might be assured of its quality and have a guarantee as to quantity before being committed to the scheme". (1) Rawlins on made trial borings which revealed water four to ten feet below the surface, two degrees in hardness, and sufficient to furnish 84,000 gallons a day for the 7,000 inhabitants. Two years later Dr. Sutherland told Chadwick, "I have seen the Alnwick works. They are beautiful. I would rather have seen them than the finest temple in the Universe". (2)

Accounts of the progress of local schemes presently began to reach Gwydyx House. They made encouraging reading for men who had need of encouragement. At Barnard Castle, for example, four miles of pipe sewers, from four to fifteen inches in diameter, had been laid at a depth of seven to eight feet at a cost of 1/3d. a lineal foot; the total cost of draining each house being only $22 / 6 / 10$, or $3 d$. a week. The water supply, instead of being taken from the river Tees, according to the former practice, was collected from soft-water springs nearly five miles distant, and brought by an earthenware pipe to a covered reservoir, and thence by a seven-inch pipe to the town. "The water is only brought into the light in the room where it may be drawn, in a constant supply as presh as at the springhead", observed Chadwick with satisfaction. The water supply for each house cost less than $1 / 2 d$. a week, so that the total rate charge for the combined public works amounted to less than $2 \%$ d. a week for each householder. (3) when, early in 1853 , Chadwick and Southwood Smith spent a pleasant day inspecting the recently completed works, they watched with benevolent approval while "an address was presented to the Local Board by several of the poorer classes expressing their gratitude for the improvements introduced into their dwellings", (4) Similar

$$
\text { -0- }
$$

1. Rawlinson - E.C., 25 September 1852.

2. Sutherland - E.C., 25 June 1854.

3. Drainage Minutes, 1852, p. 134.

4. Minutes, 6 January 1853. 
achievements were reported from other towns. At Ottery St. Mary, in Devon, combined works were constructed for less than 1d. per house per week; at Tottenham and Ely for less than 1/2d.; at Hitchin and Penrith for 1\%d. -- "all being below the average rates of charge for trading companies for separate water works alone." Even sandeate, where the number of houses was small and their size and value above the average, paid less than $3 \mathrm{~d}$. (1) A return of the Board in 1853 showed that in the towns brought under the Public Health Act, the total cost of combined public works of water supply and drainage averaged $21 / 2 d$. a week for each house; the private improvenent works (such as filling up the cesspool and fitting sink and water-closet) averaged a furtber 1 1/8d.; the total average weekly cost being thus 3 5/8d. (2)

1. Drainage Minutes, $1852,0-0$.

2. "Return of all places which have ptitioned the General Board of Health for the application of the Public Health Act, etc.", p. 22. A house to house inquiry in London showed the private expenses of each household as follows (Drainage Minutes, 1852, p. 132):

old system Annual Weekly Expense Expense
Under the Public Health Act .

Mending and

cleansing bricix

house-drains

$19 / 834$

$41 / 2$

abolished

Cleansing

cesspools

$1 / 0 / 4$

$4 \% 4$

abolished

Repairing

water-butts

and cisterns

$19 / 2$

$4 / 2$

abolished

Making house-

drains

$2 / 0 / 4$

$9 \%$

Cost of an

intermittent

water supply

$2 / 1 / 9$

$9 \%$

Cost of a

constant water

supply

2d. weekly 
These were arguments that a ratepayer could understand; and it was with such figures before him that Chadwick maintained that "the question of scales of sewers is not, as hastily supposed, merely big and little endian controversy, but it is a question on which immense sickness and many thousand lives are dependent". (1) If, as the engineers of the old school asserted, it was necessary to lay down in every street brick sewers large enough for a man to enter, the expense of the works would amount to a positive prohibition of complete drainage in a very large proportion of provincial towns. The smallest sized brick sewer recomended by the survejors of the old Commissions of Sewers cost 11/- a foot, while the average cost of the entire public drainage at Rugby, Tottenham, Barnard Castle, and ottery St. Mary was no more than 1/9d. a foot. At carlisle an eminent railway engineer had estimated $\$ 70,000$ for laying down street sewers of deposit on the old style; yet self-cleansing tubular sewers were put in for 223,000 . (2) In fourteen towns where pipe sewers were laid down the total outlay was 298,858 , as compared with a probable cost of 2249,394 for large brick sewers; and the average cost of each town was no more than $£ 7,061$ instead of $£ 17,814$. (3) Where properly laid, moreover, and adequately supplied with water, they involved no appreciable current oxpense, whilst brick sewers demended periodic cleansing by manual labour.

No part of Chadwick's theories, not even his highly coloured picture of the agricultural value of liguid sewage, aroused such violent opposition as his advocacy of pipe sewers. Captivated by the ingenuity of his "quart into Pint" reasoning, It was said, he ignored the daily instances of choked pipes and the regular working of brick sewers. Small-pipe drainage had.

1. MS eragment, n.d.

2. "Report on the administration of the Public Health Act .... from 1848 to 1854 ", PP. $39-40$. P.P. 1854, xxxV. I.

3. The detailed figures are as follows:

(Continued on next page) 
been recommended by the Metropolitan Sanitary Commission on the evidence of certain obscure and docile witnesses, all of whom were later rewarded with appointments; they were supported by the conclusions of a Trial Works Committee, who had conducted experiments under the scientific supervision of a staff of bricklayers' foremen. And if Chadwick himself did not stand to make money out of earthenware tubes (his enemies paid him the compliment of not holding him guilty of any lesser corruption than the desire for universal power), the seven pipemakers on the Lambeth Vestry were suspected of supplying funds for F.o. Ward, the press champion of the nen system. Tubular drainage, said the critics, was too delicate and sensitive for a population so barbarous as the poorer English, who, as the sewer-men testified, were in the habit of throwing away with their own excreta such unwanted articles as scrubbing brushes, (Continued from previous page)

Town

Cost of construction cleansing pipe

Rugby

Woolwich

Croydon

Tottenham

Ottery St.

St. Thomas, Exeter

Barnard Castle Southampton Coventry Lancsster Ormskirk Hitch in Alnwick Morpeth Total cost Average cost of each.t"rown Selfsewers Sewers for men to cleanse

3,600

15,500

9,500

4,000

900

37,663
39,500
10,000

2,113
6,155

3,709

$26,063 / 16 / 3$

$53,713 / 7 / \cdots$

17,500

36,065

7,500

12,000

3,000

6,000

3,300

7,000

7,500

3,000

$\frac{1,500}{98,8577}$ $16 / 3$

$249,394 / 71=$

$7,061 / 5 / 5,17,313 / 17 / 7 ?$
Annual instalment to pay off the amount, with $4 \% \%$ interest, in 30 years Selfcleansing men to pipe sewers
221
951
583
245

57

73

114

1,800

1,600

1, 074

460

184

202

214

..... from 1848 to 1854", p. 40. P.P. xxxv. 1. 
hearthstones, nightcaps, and litters of kittens. How could three hundred thousand kitchen maids in London be prevented from llushing their refuse down the sink? Englneers shuddered at the thought of the continual ripping up of hundreds of miles of streets, and the perpetual stoppages and repalrs which were bound to occur when a dead cat, a bullock's heart, a handful of lady's hair, or a bundle of stolen napkins was enough to stop up a street sewer. "hs the population cannot bastily be ifted for the sewerage", declared one, "the sewerage must be fitted in a degree for the population". (1)

\section{Whenever}

KXX failures occurred (and fallures were frequent in those crude experimental days) a triumphant "le told you so!" went up from the Institute of Cicil Engineers. To Chadwick's immense indignation the story was spread that the four-inch pipes he had fitted in his own house in Stanhope street had choked up, and had been replaced by drains of a larger bore. Pipes were laid in sandy or slippery solls without protection; their inlets were not properly guarded; they were given insufficient fall, or even, through ignorance or carelessness, were laid with reverse inclinations. They mere manufactured of clays and marls unfitted for the purpose, and were badly tempered, crudely formed, and imperfectly burned. They were rough on the surface, porous and absorbent in substance, and so untrue in section that two pipes of twelve inches diameter might show an unevenness of joint when placed together to the extent of an inch or more. A variety of joints -- butt, socket, half-socket, and rabbet -- came into confusing use. Nine-inch pipes were connected to six-inch or four-inch, and at times a tubular sewer or drain was continued by a sewer or drain of larger dimensions, square in section, and formed with dry rubble or bricks set dry together. (3) $-0-$

1. "Reports by Neil Arnott and Thomas Page on an inquiry ordered by the secretary of State, reiative to the prevalence of disease at Croydon", 1853, p. 43 (Page). 
But gradually pipes gained ground, as improved machinery secured greater accuracy of form and increased strength of materials, and experience revealed superior methods of laying and jointing the plpes, combined with more efficient means for inspecting, cleansing, and ventilating them, and guarding them against the admission of improper substances. Chadwick persuaded the Lambeth manufacturers to make pipes of superior strength and workmanship for towns under the Public Health Act. By 1852 one factory alone was turning out weekly ten or eleven miles of glazed earthenware pipes, and Chadwick estimated that not less than fifty miles of sewer and drain pipes were being produced each week. By the end of 185327,000 houses in London, nearly a tenth of the total number, were being drained by some three or four hundred miles of pipes. Dr. Sutherland could write in February 1854, after a visit to Rochdale: "The result of the plpe drainage is that there have been no obstructions, no breakages and no cost of repairs. Some of the pipes were laid in 1846. They are laying down pipe sewers in some of the widest streets in Manchester, and I find pipes everywhere. Say what they like, the pipes will eventually gain the day". (1)

Chadwick's quarrel with the Institute of Civil Engineers went deeper, however, than a clash of technical opinions. The battle of the pipes was embittered by professional jealousy and personal pique. As scornful as their chief of the "Fossil or Gwilt school"(2), Chadwick's bright young men cocked snooks at some of the taost respected names in engineering, Stephenson, Rendel, Bazalgette. At Gwydyr House it was commonly said that, in the sanitary field at least, the eminent engineers had $-0-$

1. Sutherland-E.C., 2 February 18584. The General Board give the following figures for the manufacture of pipes: $1848 \quad 104$ miles $1851 \quad 1,820$ miles 1849 $416 "$ 1852 $2,080 "$

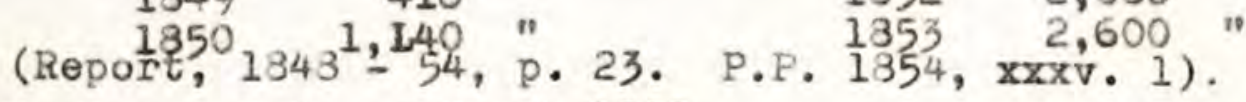
2. W. Lee - E.C., 9 March 1852. 
been eminent failures; and outside Gwydyr House it was retorted that Chadwicls had excommunicated all engineers who refused to be bound by his "Lambeth Plpe theorg". Not least anong the weaknesses of the Board's constitution was the arrangement by which their Inspectors were paid by the day, and were free, once they had completed an engagement for the Board, to undertake private commissions. They might in their official espacity examine and report on the sanitary condition of a place under the Public Health Act; and then as private individuals put in a bid to carry out the works they had recominended. And very often the services of the Inspector, who had the advantage over bis professional competitors that he had already surveyed the ground and had indicated authoritatively the works that would be required, were sought by the Local Board as it faced up to its programme of sanitary construction. Chadwick himself could see nothing wrong with this system. If the Inspector's plan were suitable, why skould he not be allowed to execute lt? "Apart from what is due in honesty to the first, the rost severe and successful labour, looking to the early conpletion of the proposed works with economy and efficiency, those objects will surely be endangered, by removing proposed woriss, from the superintendance of professional men of the greatest experience to others of the least experience, or who have all to learn. The Ingineers in the service of the Board who have stepped out of their profession to examine towns, with the view to the application of the Public Health Act are entitled to consideration, for the chief amployment, in aiding the execution of works which they have aided in preparing". (1) They could be 111 spared from their primary duty of conducting the local inquiries, but Chadwick, with his ingrained suspicion of all engineers who did not derive their practice from the principles of hls sanitary Reports, was delighted as one local scheme after another fell lnto the safe hands of the Inspectors, the only true and dependable apostles of pipe drainage.

1. MS fragment, n.d.

$$
-0-
$$


Moreover, It was pleasant to be able to tell critics that far from the Local Boards protesting against central interference, they often complained that the General Board had 1aadequate powers to assist sanitary authorities, fresh to their duties, to administer a novel and dificult measure. Gwydyr House, which had not sufficient staff even to draw up all the necessary byelaws and legal forms, was kept busy onough without the further duty of tutoring Local Boards. The Boards of Iiealth had therefore not had all the workias aids which Chadwick had been able to give the first Boards of Guardians. When appeals came in, however, he felt he must draw upon his slender resources of men and time to find them an answer. (1) Thus, up to May 1853 the Inspectors of the Board had been employed as engineers to carry out works under the Public Fealth Act at fifteen places, and at a further twenty-one places the works were being executed or about to be executed by them. (2) By 185424 towns had asised the General Board to name an engineer to plan and superintend their works; 11 had asked their advice in the appointment of survejors; 25 survejors had sought the belp of the Board's chief engineer, Henry Austin; and 44 towns had engaged the Board's Inspectors. (3)

1. Requesta for the help of an Inspector are noted, for example, in Minutes, 2 September 1350,29 september 1853 , 24 July 1854.

2. "Return of cases in which either of the Buperintending Inspectors of the General Board have been emplozed as Engineers in carrying out the works which have been executed under the Authority of the Public Health Act, 1343, and of cases in which the Works are being executed or about to be executed by the said Inspectors", 23 May 1853 (Commons, Co1. Harcourt). p.p. $1852-53, x$ cv1. 27.

Inspectors had been employed as engineers at: - Rugby, Sandgate, Barnard Castle, Southampton, Coventry, Newmarket (survey only), Ormsirirk, Hitchin, Crojdon (water works and plan only ofl drainage works), Penrith, Dartford, Launceston, Ashby-de-1a-Zouche, Selby, Epsom.

woriss were being executed or were about to be executed by themsat: - Lancaster, fluwick, Lorpeth, Nantwich, Rotherham and Iimberworth, Baildon, Altrincham, Berwick-upon-Tweed (works of sewerage only), Wigan, Knighton, Newcastle-underLymo, Burslem, Diss, Waldenhead, Gainsborough, Cardiff, Warwick, Lover, wloucester, Salisbury, Woolw1ch. 3. Repoet, $1843-54$, p. 44. P.P. 1854, xxxv. 1. 
But it was not simply as privileged rivals, backed by the authority of the Board of Health, that the professional

engineers had reason to fear the Inspectors. In conducting the local inquiry the Inspector brought under scrutiny any projected schemes for sanitary improvenent, and his opinion naturally weighed heavily with the Board, who, under the 119th section of the Public Health Act, must give their sanction to any local plans before a loan could be raised on the mortgage of the rates. It as contended that this night mean, in effect, that an engineer was obliged to submit his plang for the approval of a man who might later put himself forward for the same engagement with the Local Board. At Durham, for example, there was a brush between the Inspector, W1111am Iee, and Chadwick's one-time favourite, Thous kawkesley. Hawkesley, whose more recent utterances sometimes contralicted his opinions of that earlier period when he had been looked to as the chief engineering hope of the rowns Improvement Company, was now completely out of favour at Cwydyr Bouse. Lee, after an examination of the plans he had prepared for the improvement of Durham, could see no reasol why the work Hawsesley estimated would cost 16,000 should not be done for 24,300 .

Charles Hey, Hawkesley's Quaker partner, wrote to protest, Hawkesley himsele apparently erfusing to have any personal communication with Chadwick. " $I$ can fina nothing in the Act to authorize the Board in requiring Engineers of whatever sikill or eminence, to suonit the details of their plans and estimates to other, it may be much junior, engineers who are their airect competitors in the particular branch of engineering in question", he observed. "It was one object of my call upon thee to represent the general feeling of the profession, that this course is one aubversive of honourable competition and degrading in its character, as creating a repugnance in the mind of those best able to serve the public to such supervision". 1. Charles May - E.C., 7 July 1852. 
Despite his experience as a water works engineer, replled Chadwick, Hawksley had never drained a town in his life, and had always averred that drainage was a separate bruach of practice. "Vhy", he exclatmod, "the junior inspestor has had far nore practice in town drainage but more particularly forowed arainage than jou both put together or any one of the engineers the most exinent you have named". (1) To the Dean of Durhan he confided hiz belief that the whole affair was "uttorly srivolous". "All this means as it seens that irr. Hawkesley objects to any examination of his plans or to such examinations only as he likes or by whow be likes ...... I do not understand how proresilonal englneers could get on if they are never to act, except when they are clear of rivality". (2)

Hawkesley subsequently published a pamphlet, alleging that another Inspector, Ranger, after cundemning Hawkesley's plans for the Darlington waterworks, which he had peremptorily demanded to see, had soon afterwards reproduced the specifications verbatim as his own work at Barnard Castle and Southampton. At Croydon Ranger had rejected plans subitted by two other engineers -- and had then accepted the engagenent himself. Chadwick had personally objected to the employment of Wicksteed by the Leicester Local Borrd, and had suggested to Great Grimby that Rendel shoula be superseded by an Inspector. Ihese were grave charges, and for a tine Chadwick contemplated proceeding againgt their author by criminal inforration, so that the Board and the Inspectors right deny the ullegations on oath. (3)

Conscious of his own rectitude, and distrustivil as ever of the motives of his opponents, Chadwick did not give full weight to their criticisms until it was too late. He was always prepared to agree that it was a sound principle that the Inspectors should be paid an annual salary. It would protect

1. E.C. - Charles May, $20^{-0-}$ July 1852.

2. B.C. - Dean of Durham, 23 July 1852.

3. E.C. - Lord? , 7 June 1853. 
them against the charge that self-interest dictated their approval of any particular drainage scheme; it would relleve them from the invidious duty of passing judgment on the plans of their rivals; and it would set free all their time and abilities for the functions of their public office. The serious disadvantage, as it seemed to Chadwick, was that it would also deprive provincila towns of experienced sanitary engineers before the transition to the new system was safely accomplished. Approving the principle, therefore, he would nevertheless on this account have liked to put off its introduction till sixty towns had been completed by the Board, by which time the Institute of Civil Engineers would be in full retreat and the danger of local blundering, as at Croydon, would be greatly diminished. By the middle of 1853, however, a number of successful examples of the new works were in operation, and he consented, not without misgivings that the step was being taken prematurely, to a draft clause making it illegal for the Board to appoint an Inspector otherwise than at a fixed yearly salary. By this time the damage had been done, and the idea had become fixed in some influential heads that the Board of Health was an arrangement for the benefit of Chadwick's protégés. It afforded excellent material for Lord Seymour in the momentous debates which decided Chadwick's fate. 


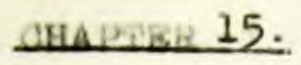

THE LOCAL BOARDS.

The constitution of the Local Boards was laid down in the schedules attached to the Confiring Acts and Orders in Council of the General Board, to whose discretion the Public Health Act had left the decision as to the size of the new local authorities and the property qualifications of their members. The schedules were short and followed a simple, unvarying pattern. The Local Board was to consist of a certain number, one-third of whom were to retire each year lhey must be resident, and be possessed of real or personal estate, or both, to a certain minimu value, or rated to the relief of the poor of some parish, township or place within the district upon a 1. Confirmins Acts ("Public Health Supplemental Acts"): 1849: 12 b 13 Vic. cap. 94, 1 August: 15 places. 1350: 15 \& 14 Vic. cap. 32, 15 July (9); cap. 90, 14 August (6); cap. 108, 15 August (16): total, 31 places.

1851: 14 : 15 Vic. cap. 80, 7 August (1); cap. 93, 7 August (13); cap. 103, 8 August (6): total, 25 places.

1852: 15 \& 16 Vic., cap. 42, 30 June (7); cap. 69, 30 June (8): total, 15 places.

1853: 16 Vic. cap. 24, 9 May (7); cap. 126, 20 August (3); total, 10 places.

1854: 17 \& 18 Vic. cap. 53, 31 July: 6 places.

Orders in Council (see "London Gazette"): -

1349: 5 September (6); 6 October (3): total, 9 places.

1350: 3 January (5); 30 January (5); 9 March (4); 19 June

(6); 13 July (6); 15 July (2); 14 August (1); 24

September (4); 19 November (1); 3 December (1); 12

December (1); total, 36 places.

1851: 11 Feoruary (3); 14 April (3); 5 lay (4); 25 June

(2); 7 August (4); 23 October (3); 26 December (1): total, 20 places.

1852: 10 Samuary (1); 2 February (1); 5 April (1); 15 llay (1); 18 August (1); 16 October (1); 2 ? November (1): total, 7 places.

1853: ? Bebruary (2); 21 February (4); 1 April (1); 13 June (1): B August (1); 25 November (1); 29 December (1): total, 11 places.

1854: 7 April (2): 8 June (2): 3 July (3): total, 7 places. 
certain annual value. The date of the first election was fixed; and its conduct entrusted to some leading citizen, the Chairman of the Board of Guardians, the Union Clerk, the Vicar, the Lord of the Manor, a Justice of the Peace, a solicitor, or a banker. The result was inevitably, as Chadvick described it, "the Local Government of a Class", and "that Class the well to do class"." (1) In 29 out of 78 places to which the Act was applied by Order in Council, the property qualirication was put at 21,000 ; in 3 places at from 2600 to 2300 ; in 31 at 2500 ; in 12 at 2300 or 2400 ; and in 3 only at less than 2300 , the lowest figure being 2200 . The alternative rating qualification tells the same story. In 50 places out of the 78 it ranged from $\$ 20$ to $\$ 30$ per annua; in a further 24 from 810 to 220 ; and in 4 places only was it less than $\$ 10$.

From the same group of places may also be illustrated the trend of the Board's policy in fixing the size of the Local Board. In 56 places the number was put at 9 ; in a further 18 at 12; in 2 the number fell to 6 , in another 2 it rose to 15 . The figures for the Provisional Orders give a similar picture, though here a few of the Boards were given 18 menbers. When the Vestry Comittee of Brighton asked for a Local Board of 42, the General Board opposed the demand with vigour. Their Pigure was 24, but they expressed their willingness to compromise on 30. The apprehension was groundless, they declared, that 30 was an inadequate number to supply committees. In large Boards responsibility was weakened and business impeded by irrelevant discussion and irregular attendance. (2) A compact sanitary executive of 9 or 12 members, with the sound views of men of substance; elected on a property franchise by plural voting; holding power for a limited term of three years -.- this was the aim of the Board's policy in the localities.

Once a Local Board had been constituted, however, the - 0 -

1. E.C. - I. P., 24 March 1848.

2. Minutes, 15 and 17 April 1352. 
menbers elected to it might well be adverse to the operation of the Act. They might be of the humour of the Local Board at Mileham, who declared that they "do not consider any Plans or Maps whatever will be required for the proper drainage of the District". (1) An unwilling Board might even commit suicide; the Bromyard Local Board, for example, who "not havins elected a Chairman, held a meeting, or taken any other step in execution of the Act, and more than three months having elapsed since the election all the members of the Board have become disqualified and the Act has become a dead letter". (2) At selby the opponents of the measure used bribery and corruption to get themselves elected to the Board, and then promptiy passed a resolution announcing their intention to prevent the construction of the combined works to which the General Board had given its approval, following this action by reducing the salary of the surveyor from 2150 to 275. (3) Sanitary powers might for years fust unused, until a more progressive Board were put in office. Thus, at Sheerness the Local Board fell under the dominance of an adverse majority shortly after its establishment, and for three years after it had passed under the Public Health Act the town, which as a naval dockyard had close relations with the central government, remained in its state of abject squalor. (4) There was some sharp comnent about the delay in the "Times", and Chadwick wrote in defence of the General Board: "A local Board is often several years in making up its mind; it then sends in its plans for exanination in a hurry; -- often essentially imperfect. We have only one engineer available for the service of exacination, who is worked night and day, and some weeks delay occurs, --- as in a private, over worked professional office: -.- but the years of delay are laid to the door of the General Board". (5)
1. Minutes, 26 October 1850.
2. ibid., 13 May 1853.
3. ibid., 13 and 29 April 1853.
4. W.F.A. Delane - E.C.. 11 June 1853.
5. B.C. - W.F.A. Delane, 9 June 1853. 
There wre complaints --- from Fareham, Epsom, Castleford, and Worcester, for example(1) of the stupor and inefficiency of the local Boards. The General Board could only reply that they had no power to compel the local authorities to carry out the requirements of the Act. When the Godmanchester Town Clerk reported that the Corporation, in accordance with the wishes of the inhabitants expressed at a public meeting, had determined not to put the provisions of the Act into force, the Board had no answer but to point out that they were thus violating an Act of Parliament. (2) The three reformers early decided "that they would not press the Act, because under the existing state of the law, it appears to them to be of no use to call into existence an administrative machinery or to impose responsibilities where there is no adequate authority, no efficient support, of means for public prosecution: and where the subject has no means to enforce them". (3) When so much of the sanitary legislation was discretionary, it was little use, they felt, waving a writ of mandamus over the heads of recalcitrant authorities. In a few of the more flagrant instances of neglect they considered recourse to the remedies of the Common Law. In a Minute of December 7th 1853, for example, they "took into consideration the question of misfeasance, malfeasance and non feasance of the Local Board of Health of Luton in relation to the recent loss of 1ife by epidemic cholera in that place, where it appears from the report of Mr. Lee that many of the population have been affected with Asiatic Cholera and a number of persons have been killed and much misery occasioned by causes which with a due execution of the law were preventible". It was an indictable nuisance under the Common Law to prevent the free pasaage of air, to corrupt the public water supply, or to divide a messuage in such a way that it became dangerous in time of infection.
1. Minutes, 17 January 1850, 28 June 1851, 7 April 1853, 8 October 1853 .
2. Ib1d., 14 November 1851.
3. WS fragment, a.d. 
Homicide by "unlawful omission" might be committed by anyone who neglected a legal obligation to apply food, clothing, or other necessaries required to sustain life or prevent injury. Now it was one duty of Local Boards to cause such sewers to be made as might be necessary for the purposes of the Public Health Act -- and that duty was no discretionary but compulsory. They could therefore be held liable to penal consequences for the imperfect discharge or unlawful omission of this obligation. In the opinion of the General Board, it might be proved by medical testimony thatilf the Luton Board had exercised due diligence in performing their duty a large proportion, if not the whole, of the disease and loss of life might have been prevented, and that other lives were still jeopardised by the continuance of the like neglect. It was no legal or moral defence against this charge that the Iuton Board had only obeyed the instructions of their constituents; a majority could not dispense with Acts of Parliament -- and, in any event, the ratepayers were not the majority of the inhabitants. "The lesson held forth to the class amongst whom the victims to the neglect occurred is that whilst offences against another class and against property as in the case of the firing of houses or the Bristol riots are punished with severity, offences by which disease and death are spread broadcast among the poor and unrepresented classes, and that too not upon any sudden excitement but wilfully with aforethought and deliberation, go unpunished". Corporate bodies, the Borrd concluded, were personally responsible for deeds done in a corporate capacity.

But no swift punitive action followed this homily.

The Board could only observe that the futon case illustrated the need of greater security for unprotected populations, and then resolve that the facts should be laid before Lord Palmerston with a view to prosecution by the Law Officers. (1) Drainage and water supply, however, were not subjects in which the 1. Minutes, 7 December 1853 . 
Government felt that its prestige was involved, and, even in the midst of an epidemic, the Law Officers of the Crown regarded the struggles of the Board of Health with a detachment which reflected the lack of interest of the ruling classes.

Only half a dozen clauses of the Public Health Act gave the Board any real measure of control over the local authorities. of their creation. Their consent was needed for the

establishment of pleasure frounds, and for the closing of an old burial ground or the opening of a new. (1) appeals of parties who believed themselves aggrieved by the Private Improvement rates imposed by the Local Board. (2) But their chief power was the sanctiohing of mortgages on local rates to supply the funds for works under the Public Health Act. (3)

Here was the instrument by which Chadwick hoped to control the financing and planning of the new sanitary works. Before the Board would consider the sanctioning of a mortgage, they insisted on seeing a complete survey of the district, together with plans and estimates of the proposed works, and details of the charges to be laid on the ratepayers. If the works were too extravagant, or were designed on the old principles, or did not combine drainage and water supply under one administration; if the rates were not calculated according to Chadwick's principle that the charges should be spread over a period coextensive with the benefits derived from the works -.. then Austin, who acted as the Board's referee on engineering questions, invariably reported against the approval of the mortgage. (4) Thus, when the Local Board of Eton requested 1. 11 \& 12 Vict. c. 63, secs. $74,82,83$

2. ibid., sec. 120. 3. Ibid., sec. 119.

4. Minutes, 6 February 1851, 31 March 1852. Ci. "Report on ..... Tuisances Removal and Diseases Prevention Act", 1849, p. 62:

"For the security then of the several interests involved, namely, for the security of absentees and reversioners, for the protection of minorities, for the prevention of the failure of the objects of the legislatube by such unskilful, inefficient, or extravagantly expensive works as have been (Continued on next page) 
permission in April 1350 to raise a loan of 21,000, the General Board withheld their approval until plans, estimates, and particulars of the works were furnished ${ }^{(1)}$; and in February 1852 they refused to sanction a plan for the drainage of Leicester for which a 235,000 loan was wanted, condemning "its imperfect, wasteful, and inefficient character". (2)

In addition to this measure of control over the public loans of the local authorities, 3 the Board had certain powers with respect to the officials appointed under the Act. The surveyor could not be dismissed without their consent, and their approval was necessary to both the appointment and the removal of the medical officer of health. (4) The intention was to

(Continued from previous page) displayed by recent local examinations, and acting under a sense of the responsible relations above set forth, we propose to adopt as a principle to sanction the mortgage of rates, and the distribution of charges only on conditions such as the following: -

First. That plans and estimates have been prepared in detail, and submitted for examination to an Inspector.

(a) And upon his Report found to be deserving of approval;

(b) As being of a nature to last, and of advantage equal to the value of the improvement rate during the period of years over whein the charge is distributed.

Secondly. That the woriks shall be executed upon contracts, on the following conditions:

(a) That before they are covered up, or put in operation they shall be examined by the Inspector.

(b) That they shall be further examined by $\mathrm{him}$ when in action, and be certified by him, to be in conformity to the plans and specifications, and to be of fair probable value, to justify the future annual improvement rates.

(c) That they shall be maintained in good action by the contractor for a term of not less than five years".

1. Minutes, 25 April 1350. 2. ibid., 12 February 1852

3. They continualiy bemoaned the limitations of this, their most salutary power. They could not, for example, prevent the raising of money for a Local Act, despite their objection on principle to such a procedure. Thus, they sanctioned 24,000 for a Local Act for Bilston, "which the Board regret that they cannot withbold under the terms of the Act, though they wish to record their sense of the impropriety and gross extravagance of such expenditure". (Ninuters vica. May. 63,1 secs. 37, 40. 
interpose a shield of impartisl aad distant authority between these officers and the interested animosities which might secure a dominating position on the Local Board. As Austin told Chadwick of the surveyor at Hull: "Te is doing his work well and with energy, but he has had much to contend with. He told me that if it had not been for the protecting clause in the Act, he could not have kept his place for six months, that without it, his position would have been unbearable, and that he would not have remalned for a thousand a year. It is certainly so with all the best men we have". (1) But despite the safeguard against removal, the officers remalned the creatures of the men who paid their salaries and fixed the conditions of their service. There was an iliuminatiag clash with the Local Board of Clitheroe on the issue. On Warch 20 th 1852 the General Board wre informed that the Clitheroe survejor had been dismissed "in consequence of the determined opposition by a large and overwhelming majority of ratepayer, property owners and other persons interested, to the further application of the provisions of the Public Health Act, and the utter impossibility or executing its provisions and duties under present circuastances". The Board replied that as they "have no power to release the local Board from their legal obligation to carry out the Public Health Act in the best way they can, they cannot legally sancition the dismissal of a Surveyor where no other reason is alleged for it than the inability of the local Board to fulfil their auties under the Act". (2) Nevertheless, although threatened by a writ of mandasus, the clitheroe authorities resolved not to carry out the Act. (3) The survejor, backed by the General Board, stuak to his post,(4) whereupon the Clitheroe Board reduced his salary to 25 shilling per annum, and he was obliged to resign.(5) $-0-$

1. Austin - E.C., 16 April 1853.

2. Minutes, 20 March 1352.

3. ibid., 3 May 1852.

4. ibid., 2 December 1852.

5. ibid., 14 March, 4 April 1853. 
Any Local Board which embarked on a scheme of public works must needs appoint a surveyor; but the necessity for an officer of health was less keenly felt, and the parsimony and short-sigbtedness of the local authorities prompted most of them to dispense with this appointment. The difficulties in the way of creating a permanent paid medical service were clearly illustrated when Bilston asked the Board to sanction the appointment of an offlcer of health -.. at $\$ 20$ a jear. (1) When the Local Board of Southampton expressed the view that it was not desirable that their officer of health should abstain from private practice, they were ilmly told that his public duties were incompatible with the demands which such private practice would make upon $\mathrm{his}$ time. (2) But what answer could be returned to the medicsl officer of Darlington, who stated that he did not intend to relinquish his private practice, since his salary was only tweaty guineas per annum? (3) The Board's solution, contained in a letter circulated to the local authorities, was to suggest that, where any district was too small for the payment of a properly qualified officer of health, the best plan would be "to appoint one person to act for several adjoining towns". (4) It was not t111 1872 that the appointment of a Medical Officer of Health and an Inspector of Nuisances was made oblizatory on the district boards; the following year grants were offered covering half the salaries of sanitary officers deamed satisfactory oy the Local Governnent Board; and their security of tenure was eventually secured by the Sanitary Officers Order of 1910 and the Pulic Health (officers) Act of 1921. It had taken two generations, since that iirst sketch in the "Sanitary Report", for Chadwick's conception of the nature and duties of an officer of health to realise itself in administrative practice.

1. Minutes, 26 December 1850 .

2. ibid., 14 Novemebr 1850.

3. ibid., I January 1851.

4. Austin (forwarding Minutes of Information as to the duties and powers of Loesl Boards under the Public kealth Act), 9 October 185. 
When Chadwick began his sanitary investigations in 1842 , hardly a town in the kingdom had a publicly owned water supply, and few voices were raised against the dominant faith in profit and private enterprise. His reports had played a decisive part in develpping among local authorities the self-confidence to take public utilities such as water and gas into their own hands. We have seen, however, that in the period from 1842 to 1848, Chadwick oscillated between advocacy of municipal trading and of large-scale private enterprise under Parliamentary regulation. The "Sanitary Report" and the Health of Towns Commission had been largely an inquest on the shortcomings of parochial and municipal bodies. In the first flush of the Towns Improvement Company, and despairing of action from a thankless and unenlightened Government, Chadwick had laid it down as a principle that commercial agencies were the only hope for sanitary reform. Much had happened to change that opinion. The golden prospects of the sewage manure project had faded. His railway inquiries had shattered the myth of capitalist efficiency, and contact with cemetery and water companies had shown him that to look to profit-making corporations to plan for the public interest was like putting the flock in the care of the wolf.

The complete shifting of his ground was admitted and defended when the Board summed up their experience in their final report in 1854. The failures pointed out in the Health of Towns Report, they stated, had justified the presumption that the local authorities were incompetent to provide water supplies; but the subsequent examination of trading companies had revealed no superiority in efficiency, economy, or management. Water companies usually limited their service to Rouses belonging to the upper and middle classes, and were obliged to recoup themselves by increased rates on the restricted number of their customers. Experience under the 
Publ1c Health Act, however, had proved that an early and general extension of woriks to the whole population of towns was both necessary and practicable. Locol authorities could supply the poor for 1\%d. a week, and at the same time avold the risks and losses of a trading body. Moreover, the wary capitalist rarely undertook the construction of works for complex objects, such as combined works for drainoge, water supply, and sewage disposal. "If an unprejudiced examination of the new works be made", concluded the Board, "notwithstanding the imperfections that may yet a.tiach to them, they w111 be found to exonerate municipal corporations and local administrative bosids from the charge of incapacity made against them; to have improved the security for good local adrinistration, and to demonstrete that such worics may be obtained isore offloiently and cheaply, including the proportion of establishment charges, under local public management, by payment for common and respongible service, than by the notive of a trading profit to be levied on individual necessitiea". (1)

Throughout its brief l1fe, inerefore, the soard of Health encouraged local Boards to take pubilc utilities into their own hands, ousting, forestalilag, or conbatiag as aecessary the agents of private enterprise. At Garlisle, for exuaple, Rawlinson recommended that tie water compang should be taken over by the Corporation. Though a corpany was as capable as any public body of constructing epflcient works, it could never have the same motives and interest to urge a general use of water for purely public objects, such as surface washing and as a means of ventilation in crowded streets; nor could they possibly have the same means at their dispusal to accomplish these purposes. (2) When a Reading deputation asked the Board whether they should oppose the Bill thea before Parliament for extending the capital and powers of the water company, the Board agreed that it was contrary to public policy to allow the 1. PP. $24-6$, P. . $1854,-0 \times x \times 1$. 2. Seport on Carlisle, pp. $79-80$ (June 1850). 
introduction of new capital by a trading company. "It was the duty of the Local Board to oppose the introduction of such new capital, and so to keep themselves free for the choice of any improved source of water supply for their district". (1) In Warch 1854, in an interview with the Clerk of the Local Board of Hull, the General Board promised their support to a Bill which aimed at consolidating the Local Board's control over the gas works and the cenetery, both of which were in the hands of trading companies. (2) A week later they declared their inbention to support a motion that a water Works Bill for Southport should be postponed, in order to sive the Local Board time to prepare a scheme which would put the gupply under their own management. (3)

Chadaick's original intention had been that the Troviblonal Orders should in epfect be local Auts, iramed to cover, not only the narrowly interpreted objects of a sanitary heasure, but also such other uatters of local administration as paving, lighting, aariets snd roads. In the first of the Coaflrming Acts (hugust 1 449 ) he succeeded in inserting a clause which ompowered Local bourds to enter lnto contracts for the supply of gas or ofl or other taeans of lighting, and to provide lanps, larap posts, and other raterials and apparatus as aecessary. (4) But the scrutiny of the larilaneatary critics was too keen, and objection was promptily roiced to the introduction of tisese supplenentary clauses. The absence of provistons of this nature was one reason why in some places, Jewcastle and Birdinghai Por example, a Local het was preferred to the simpler and cheaper procedure by rovisional order. the Board regarded it as owe of their most iaportant duties to send their experts beiore tne pivate Bill cowattees to oppose such Bilis in principle or in detail. Twice they succeeded 1. Minutes, 13 February 1851 .

2. ibid., Io Warch 1854 .

3. fuid., 18 March 1854.

4. 12 is Vic. cap. 94 sec. vili. 
In defeating a Local Aet, and In others they secured the insertion of the nortjage clause; but they failed in other attempts because they lacked the means to bring up witnesses, and the hac had no recognised locus standi belore the Comittoes. (1)

The inmense output of instructional pamphlets from the Stationery Office of today would have delighted Chadwick. Throughout his official career he was engaged in cutting channels for the regular flow of information from the localities to the central departments, and thence, digested, tabulated, - $0-$

1. As a notable example, see the Minute of 9 March 1849 on the bill for the water supply of uacclesfield:

"The scleme appears to be on the old systea, which has been decided by the Health of Monns Comittee az well as by the result of inquiries under the Public Health Act to be inadequate and unsuitable for the purposes of the Inhabitants, even supposing the quality of tho water and the source of the supply to have been carefully tested, and found to be unexcepilonable". The binute then proceeds to criticise the 8111 in detail. (1) "The corporation can scarcely have considered the necessities of the poorer classes of tenements, of fadeed of any class, when they proposed to raise capital on a scheme founded on the system of intermittent supply". (2) No security was provided for the economical laying of the pipes, on which half the capital would be spent. (3) ihe whole of the inmediate outlay would fall on the owners and occupiers, the effect being "to iapede the extension of the supply to the middle class of houses, and to act as an entire prohibition to a large proportion of the poorer class". (4) Baths were to be a separate charge, which would act as "an extensive tax on the commity" and a great "discouragement to one of the most important aids to the health of the comminity".

The Board furuished evidence in March 1851 on the defective provisions of the rexham Local Bill (Minutes, 7 March 1351). The proinoters attempted to reach an agreetent with the Board, declaring their williagness to incorporate the mortgrge clause into their Bill. The Board, however, expressed their deternination to apply the Public Health Act by Provisional Order, and so "secure to irexham the means of self-government in matters of health and cleanliness, at a cost probably of little more than onetenth the expense of a private ct $^{\prime \prime}$ (1nutes, 22 October 1351). 
and illuminated by a wider experience and a deeper science, back again to the local authoritles. As he always insisted, even if the powers of the Board of Heslth had been greater, he would at 111 have preferred to proceed, whatever the extra labour, by persuasion and on full exposition of the reasons.

For the guidance of the Lnexperienced Local Boards the body of sanitaxy doctrine which Chadwick had built up on the results of his ten years of investigution was seb out in three instructional panphlets -... on houge drainage, land arainage, and the application of sewage ranure. (1) In the first of these they were told that their priary duty was the removal of all cesspools $2 x 0 m$ anidst babitations, and their replacenent by waver-closets and tubular druinage; und for their information diagrams and descriptions nexe Given of the inproved woriss which were graciualiy colaing into usc, such as screw-jolntis for earthenware pipes, moveable dust bins, and a siapleb form of water-closet with a syphon trap and a stuneware pottery pan. bibi a compleve systeis of combined woxiss of water supply and tubular house-dcuins, coanected with properly adjusted branch and aa in sewers, there vas so exception to tise rule that refuse need not be pernitted to remain underneath or noar houses, beneatn streets or near tho sitos of towas. $21 \mathrm{~h}$ might be in a constant state of lapifocitive aded entire pesoval at a rate of about hisec miles an hour, and in a current of sich velocity that no deposit could be left to accumalate. In the second. sec of instructional fiutes the Ceneral soaxd iaformed the local authorities that the should not confine their attention 1. (1) "Minutes of information collected in respect to the drainage of the lands forming the sites of towns, to road drainage, and the facilitation of the drainage of suburban lands". P.P. 1852 (1471), xix. 1.

(2) "Minutes of information collected with reference to works for the removal of soil water, or drainage of dwelling-houses and public edifices, and for the sewerage and cleansing of the sites of towns". 1852 (1535), xix.307. (3) "Minutes of information collected on the practical application of sewer water and town wanures to agricultural production". 1352 (1472), xix. 133. 
to the drainage of houses and streets. She removal of excess moisture from the site on which the town was built, Irom the roads which connected it with other places, and from the lands which Iringed its suburbs, was equaliy a matier of concern to the sanitary econorist. Chadwick recalled how a iondon medical offleer had once taken him to an elevated Bpot overluoking his parish. "Those mists", he had said, pointine, "exactiy mark out and cover the seats of disease for which iny attendance i.s requirea. Beyond those nists I have rarely any cases to attend to but midwifery cases and accidents" (1) Catarch, rheumatisa, scrofula, rould all be decreased by as energetic policy of land drainage. Horeover, the velue of the land would bs enhanced. Heath and moorland, formerly dear at 5/- an acre, had been sold for $30 /-$ or 2.2 when thorough-drained, and clsyeg soils had risen in value from $1 / 6$ to $x ;$ or 24 an acre.

The trilogy of instructional pamphlets was cotpleted by the Minutes on Sewage manure, which assured focal Boards that for ar outiay of $6 /$ - un acre antually for piping the liquid sewage to the fields the fertility of three or four additional larms could be put upon one. Hitherto the English farmer had regarded as manure only that which he could raise with a fork: souber or later, however, he would consider that only sas regular manure which be night apply with a scoop. The local bosrds must regard themselves as trustees for the inhabitants collectively in the rasagerent of this valusible public property, waich could not properiy ve made the subject of permenent saleable or hericaole or veated and proprietary rights.

As one fat Report followed anotber, and fyydr House put out its inutes of Information and its sheaves of model byelaws, it was whispered that the printer to the Board had a very lucrative business. The tracts were exceilent, wrote J. McCulloch from the Stationery office, but wby were they distributed free? "I believe il you were bere", Chadwick. replied, "you would vote for dojng more rather than less in the 1. Minutes on laad orainage, p. l. 
way of the distribution of information to the Local Boards. We have been admonished by the highest authorities that we must "conciliate public opinion": indeed without that admonition we feel we must do so. We have very little power, and in these times it is difficult to exercise any power, and after all, it is better to proceed by the influence of instructions where we can. In consequence of the instructions five towns have agreed to work for the distribution of sewer manure, and we expect that by August they will be seen pumping it on the fields; five or six more are on their way to new works: and several have we are told been stopped erecting bad works by the information. If we can get this system in complete operation in a few towns, it will be worth I apprehend, not only the whole expense of the printing ten times over but the whole expense of the Commissi n: (1)

It was not the first time that he had clashed with the Stationery office. In 1849 ieCulloch proposed to the Ireasury, "for the sake of economy", that all reports and papers should be printed in folio. Prima racie, Chadwick at once objected, it was improbable that follo was cheaper than octavo; and to support his point he made inquiries which revealed that octavo editions could be produced for 24 per cent. less, and that if the whole of the Parliamentary printing were put in the convenient form adopted by all the world except Her Majesty's Stationery office, some $\$ 24,000$ a year might be saved on an ennual bill of 8200,000 . Nor was this the most important aspect of the question. "Bither the objects of the Board must be attained by the naked exercise of power, -- in which case it must have additional force of officers, which would be expensive, or it must act by persuasion, that is to say by the exposition of facts, and their influence on opinion". (2) To 1. E.C. - J.R. MeCulloch, 24 February 1852. "In my view it is an essential function of any competent central authority, that it should from its wide means of observation carefully collect and disteribute such information for the use of local boards". ("Economies of Sanitary Works", MS, n.d.). 2. "Administrative. Relations of the General Board of Realth with the rreasury. Winutes for a paper on", $\mathbb{M}, \mathbf{n} . \mathrm{d}$. 
the latter course printing in follo would be fatal, since, as the printers confessed, 3,000 copies in folion would not be as much read as 1,000 in octavo. In May 1849 there was a sharp correspondence between Chadwick and McCulloch, "a battle of books between offlcial follos and official octavos, between big and litile blue books". (1) Chadwick, seeking allies, wrote to remind Lord Brougham that he was the father of the practice of printing in octavo those official reports which were seriously intended to be read. "You will concur that the accessibility of legislative reports, the efficiency of legislative labour, the means of the diffusion of this branch of useful knowledge, is not a small subject". The Poor Iaw Report of 1834, and the extracts from the evidence of the Assistant Comissioners, had been the first official papers to be printed and circulated in octavo. The follo editions of those reports were now in the warehouse or had been disposed of as waste paper; of the smaller edition nine or ten thousend copies had been distributed gratuitously to the parishes and a further fifteen thousand had been sold. (2)

In 1851 and 1852 Henry Austin, relieved of his anxieties as Bngineering Secretary, was sent out as an emissary of Gwydyr House to make personal contact with the Local Bourds. From time to time he reported to headquarters his impressions of his tour. At Derby, where no plan of the town drainage had previously existed, he found the Local Board actively engaged on improvement measures, and delighted with the increased powers derived from the Public Health Act. (3) At Norwich, however, they were"fencing with the question of the Survey". (4) His intervention at $\mathrm{BIJ}$, where a majority of the Board had been hostile, cleared up a number of misconcetions and greatly

1. B.C. - ?, 1 June 1849.

2. E.C. - Lord Brougham, June 1849.

3. Minutes, 12 July 1852 .

4. H. Austin - E.C., 28 February 1852. 


\section{5}

helped the progress of the drainage schere. too, his assistance was welcomed.

"It is rather a melancholy case", he wrote Prom Towyn. "I have seen nothing out of Ireland, bearing the same deplorable appearance, or in an equally bad condition.

Nearly the whole of the property is in the hands of Trustees for a Minor and is managed by an Agent, who, in opposing all improvements, forced the inhabitants to take refuge under the Public Health Act.

The place is however far too small to support the Machinery of the Act, and is precisely one of those for which other provisions are urgently required.

There are only about 150 houses in the town, and nine tenths of those are under 25 rateable value. I need scarcely say that there is not a drain in the place, scarceig the luxury of a cesspool, soil and refuse of everg description strewing every spot, nearly, except the main street. There are two places from which the whole population has to fetch water. Accompanying this state of things is a corresponding condition of ignorance how to remedy it -- although the Board, impressed with the macnitude of the evil, are most anxious to do so. Clark, unfortunately, not considering the character of the place, had recommended a scheme of drainege and water supply which would cost more than double the amount actually required for suitable works, and more than double indeed, the whole sum which they would be empowered to borrow -- and therefore they had deternined at last upon a defective scheme of pautial drainage without water supply.

They expressed therselves very gratefully towards the General Board for sending me to them, and were most thankful for the advice given. They will proceed at once to get out a plan of complete works, and as an example of economy and of the amount of improvement which may be effected for the money 1. İ. Austin - E.C., 28 Febtuary 1852 
belleve it will be a curiosity". (1)

"Brynmawr", he wrote a few weeks later, "has been to me the most satisfactory case I have yet visited. It is a wretched place wholly dependent upon the iron works there. The mortality is frightfully high, but I was assured that they would do nothing but carry out a most objectionable plan of drainage for which they had applied to the General Board to sarction a mortgage of $\mathrm{S1}, 500$-- which $1 \mathrm{f}$ not granted, they intended to levy at once by rates. It certainly did appear a bopeless case, and the more so because they had actually entered into contracts and had commenced the works. I an happy to say however that I was enabled to induce them to stop the works and give up the contract, and begin de novo to lay out a proper plan of drainage and water supply, for which they w11l apply to the Board for a mortgage of between 24,000 and 25,000 . It will be the more important case as an example to the large populated districts here engaged for miles around on the iron works -all of the same miserable kind.

Inexperienced Local Boards, strugbling with their novel duties, received with thanxfulness the instructional Minutes of the Board of Health and the advice of their Inspectors. At more than one place votes of thanks were passed or grateful letters addressed to Gwydyr House. The arguments of Toulmin Smith here fell on unbelieving ears. The application of the Act had not deprived them of local self-government, declared a report of the Worthing Sanitary Committee; for their former Comissioners beld office for life, while one-third of the local Board nust retire every year, and no member could remain in office more than three years without re-election. As for the necessity of seeking the General Board's sanction to local achemes, "we look upon this restriction as affordinis the very best possible protection to the ratepayers against having their money fooled away upon useless works". The Local Act under

1. H. Austin - E.C., 7 October 1352.

2. H. Austin - E.C., 18 Uctober 1852. 
which the district had been governed hitherto had been quite inadequate, since it gave no power to provide a supply of water, while such powers as it did confer upon the Commissioners could not be used until they had liquidated their debt. (1)

From Ormsirir came an account of the benefits which had resulted from the application of the Public Fealth Act to the town in 1850, an account which wight have been paralleled in a score of other places:

"The population of the Town is 6,200, of whom one thixd at least are Irish, and the majority of the Inhabitants are poor Cottagers, crowded in Courts and Yards at the back of the principal Streets.

Previous to the Act, no Sewerage works of any moment existed, nor vas thexts any supply of Water. The Lodging Houses, especially those frequented by Irish labourers, were crowded to excess: iever was seidom absent from certain quarters of the lown, and a high rate of mortality existed.

Bince the introduction of the Act a complete system of Sewerage and o $\vec{i}$ Water Suppiy has been effected, for which we are largely indebted to the valuable services of dir. kawlinson. The works have boea in full operation since the sumer of 1853 , and alroady, out of an aggrogate amount anount of 1,000 dwelling houses, 700 are thoroughly drained and supplied wibh hater, and it is worthy of renark that although in the onset a strong opposition was expressed agalnst the Act, yei, in consequence of the mind of the Inhabitants becoming reconciled to its establishment, the private Works have with few exceptions been carried out voluntarily, and with hearty good will. Cottagers are furnished with an unlimited supply of bood water at the rate of 1d. per Week. A more efficient supervision of the Lodging Houses had been obtained, of which there are 120 in the registry without entering into the experience of other Towns, I am enabled to speak in behalf of myself and Colleagues (who 1. "Report to Sanitary Committee, Worthing", by H.F. Dennett; pp. 4, 5, 7. 
have done me the honour of electing me their Chairman since the introduction of the Act) that we have met with no undue interference from the General Board of Health, nor have we any accusations to bring against that body, of arbitrary treatment: on the contrary, our communications have been uniformly received with a spirit of fairness, and from the advice and co-operation afforded, a more efficient scheme of Woriks has been executed then otherwise would have been, had we been left to our own resources. Were we called upon to give evidence, our testimony would be unanimous, that in our case, the Public Eealth Act has proved to be a wise, salutary, useful, and benevolent provision of the Legislature". (1)

Quiet progress such as this, however, attracted less attention in the press and House of commons than the noisy resistance of some half dozen of the Local Boards; and the steady improvement of conditions, the cumulative effect of which must be awaited with patience over a long period, caught the eye less arrestingly than $\alpha$ sudden and startiling catstrophe, such as the Croydon epidenic of 1852.

The outbreak at Croydon in the last montbs of 1852 was one of the earliest end most striking examples of a phenomenon which was to occur from time to time during the latter half of the century in the new residentiel districts of the growing towns, and which brought perplexity to sanitary reformers despite the stoutness of their confidence - an explosion of enteric following the introduction of the new sewerage which it was claimed would put an end to the causes of zymotic disease. Croydon had been brought under the Public Bealth Act in August 1349, and by Decamber 1351 combined works of liningese and water supply had been completed in the greater part of the town.

I. J.A. Kershaw - Lord ? (Palmerston), 20 July 1854. This was one of the testimonials received by the General Board at the time of the debates in 1354 which decided their fate. For other references, see Chapter 18. 
Typhoid was apparently 1mported in September 1852, on the person of a villager from Oxted, twelve miles distant, where an epidemic was already raging. It spread along the lines of the new sewers, which, as Budd later explained in his classic thesis, acted as an extension of the diseased intestine of the typhoid sufferer; and, filtering through the cracks and leaks of a most defective pipe system, it contaminated the water supply. In a population of 16,000 , there were by December 18521,800 cases of fever with a mortality of about 60 , and numerous cases of diarrhoea and dysentery with a mortality of about 10.

Croydou was, though lis respectable and well-housed citizens could not credit it, one of the most unberlthy places in the county. But the town had experiencea nothing so dramatic as this epidemic of typhoid; an epidemic, moreover, which attacked chlefly members of the midale and upper classes, who had been the first to benefit from the new drainage and water system. It was noted that all the cases had occurred during and since the execution of the now works, and people reminded each other of the nuisance when the Local Board filled in the cesspools and open ditches throughout the town, so disturbing earth saturated with the accunulated filth of years. The outbreak, it was promptly alleged, must be due to the new pipe sewerg and the activities of the Iocal Board.

The Board's Investigators, Southwood Smith, Sutherland, Austin, and R. L. Grainger, were already in the field, when they were informed in Jenuary 1853 that the Governint had appointed Dr. Nell Arnott and Thomas Paze, an engineer from the Board of Works, as an independent Comision of Inquiry. The appointment reflected the general suspicion which now attached to the Board's every act, and Chadwick realised at once that at Croydon Cwydyr House and its works vere in the dock. The Croydon Iocal Board, under its vigorous chairman, Cuthbert Johnson, was regarded as one of the most progressive and 
successful of the General Board's satellite authorities. It was 11 ttle aore than a year before that Chadwick and Southwood Srith had attended a pleasant and heartening ceremony at the openting of the combined works. They had watched with benevolent approval as the Archbishop of Canterbury lifted the valve of the great steam engine which pumped water to the high level reservolr; and at a civic dinner in the eveaing Chadwick had gone into his familias, vell-loved statistics, and congratulated the housebolders of croydon on obtaining the benefits of pure spring water and self-cleansing severs for 5kd. a week. (1) It is easy to understand his sanoyunce and anxlety when lieil Arnott, one of his earliest allies, informed him that the report had been obliged "to speak of faults and failures in works which you had hoped were to be deeraed perfect". (2)

Since both the Board and its critics accepted the previling pythogenic theory, the Crogdon investigation developed into $\&$ hunt for stinks and an inquest on some very bad pipe laying. (3) There were some brisk exchanges on the question whether unventilated pipe sewers or brick sewers of deposit were the most 111 smelljwz, but the purity of the water supply, which was really to blame, was asserted by both sides. The investigators, in fact, were looking for the wrong tining and in the wrong place, and most of the points made would be 1. "Times", 13 December $\mathbf{1 8 5 1}$.

2. 11. Arnott - E.C. 27 April 1853.

3. "Reports on an inquiry relative to prevalence of disease at Croydon, and to plan of sewerage". P. P. $1852-53$, xcvi. 35. "Further Reports from Board of Health", ibid., 221. "Statement of preliminary inquiry, etc.", ibia., 117. "Report on state of works of drainage and sewerage, etc. (at Croyaon) by Thomas Wicksteed", 1.854, 2xi. 347. 
ruled out of court by a modern scientific inquiry. However, if the dialectical limitations of the contestants are accepted, the Board had much the better case. Before the introduction of the Public Fealth Act Croydon had been much like scores of other towns, with a cesspool in every garden and a well nearby. Vilely as the works had been carried out by the local contractors, they had reduced the sewer emanations and the potential focj. of disease. Faults in the design and construction of the croydon drains, however, were treated by the Government Comission as faults inherent in the system of tubular drainage, and Page was clearly of the opinion that four-inch and six-inch pipes were too delicate to siand up to the rough domestic habitg of the lower classes. Chadwick in vain urged Arnott to visit Tottenham, fugby, Hitchin, or some other place where such works were in successful operation, so that he might judge for himself whether the blunders comitted at Croydon were unavoidable or not. (1) The Report of Arnott and Page, published in April 1853, indicted the pipe sewers and house drains of croydon, and by implication censured as overtheoretical the engineering plans of the General Board. "Such events occurring in a place like croydor, with an intelligent Local Board of honourable men eager to perform any smount of gratuitous service which promised advantage to their town, and who were near the Central Board in London, for easy conferences, prove the desirable securities for the eficient performance of such woris are not yet possessed and further: show that some of the anticipated advantages of the pipes have not been obtained, and some of the drawback connected with the employment of them had not been foreseen".

Chadwick soent some wonths in preparing, in collaboration with the chairman of the Local Board, a massive counter attack, but his reply to the allegetions of pege and Amott remains in 1. E.C. - N.Arrott, 14 Harch and 26 March 1853 2. P. 7. P.P. $1852-53$, xcvi. 35 . 
wordy and argumentative eragments. For once Shaftesbury refused to follow his trueulent colleague into the battle. Chadwick's report was so strongly personal in tone, he wrote, that "if sent forth as I have before me in M.8.", it "would be absolutely the ruin of the Board". "You, I, and the Doctor, we three, should by our own act and deed, be cast down, bound hand and foot, lato the burning fiery furnace", (1) The Board's best defence was slow to cone; but unanswerable when it came. Iive Jears later the Chairian of the Local Board was able to send Chadwick the quarterly tables of mortality for crojdon with the coment, "You will see that the sanitary condition of the Parish for the year 1857 has been shughlarly good -.. and that instead of our veaths having been 22 per thousand per annum as they have averaged for the nine yearg ending Christmas 1356 , they have only been 15.92 per thuusand pex annuin. And as Dr. Farr in his rables called 17 per thousand per annum the 0 of his scale of Insalubrity we may rejoice dt jeing hius below his Zero ........ As to returning to cesspoois all classes now know what a comfort and advantage it is to be free from the Nuisance of Cesspools and would not return to the systen if ic were possible to evold doing so", (c)

1. Shaftesbury - E.C., 15 October 1853.
2. William Drummond-E.C., 10 Way 1353. 


\section{CHAPTER 16. \\ REACPTON, $1852-1853$.}

It was in 1852 that the current of events turned decisively against the men and principles of Gwydyr House. For over three years the Board of Health had been spreading the doctrine that, in certain spheres, the play of competition should be checked in the interests of society, and that in those spheres enterprise, even if it remained in private bands, should at all events be planned with an eye to economy and the public benefit. Was Chadwick an enemy of private enterprise and free competition? Was he a socialist? Chadwick strenuously defended himself against so terrible a charge. But it was surely possible to retain those principles, to which Bnglish capitalism ascribed its rude health, without falling into the moral and economic quagmire of Laissez faire. When he heard it objected, for example, that "in this country cemeteries like everything else ought to be established by private enterprise, and checked by free competition", he would reply "that the Interments Act goes on the principle of inviting private enterprise and bringing to bear free competition, so far from tending to supersede these wholesome and eminently English principles, the framers of the act only want to bring those principles to bear for instead of against the public interest. For this purpose a district is marked out, and private enterprise is invited to compete ireely by open tenders to perform the requisite service, according to prescribed regulations, with due solemity and greatly improved arrangements, at a scale of charges based on one capital only, and one management, and one set of oficers only". (1) But this $-0-$

1. MS Iragment, a.d. In a letter to Russell, 4 November 1851, (Continued on next page) 


\section{disarming explanation failed to carry conviction to the}

capitalists to whom it was addressed, who saw that 11 they $-0-$

(Continued from previous page) Chadwick was at pains to stress that the method of public contract would leave ample elbowroom for legitimate private enterprise:

"In respect to the Metropolitan Interments Act, the delay and the embarrassment created by acting on views without reference to the evidence on which the measure was adopted by Parliament threatens to be most disastrous.

I hear it stated for example that strong objections are entertained to the Government doing works of the description of any of those in question.

Now it has never been proposed that anything should be done by Government, and most certainly not directly or indirectly by a department occupied or constituted like the Treasury, nor by the General Board of Health, nor by the proposed commission for the works of drainage and water supply in any such sense as implied by the objections.

In respect to the Internents Act, the examples which were cited, those of Paris, and those in which we should to the uttermost act, would be to do as little as possible in detail ourselves and everything by open contract, for the execution of works and arrangements publicly notified and described. The only dealing with details would be to prepare properly for their transference to others by the contract system.

In respect to the drainage and water worics we have been labouring to impress the necessity of having all the works not only executed on contract, but maintained in good working condition on contract for long terms of years. At the Sewers Commission I proposed the construction of a set of tile kilns to make drain tiles but it was to break through a combination of traders who were exacting between two and three hundred per cent. profit, and it was to ascertain and prove at what price the articles really could be made and to obtain data for the better regulation of contracts, and opening up a wide trading corpetition.

The Commission for the betropolitan Works which we proposed would be a comission to direct examinations and reports on works and the preparation of plans, and to advertise competitions for them, and to award the contracts, and afterwards audit or hear public complaints as to their execution. Under the arrangements we proposed the works might be executed by contractors of public eninence such as Messrs. Fox and ienderson, and the Treasury or the Government have as little to do with them, or responsibility, as they have in respect to the works under the Crown Comission for the consolidation of the Wetropolitan Road Trust ......." 
accepted Chadwick's reasoning they could no longer drift passively under the influence of the push and pull of profit, but must put themselves under the dictates of a conscious social purpose. If they could find it possible to breathe the rarefied sanitary atmosphere of Gwydyr House -- if they were prepared to allow their profits to be limited, their budgets scrutinised, their activities regulated, and the minimal standards of their service defined -- the companies might still remain. But if not, if they declined to bind themselves to public service by contract, then their work could be done as well, or better, by civil servants of the Chadwick school or by local authorities tutored by his Inspectors.

The outline of Chadwick's ideal state was becoming clearer: a state where collective utilities, such as water, gas, and means of communication, were owned by the public, though they might be constructed and maintained by contract; where charges were fixed not with an eye to shareholders' dividends, but merely to defray the cost of service; where units of administration were cut to the size calculated to give the best technical and economic results.

Against this conception there seb in during 1852 a powerful and many-sided reaction. It was the reaction of local authorities, wary of re-arrangements of ancient boundaries and of encroachments on their traditional independence; of governing oligarchies, who saw in the extension of the central power an end to their patronage and perquisites; of property owners who reckoned that the fever tax would bear less heavily upon them than the cost of new drains; of engineers whose professional standing and rules of practice were endangered by the Board's Inspectors, and of Parliamentary agents whose fees were threatened by the expeditious procedure of the Provisional order. It was the reaction of commercial companies, who saw in the advance of gas and water socialism an invasion of the sphere of profit, and of manufacturers who found that sanitary regulations would add to their costs and close to them modes of 
working that had been profitable in the past. "There was no end to such kind of legislation", cried one, "and, if persevered in, there might in time, be a Bill to prevent expectoration in the streets". (1) It was the reaction, in a more general sense, of business men whose interests were not directly threatened, but who had more confldence in their own administrative ability than in that of Government with its eighteenth century traditions of aristocratic corruption and leisureliness. Criticlams of the Board's measures were frequently made in terns from the political vocabulary of a passing age, when every officlal was a place holder, and every place a plece of patronage to be dispensed by the Secretary to the Treasury. Not till the introduction of competitive examinations for the Civil Service was the sting taken out of this argunent. All 1. Hansard, vol. 107, p. 195, 11 July 1849 (Foster). A letter from Chadwick to R.A. Slaney, 17 May 1852, describes some of the sources of opposition to the Board: "Let me pray of you when attaciss are made upon the Board that you will not apologise for it: because from your known kindness and zeal for sanitary measures, the smallest admission of fault will from you be deemed equivalent to pleading guilty to a crime. I assure you if you had been with us, and heard the evidence you could have done no other than as we have, and would probably have gone further than we have done. We cannot, in duty, conciliate the interests of the shareholders of bad water Companles, who are spread throughout the public offices: nor can we in duty promote the interests of the shareholders of bankrupt cemetery Companies: nor do other than condemn wasteful worixs which agsravate the evils intended to be remedied: and set our faces against jobs. By the economy of our reports and the provisional orders for the application of the act to provincial towns at one tenth the charge of local Acts, we necessarily rouse the bostility of attorneys and of all the Parliamentary counsel, and of all the Parliamentary agents, and of all the agents of Parliamentary agents, no small body in Parliament: - these bodies, and their hatreds, are powerful, and as steady in their opposition as their interests: - while the public support we set is casual and feeble, and the interests, in the improvement of the physical condition of the population diffused and weak. Unless we have snother pestilence, the sordid interests opposed to improvement will prevail and effective sanitary measures must be left to other times and other men". 
these groups had speciflc and conscious motives for resisting the Board. There were others who shouted with them, whose notives were less explicit, whose hatred of Gwydyr House could hardly be defined In words; who were moved obscurely to oppose to 1 ts hard utilitarianism a sentimental clinging to old ways, and to meet its brisk efficiency with the inertia of comfortloving, "rroxtwe-going" men. Long ago Iord John Russell had warned Chadwick, after reading a memorandum by him on prison dietaries: "There is one thing a.lways to be kept in mind. We

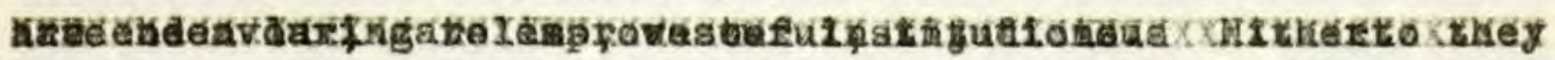
are endeavouring to improve our institutions. Hitherto they have been lax, careless, wasteful, injudicious in an extreme; but the country governed itself, and was blind to its own faults. We are busy in introducing system, method, science, economy, regularity, and discipline. But we must beware not to lose the co-operation of the country. They will not bear a Prussian Minister, to regulate their domestic affairs. So that some fauits must be indulged for the sake of carrying improvement in the mass". (1)

It was by colncidence merely that the attack developed during the brief régime of the Derby Governnent. Whatever party had been in power -- Whiga or Tories, or Radicals for that matter -- the principles of Grydydr House were offensive to them all; and any Government, not stiffened by the courage of conviction which moved Chadwick and shaftesbury and Southwood Smith, would have hesitated to defend a group of men who, through bad fortune and misunderstanding, through the misrepresentations of others and their own faulty judgment, had long overdrawn the credit of public confidence which had been - $0-$

1. Russe11 - E.C., 9 October 1336. 
extended to them under the terrors of an epidemic.

In Gwydyr House there was, indeed, a glear of hope when the I'ories ousted the Whigs. Wood, Fiaycer, and G.C. Lewis raust go. Above all, it meant a change at tike woods and Forests, and surely no new president could show less goodwili and understandiag than the outgoing seyaux. Pertaps, thought Chadwick, the Derby Goverameat could ve perauaded io go into the question of the Treasury's constitutional right to exercise a dispensing power and scrap an Act which parlianent had approved but which the ireasury regarded with disfavour. These hopes were soon disappointed. Lord John Manners, the Board's new chief, though he did not display the rancour of ford Seymour, made it plain that he intended to do no more than carry out the plaas which his predecessor had been arturing.

On April 29th 1352 Shaftesbury moved a resolution in the Lords, "That the sanitary state of the Metropolis requires the immediate interposition of Her Majesty's Government". (1) It was a test notion, designed to draw the lory Government Into the open, to discover if they had any intention of taking action against the reviving Companies. Ihese, or course, were "truisms", replied Derby, when shartesoury had concluded his depressing narrative.

"Now, if it were a tabula rasa that Parliament had to deal with -.- if the vast interests of existiag companies had not to be consulted, which had been found a practical difficulty in the way of all legislation that had been attempted -- he had no doubt it would be better and more efflcacious that there should be one single authority charged with the administration of the water and the removal of all offensive matter, than to 1. Hansard, vol. 120, PP. 1283 - 1298. Derby had refused to consider the original versíon of Shaftesbury's resolution -"ap Address to the Crom, priglng Ber Najesty to take ateps to pernit the metropolis to be no longer excluded from the advantages of the Generel Board of Healtb" -.. on the ground tbat it would have implied that obstacles were being thrown by the covernment in the way of Parliament. 
vest the separate powers of viater supply and sewerage in separate bolies, thereby lobing the unity of action that appertained to a single auttority. But there was great dificultg in deciding what that cestral authority should be. The practice of Continental Coverameats night be quoted; but other Goverwients were wuch lare free to act for the benefit of the populacion than a Governinent subject to popular influences and controi, and which had to siudy not only the lnierests, but the views and feelings, of those for whom they legislated. He did not lispute the advantages of cleanliness, and he agreed with the rost reverend Prelate (Archblshop of Canterbury) that cleanliness and decancy were the handnalds of norality and religion. But it was not by det of Parliament that you could compel people to be moral, decent, of clean; and in many cases legislation to enforce those objects would be opposed by the persons for whose real and permanent laterests they were legislating.

$$
\text { (Shaftesbury: No, no! )"(1) }
$$

In a speech of renarkable frakizess Derby thus urged the great interests of the water companies in apposition to the rights of the metropolitan population, and then went on to magniry the objectionable attributes or centralisation, to discount the popular demand fur sanitary improvements, to disparage shaftesbury's statistics, and to asserio in conclusion that beyond a certian point the Government could not go in intarferiag with the luternal affairs of tise people -.altogether, in fact, to act the part of a frime sinister who was casting round to ind justirication for legislative inaction. The speech, Chadwlek belleved, was based on the iuformation of subordinate officers in the l'seasury, who were proveoly themselves informed by shareholders in the companies; "and the suggestion of Lord Carlisle that he Lord Derby should look into the matter himsele, is a deciaration that he will find it to be 1. Hansard, vol. 120, p. 1305 . 
otherwise thas as ho has been told. as be certaluly w111, if he roally do look listo it". (1) The indignation of the reforners vas woll voleed by John Roberton, an old ally from the days of the battle over the Bumit Tunel. "Is not the sanitary state of the stables of the Gentry minded?" he demanded, "Don't their racers get plenty of pure weter? have not the well ventilated stables and room encugh to rest their bodics and stretch their lirab? Doubtiess they have: and when the wase of mankind comes to be as much valued as rucers ify Lorde and others w111 help on Sanitary ikeforn". (2)

A Lew weeks later Lord John Manners introduced a Bill to repeal the interments fct of 1850. The proper resedy, ho observed, was not the principle of monopoly and centralisation, which had railed to work despite the "great and almost extravagant powers" confided to the Board of Health, but the "more constitutional, simple, and lese objectionable method, by which from time imemorial the parochial authorities bac been entrusted with the burial of the dead". (3) Thus, by his Letropolitian Burials B117, the Secretary of Btate was empowered to close any burial grounds proved to be obnuxious, and the purishes were enabled, singly of in corioination, to provide new Grounds or to coatract with the wading cemeuries. In the same nonti (June 1352) a B111, empovering the London Necropolis and Navional sausoleun Coapazy to purchase 2,000 acres of Woxing Common on which to lay out a ceneter, was epyroved by the Comons, alter the chelraan of the select Comittee (Baines) aad renarked that it was udratted by all parties that any powers posseased by the soard of Healtis "had been tried without effect, and that, 19 this bill vere not cerried, 1t would be perfectly nopeless to expect any remedy from the Board of inealth". Lord John dianers agreed, welcomine a taeasure which appeared 1. B.C. - ? (probably Delane), 29 April 1852.

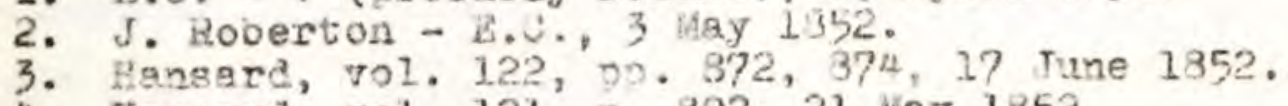

4. Hansard, vol. 121, p. 892,21 May 1852. 
calculated to remove the evils now complained of; and his approval was echoed by Lord Seymour.

"It is now with the Metropolitan Interments measure", Chadwick reflected sorrowfully, "worse than it would have been with the Metropolitan police measure; if after it had been determined upon by Parliament upon a technical difficulty as to raising the money, the measure had a check and upon that check an outcry had been raised by St. Pancras and a small minority of parishes, and as if upon that small outcry, Sir Robert had confessed that the Government had already too much to do that the larger measure was impracticable, and consented to allow the parishes to have local acts for a nightly watch of their own. It is probable the confession would have had no remonstrants and he would have been applauded for the moderation and candour of his views". (1) Lord John Manners, he thought, could not have read the evidence of the trial and fallure of the very measures which he now proposed. Powers were to be given to the parishes, the parties who had brought the evil to its helght and had obstinately resisted amendment. Under the rule of the vestrymen of Marylebone and St. Pancras, the officer of Health, on whom pivoted the whole arrangements for advice and regulation, could find no place. It was illusory to expect parishes, or even Unions, which could never be brought to combine to establish district schools, to co-operate of their own accord to acquire a cemetery, a possibility "as remote as their union to construct of themselves a locomotive". (2) One of the parish clergy, he heard, had stated that "a good and sufficient chapel" for a parochial cemetery could be built of rubble for 21,000 . (3) Rubble! What a falling off from the architectural splendour of Chadwick's National Cemetery! As for the Necropolis Bill, it was the scheme "of vulgar projectors and a vulgar architect", a bullding speculation disguised as a public measure, which included amongst its $-0-$

1. E.C. - ?, 2 February 1852.

2. E.C. - Lord John Russell, n.d.

3. E.C. - Bishop of London, 31 January 1852. 
proposals pit burial for paupers, the use of railway arches as mortuaries, and the removal of corpses in the common horse boxes of the railway. (1) Yet the Government had given the Bill their benediction -- was it because "the present solicitor General Sir Richard Bethel was deeply engaged in this speculation, his brother in law Mr. Abrahams being the architect?"

In the course of the debates on the interment question a joint attack was delivered by Lord Seyrour and the metropolitan members on the principles, constitution, and personnel of the Board of Health. Even the inoffensive Southwood Smith did not escape, and one nember asked why he should continue to draw his salary now that the Act under which he was appointed had been repealed; all he had done was to go to Paris and assist in the writing of ten thousand letters. (3)

"There was considerable inconvenience in the constitution of the Board itself", Lord Seymour told the Commons on June 21 st 1852. "Although he, when President of the Board, was

responsible to Parliament for the proceedings of that Board, yet when he attended the Board and made a proposal, it was seldom he could get a seconder, for Mr. Chadwick and Dr. Southwood Bmith, forming the majority of the Board, carried the question against him. He had told the Government that it was impossible to go on in that way. He thought it would be far better if some Lord of the Treasury were to assist Mr. Chadwick, so that the

Government might have some possibility of controlling the Board, and preventing the inconvenience and delay of business which now repeatedly occurred". (4)

The impression Seymour conveyed of bimself playing the Dormouse to Chadwick's Mad Hatter and Southwood Smith's March Hare was quite unfounded. It was not the first time in his $-0-$

1. "Objections to the Necropolis Bill", MS, n.d.

2. E.C. - ? (Russell), n.d.

3. T. Duncombe: Hansard, vol. 122, p. 1032, 21 June 1852.

4. ibid., p. 1081. 
relations with the Board of Health that he had revealed that he possessed an ingeniously constructive memory. He now arew for an appreciative House a picture of himself struggling with two sullenly stubborn colleagues, and finally giving up attendance at a Board where he could only make a useless gesture of protest. "This statement", wrote Shaftesbury blandly, "must have been caused by a confusion of the doings of our Board with some other ........ Surely you have forgotten that out of the 237 regular Boards, held during your tenure of office, you attended but three --- to these may be added two or three (not more)visits of a few minutes each -- that on one only was any resistance offered, and that was by mgself, not by Dr. Smith or Mr. Chadwick". (1) That occasion was, of course, on January 30th 1851, when Seymour had startled the Board by proposing that they should taike over two of the cemeteries and enter into competition with the remainder of the trading Companies; and it was the Board not Seymour whose representations had finally prevailed with the Treasury, short-lived though the victory was. 1. Shaftesbury - Seymour, 22 June 1852. The following memorandum was apparently drawn up at this date:

"Abstract of Attendances at Board Meetings.

Year Number of Board Meetings
Number of times Members present. Lord Lord Earl E.C. S.Smith Sey- John Mour Nanners.

\section{of}

Shaftesbury
1848

1849

1850

1851

1852

(to 22

June

inclusive)
Car1isle.

-

37
8
-
-

$\overline{-}$

$\bar{z}$

22
172
147
101
46

71
217
214
232
124

71 211 162 225 124 
Shaftesbury, who was annoyed at the suggestion implied in Seymour's speech that only Chadwick and the Doctor conducted the business, pointed out with some acerbity that he had been absent from one only of the Boarde at which Seymour had made an appearance, and that"out of the whole number 237, held during your period of office, I attended 101".

"The words reported in the Times are not quite correct", Seymour hastened to explain. "What I did say was to this effect, that though as President of the Board I was responsible to the Government and to Parliament for the proceedings of the Board, yet I remembered at the end of the year 1850 or at the beginning of 1851 attending the Board and making a proposal to the Board which was not seconded and which consequently dropped ....... I added that pinding myself in this position disinclined me attending the Board, even if I had time. I do not believe that I stated that I met with frequent opposition at the Board, but I may have said that my views were frequently opposed to those of the Board, and I said I considered the constitution of the Board defective as an executive department, because differences, which were honestly entertained on both sides, led to delay and repeated correspondence with the Treasury". (1)

1. Seymour - Shaftesbury, 24 June 1852. Cf. B.C. - Lord John Manners, 23 June 1852:

"On that occasion the only one recorded or of which I am aware, in which a proposition of Lord Seymour was dissented from at the Board, I have not the slightest remembrance of his having been told that his proposition had not been seconded; nelther have my colleagues nor the secretaries any recollection of anything of the kind having occurred; and they must have heard it, and remembered it had it taisen place; but the conditions represented, viz. of myself and Dr. Southwood Smith being the only members present besides Lord Seymour, not having taken place, render the whole impression on which such a statement can have been made to the House an entirely erroneous one. The recollection of Dr. Southwood Smith and of the Secretaries is equally confident as to every other occasion: that nothing of the kind ever took place.

In fact I scarcely recollect a suggestion or a proposal or a request made at the Board by Lord Seymour, other than (Continued on next page) 
Forwarding copies of the letters to Lord Carlisle, Chadwick urged that before the question arose of renewaing the Board's tern of office, "we ought to have in your house a Compittee of inquiry, before which any charges or fault finding of any sort may be investigated and that the measures may not be left to the mercy of the Treasury". (1) But Seywour was never confronted in public, and he never nodifled the original version of his charge against his former colleagues, which was to be revived again a weapon in the final grand cssault on the Board of Fealth.

Meanwhile, on the water question, the Government had with equal decision turned its back on Gwydyr House. Shortly before the fall of the Whigs, Lord Seymour introduced a Bill for metropolitan water supply. He did not believe it possible, he declared, for a Government commission to superintend such a function; to create a municipal corporation, however, would mean delay (and it would probably be inefficient, in any case); a combination of the companies, again, might be the means to economy, but it was not Parliament's duty to require it. (2) Thus, one by one, he disposed of the schemes of Chadwick, the parochialists, and Sir William Clay, leaving as the most practicable solution --- since securities must be given to the consumer which would not entail any undue exertion by the Government -- the proposal that the companies should be left as they were, subject only to certain conditions as to quality, distribution, and rate of charge. This Bill, which no less clearly represented the views of Sir John Johnstone than the Bill of the previous year represented those of Sir William Clay, was inherited a month later by Lord John Manners, who promptly sent it, with a batch of other Bills from the water Companies, to a select Committee. Here, after two months at a cost of -0-

(Continued from previous page) his proposal in respect to the interments that was not complied with ......"

1. E.C. - Carlisle, 26 June 1852.

2. Fansard, vol. 119, pp. 218 - 219, 6 February 1852. 
21,000 a day in retalners for a score of counsel and parliamentary agents, the Government Bill was hammered into a shape which the Companies found possible to accept. On June 17th a surprised House was requested to go into Comittee on the measure, the Government having taken the Second Reading at so late an hour that the principles of the B1ll had not so far come under discussion. (1) Both Mowatt and Lord Bbrington delivered damaging attacks upon the Bill, but it mustered ample support in a House which included 86 shareholders of the water companies; (2) and eventually it reached the Lords so late in the session, as Shaftesbury remarked, that they had to pass it without knowing more of it than if it were a Chaldee manuscript. (3)

The Metropolitan Water Supply Act of $1852^{(4)}$ obliged those companies which drew their water from the Thames to remove their intsices to some place above Teddington Lock, beyond the influence of the tide which daily agitated and re-agitated the sewage of the capital. The companies were given till August 31st, 1855 (the Chelsea Company till August 31st 1856) to do this. They were also obliged to cover in their reservolrs, and to filter all water intended for domestic use. And within five years a constant supply was to be laid on by every company.

The Government had been as gentle as possible in putting the bit on the companies. Iord Ebrington alleged that the Select Comittee had refused to hear his evidence, and that the truth had emerged only when the companies' experts disagreed anongst themselves. (5) The schedule of uniform rates and charges, which Sir John Johnstone had said would amount to a confiscation of the companies' property, had been quietly dropped, together with the clauses which were intended to compel competition between the companies. To Chadwick this second

1. Hensard, vol. 122, pp. $339-872,17$ June 1852.

2. This is the Iigure given by Joseph Hume, Hansard, vol. 120, p. 84,25 March 1852.

3. Hansard, vol. 122, p. 1267, 24 June 1852.

4. 15 \& 16 Vict. c. 84 .

5. Hansard, vol. 122, p. 856, 17 June 1852. 
Home Office Bill was "marked by an offhand ignorant and supercilious contenpt for the necessities of the population and the investigations as to the means of supplying thea", (1) and it appeared less objectionable than the sirst in one respect only: it did not suarantee to the companies a monopoly of bad supplies at three times the expense for which good supplies could be obtained de novo. But under its provisions water supply was still regarded as a separate problem fron arainage; extra cherges for baths and water closets still rematined as taxes on health and decency; and householders were still expected to provide their own connections with the main. The water of the Surrey aprings had once more been ignored, and though some of the companies were obliged to seek now intakes, their source was still the Thames, hard with lime and polluted with surface washings, which, from Oxford downwards, was the great sewer of the country through which it ran.

It is hardly possible, after reading the story of Chadwick' $\varepsilon$ struggle to give Iondon a wholesome and universal water supply, not to conclude that a splendid chance had been missed. If his recomendations had been acted upon, and the compenies had been bought out in 1851, the ratepayers of luondon would have saved themselves fifty years of disconfort and 111 health, and some $240,000,000$ of compensation which in 1902 was thrown as a back-breaking burden of debt on the Metropolitan Water Board. The solution of the "practical men", of Beymour and Wood, of Derby and Manners, proved no solution at all. Fourteen years later, when cholera ragedfor twenty-three weeks in London and killed 5,548, it was revealed that the East London Water Company continued, in contravention of the fourth section of the 1852 Act, to distribute water which had not been passed through filter beds; and though the provisions of the 1852 measure were repeated and strengthened by the Metropolis Water - 0 -

1. "Hotes of heads of remonstrance on the Metropolitan Water Bill", ils, n.d. 
Act of 1871, it was not till 1899 that Londoners were receiving a constant supply.

The history of the metropolitan water companies affords the classic example of a great vested interest, rooted so toughly among the governing classes, with its friends in the press and the departments of state, its spokesmen in the Government, and its silent battalions of shareholders in the House of Commons, that it was enabled to hold out for generations in the face of all the evidence, until the mounting exasperation of the public forced it to a capitulation -- on its own terms. How many politieians and civil servants, Chadwick wondered, were drswing dividends and directors' fees from works which the Board of fiealth had condemed as ineficient and unhealthy? "The new Secretary at War: the Right Hon. R. Vernon Smith who brought forward one of the New River Company's bills: inherited shares in it. His father was the chairman of the Nev River Company, and really wrote the report of one of the Committees on the water question. The present solicitor to the Treasury Mr. Reynolds is a Director of the West Midaleser Water Company. Several. cleriss of the House of Comnons I am told are holders of water shares. The public offices sre beset with them, and with shareholders in other companies." (1) In Parliament the Board's measures were discussed in "an atmosphere of shareholders" in similar if not the same sort of property, and the aura of influence of a great body of capital extended far beyond the circle of those with direct pecuniary interests. "The Minister may be told this is Ereat property, "capltal" invested for an important public object; you cannot sacrifice it in families; the House will not support you. You can never carry such a measure". (2) The 1. E.C. - G. Goldsmith (editior of the "Globe"), 7 February 1852. Cr. also "Notes of heads of remonstrance on the Metropolitan Water Bill", MS, n.d., apparently intended to be presented to Lord John Russell by the Sanitary

2. L.c. (J... Delane), n.d. 
rallways in Germany, he heard, charged little more than onethird of the Inglish fares, and yet returned a profit of six per cent., the reason being that they were state-owned and were free from the influence of shareholders in the chambers and Government departments. How much better than in Fngland where it was thought no disgrace for shareholders like Sir William Clay or Sir John Johnstone to vote on questions in which they had a Inancial interest! (1)

He detected sinister figures like these behind every interest disturbed by the Board. Of the two cemetery cemeteries against which they had first taken proceedings, they found "that the chairman of one was the father of one under secretary of state, and that the chairman of another was the uncle of another under secretary of state". Chadwick was indignant, therefore, but not surprised, when he discovered that these companies "had information long before we received it, that a hostile course would be taken agralnst us". (2) Then there were the great slum landlords. The Marquis of Salisbury, the Lord Privy Seal, opposed the application of the Public Health Act to Hextford, where whole rows of houses belonging to bin were without a single privy. Lord Lonsdale, ground landlord of Whitehaven, successfully tesisted the introduction of the Act into the town, which it was estimsted would cost 822,00 to put in a sound sanitary condition; though it was said that he found double this arount to back an opera Company. In the closing months of 1852 these two noblemen showed themselves as the most active opponents of the Board in the upper House. The most notable exam le of another type of critic was Toulnin Smith, the theorist of Local Self-Government and defender of the vestry and court leet, who thrust himself forward as the spokesman of various parties opposed to the Board. The Corporation of the City of London had spent $\$ 300$ in circulating his pamphlets. The Town Commissioners of Bristol had paid him \&30 for lecturing 1. E.C. - Goldsmith, 7 Pebruary 1852.

2. B.C. - ? (2roahly probably Russell), n.d.

3. L.C. - J.T. Delane, 1 November 1851 
against the Fublic Health Act. He bad acted as counsel for the Hampstead Water Company before the 1851 Comultee, and had been briefed to prowote a Local act for Birminghan to counter the application for the Public Health Act. "As it stands", Chadwick summed it up, "we have retained advocates assuming the guise of inpartial fudges in the press; and in Parlianent, actual shareholders and the agents of shareholders, appearing in the guise of impartial public representatives; and of public officers, canvassing as from a sense of daty". (1)

The defeat of the Derby Government in the elections of the summer of 1852 caused little rejoicing in Gwydyr House.

"I quietly dread the effect of changes, and negotiations, and office hunting and leaving, at this particular juncture", observed Shaftesbury. "We have not a moment to lose. The next ibree months are, "I speak as a man", inestimably valuable; and if we let slip that time fox preparation, we way be utteriy ruíned.

Yet what shall we gair by a return to our old Masters? Sejpoux will be no better than John Nanners, as John Manners proved to be no better than seypour. D'IsIaeil, to all intents and purposes, is equal to Charles Wood; and Hamilton is vastly superior to Hayter. Walpole, to be sure, und Salisbury and Ionsdale are sad specinens of knowledge and will in sanitary watters. Yet, all I have said, are neariy alike. Public men know nothlns, want to know nothing, nate to be told snjthing, which does not openjy and directly affect their political position and safoty".

Shaftesbury was at the time (July - August 1852) on the continent, recuperating from the effects of overstrain, and his letters to Ohadwick uncover the irustration and bitterness left by the disasters of the gession. "It is needless to tell you of the heat bere", be wrote from Bins, "for I. understand the 1. I.C. - ?, 28 July 1851.

2. Shaftesbury - E.J., $18 \mathrm{July} 1852$. 
weather is fiercer, $1 f$ possible, in London ...... I have sat and pietured, to myself, the sufferings of our clients in their crowded alleys, Courts, Lanes, and houses of the Metropolis, with poisonous and deadly water, until I have become more sorrowful than, perhaps, they are themselves! I cannot well describe to you the pain of my disappointment, actual and prospective; for I see that our enemies, these "Sons of Zervinat" will prove too strong for us. It comes between me and my "cure" (this is the local term), I da not receive half as much benefit as I should do, were our hopes accomplished ..."(1)

It was with appreciative envy that Chadwick, and st111 more Shaftesbury, watched the progress of Jouis Napoleon's social reforas, with their swift clean strokes of unrestricted, beneficent power. He was "laying about him furlously in Paris", noted Shaftesbury, where "he has proclaimed war against all courts, allejs, lanes, and culs de sacs". "The Galignari of yesterday contained a programme of improvements which made my hair stand on end. Bvery working man that lives will on seeing these reults shout "vive la Despotisme"; "à bas les gouvernements libres!" Why our Vestries, Boards of Guardians, paving Boards, and all the apparatus of what is called "local" and "Self" government, have only been so many obstacles in the way of physical and social amelioration.

When Kmil Chevalier came as a special Commissioner in August 1852 to examine the lodging houses and model dwellings of London, Chadwick sent him, in the company of Count Cavour, on a tour of some of the worst districts. "They agreed that your Lodging house regulation Act was working very well", he wrote to Shaftesbury, "will report very favourably of the model dwelling houses, but they were in horrors at the condition of the population in the worst districts and at the neglect". (3) 1. Shaftesbury - E.C., $16^{-0-}$ July 1852.
2. Shaftesbury - E.C., 18 July 1852.
3. E.C. - Shaftesbury, ? August 1852. 
"Your letter filled me with grief and shame", replied Shaftesbury. "The thing", as old Job said, "that I greatly feared, is come upon me"; and the Sin and sensuality of Protestant, free, and wealthy kngland towards the mass of the eivil population, will be shown up to the whole world, and then contrasted with the paternal care of Pupist, despotic, impoverished France!

To avert such an issue, anc. to stand well in a day of account, you and I and many others have laboured long, but have been reluctantly and leebly backed in the beginning; and we shall be nobly and angrily opposed in the end.

This day I have been to Frsnkfort on business -.. the City is broad, clean, and very handsome -.. but the stinks (whwnce they come I know not) were prodigious. Cesspoolbreezes were blowing from all points of the Compass; and I felt, I regret to say, something akin to a malicious comfort that some other places, besides London, had their own abominations". (1)

Barnstaple rejected Lord Ebrincton, "our only stay in the House of Conmons"(2), in the elections of 1352, hatred of the Public Eiealth Act being brought to bear in the campign in aid of the customary weapons of bribery and treating. (3) Looking over the new Covernment, Chadwick could see only one face which seemed to promise hope and a rescle from frustration; it was that of falmerston, whose caustic marginaila and ingolent little notes about the letharby of clerks in general and of the cleris who served palmorston in particular were sald to have kept the slugeish patriciens of the Foreign office in a state of unexampled activity. Here was a fellow-warrior against cant and routine, and one, moreover, related by marriage to Lord Shaftesbury, for whom he had a curious respect. Primerston

1. Shaftesbury - E.C., 12 August 1852.

2. Shartesbury - S.C., 16 July 1852.

3. Barl Eortescue - E.A., 13 November 1353. 
for his part listened more sympathetically than his predecessors at the Home Office to the theories of the General Board; and at a public dinner at Lewes, after Lord Ducle had lamented the shortage of farm manures, he delivered, to the massive amusement of the "Times", an impromptu and gallant speech on the untapped treasures of town guano, based apparently on some vague recollections of the Chadwickian thesis.

\section{(1)}

The new President of the Board was not Lord Seymour, as Shaftesbury had feared it would be, but Sir William Molesworth, yet another President who preferred to preside at a distance, and to act in embarrassing independence without consultation with his colleagues. His first move was to declare that he would not insert in a Confirming Bill any town where a majority of the ratepayers appeared to be against it. This, Chadwick pointed out, amounted to a reversal of the provision in the public Health Act giving the Board the power to intervene in any place proved to suffer from excessive mortality; it amounted, moreover, to an abandonment of the common law right of every subject to pure air and the means of healthy existence. "It has not been given to any local majority, to determine that a minority or even a single individual, shall be deprived of them and shall die. Such a power would be a sovereign power, and an arbitrary one; it would be giving to the local bodies the right if not of the gallow.s literally of the pit ......"(2)

So 1852 closed, with the Board brooding over two major defeats in the metropolis, with Shaftesbury low in spirits and Chadwick beginning to sound his friends about the possibilities of employment in the Home office. (3) When Robert Rawlinson read a paper on town drainage at the Institute of Civil

1. "Times", 19 July 1852 ,

2. E.C. - Iord Johri Russeil, n.d. (1851).

3. Sending S. Redgrave a copy of the Minutes on house and town drainage, Chadwick remarked that he did not know but that "they may not tend towards the close of my labours in sanitary works"; and he concluded by asking, probably with an eye to the future, for a talk on police matters. (7 Det. 1052) 
Engineers in December he did not get a single supporter. The mention of Chadwick's name one day in the Court of Common Council precipitated "a perfect outburst of fury". (2) There were few men alive, he thought, "so little loved and so intensely hated; and whose official position is so precarious". (3) Acceptance of this unwelcome truth, and honest bewilderment that it should be so, that the name of Chadwick, associated as it was with great measures for the improvement of health and morals, should so grate upon the public ear - - these are the key-notes of a letter of this period, addressed to an American relative, in which he reflects upon his career in the public service, and describes his preparations for a strategic retreat:

"Our Board is terminable next jear; powerful parties are labouring to prevent its renewal, and most probably they will prevent its renewal under any conditions on which I can be employed. The new elections have lost us one powerful friend, and have added one or two very certain enemies.

Under these circumstances I should be obliged, if you would warn my father's family of the uncertainty of the continuance of any assistance from me. I have felt myself obliged to give similar warnings here.

I have long considered it prudent to reduce my establishment and expenditure; but I have never sot a clear months time to look about me and to do the work, which if done at all must be done by myself for I get no assistance on which I can depend ....... I am moreover ruch observed by the enemies of our measures and it is as hazardous as changing the position of an outnumbered army in the presence of an enemy: and I have felt that it is highly dangerous to give an appearance of a retreat, or display want of confidence in the cause.

I write to you fully because you are the only one -0-

1. E.C. - F.0. Ward, 15 December 1852.

2. H.C. - Andrew Boardman, n.d.

3. ibid. 
related to me who are $11 \mathrm{kely}$ to take a public as well as private. interest in my work.

There is a prima facie case against me of imprudence, and mismeasurement of forces in bringing agalnst myself personally and the cause, so many enemies, but I knowingly entered the fleld against very large odds, much has been gained, and eminently large results have only been loat by small chances, such as the unexpected deaths of the late Earls of Carlisle and Shaftesbury removing the two most powerful allies from the House of Commons. In other respects the cause which deserved to be fortunate has been unfortunate. There has been, in some instances foul dealing against it, to an extent which has been unexampled which no more required to be calculated upon than the revival of the practices of dark ages such as poisoning and assassination. In some respects, I have felt that our measures are in advance of the time; the science of prevention is a new one: vast sums are spent in the charity of alleviation: the sanitary association can with difficulty obtain subscriptions of a few hundreds. I have a firm reliance that much that I have done, and hope to have strength, and to be left in peace to lay out, will be found available and profitable in other times, and in the bands of other men.

Some ground has been lost for the want of sufficient exposition; but for that I could get no time. The works you w111 receive from me, on the drainage of towns, and the application of the refuge of towns, have all had to be worked out by myself including the elementary principles of engineering applicable; and the consultations which from courtesy have been very extensive have been one source of obstruction. The least pleasant part of my retrospect up to this point has been the general fallure of acts of generosity, or of confidence. If I were to go over the ground again, I would exact more: insist more on the exclusive direction of my own messures, have made entire clearances of staffs habituated to measures which require change, have pressed my claims for results obtained immediately 
on the ministers or one the public for recognition and have had shorter accounts, have overlooked less frequently opportunities of personal vinâication (1)

1853 brought with it no lessening of the gloom. Its opening weeks were clouded by the unfortunate Croydon inquiry. Hawkesley and his friends grew increasingly clamorous. (2) Before a Lords' Cormittee Toulmin Smith, acting on behalf of the slum landlords of Hertford, the Marquis of Salisbury and Baron Dimsdale, routed one of the Board's Inspectors. (3) Above all, hostile elements in the localities were enormously encouraged and strengthened by the course of events in London, where Chadwick's scheries collapsed in the final disaster of an open quarrel between the Board of Health and the Metropolitan Commission of Sewers.

When the first Metropolitan Comission of Sewers succumbed to its internal disorders in september 1849, it had been succeeded by a smaller body of thirteen members, selected mainly for their scientific and technical knowledge, and including Sir John Burgoyne from the Board of Ordnance, prominent railway engineers such as Robert Stephenson and J.M. Rendel, and a number of officers from the Royal Engineers. Alarming stories presently came to Chadwick's ears. The great Mr. Rendel had been heard to use such expressions as "Sanitary Humbug", and had scoffed at the whole subject of sanitary improvement; hehhad contended that it was quite sufficient for the Comission to carry sewers down the centre of the streets, leaving the owners to drain into them or not, as they thought -0 -

1. B.O. - Andrew Boardman, n.d.

2. In April Hawkesley published a pamphlet: "Letter to the most Honourable the Marquis of Chandos, M.P., in relation to the exercise of some of the extraotdinary powers assumed by the General Board of Health, and the Superintending Inspectors". 3. "isinutes of Evidence taken before the Select Comittee of House of Lords on Ceneral Board of Eealth (no.3) Bill", P.P. $1852-53, x \times x i$, p. 231 (Lords). 
fit. (1) Chadwick's trial works were brought to an abrupt halt. The eminent engineers attended only intermittently to their unpaid public duties, and the business of the Commiszion was frequently beld up for lack of a quorum. (2) Their one considerable achievement was the notorious Victoria-street sewer, on which, after estinating that it would cost $\$ 13,854$, they spent 233,000 ; then part of it fell. into ruins almost imadiately, necessitatiag an additional large outlay for repairs. (3) As Londoners watched their rates mounting, while their streets and houses remained as foul as ever, the "Times" and Sir Benjamin Hall were preseatly as loud in complaint of the new Comission as they had bean of the old. (4) By pressure on Its more aneable members and by representations to the Governnent, Chadwick endeavoured to daintaln bis control over the course of affeirs at Greek Street. His anxiety increased as the $\mathrm{J}$ drew further and further sway from his influence. On the theory of towa drainage in general, and of the drainage of London in perilcular, the views of Chadwick and his Inspectors clashed with those of Bazalgette, the Superintending Fngineer of the Comission of Sewers, and Cubitt and Stephenson, their $-0-$

1. I.C. - Carlisle, 1 November 1849.

"Sir John Burgoyne talked I am informed of an application of Parlianent to be relieved from the trouble of

improverent rates.

I called today upon hin to remonstrate.

He said he did not believe that they could get on at all if they were to be troubled about the drainage of every nasty dirty court or place in the Metropolis!

What has all the sanitary movement been about, if it were not for the drainage of the places which he pleases so to desiznate snd which vake up the bulk of the residences of the labouring classes .........

I could not sleep last night for the trouble and acnoyance that this state of things must oriag upon us, for all the officers are in s state of excitement upon the subject and there is 1 fear no means of concaling the shame" (Tbiá.)

2. E.C. - Col. Phipps, 28 July 1851.

3. "Reports and Commancations by Bodrd of Health to Home Secretary on the Drainage of the Metropolig", D. ". 1854 . $1 \times i$, p. $3-4$.

4. e.6. Hall's attack, Eansard, vol. 116, pp. 1063 - 71, 16 May 1851. 
Consulting Engineers. "As to pipes he would not touch one", Stephenson had once declared. "He hated the very name of them, and felt inclined never to mention the word again". (1) In November 1852 the stoneware pipes, which had been laid down three years before in Church-lane and Carrier-street, St. Giles, by the first Metropolitan Commission of Sewers, were pulled up and replaced by brick drains, Bazalgette giving as his reasons the number of stoppages, the cost of removing obstructions, and the risk attendant on opening the ground for examination under old and badly built houses.

This report had a marked effect on those who did not know that the failure had occurred in a group of 49 houses, mostly comon lodging-houses occupied by the lowest type of Irish labourers, and with a most defective water supply; and that these houses represented a very small fraction of the 27,000 in London which by now were being drained by 346 miles of pipes. (3) Another damaging document put out from Greek Street was a report on "Past fallures and Present Condition of Pipe Sewers", in which Bazalgette, after examining 122 pipe-sewers, found that some were completely choked, 23 were cracked or broken, and 113 contained deposit, in 66 ranging from $2 \frac{1}{2}$ to 7 inches in depth. (4) It was thus not long before the officers of the Sewers Commission were being invoked as authorities by those who wished, from whatever motives, to resist or discredit the General Board of Health.

By August 1853 Chadwick could contain himself no longer, and Southwood Smith joined him in a letter to Lord Palmerston protesting against the wastefulness and erroneous principles of the works which the Sewers Commission was planning to execute. Bazalgette proposed to spend two million pounds on laying down another thousand miles of brick sewers, an "expenditure in worge $-\mathrm{O}-$

1. "Communicationsfrom General Board of Health, and reports of Superintending Inspectors in respect to operation of Pipe Sewers", P.P. 1854 - 55, xlv, p. 49.

2. "Pipe and Tunnel Sewers, Reports of trr. Bazalgette relating to", P.P. 1852 - 53, xevi, pp. 9- 11 .

3. P.P. $1854-55, x .1 v, p .5$.

4. P.K. $1852-53$, xevi, p. 8312. 
than waste", and the main lines of intercepting sewer which he contemplated would cost a further three millions. For onethird of this amount, self-cleansing pipes could be installed. Furthermore, by adopting Austin's methods for the drainage of the metropolis, not only would the pollution of the Thames be avoided, as Bazalgette intended, but at the same time another great object would be secured which he had sacrificed - - the sewage would be saved for disposal as manure. (1)

The letter did not stop Bazalgette's preparations, but in the debate which followed Palmerston showed himself a good friend to the General Board. In November 1853 he pointedly sent the Sewers Commission copies of reports he had received from a number of the Local Boards, "to show the cheapness and efficiency of the tubular system". (2) Bazalgette took up the challenge, and made a personal inspection of the places in question. He satisfied himself that the cost of pipe drains was considerably greater than the General Board had stated, that in four out of the five towns he had visited there had been notable failures, and that none of them had as yet possessed. pipes long enough to give them a fair trial. (3) In reply the General Board submitted reports from the engineers responsible for the works under judgwent. (4) These censured Bazalgette for conducting so hasty and superficial an examination, and showed that at Rugby pipes had worked satisfactorily for a period of two years and at St. Thomas's, Exeter, for two and a half; that at Barnard Castle only one defect had been found in three miles of pipes; and that at Tottenham Bazalgette, in order to give a "general idea" of the charges resulting from the new system had quoted one bill for 440 , -- neglecting to point out that this was incurred by the owner of one of the largest houses in the 1. "Reports and Communications by Board of Health to Home Secretary on the Drainage of the Metropolis", P.P. 1854, $1 \times 1, \mathrm{pp} \cdot 5-6$.

2. ibid., p. 139 .

3. ibid., pp. 184 - 204: "Report upon the Drainage and water Supply of Rugby, Sandgate, Tottenham, St. Thomas's, Sxeter, and Barnard Caste", 13 iebruary 1854

4. Minutes, 26 May 1854 
town, who had put in eight cocks, ${ }^{\text {f }}$ water-closets, 212 feet of private drains, and apparatus for watering his carriage and flower garden. (1)

There we must leave the controversy, which poured its subsidiary stream of hate into the flood which overwhelmed Chadwick in July 1854. In the localities Bazalgette's reports were gratuitously circulated by the enemies of the Board to inoculate local opinion against the persuasive arguments of the Inspectors. At a public meeting at Weymouth, for example, an opponent rose to ask Austin, "What guarantee can the General Board offer us at Weymouth against such fatal consequences as these", (flourishing the diagrams of stopped pipes published by the Metropolitan Comnission of Sewers), "if we adopt pipe drainage; and what course would they advise?" (2) Members of Parliament read Bazalgette's report on the pipe sewers of the metropolis, and looked at the eleven pages of diagrams which supported them, showing alarming cross-sections of pipes choked black with sediment, and the impression spread that the majority of pipe drains beneath London were cracked and oozing filth or were blocked by the retained ordure. It had a powerful effect when Chadwick's fate was in the balance in the vital debates of 1854. As F.O. Ward told him: "I referred to Bazalgette's

lithograohs as having mainly contributed to the strong impression in the House of Commons which led to your retirement: --- and Sir John Shelley confirmed that statement, referring to one particular lithograph (of a pipe from Mr. Rich's premises) shown as quite blocked up in Bazalgette's report, and which he particularly remembered as the subject of jokes about the rich state of the pipe: whereas, on turning to Grant's report, this very pipe proves among the poorest --- being in fact completely clearn. (3) -0-

1. "Communication from General Board of Health, and reports of Superintending Inspectors in respect to operation of Pipe Sewers", P.P. 1854 - 55, xlv, Pp. 58, 79, 33, 99.

2. ibid., p. 15.

3. F.O. Ward - E.C., 25 April 1855. 


\section{CHAPTER 17. \\ ACHIEVEMENTS, $1848-1854$.}

As the Board entered upon the last twelve months permitted to them by the Public Health Act, they began to weigh anxiously the chances that their mandate would be renewed by Parliament. A despondent letter from Shaftesbury, taking the cure at ibms in the summer recess of 1853, showed that he faced the coming session with gloomy foreboding. He had been cut to the quick when Palmerston withdrew support for his Mendicancy Bill, and he saw in its rejection a sign of his waning influence.

"The House, it is said, refused to listen; this, if it be so, is a sad omen for any future exertions; I have not time before me, as I had twenty years ago when I moved the factory bill; nor have I the same struggle and fire to endure disappointments. Punch and the Times have done their best for me; but my friends, it seems are weaker, and my enemies stronger, than either or both together!

I am sadly dispirited; and I shall have no heart left either to attempt, or imagine, anything more. And, at last, when our rulers give the coup de grace to the Board of Health, I shall feel, like Othello, that my occupation is gone".

They must make a defensive statement, he wrote later the same month, "but it will be to no purpose as an effort to ward off a capital sentence. That our dissolution is resolved on, I cannot doubt; the very fact of the combination against us of the Metropolitan members and the Subordinates of the preasury would make our position very difficult to a bold and just Ministry; it will render our overthrow and oppression too certain and almost agreeable to a Government that is neither 1. Shaftesbury - E.C., 3 August 1853. 
one nor the otber".

"Why should the Subslterns at the Treasury be jealous of me and by Lodgling House Act?", he went on. "I am no Candidate for place, or pension, or political favour. God knows I have had trouble enough for nothing; abundance of "monkey's allowance, more kicks than half-pence". Is it Mr. Wilson? but what is the use of asking who? the name of our enemies is 'Legion'". (1)

With this leeling that they were ringed round by a multitude of open loes, and that an even more numerous host worked secretly for their destruction, the Board drew up at the end of 1853 the apologia for their five years of activity -"The Report of the General Board of Health on the administration of the Public Health Act, and the Nuisances Removal and Diseases Prevention Acts, from 1848 to 1854". (2) It was a more modest and inoffensive document than Chadwicis had intended it to be, but its only concession to the opposition was to omit some of his more truculent passages. (3) Chadwick was less resigned to defeat than was Shaftesbury, and less convinced that defeat was inevitable. Once when he had mentioned to Lord John Russell some encouraging facts about thelx progress, the Prime Minister had asised why the Board "did not ding them into people's ears: they needed to be saturated with them".(4) There, thought Chadwick, was the fundamental reason for the general distrust with which the Board were now segarded: the ignorance of their achievements which permitted the misrepresentations of their enemies to pass current unchallenged. He hoped to enlist sympathy by a plain factual account of what the Board had done, and a reasoned explanation of the position they had taken up on certain controversial questions.

First, then, there were the figures which summarised the $-0-$

1. Shaftesbury - E.C., 28 August 1853.

2. P.P. 1354, xxxv, P. 1 .

3. e.j. in reply to Lord Seymour's charges.

4. L.C. - Lord John Russel1, n.d. (1851). 
Board's work in executing the Public Health Act

By the end of 1853284 towns had applied for the Board's intervention. The Inspectors had examined and reported on 243 of them; and 182, with a total population of 2,100,000, had been brought under the Act. (1) In 126 of these towns surveys had been completed, or were then in progress.

For 70 places plans of public works, founded on the surveys, had been prepared. In 31 towns, including Gloucester, Salisbury, Ely, Dover, Preston, Laneaster, Penzance, Wigan, and Chelmsford, plans for an entirely new set of combined works had been approved by the Board, and mortgages to the amount of \&467,000 sanctioned for their execution. In the other 39 partial plans, providing for new sewers to combine with existing water works, of for an extension of the water supply, or for other improvements contemplated by the Act, had been examined and approved, and a further $\$ 589,000$ in mortgages had been sanctioned for these purposes.

In 13 towns, including Rugby, Tottenham, Alnwick, Morpeth, Hitchin, Ormskirk, Barnard Castle, Ottery St. Mary, Ashby-de-la-Zouche, Launceston, Croydon, and st. Thomas's, Exeter, the public works for drainage and water supply were finished and in operation; and in all except croydon they were reported to be working satisfactorily. In the coming year the Board expected similar works to be completed in another 35 towns. The Report did not mention that this list was shorter than they had hoped to present, and that one main reason why it was not longer was the shortcomings of the Board of Ordnance,

1. According to Appendix $12, p .103$, the Act had been applied by Provisional Order to 86 towns and by Order in Council to 83. The Report does not give a list of the towns in question. Their names, the date of the application of the Act, and the method of its introduction may be derived from; (1) "Return as to constitution and powers of Local Boards acting under the Act of 1843", P. . 135 ? (Sess. 2), xli, p. 3i (2) "Returns of Districts where the Public Health Act, 1848, or the Local Government Act, 1858, or both of them, are in force", 1867, 1ix, p. 141. Both these returns are defective, however. 
who had greatly exceeded in time and cost their original estimates for surveying the towns brought under the Act. Even so, considering the means at the Board's command and the burden of their other commitments, they had done well. They had been engaged at the same time in their ill-iated metropolitan ventures, none the less laborious and protracted because they were ill-fated; half-a-dozen Superintending Inspectors were all the staff they had been able to employ on the local inquiries; and they had spent less than 664,000 (more than a third of which was repayable by the local Boards) in the their five jears of service, a figure well within their Parliamentary vote. (2)

So much for the extent of their operations. But had the Public Health Act brought benefit to the towns where it had been introduced? On this point the Board could adnit no doubt.

By the Act a place could, for little more than a hundred pounds, $-0-$

1. On 26 March 1851 the Board recorded in their Minutes that, despite the promises of Colonel Hall, no finished plan of the districts under the Public Health Act had yet been received. The survey for Rugby had been in hand eight months and was still unfinished; Coventry had been waiting elght months, Ware seven, Barnard Castle six, and other places from five to $\mathbf{s i x}$ months. Moreover (Minutes, 10 June 1853), the cost was proving to be from four to six times the amount originally estimated by the Ordnance; at Newcastle it was $\$ 563$ not \&200, at Chelmsford 21,025 not $\$ 300$, at Torquay ¿730 not \&350. "These delays", Chadwick told Burgoyne (20 June 1853), "have occurred in a number of the best disposed towns which were inclined to have carried out complete works. In several Towns, I believe, they have occasioned reactions against the Promoters of sanitary measures. They have occasioned the loss of much of the opinion in favour of new works which the cholera created. It is owing mainly to this delay, and the example of the delay upon other Towns than those under Survey, that, at the time when the Public Health Act must be brought under consideration for renewal, we have so few towns to shew with complete works in justification of the measure ......."

2. In reply to those critics who accused then of extravagant expenditure, the Board pointed out that they had been voted 265,563 , of which they had spent $263,969 / 4 / 6$. Of this 223,500 was to be repaid by the Local Boards. (Report, pp. $46-47)$. 
arm itself with powers which, if sought by Jocal Bills, might cost several thousands. It dould, consulting the expert counsel of the Board's Inspectors, equip itself with a system of public woriss which were novel in deslgn, cheap to construct, and efficient in operation, bringing the means of health and cleanliness down to a weekly charge of a few pence. But Greater than the economy of money which resulted was the economy of lifo. In selected groups of the working class, placed under favourable sanitary conditions, the annual death rate had declined from 30 to 13 per thousand. If the death rate throughout the kingdom were at the same level, 25,000 lives would be saved annuslly in London, and 170,000 in England and Tales; and the average age at death, which now stood at 29, would be raised above 48 . (1) In these practical exercises in social arithnetic the Boand set a plain target before administrators: to close the gap between an actual mortality of 30 per thousand and a "natural" or "inevitable" mortality of 13 per thousand or less.

These were the benefits which sanitary reform held out for the future. But they could be obtained only if certain administrative principles were recognised and acted upon. In the first place, it must be acknowledged that defence against zymotic disease was not a natter which could safely be left to the resources of the individual; the chief preventive measures were large-scale works for municipal and donestic drainage and water supoly, which could be generally and systenatically introduced only by a public board. Secondly, even a local public board could not carry out unaided works of so special a nature. To overcome the inertia of local opinion and to supply the deficiencies of local knowledge, there must be a central department with wide initiatory and supervisory powers. The flag of centralisation was thus nalled firmly to the mast. And by its side the Board ran up another, no less detested: 1. ioid., p. 30 . 
that of municipal enterprise. Recanting earlier statements, based upon the Health of Towas report, which asserted the superiority of trading water companies in efficiency and economy, they comended for initation the examples of public management oy town councils and Local Boards which in recent years had cone under their notice.

(1) The reformers of Gwydyr fiouse thus identified themselves with two unpopulas propositions: that local representative bodies were not competent to administer without centrsl aid or supervision all matters which affected their districts; and that profit-making bodies were not invariably the best instrunents for rendering service to society. Against these doctrines would certainly be ranged the advocates of local self-government, who were many, and of private enterprise, who were even nore numerous.

Brom the localities, where in nearly 250 towns the sanitary condition had been laid bare by the Inspectors and in balf of thein the first steps at least had been taken towards improvenent, the general picture was one of steady and accelerating progress. Against this advance the Board had to set the total failure of their efforts in the metropolis. Regretfully they glanced once more at the Tater Supply and Interaent schemes, denying that it was any intrinsic weakness in their conception which had orought thea to nothing, and reasserting that faitb in the principles of planned service and public ownership which formed their essence. Snough has been said already about these moasures. There was nuch else touched upon in the Report -.. all the aultifarious activities of a brisk and capable department, continually lookine for fresh opportunities to exercise its powers and for fresh pretexts to wlden them. They had advised Sir Charles Wood to abolish the Window Duties(2), supplied Lord Palmerston with ammunition for his campaign against the smoise nuisances, (3) considered what 1. See shove, pp. $537-8$.
2. B.O. - Sir Charles Hood, 1 April 1851.

3. "Letter Irom General Board of Health to Home Secretary on smoke Consumption", P.r. 1854, 1xi, p. 533. 
regulations might prevent the sale of unwholegome or adulterated articles of food. (1) Instructional letters by the thousand had taught local authorities how to fight the cholera with the powers of the Nujsances Removal and Diseases Prevention Acts.

Of these minor occupations of the Board three call for more than the incidental notice they have so far been given in this study - - their atterapt to encourage the erection of improved woricing class houses by local authorities and progressive landlords; their Act for the regulation of comnon lodging-houses; and their two reports on quarantine.

\section{A mass of memoranda remain to show that in the last} months of the Board's existence Chadwick was busy on the clauses of a General Building Bill, which would have been the firat attempt to extend to the whole country the norms of sanitary construction. (2) It was not, howaver, the first attempt of the Board to "christianise", as Bhartesbury phrased it, the domestic condition of the working classes. (3) What aight be done in this direction had been demonstrated in practice by the Metropolitan Society Por Inproving the Dwellings of the

1. Minutes, 27 November 1849, 12 May and 21 June 1853. 2. Lid., 1Q February and 18 May 1854.

Jegislation hitherto had been conceraed mainly to prevent fire and to prohibit projections which impeded straight lines of commusication. In future, accor ing to Chadwick's Bill, no house was to be occupied until. an authorising certificate had been issued by the officer of Health and the Surveyor of the Local Board of Health. "At present there 1.3 no infamous site which for the greed of en immediate supposed profit will not be used for kabitation. The certificate should be the warrant of occupation for building purposes,". It should declere that the site was free from water, and at an adequate distance from marsh land; that the water supply was suitable for drinking and sufficient in quantity: that in construction the house was water-tight and properly drained, with gutters and shoots, and with waterclosets and house drains cleansed by the ordinary elow of household waste water. It should specily, moreover, the maximum number of occupents permitted to live in the house. ("Memoranda on the principles of a buil.ding Act", MS, n.d.) 3. Fansard, vol. 115, p. 1263, \& April 1851. 
Industrious classes, who had built two blocks of model lodginghouses in the 01d Pancras Road and Mile End New Town, in which the mortality rate had aropped to 13.6 per thousand. (1) To encourage the establishment of similar lodging-houses Ashley introduced a Bill into the Commons in April 1851. (2) permissive measure, on the lines of the earlier Baths and Washhouses Act, making available to boroughs and parishes with a population over ten thousand powers to erect lodging-houses, the cost being borne upon the rates. (3) The Act was stillborn; no local authority took advantage of its provisions; and it is chiefly interesting as an example of the General Board's policy of encouraging the enterprise of public bodies.

The main reason for its failure, we may judge, lay in the inhibitions of the ratepayer, who was not prepared to risk a loss on a municlpal building programme, and whose fears were reflected in the caution and lack of initiative of the local authorities. Model houses were all very well, but could they produce a reasonable return of profit? The same doubt restrained the improving landlord. "No doubt nothing can be more desirable than to provide good houses for the Poor, but I do not see my way in it", Lord Ellenborough once told Chadwicis. ".... No Agricultural Labourer can afford to pay in rent more than one shilling a week, and I cannot build a really good Cottage for less than 280 or even $\$ 90$. In the last two years I have expended from 21,000 to 21,200 on cottages and I am sure I do not get more than 2 per cent. In Towns no Speculator will build without getting at least 6 per cent., and he ought to have that". (4) This, in Chadwick's view, was the crux of the housing problem. It was necessary to show that sound and sanitary building need not involve a lowered profit, that the 1. "Results of Sanitary Improvement, illustrated by the operations of the lietropolitan Society for Improving the Dwellings of the Industrious Classes"; pamphlet by Dr. Southwood Smith; Charles Knight, London, 1854.

2. Hansard, vol. 115, pp. $1258-76,3$ April 1851.

3. 14 \& 15 Vic. cap. 34 .

4. Lord Ellenborough - E.U., LI August 1848. 
motive for erecting model cottages might be as much good business as high principles. "The desideratum for the working classes is to bring science and capital to bear on the construction of their houses: the only way to improve them and at the same time to make them cheaper is to make them a manufacture". This ineant, in the first place, experiment with new materials and methods of construction, with fire brick grates, tubular chimneys, tile roofs, and hollow brick walls and floors. (2) It meant, secondly, the enlistment of large capital, to make possible the economies of mass production. Chadwick's eye was thus always on the watch for the progressive landlord who might be talked into trying out his ideas. He was delighted, for example, when Colonel Phipps, the Prince Consort's secretary, informed him in December 1848 that Albert was considering how to improve the labourerg' houses on his property, (3) and within a fortnight he submitted a lengthy paper on materials and building methods. (4) erected under the patronage of the Prince for the Exhibition of 1851 owed much to Chadwick's advice; and he was convinced that by large-scale operations sinilar or better cottages might be built at half or two-thirds the cost, and still give a return of 7 per cent. (5)

A second Bill was introduced by Ashley (now Shaftesbury) in the 1851 session, aimed, not at the dwellings of the $-0-$

1. E.C. - T. Bamfield, 6 January 1845.

2. The hollow brick, in particular, was Chadwick's favourite device of construction. "I find that hollow bricks, made with an Agricultural tile machine, burn harder, and are less absorbent than the ordinary solld brick by two thirds, and are cheaper" (B.C. - Russell, 5 December 1843).

3. Col.Phipps - E.C., 8 December 1843.

4. E.C. - Col. Phipps, 23 December 1848.

5. B.C. - Col. Phipps, 14 May 1851.

"I believe we shall be able to show that a very good warm weather tight cottage, containing one living room, three sleeping rooms, a scullery and a water-closet, may be constructed for about $\$ 50$ : or one half the expense incurred for Prince Albert's cottages; that is, if they are constructed in numbers" (E.C. - ? Phipps, 3 November 1851). 
stationary population, but at the doss-houses which put up from night to night the shifting thousands of homeless vagrants. (1) The common lodging-houses, maintained, as Dr. Ferriar had said, by the "keepers of fever beds", were the foci of contaglous disease in the district. Here for twopence or threepence a night bed and board were found for the thieves and prostitutes of the neighbourhood, and for the various classes of the tramping fraternity, hawkers of matches and laces, travelling tinkers and umbrella repairers, ballad singers and beggars "on the downright". Mingling with these colourful but disreputable characters were the migrant labourers, seeking work, and driven into this company for want of suitable shelter elsewhere. "Last night I spent entirely in going through all the lodginghouses and brothels in the town", Lyon Playfair once wrote to Chadwick. "I began at twelve and finished at half past four, so I saw a prodigious quantity. Such sights! frequently fourteen in a room, women and men lying stark naked togetherl" (2) The remedy, Chadwick had urged in the "Sanitary Report", was to oblige all lodging-house keepers to take out a licence, and to subject their establishments to inspection by the medical officer of the Poor Law Union. (3) The demand for public control was taken up by the Inspectors in their local Reports. Carlisle, observed Robert Rawlinson, had 72 lodging-houses, one huge forcing-bed for the generation of vice in all its forms. It was in vain, he declared, to erect workhouses, gaols, and hospitals, or to establish penal colonies for the punishment, reformation, or suppression of vice, if these places, the fountain-head of all that was depraved, were left unregulated. "The poor cannot here help themselves". (4)

Hence in 1851 a Bill "was made up for Lord Shaftesbury who got it passed, and whose name it bears". (5) It was an 1. Hansard, vol. 117, p. 1123,24 June 1351 ; vol. 118 , pp. 325 - 37, 8 July 1851. $14 \& 15 \mathrm{Vic}$. cap. 28.

2. L. Playfair - E.C., n.d., c. 1843 - 44; probably referring

3. "Sanitary Report", 1842, p. 365. to Sheffield.

4. Report on Carlisle, p.

5. E.C. - M. Verge, n.d. (18989: 
undeniable success. By the midale of 1854 Chadwick could point to a remarkable diminution in the number of fever cases reported from the lodging-houses of London. Out of a population of 30,000 in the 1,400 or 1,500 houses under inspection, there had been only ten cases of fever, whereas it had formerly been common to have as many as twenty cases in one quarter from a single lodging-house. "Whis with former fever nests, is demonstrative of administrative power, and confirmatory of the reduction of deaths in the model dwellings to less than half the usual average". (1)

Of all the Board's work none has been so completely forgotten as their reports on Quarantine ${ }^{(2)}$; yet Chadwick maintained that if the Board had rendered no other service than the publication of those reports, they would have fully justified their appointment. (3) There is something to be said for this view. Based though they were on a false epidemiology, the reports issued in practical recommendations of the greatest value to the health and well-being of the seafaring population.

The evidence the Board had collected, Chadwick believed, proved without doubt that the plague was no more than an intense typhus, and comprehended it, with choleea and yellow fever, in the category of diseases which were bred amidst filth and overcrowding, and which might therefore be prevented in the proportion that these localising conditions were removed. Bie passed on to the conclusion that the contagionist theory was utterly discredited, and with it the quarantine system which had been erected upon it. The cholera panic of 1831 - 32 had aroused governments all over Europe to unparalleled exertions, 1. E.C. - ? , 5 June 1854. "Reports made to Home Secretary by Assistant Comissioner of Police, upon operation of Common Lodging-houses Act", P.P. 1852 - 53, Ixxvili, p. 525; 1854, xxxv, p. 115. "Papers received by Board of Health, exhibiting operation of Act", 1852 - 53, Ixxvili, p. 553. 2. "Report of the General Board of Health on quarantine", P.P. 1849 (1070), xxiv, p. 137. "Second Report on quarantine: Yellow Fever", 1852 (1473), xx, p. 117.

3. E.C. - T. Thornely, 17 July 1854. 
and the old-style quarantine, directed merely at shunning contact with the unclean, had been given a thorough test. Police cordons, stiffened with troops, had been thrown round infected areas; the sick and their attendants had been isolated, old clothes had been burned, the dead had been buried in special places; in Spain infration of the regulations had been punished with death. Despite all this, in 1832 cholera had leaped from Iondon to Paris, and had attacked 35 out of the 48 quarters in five days, killing 16,000 in the month of April alone.(1) As well then raise a barrier against the wind, it seemed to the Board, as expect to keep out the epidemic atmosphere which brought the cholera by lines of soldiers at the frontier and warships at the approaches to the seaport towns. The true safeguards were not quarantine regulations but sanitary measures. A glance into the forecastles of most merchant ships would reveal at once why the outbreak of pestilence was so often associated with the landing of the mariner. The seamen of the world's greatest maritime power lived in floating cellardwellings, darker, fouler, and with less ventilation than any in a Liverpool back street. Scanty as the statistics were, they indicated without question the steady operation of local causes of preventible disease which made the working life of the sailor shorter by far than that of any other class of labourers. (2) The neglect of "this important and comparatively defenceless class of the community" was shown by the fact that of late years scurvy had reappeared amongst them with alarming force; yet, commented the Board, the special cause of this disease had been long determined, and an infallible remedy for 1. C. Creighton, "History of Epidemics in Britain", vol. 2, p. 830.

2. "Report on quarantine", P.P. 1849 (1070), xxiv, pp. 39 91. According to the Marine Register, deaths from zymotic diseases among sailors in the years 1838 - 48 formed 55.9 per cent. of the total; the comparable proportion for artisans of all ages was 21.5 per cent., and for the upper classes 12 per cent. 
its prevention was a matter of familiar knowledge. (1)

The Board therefore proposed the dissolution of the existing quarantine establishments, and their replacement by sanitary regulations. A ship at anchor, and in communication with the shore, should be regarded as coming within the scope of the Nuisances Removal and Diseases Prevention Act, and dealt with on the same principles as a dwelling on shore. In case of sickness the captain should be ordered to bring a medical officer aboard, who would take charge, and order the cleansing and purification of the ship, the diminution of overcrowding, and the removal of the sick. During the epidemic of 1848 - 49 the Board issued instructions to this effect ${ }^{(2)}$, in the face of sturdy protests from Sir William Pym, the Director General of Quarantine at the Privy Council Office.

If the quarantine regulations were useless to protect the population from disease, then, the Board suggested, the fiscal inconveniences of the system might properly be considered. Frequently the expense of twenty or thirty days' detention of a cargo was equivalent to the cost of the whole voyage home; perishables such as fruit rotted in the holds; the prices of cotton goods were raised 15 per cent. This was a train of argument that Manchester could follow; and when the British Government decided it was time steps were taken to liberalise the quarantine system, it was probably due less to the Board of Health than to the Manchester Chamber of Commerce, convinced, as Dr. Sutherland put it, that "Sanitary reforis and free commerce are synonymous terms, and that filth and restrictions will in future go together". (3)

Spain, Portugal, and the Italian states still elung superstitiously to quarantine, but in the United States, Brance, 1. Lbid., p. 96 .

2. "Special Notification to Captains of Merchant Ships, Steamers and Colliers", "London Gazette", 1 December 1343, pp. $4386-89$.

3. J. Sutherland - E.C., 31 December 1851. 
and Austria, faith in its efflcacy was waning, and there was strong support when the French Government summoned a Quarantine Conference to Paris in July 1851. The chlef British representative was Dr. Sutherland, the Board's ablest and most persuasive medical officer. By the third week of the Conference Sutherland was reporting to Chadwick that he had won over the most influential contagionist in Italy, the representative of Naples, and the delegates were condemning lazarettos root and branch as doing more harm than good in their present state. (1) As they sat at the Affajres Btrangères, discussing Sutherland's proposals for hygienic reforms in the Turkish Empire, they heard the discharge of cannon and musketry as the people of Paris manned the barricades in defence of the Republic. A terrified official rushed in crying that all was lost, and the sentries at the outer doors disappeared ("always a sign of great danger", remarked Sutherland drily), but the delegates, declining the offer of a guard from the cabinet, continued undaunted to discuss pratique and Bills of Fealth while a battle raged in the streets three or four hundred yards away. (2) "The people never ceased to cry "vive la république", reported Sutherland, who had just been to see the havoc caused by Louis Napoleon's cannon, and had had to run before a charge of lancers. (3)

The Conference resulted in a victory for Chadwick's hygienic principles, if not for his anti-contagionist views. Quarantine remained, but much of its ancient barbarity and unreason would in Puture be swept away. The Conference had accepted the recomendation that vessels should be subject to the examination and certification of a port medical officer, who would in effect be the equivalent of the urban officer of Health. "Naval hysiene is declared to be obligatory on all the governments", reported Sutherland," and the Conference has

1. J. Sutherland - E.C. 23 October 1351.
2. J. Sutherland - B.C., 8 December 1851.
3. J. Sutherland - B.C., 3 December 1851.


unanimously adopted the principles of Sanitary reform, by sending my proposals to Turkey and Bgypt, and by expressing a unanimous desire that all the governients should at once set about the sanitary improvement of sea ports and the places adjoining". (1) The die-hard Pym obstinately refused to accept the conclusions of the Conference, declaring that it was impossible to furnish every ship with a Bill of Health. Absolute nonsense, cried Sutherland; "I wish we had one hour of Sir Robert Peel or Iord Palmerston to sweep the whole buzz of objections away". (2) Half a century was to elapse before the quarantine system was finally settled on scientific principles, and the penal interdict of earlier times replaced by the modern procedure of notiflcation and medical inspection, disinfection and inoculation. In the early stages of that development the Board's Reports had a considerable and beneficial inpluence. Translated into Erench and Italian, they circulated on the continent and in all the maritime towns of the Levant and of North and South America, directing the attention of governments to the floating slums of the forecastle, and teaching that clean ships and regular medical inspections were more proof against the spread of infection than naval squadrons or a cordon of inilitary.

The Board's defence of their policy seems to have caused not the slightest ripple on the surface of opinion. Since Chadwick's "Sanitary Report" of 1842 the propagandist efforts 1. J. Sutherland - E.C., 5 December 1851.

2. J. Sutherland - E.C., 4 Auguist 1852.

The Minutes of the Conference were printed by the French Government, but were not made pidblic. For an account of its proceedings, see "The International quarantine Conference of Paris in 1851 - 52", by Gavin Milroy (one of the Board's Medical. Inspectors), in "xransactions of the Society for the Promotion of Bocial Science", 1859, pp. $605-612$. 
of the reformers had shown steadily dininishing returns, as the public mind became saturated with horrors and hardened by reiteration. This latest production of his, flattest and most pedestrian of all sanjtary manifestos, fell dead from the press.

Why should sincere and laborious effort for the good of one's fellow men receive such scant support? Why should he whose life was devoted to removing obstacles to social progress be so hated and so suspect? Conscious of his own integrity of purpose, Chadwick found the problem inexplicable. But there were other facets of his character of which he was less aware. He could not know of the irritation caused by the constant nagging of that voice, always making unpleasant truths uhplessantly obvious, and by that cocksure manner, impatient of a11 opposition, with which he sustained his erguments. In the process of editing and revising by his colleagues, Chadwick's reports were weeded of their querulous personalities and the eruder manifestations of his robust belief that his opponents must be elther fools or rogues, but his manuscript drafts and private correspondence supply innumerable examples. McCulloch reprimanded the Board for the expense of their reports --- was it not because those reports had more than once overturned his opinions as a political economist? (1) W1lliam Napier's creditors closed in on him, and forced him to plee to Brussels -- and the shortness of credit allowed to the explorer of the Surrey sand springs caused "some strong sugpicion, that a hard water interest has been foully exercised against him". (2) Professor Leibig thought that in so vet a country as England liquid manure must be washed out of the soll and wasted; but then Leibig was the patentee of a solid manure. Professors Graham, Miller, and Horfman presented a report to the Government against the soft Parnham water, and in favour of Clarks's method of softening water by chenical means -... were they not 1. E.C. - ? (Jord Brougham), 1 June 1849.

2. B.C. - 1.0. Ward, 1 Juiy 1851. 
chemists? ${ }^{(1)}$ There never was a man more suspicious of $\mathrm{h}$ is antagonists' motives than Chadwick, more convinced that their objections sprang from materialist root, a trade percentage, a family link, or some saug little place. It gave a harsh temper to his mind which rendered nugatory such efforts as he made to conclilate opposition. Whenever he moved towards an accomodation, he never left anj doubt that he felt he was striking a pact with evil things, with greed and ignorance and prejudice.

Seeking the reasons why the Board of Health fell in 1854, we note then Chadwick's inept handing of the diplomacy of Gwydyr House, the difficulty of stirring popular imagination with the tiresome minutiae of sanitary legislation, the combined strength of a score of threatened interests. A further reason was that its well-wisherg were ill-led and weakly organised. There were a few names of national weight and influence, but the political leaders of the sanitary movement were mostiy amiable nonentities. The sanitary movement suffered from its bores. The ilouse rapidiy euptied whenever $\mathrm{k}$.A. Slaney introduced his favourite motion for a combittee to report on practical plans for the improvement of the working classes; and his taik of sickness benefits, old age pensions, and savings banks was met by misterial sionewalling or the retort of some private nember that "he wished the people not to depend upon

1. E.C. - F.O. Ward, u.d. (June 1851): "there is much evidence throughout the report, in orissions and in the shaping of the points, of the operation of a sinister influence in its propagation, which has yet to be disclosed". Ward rebuked hime for the outburst: "I would not run down Clark's process which is a beautiful and quite successful one, nor would I impute a sinister interest to such men as Graham, Miller, and Hoffman. It is quite enough that they are mistaicen -and that we can prove them so, and it is quite enough that Clark's process is unnecessary ....." (26 June 1851).

On a later occasion ward returned some memoranda on the Interments Act with the comment that, while he concurred with their argument, "I strongly advise such charges as those of "maliciousness" anc the other persogal aggressions to be eliminated", since such charges onlJ excited distrust. (11 Miarch 1852). 
Government". (1) James Niackinnon lectured the House regularly and conscientiously on the evils of smoke and Smitherield market and intramural inierment, but even his friends shook their heads over the results. "Mc. hiacikinnon never succeeds. They say he has no tact", P.H. Holland remarked sadiy to chadwick. "he has a great knack at falling". (2) It was a restive team that Chadwick sought to harness to his plans. Shaftesbury and Bbringtion and Southwood. Smith moved under his control; but others did no respond so readily to his insistent rein. Carlisle was too pliable to be relled upon. Joseph Hume again, as the great advocate of retrenchment, co-operated wiliingly in urging model act procedure in place of costly Local Bills; but he looked with misgiving on Chadwick's enginteering the proposed ereation of a paid local bureaucracy throughout the country.

Chadwich bimself erowned upon the organisation of a "saaitary party". Such talk would divert attention from measures to men, would show "how fow they are and how young they are". (3) Had it not been a trick of Leslie and Byng at the Sewers Commission, when they could pick no holes in the measures themselves, to attempt to discredit them as the vork of "Chadwick's party"? - - by which suratagem they detached those members who prided themsclves on their independence of viewpoint and their froedom from party bonds, and, noreover, convinced Walter of the "Times" thot the messures were the product of cliques and cabals. A sense of professional decorum also deterred Chadmick erom becoming the contre of a body of polltical agitators. Thus he told Iord Ebrington "that for myself as a public officer I rust belong to no party, that socially I may move amongst a perty but not be of them. The Board of Health has quasi judictal duties to perform, and it may recelve any support erom any party, but it cannot itself be of 1. Fansard, vol. 109 , pp. $359-375,5$ march 1850.

2. P.H. Holland- E.C., 22 ilarch and 22 July 1846.

3. E.C. - Lord? (Eorington), 6 August 1852. 
a party. Or course no one expects, that privately or socially we may not advocate views, but not as an active nomber of a party, without laying oneself open to observations. I have kept our Inspectors when attacked and our clerks from meetings of the Sanitary Association; and have endeavoured to keep at a distance from them myself. I was somewhat reluctant to appear at the dinners, but was overruled by Ioxrds Shaftesbury and Carlisle on the grounds of purism". (1)

If anything could restore the Board's popularity, it was sn epidemic. Pear vas their most powerful and dependable ally; and, mingled with the anxiety with which they scanned the weekly mortality returns, there was perhaps a repressed hope that they would be called upon, as Shaftesbury put it, to "resume our old "aggressions" (2) Twice already, in July 1850 and in September 1352, the Board had informed the Government that they believed the country was in iminent danger of a return of the cholera (3); but neither the Whigs on the first occasion, nor the Tories on the second, could be persuaded that it was necessary to put the Diseases Frevention Act into operation, together with the additional powers which the Board were demanding on the strength of their experience in 1848 - 49. In September 1353 , however, the cholera appeared unmistakeably in Hamburg; and in a day or so it broke out again in its old haunts in Newcastle and Gateshead. In the first lifteen days of the outbreak 214 deaths were reported from Newcastle, and 1,371 before September was out. The Board's "Choleraic heroes"(4), Joha Sutherland, R.D. Grainger, and Hector Gavin, were promplty in the field. Fearing that their enemies would attempt to oust them from the administration of the Diseases Prevention Act, Shaftesbury wrote $-0-$

1. ibia.

2. Shaftesbury - E.C., 26 August 1852.

3. Alnutes, 19 July 1350, 13 September 1852.

4. Shaftesbury - I.C., 22 September 1853. 
privately to Palmerston.

(1)

At the same time he entreated

Chadwick, "Be very respectful for be assured that the slightest expression will be magnified into a crime by men who are resolved to remove us from our places, and tarnish us in reputation". (2) "Let me counsel you", he wrote again, "to take the most conciliatory tone with the Boards of Guardians, the Treasury, and all authorities; one ground of our unpopularity is, as I have been told, that we were too dictatorial. I know that it was necessary to be so to overcome resistance; but let us be as forbearing as possible". (3)

Chadwick found that he had not misplaced his trust in palmerston, who held the soundest of views on the value of cleanliness and the supineness of local authorities. The Home Secretary advised the Treasury to let the Board bave such additional medical assistants as they considered necessary, and he called for a list of nuisances in the metrdpolis to enable him to decide whother they might be made the subjects of indictment. (4) Whether it was due to Palmerston's support, or to Chadwick's studied restraint, or simply to the chastening fear of a threat so speedily renewed, the atmosphere which surrounded the Board in this latest epidemic was better than in 1848 - 49. The Board's relations with the Collees of Physicians, the Scottish Law Officers, the Customs, the Board of Trade, the Poor Law Board, and the Metropolitan Commission of Sewers, were handled with the greatest caution; and Inspectors who went round to warn the Guardians of St. Olave's and Greenwich of the impending attack reported an anxious desire to co-operate and a readiness to admit "that in 1849 things were left too late, and that the pestilence was fairly down upon them, before they took proper measures". (5) But the Board's

1. ibid.

2. Shaftesbury - E.C., 29 August 1853.

3. Shaftesbury - B.A., 17 September 1853.

4. Minutes, 24 September and 10 October 1853.

5. ibia., 30 September 1853. 
powers remalned what they had been three years before; the same ignorance and incompetence ruled intthe localities; and the filth that had been cleared away during the earlier visitation had long since returned with all the inevitability of a natural process.

"We have had the scourge you predicted, and as you predicted", the Town Clerk of Gateshead told Rawlinson. "The cholera has been true to its character. The dispensary Surgeon told me that he could have stood on a gallery in Martin Dunn's premises in Hillgate, alluded to in the Gateshead Report, and have pitched four beans into four rooms, each containing a cholera corpse ${ }^{(1)} . . .$. . The plague spot is this ... when a sanitary improvement is proposed, it is discussed with reference, not to its necessity, but its expense: and if expensive, however necessary, it is shelved. This has been the case in Gateshead and what are the consequences? Our tradesmen, wholesale and retail, have lost thousands, their customers being afraid to enter the town -- even with supplies -- an enormous expense has been incurred in tending and feeding the sick and burying the dead -- a grievous permanent charge upon the rates for the support of the widows and orphans who have lost their breadwinners -- and the work is yet to do". 1. Fron Scotland William Ijee described another "Haunted Local1ti":

"Dr. Gavin and I have today inspected "Spring Burn", a large Village about three miles out of Glasgow, where Cholera was most malignant in 1831 or 1832. Again in 1849 (see Dr. Sutherland's Reports) and now again, in the very same rows, and in the very same houses and rooms, are the neglected miserable inmates being swept away.

In two adjoining single room tenements, almost new, built within a few years of rubble, with monster dungsteads within about 12 feet distance, five human beings have been destroyed of cholera within the last eight days, and one now lies 111 -........ I valued the property in which these five victims had died at $\$ 60$ for the fee simple. How cheap is human life, when it is not worth the cost of a shelter in which it can continue to exist!" (William Lee - E.C., 11 Bebruary 1854). 
"A movement is on foot for an inquiry", went on Rawlinson, "and I trust it will be granted, in order that the saddle may be placed on the right horse -.- and the absolute necessity for granting larger powers to the General Board of Health may be made fully apparent. The powers of that Board are crippled from a miserable apprehension of interference with vested rights and local authorities, and the General Board is blaned for not exercising powers denied them". (1)

So great was the indignation amongst the working classes of Newcastle, that there was some fear that they would rise and pull down the houses which were the seats of the pestilence.(2) On 8 November the Board recorded in their Minutes their belief that the epidemic at Newcastle had been aggravated by causes which might have been prevented if the local authorities had exercised a proper regard for their Common Law obligations as well as their statutory duties with respect to the public health. "The Board believe that if a solemn and judicial inquiry into the truth of these allegations were made by the public examination of official, professional and other witnesses with the view to the redress as far as practicable of wrongs done and the provision of remedies for the future it would be productive of national advantage".

"It is stated", ran a minute of ? December, "that at Newcastle the execution of complete works would probably have interfered with the interests of a Trading Water Company and that Shareholders of the Company got thenselves elected upon the Town Council to oppose interference, and that they did obstruct the exercise of powers conferred under the Local Act for the public benefit".(3)

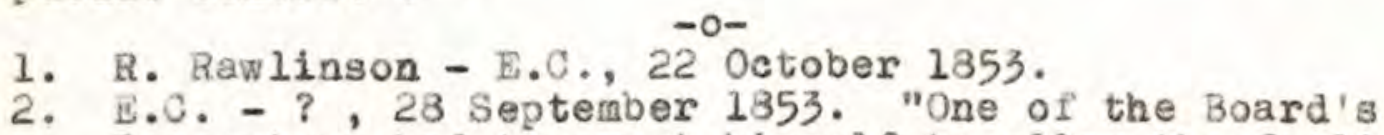
Inspectors had to exert himself to allay the feelings of irritation amongst the labouring classes. Another writes privately that the whole of the houses occupied by them ought to be bombarded".

3. The same minute alleged that at Gateshead a number of owners (Continued on next page) 
The unrest amongst the Newcastle population, the allegations of incompetence against the local authorities, and the rumours of negligence on the part of the water company, could not be ignored in the dangerously inflammable atmosphere of an impending epidemic, and the Government therefore appointed a Commission of Inquiry, which included John Simon, Joseph Fume, and J.F. Bateman. The Cormissioners demonstrated, with nearly six hundred pages of evidence, that Newcastle presented the worst features of the old walled towns, together with added evils of comparatively modern origin. They described the cellar-dwelings, the back-to-back cottages, the increased overcrowding which had resulted when the York and Berwick Railway had been driven through the town; and stated that fivesixths of its houses lacked water-closets or any other form of Paecal house-drainage, and two-fifths were entirely without drains of any kind, even for carrying off the rain. (1) They revealed that the Town Council had neglected to put into force its powers under the recent Local Act till the day after the outbreak reached its climax, and had acted then only upon the instigation of the Inspector of the General Board. (2) They gave it as their opinion that in view of the "great sanitary capabilities of Newcastle", its death rate, which had averaged 28.6 per thousand over the previous fifteen years, was nearly double the natural or necessary mortality, and that a thousand

(Continued from previous page) of small tenements had been elected for the prupose of obstructing the Public Health Act; and at Luton the proprietor of some houses in which firteen deaths had occurred was a nember of the Local Board.

1. "Report of Commissioners on Causes of Outbreak of Cholera in Towns of Newcastle-upon-Tyne, Gateshead, and Tynemouth", p. xvi; P.P. 1854, xxxv, 131.

2. Ibid., p. xili. Cf. B.C.-R.D. Grainger, 14 September 1853: "One line of opposition now being taken is that the powers vested in the General Board by the Public Health Act should be exercisdd exclusively by the local authorities. The reply is see how the exclusive powers possessed by such Boards as the Newcastle Towh Council are exercised, how the powers in respect to cellar dwellings are exercised at Manchester, where the owners of such dwellings, members of town council refused to put the act in force unless they had compensation". 
or twelve hundred lives were unnecessarily sacrificed there every year. (1) But the Commissioners could not prove that the town was much worse in 1853 than in 1849, when it had escaped very lightly; nor that 1 ts administration was more neglectful than that of a dozen other industrial towns where cholera had $n$ not appeared at all. In $1853-54$ as in 1848 - 49 the real cause of cholera remained a mystery ${ }^{(2)}$; and the medical profession was no more agreed upon its treatment, the suggestions published in the press including the use of ice, castor-oil, laughing-gas, charcoal, and mustard poultices and hot mint tea. (3)

By November 1853 the outbreak on the Tyne had burned itself out. A few months later the disease appeared in the capital. But before the epidemic reached its height, Chadwick and his colleagues had fallen from power. Not even the fear of cholera could drive out the hatred which by now gurrounded. the General Board of Health.

1. ibid., p. iv.

2. The Commissioners agreed with the Board's medical Inspector, R.D. Grainger, that the cause was a "general malaria" arising from the neglected and miserable parts of Newcastle (ibid., p. vilt. Snow had put forward his theory of water transmission in 1849 in his pamphlet, "On the Mode of Communication of Cholera", a second edition of which was published in 1854; but forty years later, as may be seen from the sceptical comments of Creighton in his "History of Epidemics in Britain" (1894), the theory was still fighting for general acceptance.

3. "Times", 15 August, 17 August, 25 August, 6 september, 13 October 1853. 


\section{GHAPTER 18.}

\section{THE FALL OE THIS BOARD.}

"I have now been engaged more than twenty-two years uninteraittently for ten or twelve hours a day, with little recess or holiday except on the occasion of 111 health in successive extraordinary services", Chadwick told Palmerston, as the Board approached the end of the tern of office allowed by the 184.3 Act (1) He was paying now the price of that unrelaxing labour. As he entered upon the last half-year of his official career, his reserves of strength, though not of spirit, were seriously lowered by sickness. He had not complately shaken off the effects of a fover which he had caught in the spring of the previous year, on one of his visits of local inspection; and he was further weakened by dyspepsia, brought on by irregular hours and habits, combined with his unresiing mental exertion and anxiety. His medical adviser had varned him that he must soon seek relief frot the exceseive burdes he was shouldering. But as yet Chadwick had no liought that the coming sirusele in Parliament would result in his being thrust into a perpetual and unwliling retirement. The Board of Health, he knew, would be in some jeopardy; there would be harsh things said about himself; and the "Timeg", the ant1centralisers, the fiter Comparies and slum landlords, the bone1. E.C. - Lord Palmerston, 31 Gay 1854.

2. "lust year 1mediately after a visit of local inspection wth my colleague Dr. Southwood Smith and one of the Superintending Inspectors, two of us, the Inspector and myself were attacked with fever. This was the second fever I have had after local and public exuminations. With me the last was dangerous, and i have suffered so severely in my seneral health that $I$ an advised that on that account I should seek some early relief of anxiety" (ibid.) 
boilers, and all the rest of that noxious alliance, would take down their weapons for the attack. But he rested his faith in a powerful and well-disposed Home Becretary -.- and also, because he was a simple man, in the merits of six years of valuable and conscientious labour. A few months" rest; then two years more at the Board of Health; and after that he might pick up and unravel some other thread of the social tangle, education, perhaps, or police or factory regulation. With some such programme in his mind, he faced with fair confidence the debates which were to decide his future. (1)

It was Palmerston's intention to introduce a Bill by which the Public Health Act should be extended for a further two years. The adrinistrative machinery at the centre, however, was to be changed, in view of the weakness which had revealed itself in the past six years. As he explained, on the second Reading of his Public Health Act Amendment Bill, to all intents and purposes the Board was an independent body, not controlled by any department, nor represented by a responsible organ in parliament. At present it was no more bound to obey the orders of the flome Secretary than was the Navy Board or the Victualling Department. He proposed therefore to make it a oranch of the Home office, giving the secretary of state the power to appoint and remove its members and to issue orders and directions to there. (2)

Thus, by putting the Board under ministerial control he hoped to remove the ground for the charges of arbitrary and irresponsible conduct; and by bringing the department under the - 0 -

1. "Gor myself my anxious wish is to serve with Lord Shaftesbury for the somplete practical application of the new principles of works for the improvement of the Public Health in a sifficient number of tows to esteblish them sufficiently safely and clearly for others to continue. My next desire is so to husband my remaining shattered strength as to be of any further public service with bin and your cordship if possible, in the advancement of the general physical and moral condition of the population" (ibid.) c. Hansard, vol. 135, p.p. 973, 974. 31 July 1354. 
protective wing of the Home Secretary to give it effective means of defonding itself in the Commons. This arrangement, it became clear at once, would not sstiefy the oritics of the Board. Judging that the Fone Secretary would exercise no real control over the Bonad and would hold no reel responslbillty for its actions (1), they demsnded that the department should be reconstructed on the lines of the poor law Board, with a new Minister, a Presldent of the Board of Heolth, at its head. It was a sound solution, pointing the way to a healthy constitutional development of the new depertment; and in this respect the critics were right, as Chadwick from the first had been wrong. But the debates of $185^{4}$ did not turn solely upon this point. In pursuing their object the advocates of a Ministry of Health poured undiscriminating abuse upon the men and measures of the General Board. Their victory would bring with it not only an end to the defective administrative structure set up in 1843, but also the expulsion of the three reformers of Gwydyr House and a general condemnation of their policy. Chadwick saw much reason to distrust a scheme the chief sponsor of which was Lord Seymour, behind whom were ranged the representatives of the manifold interests affronted by the Board. Was it to increase the efficiency of sanitary administration that the proposal was made --- or to cail a halt to the activity of himself and his colleagues? As he remariced to Russell, the change at the Poor Jaw Board, which was referred to as a favourable precedent, was thought to work well because no complaints were heard; but though there was somewhat more of

1. "The effect of the proposed control yould be simply this --that when a srievance came before the Secretary at the flome office he would write on the corner of it, "Remonstrance -for the opinion of the Board of Health"; and the Board would send in an elaborate Repont to the Noble Lord, wich the Soble Lord, according to his own announcement, would not waste his time in readins; and the Board would then act as before, except in cases where the parties agsrieved were in a position, by themselves or their representatives, to make a light against the Board: (Segmour: riansard, vol. 135, p. 990,31 July 1954). 
quiet in the House, it was at the expense of progress in the office. (1)

It wes a determined and brilliant attack which Lord Seymour eikxrea launched in the Commons. Into two speeches, compact with ridicule and contempt, he contrived to compress all the criticisms which at one time or another had been levelled at the board, garnishing his argument with personal details which gave it a convincing ring of authenticity. These speeches, delivered as they were with the athority of a former president of the Board, blasted their hopes, threw consternation anongst their friends, and swept the waverers into the division lobbies against the Bill. No stronger proof was needed of the want of isome one to represent the views of the Board of fieal th in Parliament than the way in which the ex-president misrepresented them almost without contradiction in these pinal debates.

The first attack was delivered on July Sth, on the Bosd's supply vote, a notion by Palaterston for 11,355 to defray their expenses for the next finazcial year (to 31 March 1855). (2) Lord Seymour st fnce objected to the srat of money for the maintenance hich, instesd of carrying out sanitary measures, had made sanitary neasures vapopular, since, under its rule, they were brought $i n$, not by the free will of the people, but by the despotic interference of the central Board. Sir William Holesworth had quite properly refused to be responsible for the proceedings of a Board of which be was only an individuel member, whose opinion might be overruled by his colleggues.

When he was bimself at the Board of Works, and, after compunicating with the other lembers of the Government, had made a communicstion to the Board of Health as to the course which he thought they should adopt, he was told that his proposition was not seconded -.. that the members of the soard knew nothing of 1. H. . - Ruese11, 27 Juit 1854. 2. Hansard, vol. 134, p. 1295, 6 July 1354. 
what the Government might wish; they only knew that, at their Board, the proposal was not seconded, and it consequently fell to the ground. Was that the way in which public business was to be conducted? Were they to be called on to vote money for the maintenance of a Board which carried on its proceedings in this way, and set the Government at defiance? The only way to brins these gentlemen to resson was just to stop their salaries

He next turned his scorn upon the superintendins Ingpectors and their local Reports. "He had himself visited a town imrediately after a Report of that kind had been sent in, and having taisen the feport in his hand and tested by personal examination the statemants which were made in it, he had no hesitation in declsring that a more exaggerated Report he had never read. The invariable recommendation of the inspector was, that the towns which they were sent to visit should be brought under the Board of Health; and what did the Board of Health do in return? Why, they stated that the inspector had devised a very beautiful system of drainage, and that he had better be allowed to carry it out; and if the town did not adopt this advice, and did not employ the inspector, there were such hindrances or difficulties thrown in its way that it soon bitterly resented it. Ine fact was, that the inspector brought in the Board, and then the Board brought in the inspector". Afier a dig at the Board's engineering theories ("utterly denied by the best engineers of the metropolis"), he described the report which they had published in their dePence as "almost an indecent thing to have been sent out by a Government establiahment", being full. of conclusions "arrived at by the Board of Hesitin, but denjed by everybody else". He concluded by remarking how complaints of the Pour tava administration had cessed once Chadwick had been removad. (1)

Seymour was heartily seconded by Bir benjanin Hall, the - -

1. Hansard, vol. $134, \mathrm{pp} .1298-1300$. 
member for Marylebone, who thought that the best thing the Government could do would be to give Chadwick and Southwood Smith their money and dismiss them. "The Chief Comissioners, In succession, had found it impracticable to control the mischievous vagaries and extravagances of these two persons, and the only remedy was to get rid of them altogether". And Chadwick in particular, who, after being removed from the Poor Law Board for his "rules of atrocious stringency", had "concocted a pamphlet" on sanitary subjects, on the strength of which he had manoeuvred himself into power at the Board of Realth. "He himself was quite at a loss to know what services this man had rendered to the community". (1)

It was now plain that palmerston was to have no easy passage for his Anendment Bill, which he introduced on July 10th. (2) In the days that followed the opposition interests mobilised their strength, and, in the ignorance or indifference of the mass of the Commons, the critics increasingly dominated the debates. "The lobby was crowded, with the water engineers at the head of whom was Hawikesley, and with Parliamentary agents, and with parliamentary counsel cnavassing against the measure", Chadwick told ward on his return from the House on July 18th. "Only one petition was heard against the measure: on the other side we had to lament that there was none for". Almost to a man, he informed Russell, he knew the causes of the Board's unpopularity with "the minority called the house". That member, for example, who rose to denounce their proceedings as interference with self-government, was a factory owner, whose chimney poured forth soot on 811 about him. (3)

I1-health unfitted Chadwick for the strain of combat.

\footnotetext{
1. Fiansard, vol. 134, pp. $1301-7$.

2. Hansard, vol. 134, p. 1417.

3. "Parliamentary Presidentship. Notes of draught letter to Lord John Russell on the new Public Health Board arrangements", MS, n.d.

4. "I have scarcély physical strength since my last lancing (Continued on next page)
} 
Weak as he was, however, he mustered his energies to repel the attack, pouring out hastily drafted notes of appeal to his Parliamentary acquaintances. It was the fag-end of the session, and few of his political friends were in town. (1) There was Lord Lansdowne, for example, who might make an effective reply to the anti-Poor law cry which had been raised. But Lansdowne was off to Stoke Park, whence his testimony, if it came at all, must come too late. (2) Scarcely a man with political influence had paid attention to the subject, and there was no time now to coach them in even the elements of sanitary administration. Desperately Chadwick looked round for a spokesman in the Commons. He appealed to Sir George Pechell to refute the charge that he had made the Poor law unpopular and had been dismissed from that office in consequence, reminding Pechell that in the Andover debates of 1846 he had supported the vote of censure on the Commissioners. (3) The Board would be entitled to public support, he suggested to the $-0-$

(Continued from previous page) to bear up against the wrong". (E.C. - F.O. Ward, II July 1854). J. Hodgson, his physician, wrote to Shaftesbury, 28 July 1854:

"The health of our Priend Mr. Chadwlek has for some time been a source of much anxiety to me, and the state in which I have recently seen him induces me to trouble you with a short statement of my opinion of the causes and probable effects of those 11 inesses froa which he has suffered.very

In the spring of last year I attended him during a/severe attack of Erysipelas of the Head by which his life was greatly endangered. This was brought on by exposure to cold in making inquiries in the country relating I believe to the Water Supply of London and was aggravated by a condition of great mental exertion and anxiety. On various occasions I have attended him on account of derangement of his digestive organs caused by irregular hours and habits arising from the peculiar nature of his avocations and engagements. During the last week I have found him suffering from one of these attacks and in a condition which caused myself and his other (Continued on next page)

1. E.C. - F.O. Ward, 11 July 1854.

2. Lord Lansdowne - K. ., n.d.

3. B.C. - Sir George Pechell, 12 July 1354. James Heywood replied on behalf of Pechell, 20 July 1854: Sir George thought Chadwick had been ili used in the old Poor Law eommission, and "has quite a wish to take jour part". 
Wolverhampton member, T. Thornely, if it had done no more than Its laborious investigations and reports to convince the medical authorities of the Continent how baseless and useless was quarantine with its obstructions to cominerce which cost Ingland alone upwards of two millions a year. (1) The bitter personal hostility he had aroused, he told Hume, was due largely to the complebe practical demonstration he had made of Hume's own proposals for reducing the expense of private Bills.

"You have now known me at intervals for a very long period", he wrote to B.B. Lytton, "and whatsoever weaknesses I may have I trust you will belleve I could not have acted in so foolish a manner as to set at defiance a Government, and prevent my chiefs from attending to perform the duties of his office and move illegal coercion or violence towards towns. But if you were to believe I really had done anything deserving of dismissal, I trust that you and your friends will not set the example of a condemnation by acclamation, that you will give us the benefit of the lowest criminals, and ask to have the offences distinctly stated, and proved, and to allow the accused to answer before a Committee if no other competent tribunal ... ... It is declared however that we are universally condemned: that on account of our proceedings the public and the house condemins us. Now the house is I really believe a few members and the public Mr. Walter of the Times, the views of whose $-0-$

(Continued from previous page) Friends much uneasiness, knowing as we did how deeply his mind was agitated by the

discussions in Parliament and elsewhere relating to himself. I have felt so much alarm on the score of his health on wore than one occasion as to induce me to advise him to seek some alteration in his position which would relieve him from part of his constant and laborious exertions in the public service and I hope that your Lordship will excuse me for thus making my opinion on this subject known to you, believing as I do that the labour and deep anxiety which our priend has so long endured cannot continue without producing serious evil both to his bodily and mental powers".

1. E.C. - T. Thornely, 17 July 1854.

2. B.C. - J. Hume, 23 Julg 1354. 
engineer I could not promote

Save an occasional polite acknowledgenent, Chadwick had little to show for these attempts to touch the public conscience of his correspondents. He relied too much on arguments in detail, which might convince a man on one point, or convict him of an error in fact, but could not convert him to a principle. While, with his passion for legal exactitude, he was worrying how he could tell members of Parliament what really happened at the Board of Health on that eventful January 30th 1851, they were exercised about such general questions as the limits of central control. There was Newdegate, for example, who thought it "at best a sometimes necessary evil". "I think it destroys self reliance, and prevents individuals of good capacity in their several spheres exercising that amount of independent authority, subject of course to law and the public opinion of their localities, which affords the only inducement to persons in the midale classes to act upon some more generous principles than those of mere self interest; I fear nothing more than the loss of public spirit, and this is the effect of Centralization". And so, he informed S.H. Gael, he found it impossible to speak in support of Mr. Chadwick, the arch-centraliser. (2)

What particularly exasperated Chadwick was the charge that the Board had made itself unpopular by its interference and tyranny --- the Board, which had always been ready to assist the newly formed local authorities with all the technical skill and information at its command. It hardly showed want of confidence, he suggested to the member for Droylsden, when his constituents asised that Mr. Chadwick should go down and give them advice on their works. (3) He sent appeals to the more 1. E.C. - I.B. Lytton, n.d.

2. N. Newdegate - S.I. Gael, 24 July 1354.

3. E.C. - Charles Hindley, 9 July 1854.

"You some time called upon me and asked me to fo down and see the people at Droylsden, to speak to them in relation to their works. You mentioned to me that they preferred to see (Continued on next page) 
progressive Local Boards, to Woolwich, Hull, Penzance, York, Preston, and Lancaster, urging them to inform their members and Lord Palmerston of the friendly and helpful nature of their relations with the central Board. (1) He received a sheaf of testimonials in reply. "Where would our Sanitary affairs have been had you remained quiescent or willing to accommodate yourself to ignorance and prejudice?" asked the Rev. J. Clay of Preston indignantly ${ }^{(2)}$; and he wrote a few days later to tell

(Continued from previous page) engineer or an inspector of the Board.

I have similar requests from other places which I am uhable to comply with. Several places which I could not visit in Lancashire have asked me to recommend to them an engineer.

Now whilst I am personally attacked in the Bouse, by Lord Seymour, and Sir Benjamin Hall as creating unpopularity to the law, and as having no confidence, when in truth upwards of 200 cities and towns have petitioned for the exercise of our jurisdiction would it not be an act of justice to me, to mention in the House, the fact of the application to me from Droylsden if it be as I understood, as shewing that the want of confidence is at any rate not universal".

I. E.C. - William Dunn, 14 JuIy 1854; Rev. Heary Brown, 20 July 1854; 3.H. Rodd, 21 July 185;; George Leeman, 22 July 1854. The first of these may be taken as an example:

"Whilst we are accused of coercing Towns, it is rather too bad that Members who know the fact to be otherwise as regards the towns which they represent do not state this.

Might I suggest to jou that you would request $r$. Greene when you write to him, that he will just simply state in the house on the occasion of the second reading of our Bill, just what you have kindly stated to we, that be it as it may with other places we have endeavoured to render you every assistance. You will be aware that from local connexion I had endeavoured to promote its improvement before the Public Health Act had passed.

He need not advocate the Geaeral measure, or enter into it but in two sentences only state the fact as to Lancaster, in which facts $I$ apprehend the town council must concur as a simple matter of truth."

2. Rev. J. Clay - E.C., 12 July 1854. He enclosed a copy of a letter which he had addressed "to each of our members":

"I have seen with much regret that the Conduct of two of the Comissioners of the General Board of Health has been severely commented on in "the House"; and that the Board has, more especially, been charged with unduly coercing the (Continued on next page) 
Palmerstion his opinion that "by acting, to the best of our power, on the suggestions and advice of the General Board -- we have -.. under Providence --- hitherto escaped that terrible disease which has severely visited some lowns remarkable for their resistance to the recommendations of the General Board". (1)

"I have been amused with the rabid attacis made upon the Board of Health by Lord Seymour and Sir Benjamin Hall", wrote William Dunn of Lancaster. "There is a great prejudice, arising, as it generally does, from 1gnorance; but sanitary improvement is too important and the Board of Health has done (Continued from previous page) Local Boards.

I had the honour in 1843 to report on the Sanitary State of Preston, and since that time, have watched the proceedings of our Local Board with much interest. I have had good means of knowing that in carrying out their very extensive Improvements, they have, from first to last, been able to act in Complete Harmony with the General Board. To be more fully assured to this I made inquiries this morning from some of the gentleinen who take an active part in the proceedings of our Board, and have had my impression fully confirmed. Mr. Miller, whose great influence and high character are well known to you, informed me that he had never been aware of any other feeling between the General and Local Boards than that which is founded on the best understanding. Dur lown Clerk ..... placed in my hands a copy of a letter which he had occasion to write to you (Nir. Parker) in June 1852 ... in which he says -.. "Great outcry has been made in some few places against the interference of the General Board of Health. The Public Fealth Act has now been in force at preston about two years and we have no reason to complain of their interference. They have always been ready to give us advice and assistance".

Mr. A. adds that since the date of his letter the proceedings of the Local Board have greatly increased in magnitude; and that, on every occasion, the two Boards have worked tofgether in the most cordial way ....."

After quoting a similar tribute from the engineer of the local Board, the letter concludes: "Under these circumstances I venture to hope that as an act of justice to the General Board and the gentlemen chiefly connected with its management, you will think it right to take an early opportunity of stating to the House that, as regards Preston, the very extensive and beneficial measures carried on by our Local Board are quibe incapable of justification" (sic).

1. Rev. J. Clay - Palmerston, 22 July 1854. 
too much to promote 1t, to be put down by such wholesele accusations; and I trust the parties will defeat their own object by their excessive violence, Speaking for Lancaster I know we have much reason to be grateful for the ready advice and assistance we have always recelved from the Board upon all occasions". (1)

The letters were comforting, but they had little echo in the Commons, where more attention was paid to the member for iotnes or the member for Marylebone than to some small-town engineer or the obscure chairman of a provincial Board. There were upwards of a hundred members, Chadwick estimated, who knew that as regards their own places the charges of coercion were false, yet said not a word to vindicate the truth. Barnard Castle, Ormskirk, Penzance, Wakefield, Woolwich, wrote strongly to refute the accusation, (2)ut Chadwick was annoyed at the silence of most of the Local Boards. He heard later that fourteen of them, and probably more, kad spontaneously adopted resolutions and sent them to the Home office. (3)

As the end of July approached, Palmerston faced the possibility that he might lose his Amendment Bill. One sacrifice might save the Board, he thought -.- Chadwick's head. When the suggestion reached Shartesbury's ears he wrote at once to offer his resignation, telllag palnerston that he must be $-0-$

1. William Dunn - E.C., 13 July 1854.

2. J.A. Kershaw (Ormskirk) - Lord? (Palmerston), 20 July 1854; Ihomag Darice (enzance) - E.C., 22 July 1854; George Tanday - B.C., 26 July 1854 (wakefield).

"Nothing can be more unjust than the charge of co-ercion if I am to judge of the conduct of the General Board of Health to this district ...." (George Brown(Barnard Castle) - B.C., 12 July 1854).

"All the Nembers present agreed with me in thinking, that so far from having reason to complain of attempts at coercion, or of unnecessary interference, on the part of the Gereral Board, we were most indebted to the Commigsion, and their officers, for thelfuniform courtesy, and readiness to afford us all the advice and assistance in their power". (Henry Brown (Woolwich) - E.C., 27 July 1854). 
held equally responsible for the conduct of the Board; "nothing of importance has ever been decided at the Board to which I have not been a party". (1) With a majority of new members on the Board, thought Shaftesbury, the hostility of the public night be somewhat abated, and Palmerston might thus be able to retain the services of Southwood Smith during the cholera epidemic. But the Doctor loyally followed his colleagues, being reluctant as Chadwick told Russell, to act with persons whose vilews and habits were unknown to him. (2) When Palmerston rose, therefore, on the Second Reading of the Public Health Act Amendment Bill on July 3lst, he held in his hands the resignations of all three members of the Board. Whether or not they took effect would depend upon the outcome of the debate.

Lord seymour now delivered his second and more damaging attack. (3) He dismissed in glighting terms the Board's work over the past six years. For London they had recommended "such supply of water as could be scraped out of the sand of the Surrey hills"(4); the Metropolitan Commission of Sewers had resigned in s body rather than adopt Chadwick's tubular drainage; the Board's reports, printed by the thousand, merely embodied the preconcieved views of three or four prejudiced men. The Metropolitan Interments Act aroused his particular contempt. They had spent eighteen nonths and much money in collecting information, "or what purported to be information", on the interments question, the upshot of which was that no one was to 1. Shaftesbury - Palmerston, 27 July 1854.

2. B.C. - Russe11, 29 July $13 \pi 54$.

3. Hansard, vol. 135, pp. 930 - 994. Chadwiek drew up a memorandum robutting Seymour's argument point by point. parallel passages from this document are quoted in the following foot-notes.

4. "The evidence on which the Board founded their advice was a larger mass of important information than had ever previously been collected on the same subject. It was circulated to all the Locul Boards and to Surveyors, and has been sought for by Engineers as a standard elementary work on the subject of the conbination of the water supply and the drainage ....." 
die but the Board were empowered to pounce upon the body. "All the ordinary feelings of mankind were to be set aside, all the tender emotions of relations to be trampled upon, all the decency of mourning, all the sanctity of grief to be superseded, in order that the Board of Health might set their funeral fee". (1) The Act had been passed largely owing to the popularity of Sir George Grey, who had asked him personaliy to see that there was no delay in putiing it into operation. "He had, accordingly, determined, at much personal inconvenience, to remain in town during that autumn, in order to carry out his right honourable Friend's wishes into effect, and bad taken no vacation whatever, with the exception of a few deys at a time, which themselves were spent in visits to places where the Act was to operate ${ }^{(2)} . .$. ... After Dr. Smith had been a fortnight in office, he went to the Board to hear what theyr proposed and were prepared to do. He asised them, "Well, gentlemen, have you got into order? and if so, what are you going to do? Have you made up your minds as to what shall be your first step?" "Oh, yes", said these gentlemen, "we have made up our minds what we

1. "Now if ever there was an official investigation in which the ordinary feelings of mankind previously overlooked the decency of mourning and the sanctity of grief were considered, it will be acknowledged on the examination of the reports on the subject by impartial persons to be the lietropolitan schene of extramural sepulture.

h great living writer speaks of that report emphatically as an honour to humanity. The measure by which Lord Seymour superseded it was one which after the feelings of mankind and the peculiar sufferings of the poor had been displayed, and provided for sets them aside scornfully and tramples upon them".

2. "Now the whole of this is at veriance with the truth. He declared at the first and at all times that he could not attend; be moreover avowed to the Members of tho Board that his rule was never to act until he was obliged, and then to do as little as he could. He acted in accordance with this declaration, and not in accordance with his promise to Sir George Grey to expedite the matter; be did not attend the deliberations of the Board, he made no offer to take part in them, though it was his right as well as his duty to do so". 
shall do". "What is that?"

"Woll, we're going to Paris"

... and the Board accordingly went to Paris, taising their secretary with them to write their lotters and pay their bills". (1)

on their return, he had objected to the emplogment of Paxton and Dr. Brown, and had felt his objection justified when the Exchequer had remonstrated with the Board for "determining upon expensive arrangements altogether without the sanction of the reasury". (2) He had not attended all the meetings of his colleagues, who were in the habit of holding boards every day

1. "It was not the first stept of the Board, and he was never told that it was the first step. The first steps were taken imediately the Royal assent was given, and they are stated in page 1 of the printed Minutes laid before parliament. Whilst the large measures therein recited, and in other Minutes from the 5th of August to the 4th of September were in progress, it was requisito to make other preparations for the work in hand......

"fo collect information upon which to las down a plan in outiline for legislation is one thing; to get information to fill up the plan in detail for subsequent practical execution is another and even more important step ..... The Board considered it necessary that they as well as their chief officers, who were chargedwith the executive measures should see with their own eyes the practical working of a change of systein which had been in operation for a number of years in the largest capital in Burope, and they had moreover important questions to determine, which they considered might be the most economically determined on the Bpot" ( $\mathrm{E} . \mathrm{S}$. the pedicil considerations involved in the removal of the remains of those who had died of contagious diseases, and the protection of the survivors). had taken an account of the Board's expenses on this trip to the Exchequer, he had done so without informing the Board, and he had neglected to point out that the $\$ 400$ spent was a raeans to a very large economy, not less than a quarter of a million on the cost of funerals in London.

2. The Board had thought of seeking the advice of Paxton on the vegetation and pay out of thier National Cemetery; and had consulted Dr. Braun in order to avold those violations of taste in monumental decoration which made some burial grounds "mere stone quarrieg". "This recourse to the highest available talent is sneered at by tord Seymour who speaks as if the subject in hand were coumon churchyards, as if noreover in his view they required no special care". "The only expense incurred was $\$ 20$ for one report from Dr. Braun on several of the trading cemeteries 
for some three or four minutes per diem. But he had gone to Gwydyr liouse on January 30th 1351, to tell them what steps the Treasury thought they should take to carry out the Interments Act. "The Board read to him a long letter of seven pages, which they had prepared, and in which they arzued the point with the Treasury". And flnaily they had told him that his proposal was not seconded. (1) True, Tord Shaftesbury had since denied that this was what had occurred; but "Lord Shartesbury, speaking upon his honour, spoke, it was to be remembered, upon the information of the secretary -- not having been himself present on the occasion -.- whereas he (Lord Seymour), having been present, spoke from his own recollection". After this episode, "he had ceased to attend the Board when he had found by experience that it was to no purpose that he atiended a Board $-0-$

1. "This statement is so couched as to inply a aiscepresentation to the house; nanely, thet the Board were about to proceed with the execution of a new scheme new and unauthorised by the Government, and unsanctioned by lasliament, whereas the grounds for their measure had been submitted with all the evidence to the Government and to the public. The scheme was fully considered by the then Secretary of State, Sir George Grey, who heard the objections made to it by deputations from undertakers, vestrymen and others and decided against them. In the Act provision was made for the purchase of the whole of the trading cemeteries. The duty which remained to be periormed was to comply with the provisions of the statute, the passing of which was made the subject of congratulation in Fer Majesty's speech at the close of the session. The course which his Lordship thought fit to take whether at the instance of the Chancellor of the Exchequer or upon his own suggestion was against the known intent of the statute. On the grounds stated in the letter to the Ireasury by which the Board would abide the plan proposed by Lord Seymour was absurd in itself and on the consideration of those grounds was rejected by the Treasury whp after seneral moths of time money had been lost and evil had been protracted by Lord Seymour's opposition agreed to the Board proceeding with the ineasure according to their priginal report.

Chat whilst the Secretary of State for the flome Department and the Government were in favour of the plan the reasury was against it was early intimated and clearly made manifest. It was indeed early intimated before the Chancellor of the Exchequer's objections were received that the scheme sanctioned by Parbiament would not be allowed to work". 
where he was systematically overborne, while he could occupy his time to really useful public pumposes in bis own office". He had told Shaftesbury his decision: and "1f he bed said this to the noble Barl in confidence, his confidence had been much misplaced, for the noble Eanl had taken the very first opportunity of publishing what he had sald, when he thought he could bring it out to damage his character". (1)

Curning next to the Board's conduct in the localities, he asserted that it was against the principles of the constitution for a petition from one-tenth of the ratepayers of a district to $-0-$

1. "160 Boards took place which he never attended, until on one occasion when he aid attend, when a measure wbich he proposed, was opposed sot by $k x$. Chadwick but by Lord Shaftesbury ....

The members of the Board severally declare that the business of the Board never was conducted in such a way as Lord Seymour represents, that they axe unavare of ever having received any comunication from the covernment through him as a conwunication or expression of a wish of the Government in the manner representied, and that they entered very fully into every proposition he made with a desire to its adoption. In respect to his being told that he had no geconder, the recollection of every one present was consuited at the time he made the statement, and every one was then prepared to affirm that they remembered nothing of the kind taking place and believe that he never was so told. The only pretext for such a statement was an entry made in the minutes, which the seccetary stated he made himself believing it to be the conmon fom, but that he never heard Iord Seymour told that bis motion had not been seconded.

As he had taken no part in the preparation of the law, Lord Seymour was uneware of its difficulties and if he had consulted the Government as he now states he could not have informed them correctly for on the opposite course to the one he proposed on the particular occasion to which he refers being submitted to the Govemment from the Board with the notice that he was dissentient it was approved by the Governuent.

An no occasion did it happen to Mr. Chadwick or Mr. Southwood smith to move to set aside any propositions made by ford Seymour. Fhey on all occesions endeavoured to treat him with the respect tue to his office and position, whilst they had to pass over gratuitously offensive behaviour on his part towards themselves which in one instance lord Shaftesbury considered ought not to be oassed over, and made it the subject of a remonstrant correspondence and resolutioh 
bind the rest. Horeover, opponerts in the locelity had no power to test the genuineness of the signetures, and, in fact, the Inspectors refused to allov the inhsbitants to see the petition. "The jobing of the Board of Health presented an emount of dirt which wust be very starting to the clean party in question ..... The whole thing was perfectly monstrous. Some engineer whom no one else vould employ, or some medical man whon nobody would consull, would be anxious to have the Health of Towns Act applied to his district; he would then get a few signatures, and would send up his impartial suggestion that a particular place could not get on without the interposition of the Board; the Board, jumping at the suggestion, would forthwith send down one of its elect inspectors, equally craving employment, who would, on arrival at the luckless place of his destination, place hireelf in communication with the doctor or engineering adviser, who being the person who had communicated with the Board, would thus have acquired a locus standi; the united pair would then consult with the surveyor of the local board, whose opinion, seeing that he could only be renoved by the contral Board, would be sure to take only one direction, and, by this combination of powers, the principle of self-Govemment was utterly violuted under the constitution of the Board".

It is interesting to speculate on the working of seymour's mind when he made these assertions, each with its small portion of fact econowically admixed with a large amount of obfiquity and suppression. In his limitacions and aasumptions seymour is a type of a large and influential class, who, then and since, opposed the progress of suciul reform. There is no need to postulate any deliberate ralsehood, any planneo and cold-biooded murder of the truth. It was not that be consciously cut and selected facts to suit bis purposes; but rather that, like iron filings in a jagnetic field, facts were vent and patterned by the pull of a strong mind set in decided 
courses. The whole tone of his thought was opposed to the Board of Health and what it stood for. A long process of conditioning by personal contacts in family and political relations had bred in him an aversion -.- so far removed from the sphere of reason that it might be termed instinctive --- to the idea of interference with the business of the governing classes, whether that business was in the form of commercial undertaking or of local and central administration. He hated state intervention, andetrexs "the interfering with everything and everybody" as he called it ${ }^{(1)}$, and at the Board of Health he found himself associated with men who looked on such intervention as a duty. It was intervention, moreover, in matters whose importance he lacked the knowledge and the sympathy to appreciate in full. The technicalities of sanitation, the subject matter of sanitary investigation, were foreign to him; and, because foreign, diverting. He could scarcely repress his derision at the thought of a Board solemnly discussing the dimensions of earthenware sewer pipes or the construction of Reception Houses for the corpses of the poor. And, finally, he detested the members of the Board. They were enthusiasts. They stuck out for principles when they could have had an easier time by listening to the Treasury. Like one of the worldly wise at a revivalist meeting, he was bored by their lecturing, resentful of their assumption of moral superiority, uneasy in the presence of their earnestness.

There was no one in the Commons sufficientiy informed. and sufficiently convinced to stand up to Seymour's onslaught. Many who heard bim must have believed, like historians of a later generation, that he "spoke with authority because he had at one time been an ex officio member of the Board". (2) Sir

Willam Molesworth, the Board's official spokesman, did not open his mouth in their defence; and, if he had been willing, he knev 1. Hansard, vol. 135, p. 990,31 July 1854.

2. J.L. and B. Hammond, "Lord Shaftesbury", p. 166 
nothing about the subject. When Shaftesbury rose to make his reply in the Lords, it was many hours later, after he had had time to see the reports in the "Times". After Seymour's first attack he pointed out that Seymour had put in no more than seven appearances at the Board, and that it was on the sixth of these that he made his proposition about metropolitan interments ${ }^{(1)}$; the impression given by Seymour that he had been driven away by the constant opposition of Chadwick and Southwood Smith was thus shown to be almost entirely without foundation. The Lords gave him a sympathetic hearing when, after Seymour's second speech, he declared "there is hardly an assertion which might not be met by as flat a contradiction"; but it had little effect on the Commons when he quoted the letter in which Seymour had stated that he would be unable to attend the Board without neglecting his duties at the Woods and Forests; or when he showed that the average attendances at the Board were not three or four minutes, but five, six or seven hours, even ten during the cholera, and that his hard-preseed colleagues were obliged to take some of their papers home at night. (2)

The crucial debate of July 3lst, therefore, was a victory for Lord Seymour. A storm of hate and indignation burst over Chadwicis's head. Before th fury of that general condemation even his friends hesitated or were silent. (3) His great

1. Hansard, vol. $135, \mathrm{pp} .236-3,14$ July 1854.

2. Ibid. . pp. $1079-83,1$ August 1354.

3. A letter of apology for the harshness of Joseph Hume's speech was addressed by Maria Hume to frs. Chadwick (3 August 1354):

"I assure you we one and all much regretted it when we saw it reported next day in the papers, and exclaimed aguinst him for having so spoken, and the more so, becsuse we all know, that however he may have disapproved of itr. Chadwicis's management in the Board of Health, he always allows, that he has been a zealous and industrious public servant, and deserves well of the public ..... The only explanation of his apparent unqualified condemnation is to be found in the circumstances of the moment: it was towards the close of the debate, the House very impatient, great (Continued on next page) 
public services were forgotten in an unreasoning gesture of revalsion. (1) He was the bureaucrat and centraliser, who had sought to confine the liberties of the individual within the strait jacket of a system; the ambitious careerist, perpetually intriguing for greater power and crushing without pity all who opposed his will. (2)

The legend was now complete. And though $-0-$

(Continued from previous page) fear of loging the Bill, which Mr. Hume was very anxious to avoid, and the feeling of the House being strongly against $\mathrm{kr}$. Chadwick (you will not be offended at my telling this admitted fact) Mr. Hume thought that the assurance of $\mathrm{his}$, and one or more of his colleagues', removal, and an intention to reconstruct the Board entirely might induce the House to pass the Bill. He no doubt should have named others as well as Mr. Chadwick, and have qualified this implied censure with an expression of his more favourable general opinion, but in the hurry of the moient this escaped him - - and truly sorry we a.ll are that he should therefore appear before the public as the special opponent of Mr. Chadvick"

1. Nhe intensity of the prejudice now raging against you is very extraordinary and not to be accounted for by your acts of commission or omission under the Public Health Act. I wrote and spoke to several Members of Parliament and their Agents concerning the first $B i l l$ but the answers I received were for the most part very discouraging. It is the fallacy of false Inferenee that has condemned you and made so many persons forget your past merits in the apprehension of fancied Danger. This bugbear will in time cease to frighten the minds of the weals and of the sincere but not enlightened portion of the public and then you may attack the roguish section with a chance of success. Depend upon it Justice will be donento you sometime or other. The Elory of the sanatory movement is imperishable. Near twenty years have now elapsed since you and I first discussed this matter in Mr. Senior's frouse at Kensington and you have pursued it with unceasing diligence and rare devotedness ever since". (S.H. Gael - E.O., 20 A.ugust 1854).

2. "In a word, Mr. Bdwin Chadwick suggested the original inquiries; settled the plan of operations; marshalled, selected, and digested evidence; grev from secretary into a comissioner; issued rules, regulations, and maxims; chose bis colleagues, his servants, and his witnesses, and in his offleial capacity, under the mantle of the Board, tried, condemed, and sentenced his opponents; and recomended the Board, that is to say, himself, for further powers, privileges, and honours. Never has the expedient of reiteration been so vigorously and unscrupulously used,

(Continued on next page) 
his friends might comfort him with the reminder that Wellington had become a national hero after being pelted in the street, (1) so long as he lived Chadwick's character and ideas would never be entirely freed from the taint of that suspicion. (2)

(Continued from previous page) page after page, volume after volume, pamphlet after pamphlet, speech after speech; the same reckless assertions are supported by the same fallacious evidence, selected and cooked for the occasion, and the same certain conclusions are arrived at, that is to say, that every city, town, and village may obtain universal health and a large income from the sale of sewerage on one sole condition --- unquestioning, blind, passive obedience to the ukase, decree, bull, or proclamation of the autocrat, pope, grand lama of sanitary reform, Edwin Chadwick, lawyer and commissioner ...... He was determined that the British world should be clean, and live a century, but on one condition only -.. that they consented to purchase the real patent Chadxwickian soap, the Chadwickian officiallygathered soft water, and the true impermeable telescopic earthenware pipe, and when they did die, were intereed by his official undertakers in the Chadwickian necropolis". ("Ingineers and OPficials", pamphlet, anonymous, 1856)

1. William Stuart - B.C., 19 August 1854.

2. When, two years later, a public subscription was being raised for Southwood Smith, the originators (Dr. Waller

Lewis and R.D. Grainger) decided to keep Chadwick's name off the Comittee lest it "ruin the whole proceedings".

"Moreover", Chadwick told Sir John Basthope (n.d., 1856), "they were of opinion that it was essential to the measure that it should be kept clear of the General Boaed of Health".

"I need not tell you", he went on, "that in Parliament, in the press I have been for years singled out for individual attacks for measures of joint action in which I have been precluded from calling for explanations and making any individual defence. These attacks have been chiefly in expressions of hate and scorn as towards some odious character. He whose nights as well as days were engaged in the gratuitous (service) of devising means of preventing some of the chief evils of humanity was treated as if he were absorbed by some terrible vices. The active hostility has been invariably traced to disguised enemies of sanitary reform, who have seen that the most effectual way of damaging them would be to damage him whom they deemed to be its most active promoter. It has been a most mischievous error to hold these attacks to have been of no account: they have had their effectz: and have been the occasion of large disaster to the public; the Lord Advocate declared (Continued on next page) 
On the following day Sir William Molesworth introduced a Public Health Bill, to constitute a new health department on the same lines as the Poor Law Board, comprising a President with a secretary and an under-secretary. pensioned off with a $\Sigma 1,000$ a year. Bdwin Chadwick was to be (1) In his letter of resignation to Palmerston, Shaftesbury had written with some bitterness, "in retiring from these duties, I cannot but express my regret that our five years of intense labour, productive, as will, hereafter, be seen, of great benefit to the country, have been subjected to so much suspicion and calumny".

Chadwick was even more bitter, as he reflected how he had been "discharged under the contumelies of the opposition as well as a reduced income, whilst if I had been in an office abolished on account of 1ts inutility I should have retired like the Lasterg in Chancery on a full salary". (3) But the blow fell heaviest on the unoffending and uncomplaining Southwood Smith who had been taken for six years from his profession, and now, "without fault proved and indeed after extraordinary and successful labour is dismissed a ruined man without any compensation whatsoever". (4)

(Continued from previous page) that they had created so strong a prejudice against me in the minds of the Scotch members, they knew not why as to prevent the extension of the Public Health Act to Scotland, and they supplied the majority by which the first Board of Health was destroyed. There are few who are aware of the mischiefs which it has done: of work commenced, left uncompleted and misdirected, and of the furthar large worke designed, to which there can now be no probable commencement. To a competent and impartial person who would fully examine the subject it would be no extravagance to say that the loss life in the last war, was mall in compsrison with the loss of life maintained by the public defeat on the Public Health Act. The impression created must be that there really must be something odious about a person whose character has occasioned so much hostility to a realiy beneficent course of legislation ..." 1. Hansard, vol. 135, pp. $1138-42,1$ August 1354.

2. Shaftesbury - Palmerston, 27 July 1354.

3. H.C. - ?, 7 August 1854.

4. 1bid. 
It would be some comfort if the Board fell into good hands. Lyon Playfair would be a great acquisition, Chadwick suggested, and the sight of him as secretary or chief executive officer would give satisfaction to the Inspectors. (1) But the Government had decided that the capitulation was to be complete, and that to silence the critics they must be taken into partnership. Chadwick read with horror the announcement that the President was to be Sir Benjamin Hall, the volce of the Marylebone vestry, and the Secretary Tor Taylor, the man who wrote lampoons for "Punch" sphen he should have been drafting bye-1aws.

"All that the anti-centralisers will have gained, is a huge imposture, of a man who will be engaged ten hours a day in Parliament, who will have what he calls the duties of society to attend to, and his constituents to attend to, who having come into office entirely ignorant, will have no time and little opportunity to explore and gain knowledge for himself, and who will be the mere puppet of an intriguing secretary whose interests and time have been away from his duty, who is shallow in his knowledge and incapable of himself of making any substantial progress. The only chance for the public is that either he or the president toay be advised by some of the inspectors and being under the motive to do sorething and to show a contrast, may adopt the advice". (2)

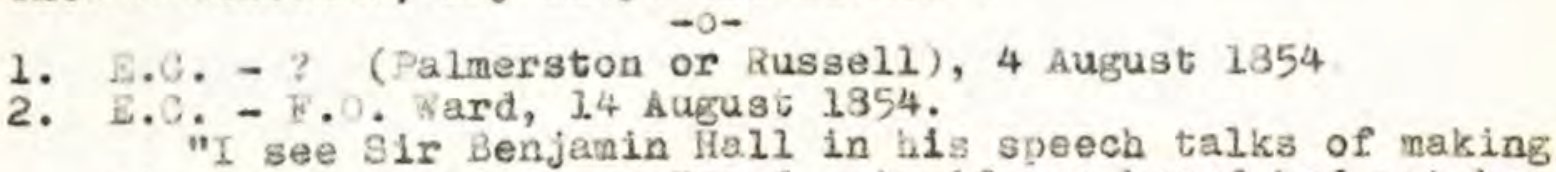
his board an advisory Board. As if our board had not been an advisory and sugsestive Bourd to an extent entirely unexampled! No administrative Board ever bestowed so much labour in preparing instructional infornation as ours did

de in no one instance, except in the cholera period against the City of London Union took any hostile steps as against any local authority whatsoever. The fact is however that we had no power to do otherwise. Hle has a large "But" if they neglect to do what they ought to do, he will step in on behalf of the General Public". (ibid.) 
He thought wildy of a dramatic intervention in the forthcoming election contest in Marylebone, and even roughed out an address to the ratepayers, asking them to consider the strictures passed by the Lords on Flall's speech, and then go to the polls and give their votes as they would give a verdict before the country. "The clergy and churchmen must be properly against Sir Benjamin for his insults to the Bishop of London. The case of Dr. Southwood Bmith ought to rouse the medical profession against the mode of his displacement and the presumption of so ignorant a layman occupying the place of Minister of Health. The affront to Lord Shaftesbury should be made apparent and should engage all the religious communities. To engage any sympathy for myself would I apprehend require more labour than there is time for". (1)

Though Chadwick was denied the pleasure of seeing the usurper humbled by the judgment of the liarylebone voters, fate dealt him satisfaction of a different sort. For the critic in office found his answer. Very shortly after his appointment, as he watched the machinery Chadwick had designed and the men Chadwick had trained going to work in the cholera epidemic, Hall was confiding to one of the Inspectors that he was astonished to find how much there was to be done, and how much his derided predecessors had done; and he observed no three men could possibly have worked harder. (2) "So far as I can judge", Dr. Sutherland told Chadwick, "the President seems quite disposed to make himself completely master of the sanitary subject, to avail himself of every means of infornation, and to take his place intthe House at the beginning of next session, as a Reformer, resting his position on his own knowledge and observation, and ready to face any opponents who may appear. I may state in confidence, that both $M r$. Austin and I are rather afraid of his going too fast, and raising the interests against him. It has indeed happened with him, as with every other $-0-$ 1. B.C. - F.O. Ward, 13 August 1854. 2. E.U. - .0. Ward, 26 April 1855. 
person, who has taken any pains in the way of enquiry, that he is astonished at the magnitude of the evils with which he has to contend, while his sympathies appear to be all engaged in their removal". (1) And presently "the London Engineering Clique" was showing that it was as dissatisfied with the new President as with the old Commissioners.

Shaftesbury had found a fit text for the Board and their officers whent they assembled for their parting dinner, in the shadow of public opprobrium and still smarting from the parliamentary boot. "We are troubled on every side yet not distressed; we are perplexed but not in despair, persecuted but not forsaken, cast down but not destroyed".

What thoughts were passing through Chadwick's mind as he listened to Shaftesbury at that final banquet? Darkened with the bitterness of those last weeks, they must yet have contained much to console and to satisfy. A rest and a thousand a year pension had never been better earned. In the twenty-two years since Nassau Senior had introduced him into the public service, he had been engaged continuously in the diagnosis of social disease and the prescription of legislative remedies. He had been a major influence on three Royal Commissions of the first importance, and produced a series of statc papers unequalled for the clarity and force of the administrative intelligence they displayed. Since its beginning he had been the heart and brain of the public healtb movement. His foresight had equipped tho Registrar General with authority to draw up the national balance sheet of sickness and death. From the Poor lav Office be had guided the nation-wide inquest which paved the way for legislation. He had been the first to see as a whole the 1. J. Sutherland - E.C., 11 September 1854.
2. J. Sutherland - E.C., 13 Detober 1854. 
problems of municipal engineering, the inter-dependence of drainage, water-supply, and sewage disposal. By the impact of his own reports and the personal influence he had exerted on politicians and the leaders of outside opinion, he had in ten years educated the law-making classes to appreciate the issues at stake, and rorced the first Public kealth Act on the statute book. From Gwydyr house, with an inadequate Act, he had done what he could; and it is just to say that in his single-minded pursuit of the public welfare, and the fertility of his projects for social betterment, he had done more than any other man of his time would have had the courage, the ability, and the toughness to attempt.

Throughout these years the motive principle of his social philosophy was the "Sanitary Idea", the conviction that the wretchedness and ill-health laid bare by his investigations were preventible; and the characteristic quality of his administrative theories was the assertion that this could be done by government, the perception that the organised power of the state was a tool which could be sharpened and applied to the shaping of the social enviroment. To the men of his day his exposition of distasteful facts, with a brutal insensitiveness to the feelings of the respectable interests concerned, was like surgery without anaesthetics. And the remedies be prescribed -- the inspection of factories and mines, the regulation of building and of noxious trades, the recognition of employer's liability for workmen's accidents, the public ownership of railways and water supplies, the extension of Whitehall's authority into the localities -- together constituted a confining system of rules and restraints which freedom-loving capitalists and Corporations regarded with horror, and for which they could find no greater condemnation than to trace it back to its un-English origins.

On these questions the balance of opinion has radically shifted, and it has shifted in favour of Chadwick. 
Generation accustomed to government intervention on a scale be never dreamed of will find little to shock in his centralising theorles, and will ascribe the outcry against the first Board of Health less to the violence of a doctrinalre department than to the restiveness of local authorities under an unfamiliar curb. In an age of municipalised gas and water and transport, of nationalised railways and coal-mines, of Ministries of Health, Labour, and irational Insurance, of public boards adninistering services as diverse as broadcasting and airways, the volces of the champions of laissez Iaire and private eaterprise speak with less assurance and authority. It has been Chadwick's misfortune, however, that he has continued to be seen through the eyes of hostile contemporaries and judged by their standards. His reputation would rank higher if subsequent historlans had examined their witnesses and allies more closely, and asked whether in fact a Cornewall Lewis or a Lord Seymour stood for a more enlightened and humanitarian administration. Chadwick has been further unfortunate in that of all his work it is the Poor Law which is best known and which his name first recalls. It is not generally realised, first, that the mained and partial measure of 1834 embodied only part of the broader schemes of preventive adninistration he had in mind; and secondly, that his years as a subordinate at Somerset House formed a less valuable episode in his oareer than his years as the animating spirit of the General Board of Health. For this reason, perhaps, he arouses in the authors of the "Minority Report on the Poor Law" of 1909 an antagonism one would not expect from the authors of the "London Programe" of 1892.

He lived thirty-six years after his retirement, busy, useful years, in which he played a prominent part in spreading the gospel of sanitary and administrative reform. We catch characteristic glimpses of him from time to time -- quietly 
telling the Aberdeen Town Council that the normal death rate of their city was 14 not 24 per thousand; instructing Louis Napoleon in the virtues of sewer manure, and telling Bismarck how to spend the millions of the French indemnity by improving the towns of Germany; Giving evidence to the Newcastle Commission on the effects of physical training in the half-time schools; contesting without success the University of London seat and three or four others; playing with newfangled notions, overhead railways, the American writing machine, tricycles for policemen, ventilation towers for the great towns. He talked and wrote without rest, addressing the British Association on the benefits of competitive examinations, and the Social science Association on the military lessons of 1870 , and discussing at the soireses of the Society of Arts anything from irrigation in India to the best methods of constructing a school; turning out correspondence and pamphlets inexhaustibly, letters to the "Times" to urge an omnibus monopoly for the metropolis, memoranda to Mr. Gladstone on the advantages of a uniform cheap telegraph service, papers for Plorence Nightingale on the health of the army in India. And, near the end, when he was old and forgotten, and a little silly, perhaps, and his political frineds were all dead or as forgotten as himself, we find him trying to persuade Lord Salisbury to get him a peerage. Walter of the "Times" went to the Lords, and the Chalman of the Metropolitan Board of Works, but there was no official recognition of the services of the greatest of the sanitary reformers. Not till a few months before his death was he granted his delayed and disproportionate honour. "Had he killed in battle as many as he saved by sanitation, he would have had equestrian statues by the dozen put up to his memory". (1)

Finally, as the writer of the "Times"' obituary remembered him at the Athenaeum, his"benevolent and leonine face, wrinkled with the lines of thought, and surmounted by the 1. "Daily News", 7 July 1890 . 
black skull cap" -- his features wearing "an expression of severe complacency". (1) And why should he not be complacent? His countrymen had good reason to thank him. He had played the chief part in founding a new department of Government. Hore than any other individual be had been responsible for civilising the life of the great towns. Owing nothing to wealth or birth, by sheer indefatigable industry and ability he fought his way to a unique place in British administration. He did not touch a field of government activity where he did not introduce some fertile idea or strengthen, with observation and experience, some proposition already advanced. It is true that while he was in Whitehall everything he touched seemed to crumble in his strong, clumsy hands into inertia and

frustration and failure. In part that was due to his personal defects. To the end he remained an imnense, tireless dynamo which it was difficult to harness. Far more vere his failures due, however, to his virtues than his faults -- to the courage that did not fear to challenge accepted principles, and the devotion to public duty which would not compromise with overmighty interests. It was the recompense for many disappointments, and the reward for his unquenchable optimism, that he should live to see that the current of the age was with him, and his enemies at the last confounded.

1. "Times", ? July 1890. 


\section{APPENDIX \\ PACTORY COMMISSION, 1833.}

In March 1833 Lord Ashley, who had recently succeeded Michael Thomas Sadler as Parliamentary leader of the Ten Hours agitation, introduced his Factory Bill. It provided that no child under the age of nine should be employed in the factories; that no person under eighteen should work more than ten hours a day, and eight hours on Saturdays; and that no person under twenty one should work during the night (from 7 p.w. to 6 a.m.). The Bill confronted the Whig Government with a dilemma. Public opinion was not likely to tolerate the continuation of a "Yorkshire Slavery", the physical and moral effects of which had been powerfully illustrated by the witnesses before Sadler's Committee of 1831. But alarmed manufacturers were persuaded that the Ten Hours men were going too far and too fast. If the inquiry had been pushed further "as many sleek, straight and chubby children would have been brought forward as there had been deformed and emaciated ones". (1) Even if it were granted that a case existed for the protection of children in factories, argued the employers, the operatives were using pity for the children as a cover for gaining their real objective: the limitation of the hours of adult workers, and the recognition of the pernicious principle of government intervention in the contractual relations between master and man. Moreover, if factory hours were cut to ten, profits and wages must decline accordingly; and English capitalists, whose predominance in the world's markets depended on working their fixed capital to the 1. Lord Morpeth; Hansard, vol. 15, p. 391. Morpeth stated the Committee had arranged that Sadler should first call his witnesses and go through his case, and then the opponents of the $\mathrm{Bill}$ should have their hearing; however, the session ended as Sadler's evidence concluded, and before his opponents had begun. 
limit, would suffer in competition with foreign manufacturers. It was darkiy hinted that capital might fly for refuge to countries where the government was more accomnodating.

By a majority of one Wilson Patten, Tory member for North Lancashire, speaking on behalf of the Association of Master Manufacturers, carried a motion referring the question to a Royal Commission ${ }^{(1)}$; and, despite an appeal by Ashley, the Government decided that the inquiry should be a secret one. It was so obvious a retreat from the plain lessons of Sader's Committee that the workers were in no doubt that the Commission would result in nothing but elaborate excuses for inaction. The Short Time Committee of Huddersield petitioned that "the persons who have authorised this method of secret examination may be impeached", alleging that "the enemies of the poor have added treason and insult to injury, by abusing the prerogatives of the Crown, and appointing a set of worthless Commissioners to perpetuate infant murder". (2) If this indeed was all that was in the mind of the Government, they made a cardinal error in appointing Chadwick as one of the three Commissioners.

Chadwick was still marshalling evidence for the Poor Law inquiry when the Government, eager to reach an early decision on factory legislation, made this further call upon his now acknowledged powers of investigation. It was, apart from Chadwick, a Comission of the traditional whig type --- Thomas Tooke to give to the inquiry the authority of the fashionable economics; a Benthamite physician, Dr. Southwood Smith, to deal with the medical evidence; and, associated with these, a dozen other investigators of uneven merit, some of outstanding ability, others with virtues known only to the Patronage Secretary. A central board of three, Chadwick, Southwood Smith, and Pooke, took control of the inquiry, and the

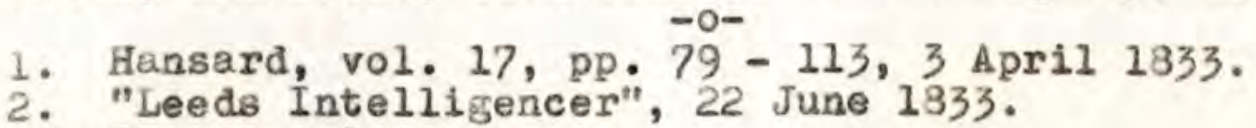

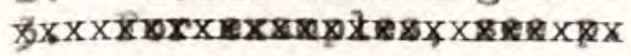


Government nominees, who could not be trusted to act singly, were sent out in pairs as Commissioners Itinerant. One or two 111 assorted characters, as Chadwick recounts, were thus coupled, who quarrelled violently, and at times came near to sending challenges to one another; and then, when the central board tried to intervene, vented their spleen on the peacemakers. (1)

An interesting series of letters from J.N. Cowell, one of the Commissioners sent to Manchester, illustrates how they interpreted their instructions to seek "the whole truth respecting the employment of children in factories". (2) Earnest and well-meaning, anxious to do the right thing, but judging what was right by the inevitable and unconscious prejudices of his class, he had gone out expecting, as he says, to conduct a quiet and methodical study of the situation. (3) He found himself, to his bewilderment, the target for conflicting agitations. To allay suspicion he decided to hear the operatives first, but a meeting of the workers promptly resolved against giving evidence lest they should be dismissed in reprisal. (4) A deputation from the worikers presented him with a remonstrance, expressing respect for the $\mathrm{King}$ and Constitution, but an "unconquerable aversion to, and suspicion of, the effects of any enguiry so constituted".

"The evidence obtained before the Committee on Mr.

Sadler's Bill was called from the suggestions of those factory Maters and their friends and dependents who have avowed their 1. E.C. - Bishop of London, 16 December 1844 .

2. "Pirst Report Prom Factory Commissioners", 1833 (4507, xx, p. 2. The Instructions to the itinerant Commissioners, drawn up by Chadwick, stated: "It should be distinctly understood that the Inquiry is in no respect to be narrowed to the views of any class, or any party or interest" (ibid., pp. $79-85$ ). A letter from the Commission to Lord Ashley, 20 April 1833, asked him to inform his supporters that any information or suggestions would be welcomed.

3. J.N. Cowell - E.C., 6 May 1833.

4. J.î. Cowell - E.C., 2 May 1833. 
heedlessness of the waste of Infant life and strength and the degradation in every way of the factory population when put in competition with the profits of capital invested in Steam Mills. That evidence is now admitted by the intelilgent part of the public to be conclusive proof of the fact that the factory system, as at present worked, does tend to deprave and degrade the labourers employed in 1t, and, what is our most especial cause of grief and despair, that it shuts out infancy from the chance of any human instruction, dwarfs their bodies, twists and bends their tender bones and deforms their figures. The numerical statements of deaths, def $\mathrm{rrmities}$ and disease furnished to Parliament leave no/doubt on these heads.

That evidence taken before a competent and ordinary Court of Enquiry is violently and without reason put aside to make way for a mode of enquiry chosen by those whose interests are openly opposed to the physical and moral well being of the factory labourers, and, these very parties, as we perceive by the series of questions issued to them, are, in their own counting houses without the responsibility of an oath or the restraint which would be imposed by a face to face examination and the chance of cross exarination, to give such answers as they think fit, which answers, as we cannot but suppose, are to be placed in opposition to the unanswerable body of evidence alluded to above. On the other hand what are the labourers to do? Experience has proved to them that there is no danger more directly threatening the very means of their existence, than Giving evidence of the facts as they exist.

The minds of the Masters must have undergone a complete revolution if any such attempt on the part of the labourers will not only cause the loss of their employment but also the posting of their names in the entrance Hall of every Mill far and near for the purpose of insuring their exclusion from any such employment in any other place".

1. J.N. Cowe11 - E.C., 3 May 1833. The itinerant Commissioners were instructed to take examinations on oath, and to sareguard woricing class witnesses ("rirst keport", pp.3 - 6) 
Who composed the "Central Committee of Operatives for the Whole of Lancashire", wondered Cowell. "All we know is that it does, at present, controul and govern the general conduct of the operatives, considered as a body, in these parts". It was backed by the vast mass of the workers in its determination to carry Ashley's Bill by clamour and agitation: "the assembling delegates from so many places and from such distances the length of their deliberations and the resolutions which they adopted can leave little doubt on that head". The workers showed "strong symptoms of insincerity", he observed, --- adding imnediately, however, that they seemed "to be acting as they think honestly and sincerely upon the whole, and they certainly send us personally assurances of their confidence and goodwill". (1)

The cotton masters were less crude in their approach. Three days after receiving the deputation from the workers, Cowell was visited by the local garrison commander, Colonel Shaw, who told him that the Central Committee lived by sgitation, and assured him, "as a result of his experience here and knowledge of the parties, that no Confidence whatever was to be placed in the assurances of the leaders of the operatives, and that he was satisfied that they would leave no means untried to Convert our Commission into a pretext and means of getting up agitation". (2) The same day, when a procession of factory children marched to his office to present a petition, Cowell had discovered a previous engagement which prevented his seeing them

Chadwick himself had remained in London, contenting himself with giving to each of the itinerant Commissioners a sheaf of printed notes and minute verbal instructions on the methods of examining witnesses. It is not surprising, in view of the quality of many of the local investigators and of the organised resistance from the Short Time Committees which they encountered, that when he came to consider what measures were 1. J.N. Cowe11 - E.C., 6 May 1833.

2. J.A. Cowell - E.C., 6 May 1833. 
to be recommended he found that the evidence collected from the manufacturing districts was gravely defective, being either insufficient or inapplicable to the points in question. Little more than $31 x$ weeks had been allowed to complete the inquiry and report, and impatient notes from Lord Melbourne were reaching the Commissioners. (1) But though time was so pressing, Chadwick felt bound to urge that the central board should examine some witnesses themselves. In the circumstances he felt it was fortunate that a number of the chief manufacturers happened to be in Iondon, and available for personal questioning. It was, he declared later, only the unavoidable necessity of redeeming the Government's pledge that they would produce a plan before the end of the session, and of suggesting an alternative to the "ruinous measure" then before the House, which induced him to recommend the application of remedies to a state of things which he had not himself investigated in person. As it was, he felt that the most formidable objections to the recommendations were that they had been devised by persons who might never have seen a factory, and that the details had not been suggested by the inquiries of the itinerant Commissioners. (2)

The First Report of the Commission occupied only seventy pages (3), but with its accompanying mass of district reports it formed the largest blue book that had appeared up to that date, and it came in for some ridicule as the "parallelopidon Report". (4) Mil1-owners could not have read it with any great satisfaction. True, the Ten Hours men were castigated, their leaders condemned as agitators, the processions and "studied 1. J.M. Phillips - T. Tooke, 5 June and 20 June 1833.

2. E.U. - N. Senior, 30 July 1834 .

3. 1833 (4507, xx. 1, dated 25 June 1833. A Second Report, dated 15 July 1333, dealt with the medical evidence relating to adult operatives; and a Third Report, 25 March 1834, summarised the answers to the queries circulated amongst the manufacturers (1833 (519), xxi.1; 1834 (167) xix. 253, xox. 1.)

4. B.C. - Sir James Graham, 2 April 1844. 
compositions"of child petitioners derided. (1) It was shown that some manufacturers had voluntarily incurred great expenditure for the health, education, and moral improvement of their workers, and with scarcely an exception the attitude to workers intthe large new factories which had recently been built was found to be paternal, and the treatment of children "considerate, gentle, and beneficial". (2) On the other hand, the Report stated bluntly that "the words "impracticable" and "impossible" are too commonly attached by many of the manufacturers to any regulation which may subject them to expence or to temporary inconvenience". (3) Regulation there must be. The case for government intervention to protect the factory children was overwhelming. Whether employed in the largest and best regulated factories or in the smaller, obscure mills where the old cruelties still lingered, whether the work was light or heavy, whether their treatment was considerate or harsh, the children testified uniformly to the extremity of latigue induced by the over-long hours. In the last hour of a winter evening it was almost impossible to keep the piecers awake; and when the machinery had stopped they would continue to go through the motions of piecing after falling asleep, and could hardly be shaken into sense enough to wash themselves or eventto eat. Combined with this drowsiness the constant standing, the peculiax attitudes of the body and motions of the limbs, the high temperature and impure atmosphere, produced pains in limbs, back, loins, and side, and swelling of the legs, feet and ankles -... sometimes terminating in peranent and incurable disease. (4)

Now it was on this very point that the Ten Fours Bill was most deficient. "Its professed object is the protection of children; but it does not protect children. For the same $-0-$

1. "First Report from Factory Commissioners", p. 45.

2. ibid., p. 21

3. ibid., p. 61.

4. ibid., pp $25-31$. 
evidence which shows that the legislative protection of children is necessary shows that the restriction of the labour of children to ten hours a day is not an adequate protection: (1) Furthermore, by extending the age of protection to eighteen the Bill reached beyond its avowed purpose, tending towards "the pernicious notion of the propriety and necessity of legislative interference to restrict the hours of adult labour". (2) For this the Commission could find no justification whatsoever. The common impression was that hours of daily labour were increasing in number; in fact, where they had once averaged 13 , they mere now only 12, or even 11\%. Moreover, though particular classes of workers might have suffered, the wages of the majority had slowly increased and the severity of their labour diminished. The Comissioners concluded that the hours of adult workers, and the general improvement of their economic condition, could safely be left to the unfettered working of the industrial system, to "self acting causes", "chierly the improvement of processes and circumstances affecting the interests of the manufacturers". (3) Leading cotton masters were agreed that a twelve hour day was essential to remunerate the capitalist for his outlay on mills and machinery, and to enable him to meet the competition of China and Bengal, where bours were unlimited and child labour could be obtained for a penny a day. To fix hours below this level would mean giving a premium to the foreign competitor; it would lessen in proportion the volume of production, and so diminish the fund whence both wages and profits were paid.

Having thus demonstrated to their own satisfaction that a twelve hour day was to the benefit of the worker as much as the employer, the Comissioners turned to indicate their specific proposals for protecting the factory children. "We found", wrote Chadwick later, "that there was no definite 1. ibid., p. 33 . - 0 -

3. ibid., p.

2. ibid., p. 50 . 
principle of legislature on the subject, and we furnished one, which appears on a review to be sound and as new and applicable to the present time (c. 1844) as then; namely that the legislature was justified in interfering for the protection of those who could not protect themselves, of those who had not arrived at the age of discretion to make their own bargains. On enquiring at what age young persons engaged themselves in the manufactures without the assent of parents or guardians being thought necessary, we found it to be about the age of puberty. We upon this evidence fixed the age of legislative interference at thirteen years of age. Beyond this we found that the facts negatived any allegations of the severity of adult labour in Cotton or other Nills; as compared with other branches of employment we sald it was 11 ghter". (1)

It was recommended, therefore, that no child under the age of nine should be employed in the textile factories; after that age, it was asserted, serious and permanent disease was rarely produced, if the labour was not immoderate. From nine to fourteen children should work not more than eight hours a daj. At fourteen legislative protection should cease. At that age children entered the stage of puberty, when they were more cepable of enduring protracted lsbour; they ceased to be treated as children, corporal punishment became rare, and in other respects the $y$ became free acents, being allowed to retaln part of their wages, to pay their board, and to make their own contracts.

The Comission thus recomended for chiddren under fourteen a working day two hours shorter than that laid down in Ashley's Bill. That is all that can be said for this proposal with its unreal picture of fourteen year olds bargaining as equals with their employers, ard entering voluntarily upon the full day's work of an adult.

1. "On the Employment of Children in Factories etc. Senior's Objection to Combated", MS, n.d.; probably notes of a speech to the Political Economy Club, c. 1844.

2. "First Report from Factory Commissioners", pp. $52-57$. 
In a further respect the Report showed a wider vision than Astley's Bill. The most important part of the scheme, in Chadwick's view, was the recommendation that three or four hours a day should be devoted to education, the children being obliged to present a ticket on entering the factory to certify that they had passed the prescribed time in school. For this purpose, it was suggested, a relay system might be worked, children employed in the morning attending school in the asternoon, and vice versa. (1) 'Phis was Chadwick's first pronouncenent in Pavour of the "lialf-time System" -- "the greatest discovery of Modern Days", as Shaftesbury called it (2) -... which in later life, in numerous pamplets and speeches, he was to advocate as the key to all sound educational progress. (3)

It was in the machinery for enforcement, however, that the Report marked the greatest advance and left the deepest impression on subsequent factory legislation. iarlier Acts had put their trust in the informer and in supervision by visiting committees of magistrates and clergymen. But experience had shown that the rewards held out to the informer could not counterbalance the threat of dismissal and blacklisting wielded by the employer; while the justices and clergymen had avoided any possible unpleasantness with friends and the relatives of friends by the simple expedient of not entering the factories to see if the reguibations were beint carried out. The proposals

1. ibid., pp. $71-72$. Ashley stated, however, that provisions for education and inspection had been omitted from his Bill merely out of the desire not to give additional offence to employers (Hansard, vol. 19, p. 224, 5 July 1833).

2. Shaftesbury - E.C., 17 September 1866.

3. See, for example: "Two papers submitted to Commission by Mr. Chadwick, as to half-time teaching and military and naval drill, and on time and cost of popular education on large and small scale", Commons Return, 1862, xli11.1; "Further return, being letter to Mr. Senior, explanatory of former paper", 1bid., 91; "National Education. On the rise and progress of the balf-time principle for mixed physical and mental training, as the foundation of a national system of education", pamphlet, Knight se Co., 1881. 
of the leaders of the factory agitation were hardly less defloient. "Ten hours and a day and a time-book" was Oastler's programie; and to enforce it on evasive employers, "flogging and the pillory". Ashley, following Sadler, also put his trugt in the informer and the time-book, hoping to deter offenders by impoalng heavier fines.

To Chadwick it appeared quite clearly a case for the interposition of the impartial power of the central government, to enforce the law against local and sectional interests. "Any measures by which the enforcement of the law shall be made chiefly dependent on those who have an interest in breaking it", observed the Report, "may be expected to prove as inefficient as the provisions of the existing law". (1) It was necessary to appoint some special agency since the proposals related solely to children, and were not directly conducive to the immediate interests of masters or operatives, or of any other powerful class. The Commissioners therefore recommended that the Government should appoint three inspectors, charged with the enforcement of the law, to go circuits of the chief manuiacturing districts. They should bave the right to enter all factories where children were employed, and there to order machinery to be fenced off, and to direct arrangements of a sanitary nature, "compatible with the execution of the manufacturing processes". The arrangements ofor the education of the children should also fall within their cognizance. (2) This was the proposal which marked the "turning point in factory legislation", (3) wich rescued it from the futility of earlier Acts, and converted it from a gesture of woolly benevolence to a practical instrument of human welfare.

Parliament, shamed into action by the revelations of Sadler's Comittee but facing uxeasily the prospect of I. "kirst Report from Factory Comissioners", p. 64. 2. ibid., p. 68 . 3. Hutchins and Harrison, "History of Pactory Legislation", p. 40 . 


\section{legislating for industry, was relieved to find that it was} possible to give factory children a larger measure of protection than the Ten Hours men had demanded without coming between the employer and his adult workers. The demands of humenity and business, it seemed, had been neatly reconciled. The Act of 1333, therefore, followed closely the main recommendations of the Report. The employnent of children under nine years of age was prohibited, and an eight hour day esteblished for children under fourteen; children were required to attend school for not less than two hours a day; and four inspectors were appointed to supervise the execution of the law. But in one respect the Act went beyond Chadwick's proposals, and in another it fell far below thom. It provided that no person under elshteen should be employed for more then twelve hours a day, or 69 hours a week. When nature had indicated so conveniently the exact age when a child became a man, Chadwick was disguisted that "the pernicious practice of legislating for the protection of adults was in fact retained". (1) But a nore serious defect, in Chadwicis's view, was the weakness of the educational provisions. The Government Bill, as it left the Commons, had contained a clause, drafted bJ Chadwick, which provided that wherever it appeared to the inspector that a new or additional school was necessary to enable the children in any factory to obtain the education required by the Aet, he was authorised to establish such a school by contract or otherwise; if the deduction of one peany in the shilling from the children's wages, already earmarked for educational purposes, were insufficient, the employer should pay the deficiency, the amount being set off against the poor rates due in respect of his factory; and if the cost exceeded the anount of his poor rate assessment, he should be reimbursed by the Poor Lew overseers. (2) In the Lords, however, this clause, as Chadwick lamented, was "Given up to an obscure - -

1. "On the Bmployment of Children in Factories etc. Senior's objections to Combrted", MS, n.d.

2. Parliamentary Papers, tx் 1833, 11. 28? 
opposition"(1), led by the Marquis of Salisbury. The inspectors were left with the authority to establish schools, but apart from the children's levy of a penny in the shilling, were given no power to raise the necessary money. The Lords also deleted the power given to the inspectors to dismiss any teacher whom they deemed incompetent or in any way unfit for the performance of his duties. It is impossible not to feel sympathy for Chadwick's complaint to Lord John Russell a few years later: "Had the Education clauses which were carried in the Comons comprehending powers to establish Schools and pay for them from the Poor Rates where there were no schools already established and giving the control of the Education in those Schools as to its sufficiency and the competency of its Masters -- been carried in the Bouse of Lords a large instalment of a national System of ducation much larger than any in measures which have of late been made the subject of contest would have been carried". (2) The obligation imposed upon the employers was in fact, not to ensure the edueation of their juvenile workers, but merely to see that they prosented a "schoolmaster's ticket or voucher" certifying that they had attended school for at least two hours on each of six days of the preceding week. To satisfy the requirements of the law class rooms were established in coul-holes and engine-rooms, and the children entrusted to "the engine man, the slubber, the burler, the overlooker, the wife of any one of these, the small shopkeeper, or the next doon neighbour, wi,th six or seven small children on the floor and on her lap". (3) Some employers found even this too much trouble, and ten years later Chadwick was noting that "instead of giving the reduced hours of labour to efficlent schools the reduction has in fact turned the children in many places out into the streets; and swollen the ranks of juvenile

1. "On the Emplojment of Children in Factories etc ......"

2. F.C. - Lord John Russe11, I August 1840.

3. "Reports Prom the Factory Inspectors on the Educational provisions of the Pactories Act", 1339, xlil. 411. 


\section{delinquents". (1)}

The Short-rime Comittees, who had been blind to the defects of Sauler's Bill, were at first equally blind to the virtues of the Pactory Act. It was assumed that the inspectors would be no more than watch-dogs of the millowners' interests. The Rev. G.S. Bull declared that "if these inspectors, in whose appointment the nill owners will have due influence, should take the sides of their patrons and masters, so axidirary are their powers that we shall want nothing but the torture room to complete their character and office as pactory inquisitors". (2) The suspicion of the workers was on $y$ equalled by the alarm of the capitalists, who had hoped to keep the appointments in the locality and so under their influence. But three years later the Rev. G.S. Bull was urging the workers "to hold last, as for life itself, to the eight-hour clause, the education clause, and the inspection clause of the present Act". (3) A more grudging recognition of the value of the inspectors: work came from the employers. "Impartiel manufacturers have adritted in respect to the appointment of the Government Inspectors, that it has been benelicial in its action, independentiy of the operation of the law of which the execution is to a ereater or less extent Insurea by them. It has been benelicial in keeping attention to the fact, that beyond the mere interests of the employers and the employed, in the bargains or the hour and the day between them, there are social and public interests to be regarded. It has been beneficial in promoting voluntary improvements of a pubijc character by capitalists. At the period of our first inquiry there were very lew model nufecturers. Now there are numerous establlshments by which the first models are surpassed, and evidence is afforded of a very important future for the working classes". (4)

1. "On the Employment of children in Factories etc. .......
2. "Leeds Inteli igencer", 28 September 1833 .
3. "Manchester and Selford Advertiser", 13 February 1836.
4. "Mem. On factory inspectors", MS, n.d. 
The Factory Act of 1833 represents Chadwick's Piret success in grafting the Benthemite principle of inspectability on to the machinery of British adinistration. The example was iawediately followed by the appointment of inspectors to supervise the education grants. Over one field after another as the century wore on the controlling hand of the Covernment Inspector was stretched, to check the Edninistration of poor Law Guardians, to discipline the capltalist in his mines and factories, and to confront in the towns the interests of builders and landlords. And more often than not Chadwick's Land may be detected at work bekind each extension of the Inspector's power.

Wobody grasped the implications of the recommendation in the last two pages of the Factory Report, if, indeed, they ever read that lar. Fiere, while his colleagues were preoccupied wi with the evidence on the relay and education clauses and the Ten lours Bill, Chadwick had slipped in his doctrine of "pecuniary responsibility", the germ from which were to spring the kimployers' Liabidity and worimen's Compensation Acts. Since later historians have also universally ignored the passage, it is worth giving in some detall. (1)

Chadwick began by sweeping away the flimsy arguments by which the employer \$usually shuffled off responsibility for accidents on to the shoulders of his workpeople. It was frequently asserted that accidents were due to culpable heediessness or temerity, and this was made an excuse for refusing to contribute to the expense of the cure. The argurent was certainly not valid against children of an age when caution and discretion did not exist; nor wes it likely that an adult worker, except in a state of deliriun, would wantonly incur the risk of losing life or limb. Excluding cases of 1. Of the Report of the Belect Comittee on Railan Labourers, thirteen years after the Factory Comission, .0. Knowles remarks, for example, "it is interesting to see the doctrine of "orkmen's Compensation set out so early". ("Industrial and Commercial Revolutions", p. 267). 
culpable temerity, the question was who should bear the pecuniary responsibility.

"We conceive", ran Chadwick's answer, "that it may be stated as a principle of jurisprudence applicable to the case of evils arising from causes which ordinary prudence cannot avert that responsibility should be concentrated, or as closely as possible apportioned on those who have the best means of preventing the mischief. Unless we are to impose on the workman the obligation of perpetual care and apprehension of danger, the nature of the injuries inflicted are of themselves evidence that all the care which can be taken by individuals attending to their work is taken by them; it is only the proprietor of the machinery who has the most effectual means of guarding against the dangers attendant upon its use.

If such an extent of pecuniary responsibility for the accidents which are incidental to the use of the machines is imposed upon him, those consequences will be more likely to be taken intb account, and to be guarded against at the time of the erection of the machinery. The workmen are not prone to regard imnediate dangers, still less dangers which are remote and contingent, and many of the accidents are of a nature apparently too uncertain to form data for insurance. It could hardly be expected that a woricran in entering a manufactory should object that any portion of the machinery is dangerous, and that it ought to be boxed off. But the proprietor of the machine is necessarily the person who can best foresee all the consequences incidental to its use, and can best guard against them.

By throwing upon him a portion of the pecuniary responsibility for those mischiefs, we combine interest with duty, and add to the efficiency of both.

If the pecuniary consequences from unavoldable accidents were considerable, the imposition of the proposed responsibility may be met by the master, or by a deduction from the wages. Considering the defective nature of most existing modes of provision against sickness and casualties by benefit or firiendly 
societies, and also unhappily the large proportion of those who from improvidence do not take advantage of these or other means (of which some portion of the working class avail themselves in so exemplary and admirable a manner), if we were to devise a form of insurance against the caaualties in question, available to all classes, we should recommend that measures should be taken to secure from the master the regular deductions of the amount of the contribution of the persons employed.

We propose that in the case of all accidents whatsoever from machinery occurring to children under fourteen years of age, the proprietor of the machinery shall pay for the medical attendance on the child, and all the expenses of the cure, until medical attendance is no longer required; and also during the same period shall continue to pay wages at the rate of half the wages employed by the individual in question at the time of the occurrence of the accident.

W are of opinion that persons above that age, in all cases where the injury was received from accidents in the ordinary course of business, where there was no culpable temerity, should receive similar treatment at the expense of the employer, and should also be allowed half wages until the period of cure, as we believe that an allowance of full wages would occasion considerable fraud in the protraction of that period, especially in the cases of accidents of a less serious nature". (1)

In the hurry with which the Report was drafted, these paragraphs eluded the attention of Chadwick's colleagues, and Tooke was dumbfounded and not a little flustered when a witness before the Mines Commission of 1841 gave a dissertation on the principle as the best way to prevent accidents -.- and in support of the idea cited the report which bore Tooke's name. He wrote at once to remonstrate with Chadwick as the fountain head of the heresy. "Our confidence in the general coincidence of your views with ours, led us wholly to overlook the tenour and tendency of the passage in question, and that we should so 1. "Iirst Report from Factory Commissioners", pp. $73-74$. 
have overlooked it, is the less to be wondered at, seeing that when published it equally passed without notice either by parliament or by the public. Indeed I never hear a single person notice the doctrine, much less expound it". (1) If the passage had been brought to his attention, he added, he felt certain that he would have detected at once the unsoundness of the doctrine, applied as it was to adults as well as children.

The frowns of theorthodox economists, however, never discouraged Chadwick. The idea found a mention in the "Sanitary Report", and was the principal remedy he proposed for the condition of the railway labourers in 1846. (2) And he never missed a chance to canvass it at the Statistical society or the Political Economy Club, and to indoctrinate with it the Assistant Poor Law Comaissioners and Superintending Inspectors who came under his comand. (3) It was not the least of his many unremembered contributions towards the civilising of modern industrial soclety.

1. T. Tooke - E.C., 15 November 1341. He wrote again on 17 November: "I an sorry to observe by the P.S. to your note that you have reason to believe that lord Ashley will take up the subject. If he does he will make nothing of it and by his failure in it, as fail he must, he will impair the influence which he would justly possess if he were to confine himself to the means of bettering the condition and shortening the hours and promoting the education of children ....."

2. See above, p. 265.

3. Lor an example, see above, p. 46 . 


\section{BIBLIOGRAPRY.}

\section{A. MANUSCRIPT SOURCES.}

\section{(1) THE CHADWICK MANUSCRIPTS.}

Chadwick kept copies or rough drafts of most of his papers, and these are now deposited in the library of University College, London. Besides letters, memoranda, and drafts of speeches, the collection includes most of his pamphlets, and proof sheets of many of the articles he contributed to newspapers and various sanitary and administrative journals.

The papers contain very little material bearing on his early career; there is practically nothing, for example, about his relations with Bentham. From the period of the Factory Commission onwards, however, the serious gaps are few, and the material relating to the sanitary movement and the General Board of Health is particularly full and valuable. No previous studies of Chadwick's career have made use of these manuscripts.

The papers have not yet (August 1948) been calendared. Some of them have been roughly bundled according to date and subject.

Unless otherwise indicated, all letters and papers quoted in this thesis are from the collection at University College.

(2) AT THE PUBLIC RECORD OFEICE.

The Ministry of Health papers deposited at the P.R.O. contain:

(a) Minute Books of the Poor Law Commission (M.H.1).

35 volumes: from August 1834 to July 1842.

Rough Minute Books (M.H.2).

37 volumes: from August 1334 to June 1347. 
Appendices to Minutes (M.H.3).

3 volumes: Irom 1835 to 1846.

Bxtracts from Minutes (M.H.4).

2 volumes: from July 1839 to December 1841.

(b) Minutes of proceedings of the Commissioners for Inquiring into the state of large Towns (M.H.7). 1 volume: $1843-45$.

(c) Minute Books of the General Board of Health (M.H.5) 12 volumes: from 22 November 1848 to 21 February 1856.

Rough Minute Books (M.H.6).

20 volumes: from 26 September 1848 to 3 March 1858.

The Minutes of the Poor Law Commission were used by the Webbs. For the defects of these Minutes, see Chadwick's comments in his evidence to the Select Committee on District Asylums (P.P. 1846 (388) vil, pp. $86-88,364-375)$. There seems to be room for a re-examination of these records, with the assistance of the material in the Chadwick MSS, which brings out and illustrates the issues underlying the colourless entries in the Minute Books.

\section{(3) AT COUNTY HALL, WDSTMINSTER.}

The Record Room at County Hall (Room B.2l) holds all the minutes and other papers of the several district Commissions of Sewers, and of the Metropolitan Commission which replaced them in December 1847. The following were found particularly useful:

(a) "Metropolitan Commission of Sewers. Orders of Court" (i.e. minutes).

Vol. 1. 6 December 1847 to 4 January 1849. Printed.

Vol. 2. 10 January 1849 to 4 October 1849. MS.

31 volumes altogether, to 31 December 1855.

(b) M.C.S. Minutes of the General Purposes Committee".

Vols 1 - 5, from 9 December 1847 to 18 December 1849.

29 volumes altogether, to 27 November 1855. 
(c) The correspondence, petitions, MS reports, etc., relating to (a) and (b) are to be found in:

"Original Papers. Court and General Purposes Committee".

Vols. 1 - 5, from December 1847 to 4 January 1849. The series then continues as "M.C.S. Court Papers", vols. 6-67, from 10 January 1849 to 31 December 1855.

(d) Proceedings of Committees:

"M.C.S. Trial Works Committee. Minutes and Report Book".

1 volume: from 6 March 1849 to 8 october 1849.

"M.C.S. Works Committee Sewage Manure Committee. Original Papers".

Trialsflorks Comittee.

2 volumes: from 22 January 1849 to 8 october 1849. "Metropolitan Sewers. Works Committee". Minutes.

1 volume: Irom 22 January 1849 to 4 June 1849.

"Oranance Survey Committee. Minute and Report Book".

1 volume: from 21 March 1849 to 1 August 1849. "Metropolitan Sewers. Finance Committee". Minutes. 1 volume: from 29 January 1849 to 9 October 1849. "Minute and Report Book. Bye-Laws Committee".

1 volume: from 9 February 1849 to 2 October 1849. "M.C.S. General Committee. Special Committee Tooting. Bye-Laws Committee. Sewage Manure Committee. Ordnance Survey Committee. Original Papers".

1 volume: from January 1849 to July 1849.

"Metropolitan Swers. Sub-Committee on Disposal of Refuse, 13 February to 8 March 1849. Sewage Manure Committee, 19 March to 8 October 1849". 1 volume.

(e) Printed papers, reports of surveyors, etc., are contained in:

"Metropolitan Comission of Sewers. Papers ordered to be printed. 1848 - 49".

1 volume.

"M.C.S. Reports, etc. 1849".

2 volumes.

(4) MISCELLANEOÚS.

There are a few letters in the Bentham Manuscripts at University College, London, and in the following collections at 
the British Museum:

Correspondence and papers of the family of Bentham (1). Letters to Francis Place (2).

Macvey Napier Papers (10).

Correspondence of C. Babbage (4).

Iiverpool Papers (1).

Original Letters to Charles Griffin (2).

Non-scientific Correspondence of Sir Richard Owen (3). Miscellaneous Papers (1).

Many of these are duplicated in the Chadwick Manuscripts.

\section{B. $\triangle$ SELECTION OF THE MORE IMPORTANT PAMPHLETS, ARTICLES, AND SPEECHES BY BDWIN CHADWICK.}

The following list should be regarded as representative rather than exhaustive, though it probably contains the most valuable of Chadwick's writings. Many others are to be found in the transactions of such bodies as the British Association, the Association for the Promotion of Social Science, the Statistical Society, the Society of Arts, and the Sanitary Institute of Great Britain.

"Life Assurances".

"Westminster Review", vol. 1x, No. xvili, pp. $384-421$, February 1828. Reprinted, with additional notes; Charles Knight, London, 1836.

"Preventive Police".

"London Review", vol. 1, No. 1, pp. 252 - 308, 1830.

"Centralization. Public Charities in France". "London Review", vol. i, No. 2, pp. 536 - 565, 1830.

"Real Incendiaries and Promoters of Crime".

"Examiner", 20 February 1831, pp. 114 - 116.

"Taxes on knowledge".

"Westminster Review", vol. xv, No. xxix, pp. $238-267$, July 1831.

"On the Principles and Progress of the Poor Law Amendment Act". "Idinburgh Review", vol. Ixili, pp. 487 - 537, July 1836. Reprdnted 1837.

"On the best modes of representing accurately, by statistical returns, the duration of life, and the pressure and progress of the causes of mortality amongst different classes of the 
community, and amongst the populations of different districts and countries".

"Journal of Statistical Soclety", vol. vii, pp. 1 - 40, April 1844.

"Papers (by John Roberton, Robert Rawlinson and Edwin Chadwick) read before the Statistical Society of Manchester on the demoralisation and injuries occasioned by the want of proper regulations of labourers engaged in the construction and working of railways, etc."

Ed. E.C. Charles, knight, London, 1846.

"Health of Towns. Report of the speeches of Idwin Chadwick, Esq., Dr. Southwood Smith ..... and others at a meeting ..... to promote a subscription in behalf of the widow and children of Dr. J.R. Lynch".

Chapman, Blcoate and Co., Iondon, 1847.

"Sewer Manure".

Report to Metropolitan Sewers Commission. 1849.

"A Letter to the Right Hon. Viscount Palmerston, etc., on the improvement of the sanitary condition of the army at home and in the field".

Eyre and Spottiswoode, 1855.

"On improvements in machinery and in manufacturing processes, as affecting the condition of the labourer".

Address to Philanthropic Congress at Brussels.

"Journal of Society of Arts", vol. iv, pp. $803-807$,

14 November 1856.

"Address to the electors of Southampton" 1857.

"The Economical, Social, Educational, and Political Importance of Open Competitive Ixxaminations for admission to the public service".

To British Association, 1857.

"Journal of Statistical Society", vol. xxi, pp. $18-51$, 1858.

"On the application of sanitary science to the protection of the Indian Army".

"Transactions of National Association for the Promotion of Social Science", 1853, pp. 437 - 504.

"The progress of the principle of competitive examination for admission into the public service".

To British Association, 1853.

"Journal of Statistical Society", vol. xxi1, pp. $44-75$, 1859.

"Results of different principles of legislation and administration in Europe; of competition for the field, as compared with competition within the field of service".

"Journal of Statistical Society", vol. xxil, pp. 381 -

$420,1859$. 
"The chief methods of preparation for legislation especially as applicable to the reborm of Parliament".

To Society for Promoting the Amendment of the Law.

Charles Knight, 1859. Re-published in "Fraser's

Magazine", vol. 75, pp. 673 - 690, May 1867.

"On the Physiological as well as Psychological Limits to mental labour".

"Transactions of British Association", 1860.

"Public Health".

"Transactions of Social Science Association", 1860, pp. 574 - 606 .

"Post Office Savings Banks".

"Journal of Statistical Society", vol. xxiv, pp. 519 - . 522, 1861 .

"The subject matters and methods of competitive examinations for the public service".

To British Association, 1862.

"Journal of Statistical Society", vol. xxvi, pp. 72 - 77, 1863.

"The comparative results of the chief principles of the Poor Law administration in England and Ireland, as compared with that of scotland".

"Transactions of Social Science Association", 1863, pp.

71.2 - 725 .

"The present state of economy and trade".

"Transactions of Social Science Associatioh", 1864, pp.

$69-105$.

"The loss of life and property by sbipwrecks".

"Transactions of Social Science Association", 1865, pp.

77 - 101.

"The Economical Principles of a reform of the legislation and administration for the convegance of passengers and goods on railways".

Longmans, Green and Co., 1865.

"The Government Purchase of Railways".

"Journal of Society of Arts", vol. xiv, pp. $198-207$,

9 February 1866.

What action, if any, ought the Government to take with regard to railways?".

"Transactions of Social Science Association", 1867, pp.

593 - 605 .

"University of London Blection; Address to members of

convocation. With a letter from J.S. Mill". 1867.

"On Standing Armies".

London, 1868. 
"National Elementary Education. 1868.

An Address".

"Les Unions Ouvrières en Angleterre au point de vue criminelle". Paris, 1868.

"The election for the Kilmarnock Burghs. Statement in relation thereto". 1868.

"Movement for International Economy of Military Expenditure". "Journal of Statistical Society", vol. xxxi1, pp. 456 -

"The Military and Naval Force derivable from the introduction of military drill, and gymastic exercises, as part of a national system of education in all elementary schools". Royal United Service Institution, May 1870.

"National Education. Letter thereon to the Lord President of the Counc11". London, 1870.

"The sanitary and economical advantages of smooth and impermeable street surfaces".

"Transactions of Social Science Association", 1871, pp. 489 - 501.

"The chief economical principles for consideration in relation to National as against Standing Armies, as displayed in the present war on the continent".

"Transactions of Social Science Association", 1870, pp. $500-516$.

"Memorandum on plan and estimate for drainage of Cawnpore", 1871.

"Iettre sur l'instruction obligatoire en France, adressée par E.6. à M. Mignet".

Academie des Sciences Morales et Politiques. Orleans, 17 November 1871.

"On the jurisprudence of chargeability for sanitary works and for poor rates, police rates, and other branches of local administration".

London, 1873.

"What are the best means of drawing together the interests of the United Kingdom, of India, and of the Colonies?" "Transactions of Social Science Assoclation", 1874, pp.
850 - 869 .

"The system of the water supply of the metropolis". "Sanitary Record", vol. iv, pp. 243 - 248, 8 April 1376.

"Address on Public Health".

"Transactions of Social Science Association", 1877, pp. $74-121 . \quad$ Reprinted, Spottiswoode and Co., 'London,
1877 . 
"Sanitary Condition of Aberdeen".

"Transactions of Social Science Association", 1877, pp. 582 - 591 .

"The sanitation of a county".

"Sanitary Record", vol. vi11, pp. 257 - 262, 26 April 1873.

"National water supply".

"Journal of Soclety of Arts", vol, xxv1, pp. 767 - 774, 5 July 1878.

"The need of reforms in the administrative organisation of the sanitary service, with special reference to the appointment of Medical officers of Health".

To Sanitary Institute of Great Britain, 1878.

"Sanitary Register", October 1878, pp. 5 - 19.

"The Fequisite Attributions of a Minister of Health".

To International Congress of Hyeiene, Paris, 4 August 1878.

"Sanitarian", vol. vil, pp. 59-67, February 1879.

"Address as President to International Association for the

Promotion of Means for Improving the Supplies of Drinking Water to Populations".

Delivered at Amsterdam, September 1879.

G. Nomuan and Son, London, 1879.

"On the Norma of sanitation in the school stages of life".

"Transactions of sonitary Institute", vol. i, pp. 271 $279,1879$.

"Letter from Mr. Bdwin Chadwick, on the application of sanitary science to the reduction of infantile mortality among the wage classes in Croydon".

"Transactions of Sanitary Institute", vol. i, po. 310 $314,1879$.

"Circulation or stagnation: being the translation of a paper by F.O. Ward on the arterial and venous system for the sanitation of towns, with a statement of the progress made since then for its completion by Edwin Chadwick, G.B.".

"Transactions of Sanitary Institute", vol. il, pp. 259 $287,1880$.

"The Census of 1881".

"Journal of Soctety of Arts", vol. xoxvili, pp. $717-723$, 16 July 1880.

"Enployers" Liability for accidents to workpeople". "Fraser's Magazine", New Beries vol. 23, pp. 680 - 692 , May 1381.

"National Education. On the rise and progress of the half-time principle for mixed physical and mental training, as the foundation of a national system of education". Charles Knight and Co., London, 1381. 
"Progress of sanitation: in preventive as compared with that in curative science".

"Transactions of Social Sclence Association", 1881.

"The Prevention of Epidemics".

To Brighton Health Congress, December 1882.

"Sanitary Record", New Series vol. 3, pp. 270 - 277 ,

15 January 1882.

"Position of Sanitation in England".

To Association of Public Sanitary Inspectors, June 1884.

"Sanitary Eingineering", vol. vili, pp. $482-485,13$ June 1884.

"On the evils of disunity in central and local administration, especially with relation to the metropolis, and also on the new centralisation for the people, together with improvements in codification and in legislative procedure".

Longmans, Iondon, 1885.

"Commentaries on the report of the Royal Commission on. Metropolitan Sewage Discharge, and on the combined and the separate systems of town drainage".

Longmans, London, 1885.

"Sanitary review of the session".

To Association of Public Sanitary Inspectors, May 1885.

"Sanitary Engineering", vol. x, pp. 296 - 298, 8 May

1885.

"Ventilation with air rom superior couches in place of inferior couches".

"Sanitarian", vol. xv, pp. 11 - 15, July 1885.

"Sanitary Sewage and Water Supply".

To Sanitary Institute of Great Britain, 1887.

"Transactions", vol. ix, pp. $34.3-348$.

"Sanitary Condition of Water Supplies".

To Sanitary Institute of Great Britain, 1887.

"Transactions", vol. ix, pp. 348 - 351.

"Elementary Education Question and the Half-time System". Longmans, 1887 .

"Progress of sanitation, civil and military, to the year 1838". To Asgociation of Public Senitary Inspectors, 1888.

"Journal of Society of Arts", vol. xxvi, pp. 1029 - 34,

7 September 1888.

"General History of Prinoiples of Sanitation".

Cassell and Co., London, 1889.

"Present Condition of Sanitary Science".

To Association of Public Sanitary Inspectors.

"Sanitarian", vol. xil, pp. 385 - 395, May 1889.

"Competitive exumination".

Iuondon, 1890. 
"First Report from Comissioners appointed to collect information ..... relative to employment of children in factories". $1833(450), x x \cdot 1$.

Second Report. 1833 (519), xxi. 1.

Supplementary Reports. 1834 (167), xix. 253, xx. 1.

"Report from Commissioners for Inquring into the administration and practical operation of the Poor Laws". 1834 (44), xxvil. 1 Appendix (A) Parts II, III, IV: Evidence collected by Edwin Chadwick; Rural Questions. 1834 (44), xxix. 1. Chadwick's Report on London and Berkshire was reprinted in "Bxtracts from the information received by His Majesty's Commissioners, as to the administration and operation of the Poor Taws", London, 1833. (pp. 201 - 339)

"First Report of Comissioners appointed to inquire into the best means of establishing an efficient constabulary force in the counties of Ingland and Wales". 1839 (169), xix. 1.

"Report of the Poor Lraw Commissioners to the Secretary of State, on an inquiry into the sanitary condition of the labouring population of Great Eritain". 1842, xxvi. 1. (House of Lords). District Reports. 1842, xxvii. 1. (House of Lords). Report on Scotland. 1842, xxvili. 1. (House of Lords). "Supplementary Report on the result of a special inquiry into the practice of interment in towns". 1843 (509), xil. 395. "First Report of Comissioners for inquiring into the state of large towns and populous districts". 1844 (572), xvil. 1. second Report. 1845 (602) (610), xvili. 1. 299.

"Firgt Report of Commissioners appointed to inquire whether any and what special. means may be reoulsite for the imrpovement of the health of the metropolis". 1847 - 48 (888) (895), xxxil. 1. 57 .

Second Report. 1847 - 48 (911), xxxi1. 253.

Third Report. $\quad 1847$ - 48 (979), xxxii. 339.

The Reports of the General Board of Fiealth are included in Section $\mathrm{E}$ below.

Of the Annual Reports of the Poor Law Commission, Chadwick's influence is nost visible in the First (1835), Fourth (1838), and Fifth (1839). 


\section{D. BVIDENCE GIVEN BY CHADWICK B.SFOLE ROYAL COMAISSIONS AND PARLIAMENTARY COMMIT PESS.}

Select Committee on Metropolitan Police. 1828 (533), vi. 1. Chadwick was appartently not suamoned as a witness; but the paper at Appendix F, Pp. $322-325$, is probabiy his: "Outine of the advantages which would result from extending the circulation of the "Police Gazette"; apprehension of offenders; recovery of stolen property; prevention of crime".

Select Comittee on intoxication amons the labouring classes. 1834. (559), vili. 315. 11 June 1334, pp. 29 - 40.

Select Committee on the Highways Act. $1837-38$ (463), xxili. 253.

5 March 1838, pp. 11 - 25: 7 March, pp. $34-46$.

Select Committee on District Asylums for the houseless poor in the metropolis. 1846 ( 333 ), vil. 1.

27 Eebruary 1846, pp. 86 - 88; 5 hay 1846, pp. $364-375$.

Select Committee on Local Acts. 1846 (556), xil. 1,

28 May 1846, pp. 21 - 41.

Select Comittee on Railway Labourers. 1346 (530), xili. 411. 16 June 1846, pp. 146 - 154.

Select Comittee on Sewage Manure. 1845 9474), x. 535.

26 June 1846, pp. 106 - 120.

Belect Committee on the administration of the Poor Law in the Andover Union. 1846 (663 - I) (663 - II), v. Part I. 1, Part II. 1 .

25 July 1846, pp. 549 - 568; 28 July, pp. $869-892 ; 29$ July, pp. 393 - 909; 30 July, pp. 912 - 926; 927 - 933; 934 - 936; 11 August, pp. 1106 - 7; 15 August, pp. 1274 $1292 ; 1310$ - 1311.

Select Comittee on the Liaw of Settlement. 1847 (82), xi. 1 , etc.

Fourth Report, 184 ? (213), xi. 201. 4 March 1847, pp. 1 - 18; 9 March, pp. $18-40 ; 11$ March, pp. $40-63$;

16 March, pp. $64-95$.

Select Committee (Lords) to consider the subject of printing papers for the House of Lords. 1854, xxi. 135 (House of Lords) 30 May 1854, pp. 25 - 30, $35-37$.

"Papers relating to re-organisation of Civil Bervice". $1854-$ $55, \mathrm{xx} \cdot 1$.

Chadwick's paper, 1 August 1854, pp. $136-227$.

Select Committee on operation of Corrupt Practices Prevention Act, 1854. $1860, \mathrm{x} .1$.

15 March 1860, pp. 153 - 167. 
"Two papers submitted to Commission (on Popular Education) by Mr. Chadwick, as to half-time teaching and military and naval drill, and on time and cost of popuiar education on large and small scale". 1862, xli1i. 1 .

"Further return, being lettex to Mr. Senior, explanatory of former paper", ibid., 91.

Select Committee on Metropolitan Local Government. 1866, xili. 171.

Second Report. 1866, xili. 317. 23 July, pp. $223-31$

Select Committee on employment of steam on tramways. 1877 , xvi. 445.

22 lfarch 1877, pp. 208 - 114.

B. PARIIAUINTARY AND DEPARTMGNTAI PAPERS.

\section{(1) 1831 - 1847: PUBIIC ESAITH, POOR IAW, BACTORX ACT, PRIVATE BIIIS.}

Select Comaittee on Bill to regulate the labour of children in mines and factories. 1831 - 32 (706), xv. 1 .

"Instructions from the Central Board of Factory Comissioners to the District and Medical Commissioners". 1833 (274), xxxi. 349 "Extracts from Reports made to the Poor Law Commissioners on the subject of the education of the poor". 1833. cccxxiv. 657.

(House of Lords).

Reports from the Pactory Inspectors on the effects of the educational provisions of the factories Act, 1839 (42), xl1i. 353.

Select Comitiee (Lords) on the supply of water to the metropolis. 1840, zxil. 715. (House of Lords).

Select Committee on health of towns. 1840 (384), xi. 277.

Select Comittee on building regulations and the improvement of boroughs. 1842 (372), x. 161.

Select Committee on interments in towns. 1842 (327), x. 349. "Letters Irom S.H. Greig and H. Ashworth to $\mathrm{L}$. Chadwick; also, correspondence and return relative to the removal of labourers from agricultural districts to manufacturing districts". 1843 (254), xiv. 119 .

Select Committee on medical relief to the sick poor. 1844 (312) ix. 1. Second Report: 1844 ksex (387), ix. 31.

Third Report: 1844 (531), ix. 93 
Resolutions relative to Private Bills. 1345 (11) (113) xxxvi.

"Instructions to Surveying officers appointed by the

Compissioners of Woods and Forests to institute prelininary inquiries, under 9 \& 10 vict. c. 106, in ceses of application for Acts for the formation of cemeteries". 1847 (in 33), xxxili. 87.

"Letters from the Foor Law Commissioners to the Secretary of State respecting the transaction of the business of the Commission". 1847 (148), xlix. 1 .

(2) 1848 - 54: REPOKNS, RETURNS, AND OTHER PAPERS RELATING TO THE GEMERAL BOARD OF HEATAFI.

(a) Administration of Public Health and Nuisances Acts.

"Report on the measures gdopted for the execution of the Nuisances Rexoval and Diseases Preveation Act, and the Public Health Act, up to July 1849". 1849 (1115), xxiv, 1.

"Minutes of information collected in respect to the drainage of the lands forming the sites of towns, to road drainage, and the facilitation of the drainage of suburban lands". 1352 (1471), $\mathrm{x} 1 \mathrm{x} .1$.

"Minutes of information collected wtth reference to works for the removal of soil water, or drainage of dwelling-houses and public edifices, and for the sexerage and cleansing of the sites of towns". 1852 (1535), xix. 307.

"Minutes of ioformation collected on the practical application of sewer water and town manures to agricultural production". 1852 (1472), xix. 133 .

"Coples of the correspondence between the General Board of Health and the Wetropolitan Sanitary Association, on the subject of amenoments in the Nuisances Reroval Act". 1852, xvii. 285. (House of Juords).

"Reports on an inquiry relative to prevalence of disease at Croydon, and to plan of sewerage". $1852-53$, xev1. 35. Further Reports from Soard of Health, Ibid. 221. Statement of preliminary inquiry, etc., ibid. 117

"Minutes of Evidence taken before the Select Committee of the House of Lords on the Bill "to confirm certain Provisional Orders of the Genersl Board of Health for Hertford, Accrington, Bangor, and Uxbridge, etc". $1852-53$, xxxi. 231. (House of Lords). 
"Report on State of works of drainage and sewerage, etc., (at Croydon) by Thomas Wicksteed". 1854, 1xi. 347.

"Copies of all correspondence, memorials and reports, in reference to the application of the Public Health Act to the township of Barton-upon-Irwel1". 1854, Ixi. 1.

"Report on administration of the Public Health Act, and

Nuisances Removal and Diseases Prevention Acts, from 1848 to $1854^{\prime \prime}$. 1854, xxxv. 1 .

Details of the receipt and expenditure of the Board, the persons in their employment, the number and names of places from which applications were made, the method of applying the Act, the amounts of the mortgages secured on local rates, the average cost of the works, etc., may be found in the following returns:

$$
\begin{aligned}
& 1850 \text { (755), xxxi1i. } 335 . \\
& 1850 \text { (110), xxxili. 591. } \\
& 1851 \text { (504), x11i1. } 321 . \\
& 1352 \text { (573), 11i1. } 1 . \\
& 1852 \text { - 53, xevi. } 1 . \\
& 1854-55 \text {, liii. } 19 . \\
& 1357 \text { (Sess. 2), xli. } 3 . \\
& \text { 1867, 1ix. } 241 .
\end{aligned}
$$

orders in Council for the application of the Public Health Act were published in the "Irondon Gazette" (see above, p. 528, foot-note); as were also the Notifications in respect to the Nuisances Removal and Diseases Prevention Act ( $p$. 368, footnote). Specimens of the provisional Orders are given in P.P. 1850, xx. 321 (House of Lords): "Provisional Orders for the application of the Public Health Act to Stratford-upon-Avon, Dartford, Newport (Mon.), Brecon, Harrow, Derby, Dover, Chelsford, and York".

The collection of Chadwick's pamphlets in the British Museum contuins some 140 of the local reports by the Inspectors of the General Board. 


\section{(b) Cholera, 1848 - 1849 and 1853 - 1854 .}

"Report to the Poor Law Commission on the capabilities of the Metropolitan Workhouses for the reception and treatment of cholera cases". 1847 - 48 (917), 11. 431.

"Report of the General Board of Health on the epidemic cholera of 1848 and 1849".

1850 (1273), xxi. 3.

Appendix (A), ibid. p. 185. Appendix (B), ibid., p. 365 Appendix (C), 1852 (1523), xx. 1 .

"Despatches and other documents relating to the outbreak of the cholera in the island of Jamaica". 1851 (104), xxxvi. 561. "Memorandum addressed to Viscount Palmerston, Her Majesty's Secretary of State for the Home Department, on behalf of a deputation which waited on him, on 27th February 1854, for the purpose of urging the necessity of preparations against the apprehended return of the cholera". 1854, xix. 43. (House of Lords).

"Letter from Dr. H. Gavin, Medical Superintending Inspector General Board of Health, showing benefits resulting from houseto-house visitation in Newcastle, Dundee, and Glasgow". 1854, Lxi. 109.

"Report of Commissioners on causes of outbreak of cholera in towns of Newcastle-upon-Tyne, Gateshead, and Tynemouth". 1854, Xxxv. 131.

(c) Metropolitan Interments Act.

"Report on a general scheme for extra-mural sepulture". 1850 (1158), xxi. 573.

"Report to the General Board of Health, by Dr. Sutherland, on the practice of intramural interments in the metropolis". 1850, xxxix. Part I. p. 153. (House of Iords).

"Namber of interments that have taken place in the churchyard and vaults of the church of St, Margaret's (Westminster), 1840 to 1849". 1850 (137), xxxiil. 369.

"Report "on the circumstances attending the revolting practices that have been said to occur in the St. Giles's cenetery in the parish of St. Pancras", by H. Austin and R. Rawlinson.

1850, xxxix. Part I. p. 1. (House of Lords).

"Report of preliminary proceedings under the Metropolitan Interment Act from 5th August to 3lst December 1850". 1851 (479), xoxili. 429.

"Second Annual Report of the General Board of Health, under sec. 73 of the Netropolitan Interment Act". 1852 (264), xx. 97. 
"Minutes of the Board of Health relating to the Metropolitan Interments Act since August 1850; and correspondence relative to the purchase of cemeteries, and the Abbey Wood Estate". 1852 (190), 1ii1. 37.

Expenditure under the Act is showh in the following returns :

1851 (in 479), xxili. 429.
$1852(283), 11 i 1.227$.
1852 (in 573), liii. i.

(d) Metropolitan Water Supply Bill.

"Report by the General Board of Health on the supply of water to the metropolis". 1850 (1218), xxil. 1. Appendix No. I, ibid., p. 341; No. II, 1b1d., p. 342; No. III, ibid., p. 669; No. IV, ibid., p. 931.

"Extract Minute from the proceedings of the General Board of Health, 7 February 1850, respecting supply of water to the metropolis by proposed new companies". 1850 (1140), xxil. 965. "Letter from the General Board of Health to the Secretary of State, dated 5th July 1850, transmitting a Minute of the Board with reference to the River Lea Trust Bill and the New River Company's Bil1". 1850, xx. 351. (House of Lords).

"Report on the proposed gathering grounds for the supply of the metropolis from the soft water springs of the Surrey sands, by the Hon. William Napier". 1851 (1371), xxili. 61.

"Report by Mr. Rammell, an Inspector of the Board of Health, on the soft water springs in the Surrey sands, etc." 1851 (345), xxi1i.137.

"Report of the Commissioners on the chemical quality of the supply of water to the metropolis". 1851 (421), xxili. 401. Select Committee on the Metropolis Water Bill. 1851 (643), xv.

Select Committee on the Metropolis Water Supply Bill, and the Chelsea Waterworks Bill. 1852 (395), xil. 1.

Further minutes of evidence relative to the New River, East London Waterworks, and Lee River Trust Bills, and the Wandle Water and Sewage Bill. 1852 (395 - I), xil. 221.

Further minutes of evidence relative to the East Iondon, Southwark and Vauxhall, Grand Junction, West Middlesex a and London (Watford) Spring Water Companies' Bills. 1852 (527), xil. 561 . 
Select Committee of the House of Lords on the Metropolitan Water Supply. 1852, xxi. 339. (House of Lords).

"Return of gaugings, reports, and communications in relation to the sources of the soft-water springs in the Surrey or other sands for the supply of the metropolis, recelved by the General Board of Health since the presentation of their Report on the supply of water to the metropolis". 1852, xxxi. 515. (House of Lords).

(e) Relations with the Metropolitan Commission of

"Statement transmitted by Mr. John Leslee, to the Secretary of State for the Home Department, complaining of the constitution and administration of the Commission of Westminster Sewers, etc." 1847 (686), Ivil. 123.

"Letter from the Chairman of the Metropolitan Commission of Sewers to the Secretary of State, transmiting a report on the transactions of the Commissioners during the jear $1850^{\prime \prime}$.

1851 (82), xlviil. 75.

"Reports of Mr. Bazalgette relating to Pipe and Tunnel Sewers". 1852 - 53, xcvi. 511 .

Select Committee on Great London Drainage Bill. 1852 - 53, xxvi. 387.

"Reports and Communications by Board of Health to Home Secretary on the drainage of the metropolis". 1854, 1xi. 113.

"Communication from General Board of Health, and reports of Superintending Inspectors in respect to operation of pipe sewers". 1854 - 55, x1v. 295.

"Reports of District Engineers on working of pipe sewerg". 1854 - 55, 1111. 173.

(f) Miscellaneous Activities.

"Letter, dated 19 March 1849, from the Board of Health to the Treasury, on the advantages of printing oflicial reports in the octavo, instead of the follo form". 1849 (293), x1v. 21 "Report of the General Board of Health on Quarantine". 1849 (1070), xxiv. 137.

"Report of Dr. Arthme Farre and Mr. Grainger to the General Board of Health, on Thirty-eight metropolitan workhouses". 1850 (133), xxi. 737. 
"Report to the Board of Health in reference to the sanitary condition of Agar Town, St. Pancras, and other parts of the metropolis". 1851 (388), xxi11. 1 .

"Report on a general scheme of extra-mural sepulture for country towns". 1851 (1348), xxi1i. 177.

"Second Report on Quarantine: Yellow Eever". 1852 (1473), xx. 117.

Reports made to the Home Eecretary by the Assistant Commissioner of Police on the operation of the Common Lodging-Houses Act, 1851. 1852 - 53, lxxvi1i. 525; 1854, xxxv. 115.

"Papers received by Board of Health, exhibiting operation of Common Lodging-Houses Act". 1852 - 53, 1xxviii. 553. "Letter from the General Board of Health to the Home Secretary on smoke consumption". 1854, Ixi. 533 .

\section{A SEIECTION OF BOOKS.}

\section{(1) BIOGRAPHIES OF CHADEICK.}

The memoir prefixed to "The Eiealth of Nations" (2 vols., 1887). Written by Sir Benjamin Ward Richardaon from information comnualcated by Chadwiek himself, is the most authoritative source for Chadwick's personal and family kistory. It is unfortunately brief and very reticent. The Board of Health is dismissed on one page, and the mildness of the narrative points to the exercise of a strong censorship by Richardson. The survey of Chadwick's works which follows is larfely an uncritical précis, but it contains a few comments by Chadwick himself. An abridged version in one volume, "National Health", was published in 1890.

Richardson's memoir may be compared with the articles in the "North British Review", vol. xili, pp. $40-84,1850$, (by Professor Masson), and "The Sanitarian, vol. v, pp. $176-182$, April 1877, both of which incorporate materlal supplied by Chadwick himself. 
Maurice Marston's "Sir Edwin Chadwick" (1925) is a popular account, of little weight, and based largely on Richardson. "Edwin Chadwick and the Barly Public Health Movement in England" by Dorsey D. Jones (University of Iowa Studies in the Social Sciences, vol. ix, No. 3, 1931) is a more scholarly work, but its sources are limited to the more accessible of the printed materials.

Portraits of Chadwick are given in Richarōson and Marston (both late, aet. c. 70); J.A. Doluege, "Towards National Health" (1931), aet. c. 45; and, with B.W. Richardson and Professor R. Owen, "A Scientific Iriad", in the "Pictorial World" for 29 liay 1890. There is a bust of Chadwick in the library of University Coliege, Lonàon.

\section{(2) MEOIRS AND LECMERS OF CONTEMPOAARIES.}

Since sanitary measures were at the very margin of political interest, very little can be derived from the biographies and printed papers of the leading political figures of the time.

E. Hodder's "Iife and Work of the Seventh Earl of Shaftesbury" (1886) contains some valuable extracts from Shaftesburg's diary, but is very discreet on controversial issues. Chadwick had to be restrained by Richardson from bursting into print to attack this book, presumably on account of its omissions and the emphasis it lays on Shaftesbury's work at the Board of Health at the expense of his colleagues.

"Dr. Southwood Smith" (1899) by the Doctor's granddaughter, C.L. Lewes, is a guileless essay in hero worship, which regards him as the originator and chief figure in the public health agitation, barely mentioning its documentary value is slight, however, it succeeds in conveying an impression of Southwood Smith's charin of character. See also F. Howell, "Sanitary Reform and Services of Dr. 
Southwood Smith in connection therewith" (pamphlet, 1855).

For the Earl of Carlisle there is little except the D.N.B. article and the essay by Harriet Martineau in "Biographical Sketches" (4th ed., 1876).

mpe Letters, Remains, and Memoirs of Edward Adolphus Seymour, Twelfth Duke of Somerset, K.G.", ed. W.H. Mallock and Lady Gwendolen Ramsden (1893), is quite useless, Chadwick and the Board of Health being nowhere mentioned. There is a sketch of Seymour's life in "The Seymour Family" by A. Audrey Locke (1911).

For G.C. Lewis there are the "Letters", edited by Sir Gilbert Frankland Lewis (1870), and the essay by $W$. Bagehot in his "Biographical Studies" (1881). A memolr of George Nicholls, by H.G. Willink, is prefixed to vol. 1. of the 1898 edition of his "English Poor Law".

\section{Also:}

u. Bowley, "Nassau Senior and Classical Economics" (1937)

J. Bowring, "Memoirs of Jeremy Bentham" (1843).

H. Cole, "Fifty lears of Public Work" (1894).

E.B. de Fonblanque, "Life and Letters of Albany Fonblanque"

Mirs. Grote, "The fersonal Life of George Grote" (1873).

M. Greenwood, "The Medical Dictator, and other Blographical Studies", (1936) (For William Farr).

w. Hale-White, "Great Doctors of the Nineteenth Cemtury" (1935) (for Jobn Simon and Neil Arnott).

N.A. Humphreys, "Vital Statistics: a memorial volume of selections from the reports and writings of william Farr" (1385).

R.E. Leader, "Life and Letters of J.A. Roebuck" (189?). J.G. Lockhart, "Viscount Halifax, 1839 - 1885 " (1935)

(for Sir Charles Wood).

A. Newsholme, Lecture on William Farr, "Economica", Hov. 1923. R. Owen, "Life of Richard Owen" (1894).

$\therefore$ Reid, "Memoirs and Correspondence of Iyon Playfair" (1899). B.3. Richardson, "Disciples of Aesculapius" (1900).

(For Thomas Wakley and John Snow).

F. Smith, "Life and Work of Sir J. Kay-Shuttleworth" (1923). J.I. and B. Hammond, "Lord Shaftesbury" (1923). 
(3) THE PUBLIC HEALTH MOVEMENT.

Sir John Simon's "Lnglish Sanitary Institutions" (1890) is the fullest and best account, written by an authority who knew and respected the leaders of the movenent and very largely shared their theories. "ithe Public Health Agitation, 1833 48", by. B.L. Hutchins (1909), reprints a series of lectures delivered at the London School of Lconomics, and contains short but useful studies of Southwood Smith and Chadwick. "The Story of inglish Public Health", by Sir Walcolm Morris (1919), is admittedly based on Siton. A more recent study, "Towards National Health" by J. A Dolmege (1931) pushes the story back into earlier centurios.

The work of earlier reformers is described in M.C. Buer, "Health, Wealth, and Population in the early days of the Industrial Revolution" (1926); M.D. George , "London Life in the Eighteenth Century" (1925); G.T. Griffith, "Population Problems of the Age of Malthus" (1926).

\section{Also:}

Sir George Newman, "The Rise of Preventive Medicine" (1932) "The Building of a Nation's Health" (1939). "Health and Social Evolution" (1931).

Sir A. Newsholme, "Eiements of Vital statistics" (1889)

(contains examples of Chadwick's statistical blunders).

"Ministry of Health" (1925).

H.M.S.O., "The Story of the General Registry Office"

(centenary volume, 1937).

The best introduction to the medical theories of the time is probably given by the two classics of epidemiology, John Snow's "On the Wode of Communication of Cholera" (1849; reprint of second edition of 1854, entiled "Snow on Cholera", New York, 1936), and William Budd's "Typhoid Fever" (1874; reprinted, New York, 1931). Southwood Smith's views are stated in his "Philosophy of Health" (1835).

Also:

C. Creighton, "History of Epidemics in Britain" (1394). 
F.H. Garrison, "An Introduction to the History of Medicine"

I. 11.00 (1914).

E.W. Goodall, "A Short History of Infectious Epidemic Diseases".

M. Greenwood, "Epidemiology, Historicel and Ixperimental"

D.J. Guthrie, "History of Nedicina" (1945). (1932).

H.H. Scott, "Some Hotable Epidemics" (1934).

H.L. Sigerist, "Man and thedicine" (1932).

C. Singer, "A Short History of Medicine" (1928).

H. Zinsser, "Rats, Lice, and History" (1935).

(4) ADMINISTRATIVE AND BCONOMIC HISTORY.

i. Cannan, "Bistory of Local lates in England" (1896). c.T. Carr, "Concerning English Administrative Law" (1941). J.H. Clapham, "Economic History of Modern Britain" (1930). F. Clifford, "History of irivate Bill Jegislation" (1385). M. Cohen, "The Growth of the Rritish Civil Service" (1941). 8. Dowell, "History of Taxation and Taxes in kngland from the "Earliest Times to the year 1385" (1383).

H. Finer, "The British Civil Service" (revised ed., 1937). G. I. Gomme, "London in the Reign of Victoria" (1898).

B.K. Gray, "Philanthropy and the Btate" (1908).

H.R.G. Greaves, "The Givil Service in the Changing State" (1947) E. Halévy, "History of the English People" (1924-7). J.L. and B. Hamond, "Age of the Chartists" (1930).

Hutchins B.I. and Farrison J.A., "History of Pactory

Legislation" (1911)

H. Jephson, "The Sanitary Erolution of London" (1907).

H.J. Laski, W.I. Jennings, and W.A. Robson, ed., "A Century of Hunicipal Progress" (1935).

G. Nicholls, "History of the English Poor Law" (1854).

A. Redford, "History of Local Government in Manchester" (1939). A.H. Robson, "The Education or Children engaged in Industry,

$$
1333 \text { - 1376" (1931). }
$$

G. Slater, "Poverty and the State" (1930).

K. Smellie, "A Hundred Years of English Government" (1937). F.H. Spencer, "ivnicipal Origing" (1911).

S. and B. Webb, "Statutory Authorities"

"English Poor Law History",

(vols. 4 and 7 - 9 of "Eaglish Local Government" $1906-29)$.

W.ti. Wickwar, "The Public Services" (1938).

A. Wilson and H. Levy, "Workmen's Compensation" (1939). "Burial Reform and Funeral Costs".(1938) R. Moses, "History of the Civil Service" (1914). 
G. EAMPHLETS.

The great majority of Chadwick's collection of pamphlets, covering all his multifarious interests, poor law, public health, education, police, agriculture, etc., are deposited in the British liuseum. They 1 ill 535 volumes, under the press mark C.T.

Part of Chadwick's library, 274 books and 43 pamphlets, was given to the Manchester Public Iibraries in 1891 by his son, Osbert Chadwick. 